LUIS FABIANO DE ASSIS

\title{
ATIVISMO JUDICIAL NA JUSTIÇA DO TRABALHO
}

\author{
TESE DE DOUTORADO \\ Orientador: Prof. Antônio Rodrigues de Freitas Junior
}

Faculdade de Direito da USP São Paulo

2011 


\section{ATIVISMO JUDICIAL NA JUSTIÇA DO TRABALHO}

TESE APRESENTADA À FACULDADE DE DIREITO DA UNIVERSIDADE DE SÃO PAULO COMO REQUISITO PARCIAL PARA A OBTENÇÃO DO TÍTULO DE DOUTOR EM DIREITO, SOB A ORIENTAÇÃO DO PROFESSOR ANTÔNIO RODRIGUES DE FREITAS JUNIOR.

Faculdade de Direito da USP

São Paulo

2011 


\section{AGRADECIMENTOS}

Ao professor Antônio Rodrigues de Freitas Junior, pela riquíssima orientação ao longo da pesquisa e do desenvolvimento deste trabalho.

À Velha Academia do Largo São Francisco, locus extraordinário em que a "disciplina da convivência humana” sempre foi ensinada não por afirmações estáticas, que tendem a interromper a reflexão; mas pela sucessão dinâmica de indagações cujas respostas levam sempre a novas e mais profundas perguntas.

Às bibliotecas da Faculdade de Direito da Universidade de São Paulo, pelos convênios internacionais que permitiram o acesso a diversas obras em língua estrangeira, o que ampliou significativamente o horizonte desta pesquisa. Agradeço, igualmente, aos dedicados funcionários das bibliotecas.

Aos meus amigos Miron Tafuri Queiroz, Laurent Azevedo Marques de Saes, Tabajara Medeiros de Resende Filho e Lauro Joppert Swensson Junior, pela ajuda na obtenção de textos em língua estrangeira.

A todos aqueles com quem convivi nas Arcadas ao longo de mais esta etapa de minha formação (Ana Francisca Moreira de Souza Sanden, Candy Florêncio Thomé, Cristiane Ferreira, Célia Zapparolli, Cleber Bastazine, Edson Gramuglia, Jorge Cavalcanti Boucinhas Filho, Maria Isabel Cueva Moraes, Ricardo Valente, Rodrigo Schwartz, Tales Picchi Alves, Tatiana Waldman, entre muitos outros), pelas conversas enriquecedoras dentro e fora das salas de aula.

Aos professores Antônio Rodrigues de Freitas Junior, Enoque Ribeiro dos Santos, Estêvão Mallet, Lídia Reis de Almeida Prado e Virgilio Afonso da Silva, pela riqueza de conteúdo das disciplinas cursadas, todas elas de grande importância no desenvolvimento da pesquisa que deu origem a esta tese.

Aos professores Ronaldo Lima dos Santos e Otávio Pinto e Silva, pelas valiosas observações por ocasião da qualificação deste trabalho. 
À minha família. 


\section{SUMÁRIO}

\section{CAPÍTULO 1}

INTRODUÇÃO

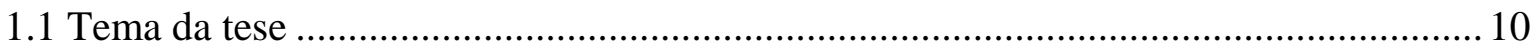

1.2 Delimitação, metodologia e desenvolvimento do trabalho.......................................... 17

1.2.1 Juridificação, potencial protagonismo judicial e tipos de ativismo judicial ........ 18

1.2.2 Relevância da abordagem comparatística........................................................ 22

1.2.3 Tipos ideais de ativismo judicial e a Justiça do Trabalho .................................. 24

1.2.4 Esclarecimentos metodológicos complementares …..............................................30

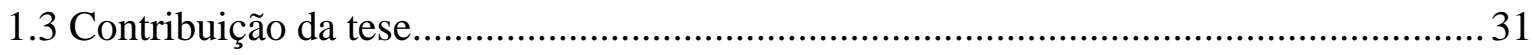

\section{CAPÍTULO 2}

PONTOS DE PARTIDA

JURIDIFICAÇÃO E POTENCIAL PROTAGONISMO JUDICIAL

2.1 Considerações preliminares: a ascensão do Poder Judiciário nas democracias ocidentais

2.2 Juridificação: aspectos, desdobramentos e relação com o potencial protagonismo judicial

2.2.1 Expansão dos padrões regulatórios e o problema da "indeterminação"

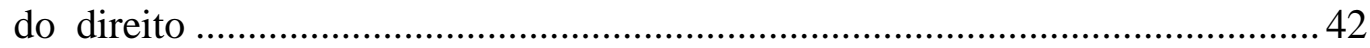

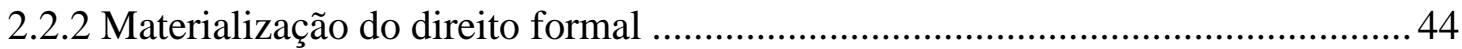

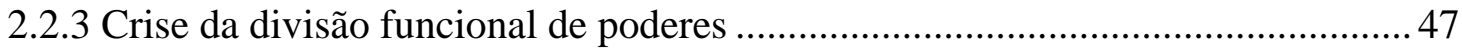

2.2.4 Enfraquecimento do "modelo subsuntivo" e fortalecimento da função pragmática da hermenêutica jurídica................................................................ 48

2.2.4.1 Decisão judicial: as éticas da convicção e da responsabilidade ............... 53

2.2.5 A expropriação dos conflitos ............................................................................. 55

2.2.6 Ampliação do controle judicial contramajoritário e da independência

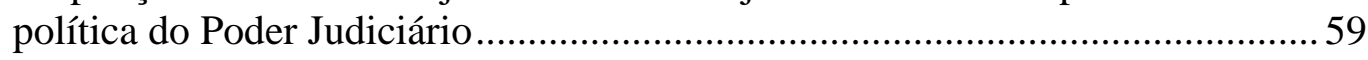

2.2.7 Convergência das experiências jurídicas democráticas: aspectos normativos e institucionais

2.2.7.1 Aproximação entre common law e civil law e ambivalência das leis e dos precedentes 
2.2.7.2 A influência do ideário dos Direitos Fundamentais e dos Direitos Humanos

2.2.7.3 A metáfora da “migração de ideias” no direito comparado .................... 71

2.2.7.4 A ideia de proporcionalidade .................................................................. 75

2.2.8 O ideário do juiz ativo: origens, influências e expansão mundial ........................ 80

2.2.8.1 A ampliação do ideário do “juiz ativo” ................................................. 84

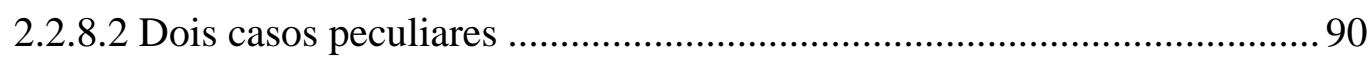

2.2.8.2.1 França: “descolamento” entre o comportamento judicial e as leis processuais ............................................................. 90

2.2.8.2.2 Inglaterra: o active case management .................................... 92

2.2.9 Poder judiciário e litigância de interesse público ............................................. 94

2.2.9.1 Public interest litigation nos EUA .......................................................... 95

2.2.9.2 Litigância de interesse público em outros países e estruturas de suporte à mobilização jurídica ............................................................... 100

2.2.10 Poder Judiciário e meios de comunicação de massa ....................................... 107

2.3 Juridificação de relações sociais no Brasil e potencial protagonismo judicial ............. 111

2.3.1 Perplexidades suscitadas pela experiência brasileira de "Welfare State"

(1930 a 1988) ............................................................................................. 112

2.3.2 Juridificação, Constituição de 1988 e expansão efetiva do potencial protagonismo judicial no Brasil ..................................................................... 116

2.3.3 Especificidades do potencial protagonismo judicial na Justiça do Trabalho .... 129

2.3.3.1 Breves considerações históricas ......................................................... 129

2.3.3.2 Os dissídios coletivos e o poder normativo......................................... 133

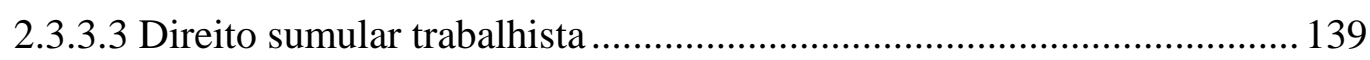

2.3.3.4 O pioneirismo do modelo trabalhista de juiz ativo.............................. 143

\section{CAPÍTULO 3}

NOÇÕES DE ATIVISMO JUDICIAL: PROBLEMATIZAÇÃO E REFLEXÕES CONCEITUAIS

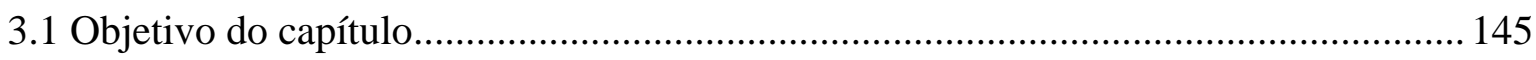

$3.2 \mathrm{O}$ ativismo judicial na experiência jurídica dos EUA............................................... 145

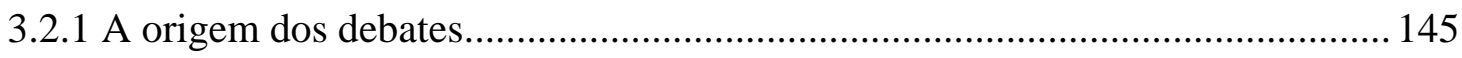

3.2.2 Noções comuns na retórica da crítica judicial nos EUA .................................. 148

3.2.3 Ativismo judicial e controle político da composição de tribunais....................... 164

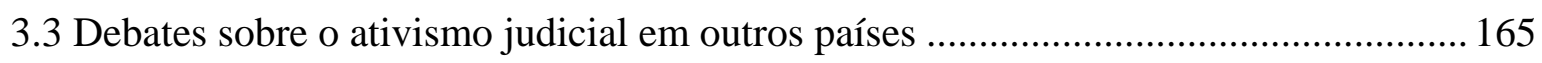

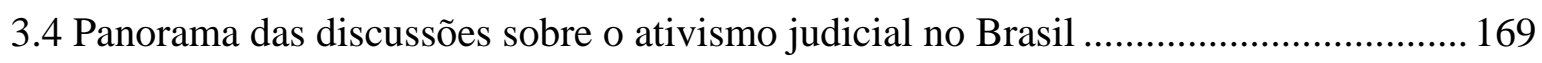

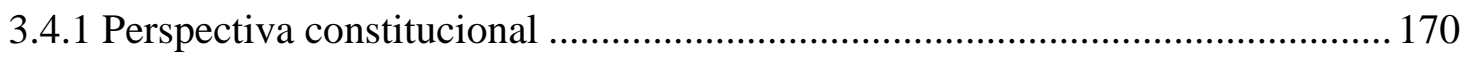


3.4.1.1 Noções presentes em decisões do STF e em discursos de seus ministros

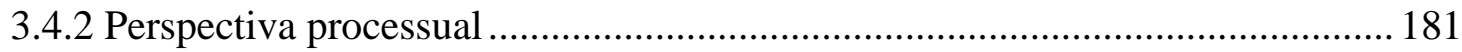

3.4.2.1 Críticas aos instrumentos processuais de padronização decisória ......... 182

3.4.3 Perspectiva trabalhista ...................................................................................... 184

3.4.3.1 Noções presentes em decisões do TST ............................................... 188

3.4.3.2 Noções de ativismo judicial nos debates entre magistrados do Trabalho

3.4.4 Direito alternativo, uso alternativo do direito e manifestações do potencial protagonismo judicial

\section{CAPÍTULO 4}

\section{ATIVISMO JUDICIAL: TIPOS IDEAIS}

4.1 Objetivos do capítulo

4.2 Esclarecimentos complementares sobre a construção dos tipos ideais de ativismo judicial

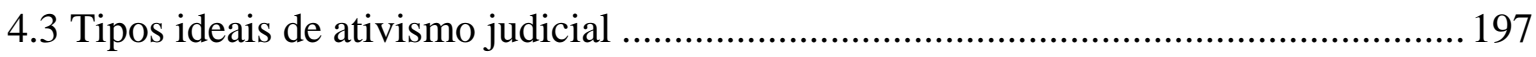

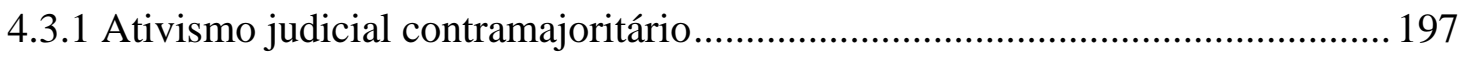

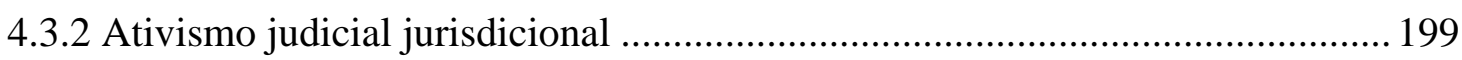

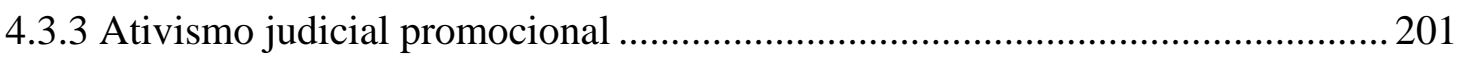

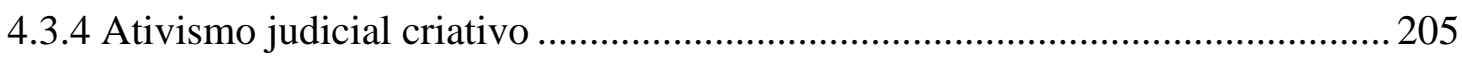

4.3.5 Ativismo judicial de padronização decisória .................................................... 208

4.3.6 Ativismo judicial em face de precedentes ......................................................... 211

4.3.7 Ativismo judicial contra legem ..................................................................... 213

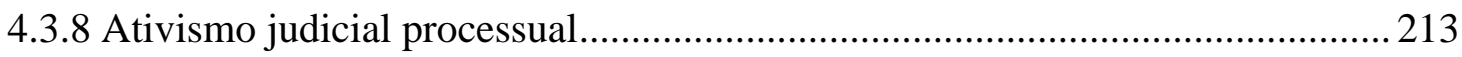

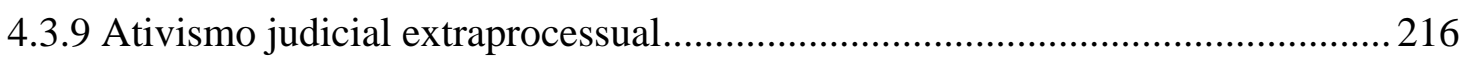

\section{CAPÍTULO 5}

ATIVISMO JUDICIAL NA JUSTIÇA DO TRABALHO

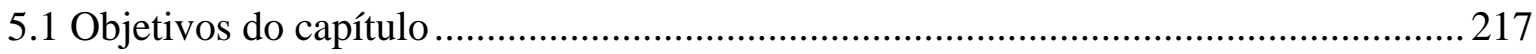

5.2 Ativismo judicial no Caso Embraer (dispensas em massa) ....................................... 218

5.2.1 Linhas gerais do litígio e decisão liminar ......................................................... 218

5.2.2 Julgamento do dissídio coletivo de natureza jurídica (TRT) ............................ 220

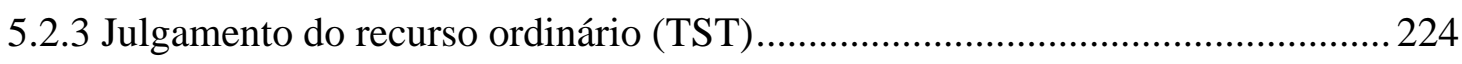

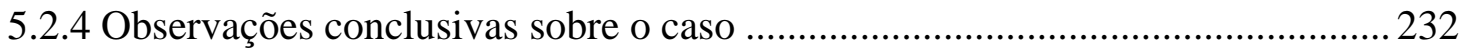


5.3 Ativismo judicial no direito sumular trabalhista.

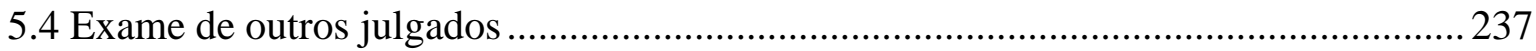

5.4.1 Controle judicial de políticas públicas.............................................................. 237

5.4.2 Exploração sexual de crianças e adolescentes para fins comerciais ................... 241

5.4.3 Dispensas discriminatórias de portadores do vírus HIV ................................... 242

5.5 Ativismo judicial extraprocessual da magistratura do Trabalho ................................. 243

5.6 Ativismo judicial no STF e seus reflexos na Justiça do Trabalho ............................... 247

5.6.1 Breves considerações sobre o ativismo judicial no STF ................................. 247

5.6.2 Limitação à garantia de emprego da gestante..................................................... 253

5.6.3 A definição da base de calculo do adicional de insalubridade .......................... 255

5.6.4 Terceirização e responsabilidade subsidiária da Administração pública ........... 258

5.6.5 Reflexos trabalhistas de outros julgados do STF............................................ 260

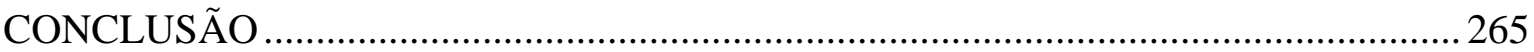

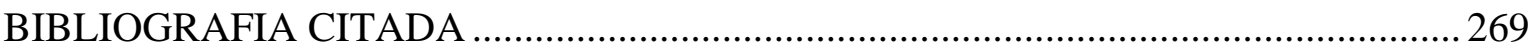

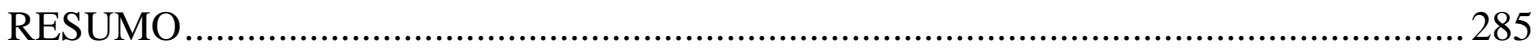

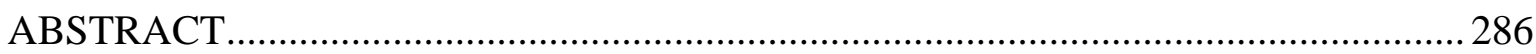

RIASSUNTO

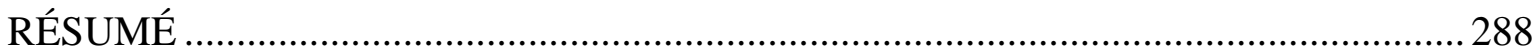


"De todas as coisas que nos vêm por natureza, primeiro adquirimos a potência e mais tarde exteriorizamos os atos. (...) Com as virtudes dá-se exatamente o oposto: adquirimo-las pelo exercício, como também sucede com as artes. Com efeito, as coisas que temos de aprender antes de poder fazê-las, aprendemo-las fazendo; por exemplo, os homens tornamse arquitetos construindo e tocadores de lira tangendo esse instrumento. Da mesma forma, tornamo-nos justos praticando atos justos, e assim com a temperança, a bravura, etc."

Aristóteles 


\title{
CAPÍTULO 1
}

\section{INTRODUÇÃO}

\begin{abstract}
Sumário: 1.1 Tema da tese; 1.2 Delimitação, metodologia e desenvolvimento do trabalho; 1.2.1 Juridificação, potencial protagonismo judicial e tipos de ativismo judicial; 1.2.2 Relevância da abordagem comparatística; 1.2.3 Tipos ideais de ativismo judicial e a Justiça do Trabalho; 1.2.4 Esclarecimentos metodológicos complementares; 1.3 Contribuição da tese.
\end{abstract}

\subsection{Tema da tese}

Em meados de 2008, quando os arautos da chamada "crise econômica global” verberavam seus vaticínios mais pessimistas, avultavam seguidas ameaças de despedimento em massa de trabalhadores de grandes empresas, o que colocava em cheque não só a efetividade da dimensão trabalhista dos direitos fundamentais sociais, mas uma série de outras promessas de bem-estar enunciadas na Constituição de 1988, como o pleno emprego, a justiça social e a garantia de existência digna.

Questionadas perante a Justiça do Trabalho, algumas das dispensas coletivas então ultimadas foram suspensas, o que suscitou (a exemplo do que já ocorria em relação a outros ramos da justiça brasileira) fortes críticas ao Judiciário Trabalhista ${ }^{1}$. Em síntese, alegava-se que essas decisões judiciais, havidas por instrumentos do que os críticos chamavam de “ativismo judicial”, transgrediriam os “limites” da atuação de magistrados e tribunais.

A postura da Justiça do Trabalho diante daqueles megaconflitos teve grande repercussão. Abruptamente, o assunto passou a ocupar espaços relevantes na mídia em geral, em congressos jurídicos, em salas de aula de Universidades e em corredores de

\footnotetext{
${ }^{1}$ No início de 2010, editorial do jornal “O Estado de São Paulo” diagnosticava que, na última década, quando juízes teriam passado "a praticar o que nos meios jurídicos é chamado de 'ativismo judicial”, estaria ocorrendo um "processo de politização das primeiras instâncias do Judiciário". Para o jornal, esses juízes tenderiam a interpretar a Constituição "conforme suas inclinações ideológicas, desprezando a segurança jurídica e justificando a iniciativa em nome do combate do 'bem contra o mal' e dos 'pobres contra os ricos'”. No texto, também se intentou uma explicação para o fenômeno: "como os princípios constitucionais são muito vagos, admitindo interpretação ao gosto do freguês", o ativismo judicial abriria caminho "para a politização na aplicação do direito”. Assim, o jornal concluía que, a pretexto de fazer justiça social, os juízes "ativistas" poriam "os pés pelas mãos, prejulgando, desprezando garantias individuais, desfigurando o devido processo legal e subvertendo a lógica do Estado de Direito”. Editorial publicado na edição 18-01-2010.
} 
fóruns e tribunais. Com o passar do tempo, perceberam-se sinais de que tanto as dispensas quanto as decisões transcenderiam a esfera de interesses dos trabalhadores e dos empregadores envolvidos.

Sobretudo no caso Embraer (Empresa Brasileira de Aeronáutica), as repercussões alcançariam claramente o campo político. Os dirigentes da empresa foram chamados pelo presidente da República para explicitar os motivos das dispensas, já que o governo, apesar de seu interesse estratégico, acionário, econômico e social, não havia sido comunicado dos cortes. Parlamentares convocaram audiência pública para discutir as demissões e se manifestaram publicamente sobre o assunto em sessões da Câmara e do Senado. Além disso, tornaram-se mais tensas as discussões sobre o Decreto n. ${ }^{0}$ 2.100/96, por meio do qual o Brasil denunciara a Convenção n. ${ }^{\circ} 158$ da Organização Internacional do Trabalho (OIT), relativa ao término da relação de trabalho por iniciativa do empregador. Ao mesmo tempo, novas propostas de regulamentação dos despedimentos em massa se somaram ao PL n. ${ }^{\circ}$ 6.356/05, que permanecia em sono letárgico até o advento da indigitada “crise”. De um lado, o PL n. ${ }^{\circ}$ 5232/2009 apresentava, em sua exposição de motivos, longos excertos retirados, ipsis litteris, da decisão liminar proferida pelo Tribunal Regional do Trabalho (TRT) da 15 Região no caso Embraer²; e, de outro lado, o PL n. ${ }^{\text {o }}$ 5353/2009, em seus fundamentos, ao considerar a mobilização social que esses fatos haviam produzido, fazia referência expressa a manifesto intitulado "contra oportunismos e em defesa do direito social”, assinado por dezenas de magistrados trabalhistas ${ }^{3}$.

Curiosamente, o Supremo Tribunal Federal (STF), mais ou menos na mesma época, retomaria o julgamento da ADI ajuizada pela Confederação Nacional dos

\footnotetext{
${ }^{2} \mathrm{O}$ artigo $7^{\circ}$ de referido projeto de lei prevê que, "recusando-se qualquer das partes à negociação coletiva, é competente a Justiça do Trabalho para decidir o conflito, podendo inclusive suspender a demissão coletiva liminarmente, e/ou aplicar o disposto no artigo 476-A da Consolidação das Leis do Trabalho”. Por sua vez, o artigo $8^{\circ}$ autoriza que os sindicatos requeiram à Justiça do Trabalho "a apuração das causas de demissão e esta poderá atuar de ofício para determinar as apurações previstas no artigo $5^{\circ}, 6^{\circ}$ e incisos”. Consoante o artigo $9^{\circ}$, a "falta da comunicação" ao ente sindical, na forma prevista no projeto, autoriza a Justiça Especializada a "reintegrar os funcionários liminarmente e de imediato, atribuindo-se multa diária”.

${ }^{3}$ Com efeito, extrai-se do texto da exposição de motivos o seguinte trecho de referido manifesto: “(...) Além de constituírem atentado à ordem jurídica, por ferirem o disposto no inciso I, do art. $7^{\circ}$, da Constituição Federal, as ameaças de dispensas coletivas representam meras estratégias de pressão, de natureza política, para se extraírem vantagens econômicas a partir do temor e da insegurança que geram sobre os trabalhadores e, por via indireta, ao governo. (...) não se podem ver nos preceitos fixados nos incisos do art. $7^{\circ}$ os fundamentos jurídicos para fornecer aos empregadores a possibilidade de, por um exercício de poder, induzirem os trabalhadores, mesmo que coletivamente organizados, a aceitarem a redução dos direitos trabalhistas legalmente previstos, ainda mais quando tenham sede constitucional e se insiram no contexto dos Direitos Humanos, que são, como se sabe, abarcados pelo princípio do não retrocesso. As ameaças de dispensas coletivas e o ataque generalizado às garantias trabalhistas constituem, portanto, um atentado contra a ordem jurídica e o Estado Social, até porque o desenvolvimento da economia está, necessariamente, atrelado aos postulados da boa-fé e da justiça social (art. 170, da CF).”
} 
Trabalhadores na Agricultura (Contag) e pela Central Única dos Trabalhadores (CUT) para questionar a referida denúncia da Convenção n. ${ }^{\circ} 158$ da $\mathrm{OIT}^{4}$.

Ademais, com a suspensão judicial das dispensas em massa, a exposição midiática da Justiça do Trabalho se acentuou consideravelmente. Muitos veículos de comunicação, com sua importante influência sobre a opinião pública, contestavam ardorosamente a juridicidade e a legitimidade das decisões dos órgãos judiciais trabalhistas. Em reação dirigida a tais manifestações depreciativas da imprensa sobre um alegado ativismo judicial ${ }^{5}$ dos TRTs, Guilherme Guimarães Feliciano publicou, na "Folha de São Paulo”, artigo intitulado “ativismo judicial para bom entendedor”, no qual sustentava que o exame da atuação do Judiciário diante das dispensas em massa haveria de excluir interpretações "pelas lentes míopes das leis, como se o legislador fosse o único intérprete autorizado”6 . Além da "Folha”, o jornal “O Estado de São Paulo”, no que tange especificamente à Justiça do Trabalho, proclamava não só que as decisões seriam ilegítimas e sem "fundamentação legal”; mas também que a postura dos TRTs diante das dispensas coletivas poderia agravar os "efeitos sociais da crise”, criando um "problema econômico adicional” para as empresas ${ }^{7}$. Assim, em réplica a opiniões nesse sentido,

\footnotetext{
${ }^{4} \mathrm{O}$ ministro Joaquim Barbosa, em voto vista, julgou o pedido integralmente procedente para declarar a inconstitucionalidade do decreto impugnado por não ser possível ao Presidente, sem o consentimento do Congresso Nacional, denunciar tratados sobre direitos humanos, em cujo âmbito o julgador reconhecia se encontrar a Convenção n. ${ }^{0} 158$ da OIT. Assim, apesar de o Decreto responsável pela incorporação da Convenção ao direito brasileiro ser de 1996 (i.e., ainda que não se admitisse a tese da estatura constitucional dos tratados de direitos humanos antes da EC n. ${ }^{\circ}$ 45/2004), seria plausível defender sua estatura supralegal, posto que infraconstitucional (ADI 1625/DF, rel. orig. Min. Maurício Corrêa, julg. 03-06-09). A votação da referida ADI ainda não foi concluída.

${ }^{5}$ A imprensa se dirigia, em especial, à decisão liminar proferida em 26-02-09 nos autos do dissídio coletivo n. ${ }^{o}$ 30900-12.2009.5.15.0000, rel. Des. José Antônio Pancotti (TRT da 15a Região).

${ }^{6}$ Artigo “Ativismo judicial para bom entendedor", publicado no jornal "Folha de São Paulo", edição de 2505-09 ("Tendências e Debates"), p. 03.

${ }^{7}$ Editorial do jornal "O Estado de São Paulo”, intitulado “Ativismo dos TRTs pode agravar efeitos sociais da crise”, publ. 08-04-09. As decisões, além de suspenderem as dispensas, condicionavam sua formalização à prévia tentativa de negociação com o sindicato; impunham a realização de audiências com a presença de líderes sindicais e de representantes do Ministério Público do Trabalho; e exigiam a apresentação de balanços patrimoniais, demonstrativos contábeis e relação de empregados prejudicados, com a indicação do tempo de serviço de cada um deles. Essas medidas foram entendidas, pelo jornal, como "intervenções abusivas na liberdade de iniciativa" e disseminadoras de "insegurança jurídica". Referidas críticas sustentavam, ainda, que a determinação de apresentação de balanços referentes a resultados de anos pretéritos não ajudaria a entender nem o que vinha ocorrendo com a economia, nem os "planos formulados pelas empresas para enfrentar um período de crise". Destaquem-se, do editorial, ademais, os seguintes excertos: "Além de criar um problema econômico adicional, as liminares dos TRTs da $3^{\text {a }}$ e da $15^{a}$ Região têm problemas de fundamentação legal. Os dirigentes dessas Cortes invocaram princípios constitucionais, entendendo que estavam fazendo Justiça social. É o que os analistas chamam de 'ativismo judicial’. No direito, princípios são diretrizes que orientam a interpretação das regras, permitindo aos juízes ajustar suas decisões às especificidades dos chamados 'casos difíceis' - litígios sobre os quais não há jurisprudência firmada e os doutrinadores estão divididos. Invocados isoladamente, os princípios - que são formulados com base em conceitos abertos, como 'valor social do trabalho' e 'responsabilidade social da empresa' - tendem a
} 
sustentava o referido jurista que tais decisões não veiculariam nenhum abuso por parte do judiciário trabalhista, mas apenas uma “inexorável mudança de perspectiva” baseada na percepção de condicionalidades que, se não previstas textualmente na lei ordinária, estariam em total consonância com o sistema constitucional.

A polêmica ocorria em época na qual a preocupação com a situação dos direitos sociais trabalhistas vinha crescendo, multiplicando o número de estudos sobre o desemprego, os despedimentos em massa e as alternativas (inclusive as judiciais) para a manutenção de postos de trabalho ${ }^{8}$.

No que tange a esses diagnósticos sobre a prática do chamado ativismo judicial, importa, antes de aceitá-los ou não, responder a uma série de perguntas: o que seria, afinal, esse ativismo? Seria um fenômeno uniforme ou haveria diferentes tipos desse agir judicial ${ }^{9}$ ? Haveria uma jurisdição “não ativista”? Se houver, o que a faria distinta da jurisdição “ativista”? Quais seriam as origens desse ativismo? Ele depende da vontade dos juízes? Ou, para que ele se manifeste, é preciso que haja condições que possibilitem essa concretização? O ativismo judicial sempre ocorre no sentido da defesa de direitos fundamentais, ou pode também implicar sua restrição?

disseminar insegurança jurídica. Por representar uma intervenção abusiva na liberdade de iniciativa e empreendimento, decisões judiciais 'protetoras' comprometem o jogo de mercado, que precisa de regras claras e objetivas para funcionar. Em vez de atenuar os efeitos sociais da crise econômica, esse tipo de 'ativismo' só tende a agravá-los.”

8 AMAURI MASCARO NASCIMENTO, "Crise econômica, despedimentos e alternativas para a manutenção dos empregos”, in: Revista LTr, ano 73, n. ${ }^{\circ}$, São Paulo: LTr, jan. 2009; WLADIMIR NOVAES MARTINE, “Licença qualificatória em face da crise econômica”, in: Revista $\operatorname{LTr}$, ano 73, n. ${ }^{\circ} 1$, São Paulo: LTr, jan. 2009; ENOQUE RIBEIRO DOS SANTOS, "Revisitando um plano nacional de ação frente ao desemprego", in: Revista LTr, ano 73, n. ${ }^{\circ}$ 3, São Paulo: LTr, mar. 2009; RENATO RUA DE ALMEIDA, “Subsiste no Brasil o direito potestativo do empregador nas despedidas em massa?”, in: Revista LTr, vol. 73, n. ${ }^{\circ}$ 4, abr. 2009; SÉRGIO PINTO MARTINS, “Despedida coletiva”, in: Revista Magister de direito trabalhista e previdenciário, vol. 6, n. ${ }^{\circ}$ 31, jul./ago., 2009; ANTÔNIO ÁLVARES DA SILVA, "Dispensa coletiva e seu controle pelo judiciário", Revista $L T r$, vol. 73, n. ${ }^{\circ}$ 6, jun., 2009. No âmbito das organizações internacionais, v. OIT. Global Employment Trends For Youth - Special issue on the impact of global economic crisis on youth, Genebra: OIT, 2010; OIT. Global Employment Trends. Genebra: OIT, 2010. OIT. Global Employment Trends. Genebra: OIT, 2009. Mais recentemente, v. MARCUS ORIONE GONÇALVES CORREIA, “A análise dos julgados envolvendo a demissão coletiva na Embraer”, in: GRIJALBO F. COUTINHO et. al. (coord.), O mundo do Trabalho: leituras críticas da jurisprudência do TST em defesa do Direito do Trabalho. São Paulo: LTr, 2011. KÁTIA MAGALHÃES ARRUDA, WALMIR OLIVEIRA DA COSTA (org.), Direitos Coletivos do Trabalho na Visão do TST - Homenagem ao Ministro Rider Nogueira de Brito. São Paulo: LTr, 2011. A obra contém vários artigos de ministros do TST, alguns deles sobre o tema supracitado.

9 Usamos a palavra “agir”, em lugar de “ação”, pela possível confusão semântica que o segundo termo provocaria em algumas frases. 
Todos esses esclarecimentos são necessários para diagnosticar o ativismo judicial na Justiça do Trabalho, ramo do Poder Judiciário brasileiro que se situa num cenário mais abrangente de transformações contínuas na função judicial ${ }^{10}$.

Sem dúvida, a história da magistratura e do Poder Judiciário como instituição revela diferentes concepções a respeito do papel social e político dos órgãos judiciais. Entre os fatores que decisivamente influenciaram as mudanças nesse papel, DALLARI destaca a evolução das sociedades humanas, a complexidade crescente das relações sociais e a experiência com diversas formas de governo. Para o jurista, os próprios juízes, em determinados momentos, teriam sido responsáveis, com suas “boas rebeliões”, por “movimentos renovadores e democratizantes”, conforme registram diversos estudiosos. Consoante ele cita a título ilustrativo, essa mobilização, na França, foi examinada por Boucher (Le Guetto Judiciaire: Pouvoir et Justice, 1978). Do mesmo modo, a ação da Magistratura Democratica italiana foi descrita por Senese (Crisi politico-istituzionale e indipendenza della magistratura, 1982). DALLARI também cita, similarmente, na experiência brasileira, o movimento do Direito Alternativo e, mais recentemente, mobilizações relevantes como a da Associação Juízes para a Democracia ${ }^{11}$.

Nessa linha, o aprofundamento das transformações sociais revela que a função judicial tem se diversificado para se traduzir não só em considerável número formas de atuação da jurisdição stricto sensu, mas também em outros modos de agir que são de grande relevância, não obstante transcenderem o palco estritamente jurisdicional. É o caso das ações associativas da magistratura, das políticas judiciárias institucionais, do engajamento de representantes de instituições judiciais no processo legislativo, entre outras posturas.

Considerando que várias formas de manifestação desse agir judicial podem ser consideradas “ativistas”, o ativismo judicial parece desvelar, desde logo, como em geral ocorre com os fenômenos da sociedade contemporânea, uma notável

\footnotetext{
${ }^{10}$ No Brasil, recentemente, destaque-se, sobre essas transformações, a obra de RODOLFO DE CAMARGO MANCUSO, A resolução dos conflitos e a função judicial no contemporâneo Estado de Direito, São Paulo: Revista dos Tribunais, 2009.

${ }^{11}$ Conforme lições de DALMO DE ABREU DALlARI, O poder dos juízes, $3^{\text {a }}$ ed., São Paulo: Saraiva, 2010, pp. 9, 82-83. O jurista acrescenta que, na raiz da função jurisdicional, está também a "necessidade de esclarecer o direito e de garantir sua aplicação justa". Mas está sempre presente uma dificuldade, "inerente à condição humana do juiz, pois ainda que procure ser justo ele será, em certa medida, influenciado pelas circunstâncias de sua vida". Ele terá de "fazer escolhas, entre normas, argumentos, interpretações e até mesmo entre interesses, quando estes estiverem em conflito e parecer ao juiz que ambos são igualmente protegidos pelo direito. A solução dos conflitos pelo juiz será política nesse caso, mas também terá conotação política sua decisão de aplicar uma norma ou de lhe negar aplicação, pois em qualquer caso haverá efeitos sociais e alguém será beneficiado ou prejudicado".
} 
complexidade em sua substância. Assim, seu estudo não seria bem sucedido se pretendêssemos captar essas formas peculiares de agir judicial por intermédio de uma noção pretensamente unívoca e uniforme. Deixar de acentuar a diversidade de fenômenos associados à expressão “ativismo judicial” traria como consequência a falta de clareza que em geral se nota em seu uso ${ }^{12}$.

A compreensão pode ficar ainda mais difícil quando essa expressão é utilizada de forma estigmatizante, o que em geral ocorre, com grande carga de subjetivismo, para disfarçar um juízo de discordância ou de desapreço por certa postura judicial pejorativamente havida por "ativista”.

Em muitos dos casos nos quais o sentido da expressão não é claramente explicitado, é comum a associação da postura judicial considerada “ativista” à violação da idéia de "separação de poderes". Pondere-se, entretanto, que o uso meramente retórico dessa noção parece supor a existência de uma divisão estanque das funções estatais, com apriorismos que em geral desconsideram a maneira como funcionam as relações sociais e políticas na sociedade contemporânea ${ }^{13}$. Se certas posturas judiciais (ativistas ou não) devem ser condenadas, isso não significa que o discurso de quem as reprove conseguirá atenção se baseado apenas em uma discordância oca, sem aptidão de contribuir com o relevante debate. Do mesmo modo, se outras condutas judiciais puderem ser louvadas, não seria responsável fazê-lo apenas pela perspectiva da ética da convicção, em detrimento de uma ética da responsabilidade, para usar a terminologia weberiana ${ }^{14}$.

\footnotetext{
${ }^{12}$ Ilustrativamente, uma decisão que determinasse ao Estado o fornecimento de um medicamento ou de tratamento de saúde a um particular poderia ser considerada "ativista" pelos mais variados fundamentos. Alguns usariam a expressão para referir a falta de fundamentação adequada ou o desapego a uma metodologia decisória consagrada. Outros, reconhecendo ou não a "justiça” da decisão, apontariam a irresponsabilidade de sua adoção em função dos efeitos sistêmicos que ela poderia provocar, inclusive a multiplicação de outras demandas e decisões similares; outros, ainda, indicariam o ativismo no uso de princípios em detrimento do direito legislado. Haveria ainda quem dissesse, em indisfarçável petição de princípio, que a decisão é "ativista" e por isso "errada" e "equivocada".

${ }^{13}$ Alertando para essa falta de cuidado, VIRGILIO AFONSO DA SILVA, "O Judiciário e as políticas públicas: entre transformação social e obstáculo à realização dos direitos sociais”, in: CLÁUDIO PEREIRA DE SOUZA NETO, DANIEL SARMENTO. Direitos sociais: fundamentação, judicialização e direitos sociais em espécies. Rio de Janeiro: Lumen Juris, 2008, pp. 588-589.

${ }^{14}$ Como observa Raymond Aron, em qualquer ação (inclusive, acrescentamos, o agir que constitui o ativismo judicial), dividimo-nos entre duas atitudes ou entre o "desejo de duas atitudes". De um lado, uma atitude instrumental, que procura "produzir resultados de acordo com os nossos objetivos e, por isso, obriganos a olhar o mundo e a analisarmos as consequências prováveis do que dissermos ou fizermos." De outro lado, uma atitude moral, que nos impele a falar e a agir sem termos em conta nem os outros, nem o determinismo dos acontecimentos. Estabelecer idealmente essas duas atitudes nos auxilia a entender o porquê de uma ação razoável ser inspirada em ambas. Ambas as éticas, a da responsabilidade e a da convicção, para Weber, não são contraditórias, mas completam-se uma à outra. RAYMOND ARON, Etapas do pensamento sociológico, 8 $8^{\mathrm{a}}$ ed. São Paulo: Dom Quixote, 2007, pp. 500-503.
} 
Como se vê, o exame do ativismo judicial deve ser antecedido de reflexões aprofundadas, inclusive para reconhecer os limites da investigação.

A abordagem do tema poderia partir do exame de significantes, significados, denotações e conotações da designação “ativismo judicial”. Assim, de início, poder-se-ia destacar o nome “ativismo” de seu qualificador, “judicial”, para, enfim, após descoberto o sentido de cada vocábulo, reuni-los em uma noção que explicitasse uma ideia seminal do fenômeno. Recorreríamos então ao dicionário e descobriríamos que a origem do termo “ativismo” é francesa (activisme). Em seguida, constataríamos que, num sentido mais geral, essa palavra denota qualquer doutrina ou argumentação que, dada uma determinada orientação ideológica, privilegie a prática efetiva de transformação da realidade em detrimento da atividade exclusivamente especulativa, subordinando sua concepção de verdade e de valor ao sucesso ou pelo menos à possibilidade de êxito da ação ${ }^{15}$. Observaríamos, ademais, que, num outro sentido, o termo se refere a um gênero literário politicamente engajado, do qual seria exemplo o Operário em Construção, de Vinicius de Moraes, obra em que o poeta descreve a tomada de consciência de um trabalhador "alienado" que "tudo desconhecia de sua grande missão”; até que se fez forte e passou a dizer “não”, como “operário construído”, consciente daquilo “a que não dava atenção.” Se buscássemos conotações vinculadas à ação política, notaríamos que o termo “ativismo” pode se referir à militância a serviço de uma doutrina ideológica com as mais variadas motivações: partidária, sindical, ambiental, feminista, homoafetiva, racial, revolucionária e estudantil ${ }^{16}$. Poderíamos citar, assim, exemplos históricos, como o ativismo antiapartheid ao longo das décadas em que o regime vigorou na África do Sul; e o ativismo do civil rights movement, nos Estados Unidos da América (EUA).

Contudo, ao examinarmos o termo "ativismo" em conjunto com seu primeiro qualificador, “judicial” (concernente a órgãos judiciais e às instituições de justiça), perceberíamos, de forma mais próxima da problemática desta tese, que a consulta aos dicionários está muito longe de esgotar o assunto.

\footnotetext{
${ }^{15}$ ANTÔNIO HOUAISS, MAURO DE SALLES VILLAR, Dicionário Houaiss da Língua Portuguesa. $1^{\text {a }}$ ed. Rio de Janeiro: Objetiva, 2001, p. 335.

${ }^{16}$ ANTÔNIO HOUAISS, MAURO DE SALLES VILLAR, op.cit., p. 335. A respeito de ativismos revolucionários (como o marxista), instrumentais (como o descrito pelo funcionalista Parsons) e outros que constituem objetos de estudo da sociologia, v. ANTHONY GIDDENS, Política, Sociologia e Teoria Social: encontros com o pensamento social clássico e contemporâneo, São Paulo: Fundação Editora da UNESP, 1998, pp. 79, 134, 243, 274.
} 
O uso frequente da expressão "ativismo judicial”, dessarte, pede uma investigação mais aprofundada com a qual, se não alcançarmos todas as respostas, pelo menos poderemos contribuir com o debate para reformular ou reorientar algumas perguntas.

Feitos esses esclarecimentos preliminares a título de pré-compreensão ${ }^{17}$, esta tese, dedicada ao estudo do ativismo judicial na Justiça do Trabalho, precisará problematizar o fenômeno, que transcende as instituições judiciais trabalhistas e a experiência jurídica brasileira. Em outras palavras, é preciso situar num panorama geral o fenômeno institucional trabalhista a ser examinado em particular.

\subsection{Delimitação, metodologia e desenvolvimento do trabalho}

Nesta tese, o ativismo judicial será examinado pelo prisma metodológico da sociologia jurídica. Nessa linha (como bem destaca RAMOS, ao apresentar as diferentes perspectivas pelas quais o cientista do Direito pode enfocar o tema), concebe-se o ativismo judicial como um "fenômeno social, o qual, portanto, existe no plano fático, independentemente do juízo de valor que se possa fazer a seu respeito”18.

Para KELSEN, a tentativa mais bem-sucedida de definir o objeto de uma sociologia do Direito foi feita por Max Weber, que recomendava o respeito à distinção entre os pontos de vista jurídico-dogmático e sociológico-jurídico. Destarte, se pela perspectiva jurídico-dogmática as normas são consideradas válidas para permitir elucubrações a respeito de seu significado, pelo prisma sociológico-jurídico é possível investigar “o que efetivamente está acontecendo na sociedade” em razão de seus membros acreditarem na validade de uma ordem jurídica e por ela orientarem suas condutas. Desse modo, o objeto da sociologia do Direito é a ação, a conduta humana orientada de acordo com uma ordem que os atores sociais (inclusive os julgadores) consideram válida. Isso significa que, na ação que constitui o objeto da sociologia do Direito (no caso desta tese, o

\footnotetext{
${ }^{17}$ Fala-se em pré-compreensão como um entendimento provisório das coisas, propiciando orientação inicial que põe em marcha o processo do compreender - o qual tende a continuar, então, a ser impulsionado pela pesquisa. KARL LARENZ, Metodologia da ciência do direito, $3^{\mathrm{a}}$ ed., Lisboa: Fundação Calouste Gulbenkian, 1997, p. 293.

${ }^{18} \mathrm{O}$ jurista esclarece que esta seria uma das formas pelas quais o cientista do Direito poderia abordar o fenômeno do ativismo judicial. Essa perspectiva não permite, todavia, o enquadramento do tema "em face das prescrições de um determinado ordenamento jurídico constitucional”, objetivo central de sua tese. ELIVAL DA SILVA RAMOS, Parâmetros dogmáticos do ativismo judicial em matéria constitucional, São Paulo: Faculdade de Direito da USP (Tese de Titularidade), 2009, p. 9.
} 
ativismo judicial), o indivíduo agente considera a ordem jurídica da mesma maneira que a dogmática considera o Direito. Para ser o objeto de uma sociologia do Direito, a ação humana deve ser determinada pela ideia de uma ordem válida ${ }^{19}$.

No presente trabalho, essa idéia, sem dúvida, também inclui o sentimento da própria sociedade, imanente às democracias, de que os juízes devem ser obedecidos mesmo quando suas decisões desagradem ou pareçam “injustas”. Afinal, é de assunção geral o fato de o Judiciário possuir o poder da última palavra sobre o significado das normas $^{20}$.

Como se trata de tema com reflexos multidisciplinares, incursões em outros campos do conhecimento serão necessárias. É que algumas questões examinadas neste trabalho têm sido debatidas não apenas por juristas (com conotação ora sociológica, ora dogmática), mas também por cientistas políticos. Seguramente, essa interação (respeitada, entretanto, a linha metodológica nuclear ora definida) pode trazer contribuição significativa para a compreensão das funções contemporâneas das instituições judiciais, em especial o judiciário trabalhista.

\subsubsection{Juridificação, potencial protagonismo judicial e tipos de} ativismo judicial

Em noção preliminar, assume-se que o ativismo judicial, inclusive o identificável na Justiça do Trabalho, é constituído pela conversão de um potencial protagonismo judicial em ação. Considerados os fatores que tornem essa ação viável, falase, assim, na possibilidade de o órgão judicial agir num determinado sentido, o que, obviamente, pode não ocorrer.

A ideia de potência que antecede um ato não é nova no pensamento humano. Em sua "Ética a Nicômaco”, Aristóteles observava que “de todas as coisas que nos vêm por natureza, primeiro adquirimos a potência e mais tarde exteriorizamos os

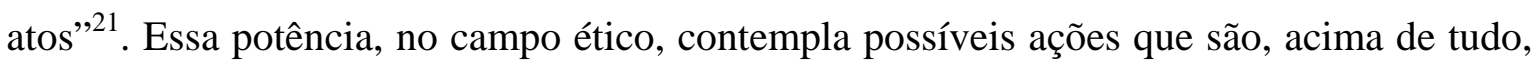

\footnotetext{
${ }^{19}$ HANS KELSEN, Teoria Geral do Direito e do Estado, trad. Luis Carlos Borges, São Paulo: Martins Fontes, 2000, pp. 253-254.

${ }^{20}$ Há muito tempo povoa o imaginário da doutrina a ideia de que "o intérprete oficial, definitivo, é o magistrado, sendo provisória a interpretação primeira do advogado, do professor”. AMAURI MASCARO NASCIMENTO, “Organização da Justiça do Trabalho”, in: IVES GANDRA DA SILVA MARTINS (org.), A Constituição Brasileira de 1988: Interpretações, Rio de Janeiro: Forense Universitária, 1988, p. 248.

${ }^{21}$ ARISTÓTELES, Ética a Nicômaco. São Paulo: Abril, 1984, p. 67.
} 
livres e contingentes. Essa perspectiva que separa a potência de agir (potencial protagonismo judicial) da ação parece permitir a problematização adequada do ativismo judicial, em especial porque a liberdade de decidir (a independência do Judiciário) e a contingência do conteúdo da decisão são atributos fortíssimos da função judicial contemporânea.

É verdade que, em certo sentido, examinar o potencial protagonismo judicial parece implicar a consideração da totalidade do poder judicial. Todavia, falar apenas no poder judicial ou em sua expansão (paralelamente à existência e à expansão dos poderes Legislativo e Executivo) não permitiria dar ênfase às formas emergentes pelas quais os órgãos judiciais atuam de maneira desvinculada do papel de meros aplicadores de regras estruturadas pela perspectiva de um modelo lógico-dedutivo. É que a atuação judicial se expandiu para contemplar formas paradigmaticamente distintas de uma atividade meramente silogística que rendeu à figura do magistrado a alcunha de "ser inanimado", como uma simples "boca” que serviria para pronunciar as palavras da lei, como dizia Montesquieu. Como veremos, todas as formas de ativismo judicial havidas por atualizações (na acepção de tornar-se presente, de transformar-se em ato efetivo) do potencial protagonismo judicial escapam desse modelo eminentemente subsuntivo e no qual havia muito pouca liberdade para decidir. Hoje, pode-se afirmar que a expansão dessa liberdade faz do juiz um protagonista, metaforicamente comparável aos personagens em torno dos quais (desde o teatro grego clássico) constrói-se toda a trama, à vista de seu papel de destaque na sucessão dos acontecimentos.

A delimitação dessas manifestações concretas de um potencial protagonismo judicial que possuem especificidades em relação às formas tradicionais de atuação judicial parece afastar, desse modo, eventual afirmação, baseada na ideia de proibição do non liquet, de que todo agir judicial seria um tipo de ativismo, dada a inevitabilidade da decisão. Em outros termos, uma decisão judicial, posto que agir judicial inevitável, pode ocorrer em vários sentidos (ilustrativamente, diferentes julgadores, diante de um mesmo caso concreto, poderiam julgá-lo diferentemente ${ }^{22}$ ), mas apenas alguns

\footnotetext{
${ }^{22}$ Como observa Lopes, se assim não fosse, “(...) não haveria necessidade de recursos, de tribunais compostos por vários juízes, ou todos os outros mecanismos que tradicionalmente conhecemos para assegurar a diversidade de entendimentos e a possibilidade de mudanças de interpretação judicial. Outro aspecto importantíssimo a destacar: todos os argumentos técnico-jurídicos podem servir a duas decisões diversas, a de primeira instancia num sentido, a de segundo grau noutro". JOSÉ REINALDO DE LIMA LOPES, "Em torno do direito alternativo", in: Revista de informação legislativa, ano 31, n. ${ }^{\circ} 121$. Brasília: Senado Federal, 1994, p. 257.
} 
desses sentidos, por suas especificidades reveladoras de diferentes formas de protagonismo (a serem examinadas ao longo deste trabalho), parecem desvelar tipos de ativismo judicial.

Isto não encerra todas as dificuldades do assunto, que poderiam ser levadas ao infinito se considerássemos que, independentemente de qual seja a decisão (ingressando ela no mérito da causa ou não, sendo ela de procedência ou de improcedência), a intenção última do magistrado pode ser vista como uma forma de ativismo, a depender da orientação da decisão em sua dimensão ético-política; i.e., quais os caminhos buscados e quais o julgador não pretende seguir ${ }^{23}$.

Para tentar contornar o problema, optou-se por aferir os tipos de ativismo pela observação do referente imediato do agir (seu objeto, o quid ao qual esse agir transita), sem indagar sobre o que estaria "por detrás” da ação. Em outros termos, se o ativismo judicial não é um fenômeno intransitivo e se sua transitividade revela vários focos, a identificação do objeto ao qual ele transita pode contribuir para definir seu tipo.

O crescimento desse potencial protagonismo judicial, que na linguagem comparatística tem sido descrito como um processo de expansão global do poder judicial ${ }^{24}$ decorre, na perspectiva desta tese, do fenômeno abrangente da juridificação, consistente, como veremos, num processo de colonização do mundo da vida pelo Direito. O conceito de juridificação, dada a sua complexidade, abrangência e multiplicidade de aspectos ${ }^{25}$, permite que cada autor se aproprie da noção com ênfase nas questões que entenda mais pertinentes, conforme o tema que pretenda enfocar ${ }^{26}$.

Neste trabalho, serão destacados os seguintes aspectos e desdobramentos do processo de juridificação em sua relação com a ampliação do potencial protagonismo

\footnotetext{
${ }^{23} \mathrm{Na}$ linha do que, em diálogo com Tate, observa Liberati, note-se que optar por não optar (decidir num sentido, e não no outro) é também fazer uma escolha. Em outras palavras, ao optar por não agir em determinado sentido, um juiz não faz nada além de reforçar a política existente, e isso, indiretamente, pode ser visto como uma forma de ativismo. EDMONDO BRUTI LIBERATI, "Potere e giustizia", in: EDMONDO BRUTI LIBERATI, ADOLFO CERETTI, ALBERTO GIASANTI (org.), Governo dei Giudici: la magistratura tra diritto e politica, Milano: Feltrinelli, 1996, p. 191.

${ }^{24}$ NEAL TATE, TORBJORN VALLINDER (org.), The Global Expansion of Judicial Power, New York: New York University Press, 1995. O livro contém vários estudos realizados no âmbito da International Political Science Association, entidade que, por meio de seu Research Committee on Comparative Judicial Studies, organizou um encontro em Bolonha, Itália, no ano de 1992. As discussões enfocaram a expansão global do poder dos juízes por diferentes perspectivas, como a da judicialização da política, a do processo decisório democrático e a da accountability dos magistrados. Os papers apresentados à época foram organizados sob a forma de livro. A obra é de grande relevância, dada a amplitude dos estudos, que contemplam tanto a tradição da common law quanto países do sistema romano-germânico.

${ }^{25}$ Sobre a vasta problemática da juridificação, LARS BLICHNER, ANDERS MOLANDER, "Mapping Juridification”, in: European Law Journal, vol. 14. jan. 2008, pp. 36-54.

${ }^{26}$ Utilizando-se desse conceito, ANTÔNIO RODRIGUES DE FREITAS JUNIOR, Os direitos sociais e a constituição de 1988: crise econômica e políticas de bem-estar, Rio de Janeiro: Forense, 1993, pp. 45-46.
} 
judicial: expansão dos padrões regulatórios (qualitativa, quantitativa e temática); o problema da indeterminação do direito contemporâneo; a materialização do direito formal; a crise da divisão funcional dos poderes; o afastamento do modelo subsuntivo, com o consequente fortalecimento da função pragmática da hermenêutica jurídica; a expropriação de conflitos; a ampliação do controle judicial contramajoritário e da independência política do Poder Judiciário; a convergência normativa e institucional das experiências jurídicas democráticas; a universalização do ideário do juiz ativo nos modelos processuais ocidentais, bem como sua expansão mais recente em decorrência da pretensão estatal de dar tratamento a conflitos de massa e de fomentar judicialmente soluções não adjudicatórias; a expansão da litigância de interesse público e de estruturas de suporte à mobilização jurídica; e, ainda, as mudanças na relação entre o Poder Judiciário e os meios de comunicação de massa.

A investigação sobre esses fenômenos, a ser realizada no Capítulo 2, demonstrará que o potencial protagonismo judicial se expandiu à medida que avançou o processo de colonização do mundo da vida pelo Direito, em especial ao longo do século XX, em que se edificou o modelo de Estado Social.

Independentemente das inegáveis diferenças nas experiências de Welfare State que emergiram nesse processo juridificante, o foco a ser dado neste trabalho se dirige a um legado que é mais ou menos comum: a emergência de um potencial protagonismo judicial e a consequente ampliação das formas de agir (os tipos de ativismo judicial) nas quais ele se atualiza.

Não serão problematizadas as iniciativas de desconstrução do Estado Social. Com efeito, a amparar a perspectiva adotada, HABERMAS destaca que a leitura da chamada "crise" desse modelo teria dificuldades de se sustentar se defendesse que a construção operada pela juridificação poderia ser “rebobinada” novamente para um formato puramente liberal ${ }^{27}$. Também nessa linha, é lúcida a afirmação de FARIA, de que a mobilização em prol da desregulação, ao menos até hoje, não foi significativamente forte para desconstruir as heranças dessa tendência colonizadora do Direito ${ }^{28}$. Acrescente-se,

${ }^{27}$ JÜRGEN HABERMAS, Direito e democracia entre facticidade e validade, Rio de Janeiro, Tempo Brasileiro, 1997, vol. 2, pp. 178, 207-208.

${ }^{28}$ Grimm também destaca, comparativamente, o movimento contemporâneo pela desregulação, de um lado, e as heranças desse vasto processo de regulação, de outro lado. DIETER GRIMM, "L'activisme judiciaire”, in: ROBERT BADINTER, SEPHEN BREYER, Les Entretiens de Provence: Le juge dans societé contemporaine, Paris: Fayard, 2003, p. 24 (A obra registra debates entre juristas europeus e americanos, que contrapuseram suas experiências jurídicas tendo em mente as distinções originárias (bem como as contemporâneas tendências de aproximação recíproca) entre as famílias da Civil Law e da Common Law). A 
ademais, que não é intenção desta tese fazer prognósticos para o futuro, mesmo porque, em relação a isso, há muitas dúvidas e poucas certezas, se é que certezas há. Também não nos parece possível, sem grande dose de ingenuidade e reducionismo, delinear todos os aspectos da crise do "Estado Social”, dos destinos do neoliberalismo ou de movimentos em prol da desregulação ou da desconstitucionalização ${ }^{29}$.

\subsubsection{Relevância da abordagem comparatística}

Os estudos de direito comparado e a observação da experiência jurídica e política de outros países têm grande relevância no desenvolvimento desta tese, seja para esclarecer a maneira como a juridificação se difundiu largamente pelas democracias ocidentais, seja para demonstrar que, em decorrência dela, emergiu gradativamente um potencial protagonismo judicial em todas essas experiências. Essa perspectiva permitirá, além disso, perceber que, no Brasil, o ativismo judicial é fenômeno de discussão recente, diferentemente do que ocorreu em outros países, notadamente nos EUA. Mas isso não impedirá a identificação, entre nós, de seus importantes antecedentes, sobretudo na Justiça do Trabalho. Além disso, o exame de debates sobre o tema já travados alhures pode ser útil à compreensão das peculiaridades da experiência brasileira.

O enfoque do ativismo judicial nos EUA terá certa profundidade, não só pelo pioneirismo norte-americano em relação a um potencial protagonismo judicial (como já sugeriam as lições de TOCQUEVILLE, em 1835) ${ }^{30}$; mas também pelo fato de os debates sobre o assunto haverem surgido naquele país ${ }^{31}$, com um notável aprofundamento

apontar essas “pressões” pela desregulação de alguns setores, JOSÉ EDUARDO FARIA, Sociologia Jurídica - Direito e Conjuntura, 2a ed. São Paulo: Saraiva, 2010, pp. 53-112 (em especial). O autor observa que, atualmente, o cenário é de "sobrejuridificação”.

${ }^{29}$ Apresenta essas ponderações JOSÉ EDUARDO FARIA, "Poucas certezas e muitas dúvidas”, Texto de seminário no International Institute for Sociologia of Law, Onnati, jul. 2009.

30 ALEXIS DE TOCQUEVILLE, Democracy in America, New York: New American Library, 1956. Na obra, o pensador sugere esse potencial ao examinar, com grande destaque, o pioneiro judicial review norteamericano. Posteriormente, como veremos, esse potencial se expandiu para outras experiências democráticas ocidentais. Maria Tereza Sadek, baseando-se nessas lições, trata como potencialidade, do ponto de vista da Ciência Política, a possibilidade de o Judiciário exercer "o controle de constitucionalidade de leis e atos normativos”. E acrescenta que tal potencial de participação de juízes na arena pública tem crescido e cada vez mais se convertido em fenômeno real. MARIA TEREZA SADEK, "Poder Judiciário: uma nova instituição”, in: HUMBERTO DANTAS et. al., Reforma do Estado Brasileiro: perspectivas e desafios, Rio de Janeiro: Fundação Konrad Adenauer, 2010, pp. 28-29.

${ }^{31}$ Luis Roberto Barroso reconhece que as origens do debate remontam aos primórdios do constitucionalismo nos Estados Unidos, tornando-se universal ao passar a gravitar "em torno das tensões e superposições entre constitucionalismo e democracia”. LUIS ROBERTO BARROSO, Curso de Direito Constitucional contemporâneo, São Paulo: Saraiva, 2009, p. 286. 
desde então ${ }^{32}$. Esse exame aprofundado da experiência ianque também se impõe uma vez que culturas jurídicas estruturadas pelo sistema da civil law, por força da tendencial convergência normativa e institucional das experiências democráticas, têm cada vez mais adotado soluções típicas de common law (e vice versa), como apontam os estudos de direito comparado já há algum tempo e de forma praticamente uníssona. Assim, não obstante a expressão “ativismo judicial” possa evocar, conforme o momento e o sistema jurídico, um repertório de debates variável, a percepção da referida convergência permite afirmar que os fenômenos que decorrem da atuação concreta de um potencial protagonismo judicial tendem, cada vez mais, a se assemelhar em diferentes países, inclusive de tradições jurídicas distintas.

Apesar de alguns desses fenômenos serem mais recentes (como o agir judicial em face de megaconflitos, em decorrência dos litígios de interesse público), outros são bem antigos. Nos EUA, a força e o papel político do Poder Judiciário já eram debatidos desde o início do século XIX, dado o potencial de exercício do judicial review. Em seguida, antes de ser cunhada a expressão “judicial activism” no final da década de 1940, já se debatia a prática da "legislação judicial” (judicial legislation). Ademais, mesmo que não se pudesse identificar, na Europa, um potencial protagonismo judicial similar ao norteamericano, também ali já se falava, na mesma época, de uma “revolta de juízes” contra a lei. Posteriormente, defendeu-se a ideia de “direito livre”, por obra de autores alemães e franceses que levaram até as últimas consequências certos pontos de vista de Ehrlich ${ }^{33}$ e de Gény, segundo a linha do opúsculo Der Kampf um die Rechtswissenschaft, publicado em 1906 por Kantorowicz ${ }^{34}$.

\footnotetext{
${ }^{32}$ Apenas na base de dados Heinonline, foram encontrados mais de 15 mil estudos a respeito.

${ }^{33}$ Observe-se que, em diálogo com Ehrlich, a problemática da juridificação poderia ser confrontada com a perspectiva do pluralismo jurídico, i.e., a ideia de desenvolvimento de mecanismos regulatórios não estatais. Todavia, para os fins desta tese, partimos da premissa de que, à medida que essa regulação não oficial se desenvolve, eventuais interesses que dela brotem só se tornam passíveis de judicialização se as relações por eles motivadas são, em alguma medida, reconhecidas ou reguladas também pelo direito estatal, o que, no estágio atual da sobrejuridificação, tende a ocorrer. Sobre o tema, v. DAVID NELKEN. "Eugen Ehrlich, Living Law, and Plural Legalities", in: Theoretical Inquiries in Law, vol. 9, n. ${ }^{\circ}$ 2, 2008, p. 467. Santos destaca a grande contribuição de Ehrlich para a sociologia jurídica. BOAVENTURA SOUSA SANTOS, $O$ discurso e o poder: ensaio sobre a sociologia da retórica jurídica, Sérgio Antonio Fabris: Porto Alegre, 2008, p. 73.

${ }^{34}$ Além de destacar esses fatos, Miguel Reale observa: "Um dos momentos mais interessantes da Jurisprudência, nos fins do século XIX e nas primeiras décadas do nosso, foi a busca de métodos mais concretos, e também mais humanos, de interpretação do Direito, partindo do pressuposto de que o fato é elemento predominante e essencial e que nele já está inerente a regra suscetível de revelação ou explicitação graças a processos de pesquisa de caráter científico: em lugar de se tornar explícita a lei, pregava-se a explicitação do fato, no qual já estariam implícitas as normas suscetíveis de serem cientificamente reveladas, dispensado progressivamente o arbítrio do legislador. Daí a conclusão extremada de que o juiz deve ser
} 
Conquanto se possa associar o ativismo judicial à chamada judicialização da política, num contexto de expansão global do poder judicial, evitaremos reduzir uma figura à outra. Isso porque a perspectiva da juridificação permite ir além, para situar o potencial protagonismo judicial e, consequentemente, o ativismo judicial, no âmbito não apenas da judicialização da política, mas da judicialização de todas as relações sociais ${ }^{35}$.

Dessarte, com base nesse fio condutor da juridificação, observado em alguns de seus aspectos e desdobramentos mais importantes, poderão ser vislumbrados com mais clareza os elementos constitutivos desse potencial protagonismo judicial que pode se converter nas mais variadas formas de ativismo judicial.

\subsubsection{Tipos ideais de ativismo judicial e a Justiça do Trabalho}

Ao longo da tese, serão examinados não só os ingredientes que contribuíram para o referido cenário de potencial protagonismo judicial; mas também as noções de ativismo judicial utilizadas para descrever as principais formas de manifestação daquele potencial. Esse conjunto de noções e fenômenos observáveis, por sua substância eminentemente empírica, fornecerá ingredientes importantes para, com base em metodologia weberiana, construirmos tipos ideais de ativismo judicial a serem utilizados no estudo específico da incidência do fenômeno na Justiça do Trabalho.

A importância da obra de Max Weber para as pesquisas contemporâneas nas ciências jurídicas é bem explanada por TRUBEK, para quem o “método tipológico ainda tem muito valor, embora o desenvolvimento de novas tipologias ainda se faça necessário”. Acrescenta o jurista que a contribuição ímpar de Weber, com inegável alcance

sempre o criador da norma jurídica, tendo em vista o fato que lhe cumpre examinar, desde que senhor das verdades e da técnica proporcionadas pelo estudo das ciências sociais: o jurista deveria, assim, ser aplicador de conhecimentos sociológicos, servindo-se das leis positivas como de simples padrões de referências. Hoje, depois da crítica serena de tais argumentos, já voltamos a atingir uma posição de maior equilíbrio; se não subordinamos rigidamente o juiz aos textos lógico-formais, é porque não o compreendemos mais alheio ao mundo das realidades humanas, aplicando, como simples autômato, imperativos de leis resultantes tão só de diretivas abstratas, ou agindo perigosamente à margem da lei positiva, que lhe cabe aplicar com o sentido integral do Direito; mas também não o colocamos acima da lei e das necessidades sociais de sua interpretação.” MIGUEL REALE, Filosofia do Direito, São Paulo: Saraiva, 2002, pp. 437-438.

${ }^{35}$ Citando o entendimento de Helmut Schultze-Fielitz nesse sentido (em seus comentários à Constituição Alemã), v. RUSSELL MILLER. "Lords of Democracy: The Judicialization of 'Pure Politics' in the United States and Germany”, in: Wash \& Lee Law Review, 61, 2004, p. 593, nota 31. Destaque-se o excerto citado, por oportuno, aqui traduzido livremente: "Der ubiquitäre Prozeß der Verrechtlichung (...) hat gleichzeitig zu einer Justizialisierung nicht nur des staatlichen Handelns, sonder aller gesellschaftlichen Beziehungen geführt". Em tradução livre: “o processo ubíquo da juridificação levou (...) à judicialização não apenas de questões estatais, mas de todas as relações sociais”. 
contemporâneo, foi a de analisar o direito de uma perspectiva holística e social. Nela, fenômenos jurídicos não são "nem totalmente independentes, nem totalmente dependentes dos outros aspectos da vida social”. Assim, esse método que "simultaneamente respeita a autonomia e a dependência da experiência jurídica na sociedade” seria a "contribuição mais duradoura de Weber para a sociologia do direito”36.

Comentando a obra de Weber, GIDDENS ensina que um tipo ideal é construído pela abstração e pela combinação de um indefinido número de elementos que, embora encontrados na realidade, são raramente descobertos nesta forma pura. Um tipo ideal não é, assim, nem uma descrição de um aspecto definido da realidade, nem uma hipótese; mas pode ajudar tanto na descrição quanto na explicação. Além disso, um tipo ideal também não é ideal em sentido normativo, isto é, ele não almeja a conotação de que sua realização seja desejável. Ele é um tipo “puro” no sentido lógico, não no sentido exemplar. Sua criação, não sendo um fim em si mesmo, tem o único propósito de facilitar a análise de questões empíricas. Para isso, acentua-se unilateralmente um ou vários pontos de vista, de modo que, mediante o encadeamento de grande quantidade de fenômenos isoladamente dados, difusos e discretos (que podem ocorrer em maior ou menor número ou mesmo faltar por completo, e que se ordenam segundo os pontos de vista unilateralmente acentuados), busca-se formar um quadro homogêneo de pensamento. Ademais, a intenção desses tipos ideais não é a de encontrar empiricamente esse quadro em sua pureza conceitual, mas a de determinar, em cada caso particular, a proximidade ou o afastamento entre a realidade e o quadro ideal. Tipos ideais, como ênfases unilaterais de um ou mais pontos de vista, são distintos (seja pelo âmbito, seja pela aplicação) dos conceitos descritivos, que operam como reuniões de atributos comuns de agrupamentos de fenômenos empíricos (i.e., como sínteses abstratas de elementos comuns a vários fenômenos concretos). Apesar disso, nada impede que conceitos descritivos sejam convertidos em tipos ideais, a depender dos objetivos da investigação ${ }^{37}$.

Em Weber, a construção de tipos ideais ou puros é uma expressão do esforço científico para tornar inteligível determinado tema, identificando sua racionalidade interna e eventualmente construindo essa racionalidade a partir de uma matéria semi-

\footnotetext{
${ }^{36}$ DAVID M. TRUBEK. “Max Weber sobre direito e ascensão do capitalismo”, trad. José Rafael Zullo, in: Revista Direito GV, vol. 3, n. ${ }^{\circ}$ 1, jan./jul. 2007, pp. 151-186. Referindo obras de Guarnieri, Wróblewski, Ost e Bell, que discutem e refinam modelos ideais-típicos de juiz, v. CELSO FERNANDES CAMPILONGO, Política, Sistema Jurídico e Decisão Judicial, São Paulo, Max Limonad, 2002, p. 46.

${ }^{37}$ ANTHONY GIDDENS. Capitalism \& Modern Social Theory - An Analysis of the Writings of Marx, Durkheim and Max Weber, Cambridge: Cambridge University Press, 1971, pp. 141-145.
} 
informe. Mesmo que, na aparência, tenha a pretensão de totalidade, um tipo ideal consubstancia uma apreensão parcial de fenômenos, e neste atributo reside o reconhecimento de algumas de suas limitações imanentes ${ }^{38}$.

Para evitar a confusão decorrente do uso do conceito de tipo ideal ao mesmo tempo para "designar todos os conceitos das ciências da cultura e para precisar certas e determinadas espécies de conceito”, ARON propõe uma distinção que estaria implícita em Weber ${ }^{39}$. De um lado, ele identifica a "tendência ideal-típica de todos os conceitos das ciências da cultura"; e, de outro, as "espécies definidas de tipos ideais". Neste último caso, um conceito não retém os caracteres apresentados por todos os fenômenos incluídos em sua extensão, e menos ainda os caracteres médios dos fenômenos considerados. Quando se afirma que o Brasil seria o “país do futebol”, não se quer dizer que todos joguem e gostem do esporte, mas que de certa forma são visualizadas determinadas características que compõem traços de originalidade e de identidade do povo. Desse modo, o conceito não será definido nem pelos caracteres comuns a todos os indivíduos nem pelos caracteres médios; será reconstrução estilizada, com o isolamento dos traços típicos. O tipo ideal se concentra, dessarte, na observação do "típico”, do “essencial”. Nessa linha, Weber trata dos tipos como diferentes espécies de conceitos.

Uma primeira espécie conceitual seria a dos tipos ideais referentes a indivíduos ou fenômenos históricos. Trata-se de reconstrução inteligível de uma realidade histórica global (o conjunto é designado por um termo, v.g., o “capitalismo”) e singular (por se realizar em determinadas experiências, o que no caso do "capitalismo” se percebe por sua ocorrência clara apenas nas “modernas sociedades ocidentais”). Nessa primeira espécie, a reconstrução é apenas uma das possíveis, já que formada pela seleção de alguns traços que tornem um “todo” inteligível.

A segunda espécie de conceito referida na obra weberiana é a dos tipos ideais como reconstruções racionalizantes de comportamentos com um caráter particular. O conjunto das proposições da teoria econômica, segundo Weber, "não é mais do que a reconstrução ideal-típica da maneira como os sujeitos se comportariam se fossem sujeitos econômicos puros”, i.e., a teoria econômica pensa rigorosamente o comportamento econômico de acordo com a sua essência e definição precisa ${ }^{40}$.

\footnotetext{
${ }^{38}$ MAX WEBER, Textos selecionados, São Paulo: Nova Cultural, 1997. Relevante, outrossim, é a apresentação da obra, por Maurício Tragtenberg.

${ }^{39}$ RAYMOND ARON, op.cit., pp. 495-497.

${ }^{40}$ RAYMOND ARON, op.cit., pp. 497-498.
} 
Uma terceira espécie de conceitos envolve tipos ideais que designam elementos abstratos da realidade encontrados em grande número de circunstâncias. Quando combinados, tais conceitos permitem caracterizar e compreender conjuntos reais. Nessa terceira espécie, são variáveis os níveis de abstração. Em nível inferior de abstração teríamos, ilustrativamente, a ideia de “burocracia”. Em grau de abstração elevado, podem ser lembrados os três tipos ideais de dominação (racional-legal, tradicional e carismática), definidos pela motivação da obediência ou pela natureza da legitimidade reclamada pelo chefe. A racional se justifica pelas leis e regulamentos; a tradicional, pela referência ao passado e aos costumes; a carismática, pela virtude excepcional, quase mágica, que o chefe possui e que lhe é atribuída pelos que o seguem e a ele se dedicam. Num último nível de abstração, encontramos os quatro tipos de ação: racional em relação aos fins, racional em relação aos valores, tradicional e afetiva.

É interessante notar, com BENDIX, que a construção weberiana, ao referir “tipos puros” de dominação (carismática, tradicional, legal), supõe que, no mundo dos fatos e da história, elas sejam combinações, misturas, adaptações ou modificações do tipo ideal. Em cada caso, a análise de Weber começa pelos tipos “puros”, ideais, mas cada situação concreta pode revelar vários traços de um e de outro ao mesmo tempo ${ }^{41}$. Segundo ARON, os tipos ideais de dominação seriam conceitos "atômicos" pelos quais reconstruímos e compreendemos regimes políticos concretos em que se combinam elementos dos três tipos, cada qual construído também pela observação de elementos concretos. A proposta é a de abordagem de uma realidade confusa com ideias claras. No real, os tipos se misturam, de modo que, para identificá-los, devemos definir cada um deles.

Como se vê, a construção dos tipos ideais não é o fim da investigação científica, mas seu meio. É pela utilização de conceitos definidos que medimos a distância entre eles e a realidade; é pela combinação de conceitos múltiplos que apreendemos uma realidade complexa ${ }^{42}$. Desse modo, a construção de tipos ideais como elementos abstratos da realidade encontrados em grande número de circunstâncias será particularmente útil à apreensão do fenômeno do potencial protagonismo judicial que se manifesta em diferentes formas de ativismo judicial. Destarte, para apreender essas formas, serão construídos tipos ideais que, em meio à complexidade substancial do fenômeno, poderão contribuir para a

\footnotetext{
${ }^{41}$ REINHARD BENDIX, Max Weber: um perfil intelectual, Brasília: UnB, 1986, p. 259.

${ }^{42}$ RAYMOND ARON, op.cit., p. 497.
} 
elucidação de situações concretas. Em outras palavras, pretende-se edificar um instrumental (os tipos ideais de ativismo judicial) que possa ser usado para trazer lume ao fenômeno do ativismo judicial, com destaque para o exame da atuação da Justiça do Trabalho em casos relacionados à tutela de direitos fundamentais sociais. Assim, não obstante sua abstração, os tipos ideais de ativismo judicial permitirão a identificação de elementos encontráveis em grande número de circunstâncias. Ademais, a combinação de diferentes tipos poderá auxiliar a reconstrução e a compreensão da realidade complexa de certas formas do agir judicial contemporâneo ${ }^{43}$ concretizadoras do potencial protagonismo judicial, no processo ou fora dele.

Com base na ideia de que a construção dos tipos ideais não é o fim da investigação, mas seu meio, este trabalho, antes do exame do ativismo judicial na Justiça do Trabalho, construirá seus instrumentos investigatórios. Desse modo, suas proposições são oferecidas a estudos futuros que eventualmente possam considerar os tipos ora construídos. Apesar da aparente pretensão de totalidade, a construção de tipos ideais como apreensões parciais de fenômenos tem a vantagem de constituir criação que pode ser modificada e aperfeiçoada à medida que se realizem, por seu intermédio, exames de problemas concretos. Assim, a construção se mantém aberta a aportes futuros.

Pondere-se que o fato de não enunciarmos conceitos meramente descritivos não impedirá, que, na construção dos tipos ideais de ativismo judicial, sejam problematizadas várias noções daquela natureza ${ }^{44}$.

O exame de uma situação concreta pela perspectiva dos tipos ideais de ativismo judicial poderá revelar traços de vários desses tipos ao mesmo tempo. Além disso, o uso dos tipos, por também possibilitar estudos quantitativos, pode servir de contestação a

\footnotetext{
${ }^{43}$ Kelsen, ao tratar da "conduta humana orientada para a ordem jurídica", invoca Weber para por em destaque a importância da compreensão da conduta na sociedade "por interpretação". Com efeito, afirma o jurista que essa conduta "tem uma significação porque os indivíduos atuantes vinculam uma significação a ela, porque eles a interpretam". Assim, interpretam-se "ações que já foram submetidas a uma interpretação por parte dos indivíduos atuantes”. Ilustrativamente, o fenômeno do Estado, no entender de Weber, como bem lembra Kelsen, surgiria como um "complexo de ações” em um "processo de conduta social efetiva”. Desse modo, "essas ações possuem determinada significação porque são interpretadas pelos indivíduos atuantes de acordo com um determinado esquema”. Em outras palavras, as ações são, na terminologia de Weber, "orientadas" para certa idéia, ou seja, adaptadas a certa ideia que, destaca Kelsen, encontra seus parâmetros na ordem normativa, na ordem jurídica. Destarte, a ordem jurídica fornece um esquema "de acordo com o qual os próprios indivíduos, atuando como sujeitos e órgãos do Estado, interpretam sua conduta”. Esse objeto não seria o Estado, que não é uma ação ou uma quantidade de ações, não mais do que é "um ser humano ou uma quantidade de seres humanos”. O Estado é aquela ordem da conduta humana que chamamos de ordem jurídica, a ordem "à qual se ajustam as ações humanas” e "à qual os indivíduos adaptam sua conduta”. HANS KELSEN. Teoria Geral do Direito e do Estado, op.cit., pp. 271-272.

${ }^{44}$ Esse iter metodológico é bem descrito por Giddens. ANTHONY GIDDENS, Política, Sociologia e Teoria Social: encontros com o pensamento social clássico e contemporâneo, op.cit., p. 145.
} 
diagnósticos precipitados que, com base em uma única ocorrência, afirmem que "o Judiciário é ativista” ou “a Justiça do Trabalho é ativista”. Nosso objetivo não é dizer se o Tribunal Superior do Trabalho (TST), a Justiça do Trabalho, o Juiz do Trabalho ou o Poder Judiciário como um todo são ou não ativistas. Uma afirmação tal pareceria ingênua diante da constatação de que grande parte das decisões judiciais, apesar de publicada, é desconhecida. Sabe-se que, não obstante isso, um órgão judicial ou um ramo do Judiciário geralmente é avaliado com base em poucos casos polêmicos ${ }^{45}$.

Como veremos, a maioria dos tipos ideais de ativismo judicial é jurisdicional, isto é, refere-se à postura de órgãos judiciais orientada diretamente às práticas jurisdicionais e processuais. Mas o potencial protagonismo judicial também pode se manifestar fora do contexto da jurisdição stricto sensu.

Com essas premissas, o capítulo 5 examinará a presença de traços de diferentes tipos de ativismo judicial em situações concretas. Dar-se-á ênfase ao exame da produção jurisprudencial da Justiça do Trabalho, sem desconsiderar os reflexos, sobre a jurisdição trabalhista, da atuação do STF em matéria constitucional.

Sabe-se que, no Brasil, não há tradição acadêmica sólida de utilização de decisões judiciais como material de trabalho. Como observa SILVA, entre nós há uma crença (baseada na antiga dicotomia que opõe as famílias da common law e da civil law) de que esse material jurisprudencial teria relevância apenas para a tradição anglo-saxônica, e não para a tradição romano-germânica. Em razão disso, a cultura jurídica brasileira seria fundada, sobretudo, na doutrina, o que pode ser percebido mesmo em decisões judiciais que, não raramente, "baseiam seus argumentos quase exclusivamente na doutrina, e não em seus próprios precedentes”46.

A problematização de um material propriamente jurisprudencial permitirá, a um só tempo, demonstrar a instrumentalidade dos tipos ideais construídos e chegar a conclusões relevantes sobre a incidência potencial e concreta do ativismo judicial em órgãos judiciais da Justiça do Trabalho.

Se o objetivo do trabalho é o de contribuir para a explicação de fenômenos reconhecidamente complexos, observados e observáveis; nele não existe

\footnotetext{
${ }^{45}$ Sobre a abordagem quantitativa, são relevantes as observações de SUJIT CHOUDHRY, CLAIRE E. HUNTER, "Measuring Judicial activism on the Supreme Court of Canada: a comment on Newfoundland (Treasury Board) v. Nape”, in: McGill Law Journal, vol. 48, 2003, p. 526.

${ }^{46}$ VIRGÍlIO AFONSO DA SILVA, Direitos fundamentais: conteúdo essencial, restrições e eficácia, São Paulo: Malheiros, 2009, pp. 32, 113. Note-se, ademais, ponto de vista de PETER SCHUCK. "Why don't law professors do more empirical research?”, in: Journal of Legal Education, n. ${ }^{\circ}$ 39, 1989, p. 323.
} 
nenhuma intenção de construir um pensamento de Filosofia da Justiça ou um discurso ideológico (apologético ou condenatório, de justificação formal ou material) acerca do ativismo judicial. Todavia, serão apresentadas algumas reflexões acerca das dificuldades de qualificar o fenômeno como bom ou como ruim por critérios estritamente jurídicos.

No estudo do ativismo judicial na Justiça do Trabalho, examinar-se-á, com mais atenção, o caso Embraer. Isso se justifica pela suspeita de que a ênfase no exame empírico de determinados casos que resultaram em decisões judiciais de grande impacto pode revelar elementos mais importantes do que o seu objeto principal tende a sugerir.

\subsubsection{Esclarecimentos metodológicos complementares}

Entendemos como sinônimas, para os fins desta tese, as expressões “ativismo judicial”, “ativismo judiciário” e “ativismo de órgãos judiciais”. Apesar de não se examinar, como objeto principal, o ativismo na propositura de demandas (com o patrocínio dos próprios demandantes ou de quem os represente), serão destacados aspectos relevantes dessa mobilização (notadamente no caso dos litígios de interesse público), que tende a fomentar a atuação concreta do potencial protagonismo judicial.

Na linha do que já se expôs no tópico 1.1, a ideia de "separação de poderes” não será utilizada de forma determinante para a construção dos tipos ou para supor que o ativismo judicial implicaria eventual “desrespeito” ao modelo preconizado pela teorização de Montesquieu. No Brasil, como em outros países da América Latina, aquela teoria costuma ser vista de forma “estanque e rígida”, consoante diagnostica SILVA. Isso pode resultar em uma visão enviesada das ideias do teórico iluminista, aplicadas a regimes presidencialistas de sociedades muito mais complexas e cujos atributos são substancialmente diferentes daqueles presentes no contexto social ao qual o citado pensador dirigia suas consagradas reflexões ${ }^{47}$. Destarte, qualquer argumento baseado nesse modelo ou que defenda a suposta "falta de legitimidade democrática”,48 do Poder Judiciário não será considerado como critério para a construção dos tipos ideais. Não parece razoável, ademais, excluir o Judiciário do debate público aprioristicamente, com base em ideias

${ }^{47}$ VIRGILIO AFONSO DA SILVA, "O Judiciário e as políticas públicas: entre transformação social e obstáculo à realização dos direitos sociais”, op.cit., pp. 588-589.

${ }^{48}$ Reflete sobre o tema, entre outros, RAN HIRSCHL, "The New Constitutionalism and the Judicialization of Pure Politics Worldwide”, in: Fordham L. Rev, n. ${ }^{\circ}$ 2, vol. 75, 2006, pp. 723-724. 
relativamente anacrônicas, notadamente se usadas com tom maniqueísta ${ }^{49}$. Todavia, não podem ser totalmente desconsideradas algumas noções relevantes presentes naquela teorização, sobretudo a de divisão das funções estatais conforme atribuições executivas, legislativas e judiciais, o que será problematizado com o cuidado de tentar não incidir nas inconsistências referidas.

No que tange aos tipos de ativismo judicial vinculados à prática jurisdicional stricto sensu, a ênfase se dará no campo da jurisdição civil (a incluir a trabalhista), não penal. Contudo, não se exclui a possibilidade de alguns tipos de ativismo ora desenhados serem encontrados no exercício da jurisdição penal.

\subsection{Contribuição da tese}

Esta tese oferece contribuição original à ciência jurídica brasileira ao apresentar as conclusões de aprofundada pesquisa sobre o ativismo judicial com a preocupação de situar o Judiciário trabalhista num cenário mais abrangente de profundas transformações na função judicial, em especial pela emergência, como resultado do processo de juridificação das relações sociais, de um potencial protagonismo judicial crescente e que pode se manifestar de diferentes formas.

Com essas preocupações, a tese pretende subsidiar diagnósticos mais precisos sobre a atuação contemporânea da Justiça do Trabalho. Sem dúvida, esses diagnósticos devem ser considerados, de um lado, em estudos dedicados ao problema da efetividade do Direito do Trabalho (sobretudo se considerado o movimento em prol de sua desconstrução ${ }^{50}$ ), da instrumentalidade do Direito Processual do Trabalho e da tutela

\footnotetext{
${ }^{49}$ VIRGILIO AFONSO DA SILVA, op.cit., pp. 588-589. Como observa o autor, não se pode esquecer que a chamada "teoria da separação de poderes", atribuída a Montesquieu, baseia-se sobretudo em um capítulo de seu 'Espírito das Leis', no qual Montesquieu 'descreve' o sistema político inglês por volta de meados do século XVIII, e que isso tem muito pouco em comum com as democracias presidencialistas contemporâneas".

${ }^{50}$ José Eduardo Faria diagnostica, paralelamente a um "refluxo do direito público", um "enfraquecimento firme e progressivo do Direito do Trabalho" como conjunto de princípios, normas e procedimentos que surgiram a partir de conquistas históricas na dinâmica de expansão do capitalismo industrial, com a finalidade de circunscrever, controlar e dirimir os conflitos laborais. E, examinando a "crescente automação e informatização dos sistemas de gestão e produção, o avanço da terceirização e da subcontratação e o advento de modos novos e bem mais seletivos de inserção na economia formal", ele acrescenta: "Foi graças a muito sangue e muita pancadaria, como é sabido, que a livre associação sindical e o recurso da greve como instrumento de pressão e barganha deixaram de ser tipificados como crimes previstos em leis penais para se converterem em direitos fundamentais constitucionalmente assegurados, entre os séculos XIX e XX; foi a ferro e fogo que o emprego se tornou categoria jurídica no âmbito do Estado Providência e sua regulação se converteu numa das vias de acesso à cidadania; e que a generalização de padrões mínimos de trabalho, os assim chamados labour standards, abriu caminho para a adoção de diferentes medidas de discriminação
} 
judicial dos direitos sociais fundamentais do trabalhador (sempre considerada a perspectiva mais ampla dos direitos humanos); e, de outro lado, do ponto de vista institucional, em reflexões que visem ao fortalecimento do Judiciário Trabalhista em contexto no qual, em meio às reformas do Judiciário brasileiro, renovam-se as propostas em prol da extinção daquele ramo especializado, não obstante sua relevante vocação para a tutela dos direitos sociais trabalhistas.

FARIA, ao analisar os ganhos políticos e institucionais da Justiça do Trabalho com as reformas do Judiciário, alerta para a necessidade de os magistrados trabalhistas tratarem essa vitória “com o mínimo de coerência e cuidado”, sobretudo pelo papel pedagógico que as decisões judiciais trabalhistas possuem, quando sinalizam para a economia a forma como a instituição tende a decidir. Nessa linha, observa o jurista que o tempo do Direito é completamente incompatível com o tempo da economia, das empresas e dos sindicatos; e que, para compreender todo esse cenário, exige-se uma visão interdisciplinar econômica, política e sociológica. O estudioso alerta, ainda, para as implicações da excessiva juridificação das relações sociais (fio condutor para o exame, nesta tese, do potencial protagonismo judicial que se situa na gênese do ativismo judicial), em razão da qual ganham vida nova os influxos interpretativos do Judiciário, em verdadeiras “cadeias produtivas” cujo processo de formação altera a “identidade do sistema jurídico brasileiro" ${ }^{51}$.

positiva destinadas a proteger as partes mais fracas nas relações laborais. Também foi graças a muito conflito político e muito confronto sindical que o encurtamento da jornada e o descanso semanal remunerado, a limitação do trabalho noturno, a fixação de salários básicos, a concessão de reajustes em níveis proporcionais aos ganhos de produtividade e/ou ao aumento do custo de vida, a garantia de condições salubres de trabalho, a normatização das formas de admissão e contratação, o estabelecimento de condições para demissões e sanções pecuniárias para as despedidas arbitrárias, o pagamento de pensões temporárias para os trabalhadores acidentados e a aposentadoria pública puderam transformar-se na espinha dorsal da rede jurídica de proteção constituída pelo direito do Trabalho, ao longo dos últimos 150 anos. No entanto, diante das transformações no padrão mundial de produção e concorrência ocorridas nas duas ou três ultimas décadas, toda essa herança passou a ser contestada, em nome da força expansiva dos mercados e da adequação dos recursos humanos às oscilações econômicas, e a ser progressivamente desmontada, em face das pressões dos agentes econômicos para que os níveis salariais locais e o valor dos encargos trabalhistas se uniformizem por baixo, no plano internacional. Obrigado agora a lidar com as formas variáveis e cambiantes dos novos modos de organização da produção e a disciplinar situações inéditas, ainda não inteiramente estruturadas, cada vez mais funcionalmente diferenciadas e, portanto, dificilmente padronizáveis, o escopo, a estrutura, o alcance e a eficácia do Direito do Trabalho estão sendo profundamente afetados pela extrema volatilidade e mobilidade dos capitais, pelas mudanças ocupacionais e organizacionais subjacentes ao fenômeno da globalização econômica e pela subsequente explosão do trabalho urbano flexível, informal, descontínuo e altamente precarizado” (JOSÉ EDUARDO FARIA. Sociologia jurídica - direito e conjuntura, op.cit., pp. 97-98).

51 JOSÉ EDUARDO FARIA. "Reformas institucionais não têm receita ideal”, in: Revista da Anamatra, disponível em: www.anamatra.org.br, acesso em 01-10-10. O jurista também destaca a dificuldade de visualização, pelo Judiciário, da concorrência externa de países que, como a China e a Coréia, "não embutem no preço final de seus bens e serviços o preço da democracia, o que fazemos”. E acrescenta a preocupação com a irresponsabilidade de tentar "corrigir os direitos do dia pra noite sem avalizar as consequências das 
A percepção dessas dificuldades enfrentadas pela Justiça do Trabalho tende a se acentuar se considerarmos, como observa MASCARO, que a ordem jurídica brasileira pode não estar devidamente preparada "para o enfrentamento de crises econômicas em qualquer de suas dimensões”, seja a “menor que é a crise que afeta uma empresa ou um dos seus estabelecimentos”, seja a “crise maior que é a globalizada”52.

Não se pode perder de vista, ademais, que as transformações estruturais sofridas pelo Direito na passagem do século XX para o século XXI alcançaram a redefinição das categorias de trabalho e de seu valor, a mudança das formas de organização e de gestão da produção, o aumento do nível de desemprego e a elevação do número de trabalhadores ocupados nos setores informais ${ }^{53}$.

Diante desse quadro, onde se situa e como se mostra a atuação dos órgãos judiciais trabalhistas?

Há mais de uma década, o citado professor FARIA comentava o comportamento das diferentes instâncias da Justiça do Trabalho e observava uma cisão doutrinária da magistratura trabalhista em face das citadas mudanças, que já vinham ocorrendo com grande intensidade. Essa cisão, segundo ele, decorreria dos diferentes graus de percepção que os magistrados trabalhistas teriam do impacto exercido por inovações e transformações sobre seu papel profissional. Seguramente, o cenário atual, além de agregar novos desafios que surgem a todo instante, é de continuidade das transformações então diagnosticadas e de confirmação dos problemas então vaticinados, razão pela qual não seria despropositado indagar, como fizera o mesmo autor à época: “como pode o juiz trabalhista articular, numa decisão, as questões sociais concretas a ele submetidas e os imperativos macroeconômicos?” O magistrado trabalhista seria “um simples decisor de soluções controvertidas do trabalho e do emprego ou, mais do que isso, um juiz de direitos fundamentais?"54

decisões", sendo este "um calculo muito delicado da Justiça do Trabalho” e, ao mesmo tempo, "seu grande desafio”. Não se pode deixar de lado, nessas referências preliminares, o fato de que a PEC n. ${ }^{\circ}$ 32/2010, recentemente aprovada pela Comissão de Constituição e Justiça do Senado Federal, fortalece ainda mais a Justiça do Trabalho, ao propor seja o TST alçado, no esquema de atuação política do Judiciário brasileiro, a uma posição similar à que ocupa atualmente o STJ, dada a sua "similaridade" com este, como "uniformizador e último intérprete da legislação infraconstitucional”. Para isso seria instituída a competência do TST para, mediante reclamação, impor aos demais órgãos judiciário a ele subordinados a autoridade de suas decisões. Ademais, aprovada a PEC, seria exigido um requisito adicional à escolha de ministros, consistente na exigência de "notável saber jurídico e a reputação ilibada”.

52 AMAURI MASCARO NASCIMENTO, "Crise Econômica, Despedimentos e Alternativas para a Manutenção dos Empregos”, op.cit, p. 16.

53 JOSÉ EDUARDO FARIA, Sociologia jurídica - direito e conjuntura, op.cit., pp. XII-XIII (prefácio)

54 JOSÉ EDUARDO FARIA, Os novos desafios da justiça do trabalho. São Paulo: LTr, 1995. 
De um modo geral, as estruturas normativas contemporâneas revelam grande contingência e crescente mutabilidade. Como corolário, percebe-se "uma ambiguidade enorme quanto aos fins da atuação jurisdicional”. E, nessa equação que combina “expansão dos usuários dos serviços jurídicos” (novos atores), "hipertrofia normativa” (com a multiplicação das fontes do direito) e incremento quantitativo e qualitativo das funções do Judiciário, é natural que os paradigmas mais convencionais de enquadramento teórico da atuação judicial estejam em crise ${ }^{55}$, afetando todos os ramos do Judiciário (inclusive o trabalhista), bem como a percepção de seus órgãos a respeito de sua própria função.

${ }^{55}$ CELSO FERNANDES CAMPILONGO, “Os desafios do Judiciário: um enquadramento teórico”, in: JOSÉ EDUARDO FARIA. (org.). Direitos humanos, direitos sociais e justiça. São Paulo: Malheiros, 1994, pp. 3031. Sobre o a ideia de paradigma, v. THOMAS KUHN, A estrutura das revoluções científicas, São Paulo: Perspectiva, 1982. 


\title{
CAPÍTULO 2
}

\section{PONTOS DE PARTIDA: JURIDIFICAÇÃO E POTENCIAL PROTAGONISMO JUDICIAL}

\begin{abstract}
Sumário: 2.1 Considerações preliminares: a ascensão do Poder Judiciário nas democracias ocidentais; 2.2 Juridificação: aspectos, desdobramentos e relação com o potencial protagonismo judicial; 2.2.1 Expansão dos padrões regulatórios e o problema da "indeterminação" do direito; 2.2.2 Materialização do direito formal; 2.2.3 Crise da divisão funcional de poderes; 2.2.4 Enfraquecimento do "modelo subsuntivo" $e$ fortalecimento da função pragmática da hermenêutica jurídica; 2.2.4.1 Decisão judicial: as éticas da conviç̧ão e da responsabilidade; $2.2 .5 \mathrm{~A}$ expropriação dos conflitos; 2.2.6 Ampliação do controle judicial contramajoritário e da independência política do Poder Judiciário; 2.2.7 Convergência das experiências jurídicas democráticas: aspectos normativos e institucionais; 2.2.7.1 Aproximação entre common law e civil law e ambivalência das leis e dos precedentes; 2.2.7.2 A influência do ideário dos direitos fundamentais e dos direitos humanos; 2.2.7.3 A metáfora da migração de ideias no direito comparado; 2.2.7.4 A ideia de proporcionalidade; 2.2.8 O ideário do juiz ativo: origens, influências $e$ expansão mundial; 2.2.8.1 A ampliação do ideário do "juiz ativo"; 2.2.8.2 Dois casos peculiares; 2.2.8.2.1 França: "descolamento" entre o comportamento judicial e as leis processuais; 2.2.8.2.2 Inglaterra: o active case management; 2.2.9 Poder judiciário e litigância de interesse público; 2.2.9.1 Public interest litigation nos EUA; 2.2.9.2 Litigância de interesse público em outros países e estruturas de suporte à mobilização jurídica; 2.2.10 Poder Judiciário e meios de comunicação de massa; 2.3 Juridificação de relações sociais no Brasil e potencial protagonismo judicial; 2.3.1 Perplexidades suscitadas pela experiência brasileira de "Welfare State" (1930 a 1988); 2.3.2 Juridificação, Constituição de 1988 e expansão efetiva do potencial protagonismo judicial no Brasil; 2.3 .3 Especificidades do potencial protagonismo judicial na Justiça do Trabalho; 2.3.3.1 Breves considerações históricas; 2.3.3.2 Os dissídios coletivos e o poder normativo; 2.3.3.3 Direito sumular trabalhista; 2.3.3.4 O pioneirismo do modelo trabalhista de juiz ativo.
\end{abstract}

\subsection{Considerações preliminares: a ascensão do Poder Judiciário nas} democracias ocidentais

A expansão do poder judicial é fenômeno notável na experiência democrática ocidental. O aumento sem precedentes da influência das decisões de magistrados sobre a vida coletiva tem sido apontado como uma das tendências mais significativas das últimas décadas. É este o porquê das conclusões de BADINTER, 
segundo o qual se poderia falar de uma nova forma de “pontificado” não eclesiástico, laico, secular ${ }^{56}$.

Num mundo em que instituições decisórias tradicionais e seus repositórios de critérios enfrentam grave crise de legitimidade, os juízes são cada vez mais procurados para desempenhar funções que transcendem a concepção clássica de “julgador”. Como interventores lato sensu em conflitos de justiça, os magistrados, indo além da atividade decisória tradicional, investem em técnicas alternativas de solução de disputas, interferem em políticas públicas, compõem conflitos entre agentes políticos, afirmam-se como os mais relevantes veículos de proteção aos direitos fundamentais, engajam-se em mobilizações sociais e se manifestam constantemente nos meios de comunicação sobre temas relevantes da agenda pública.

Essas constatações preliminares suscitam uma série de questionamentos: como o sistema judicial teria reagido diante de tantas transformações? Como reagiram os legisladores, os governantes e a sociedade? Esse fortalecimento decorre da mobilização

56 “....) le juge, lui, ne cesse de grandir. On se passione pour ses décisions, on les publie, on les commente. Sa fonction plus que sa personne - c'est là le plus saisissant - lui assure bien souvent une autorité qui tient, à mon sens, à deux facteurs: nos sociétés, de plus en plus sujettes à conflits, sont de plus en plus codifiées et réglementées; d'autre part, les mécanismes traditionnels de règlement des conflits (...) ont disparu. Autrefois, le curé de village, le notaire, l'instituteur, le maire, la père de famille réglaient les litiges. Désormais, alors que leur autorité morale s'est affaiblie et qu'elle ne permet plus de tarir le conflit à la source, on se tourne vers le juge. Par sa fonction, il dit le juste. Or, le juste est une valeur essentielle de notre temps. Dans un monde où la justice divine reste hypothétique, la justice sur terre est une revendication majeure. Les gens aspirent avant tout à vivre au sein de sociétés justes, souhaitent que justice leur soit rendue, telle qu'ils la conçoivent bien sûr. C'est une aspiration constante, aussi bien communautaire qu'individuelle. Or qui, in fine, est fonctionnellement voué à dire ce qui est juste, la juste solution? C'est le juge! A partir de là, évidemment, il est soumis à critique, parce que, par définition, le jugement ne satisfait pas tout le monde, les parties ou l'opinion. Mais il demeure que, intrinsèquement, le juge est la source de la justice et qu'en même temps qu'il va dire le droit, il va créer du droit. A cette occasion, en particulier pour les juridictions suprêmes, il est amené à codifier les valeurs de notre temps, d'où ma référence au pontificat laic." Em tradução livre: "O juiz vê sua influência crescer incessantemente. Pessoas se comovem com suas decisões, que são publicadas e comentadas. É sua função, mais do que sua personalidade individual (este é o ponto mais importante) o que lhe confere autoridade. Essa conclusão se baseia em dois fatores: de um lado, nossas sociedades, ao mesmo tempo em que são cada vez mais marcadas por conflitos, são cada vez mais codificadas e regulamentadas; de outro lado, os mecanismos tradicionais de solução de litígios desapareceram. Outrora, o pastor de uma vila, o notário, o professor, o prefeito, o chefe de família arbitravam litígios. Hoje em dia e doravante, considerando que a autoridade moral desses atores se enfraqueceu e que eles não mais conseguem extinguir as raízes do conflito, nós nos dirigimos aos juízes. É ele que, em sua função de dizer o que é o direito, diz o que é o justo. A justiça é um valor essencial de nosso tempo. E num mundo no qual a justiça divina se afigura hipotética, as pessoas buscam justiça aqui na terra.” ROBERT BADINTER, STEPHEN BREYER, op.cit., p. 19. Nesse sentido, v., entre outras obras, ALESSANDRO PIZZORNO, Il potere dei giudici. Stato democratico e controllo della virtù, Roma, Bari: Laterza, 1998, pp. 12-13, apud: PIER PAOLO PORTINARO, "Oltre lo Stato di Diritto - Tirannia dei giudici o anarchia degli avvocati”, in: PIETRO COSTA, DANILO ZOLO (org.). Lo stato di diritto: storia, teoria, crítica. $2^{\text {a }}$ ed., Milano: Giangiacomo, 2003, p. 393. Sobre o fenômeno da expansão e do fortalecimento do Poder Judiciário, v., entre outros, NEAL TATE, TORBJORN VALLINDER (org.), The Global Expansion of Judicial Power. op.cit. ALEC STONE SWEET, Governing with Judges: Constitutional Politics in Europe, Oxford: Oxford University Press, 2000. 
social, provém de um movimento dos próprios juízes ou deriva das opções daqueles que elaboram os textos legais e constitucionais? Transformou-se a percepção dos juízes acerca de sua própria função? A expansão do poder judicial e de seu potencial protagonismo decorreria do fenômeno do ativismo judicial, ou, diferentemente, o ativismo judicial seria uma manifestação desse potencial? O ativismo judicial estaria entre as causas de todas essas mudanças, ou seria um de seus sintomas?

Antes de ensaiar respostas a essas perguntas, é preciso situar de forma adequada o problema a ser enfrentado. Para isso, importa examinar um fenômeno mais abrangente, situado na gênese da expansão do potencial protagonismo judicial. Trata-se de um movimento que, na experiência das democracias ocidentais, de um modo ou de outro, tem sido diagnosticado por toda a parte.

\subsection{Juridificação: aspectos, desdobramentos e relação com o} potencial protagonismo judicial

Uma das formas de identificar a gênese e os atributos do potencial protagonismo judicial é recorrer à noção de juridificação e à observação de seus “surtos” (Verrechtlichungshübe), em especial o ocorrido ao longo do século XX.

O fenômeno, a partir da década de 70, despertou a atenção de vários sociólogos do direito. A designação foi introduzida na discussão científica por Otto Kirchheimer, que durante a República de Weimar observava um processo de "redefinição jurídica” que alcançou não apenas a institucionalização dos conflitos de classes sob as categorias do Direito do Trabalho, mas também, de um modo geral, a captação dos enfrentamentos sociais e das lutas políticas. HABERMAS descreve a juridificação (Verrechtlichung) como uma tendência expansiva do direito escrito, seja por sua extensão (regulação de novos temas que até então não haviam recebido tratamento jurídico específico), seja por seu adensamento (desmembramento de temas globais em matérias jurídicas particulares) $)^{57}$.

O conceito de juridificação possui grande complexidade e abrangência ${ }^{58}$. Na visão de FREITAS JUNIOR, trata-se da “formação, do aumento e da diversificação dos mecanismos jurídicos de interferência do Poder Público sobre relações historicamente

\footnotetext{
57 JÜRGEN HABERMAS, Teoria de la accion comunicativa, vol. 2, Madrid: Taurus, 1987, pp. 503-505.

58 Examinando panoramicamente a problemática da juridificação, LARS BLICHNER, ANDERS MOLANDER, pp. 36-54.
} 
concebidas como pertencentes à esfera privada”, regidas “quer por critérios tradicionais, quer por padrões de mercado". Com isso, ditas relações emergem “de um campo originariamente privado para o terreno da esfera pública”59.

Na descrição de HABERMAS, essa progressiva "colonização do mundo da vida” (Kolonialisierung der Lebenswelt) pelo Direito teve seu "surto” mais significativo com o advento do Estado Social e Democrático de Direito (demokratisch und sozialen Rechtsstaat $)^{60}$. Assim, a ascensão do Estado Social seria o último e mais significativo elo de uma série de quatro grandes “surtos” de juridificação, que merecem breve enunciação conforme a descrição habermasiana.

O primeiro “surto" juridificante levou ao Estado Burguês moderno que se desenvolveu na Europa Ocidental na época do Absolutismo, pelo descolamento de relações pré-modernas de poder e de dependência.

O segundo desses “surtos” juridificantes serviu à construção do Estado de Direito burguês (bürgerliche Rechtsstaat), presente, paradigmaticamente, na monarquia germânica do século XIX, em que o direito privado se coordenava com o aparato de exercício da dominação estatal.

O terceiro “surto” de juridificação levou ao Estado Democrático de Direito (demokratische Rechtsstaat). Difundindo-se gradativamente na Europa e na América do Norte como consequência da Revolução Francesa, esse modelo, consoante o ideário de Rousseau e Kant, passou a orientar os debates da teoria do Estado. Além de ganharem destaque os direitos de participação política, as leis passaram a ser consideradas válidas quando em seu favor contassem com uma presunção de expressarem um interesse geral. Esse elemento tornou relevante o consentimento de todos os afetados por mecanismos de participação democrática, exigência que foi satisfeita pelo procedimento que liga a legislação a processos de decisão parlamentar e à discussão pública. A juridificação do processo de legitimação se implanta sob a forma do direito de voto,

\footnotetext{
${ }^{59}$ Prossegue o jurista: "Assim, a exemplo do que se pode dizer das relações familiares e educacionais, as relações de emprego passam a adquirir progressivo relevo para o direito e, consequentemente, para a dimensão pública da ordem jurídica". E acrescenta: "não é apenas o direito que se expande e se diversifica para uma acomodação às novas relações sociais, mas, numa perspectiva oposta, são estas ultimas que passam a ser, em grande medida, instituídas e/ou reinstituídas por via da preceituação jurídica. É mais precisamente este último aspecto que tende a conferir ao vocábulo Verrechtlichung uma conotação pejorativa”. ANTÔNIO RODRIGUES DE FREITAS JUNIOR, Os direitos sociais e a constituição de 1988: crise econômica e políticas de bem-estar, op.cit., pp. 46-47.

${ }^{60}$ Habermas esclarece que esses conceitos são por ele utilizados com propósitos analíticos, i.e., para esclarecer o processo de incorporação jurídico-constitucional da ideia de liberdade que o conceito jusnaturalista de lei trazia em seu seio. JÜRGEN HABERMAS, Teoria de la accion comunicativa, op.cit., pp. 503-509.
} 
universal e igual, e do reconhecimento da liberdade de organizar e pertencer a associações e a partidos políticos. Com esse terceiro "surto” fica mais visível o problema da tensão entre os poderes (Legislativo, Executivo e Judiciário), em razão da diferenciação mais clara nas funções estatais.

O quarto e último "surto" edificou o Estado Social e Democrático de Direito (demokratisch und sozialen Rechtsstaat), cuja institucionalização progressiva em leis e em constituições, durante o século XX, vincula-se ao movimento operário europeu e ao crescente intervencionismo estatal em matéria econômica e social ${ }^{61}$. Como destaca SIMITIS, o Estado, que vinha adotando postura meramente contemplativa, passou a manifestar, pouco a pouco, forte pretensão de controlar as relações sociais em geral por instrumentos jurídicos ${ }^{62}$. Surge, na Europa, o constitucionalismo social, conforme o ideário da constituição de Weimar, de 1919; e, na América, sente-se a influência do mesmo movimento, com a constituição do México, de 1917. Gradativamente, experiências de Welfare State vão se consolidando com o New Deal, de 1933, nos EUA, e com a reconstrução europeia do Segundo Pós-Guerra. Desse modo, juridificaram-se, em vários países, além das relações civis e políticas, uma série de relações econômicas e sociais.

Como se vê, um estudo de todas as dimensões e repercussões de cada um desses quatro "surtos" seria muito abrangente e escaparia do objetivo desta tese. Todavia, alguns de seus aspectos e desdobramentos são de grande relevância para a compreensão do fenômeno do potencial protagonismo judicial na sociedade contemporânea, bem como das formas mais marcantes de suas manifestações concretas.

À medida que se consolida essa colonização do mundo da vida pelo Direito, o Estado como um todo fortalece seu potencial de intervenção sobre os conflitos sociais, inclusive pela via judicial. No ponto culminante desse processo, institucionalizamse setores específicos do mundo real em seus modos de funcionamento, seus critérios de racionalidade e suas formas de organização, o que também leva a falhas na obtenção dos resultados almejados pelo arcabouço instrumental da juridificação. Com efeito, dessa mesma marcha avulta a ambivalência do processo juridificante, uma vez que a pretensão de garantir a liberdade implica a privação dessa garantia. Em outras palavras, da promoção de tal valor deriva, paradoxalmente, a necessidade de sujeição de todos à lógica do sistema.

\footnotetext{
${ }^{61}$ A descrição desses surtos se encontra em JÜRGEN HABERMAS, Teoria de la accion comunicativa, vol. 2, op.cit., pp. 503 e ss.

62 SPIROS SIMITIS, “Juridification of labour relations”, in: GUNTER TEUBNER (org.), Juridification of Social Spheres: A Comparative Analysis in the Areas of Labor, Corporate, Antitrust and Social Welfare Law, Berlin, New York: Gruyter, 1987, p. 113.
} 
Vista dessa perspectiva, a juridificação descreve uma realidade que não seria um mero problema de juristas, nem uma circunstância localizada e muito menos um simples epifenômeno. Apesar das diferenças nas experiências de vários países, o processo seria universal, com repercussões internacionais e contornos multidisciplinares ${ }^{63}$.

Assim, considerando o objetivo de demonstrar o surgimento e a evolução do potencial protagonismo judicial como um dos produtos da juridificação, cumpre observar os aspectos e desdobramentos que se afiguram mais relevantes (jurídicos, sociológicos e politológicos) para esse propósito: a expansão dos padrões regulatórios e o problema da "indeterminação" do direito; a materialização do direito formal e o afastamento do modelo subsuntivo, com o consequente fortalecimento da função pragmática da hermenêutica jurídica; a expropriação de conflitos, a incluir, em certos momentos e contextos, a restrição do espaço de ação dos movimentos sociais e grupos de interesses por meio de medidas repressivas em prol de sua despolitização.

Esses aspectos serão capturados pela perspectiva comparatística, que também revelará desdobramentos relevantes da juridificação, como a crise da divisão funcional de poderes, a ampliação do controle judicial contramajoritário e o aumento da independência política do Poder Judiciário. Examinar-se-á, também dessa perspectiva, a convergência normativa e institucional das experiências jurídicas democráticas, expressa na aproximação recíproca das tradições da civil law e da common law ${ }^{64}$; na consagração do ideário dos direitos fundamentais e dos direitos humanos; e no surgimento de um modelo processual baseado no ideário do juiz ativo, gradativamente ampliado não só para fortalecer a atuação judicial em face dos conflitos de massa (dada a crescente litigância de interesse público), mas também para incorporar na agenda judicial, com certa ambiguidade, os meios alternativos de solução de conflitos.

Ademais, destacar-se-á que essa função judicial extraordinariamente ampliada, em época na qual os meios de comunicação se sofisticam e se expandem com velocidade assustadora, passa a despertar ainda mais o interesse da agenda midiática, o que

\footnotetext{
${ }^{63}$ Consciente dessa miríade de aspectos e das dificuldades que eles suscitam, Teubner apresenta construção multidisciplinar que enfoca a evolução do direito em Marx, Maine, Durkheim, Parsons, Unger, Nonet, Selznick, Habermas, Luhman e Weber (GUNTHER TEUBNER, "Juridification: concepts, aspects, limits, solutions”, in: GUNTHER TEUBNER, op.cit., pp. 3-9).

${ }^{64}$ Sobre o tema, Larenz observa que a "notada aproximação dos modos de pensamento de case law e do Direito codificado encontraria assim a sua explicação no fato de que aquele está atualmente numa fase de formação e consolidação de princípios, portanto na fase inicial de sistematização, e este, em contrapartida, numa fase de desbloqueio do sistema e de um renovado interesse pelo pensamento problemático”. KARL LARENZ, op.cit., pp. 232-233.
} 
resulta não só na grande visibilidade do Poder Judiciário e de seus membros, mas também, segundo apontam alguns estudos, em reflexos relevantes sobre o próprio processo decisório judicial.

Todos esses fenômenos decorrem, direta ou indiretamente, do quarto “surto” de juridificação que levou à emergência do Estado Social e Democrático de Direito, do ideário do Welfare State e dos modelos de Estado-Providência ${ }^{65}$. Fortalecendose no alvorecer do século XX, esse "surto” prosseguiu após a Segunda Guerra Mundial, com o crescente intervencionismo estatal no campo econômico e social, deixando às diferentes experiências democráticas ocidentais um legado que, como já se afirmou (1.2.1, supra), não parece comportar um uma desconstrução pura e simples, com um retorno, em tempos de "crise”, a um modelo liberal.

Fixados esses pontos, note-se que os fenômenos destacados a seguir ${ }^{66}$, como aspectos e desdobramentos da juridificação, permitem identificar as causas da expansão do potencial protagonismo judicial que atua nas diversas formas de ativismo judicial.

\footnotetext{
${ }^{65}$ Sem dúvida, visualizadas as peculiaridades de cada país, podem ser identificadas diferenças cronológicas, contextuais e causais entre as experiências concretas de demokratisch und sozialen Rechtsstaat (descrito, entre outros, por Habermas) ou Welfare State (conforme o nome utilizado por Teubner). Todavia, importa apontar os denominadores comuns dessas experiências. De qualquer modo, as origens do ideário do "bemestar social” podem ser sondadas na própria Revolução Francesa, ocorrida, no esquema conceitual ora apresentado, com o terceiro surto de juridificação. Ao enfrentar uma crise econômica sem precedentes e que havia minado a legitimidade do Antigo Regime, a revolução tinha como uma de suas bandeiras a criação de um sistema nacional de bem estar social cujos ingredientes, então discutidos, eram coincidentes com os que caracterizavam os Welfare States europeus após 1945: secularização, centralização, direitos sociais. Além de comitês de bem-estar (Comité de bienfaisance), a Assembleia Nacional, para identificar as origens da mendicância na França, chegou a reunir um comitê específico (Comité de Mendicité), liderado por Rochefoucauld de Liancourt, que sustentou que "direito à subsistência" deveria estar nas bases de todas as leis e de todas as instituições políticas que se propusessem a eliminar a miséria, "Là où il existe une classe d'hommes sans subsistance, là il existe une violation des droits de l'humanité, là l'équilibre social est rompu." Uma pesquisa de fôlego sobre o tema foi realizada por LISA DICAPRIO, The origins of the welfare state: women, work, and the French Revolution, Chicago: University of Illinois Press: 2007, pp. 1-3, Muito interessante, na obra, é a abordagem do engajamento das mulheres. A autora destaca ondas de demandas sociais por políticas de bem-estar social, que se iniciam pela Revolução Francesa, pela Comuna de Paris e pela legislação social da Terceira República (1840 a 1940). Todavia, assim como nos demais países europeus, só depois da Segunda Guerra Mundial o governo francês conseguiu amadurecer o ideário e implantá-lo, concretizando medidas que vinham sendo postuladas desde a Revolução de 1789 (pp. 195 e ss.).

${ }^{66}$ A ordem expositiva desses fenômenos não tem a pretensão de ressaltar a importância maior ou menor de um ou outro desses ingredientes.
} 


\subsubsection{Expansão dos padrões regulatórios e o problema da “indeterminação” do direito}

As causas da progressiva expansão do potencial protagonismo judicial, além dos problemas dela decorrentes, podem ser sondadas no crescimento quantitativo, qualitativo e temático de normas e padrões regulatórios em geral, notadamente em áreas como os direitos do trabalho, empresarial, concorrencial e da seguridade social. Mais recentemente, essa expansão parece haver atingido os chamados "novos direitos", como o direito ambiental e, com uma conotação nitidamente "pós-moderna”, o direito do consumidor $^{67}$.

Com essa expansão, a juridificação passou a dificultar o controle consistente do repertório decisório e a construção de suas estruturas conceituais, duas tarefas básicas da doutrina jurídica. Ganhou espaço, consequentemente, uma nova forma de pensamento que se vê obrigada a lidar com a incoerência de um grande número de normas produzidas em reposta a situações particulares e agregadas em pilhas desordenadas, o que embaraça as construções intelectuais dirigidas à solução de $\operatorname{conflitos}^{68}$. Nesse cenário sobrejuridificado, pode-se denunciar uma "limitação estrutural do direito positivo”, com inequívocos reflexos sobre as instituições judiciais encarregadas de aplicá-lo, como observa FARIA ${ }^{69}$. Normas tradicionalmente padronizadoras, “editadas com base nos princípios da impessoalidade, da generalidade, da abstração e do rigor semântico", organizadas "sob a forma de um sistema unitário, lógico, fechado, hierarquizado, coerente e postulado como isento de lacunas e antinomias" se mostram incapazes de enfrentar "situações sociais, econômicas, políticas e culturais cada vez mais diferenciadas”. O formalismo impede a visualização da complexidade socioeconômica e da crescente singularidade dos conflitos. Princípios gerais, regras e procedimentos juridificados não mais conseguem regular e disciplinar, guardando a devida coerência sistêmica, fatos multifacetados e heterogêneos. Como o Estado não pode deixar sem controle esses fatos, situações e conflitos que se multiplicam em quantidade e

\footnotetext{
${ }^{67}$ A centralidade do consumo na sociedade contemporânea leva alguns teóricos "pós-modernos” a considerar que o fenômeno revelaria um novo Cogito: "I shop therefore I am ...", ZYGMUNT BAUMAN, Consuming life, Cambridge: Polity, 2007, p. 17. Indubitavelmente, o crescimento da importância das relações de consumo leva a que elas também sejam largamente juridificadas.

${ }^{68}$ GUNTHER TEUBNER, op.cit., p. 6.

${ }^{69} \mathrm{O}$ jurista retoma o tema em estudo recente. JOSÉ EDUARDO FARIA, “A globalização econômica e sua arquitetura jurídica - dez tendências do direito contemporâneo”, in: Revista Academia Judicial, Florianópolis: dez. 2010, pp. 6-9.
} 
complexidade, as tentativas de regulação continuam a avançar sob as mais diversas formas $^{70}$.

De um lado, isso ocorre pela edição de "normas ad hoc para casos altamente específicos e singulares, o que (com a proliferação de textos legais com um potencial de aplicação bastante circunscrito no tempo e no espaço) aumenta a confusão e a desordem na expansão do direito positivo, alimenta os conflitos e, tratando-se de conflitos juridificados, amplia o potencial de judicialização desses litígios.

De outro lado, o legislador passa a recorrer, com frequência cada vez maior, a cláusulas gerais, noções vagas e conceitos jurídicos indeterminados, que proliferam ao lado de dispositivos legais de caráter programático e outras normas com textura e tipologia abertas ${ }^{71}$. Isso provoca um distanciamento progressivo de um modelo subsuntivo (2.2.4, infra) e exige muito mais da atividade hermenêutica pelas dúvidas que passam a surgir acerca do efetivo alcance das disposições. Amplia-se, assim, não só a potencial conflituosidade, mas também a liberdade dos juízes para decidir os litígios. Além de leis relativas, sobre medidas específicas, experimentais e temporárias, essa proliferação de cláusulas gerais e referências "em branco" na linguagem do legislador, ao contribuir para a crescente “indeterminação do direito”, alimenta a inquietação da jurisprudência. Nessa busca pelo sentido que deve prevalecer, os juízes são procurados para desenvolvê-lo, para determiná-lo, para concretizá-lo. Renova-se, então, a crítica à atividade criativa dos juízes, que para muitos poderia levar à usurpação da atividade do legislador ${ }^{72}$.

Desse modo, a juridificação, como processo altamente disfuncional de evolução e mudança do Direito, transcende a mera inflação legislativa e constitui

\footnotetext{
${ }^{70}$ Acrescenta Faria: "E quanto mais sua produção normativa caminha nessa linha, aumentando o número de textos legais com um potencial de aplicação bastante circunscrito no tempo e no espaço, mais o direito positivo vai se expandindo de maneira confusa e desordenada. As micro-racionalidades surgidas com essa expansão caótica revelam-se incapazes de convergir em direção a uma racionalidade macro, de tal modo que, numa situação-limite de 'hiperjuridicização' ou 'sobrejuridificação', o direito positivo já não conta mais com uma hierarquia de normas e leis minimamente articulada e com princípios integradores compatíveis entre si. Deste modo, face à sua pretensão de abarcar uma intrincada e contraditória pluralidade de interesses, disciplinar comportamentos altamente particularísticos e balizar a ação de uma enorme multiplicidade de operadores e atores jurídicos, ela acaba perdendo sua organicidade programática, sua racionalidade sistêmica, sua força diretiva - numa palavra, toda sua potencial efetividade.” (JOSÉ EDUARDO FARIA, pp. 6-7)

${ }^{71}$ A propósito do tema, transcreva-se trecho da doutrina de Barroso: “(...) a norma jurídica já não é percebida como antes. Em primeiro lugar porque, em múltiplas situações, ela fornece apenas um início de solução, não contendo, no seu relato abstrato, todos os elementos para determinação do seu sentido. É o que resulta da utilização, frequente nos textos constitucionais, da técnica legislativa que recorre e a cláusulas gerais.” LUIS ROBERTO BARROSO, Curso de Direito Constitucional contemporâneo, op.cit., p. 307.

72 JÜRGEN HABERMAS, Direito e democracia entre facticidade e validade, vol. 2, op.cit., pp. 174-175. É interessante notar a observação do autor, de que a "tensão entre facticidade e validade, imanente ao direito, manifesta-se na jurisdição como tensão entre o princípio da segurança jurídica e a pretensão de tomar decisões corretas”.
} 
ingrediente relevante para a explosão da litigiosidade. Num cenário difuso, à medida que se multiplicam as situações reguladas e normas "indeterminadas", mais intensas são as dúvidas a respeito da aplicação dos dispositivos e mais o Judiciário tende a ser procurado para dirimi-las. Litígios antes resolvidos eticamente (com base nos costumes, na lealdade ou na confiança) são reorganizados de tal maneira que os participantes do conflito podem apelar para pretensões de direito, as quais, se não resolvidas, tendem a ser levadas ao Juiz $^{73}$.

\subsubsection{Materialização do direito formal}

O fenômeno da materialização do direito formal é perceptível do ponto de vista da distinção weberiana entre racionalidade formal e material. Em linhas gerais, nota-se que, no lugar de conceitos estritamente jurídicos, de direito formal, noções sociológicas, econômicas e morais passam a ser adotadas cada vez mais como partes dos textos normativos. Nesse percurso, demandas materiais se tornam objeto de regulação jurídica, tanto pela pressão de grupos de interesses no jogo democrático quanto pela percepção estatal, alinhada ao ideário do Welfare State, de relações que demandariam proteção social ou o controle sobre o poder econômico que nelas avulta ${ }^{74}$. Pretensões de “interesse público” surgem, questões metaindividuais são percebidas e, sobretudo quando coletividades não conseguem se organizar para postular direitos na Justiça, pode surgir um apoio para que seus interesses sejam representados, tornando possível a judicialização de suas pretensões ${ }^{75}$.

Como se vê, a referida racionalidade material se esboça pelo surgimento de normas com características que discrepam das que operavam num modelo paradigmaticamente baseado em operações de subsunção. Destarte, ganham relevo, para o operador do Direito, máximas políticas, noções morais e imperativos éticos introduzidos nas normas jurídicas (“justiça social”, “dignidade da pessoa”, entre outros). Ao tomarem o lugar de conceitos estritamente jurídicos, essas noções sociológicas, econômicas e éticas não só ampliam o espectro de percepção do conflito, mas também multiplicam os

\footnotetext{
73 JÜRGEN HABERMAS, Direito e democracia entre facticidade e validade, vol. 1, op.cit., p. 105.

${ }^{74}$ GUNTHER TEUBNER, op.cit., pp. 8-14.

75 ABRAM CHAYES, “The role of the judge in public law litigation”, in: Harvard Law Review, vol. 89, n. ${ }^{\circ}$

7, mai. 1976. pp. 1281-1316. Cf. tópico 2.2.9, infra.
} 
entendimentos possíveis sobre a maneira pela qual, com base nessas concepções agregadas às normas, deverão ser compostos os litígios ${ }^{76}$.

Essa materialização do direito formal permeia a expansão dos padrões regulatórios e aumenta a indeterminação do direito (2.2.1, supra), à medida que se intensificam as intervenções estatais a fim de controlar juridicamente áreas antes submetidas à autorregulação ${ }^{77}$. Com isso se produz uma alteração na função, na legitimação e na estrutura normativa. Modifica-se a função porque as normas, transcendendo a finalidade de solucionar conflitos jurídicos, atendem também à intenção política de intervenção estatal, e com isso o próprio sistema político chama para si a responsabilidade pelos processos sociais, definindo objetivos, programas de comportamento e mecanismos de implementação. Altera-se, igualmente, a legitimação das normas, uma vez que as expectativas pelos resultados sociais da regulação crescem. Muda, no mesmo movimento, a própria estrutura normativa, como resultado da modificação no alcance dos comandos das normas e nas concepções sobre os métodos de sua interpretação ${ }^{78}(2 \cdot 2 \cdot 4$, infra).

Demandas por justiça material, quando introduzidas no médium do direito, seriam responsáveis pela destruição de sua racionalidade formal. Em contraposição ao direito liberal privado, cuja função era garantir, através de leis públicas, abstratas e gerais, a vida, a liberdade e a propriedade dos sujeitos de direito que celebram acordos; surgem direitos especiais (direitos do trabalho, concorrencial, empresarial,

\footnotetext{
${ }^{76}$ Note-se que Weber entendia que esse processo seria marginal, comparativamente aos poderosos processos do direito formal. Todavia, Teubner observa que em teorias recentes a "materialização do direito formal" aparece como o processo dominante e várias abordagens evolutivas são construídas para explicá-lo. GUNTHER TEUBNER, op.cit., pp. 8-14. Importa citar, outrossim, JÜRGEN HABERMAS. Direito $e$ democracia entre facticidade e validade, vol. 2, op.cit., p. 194. Seja como for, importa registrar que TRUBEK vê, em Weber, certos exageros na perspectiva de que o direito seria uma "organização formal", com o que ele subestima certas qualidades jurídicas (sobretudo as finalísticas e as instrumentais) e superestima a importância da calculabilidade na vida econômica. DAVID M. TRUBEK. Max Weber sobre direito e ascensão do capitalismo, op.cit., p. 179.

${ }^{77}$ GUNTHER TEUBNER, op.cit., pp. 14. O exemplo do tratamento das relações de trabalho é emblemático. Para SIMITIS, o Direito do Trabalho seria um verdadeiro paradigma para o processo de juridificação, cujo background e evolução podem ser bem compreendidos pela observação das origens e do desenvolvimento daquele ramo do direito: quanto mais a juridificação se intensifica, mais o Direito do Trabalho se torna distinto como ramo, mais suas determinações interferem sobre as condições de trabalho em suas especificidades, reestruturando, assim, tanto a atividade dos trabalhadores quanto dos tomadores de seus serviços, em fenômeno que ocorreu em todo o mundo, em especial ao longo do século XX e até o avento do neoliberalismo. SPIROS SIMITIS, "Juridification of labour relations”, op.cit., p. 113. Tradução livre. Sobre o caso italiano, v. GINO GIUGNI, “Juridification of italian labor relations", in: Comparative Labour Law Journal, n. ${ }^{\circ}$ 8, 1986-1987, p. 309. E, do mesmo autor, No que tange ao caso brasileiro, v. ANTÔNIO RODRIGUES DE FREITAS JUNIOR, Os direitos sociais e a constituição de 1988: crise econômica e políticas de bem-estar, op.cit., pp. 44 e ss.

${ }^{78}$ GUNTHER TEUBNER, op.cit., pp. 15-16.
} 
ambiental, do consumidor, entre outros). Ademais, essa incorporação de pretensões de justiça material é captada, claramente, na positivação de inúmeros direitos sociais.

Weber, em época na qual imperava a ciência das pandectas, explicava as qualidades formais do direito, nitidamente sublinhadas naquela tradição, como resultado dogmático do trabalho doutrinário de especialistas em direito com formação acadêmica. Esses especialistas protegiam um formalismo tridimensional: a primeira dimensão desse formalismo radicava na estruturação sistemática de um corpus de proposições jurídicas que colocava as normas vigentes numa ordem visível e controlável; a segunda dimensão se situava na forma da lei abstrata e geral, não configurada para contextos particulares ou especiais, nem dirigida a destinatários determinados, o que conferia ao sistema de direitos uma estrutura uniforme; a terceira dimensão, por fim, identificava-se com a vinculação da justiça e da administração à lei, o que garantia uma aplicação ponderada, conforme o processo, bem como uma implementação confiável dessas normas. Visualizadas essas características formais, é possível entender eventuais desvios em relação ao modelo liberal como perda das qualidades formais do direito ${ }^{79}$.

O aprofundamento da juridificação no Estado Social torna insustentável não somente a imagem clássica do sistema do direito privado, mas também a ideia de uma separação clara entre este e o direito público. Põe-se em cheque, igualmente, a ficção de um sistema jurídico bem ordenado, uma vez que a unidade das normas do direito em seu todo só pode ser percebida, caso a caso, por uma pré-compreensão reconstrutiva, guiada por princípios, e essa reconstrução não estaria objetivada, enquanto tal, no texto da lei. Como a normatização do direito programa intervenções políticas na sociedade com resultados que não podem ser previstos com facilidade, nota-se que programas finalísticos orientados pelas consequências reprimem as formas jurídicas que se orientam pela regra. Não somente fatos concretos, mas também objetivos abstratos podem adotar a linguagem da lei; e características que antes eram exteriores ao direito são assumidas cada vez mais nas determinações jurídicas. Finalmente, esse aumento da importância da finalidade no direito enfraquece a ligação legal entre a justiça e a administração, tida anteriormente como evidente. Os tribunais têm que trabalhar com cláusulas gerais e, ao mesmo tempo, fazer jus ao maior grau de variação de contextos, bem como à maior interdependência de proposições jurídicas subordinadas ${ }^{80}$.

\footnotetext{
79 JÜRGEN HABERMAS, Direito e democracia entre facticidade e validade, vol. 2, op.cit., pp. 194-196.

80 JÜRGEN HABERMAS, Direito e democracia entre facticidade e validade, vol. 2, op.cit., pp. 196-197.
} 
Antigamente, quando as qualidades formais do direito se caracterizavam pela sistematização do corpo jurídico, pela forma da lei abstrata e geral e pelos processos estritos, que limitavam os juízos dos juízes e funcionários, visualizava-se uma ordem graças a uma forte estilização. Porém, as transformações do sistema jurídico, surgidas com o Estado social, estremeceram a autocompreensão liberal do direito formal. Destarte, e possível falar, em sentido descritivo, de uma "materialização" do direito. Para atribuir a esta expressão um sentido crítico, Weber estabeleceu duas relações esclarecedoras: a) a racionalidade do direito está fundamentada nas suas qualidades formais; e b) a materialização configura uma moralização do direito, isto é, a introdução de pontos de vista da justiça material no direito positivo. Disto resultou a afirmação crítica segundo a qual o estabelecimento de um nexo interno entre direito e moral destrói a racionalidade que habita no medium do direito enquanto tal $^{81}$.

Como se vê, a multiplicação de pretensões de justiça material juridificadas e que, como corolário, podem ser judicializadas, contribui, igualmente, para a expansão do potencial protagonismo judicial.

\subsubsection{Crise da divisão funcional de poderes}

O avanço da juridificação também levou a uma crise da tradicional concepção de divisão funcional de poderes.

No Estado Democrático de Direito, essa “divisão”, apesar de já revelar certa tensão potencial entre as funções do Estado, era atual e de funcionalidade indiscutível, do ponto de vista conceitual. No Estado Social e Democrático de Direito essa tensão se intensifica extraordinariamente à medida que se multiplicam programas finalísticos com conteúdo normativo ao lado de normas repletas de cláusulas gerais e noções indeterminadas, dirigidas a indivíduos, coletividades e a pretensões de justiça material (2.2.2, supra).

Uma administração que planeja, executa e configura não pode mais deixar de lado questões normativas, o que abre ao governo um amplo espaço de opinião e de intervenção ${ }^{82}$. Em outros termos, se do ponto de vista jurídico tudo o que foi

\footnotetext{
${ }^{81}$ JÜRGEN HABERMAS, Direito e democracia entre facticidade e validade, vol. 2, op.cit., pp. 2, 197.

82 JÜRGEN HABERMAS, Direito e democracia entre facticidade e validade, vol. 1, op.cit., p. 237. O autor destaca, desse ponto de vista, que a juridificação atingiu tanto a Europa quanto os EUA. O exemplo que ele dá, em relação a este último, é o das agências reguladoras e sua atuação conforme os statutes (Water Quality
} 
juridificado pode ser transformado em pretensão judicializável, esse novo catálogo de tarefas incorporadas pelo Estado amplia os horizontes dos freios e contrapesos ${ }^{83}$.

Assim, o agigantamento do Legislativo (cuja produção normativa se avoluma) e do Executivo (que intervém cada vez mais com base em parâmetros normativos cada vez menos precisos) tende a alimentar, dessa forma peculiar, a expansão do Judiciário e do potencial protagonismo judicial.

\subsubsection{Enfraquecimento do "modelo subsuntivo" e fortalecimento da}

\section{função pragmática da hermenêutica jurídica}

Na linha da exposição até aqui desenvolvida, é fácil perceber que a evolução da juridificação também incita mudanças nas concepções hermenêuticas e metodológicas que guiam a tomada de decisões judiciais ${ }^{84}$.

À medida que os intérpretes adquirem liberdade cada vez maior para definir o sentido de normas, o julgador se afasta progressivamente de um modelo de aplicação essencialmente lógico, dedutivo, subsuntivo ${ }^{85}$.

Destarte, a evolução da juridificação faz emergir uma orientação eminentemente pragmática para a metodologia decisória e para a hermenêutica jurídica. Como destaca NEVES, de um modelo de primazia da segurança formal ${ }^{86}$, passando pelo

Act, the Airs Quality Act, the Sumer Product Safety Act, the Occupational Safety and Health Act, the Motor Vehicle Safety Act, Toxic Safety Act). Essas agências devem ponderar e realizar complexos trade-offs que relacionem saúde pública, segurança pública, emprego, diversidade de produtos e dinamismo econômico.

83 JÜRGEN HABERMAS, Direito e democracia entre facticidade e validade, vol. 2, op.cit., p. 127.

${ }^{84}$ Como veremos, um dos temas mais discutidos em relação à prática do ativismo judicial é justamente o método da decisão judicial, inclusive as concepções hermenêuticas que conduzem o processo decisório.

${ }^{85}$ Um rico panorama dessas concepções é oferecido por KARL LARENZ, op.cit., pp. 20 e ss.

${ }^{86} \mathrm{O}$ jurista destaca que, no século XIX, tanto a escola da exegese (pela concatenação horizontal entre termos e proposições legais) quanto a jurisprudência dos conceitos (em que a concatenação era realizada entre conceitos tecnicamente precisos) exigia do intérprete do direito a descoberta do único sentido juridicamente possível dos signos legais, em operação semântica que partia da suposição da precisão denotativa e conotativa da linguagem legal (como meio de alcançar, metodologicamente, o sentido essencial dos termos e expressões jurídicas). O modelo seria, pois, sintático-semântico. Em seguida, na primeira metade do século XX, sem olvidar a importância da dimensão sintática na interpretação, a ênfase recaía sobre o aspecto semântico. Nesse modelo semântico-sintático, destaca-se como paradigma a Teoria Pura do Direito, de Kelsen. Aqui já se reconhece o problema da ambiguidade e da vagueza dos termos e expressões jurídicas, cabendo ao intérprete determinar o quadro semântico das aplicações jurídicas corretas. Todavia, a delimitação dessa moldura (de diversas aplicações que seriam objetivamente possíveis) seria intermediada por operações lógico-sintáticas orientadas por um ato subjetivo e voluntário que envolveria uma questão de política do direito, e não teórico-jurídica. Em outras palavras, as operações sintáticas determinariam as "conexões lógico-sistemáticas entre termos, expressões e enunciados legais, viabilizando uma complexa operação semântica de determinação do juridicamente possível, ou seja, do conteúdo jurídico de sentido no âmbito do qual diversas aplicações podem ocorrer”. O aspecto pragmático, assim, seria limitado pelo reconhecimento de um sujeito posto em "segundo plano", "transcendental, infenso aos voluntarismos da 
predomínio da descoberta do sentido material" ${ }^{87}$, chega-se “ao problema da incerteza condicionada pelo pluralismo e pelo dissenso estrutural da esfera pública”88. Todos os problemas referentes à determinação das interpretações ou concretizações juridicamente corretas passam a ser eminentemente pragmáticos, como corolário da "relação discursivodialógica entre os intérpretes” (sejam estes os agentes ou os destinatários da decisão) e da "multiplicidade de expectativas que se contradizem e conflitam com relação ao texto da norma" ${ }^{, 89}$.

Isso fica claro no diagnóstico de FARIA acerca da noção de interesse público, normalmente visto como uma espécie de "princípio totalizador dos interesses

escolha entre as variáveis possíveis de aplicação". Na segunda metade do século XX, a teoria do direito caminhou para "considerar a interpretação do direito sobretudo como problema de determinação semântica do significado dos textos jurídicos", mas condicionada pragmaticamente. Surge, então, um modelo semântico-pragmático, em que operações sintáticas "serviriam à delimitação estrutural dos contornos lógicosistemáticos da interpretação", apesar de "a tônica do processo recair na busca do sentido normativo de textos jurídicos em contextos históricos específicos”. Iniciando-se com a hermenêutica de Gadamer, ao intérprete caberia "descobrir o sentido latente dos textos normativo-jurídicos, adequando-os ao momento de sua aplicação ao caso dado". O aspecto semântico radicaria na variação dos textos em face do seu campo de denotação concreta, i.e., o caso; já o aspecto pragmático residiria na noção de pré-compreensão ou préconceito do intérprete a respeito da lei e do caso (como propunha, v.g., Josef Esser). Em outras palavras, essa linha compreende a interpretação como processo de conhecimento e de reconhecimento do sentido válido da lei, que se adaptaria às necessidades do presente, de modo que não consideraria suficientemente a relevância da dimensão pragmática no processo de interpretação do direito, desconhecendo ou, no mínimo, subestimando a função construtiva do intérprete em face dos textos normativos. MARCELO NEVES, Entre Têmis e Leviatã: o estado democrático de direito a partir e além de Luhmann e Habermas, São Paulo: Martins Fontes, 2006, pp. 197-199.

${ }^{87}$ Apesar de se manter na perspectiva semântico-pragmática (enfatizando a dimensão semântica da interpretação), a "teoria jurídica estruturante" (de Friedrich Müller) dá "maior relevância ao fator pragmático do processo interpretativo do que a tradição hermenêutica que remonta a Gadamer". Isso porque se concebia o problema não como de ordem interpretativa, e sim relacionado à "concretização" da norma jurídica. Enfatiza-se, então, a diferença entre o texto normativo, de um lado, e norma jurídica, de outro. Entre as várias premissas e implicações, essa teorização parte da ideia de que a "concretização" da norma jurídica não pode ser reduzida à "interpretação aplicadora". Não se fala em legislação e em atividade constituinte como procedimentos de produção de normas jurídicas, mas de emissão de textos normativos, legais ou constitucionais. A norma jurídica seria produzida ao longo do processo de concretização. A abordagem, aqui, não reduz a relevância da dimensão pragmática (dado o papel ativo e criador do agente de interpretaçãoaplicação jurídica em relação à norma jurídica geral), mas teria seu método lastreado na semântica, deixando de "enfrentar algumas questões eminentemente jurídico-pragmáticas" ou de oferecer-lhes respostas suficientes. Isso porque, entre outros motivos, sustenta-se que a decisão concretizadora, "embora possa apresentar conteúdos os mais variáveis, tem de ser justificada com argumentos objetivos” atribuíveis aos textos normativos do direito vigente. Todavia, apesar da proposta segundo a qual na interpretação caberia delimitar os limites textuais das "concretizações juridicamente corretas", não se sabem quais são os critérios semânticos para definir, entre essas concretizações possíveis, quais seriam compatíveis com o texto, algo que só pode ser discutido satisfatoriamente no plano pragmático. MARCELO NEVES, op.cit., pp. 202-203.

${ }^{88}$ MARCELO NEVES, op.cit., p. 197.

${ }^{89}$ MARCELO NEVES, op.cit., p. 203. Como um dos pontos culminantes dessa tendência, podem ser citados os trabalhos de Häberle que, reconhecendo o papel central desempenhado pelas Constituições nos debates hermenêuticos, fala na "sociedade aberta dos intérpretes" e na "interpretação procedimental" e "pluralista". Sua tese fundamental é a de que, nesse processo interpretativo "estão potencialmente vinculados todos os órgãos estatais, todas as potências públicas, todos os cidadãos e grupos". PETER HÄBERLE, Hermenêutica Constitucional. A sociedade aberta dos intérpretes da Constituição: contribuição para a interpretação pluralista e "procedimental" da Constituição. Porto Alegre: Sergio Antônio Fabris. 2002, p. 13. 
tutelados pelo direito”. Funcionalmente tópico e pragmático, ele serve como um filtro seletivo de alguns valores dentre aqueles em confronto na vida social. Alcança-se, com ele, uma ideia de "fechamento e acabamento lógico daqueles valores majoritariamente reclamados por parte da sociedade”, de forma a despertar a crença em sua consagração pelo Direito. Sucede que, diante de tantos interesses conflitantes, a noção de interesse público se esvazia e se torna cada vez mais retórica e mais difícil de ser aplicada ${ }^{90}$.

Apesar dos vetores fornecidos pelo ideário dos direitos humanos e dos direitos fundamentais (2.2.7.2, infra), percebe-se que a esfera pública não constitui uma unidade, mas uma pluralidade de valores e interesses conflitantes que traduzem expectativas contraditórias em torno do texto normativo. Se essas expectativas podem ser acolhidas ou afastadas no processo de sua interpretação, a própria atividade interpretativa (aberta às diversas concepções que avultam da esfera pública) tem seu resultado determinado por uma seletividade (similar à da ideia de interesse público) que implica a inevitável rejeição de expectativas relevantes, a aprofundar as discussões sobre a legitimidade da hermenêutica jurídica aplicada ao processo decisório ${ }^{91}$.

Conquanto constitua um lugar-comum, não perde a verdade e a utilidade a afirmação de que a linguagem é ambígua e vaga, e que por isso implica infinitas interpretações divergentes. Atualmente, isso decorre da multiplicidade de identidades, ideologias, valores e interesses perceptíveis em uma sociedade complexa e que se traduzem na “variedade estrutural de expectativas sobre textos jurídicos”. Em relação à Constituição, mais abrangente nas dimensões material, pessoal e temporal, essa multiplicidade se acentua, já que tudo pode ter, hoje, uma conotação constitucional, a atrair, potencialmente, um conflito interpretativo. Diagnosticam-se cada vez mais "casos difíceis”, que refletem a miríade de expectativas (atrelada ao dissenso estrutural sobre valores e interesses) sobre o significado da Constituição.

Assim, se não é possível dizer que a tarefa de interpretar o Direito envolveria a produção arbitrária da decisão com base em uma infinidade de sentidos dos textos normativos, nos termos do contextualismo decisionista; é igualmente insustentável “a concepção ilusória de que só há uma solução correta para cada caso, conforme os

\footnotetext{
${ }^{90}$ JOSÉ EDUARDO FARIA, “A definição do interesse público”, in: CARLOS ALBERTO DE SALLES. Processo Civil de Interesse público. São Paulo: RT, 2003, p. 79. Justifica-se, assim, a ideia da "exigência de fundamentação", de "ônus argumentativo", de que deverá se encarregar aquele que decidirá, notadamente o juiz. VIRGÍlIO AFONSO DA SILVA, Direitos fundamentais: conteúdo essencial, restrições e eficácia, op.cit., pp. 41, 112, 115, 150.

${ }^{91}$ MARCELO NEVES, op.cit., p. 204.
} 
critérios de um juiz hipotético racionalmente justo”. Parte-se sempre, então, da evidência sobre a possibilidade de mais de uma decisão justificável, de modo que o problema residiria na delimitação das fronteiras entre as interpretações justificáveis e as não vinculáveis aos textos constitucionais e legais no Estado Democrático de Direito ${ }^{92}$.

Não se almeja propor uma resposta definitiva para essas dificuldades. Pretende-se, tão somente, tê-las em consideração como pontos relevantes para a compreensão do fenômeno do potencial protagonismo judicial que se materializa na prática dos diferentes tipos de ativismo judicial.

Dessa perspectiva, parecendo claras as razões pelas quais não mais se sustenta a ficção da "não criatividade judicial”, as questões decorrentes da desconstrução desse mito tendem a ser problematizadas. Talvez por isso, como aponta LARENZ, a compreensão do método da decisão judicial (o estudo da maneira pela qual, na prática

92 Ainda segundo o jurista, apesar da "plurivocidade e vagueza do texto constitucional, condicionada pragmaticamente pelos valores, interesses e expectativas presentes na esfera pública pluralista, não se pode afirmar que a linguagem jurídica, especialmente a constitucional, seja arbitrária”. Ora, se "os sentidos objetivos são construídos em cada contexto específico de uso", os "sentidos construídos socialmente passam a ter uma força que ultrapassa a vontade ou a disposição subjetiva do eventual intérprete ou utente”. O autor destaca, ademais, que os limites das "interpretações justificáveis" são dinâmicos, já que "metamorfoses normativas sem alteração textual podem conduzir à mudança das fronteiras entre os campos das interpretações legítimas e ilegítimas”. Seja como for, é importante destacar o papel relevante da intermediação seletiva realizada pelos usos dos intérpretes oficiais dos textos. Quanto às "regras do jogo" decisório, haveria um acordo de fundo eminentemente procedimental, sem tangenciar o entendimento sobre valores ou interesses, referindo-se, na verdade, à "partilha de sentido da linguagem concernente às regras do jogo que devem ser respeitadas no Estado Democrático de Direito”. Não se trataria de um sentido único, mas da "congruência de expectativas em relação à pluralidade de sentidos plausíveis" de normas processuais e de direito material. As normas constitucionais e legais substantivas do ponto de vista jurídico-dogmático configuram, para o interprete oficial, as partes e a esfera pública, regras procedimentais do jogo jurisdicional. A congruência de expectativas em relação aos sentidos plausíveis do respectivo texto não significa consenso sobre o seu conteúdo. Pode haver divergências e conflitos profundos sobre o conteúdo da norma legal ou constitucional aplicável, o que tanto pode remontar a uma crítica a própria legislação, ordinária ou constitucional, assim como a construção judicial do sentido concreto entre outros possíveis, mas não se observar a "estranheza" ou "absurdidade" do enunciado interpretativo. O relevante é saber se o enunciado interpretativo é capaz de generalização congruente como expressão de segundo grau de uma regra extraída produtivamente do texto constitucional ou legal. Isso envolve a partilha do sentido expresso na proposição interpretativa como correspondente a uma regra do jogo a ser observada. Em outras palavras, implica um consenso sobre as regras procedimentais do jogo da concretização jurídica. O dissenso quanto ao conteúdo, entretanto, permanece na esfera publica, apontando às vezes para a própria mutação das regras procedimentais do jogo jurisdicional, seja com vistas a reconstrução judicial do sentido normativo ou a reforma legislativa e constitucional de textos.” MARCELO NEVES, op.cit., pp. 205-207. Norberto Bobbio também reflete sobre as implicações gnoseológicas de concepções paradigmaticamente conflitantes sobre a "natureza cognoscitiva da jurisprudência”, a ilustrar, em certa medida, algumas dificuldades incontornáveis pela perspectiva filosófico-jurídica. NORBERTO BOBBIO, Positivismo Jurídico: lições de Filosofia do Direito, São Paulo: Ícone, 1995, p. 211. Habilmente, o autor destaca que o paradigma positivista tradicional contempla a ideia de que a atividade judicial é "puramente declarativa ou reprodutiva de um direito preexistente”, num “conhecimento puramente passivo e contemplativo de um objeto já dado”. Assim, qualquer ponto de vista que caminhe para o reconhecimento da menor ou da maior da "contribuição” do juiz, como sujeito cognoscente, na produção ou concretização do direito, afastar-se-á, mais ou menos, daquele paradigma. 
judiciária, o magistrado chega à decisão “justa” dos casos, com a ajuda da lei ou, porventura, sem ela) tem ocupado todos os autores da metodologia jurídica contemporânea ${ }^{93}$.

Hoje, a atividade do juiz não é mais vista como mera subsunção, mas como um “processo intelectual multímodo”, cujo resultado se manifesta "no conteúdo da própria proposição jurídica”"94. Como bem ressalta CAPPELLETTI, a aceitação da premissa de que a intervenção criativa do juiz é decisiva leva ao reconhecimento de que a interpretação sempre implica certo grau de discricionariedade de escolha e, portanto, de criatividade, que tende a se intensificar quando se trata da justiça constitucional, da proteção de direitos sociais e de interesses de coletividades. Consideradas as dificuldades práticas da concepção tradicional de divisão funcional de poderes, pode-se afirmar que a ideia de criatividade judicial e o crescimento do chamado direito jurisprudencial envolve uma aparente transformação da figura arquetípica do juiz, que tem incorporado certos atributos da tradicional figura arquetípica do legislador ${ }^{95}$. Poderíamos ainda recorrer à metáfora da moldura, de KELSEN ${ }^{96}$, para arriscar a afirmação de que, intensificada a juridificação, o esboço de seus limites (os limites da moldura) se tornou bastante difícil, por depender, cada vez mais, da atividade intelectiva dos juízes.

Não se trata, especificamente, da independência política dos juízes para decidir de modo contramajoritário, como ocorre no exercício do controle de

\footnotetext{
${ }^{93}$ KARL LARENZ, op.cit., p. 190. Na discussão da metodologia contemporânea, um dos poucos pontos em relação aos quais há unanimidade entre os juristas é que, "em um grande número de casos, a afirmação normativa singular que expressa um julgamento envolvendo uma questão legal não é uma conclusão lógica derivada de formulações de normas pressupostamente válidas, tomadas junto com afirmações de fatos comprovada ou pressupostamente verdadeiros(...). Para tanto ha no mínimo quatro motivos: (1) a imprecisão da linguagem do Direito, (2) a possibilidade de conflitos entre as normas, (3) o fato de que é possível haver casos que requeiram uma regulamentação jurídica, que não cabem sob nenhuma norma válida existente, bem como (4) a possibilidade, em casos especiais, de uma decisão que contraria textualmente um estatuto" É o que observa Alexy, ao destacar as dificuldades da metodologia jurídica diante do problema de como justificar plenamente um julgamento jurídico. ROBERT ALEXY. Teoria da Argumentação Jurídica. São Paulo: Landy, 2001, pp. 17-18.

${ }^{94}$ KARL LARENZ, op.cit., p. XXI (prefácio).

${ }^{95}$ MAURO CAPPELLETTI, Juízes Legisladores?, Porto Alegre: Sérgio Antônio Fabris, 1999, p. 128.

${ }^{96}$ HANS KELSEN. Teoria pura do Direito. São Paulo: Martins Fontes, 1999. v., em especial, o capítulo VIII, dedicado ao tema da interpretação (pp. 387 e ss). Em vários pontos da obra Kelsen faz referência à moldura: "Em todos estes casos de indeterminação, intencional ou não, do escalão inferior, oferecem-se várias possibilidades à aplicação jurídica. $\mathrm{O}$ ato jurídico que efetiva ou executa a norma pode ser conformado por maneira a corresponder a uma ou outra das várias significações verbais da mesma norma, por maneira a corresponder à vontade do legislador - a determinar por qualquer forma que seja - ou, então, à expressão por ele escolhida, por forma a corresponder a uma ou a outra das duas normas que se contradizem ou por forma a decidir como se as duas normas em contradição se anulassem mutuamente. O Direito a aplicar forma, em todas estas hipóteses, uma moldura dentro da qual existem várias possibilidades de aplicação, pelo que é conforme ao Direito todo ato que se mantenha dentro deste quadro ou moldura, que preencha esta moldura em qualquer sentido possível”.
} 
constitucionalidade. Fala-se, de um modo geral, da maior liberdade para participar da criação do direito, o que fortalece ainda mais aquela independência. Mesmo que não exista nenhuma forma de controle judicial contramajoritário ${ }^{97}$, esse afastamento do modelo meramente subsuntivo constitui, por si só, um ingrediente relevante para a investigação do potencial protagonismo judicial ${ }^{98}$.

\subsubsection{Decisão judicial: as éticas da convicção e da responsabilidade}

O potencial protagonismo judicial, no que tange ao fortalecimento da função pragmática da hermenêutica jurídica, pode ser examinado pela perspectiva de dois tipos de ação racional: a ação racional relativamente a fins (zweckrational); e a ação racional relativamente a valores (weitrational) ${ }^{99}$, que revelam a atuação, respectivamente, da ética da responsabilidade (Maquiavel) e da ética da convicção (Kant).

A ética da responsabilidade (Verantwortungsethik) determina ao indivíduo que se coloque diante de certa situação, encare as consequências de decisões possíveis e tente introduzir, na trama dos acontecimentos, um ato que levará a certos resultados ou determinará certas consequências desejadas. Interpreta-se a ação, desse modo, pela ótica dos meios-fins. Como destaca ARON, Max Weber gostava de tomar como símbolo dessa ética o cidadão de Florença que, segundo Maquiavel, teria preferido a grandeza da cidade à salvação da sua alma. Nessa linha, o homem de Estado, para realizar um objetivo supraindividual que é o bem de coletividade, aceitaria empregar até mesmo meios reprovados pela ética corrente. Weber "não faz o elogio do maquiavelismo”, nem torna a ética da responsabilidade, necessariamente, uma ética maquiavélica, no sentido habitual do termo. Na verdade, trata-se, simplesmente, de preocupação com a eficácia e com a escolha dos meios adequados ao fim que queremos atingir. Mas essa ética não se

\footnotetext{
${ }^{97}$ Fala-se no controle de constitucionalidade de leis. É interessante notar, ilustrativamente, o que ocorreu no caso holandês, descrito no tópico 2.2.9.1, infra.

${ }^{98}$ Isso ficará claro, na tese, quando do exame de experiências jurídicas em que não existe esse controle, o que não impediu manifestações do ativismo judicial.

${ }^{99}$ Como nota Giddens, o "diálogo vivo com Weber continua”. ANTHONY GIDDENS, Política, Sociologia e Teoria Social: encontros com o pensamento social clássico e contemporâneo, op.cit., p. 16. Sem dúvida, poder-se-ia cogitar de traços de ação afetiva, mas se trata, afinal, de algo de difícil sondagem; ou, ainda, de uma ação tradicional, notadamente em relação ao que ocorre com a formação jurisprudencial. RAYMOND ARON, op.cit., pp. 478-479. A atualidade dessa classificação radica no fato de ela continuar a ser "discutida e refinada”. Weber parte da ideia de que o traço característico do mundo que ele observa seria a racionalização. Disto resulta o alargamento da esfera de ações zweckrational, como a gestão do Estado: “A sociedade moderna no seu conjunto tende para a organização zweckrational, e o problema filosófico do nosso tempo, problema eminentemente existencial, é o de delimitar o setor da sociedade em que subsiste e deve subsistir uma ação de outro tipo”.
} 
basta a si própria, uma vez que implica a "busca dos meios adequados aos fins enquanto esses fins permanecem indeterminados”. Numa espécie de niilismo, Weber não acreditava fosse possível um acordo acerca dos fins a atingir. Com razão ou não, ele tinha uma concepção voluntarista dos valores criados pelos homens, negava a existência de uma hierarquia universal dos fins e, mais ainda, pensava que cada um de nós seria obrigado a escolher entre valores em última análise incompatíveis entre si. Em matéria de ação (e, acrescente-se, de ativismo), sempre há escolhas que não podem ser feitas sem sacrifícios. Ademais, no interior de dada coletividade, não haveria escolha vantajosa para alguns que não fosse desvantajosa para outros.

Assim, decisões políticas (e, cada vez mais, as judiciais) serão sempre, em última análise, ditadas por juízos de valor não suscetíveis de demonstração. Ninguém pode decretar com segurança a medida na qual tal indivíduo ou grupo deva ser sacrificado para o bem de outro grupo ou da coletividade global. Por outro lado, o bem da coletividade global não pode ser definido a não ser por um grupo particular. Essa problemática, pela perspectiva da teoria da justiça, conduz-nos ao problema da escolha dos valores que devem prevalecer, e esse problema é da substância da ética da convicção ${ }^{100}$.

A ética da convicção incita cada um de nós a agir segundo os sentimentos e valores, sem referência, explícita ou implícita, às consequências. Os exemplos de Weber são os do pacifista absoluto e o do sindicalista revolucionário. O primeiro, se imaginar que impedirá a guerra por meio de tal recusa, seria ingênuo ou (no plano da ética da responsabilidade) ineficaz. Mas se a finalidade única de sua ação for a conformidade em relação à sua consciência, se a recusa em si for o propósito do seu comportamento, “tornar-se-á sublime ou absurdo, pouco importa, mas irrefutável”, já que sua consciência ambiciona, exclusivamente, ser fiel a si própria, independentemente dos resultados alcançados. No caso do sindicalista revolucionário, ele não dará ouvidos a discursos que avaliem sua ação pelos efeitos que elas possam acarretar, pelos quais seria responsável o mundo, a “estupidez dos homens” ou ainda a "vontade de Deus” que fizera os homens “assim”101.

É difícil imaginar que a moral do Estado deva ser a da convicção, a qual, no sentido extremo do termo, não passa de um tipo ideal “do qual ninguém se deve aproximar demais se quiser permanecer no interior dos limites de um comportamento

\footnotetext{
${ }^{100}$ RAYMOND ARON, op.cit., pp. 500-503.

101 RAYMOND ARON, op.cit., p. 503. Cite-se, outrossim, MAX WEBER, Ciência e Política: duas vocações, São Paulo: Cultrix, 2004, p. 122.
} 
razoável”. Vê-se, todavia, uma ideia profunda nessa oposição entre convicção e responsabilidade como elementos nucleares da ética que move a ação. Isso porque, em qualquer forma de agir, dividimo-nos entre duas atitudes ou entre o "desejo de duas atitudes”. De um lado, uma atitude instrumental, que procura "produzir resultados de acordo com os nossos objetivos e, por isso, obriga-nos a olhar o mundo e a analisar as consequências prováveis do que dissermos ou fizermos”. De outro lado, uma atitude moral, que nos impele a falar e a agir sem termos em conta nem os outros, nem o determinismo dos acontecimentos. Estabelecer os tipos ideais dessas duas atitudes nos auxilia a esclarecer que uma ação razoável seria inspirada a um só tempo nestas duas atitudes. Ambas as éticas, a da responsabilidade e a da convicção, para Weber, não são contraditórias, mas se completam uma à outra ${ }^{102}$.

Em um cenário de elevado pragmatismo nas decisões judiciais, ambas as éticas parecem relevantes na avaliação das formas de manifestação do potencial protagonismo judicial.

\subsubsection{A expropriação dos conflitos}

A ideia de juridificação como progressiva colonização do mundo da vida pelo Direito também implica uma crescente expropriação dos conflitos, que são retirados de seus contextos naturais pela sujeição a métodos e a processos jurídicos. Em outros termos, o que é regulado pelo Direito positivo passa a ser de interesse estatal.

Mesmo para os que considerem exagerada a ideia de expropriação, ela é adequada tanto para orientar as reflexões sobre a aptidão do Direito de bem exercer (no que tange aos conflitos que foram expropriados) sua primordial função pacificadora, inclusive por intermédio das instituições judiciais encarregadas de aplicar normas; quanto para identificar experiências institucionais que traduzam uma modificação da função judicial em seus moldes tradicionais, o que tem ocorrido para dar tratamento mais célere à explosão de litígios com inequívoco crescimento quantitativo, inegável sofisticação qualitativa e inobscurecível multiplicação temática.

À vista da multiplicidade de pretensões com conotação jurídica (2.1.1, 2.2.2 e 2.2.4, supra), é intuitivo crer que os conflitos que elas suscitem tendam a ser levados ao Judiciário. Surgem, assim, dificuldades de canalizar essas demandas

${ }^{102}$ RAYMOND ARON, op.cit., pp. 500-503. 
adequadamente (óbices de acesso, medo de ingressar em Juízo, duração excessiva dos casos, custos do processo, desigualdades processuais, discrepâncias nas chances de sucesso) e, como resultado dessas vicissitudes, pode avultar a ineficiência do aparato judiciário $^{103}$.

Dessa perspectiva, a juridificação não necessariamente implica a resolução do conflito, mas, pura e simplesmente, sua apropriação, com o que pode ser mutilada parte importante de sua dimensão social. Para agravar esse quadro de redução da multidimensionalidade do conflito à dimensão exclusivamente jurídica, os obstáculos à promoção de sua pacificação no plano sociológico tendem a ser obscurecidos pela ideia de que o acesso à justiça se confundiria com o mero acesso ao Judiciário. A percepção dessas dificuldades engendra, em seguida, movimentos sociais de contestação que defendem, com a bandeira da desregulamentação (delegalization), a “expropriação dos expropriadores” e a adoção de "alternativas ao Direito", como é o caso dos mecanismos não jurisdicionais de tratamentos de conflitos, que devolveriam aos diretamente envolvidos a responsabilidade pela solução das disputas.

Esses fenômenos, coerentemente com a perspectiva expropriatória, de um lado fomentam novas reações institucionais que desenvolvem reformas no processo para torná-lo pretensamente mais eficaz, inclusive com o fortalecimento e a ampliação do ideário do juiz ativo (2.2.8, infra); e, de outro lado, incorporam, de algum modo, aquelas “alternativas ao direito”, por cujo fomento esses juízes “ativos” também passam a ser responsáveis.

Assim, observa-se que, paralelamente aos mecanismos extrajudiciais de soluções de conflitos (adjudicatórios e não adjudicatórios), surgem experiências institucionais, no âmbito do próprio Judiciário, que envolvem o fortalecimento do elemento conciliatório no processo, com a participação laboriosa e ativa dos juízes no fomento de negociações, de acordos amigáveis e de várias outras formas de solução alternativa, não adjudicatória, de conflitos. Não obstante o surgimento de reações contrárias à expropriação de conflitos (alimentadas pela percepção de que as sociedades não podem ser governadas racionalmente de um modo excessivamente burocrático e hierárquico), o

${ }^{103}$ GUNTHER TEUBNER, op.cit., pp. 8-9. 
Estado mantém sua desconfiança sobre a aptidão pacificadora dos mecanismos de autorregulação espontânea ${ }^{104}$.

Nesse percurso expropriatório, a função judicial vai se estendendo gradativamente à resolução de problemas sociais e políticos não percebidos ou não resolvidos satisfatoriamente por outros órgãos públicos ou por outras instituições da sociedade. Considerando o vastíssimo repertório de temas que, em razão da juridificação, podem ser levados à apreciação do Judiciário, a necessidade de provocação dos juízes é alimentada pela percepção de que os órgãos judiciais seriam uma espécie de factótum institucional. Do ponto de vista dos resultados que podem ser alcançados, o recurso ao juiz traz, para o cidadão usuário dessas instituições, certas vantagens comparativamente à demanda de intervenção dirigida a outros poderes. O judiciário tende a ser visto como um Poder menos hostil, mais aberto e menos discricionário do que são os poderes propriamente políticos. Assim, havendo estruturas de suporte à mobilização jurídica (2.2.9.1, infra), o recurso ao Judiciário (cujos membros são cada vez mais independentes para decidir sobre número cada vez maior de temas) pode se tornar mais frequente também em razão do deslocamento, para os órgãos judiciais, de todas as "expectativas crescentes" engendradas por uma “cultura de direitos”, em especial os direitos sociais ${ }^{105}$.

Além disso, e considerada a participação decisiva dos magistrados na definição dos desdobramentos das normas e de seus possíveis sentidos (2.2.4, supra), PIZZORNO constata uma intensa “delegação” ao Judiciário, operada pelos órgãos legislativos e administrativos, da faculdade de decidir sobre questões “delicadas”. Essa delegação tende a ser incrementada: a) por uma mobilização social em busca de soluções judiciais para controvérsias de cuja resolução não conseguem cuidar as tradicionais autoridades sociais ou administrativas; b) pela criação de órgãos especiais de controle de constitucionalidade; e c) pelo aparecimento e a difusão de uma prática judicial que ele define como de controle de correção política (controllo di correttezza política) ou controle de virtude (controllo di virtù ${ }^{106}$. Desse modo, a provocação dos juízes também é motivada

\footnotetext{
${ }^{104}$ GUNTHER TEUBNER, op.cit. Associando o processo de juridificação, no sentido de monopolização, por profissionais do Direito, dos mecanismos alternativos de soluções de disputas, v. PENNY BROOKER, "The juridification of alternative dispute resolution”, in: Anglo American Law Review, vol. XX, 1999, p. 1. JOHN FLOOD, ANDREW CAIGER, "Lawyers and Arbitration: The Juridification of Construction Disputes", in: The Modern Law Review, vol. 56, n. 3 (Dispute Resolution. Civil Justice and Its Alternatives). mai. 1993, pp. 412-440. Isso desvela, como veremos no tópico 2.2.8, uma ampliação do modelo do "juiz ativo" no processo.

105 PIER PAOLO PORTINARO, op.cit., p. 393.

106 ALESSANDRO PIZZORNO. op.cit., pp. 12-13.
} 
pela necessidade de colmatar vazios políticos e lacunas na implementação de direitos da pessoa e de coletividades por meio da interpretação e da aplicação judicial de documentos escritos que os garantam ${ }^{107}$.

Com isso, pouco a pouco, consolida-se a expropriação de conflitos em todos os campos, não só o social, mas também o político.

Essa noção de expropriação explica a postura estatal no que tange ao chamado "movimento de acesso à Justiça", descrito nos estudos comparativos de CAPPELLETTI e GARTH como o abandono de uma proteção meramente formal do indivíduo em busca de um sistema em que as pessoas pudessem "reivindicar seus direitos ou resolver seus litígios sob os auspícios do Estado” (2.2.9, infra). Essa tutela estatal haveria de ser acessível a todos para produzir resultados justos, do ponto de vista individual e social, sobretudo diante da percepção dos chamados conflitos de massa ${ }^{108}$. Referido “movimento de acesso à Justiça” é facilmente associável ao quarto "surto" de juridificação examinado, uma vez que, com o aprofundamento do processo de colonização do mundo da vida, as demandas judicializáveis se multiplicaram não apenas para tutelar os interesses dos indivíduos, mas também as reivindicações de minorias, de coletividades e de grupos que passaram a encontrar fundamento para suas pretensões em imperativos éticos e de justiça social frequentemente incorporados ao discurso de legisladores, de governantes e de juízes.

Com essas características, a sobrejuridificação do mundo da vida, por favorecer a intervenção judicial em face de conflitos expropriados, incrementa, em relação a eles, o potencial protagonismo judicial. Não se trata aqui, tão somente, do incremento da chamada judicialização da política, que contribui para o acirramento da tensão interpoderes (2.2.3, supra; 2.2.6, infra), mas da judicialização de todas as relações sociais, como já se afirmou $^{109}$.

\footnotetext{
${ }^{107}$ Cappelletti nota que, na Europa, a consolidação das Cortes Constitucionais e do controle concentrado, bem como o fortalecimento da jurisdição administrativa especializada, foram respostas à própria expansão do Executivo e do Legislativo, bem como à necessidade, disto decorrente, de preencher "a ampla e profunda lacuna na tutela jurisdicional”. MAURO CAPPELLETTI, Juízes Legisladores?, op.cit., p. 52.

${ }^{108}$ MAURO CAPPELLETTI, BRYANT GARTH. Acesso à Justiça, Porto Alegre: Sérgio Antônio Fabris, 1988, pp. 8-9.

${ }^{109}$ Conforme observa SCHULTZE-FIELITZ, apud: RUSSELL MILLER, op. cit. p. 593, nota 31.
} 


\subsubsection{Ampliação do controle judicial contramajoritário e da independência política do Poder Judiciário}

Como foi visto, a juridificação progressiva das relações sociais engendrou, por ocasião do surgimento do Estado Democrático de Direito, o problema da tensão entre instituições estatais funcionalmente diferenciadas (Executivo, Legislativo e Judiciário) que naturalmente estabelecem relações entre si, conforme a metáfora dos freios e contrapesos. Em seguida, com o advento do Estado Social e Democrático de Direito, intensificou-se aquela tensão, a ensejar questionamentos ao modelo de divisão de funções (2.2.3, supra).

Se considerada exclusivamente a questão da independência política dos juízes, o modelo de divisão funcional de poderes dos EUA (com o matiz do presidencialismo e a nota do controle judicial contramajoritário) já desvelava, em suas origens, muitos ingredientes daquela tensão. Diferentemente, na Europa, essa tensão só se tornou mais visível na segunda metade do Século XX, em processo que se iniciou com o término da Segunda Guerra Mundial. No Brasil, assim como em geral ocorreu com os demais países latino-americanos que experienciaram longos períodos ditatoriais, essa tensão só se fez presente muito tempo depois.

Observada essa evolução, uma das primeiras formas identificáveis de potencial protagonismo judicial em experiências democráticas surgiu com a prerrogativa do Judiciário de controlar, contramajoritariamente, decisões do Legislativo e do Executivo. É oportuno esclarecer que esse controle é qualificado como contramajoritário com referência ao fato de os poderes controlados possuírem representantes escolhidos pela regra da maioria. Trata-se, especificamente, do controle de constitucionalidade em seus moldes mais tradicionais, relacionados ao exame da adequação da conformidade de normas à Constituição. A atuação desse controle depende, entretanto, da efetiva independência política dos juízes. Sucede que a presença concomitante desses dois ingredientes (os instrumentos de controle majoritário e a independência efetiva dos juízes) não respeita uma cronologia uniforme nas experiências democráticas ocidentais.

Nos EUA, a efetiva possibilidade de exercício de um controle judicial contramajoritário surgiu com o próprio Estado Democrático de Direito (2.2, supra) e está enraizada no imaginário político da sociedade. Já em 1835, TOCQUEVILLE observava que, naquele país, se um juiz considerasse uma lei contrária à Constituição, poderia, no exercício do judicial review, recusar-se a aplicá-la ao caso concreto. Essa possibilidade de 
emitir decisões contramajoritárias constituía, à época, a única peculiaridade da magistratura norte-americana em relação aos seus correlatos de outras experiências democráticas. Contudo, era justamente essa característica que garantia ao Judiciário a possibilidade de, mediante provocação, exercer uma imensa influência política ${ }^{110}$. É que a forma de organização desse controle engendrava, segundo o pensador francês, "uma das barreiras mais poderosas já planejadas contra a tirania do parlamento"111. Tais garantias preservariam o poder da maioria sem impossibilitar a proteção das minorias, o que atendia, na origem, à necessidade de sofisticação do ideário democrático e dos mecanismos de proteção a valores cristalizados na constituição ${ }^{112}$.

Desse modo, dada a prerrogativa conferida ao Judiciário, de proferir a “última palavra” em matéria constitucional, sempre houve, entre os ianques, no sentido contramajoritário, um potencial protagonismo judicial. Sem dúvida, a atuação efetiva desse potencial em alguns momentos se acentuou, noutros se reduziu. Afinal, como foi

${ }^{110}$ ALEXIS DE TOCQUEVILLE, op.cit. Em especial, referimo-nos ao capítulo intitulado “Judicial power in the United States, and its influence on political society” (“O Poder Judiciário nos EUA e sua influência sobre a sociedade política”). A primeira publicação da obra do pensador é de 1835, pouco tempo depois da paradigmática decisão do Judiciário americano no caso Marbury v. Madison (1803).

111 Transcreva-se o seguinte excerto, por oportuno: "Whenever a law that the judge holds to be unconstitutional is invoked in a tribunal of the United States, he may refuse to admit it as a rule; this power is the only one peculiar to the American magistrate, but it gives rise to immense political influence (...)I am inclined to believe this practice of the American courts to be at once most favorable to liberty and to public order. If the judge could attack the legislator only openly and directly, he would sometimes be afraid to oppose him; and at other times party spirit might encourage him to brave it at every turn. The laws would consequently be attacked when the power from which they emanated was weak, and obeyed when it was strong; (...) He judges the law only because he is obliged to judge a case. The political question that he is called upon to resolve is connected with the interests of the parties, and he cannot refuse to decide it without a denial of justice. (...) It is true that, upon this system, the judicial censorship of the courts of justice over the legislature cannot extend to all laws indiscriminately, inasmuch as some of them can never give rise to that precise species of contest which is termed a lawsuit; and even when such a contestation is possible, it may happen that no one cares to bring it before a court of justice. The Americans have often felt this inconvenience; but they have left the remedy incomplete, lest they should give it an efficacy that might in some cases prove dangerous. Within these limits the power vested in the American courts of justice of pronouncing a statute to be unconstitutional forms one of the most powerful barriers that have ever been devised against the tyranny of political assemblies" (Idem).

${ }^{112}$ No que concerne aos interesses das minorias, é comum o argumento de que a eventual falta de medidas protetivas (explicável, ilustrativamente, por dificuldades deliberativas típicas do processo legislativo) constituiria um "preço da democracia", de modo que, para a preservação desta, dever-se-ia elogiar apenas a promoção da vontade da maioria. Disto certamente discordaria Tocqueville, cujas lições denunciam que, não obstante arraigada (acriticamente) em nosso imaginário, a "regra da maioria”, se levada às últimas consequências para consagrar normativamente um padrão de comportamento majoritariamente aceito, pode resultar na repressão exagerada de condutas reputadas incompatíveis com os valores que levaram àquela consagração, entre os quais se destacam alguns que merecem igual proteção. Em outras palavras, o resultado da absolutização da regra da maioria pode prejudicar as minorias (num sentido amplo, não necessariamente quantitativo) sob as mais variadas formas de dominação e opressão, incompatíveis com o ideário dos direitos fundamentais imanente à estruturação de um Estado Democrático. Acrescente-se, por oportuno, que a indagação a respeito de o Judiciário dever ser ou não o árbitro desses conflitos não se confunde com a ponderação que aclara a dificuldade engendrada pela pretensa "suficiência” da regra da maioria. 
visto, esse poder de emitir decisões contramajoritárias não é suficiente per se para que os magistrados atuem concretamente de forma contrária às decisões dos atores políticos. As variáveis desse movimento pendular são múltiplas e complexas, e incluem a orientação política dos juízes, a composição dos tribunais, a relação dos magistrados com os demais poderes e com a sociedade, a eficiência dos mecanismos que permitem o rompimento da inércia jurisdicional, entre outros.

Como aponta SADEK, todos os países que se inspiraram no modelo institucional norte-americano já apresentavam “em tese” esse potencial de participação do Judiciário no debate público, o que na prática se mostrou, por muito tempo, mais como uma virtualidade do que como um fato real ${ }^{113}$.

Na América Latina, qualquer manifestação jurisdicional de relevo era refreada por fatores como a instabilidade política e a força excessiva do Executivo. Só após a superação das experiências autoritárias, com o processo de reconstrução democrática e o aumento da independência dos magistrados, surgiram condições necessárias ao exercício efetivo desse controle judicial contramajoritário. É o caso do Brasil após a Constituição de 1988.

Na Europa, a efetiva independência para prolatar decisões contramajoritárias foi fortalecida após o fim da Segunda Guerra Mundial ${ }^{114}$. Ao longo da segunda metade do século XX, com a emergência gradativa do Welfare State naquele continente $^{115}$, muitos países, seguindo mutatis mutandis os passos da experiência norteamericana, conferiram aos juízes novos poderes de revisão de atos oficiais e de defesa de direitos individuais e sociais enunciados em constituições e em tratados internacionais. Relativamente à experiência norte-americana, a demora desse “despertar” do Judiciário europeu decorre de uma série de circunstâncias históricas relevantes. Além dos grandes conflitos armados, das experiências autoritárias e da unificação tardia de alguns países (como a Itália e a Alemanha), a tradição do parlamentarismo trazia consigo, desde o século XVIII, certa desconfiança em relação aos juízes. Esses valores levaram ao “deslocamento do poder do monarca para o Legislativo” e à redução, por muito tempo, do espaço de ação do Judiciário, que deveria apenas “aplicar a lei” de forma mais ou menos mecânica e previsível. Contudo, se por muito tempo a "palavra final” sobre a esfera pública

\footnotetext{
113 MARIA TEREZA SADEK, “Poder Judiciário: uma nova instituição”, op.cit., pp. 28-30.

114 Segundo Alexandre de Moraes, no começo do século XX os países europeus ainda consagravam, em geral, “a absoluta supremacia do Parlamento”. ALEXANDRE DE MORAES. Jurisdição constitucional e tribunais constitucionais. $2^{\mathrm{a}}$ ed., São Paulo: Atlas, 2003, p. 115.

${ }^{115}$ MARIA TEREZA SADEK, “Poder Judiciário: uma nova instituição”, op.cit., p. 29.
} 
permaneceu com o parlamento, o advento dos direitos sociais e das instituições do Estado Social e Democrático de Direito se encarregaram de alterar os desenhos originais ${ }^{116}$, notadamente após a Segunda Guerra Mundial ${ }^{117}$, o que possibilitou aos órgãos judiciais dos países europeus se destacarem, continua e progressivamente, pela emissão de decisões contramajoritárias $^{118}$.

Sem dúvida, a emergência do Estado Social e Democrático de Direito engendrou uma considerável ampliação do espectro do controle de constitucionalidade, de modo que o movimento pendular a que se fez referência neste tópico passou a ser mais

${ }^{116}$ MARIA TEREZA SADEK, "Poder Judiciário: uma nova instituição”, op.cit., pp. 28-30.

${ }^{117}$ A ponderação é relevante em razão de os marcos do Constitucionalismo Social normalmente serem identificados com a Constituição de Weimar, de 1919; e do México, de 1917. Sem dúvida, tais marcos são importantes para o ideário e como indícios do quarto surto de juridificação relacionado ao Estado social e Democrático de Direito, mas a prática desse ideário só se consolidaria nas décadas seguintes. Sobre o caso brasileiro, v. 2.3.1, infra. Note-se, a propósito dessa evolução, as lições de MAURO CAPPELLETTI. "Trends of 'Procedural Justice in Contemporary Europe'", in: ARTHUR KAUFMANN, (org.). Rechtsstaat und Menschenwürde. Festschrift Für Werner Maihofer Zum 70. Geburststag. Frankfurt Am Main: Klosterman, 1988, pp. 61-63. Não obstante a obra ser em língua alemã, o artigo de Cappelletti, de fato, foi publicado em língua inglesa.

${ }^{118}$ Em conferência de Direito Público realizada na década de 1920, Kelsen destacava o papel que a jurisdição constitucional teria em um sistema democrático, em uma espécie de vaticínio sobre o que se seguiria na Europa: "Ao lado dessa significação geral comum a todas as Constituições, a jurisdição constitucional também adquire uma importância especial, que varia de acordo com os traços característicos da Constituição considerada. Essa importância é de primeira ordem para a República democrática, com relação à qual as instituições de controle são condição de existência. Contra os diversos ataques, em parte justificados, atualmente dirigidos contra ela, essa forma de Estado não pode se defender melhor do que organizando todas as garantias possíveis da regularidade das funções estatais. Quanto mais elas se democratizam, mais o controle deve ser reforçado. A jurisdição constitucional também deve ser apreciada desse ponto de vista. Garantindo a elaboração constitucional das leis, e em particular sua constitucionalidade material, ela é um meio de proteção eficaz da minoria contra os atropelos da maioria. A dominação desta só é suportável se for exercida de modo regular. A forma constitucional especial, que consiste de ordinário em que a reforma da Constituição depende de uma maioria qualificada, significa que certas questões fundamentais só podem ser solucionadas em acordo com a minoria: a maioria simples não tem, pelo menos em certas matérias, o direito de impor sua vontade à minoria. Somente uma lei inconstitucional, aprovada por maioria simples, poderia então invadir, contra a vontade da minoria, a esfera de seus interesses constitucionais garantidos. Toda minoria - de classe, nacional ou religiosa - cujos interesses são protegidos de uma maneira qualquer pela Constituição, tem pois um interesse eminente na constitucionalidade das leis. Isso é verdade especialmente se supusermos uma mudança de maioria que deixe à antiga maioria, agora minoria, força ainda suficiente para impedir a reunião das condições necessárias à reforma da Constituição. Se virmos a essência da democracia não na onipotência da maioria, mas no compromisso constante entre os grupos representados no Parlamento pela maioria e pela minoria, e por conseguinte na paz social, a justiça constitucional aparecerá como um meio particularmente adequado à realização dessa idéia. A simples ameaça do pedido ao tribunal constitucional pode ser, nas mãos da minoria, um instrumento capaz de impedir que a maioria viole seus interesses constitucionalmente protegidos, e de se opor à ditadura da maioria, não menos perigosa para a paz social que a da minoria. (Kelsen, Hans. Jurisdição Constitucional. São Paulo: Martins Fontes, 2003, pp. 181-182). O texto central, que deu título à compilação, corresponde à exposição proferida em outubro de 1928, em sessão do Instituto Internacional de Direito Público". Nesse sentido, v. GILMAR FERREIRA MENDES. "Controle de Constitucionalidade: Hermenêutica Constitucional e Revisão de Fatos e Prognoses Legislativos pelo órgão judicial", in: Revista Jurídica da Presidência da República, Brasília, vol. 1, n. . 8, jan. 2000. 
fraco no sentido da inação ${ }^{119}$ (ou da autocontenção) e mais forte no sentido do agir (ou do ativismo).

À medida que a juridificação progrediu, o reconhecimento dos direitos sociais, o aprofundamento da teorização sobre os direitos fundamentais, a litigância de interesse público, a migração de ideias e a propagação do ideário dos direitos humanos, como veremos a seguir, ampliaram significativamente o potencial protagonismo judicial contramajoritário.

Nos EUA, esse potencial, que já era considerável, cresceu significativamente; na Europa, livre de grande parte dos mecanismos de contenção da tradição parlamentarista, ele foi se tornando mais visível e efetivo. Mais recentemente, a contenção à atuação judicial também foi reduzida em vários países da América Latina.

Não se afirma que a tutela judicial de direitos sociais depende, necessariamente, dessa ampliação do controle de constitucionalidade. Essa relativa “independência” parece desvelar certa especificidade do protagonismo judicial que se manifesta num agir em prol da promoção de direitos sociais e de interesses de coletividades, como veremos a seguir (2.2.9 e 2.2.9.1, infra). Seja como for, o reconhecimento dos direitos sociais, como mecanismos de materialização do direito (2.2.2, supra), ampliaram extraordinariamente a agenda judicial, que passou a contemplar o controle da ação legislativa e executiva, inclusive em matéria de políticas públicas, omissões e outros aspectos da atribuição dos poderes propriamente majoritários.

É importante ponderar que antes da suposta “invasão”, pelo Judiciário, do espaço “exclusivo” de outros poderes, em geral os juízes receberam atribuições para fazê-lo. Assim, não parece razoável afirmar serem os juízes, por si sós, os responsáveis pelo avanço das fronteiras de sua atuação. Com efeito, não se pode desconsiderar que a própria esfera política, à proporção que juridifica as relações sociais, amplia a função judicial e faz explodir, inclusive contra os próprios legisladores governantes, o número de pretensões judicializáveis.

Apesar de a possibilidade efetiva de controle judicial contramajoritário (sobretudo em seus moldes tradicionais) não encerrar todas as formas de manifestação do potencial protagonismo judicial, foi ela a responsável por uma das revelações pioneiras desse potencial. Com isso, ele não só se tornava relevante do ponto de vista político, jurídico e social; mas também abria os caminhos para sua própria sofisticação à medida

\footnotetext{
${ }^{119}$ Não nos referimos, na menção a tal inação, a um non liquet (Cf. tópico 1.2.1, supra).
} 
que, paralelamente, evoluíam outros fatores de expansão do Poder Judiciário, em processo que, como se vê, é identificável de maneira mais ou menos convergente em todas as democracias ocidentais, a incluir aquelas que mais recentemente superaram experiências autoritárias $^{120}$.

\subsubsection{Convergência das experiências jurídicas democráticas: aspectos}

\section{normativos e institucionais}

A expansão da juridificação, notadamente ao longo do século $\mathrm{XX}$, associa-se à tendencial convergência normativa e institucional das experiências jurídicas democráticas, o que alcança sistemas vinculados às tradições romano-germânica e anglosaxônica, em fenômeno praticamente consensual entre os comparatistas ${ }^{121}$. Cabe, neste tópico, examinar os aspectos dessa convergência que mais claramente contribuíram para a expansão do potencial protagonismo judicial.

\footnotetext{
${ }^{120}$ Sobre essa evolução, cite-se a seguinte exposição de Badinter: "Je vais évoquer um phénomène qui concerne toutes les démocraties occidentales - je dis bien démocraties, les choses ne se posant pás em ces termes dans les autres régimes -, à savoir la montée em puissance du juge. Aux Etats-Unis, le mouvement est depuis longtemps enraciné dans la société. Il est, em Europe, particulièrement saisissant depuis la finalmente de la Seconde Guerre mondiale pour la génération à laquelle j'appartiens. Si on compare l'importance donnèe à la Justice em France juste après la guerre - prenons comme point de départ les annés 1950, après les grandes épreuves de l'Ocupation et de la Libération - à la situation actuelle, la différence est considérable. Nous em connaissons tous les facteurs, visibles partout: la montée em puissance d'une Justice constitutionelle née aux Etats-Unis et conceptualisée, en Europe, par Kelsen. Um second fait, plus original encore à mês yeux, est la montée em puissance des juridictions internationales. Elle entraîne de multiples conséquences em matière de souveraineté desembargador Etats et remet em cause, à travers cette souveraineté, le pouvoir de ceux qui décident pour le competente desembargador Etats. Cela a abouti, à la finalmente du XX siècle, à um phénomène passionnant, la naissance de la Justice pénale internationale” (ROBERT BADINTER, “Activisme Judiciaire”, in: ROBERT BADINTER, STEPHEN BREYER (org.), op.cit., p. 17). STRECK anota, em seus estudos, que o "desejo de juridificar toda a atividade estatal levou Kelsen a criar a justiça constitucional”. Porém, o “espírito da época, 'da revolta dos juízes contra a lei’, imperante no início do novo século, leva Kelsen a criar um tribunal especial alheio a jurisdição ordinária. A desconfiança tradicional existente na Europa sobre os juízes desde a Revolução Francesa que contribuiu, por exemplo, junto a outras razoes, a configuração dos tribunais contenciosos-administrativos como tribunais especiais, se agudiza no mundo centro-europeu no inicio do século XX. É certo, sem duvida, que a criação de um tribunal constitucional acarreta certos problemas técnicos e racionaliza a justiça constitucional. Porém, sua natureza de tribunal especializado, ad hoc, situado fora da jurisdição ordinária, somente pode ser explicada plenamente por essa desconfiança política acerca dos juízes”. LENIO LUIZ STRECK, Jurisdição constitucional e hermenêtica: uma nova crítica do Direito, Porto Alegre: Livraria do Advogado, 2002, p. 306.

${ }^{121}$ Conforme destaca ELIVAL DA SILVA RAMOS, op.cit., p. 80. E, também, MAURO CAPPELLETTI, Juízes Legisladores?, op.cit., pp. 111-128.
} 


\subsubsection{Aproximação entre common law e civil law e ambivalência das}

\section{leis e dos precedentes}

Como foi visto, o aprofundamento da juridificação leva ao crescimento da judicialização de conflitos cada vez mais complexos em sociedades cujas relações se estabelecem com crescente dinamismo e nas quais as normas (gerais, especiais e “abertas”) se proliferam com foco em interesses individuais e coletivos de grande heterogeneidade. Paralelamente, à medida que a solução judicial de conflitos se desvincula de um modelo meramente subsuntivo para se alinhar a um crescente pragmatismo (2.2.4, supra), a natural proliferação de decisões discrepantes leva ao surgimento de forte pretensão estatal de controle sobre os padrões decisórios.

O empenho do Estado no combate à insegurança jurídica, fenômeno intensificado pela indeterminação das normas que ele próprio produz (2.2.1, supra), tende a ser fomentado por atores nacionais e transnacionais que exigem rapidez em ritos e processos decisórios para que estes se tornem cada vez mais instantâneos e condizentes com a simultaneidade das decisões comerciais e de investimentos. Com o incremento da previsibilidade judicial, busca-se a redução de custos, a antecipação de cenários, a equalização de oportunidades, a facilitação de transações internacionais de vários tipos e a geração de confiança no ânimo de grandes investidores ${ }^{122}$.

Com esse intuito, os países vinculados à tradição da common law, influenciados por instrumentos típicos da civil law, intensificam sua produção legislativa para enfrentar a grande incapacidade de gerar certeza. CALABRESI, comentando essa incapacidade (incapacity to provide certainty), diagnostica tendência de a fonte primordial do direito nos EUA passar a ser o statute, num processo qualificado como statutorification, perceptível, em especial, a partir do advento da experiência americana de Welfare State. Ao sustentar que a ideia de common law sofreu grande esvaziamento em sua concepção tradicional, o jurista observa que as razões da statutorification seriam muito profundas para serem revertidas. Para ele, os tribunais jamais seriam capazes de escrever com velocidade suficiente todas as regras que a sociedade contemporânea demanda. Além disso, é interessante notar que, não obstante a adoção da solução legislativa, os juízes continuam a criar o direito (to make law), seja em áreas reguladas pela common law, seja em setores

${ }^{122}$ JOSÉ EDUARDO FARIA, Sociologia jurídica - direito e conjuntura, op.cit., pp. 78-79. 
disciplinados pelos statutes, dada a imprecisão dos textos e a multiplicidade de recursos interpretativos $^{123}$.

Por sua vez, os países vinculados à tradição da civil law sofrem cada vez mais os efeitos da expansão da cultura e dos padrões legais tradicionais anglo-saxônicos, que valorizavam, até as mudanças supracitadas, a formação jurisprudencial do direito com base em precedentes e na regra do stare decisis ${ }^{124}$. Enfraquece-se, com isso, a tradição romano-germânica de apego às fontes formais do direito, à norma, às leis e aos códigos ${ }^{125}$. É verdade que, na linha do que sugerem MERRYMAN e PÉREZ-PERDOMO em seu profundo estudo comparatístico, a inexistência de uma regra formal impositiva do stare decisis na tradição da civil law nunca impediu que juízes fossem influenciados por decisões anteriores. Nesses países, ainda que decisões judiciais não sejam vistas como fontes do direito, todas elas são utilizadas como argumentos em demandas (de um e de outro lado do litígio) e referidas pelos próprios juízes e tribunais como "jurisprudência consolidada”, “dominante”, “majoritária”, muitas vezes cristalizada em enunciados que as sintetizam. Em outras palavras, o exame da prática de órgãos judiciais de vários países demonstra que suas decisões tendem a ser afetadas pela autoridade e pelo conteúdo argumentativo de decisões anteriores, sobretudo das instâncias superiores. Além disso, havendo um raciocínio oficial já construído e cristalizado, poupa-se tempo de julgamento. A percepção desse atalho tende a engendrar um provimento jurisdicional em consonância com o precedente, de forma a contornar a expectativa de que, se o julgador decidir diferentemente, sua decisão será possivelmente reformada. Assim, os autores referidos concluem que os juízes e tribunais da tradição romano-germânica não agem de forma substancialmente diferente em relação aos seus correlatos anglo-saxônicos. Indo além em

\footnotetext{
${ }^{123}$ GUIDO CALABRESI. A Common Law for the Age of Statutes. Lawbook: Nova Jersey, 1999, pp. 76, 163. Calabresi, ao examinar essa statutorification em suas origens e desdobramentos, parece se referir aos traços da juridificação examinados nos tópicos 2.2.1 e 2.2.2, inclusive em suas correlações com os temas abordados nos tópicos 2.2.3, 2.2.4 e 2.2.5, supra. Dedicando-se a problemática análoga, v. RALF MICHAELS, “American Law (United States)”, in: JAN SMITS (org.), Enciclopedia of Comparative Law. Cheltenham: Elgar, 2006, p. 69. A mesma tendência atinge países que a ela resistiram por muito tempo, como a Inglaterra. Examinando o assunto do ponto de vista histórico, desde os primeiros movimentos pela codificação do direito inglês, v. MAURICE EUGEN LANG. Codification in the British Empire and America. Nova Jersey: Lawbook, 2005.

${ }^{124}$ A expressão latina stare decisis (ou, em inglês, “to stand by things decided”) representa a doutrina dos precedentes, segundo a qual as autoridades judiciais respeitam decisões anteriores quando as mesmas questões jurídicas forem postas novamente em litígio. BRYAN GARNER (org). Black Law Dictionary, Westgroup, 1996, p. 590. Mauro Cappelletti também destaca a crescente convergência das instituições jurídicas de ambos os sistemas: os da common law, ao adotar mais e mais soluções típicas de civil law, como a positivação; e os de civil law, por sua vez, aderindo a soluções baseadas em precedentes. MAURO CAPPELLETTI, Juízes Legisladores?, op.cit., pp. 43-69.

${ }^{125}$ JOSÉ EDUARDO FARIA, Sociologia jurídica - direito e conjuntura, op.cit., pp. 78-83.
} 
sua proposta explicativa, os mesmos comparatistas destacam que, historicamente, no âmbito da common law, a substância do stare decisis estaria menos no apego a uma regra puramente formal de respeito a decisões anteriores, e mais no costume de referir precedentes pelos mais variados motivos. Desse modo, o que estaria ocorrendo com a tradição da civil law, contemporaneamente, seria uma valorização formal dos precedentes, de modo a legitimar e a estimular ainda mais essa forma de manifestação da função judicial $^{126}$.

FUNKEN, também do ponto de vista comparatístico, reforça a idéia de semelhança, nos dias de hoje, na maneira como os precedentes são utilizados em países das tradições anglo-saxônica e romano-germânica. Consoante seu estudo, observa-se que em países da tradição da civil law (Espanha, Alemanha, França, entre outros) a influência dos precedentes pode ser percebida até mesmo pela perspectiva da carreira de um juiz. Com efeito, a expectativa de que a ascensão para outro cargo possa ser prejudicada pelo insistente não acatamento de precedentes de tribunais superiores (que tendem a reformar decisões contrárias à sua jurisprudência) levaria a certo empenho dos magistrados na tomadas de decisões em consonância com orientações jurisprudenciais já fixadas ${ }^{127}$.

Destarte, se considerarmos que, de um lado, os juízes romanogermânicos sempre aplicaram precedentes; e que, de outro, os juízes anglo-saxônicos sempre puderam ignorá-los por intermédio de expedientes como o distinguishing e o overruling, a conduta de um ou de outro magistrado, substancialmente, nunca teria sido muito divergente.

Seja como for, as mudanças que se notam nos países vinculados a ambas as tradições (common law e civil law), como denominador comum do aprofundamento da juridificação, são orientadas pela busca da eliminação de incertezas decorrentes da falta de padronização decisória num cenário de fortes pressões por previsibilidade e velocidade de julgamentos.

No que concerne à tradição anglo-saxônica, isso tem sido alcançado pela adoção do direito legislado para eliminar dois “inconvenientes” da common law: primeiro, as incertezas derivadas da multiplicação descontrolada de precedentes, que podem, inclusive, ser afastados por distinguishing ou overruling; e, segundo, a insuficiência do

\footnotetext{
${ }^{126}$ JOHN HENRY MERRYMAN, ROGELIO PÉREZ-PERDOMO, The civil law tradition: an introduction to the legal systems of Europe and Latin America. $3^{\mathrm{a}}$ ed., Stanford: 2007, pp. 34 e ss.

${ }^{127}$ KATJA FUNKEN, The Best of Both Worlds - The Trend Towards Convergence of the Civil Law and the Common Law System, jul. 2003 (SSRN).
} 
dinamismo desses precedentes em relação à necessidade (muito mais dinâmica) de promover soluções rápidas, pari passu com as demandas por certeza que se renovam a cada instante.

No que se refere à tradição romano-germânica, a mesma pretensão padronizadora está presente no fortalecimento dos tribunais superiores como construtores de teses jurídicas, sobretudo aquelas que se cristalizam em enunciados de verbetes e súmulas vinculantes e não vinculantes ${ }^{128}$.

No caso de precedentes vinculantes, indicam-se sentidos autorizados para o legislado ou para o que não estiver satisfatoriamente regulado, neutralizando, de imediato, todos os sentidos que deles divirjam, “razoáveis” ou não. No caso de precedentes não vinculantes, parece clara, pelos motivos já destacados, sua grande força persuasiva ${ }^{129}$.

Consoante as lições de FERRAZ JUNIOR, na tradição romanística, em oposição à anglo-saxônica, os juízes não se vinculam às decisões dos tribunais superiores. Do mesmo modo, “cada juiz não se vincula às decisões dos demais juízes de mesma hierarquia” (podendo decidir casos semelhantes de modo diferente). Além disso, os órgãos judiciais não se vinculam nem sequer às próprias decisões, de forma que podem mudar de orientação mesmo diante de casos semelhantes. Trata-se da regra, estrutural ao sistema, da independência da magistratura judicial, segundo a qual o "juiz deve julgar

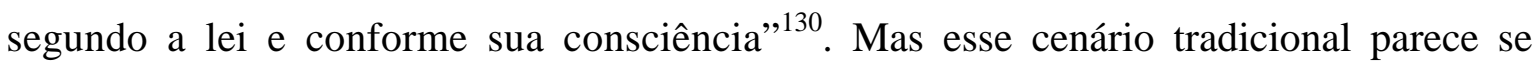
modificar pouco a pouco, inclusive com o enfraquecimento da magistratura de primeira instância (cuja atuação tende, cada vez mais, a ser limitada ao exame dos fatos e à

\footnotetext{
${ }^{128}$ No Brasil, isso parece claro, conforme veremos a seguir. No caso da Europa, esse fortalecimento também tem ocorrido. Ilustrativamente, citemos, por oportuno, o exemplo da Espanha, cujo Código Civil estabelece, no artigo 1, 6: "La jurisprudencia complementará el ordenamiento jurídico con la doctrina que, de modo reiterado, establezca el Tribunal Supremo al interpretar y aplicar la ley, la costumbre y los principios generales del derecho."(Disponível em http://civil.udg.es, acesso em 02-04-2011).

${ }^{129}$ De um lado, há súmulas vinculantes, cuja natureza é normativa, por constituírem um ato de criação, mais do que de aplicação do direito, com o que elas se desvinculam dos chamados princípios da inércia e da inafastabilidade. De outro lado, há súmulas persuasivas, que se restringem a apresentar um enunciado "propositivo-descritivo, expressando o fato de o Tribunal haver consolidado entendimento jurisprudencial sobre determinado assunto”, com a pretensão enfatizar ser inútil eventual resistência. No Brasil, as súmulas vinculantes, além de "estamparem a orientação prevalecente no âmbito do STF acerca de um determinado tema constitucional", consubstanciam "comandos dirigidos aos órgãos administrativos e judiciários, para que interpretem determinada lei ou dispositivo legal (ou constitucional) ou adotem postura quanto à validade ou eficácia de determinada lei ou dispositivo legal de modo coerente com o entendimento sumulado”. Destaque-se, com o autor, que o aspecto criativo residiria basicamente na "liberdade de escolha que se reconhece ao Supremo Tribunal Federal de editá-la (e também de modificá-la ou cancelá-la) ou não”. ELIVAL DA SILVA RAMOS, op.cit., 251-254. O autor cita, ainda, relevante estudo de Fernando Dias Menezes de Almeida, "Súmula do Supremo Tribunal Federal: natureza e interpretação". in: Revista de Direito Constitucional e Internacional. São Paulo: Revista dos Tribunais, out./dez. 2006.

${ }^{130}$ TÉRCIO SAMPAIO FERRAZ JUNIOR, Introdução ao Estudo do Direito: técnica, decisão, dominação. $4^{\mathrm{a}}$ ed., São Paulo: Atlas, 2003, p. 245.
} 
aplicação de teses desenvolvidas por instâncias superiores) e o fortalecimento de órgãos judiciais de acordo com a posição que ocupem em uma "hierarquia” judicial cada vez mais clara.

Não parece desarrazoado entrever, inclusive, certa ambivalência tanto dos precedentes (como as teses jurídicas instituídas por órgãos judiciais de cúpula no sistema romanístico) quanto da própria lei (no sistema anglo-saxônico). Isso porque ambos, transcendendo sua função originária ${ }^{131}$ que é respectivamente compositiva concreta e regulatória abstrata, passam a se orientar um ao outro: os precedentes, como mecanismos de controle das incertezas da lei (de forma a evitar que sua aplicação resulte em decisões discrepantes), adquirem os atributos de generalidade e de abstração do objeto controlado; as leis, por sua vez, como instrumentos de “domesticação” dos precedentes, tornam-se cada vez mais próximas da regulação específica de casos.

\subsubsection{A influência do ideário dos Direitos Fundamentais e dos}

\section{Direitos Humanos}

Outro fator relevante da convergência das experiências jurídicas democráticas é o desenvolvimento do ideário internacional dos Direitos Humanos e o aprofundamento da construção jurisprudencial e teórica acerca dos direitos fundamentais.

Conforme as lições comparatísticas de KUMM, os direitos humanos são tratados com status superior ao das leis nos diferentes ordenamentos democráticos. Possuem, assim, um importante papel a desempenhar no que tange à orientação da compreensão e da aplicação prática de direitos constitucionalmente garantidos que lhes sejam correlatos, i.e., as declarações de direitos fundamentais ${ }^{132}$.

A ideia de direitos humanos, ao lado do princípio da soberania popular, alimenta a “autocompreensão normativa” dos Estados Democráticos. Como denominadores finalísticos comuns, essas noções servem como fontes de justificação do direito contemporâneo. Trata-se de valores que se somam aos conteúdos que (felizmente)

\footnotetext{
${ }^{131}$ Fala-se em função originária de um precedente porque ora sua edição é antecedida de uma série de casos decididos da mesma forma, como é comum na tradição romano-germânica, de modo que seu enunciado se dirija, ainda que mediatamente, a casos concretos futuros ou ainda não decididos; ora sua constituição resulta do julgamento de um caso, como ocorre tradicionalmente nos países de common law.

${ }^{132}$ MATTIAS KUMM, "Democratic constitutionalism encounters international law: terms of engagement", in: SUJIT CHOUDHRY (org.). The Migration of Constitutional Ideas. Cambridge: Cambridge University Press, 2006, p. 257.
} 
sobreviveram depois que a substância normativa de um ethos ancorado em tradições metafísicas e religiosas passa pelo crivo das fundamentações pós-tradicionais. Esses valores atingiram um patamar tal de consagração jurídica que não mais se discute seu reconhecimento: a) como saber moral ancorado num estado natural fictício; b) como produto da vontade ético-política de uma comunidade que está se autorrealizando em decorrência de um projeto de vida autêntico; c) como reflexão kantiana que, com base no dever moral, chega ao dever jurídico; d) como decorrência de um contrato, ato existencial da socialização, por meio do qual os indivíduos singulares, voltados ao sucesso, transformam-se em cidadãos de uma comunidade ética, orientada ao bem comum; e) ou, à moda de Habermas, como “arranjo comunicativo" em que a legitimidade de uma norma se apoia em discursos racionais, vale dizer, em debates cujos participantes possam examinar se uma disposição controvertida encontra ou poderia encontrar o assentimento de todos os possíveis atingidos. Isso porque, hoje, os direitos humanos, inscritos na prática democrática como produtos da juridificação, "têm de ser interpretados a limine como direitos jurídicos, não obstante seu conteúdo moral”133.

O ideário dos direitos humanos fortalece o papel axial dos direitos fundamentais para o constitucionalismo, uma vez que alimenta a construção teórica e jurisprudencial que sobre eles se desenvolveu e se desenvolve nas mais variadas experiências jurídicas. Note-se que os chamados direitos sociais, nos EUA, desenvolveram-se com base na "equal protection clause"; na Alemanha, por uma dogmática da jurisprudência constitucional baseada em aferições de prerrogativas implícitas; em países como o Brasil e a África do Sul, pela enunciação expressa em textos de constituições mais recentes e que tendem a ser desdobrados jurisprudencialmente. Isso leva à discussão de "princípios de uma ordem jurídica geral cujo conteúdo normativo estrutura o sistema de regras em seu todo". Nesse percurso, essas teorizações se desenvolvem para tratar de temas como o conteúdo essencial desses direitos, seus limites

\footnotetext{
133 JÜRGEN HABERMAS, Direito e democracia entre Facticidade e Validade, vol. 1, op.cit., pp. 128-140. Sobre a perspectiva Kantiana, prossegue o autor: "Na sua "introdução à metafísica dos costumes, Kant (...) parte do conceito fundamental da lei da liberdade moral e extrai dela as leis jurídicas, seguindo o caminho da redução. A teoria moral fornece os conceitos superiores: vontade e arbítrio, ação e mola impulsionadora, dever e inclinação, lei e legislação, que servem inicialmente para a determinação do agir e do julgar moral. Na doutrina do direito, esses conceitos fundamentais da moral são reduzidos a três dimensões. Segundo Kant, o conceito do direito não se refere primariamente à vontade livre, mas ao arbítrio dos destinatários; abrange a relação externa de uma pessoa com outra; e recebe a autorização para a coerção, que um está autorizado a usar contra o outro em caso de abuso. O principio do direito limita o principio da moral sob esses três pontos de vista. A partir dessa limitação, a legislação moral reflete-se na jurídica, a moralidade na legalidade, os deveres éticos nos deveres jurídicos, etc.”
} 
imanentes, sua irradiação para outras esferas do Direito, sua eficácia horizontal, os deveres de proteção e de prevenção, entre outros valores que passam a ser inferidos do “caráter objetivo" reconhecido aos direitos fundamentais ${ }^{134}$.

Nesse percurso, a gradual construção de conceitos-chave de direito constitucional (razoabilidade, proporcionalidade, reserva do possível, mínimo existencial, entre outros) tem ocorrido em grande medida no âmbito do Judiciário, notadamente pela jurisprudência dos tribunais constitucionais e assemelhados ${ }^{135}$.

Desse modo, situando-se entre os desdobramentos do processo de juridificação, no que tange especificamente à sofisticação do ideário da liberdade que surge com o Estado Democrático de Direito (2.2, supra), essa evolução de ideias, de que participam órgãos judiciais das mais variadas experiências jurídicas ocidentais, constitui outra dimensão da convergência institucional e normativa sob exame.

Influenciadas pelo ideário dos direitos humanos e dos direitos fundamentais, há outras manifestações relevantes dessa tendencial convergência das experiências jurídicas democráticas, relacionadas ao compartilhamento de ideias por diferentes experiências jurídicas, como veremos no tópico seguinte.

\subsubsection{A metáfora da “migração de ideias” no direito comparado}

O modelo de democracia constitucional, em que o Poder Judiciário se consolida como o guardião da Constituição e das declarações de direitos fundamentais não só se estendeu pela Europa e pelas Américas, mas também deitou suas raízes em vários países da Ásia, da África e do Oriente Médio. Trata-se, nos dizeres de BEATTY, da “globalização de uma boa idéia”136.

\footnotetext{
${ }^{134}$ Esse panorama é apresentado por JÜRGEN HABERMAS, Direito $e$ democracia entre facticidade $e$ validade, vol. 1, op.cit., p. 307. Um exame do tema do conteúdo essencial, no direito brasileiro, está na obra de Virgilio Afonso da Silva. É interessante observar que, não obstante esse conteúdo essencial, e independentemente do pressuposto de que esses direitos gozam de uma proteção "amplíssima, ainda que prima facie", há uma tendência "a um grande aumento no número de colisões entre direitos fundamentais", o que levar à "necessidade de restrição" a esses direitos "quando isso for necessário para a solução de colisões”. Desse modo, conclui o autor, "todo direito fundamental é restringível”. VIRGílLIO AFONSO DA SILVA, Direitos fundamentais: conteúdo essencial, restrições e eficácia, op.cit., p. 253.

135 JÜRGEN HABERMAS, Direito e democracia entre facticidade e validade, vol. 1, op.cit., p. 308. No mesmo sentido, v. ROBERT BADINTER, STEPHEN BREYER, op.cit., pp. 27-28, 59, 68-71.

${ }^{136}$ DAVID M. BEATTY, The Ultimate Rule of Law, New York, Oxford University Press, 2004, p. 159. Apesar de reconhecer tais fatos, confessa sua perplexidade: “The unprecedented globalization of judicial review has occurred despite the fact that an adequate justification for making judges so powerful has still to be written". Ao descrever o paradoxo da crescente judicialização da política, observa, ironicamente: "To
} 
As constituições, documentos mais relevantes dos estados democráticos do ponto de vista jurídico e político, constituem referenciais de garantia da proteção aos direitos fundamentais, o que se dá, contemporaneamente, em diálogo com a produção normativa internacional e comunitária sobre os direitos humanos.

KUMM, considerando essa tendência evolutiva, nota um grande arrefecimento nos debates entre monistas (Kelsen e Scelle) e dualistas (Triepel e Oppenheim). Como costuma ocorrer em celeumas acadêmicas, essas discussões não terminaram com a pretendida "vitória” de um lado sobre o outro após o reconhecimento de um argumento aceito à unanimidade. Tais cizânias simplesmente se atrofiaram quando dúvidas surgiram sobre a fecundidade das questões que eram postas. Como praticamente tudo no Direito contemporâneo adota uma linha mais pragmática e menos idealista, "versões radicais" de uma ou de outra teoria foram deixadas de lado em nome da observação da prática de cada experiência jurídica, bem como das interações entre elas ${ }^{137}$.

Vistos esses parâmetros pragmáticos e diante de um cenário global de compartilhamento de modelos constitucionais consagradores de direitos da pessoa humana, a observação dessas experiências permite identificar a crescente apropriação, por juízes de um país, de materiais decisórios ou legislativos provindos de outros. No caso dos EUA, conforme narra DORSEN, pelo menos três dos mais importantes julgamentos da Suprema Corte ocorridos na última década se utilizaram parcialmente desse expediente para decidir questões versando sobre interesses de homossexuais, ações afirmativas e pena de morte. Em um ambiente tradicionalmente infenso a ideias que contrariem as tradições vinculadas ao legado dos “pais-fundadores”, naturalmente surgiram opiniões, durante tais julgamentos, radicalmente distintas. Mas há registros fiéis de manifestações de magistrados

unravel this paradox we have undertaken an extensive, though far from exhaustive, review of what the judges have been doing while the theorists have been trashing each other's work".

${ }^{137}$ MATTIAS KUMM, “Democratic constitutionalism encounters international law: terms of engagement”, op.cit., p. 257. No que tange à experiência europeia, o jurista trata da experiência com o princípio da subsidiariedade (utilizado como guia da elaboração do Tratado da Constituição da Europa, de 2004) e que, segundo ele, deve ser visto como presente no direito internacional em geral. Tratar-se-ia de um princípio "estrutural" que se aplicaria a todos os níveis de análise institucional, desde a perspectiva macroavaliativa da estrutura institucional e das possibilidades da jurisdição até a microanálise de processos decisórios ou da substância de decisões específicas. A obra The migration of constitutional ideas (SUJIT CHOUDHRY, op.cit.) reúne estudos de pesquisadores do Direito Constitucional comparado a respeito da America do Norte, Europa e Austrália, que discutem os processos dinâmicos pelos quais diferentes sistemas constitucionais sofrem influências recíprocas. É interessante observar, na obra, a abordagem de questões metodológicas relevantes (com a visão multidisciplinar do direito comparado, da ciência política comparada e de estudos culturais do direito) e o exame da complexa relação entre o constitucionalismo nacional e supranacional (sobretudo do ponto de vista da experiência europeia). Além disso, os artigos examinam casos relevantes da Austrália, Hungria, Índia, África do Sul, Reino Unido, Estados Unidos e Canadá. 
daquele tribunal, segundo aquele autor, em que se reconhece claramente a "validade" daquela prática com base na ideia de que atores que debatem direitos fundamentais (como as cortes supremas de diferentes países) estariam engajados em uma espécie de empreendimento interpretativo comum ${ }^{138}$.

Estudos comparatísticos têm referido essa prática pela metáfora da “migração” de ideias. Como destaca CHOUDHRY, tal migração envolve não só o uso do direito comparado e do direito internacional, mas, sobretudo, de julgamentos estrangeiros como uma fonte de saber prático no processo decisório de casos difíceis, mormente na hipótese de o material jurídico positivo disponível haver se esgotado, o que depende das postulações e dos fins almejados pelo órgão decisor. Seguramente, não se trata de nada muito estranho. Afinal, aqueles que agem conforme suas próprias tradições constitucionais tendem, em especial num mundo globalizado, a se interessar tanto pela forma como atores que ocupem o mesmo papel em outras experiências jurídico-constitucionais interpretam suas próprias tradições sobre a mesma matéria; quanto pela maneira como tribunais internacionais interpretam tratados de direitos humanos. Trata-se de examinar linguagens semelhantes, valores semelhantes $e$ "necessidades de sentido" semelhantes. São essas variáveis que motivam, antes mesmo de decisões judiciais serem tomadas, as influências do direito de um país na elaboração legislativa e constitucional de outro; e isto expande ainda mais o espectro dessa metáfora da "migração”, a demonstrar que ela ocorre em vários estágios dos ciclos de vida das constituições, a incluir sua gênese. Em todos os países em que isso ocorre, nota-se que demandas de justificação precisam ser satisfeitas. O problema que se põe (mesmo para experiências como a sul-africana, em que a constituição prevê expressamente o dever dos juízes de “considerar”, na interpretação de direitos fundamentais, o direito estrangeiro, comparado e internacional ${ }^{139}$ ) é o de saber

138 NORMAN DORSEN, "The relevance of foreign legal materials in U.S. constitutional cases: A conversation between Justice Antonin Scalia and Justice Stephen Breyer", in: International Journal of Constitutional Law, vol. 3, out. 2005, pp. 519-541. Ramsey, referindo-se aos EUA, fala da polêmica tentativa de utilização, nos casos Atkins v. Virginia e Lawrence v. Texas, de influentes construções jurisprudenciais europeias para expandir o escopo dos direitos constitucionais nacionais. MICHAEL RAMSEY, "International materials and Domestic Rights: Reflections on Atkins and Lawrence", in: American Journal of International Law, n. ${ }^{\circ}$ 98, 2004. Note-se, v.g., no caso brasileiro, as decisões do STF: HC 93.050, rel. Min. Celso de Mello, julg. 10-6-08, Segunda Turma, DJE de 01-8-08; HC 90.094, rel. Min. Eros Grau, julg. 8-610, Segunda Turma, DJE de 6-8-10; HC 90.298, rel. Min. Cezar Peluso, julg. 8-9-09, Segunda Turma, DJE de 16-10-09. (MS 24.510, rel. Min. Ellen Gracie, voto do Min. Celso de Mello, julg. 19-11-2003, Plenário, DJ de 19-3-2004.)

${ }^{139}$ Prescreve o item 39 da Constituição Africana (Interpretation of Bill of Rights): "1. When interpreting the Bill of Rights, a court, tribunal or forum a. must promote the values that underlie an open and democratic society based on human dignity, equality and freedom; b. must consider international law; and c. may consider foreign law.2. When interpreting any legislation, and when developing the common law or 
como esse uso será feito. Nas discussões a respeito, surgirá, possivelmente, além da alegação de que tal uso constituiria uma espécie de ativismo judicial, um questionamento sobre eventual “erosão” da soberania pelas “forças da globalização” e pelas experiências supranacionais de constitucionalização (como ocorreu com as discussões em torno da Constituição Europeia) $)^{140}$.

Apesar dessas resistências, a migração de ideias emerge como um dos fatores mais importantes da prática constitucional contemporânea, e se esboça com grande força no âmbito do Judiciário, entre diferentes jurisdições e também no âmbito internacional $^{141}$.

A materialização e a indeterminação do direito (2.2.1 e 2.2.2, supra), ao conferirem grande poder criativo e discricionariedade aos juízes, tendem a aprofundar o fenômeno. Para decidir, é frequentemente útil consultar a jurisprudência de outros países cujos juízes já se defrontaram com problemas similares. A jurisprudência estrangeira pode também ser relevante em outras situações. Com efeito, um argumento segundo o qual uma noção ou um princípio implícito (mínimo existencial, reserva do possível, entre outros) seria necessário para complementar os propósitos constitucionais pode ser testado em referência à experiência de outros países cujas constituições desvelem os mesmos propósitos. Assim, os juízes tendem a ser guiados pelo que aparenta ser a "melhor prática” decisória, como destaca GOLDSWORTHY ${ }^{142}$.

Desse modo, o reconhecimento da possibilidade dessa migração de ideias (como resultado da expansão do modelo de democracia constitucional) poderá, a

customary law, every court, tribunal or forum must promote the spirit, purport and objects of the Bill of Rights.2. The Bill of Rights does not deny the existence of any other rights or freedoms that are recognised or conferred by common law, customary law or legislation, to the extent that they are consistent with the Bill". Disponível em www.info.gov.za, acesso em 24-04-11.

${ }^{140}$ SUJIT CHOUDHRY, op.cit., pp. 3-14, 158. O Brasil, nesse sentido, também não se distancia, em matéria de proteção aos direitos humanos, do caso sul-africano, dado o teor do $\S 5^{\circ}$ do artigo $2^{\circ}$ da Constituição, potencializado pela tese da supralegalidade dos tratados com esse objeto. STF. RE 466.343, rel. Min. Cezar Peluso, voto do Min. Gilmar Mendes, julg. 3-12-08, Plenário, DJE de 5-6-09. Descortina-se, assim, novos horizontes para o uso do "direito comparado" no Direito do Trabalho, conforme prevê o artigo $8^{\circ}$ da CLT.

141 SUJIT CHOUDHRY, op.cit., p. 13. No direito comparado, é conhecida, igualmente, a metáfora do "transplante" (legal transplant); e, no direito constitucional comparado, a metáfora do empréstimo (constitutional borrowing).

${ }^{142}$ No original: "Foreign jurisprudence may be relevant in other situations too. For example, any argument that an implied principle is necessary to fulfill one of the constitution's purposes (such as federalism, democracy, or the separations of powers) could possibly be tested by reference to experience in other countries whose constitutions have the same purpose (...) judges can legitimately be guided by what appears to be international 'best practice'(...)". JEFFREY GOLDSWORTHY. "Questioning the Migration of Constitutional Ideas: Rights, Constitutionalism and the Limits of Convergence", in: SUJIT CHOUDHRY (ed.), op.cit., pp. 140-141. 
depender da "permeabilidade" de cada experiência jurídica, fortalecer o potencial protagonismo judicial.

\subsubsection{A ideia de proporcionalidade}

A ideia de proporcionalidade, segundo relata GRIMM, teria sido criada pela jurisprudência do tribunal constitucional alemão (Bundesverfassungsgericht - BVG) com base na interpretação de disposições de uma Constituição que, em lugar de reconhecer amplamente direitos de liberdade e de igualdade, oferece um catálogo de direitos fundamentais instituídos como resposta às experiências totalitárias do passado. Por predominar nessas disposições protetivas uma série de noções vagas, o espectro de seu alcance precisou ser definido no momento da aplicação, o que poderia implicar sua ampliação ou sua redução ${ }^{143}$.

No exercício desse poder (ou, em outros termos, desse potencial protagonismo judicial) de ampliar ou de reduzir esses direitos, a Corte constitucional optou pela primeira orientação. Assim, pela expansão jurisprudencial da ideia de in dubio pro libertate, foram identificadas e colmatadas várias lacunas no texto constitucional. A base dessa operação foi uma garantia extraordinariamente ampla, constante do artigo 2, seção 1, da Lei Fundamental, segundo a qual todos terão o direito ao desenvolvimento livre de sua personalidade ("Jeder hat das Recht auf die freie Entfaltung seiner Persönlichkeit, soweit er nicht die Rechte anderer verletzt und nicht gegen die verfassungsmäßige Ordnung oder das Sittengesetz verstößt”). Como essa disposição era reconhecida como meio de oferecer tutela a toda e qualquer situação que envolvesse direitos fundamentais não protegidos explicitamente, criaram-se condições de amparo contra ameaças não consideradas à época em que a Constituição fora instituída. Foi o que ocorreu, ilustrativamente, com o direito à reputação, à orientação sexual, à privacidade e à autodeterminação informativa (Informationelle Selbstbestimmung), esta última idealizada para proteger os indivíduos contra ameaças derivadas do processamento eletrônico de dados. A mesma tendência expansiva se manifestou no reconhecimento de garantias contra ameaças à saúde das

\footnotetext{
${ }^{143}$ Ilustrativamente, esta proposição bem se conforma à chamada teoria dos princípios. Como explica Virgilio Afonso Da Silva, o principal traço distintivo entre regras e princípios, "segundo a teoria dos princípios, é a estrutura dos direitos que essas normas garantem. No caso das regras, garantem-se direitos (ou se impõem deveres) definitivos, ao passo que no caso dos princípios são garantidos direitos (ou são impostos deveres) prima facie.” VIRGÍLIO AFONSO DA SILVA, Direitos fundamentais: conteúdo essencial, restrições e eficácia. op.cit., p. 45.
} 
pessoas. Para isso, recorreu-se ao artigo $2^{\circ}$, seção 2, da Constituição Alemã, que afirmava o direito à vida e à integridade física (Jeder hat das Recht auf Leben und körperliche Unversehrtheit; die Freiheit der Person ist unverletzlich; in diese Rechte darf nur auf Grund eines Gesetzes eingegriffen werden). A interpretação desse conjunto de disposições levou, assim, a restrições contra a energia nuclear, as experiências genéticas e a poluição $^{144}$.

Ao longo desse processo jurisprudencial construtivo, a ideia de proporcionalidade surgiu para dar tratamento à premissa constitucional de que, por não haver direitos absolutos, o legislador poderia limitá-los com maior ou menor grau de detalhamento. Com base nessa premissa, a BVG se valeu da disposição, aplicável a todos os direitos fundamentais, constante do artigo 19, seção 2, da Constituição Alemã, que estatui regra de que em nenhum caso a limitação pode afetar a essência do direito que estiver em jogo (In keinem Falle darf ein Grundrecht in seinem Wesensgehalt angetastet werden). Para conter o poder de limitação amplo que o texto reconhece aos legisladores, a jurisprudência constitucional deu prioridade à tutela de direitos fundamentais em relação a qualquer lei que pretendesse restringi-los. O surgimento da ideia de proporcionalidade traduz precisamente essa prioridade, ao estabelecer que qualquer lei limitadora de direitos fundamentais só seria constitucional se respeitasse, a um só tempo, os seguintes requisitos (1) adequação; (2) necessidade para alcançar determinado propósito e; (3) balanço (ponderação) razoável entre o direito fundamental limitado pela lei, de um lado, e o bem em nome do qual a limitação é realizada, de outro.

A aplicação da ideia de proporcionalidade fortaleceu a barreira contra a ação governamental, já que a maioria dos casos envolvendo direitos fundamentais passou a ser decidido com base nessa orientação, com ênfase no “teste” decisivo da ponderação das escolhas, que dá grande discricionariedade aos juízes e instrumentaliza a manifestação do potencial protagonismo judicial. De início, decisões que se utilizavam da proporcionalidade foram dirigidas à proteção de direitos individuais contra interferências governamentais limitadoras da liberdade.

\footnotetext{
${ }^{144}$ Em outros países, Grimm também cita o esforço da Suprema Corte de Israel, que, na ausência de uma declaração de direitos fundamentais, deduziu-a do princípio democrático. DIETER GRIMM, "L’activisme judiciaire”, in: ROBERT BADINTER, STEPHEN BREYER, op.cit., pp. 23-35.
} 
Em $1958^{145}$, entretanto, em decisão paradigmática no chamado caso Lüth $^{146}$, a Corte passou a entender os direitos fundamentais não só como direitos subjetivos destinados à defesa contra atos do governo que violassem garantias constitucionais; mas também como princípios objetivos presentes na totalidade da ordem jurídica (que traduziria uma ordem de valores objetivos, objektive Wertordnung), como vetores para a criação e para a aplicação da lei pelos magistrados. De um lado, a decisão do caso alargava a influência das disposições constitucionais sobre as leis, que ocorreria tanto no momento de sua criação quanto, tendo em vista o chamado efeito de irradiação (Ausstrahlungswirkung), no átimo de sua interpretação e aplicação. De outro lado, ampliava-se a ideia de direitos fundamentais, uma vez que, conforme o entendimento então desenvolvido, o conjunto dessas prerrogativas constituiriam imposições, ao Estado, não apenas de abstenções (direitos negativos), mas também de ações para estabelecer ou para manter a liberdade no segmento da realidade social em que certo direito fundamental devesse produzir seus efeitos (direitos positivos). A liberdade, desse modo, não seria exclusivamente liberdade individual, mas liberdade institucional, coletiva e social.

Essa interpretação dos direitos fundamentais orientada por valores tornou muito relevantes os deveres governamentais e legislativos de proteger as liberdades constitucionais quando estas são ameaçadas, inclusive na hipótese de tal ameaça surgir na

\footnotetext{
${ }^{145}$ Note-se, a propósito, que se trata de decisão tomada quatro anos depois de solucionado o caso Brown $v$. Board of Education, de 1956, nos EUA.

146 “O cidadão alemão Erich Lüth, conclamou , no início da década de cinquenta (à época crítico de cinema e diretor do Clube da Imprensa da Cidade Livre e Hanseática de Hamburgo), todos os distribuidores de filmes cinematográficos, bem como o público em geral, ao boicote do filme lançado à época por Veit Harlan, uma antiga celebridade do filme nazista e co-responsável pelo incitamento à violência praticada contra o povo judeu (principalmente por meio de seu filme 'Jud Süß', de 1941). Harlan e os parceiros comerciais do seu novo filme (produtora e distribuidora) ajuizaram uma ação cominatória contra Lüth, com base no § 826 BGB. O referido dispositivo da lei civil alemã obriga todo aquele que, por ação imoral, causar dano a outrem, a uma prestação negativa (deixar de fazer algo, no caso, a conclamação ao boicote), sob cominação de uma pena pecuniária. Esta ação foi julgada procedente pelo Tribunal Estadual de Hamburgo. Contra ela, ele interpôs um recurso de apelação junto ao Tribunal Superior de Hamburgo e, ao mesmo tempo, sua Reclamação Constitucional, alegando violação do seu direito fundamental à liberdade de expressão do pensamento, garantida pelo Art. 5 I 1 GG. O TCF julgou a Reclamação procedente e revogou a decisão do Tribunal Estadual. Trata-se, talvez, da decisão mais conhecida e citada da jurisprudência do TCF. Nela, foram lançadas as bases não somente da dogmática do direito fundamental da liberdade de expressão e seus limites, como também de uma dogmática geral (Parte Geral) dos direitos fundamentais. Nela, por exemplo, os direitos fundamentais foram, pela primeira vez, claramente apresentados, ao mesmo tempo, como direitos públicos subjetivos de resistência, direcionados contra o Estado e como ordem ou ordenamento axiológico objetivo. Também foram lançadas as bases dogmáticas das figuras da Drittwirkung e Ausstrahlungswirkung (eficácia horizontal) dos direitos fundamentais, do efeito limitador dos direitos fundamentais em face de seus limites (Wechselwirkung), da exigência de ponderação no caso concreto e da questão processual do alcance da competência do TCF no julgamento de uma Reclamação Constitucional contra uma decisão judicial civil.” Excerto extraído de JÜRGEN SCHWAB. Cinquenta anos de Jurisprudência do Tribunal Constitucional Alemão. Org. Leonardo Martins. Montevidéu: Konrad Adenauer, 2005, pp. 381-382.
} 
própria sociedade. Ademais, a ideia de “dever de proteção” (Schutzpflicht) fez avultar a problemática da abstenção legislativa em relação a vários temas de reconhecida repercussão sobre os direitos fundamentais (v.g., as ameaças trazidas pelas inovações tecnológicas, pela energia nuclear e pela manipulação genética).

O cumprimento de tal dever protetivo não se restringiria à regulação da matéria, já que não se poderia ignorar a necessidade de uma estrutura organizacional adequada à promoção do propósito da garantia constitucional e de regras procedimentais que, diante da dificuldade de formular normas substanciais para certos casos, fomentassem decisões sempre orientadas pelo valor-liberdade. Em outras palavras, a obrigação de legislar a fim de manter a liberdade se estendeu gradativamente às precondições do exercício de direitos fundamentais, particularmente nas áreas em que esse exercício, além da vontade individual, dependesse da existência de pré-requisitos legais ou sociais. Ilustrativamente, a educação seria um pré-requisito do exercício da livre escolha da profissão, assim como o auxílio estatal (v.g. a assistência aos necessitados e outras matérias em torno das quais se discutem políticas públicas) constituiria um pré-requisito para a fruição de várias outras garantias fundamentais.

Sem dúvida, subsistiria uma diferença incontornável de alcance entre direitos fundamentais em sua dimensão negativa e positiva. De um lado, as obrigações que as liberdades negativas impõem ao Estado só podem ser alcançadas de um modo: a abstenção. O controle de constitucionalidade, no caso, limita-se a verificar se essa abstenção foi respeitada e à anulação da eventual ação contrária a esse dever. De outro lado, as obrigações decorrentes das liberdades positivas podem ser cumpridas de várias formas, desde que estejam em harmonia com a Constituição, que não prescreve um modo específico para sua realização. O controle de constitucionalidade, nesse caso, verifica se o Legislativo atuou contrariamente à ameaça contra certa liberdade, e se a solução adotada tem aptidão para evitar prejuízos indesejados. Isso pode levar ao afastamento da lei, não porque ela exagerou na restrição de determinado direito fundamental, mas porque ela teria feito menos do que deveria fazer para protegê-lo. Esse processo desvela, em última análise, um estreitamento do espaço para a decisão política e um crescimento do domínio do Judiciário, que por intermédio da noção de proporcionalidade ampliou o significado da Constituição. Ao se distanciar do entendimento original a respeito de seus preceitos, a 
BVG promoveu “emendas” muito mais relevantes do que as formalmente editadas pelo Legislativo $^{147}$.

O desenvolvimento da noção de proporcionalidade (e da construção jurisprudencial a ela atrelada) constitui exemplo relevante de manifestação do potencial protagonismo judicial. Relacionada a vários aspectos da juridificação examinados nos tópicos anteriores deste capítulo, essa noção, movida pela convergência das experiências jurídicas democráticas, tem influenciado a prática jurisprudencial de vários outros países, a incluir o Brasil.

Há diagnósticos, em estudos comparatísticos, de convergência mundial da prática jurisprudencial (notadamente a de conotação constitucional) em torno da ideia de proporcionalidade ${ }^{148}$. Independentemente de se tratar de “critério” ou "princípio”, busca-se, com ela, uma resposta “correta” ou, no mínimo uma resposta que se possa considerar adequada, mesmo que se reconheça a incomensurabilidade de muitos bens jurídicos em jogo e a incalculabilidade dos resultados finais de determinada decisão. Podese entrever, assim, no desenvolvimento dessa idéia, uma tentativa de conciliação entre as éticas da convicção e da responsabilidade (2.2.4.1, supra).

Para HABERMAS, a proporcionalidade constitui um dos “conceitoschave do direito constitucional” contemporâneo, engendrado por uma mudança na ideia de direitos fundamentais, resultante, em última análise, da ordem jurídica materializada do Estado Social (2.2.2, supra) ${ }^{149}$.

\footnotetext{
${ }^{147}$ Nesses parágrafos, tentou-se sumariar a riquíssima descrição de DIETER GRIMM, "L’activisme judiciaire”, in: ROBERT BADINTER, STEPHEN BREYER, op.cit., pp. 23-35.

${ }^{148}$ DAVID BEATTY, op.cit., pp. 159-160. Sobre o uso do princípio da França, em especial pelo Conseil d'Etat, v. ROBERT BADINTER. No original, observa o jurista que se trata de "instrument commode, très ancien chez nous - le Conseil d'Etat l'utilise depuis bien longtemps -, qui permet au juge de choisir au nom de la proportionnalité. C'est un très grand avantage pour lui." op.cit., pp. 70-71.

149 JÜRGEN HABERMAS, Direito e democracia entre facticidade e validade, vol. 1, op.cit., pp. 306-307. Essa dogmática implícita dos direitos fundamentais (em torno do qual, como se vê, desenvolveu-se o ideário da proporcionalidade) faz jus, segundo Habermas, ao fato de que "o sistema de direitos não pode mais ser garantido na base tradicional de uma sociedade econômica liberada, que se reproduz espontaneamente através das decisões particulares autônomas privadas, devendo, ao invés disso, ser concretizado através das realizações de um Estado que dirige reflexivamente, que prepara infraestruturas e afasta perigos, que regula, possibilita e compensa. Nas sociedades complexas, com sistemas parciais diferenciados horizontalmente e interligados, o efeito protetor dos direitos fundamentais não atinge apenas o poder administrativo, mas também o poder social das organizações superiores. Além do mais, o efeito protetor não pode mais ser entendido como algo meramente negativo, como defesa contra ataques, uma vez que fundamenta também pretensões e garantias positivas. Por isso, as decisões do Tribunal Constitucional Federal qualificam os direitos fundamentais como princípios de uma ordem jurídica geral, cujo conteúdo normativo estrutura o sistema de regras em seu todo. A partir daí, a dogmática alemã dos direitos fundamentais ocupa-se principalmente com o 'conteúdo essencial' dos direitos intocáveis e as simples leis; com os 'limites imanentes' dos direitos humanos, que atingem também os direitos público-subjetivos absolutamente válidos; com a 'irradiação' dos direitos fundamentais para todas as esferas do direito; com os encargos da ação,
} 


\subsubsection{O ideário do juiz ativo: origens, influências e expansão mundial}

O modelo programático seminal do “juiz ativo” foi idealizado por KLEIN, na Áustria da última década do século $\mathrm{XIX}^{150}$. O jurista entendia que o fortalecimento do papel ativo do juiz seria a solução para problemas como a falta de celeridade e os altos custos do processo. Ao se insurgir contra o modelo processual liberal, Klein defendia a oralidade, a celeridade, a simplificação dos ritos, a busca da verdade real e a facilitação do acesso à justiça, de forma a valorizar o processo como uma instituição pública de bem-estar social (Wohlfahrtseinrichtung). Nele, os juízes teriam um papel central $^{151}$.

Klein inaugurava, com sua obra, uma influente linha de pensamento sobre a função social do processo, sua estrutura e os poderes instrumentais do juiz. O

deveres de proteção e de prevenção do Estado, que podem ser inferidos do caráter jurídico objetivo dos direitos fundamentais, como princípios elementares de ordem; finalmente, com a 'proteção dinâmica do direito fundamental' e com o processo que liga o conteúdo subjetivo e objetivo do direito fundamental".

${ }^{150}$ A expansão do ideário do juiz ativo poderia ser examinada no tópico anterior, por se tratar de outro aspecto (de ordem processual) da convergência normativa e institucional das experiências jurídicas democráticas. Todavia, a progressiva harmonização dos modelos processuais ao redor desse ideário, por sua grande relevância como desdobramento da juridificação, merecerá exame neste tópico específico.

${ }^{151}$ FRANZ KLEIN, Zeit-und Geistesströmungen im Prozesse. Frankfurt am Main: Vittorio Klostermann, 1958. Não obstante a publicação de 1958, o texto original é de 1901. Não se pode olvidar, nesse percurso evolutivo da ciência processual, o nascimento desta na obra de Von Bülow sobre exceções e pressupostos processuais, de 1868. Como destaca Dinamarco, a obra de Von Bülow “foi uma revolução”, por destacar que “entre o juiz e as partes” haveria uma "relação, progressiva sim, mas verdadeira relação jurídica, por força da qual, de um lado, o juiz assume a concreta obrigação de decidir e realizar o direito deduzido em juízo; e, de outro, as partes ficam obrigadas, perante ele, a prestar uma colaboração indispensável e a submeter-se aos resultados dessa atividade comum”. CÂNDIDO RANGEL DINAMARCO, Fundamentos do processo civil moderno, $5^{\mathrm{a}}$ ed., tomo I, São Paulo: Malheiros, 2002, pp. 41-42. O mesmo autor destaca, com grande lucidez, que "ninguém consegue, de um salto, renegar toda uma cultura sedimentada e passar para uma dimensão diversa, um plano estanque, imune a todo e qualquer influxo das doutrinas precedentes”. Desse modo, obviamente, assim como Von Bülow, que se referia às ideias seminais de Bethmann-Hollweg, Klein teve seus antecessores, contemporâneos e sucessores que auxiliaram na co-construção das bases científicas do direito processual. Assim, podem ser esquecidos nomes de destaque como Windscheid, Muther, Calamandrei, Carnelutti, Chiovenda, Fazzalari, Wach, Capograssi, Satta, Ascarelli, Liebman e, entre muitos outros, o próprio Kelsen. Referir todo esse processo evolutivo e todos os seus principais artífices, entretanto, refoge ao objetivo desta tese. Nessa linha, a ênfase que esta tese dá à obra de Klein se justifica não por um eventual desapreço a qualquer outro jurista, ou mesmo à riquíssima construção doutrinária do processo civil brasileiro, em diálogo, sobretudo, com o direito processual italiano; mas ao destaque que o autor dá à figura do juiz e à maneira como suas ideias, nesse particular, desenvolveram-se em todo o mundo. Outra obra importante de KLEIN, intitulada Pro Futuro, anterior à reforma processual austríaca de 1895, foi publicada, conforme destaca RHEE, em 1891, como uma espécie de proposta programática em que ele sintetizava as linhas mestras das ideias que defendia. C.H. VAN RHEE, REMME VERKERK, “Civil Procedure”, in: JAN SMITS (org.), Enciclopedia of Comparative Law, op.cit., p. 123. O autor cita uma tentativa ainda mais remota (malsucedida, entretanto) de fortalecer o papel ativo do juiz: "An early but in the end unsuccessful attempt to introduce an active judge was the First Book of the Corpus Iuris Fridericianum of Frederic the Great of Prussia, dating from 1781.” A destacar, igualmente, a importância da obra de Klein, v. MAURO CAPPELLETTI, BRYANT GARTH, Acesso à Justiça, op.cit., p. 77. Por detrás da ideia de juiz ativo, afigurava-se a percepção de que os institutos processuais deveriam evoluir de acordo com o desenvolvimento cultural dos povos. 
modelo proposto pelo jurista conduziu à elaboração do Código de Processo Civil austríaco de 1895 e serviu como diretriz para todas as transformações no direito processual ocidental ao longo do século $\mathrm{XX}^{152}$. Com efeito, nos sistemas processuais de diferentes países ocorreram alterações convergentes que aproximaram ainda mais as tradições romanogermânica e anglo-saxônica, obscurecendo, inclusive no processo, as fronteiras tradicionais entre common law e civil law $w^{153}$.

No final da década de 1980, em confessado diálogo com Klein, CAPPELLETTI $^{154}$ evocava a ideia de processo como um espelho no qual se refletiriam as grandes questões sobre a liberdade, a justiça e a relação entre os indivíduos, os grupos, as sociedades e os Estados. Assim, o jurista italiano refletia sobre a evolução do direito processual após a Segunda Guerra Mundial e o impacto do ideário do Estado Social sobre o crescimento do papel, dos poderes e das responsabilidades dos juízes. Paralelamente ao aumento da confiança depositada no Judiciário como defensor das constituições e dos direitos fundamentais, esse ideário levou ao crescimento das demandas por acesso à justiça, à constitucionalização de garantias processuais, à percepção de conflitos

\footnotetext{
${ }^{152}$ Destacando as influências da experiência pioneira do Código Austríaco de 1895, v., entre outros autores, MAURO CAPPELLETTI, "Governmental and Private Advocates for the Public Interest in Civil Litigation: a Comparative Study", in: Michigan Law Review, n. ${ }^{\circ} 793,1975$, p. 832. E destaca o autor: "This phenomenon of procedural publicization has occurred, to a greater or lesser extent, in many of the civil-law countries of Europe. Austria was the forerunner in 1895. As for the common-law world, there is evidence that centurieslong tradition has favored a certain measure of judicial control".

153 "Apart from the above projects, it seems that systems of civil procedure have a tendency to converge 'naturally' as a result of the increasing interaction between the systems. There is, for example, reason to believe that the divide between common law and civil law countries is narrowing. The forms of action that set civil procedure in civil and common law countries apart have been abandoned in most, if not all, common law jurisdictions during the 19th and 20th centuries. Apart from the United States of America, the AngloAmerican civil jury has nearly disappeared from the legal landscape.Written elements gain in importance in civil litigation in common law countries (e.g., witness statements in England which may serve as an alternative for examination in chief). (...) Currently, the adversarial system is under attack. England has witnessed a major reform in this respect. As stated above, the role of the judge has been strengthened in that country, giving him extensive case-management powers. Consequently, the English judge has become much more like his Continental European counterpart". No mesmo sentido, o seguinte excerto: "More successful was the procedural model advocated in Austria by Franz Klein (1854-1926) at the end of the 19th century. This model became the focus of attention in Continental Europe and beyond (Jelinek, 1991). In his programmatic work Pro Futuro Klein stated, amongst other things, that an active judge would be a solution to undue delay and high costs (Klein, 1891). The judge should establish the 'substantive truth' instead of basing his judgment on the truth as fabricated by the parties (the 'formal truth'). Klein's 1895 Code of Civil Procedure became very influential outside Austria and paved the way to an approach of civil procedural law which at the end of the 20th century even became popular in England with its traditionally adversarial model of civil litigation. The 1999 English Civil Procedure Rules are the result of this development”. C.H. VAN RHEE, REMME VERKERK, “Civil Procedure”, in: JAN SMITS (org.), Encyclopedia of Comparative Law, op.cit., pp. 123-135.

${ }^{154}$ MAURO CAPPELLETTI, "Trends of 'Procedural Justice in Contemporary Europe’", op.cit., pp. 61-63.
} 
metaindividuais, ao surgimento de novas formas de adjudicação e à discussão sobre uma possível internacionalização de padrões processuais ${ }^{155}$.

Note-se que, contemporaneamente, alinhadas a todas essas preocupações, há relevantes propostas de harmonização internacional e nacional de diferentes sistemas processuais, como forma de reduzir, em diferentes sistemas, os riscos de resultados substancialmente discrepantes (2.2.7.1, supra).

Com efeito, a UNIDROIT (International Institute for the Unification of Private Law), em 2004, enunciou uma série de 31 princípios de um processo civil transnacional (Principles of transnational Civil Procedure). Essas diretrizes, de cuja confeç̧ão participaram influentes processualistas do mundo todo, buscam reconciliar diferenças entre várias regras nacionais de direito processual para facilitar a solução de disputas internacionais e fomentar reformas uniformizadoras de normas processuais de diferentes ordenamentos jurídicos. Entre os vários pontos abordados no documento (como o fomento ao uso da tecnologia e dos meios eletrônicos), o princípio 14, que trata da “responsabilidade pela condução do processo”, recomenda que, o quanto antes, os órgãos judiciais nacionais implantem mecanismos efetivos para "administrar ativamente o curso do processo, exercendo sua prudência para alcançar a resolução dos conflitos de modo justo, eficiente e com tempo razoável”156.

Desse modo, os poderes e responsabilidades atribuídas ao juiz para a promoção do desenvolvimento ordenado, rápido e efetivo do processo têm se ampliado consideravelmente. As atribuições do magistrado, considerada a dimensão pública do processo, abrangem não apenas o controle formal do procedimento, mas também a busca da verdade, a determinação do escopo do litígio e a tomada de iniciativas que independem das alegações e das postulações das partes. Desse modo, visualiza-se no processo um ingrediente "público” sempre presente e potencialmente preponderante, a explicar o porquê do fomento à busca de provas ex officio; à concessão, em determinados casos, de mais do que fora postulado; à recusa de determinados tipos de propostas conciliatórias formuladas pelas partes; e a outras medidas processuais que podem ser serem empreendidas independentemente de provocação dos litigantes.

\footnotetext{
${ }^{155}$ MAURO CAPPELLETTI, "Trends of 'Procedural Justice in Contemporary Europe'", op.cit., pp. 63-65. 156 "Commencing as early as practicable, the court should actively manage the proceeding, exercising discretion to achieve disposition of the dispute fairly, efficiently, and with reasonable speed". Destacando essas tendências, v., outrossim, C.H. VAN RHEE, REMME VERKERK, “Civil Procedure”, in: JAN SMITS (org.), Encyclopedia of Comparative Law, op.cit., p. 130.
} 
O modelo de Klein, idealizado há mais de um século, ao orientar a evolução do direito processual como fonte de inspiração de todas as reformas na legislação processual dos países vinculados à tradição romano-germânica, estendeu seus reflexos, como veremos, ao direito brasileiro ${ }^{157}$. Mais recentemente, esse ideário também influenciou as reformas processuais operadas em países vinculados à tradição anglosaxônica, como os EUA (nas alterações das Federal Rules of Civil Procedure ${ }^{158}$ ), e a

157 Também sobre a influência de Klein, de uma perspectiva comparatística, v. C. H. VAN RHEE, “Civil Litigation in Twentieth Century Europe”, in: Buffalo Law Review, vol. 11, pp. 78-100. Para estudo ainda mais aprofundado e abrangente dessa tendência à harmonização de sistemas, v. C.H. VAN RHEE, REMME VERKERK, “Civil Procedure”, in: JAN SMITS (org.), Encyclopedia of Comparative Law, op.cit., pp. 130. No Brasil, v. HUMBERTO THEODORO JUNIOR, DIERLE NUNES, ALEXANDRE BAHIA, "Breves Considerações sobre a politização do Judiciário e sobre o panorama de aplicação no direito brasileiro análise da Convergência entre o civil law e o common law e dos problemas da padronização decisória”, in: Revista de Processo, Ano 35, n. ${ }^{\circ}$ 189, nov. 2010, pp. 10-52.

${ }^{158}$ Nesse sentido, v. C.H. VAN RHEE, REMME VERKERK, “Civil Procedure”, in: JAN SMITS (org.), Encyclopedia of Comparative Law, op.cit., pp. 124-130. Tratando da emergência do case management e da ideia de managerial judges, $v$. JUDITH RESNIK, "Managerial Judges”, in: Harvard Law Review, 96, 1982, p. 376. Do artigo, destaquem-se os seguintes excertos, que tratam claramente dessa mudança: "Until recently, the American legal establishment embraced a classical view of the judicial role. Under this view, judges are not supposed to have an involvement or interest in the controversies they adjudicate. Disengagement and dispassion supposedly enable judges do decide cases fairly and impartially. (...) Many federal judges have departed from their earlier attitudes; they have dropped the relatively desinterested pose to adopt a more active, 'managerial' stance. In growing numbers, judges are not only adjudication the merits of issues presented to them by litigants, but also are meeting with parties in chambers to encourage settlement of disputes and to supervise case preparation. Both before and after the trial, judges are playing a critical role in shaping litigation and influencing results.” No caso dos EUA, esse ideário orienta a previsão do artigo 16 da Federal Rules of Civil Procedure e dá substância finalística às pretrial conferences, ao scheduling e ao chamado do case management. Do dispositivo, importa destacar, ilustrativamente, algumas regras: "Rule 16. Pretrial Conferences; Scheduling; Management (a) Purposes of a Pretrial Conference. In any action, the court may order the attorneys and any unrepresented parties to appear for one or more pretrial conferences for such purposes as: (1) expediting disposition of the action; (2) establishing early and continuing control so that the case will not be protracted because of lack of management; (3) discouraging wasteful pretrial activities; (4) improving the quality of the trial through more thorough preparation, and; (5) facilitating settlement. (b) Scheduling. (1) Scheduling Order. (...) The judge must issue the scheduling order as soon as practicable(...) The scheduling order must limit the time to join other parties, amend the pleadings, complete discovery, and file motions. (...) A schedule may be modified only for good cause and with the judge's consent. (...) At any pretrial conference, the court may consider and take appropriate action on the following matters: (A) formulating and simplifying the issues, and eliminating frivolous claims or defenses; (B) amending the pleadings if necessary or desirable; (C) obtaining admissions and stipulations about facts and documents to avoid unnecessary proof, and ruling in advance on the admissibility of evidence; (D) avoiding unnecessary proof and cumulative evidence, and limiting the use of testimony under Federal Rule of Evidence 702; (E) determining the appropriateness and timing of summary adjudication under Rule 56; (F) controlling and scheduling discovery, including orders affecting disclosures and discovery under Rule 26 and Rules 29 through 37; (G) identifying witnesses and documents, scheduling the filing and exchange of any pretrial briefs, and setting dates for further conferences and for trial; $(\mathrm{H})$ referring matters to a magistrate judge or a master; (I) settling the case and using special procedures to assist in resolving the dispute when authorized by statute or local rule; $(\mathrm{J})$ determining the form and content of the pretrial order; $(\mathrm{K})$ disposing of pending motions; (L) adopting special procedures for managing potentially difficult or protracted actions that may involve complex issues, multiple parties, difficult legal questions, or unusual proof problems; (M) ordering a separate trial under Rule 42(b) of a claim, counterclaim, crossclaim, thirdparty claim, or particular issue; (N) ordering the presentation of evidence early in the trial on a manageable issue that might, on the evidence, be the basis for a judgment as a matter of law under Rule 50(a) or a judgment on partial findings under Rule 52(c); (O) establishing a reasonable limit on the time allowed to present evidence; and (P) facilitating in other 
Inglaterra (sobretudo na edição das Civil Procedure Rules and Practice Directions for civil litigation).

RESNIK, ao examinar a mudança ocorrida na experiência dos EUA, destaca que, no direito processual daquele país, a abordagem adversarial e o passivismo do magistrado deram lugar a um tipo de processo no qual os juízes atuam de forma determinantemente ativa, seja em conflitos rotineiros, seja em litígios complexos, de interesse público (public law litigation, cf. 2.2.9, infra). Em muitos desses casos, as demandas pretendem desencadear reformas estruturais (structural reform cases) institucionais e sociais, de modo que, se as postulações são acolhidas, espera-se do magistrado um papel de supervisão e controle (nesse sentido, o autor fala em managerial judges) durante o processo (pretrial phases) e após a decisão (postdecision judicial work $)^{159}$. A expansão do papel processual do juiz nesses megaconflitos teve um papel decisivo para o movimento de acesso à justiça, especialmente no que se refere aos interesses metaindividuais (como veremos no tópico 2.2.9, infra) ${ }^{160}$.

Como se vê, a consagração desse modelo proposto por Klein há mais de um século fortaleceu, pela perspectiva processual, o potencial protagonismo judicial. Destarte, explica-se a afirmação de CAPPELLETTI, de que ativismo judicial, nesse sentido propriamente processual, tem sido largamente aceito ${ }^{161}$.

\subsubsection{A ampliação do ideário do “juiz ativo”}

O “surto" de juridificação que levou à edificação de um modelo de Estado Social e Democrático de Direito (2.2, supra) engendrou não só o surgimento do ideário do juiz ativo, mas também sua gradativa ampliação ${ }^{162}$.

Do ponto de vista da concepção tradicional da função judicial, de viés eminentemente adjudicatório, a emergência do ideário do juiz ativo tornou o magistrado

ways the just, speedy, and inexpensive disposition of the action. (d) Pretrial Orders. After any conference under this rule, the court should issue an order reciting the action taken. This order controls the course of the action unless the court modifies it. (e) Final Pretrial Conference and Orders. The court may hold a final pretrial conference to formulate a trial plan, including a plan to facilitate the admission of evidence.

159 A autora trata da emergência do case management pelo magistrado. JUDITH RESNIK, "Managerial Judges”, in: Harvard Law Review, 96, 1982, p. 376.

${ }^{160}$ MAURO CAPPELLETTI, BRYANT GARTH, Acesso à Justiça, op.cit., p. 50. Sobre o tema, no Brasil, v., entre outros: HUGO NIGRO MAZZILLI. A defesa dos interesses difusos em Juízo. $21^{a}$ ed., São Paulo: Saraiva, 2008, p. 48.

161 MAURO CAPPELLETTI, "Governmental and Private Advocates for the Public Interest in Civil Litigation: a Comparative Study”, op.cit., pp. 831.

162 Alguns desses aspectos podem ser inferidos na descrição de GUNTHER TEUBNER, op.cit., p. 5. 
um protagonista processual da promoção de valores como celeridade, eficiência, redução dos custos, busca da verdade substancial, contraditório, flexibilização de formalidades, oralidade e tutelas judiciais diferenciadas, adequadas ao caso concreto. $\mathrm{O}$ avanço desses parâmetros nas reformas processuais levou ao gradativo enfraquecimento de institutos adversariais, forjados por legisladores que concebiam o julgador como um órgão dependente da iniciativa das partes. Consequentemente, abriu-se caminho para uma concepção de magistrado como gestor ativo do processo, orientado pelo "ativismo”, em lugar da "neutralidade” ou da "passividade"163.

O ideário do juiz ativo, desse modo, descortina o processo como locus em que tende a se manifestar um tipo específico de potencial protagonismo judicial identificável não só no momento da decisão, mas desde o início do processo, na condução do procedimento e na definição da marcha processual como um todo.

Surgido no final do século XIX, esse standard se desenvolveu, na primeira metade do século $\mathrm{XX}$, sobretudo em ordenamentos jurídicos vinculados à tradição romano-germânica, com preocupações essencialmente adjudicatórias e relacionadas a litígios individuais. Pouco a pouco, notadamente nas últimas décadas do século XX, dada a explosão da litigiosidade, houve considerável ampliação de seu escopo, o que é perceptível em medidas dirigidas à colonização de conflitos de massa e ao fomento, inclusive no âmbito do processo, de soluções não adjudicatórias. Atualmente, a influência dessa acepção mais ampla de “juiz ativo” é notável, outrossim, em reformas ocorridas no direito processual de sistemas jurídicos vinculados à tradição anglo-saxônica ${ }^{164}$.

\footnotetext{
${ }^{163}$ Cite-se, por oportuno, o seguinte excerto de Cappelletti: "For many years a growing number of countries(...), after balancing costs and benefits, have fostered 'activism' in lieu of the traditional passivity or "neutrality" of the judge. (...) Judicial activism is now fully accepted in (...) many civil-law nations (from Austria since the end of the nineteenth century, to most of Central Europe and, more recently, France and Italy) and in a growing number of "developing" nations." Even in common-law countries, the "sacred" principle of adversaryness has long been subject to the corrosive acid of criticism - and even scorn". MAURO CAPPELLETTI, "Governmental and Private Advocates for the Public Interest in Civil Litigation: a Comparative Study”, op.cit., pp. 831-832. Infere-se a influência dessas ideias no processo civil brasileiro na abalizada doutrina de CÂNDIDO RANGEL DINAMARCO, Fundamentos do processo civil moderno, op.cit., pp. 130-131.

${ }^{164}$ Neste caso, sem dúvida o pioneirismo foi europeu, e não norte-americano, como ocorreu em relação ao controle judicial contramajoritário, que antes se desenvolveu nos EUA (judicial review) para muito depois se estender efetivamente a outras experiências. Cf. tópico 2.2.6, supra. Os magistrados dos países vinculados ao sistema romano-germânico sempre possuíram um controle maior do procedimento em relação aos juízes anglo-saxônicos, cuja ação, tradicionalmente, dependia da iniciativa das partes e de seus advogados. A salientar essas distinções, v. prefácio de ROBERT BADINTER, SEPHEN BREYER, op.cit. Sobre essa tendência na America Latina e no Brasil, v. CANDIDO RANGEL DINAMARCO, Fundamentos do processo civil moderno, op.cit., vol. 2, p. 742.
} 
Essa ampliação do ideário do juiz ativo se revela em dois aspectos de grande relevância. O primeiro radica na expropriação, pelo estado, dos chamados conflitos de massa (2.2.5, supra), que levou à expansão ainda maior dos poderes processuais dos magistrados a fim de propiciar o tratamento adequado a litígios relacionados a direitos transindividuais e de interesse público. A litigância de interesse público, pouco a pouco, estrategicamente ou não, propiciou profundas mudanças na morfologia e no alcance potencial do processo e das decisões judiciais. Por sua especificidade, esses pontos serão enfocados pormenorizadamente a seguir (2.2.9, infra). O segundo aspecto envolve uma aparente mudança de foco da função jurisdicional, que se distancia do viés tradicionalmente adjudicatório para fomentar, no processo, de forma preferencial, a solução não adjudicada de conflitos como forma alternativa de “pacificação” social.

À medida que mais e mais pretensões materiais adquirirem conotação jurídica, os conflitos em que elas se manifestam tendem a ser levados ao Judiciário. A judicialização excessiva pode trazer dificuldades de canalizar essas demandas adequadamente (óbices de acesso, medo de ingressar em Juízo, duração excessiva dos casos, custos do processo, desigualdades processuais, discrepâncias nas chances de sucesso) e, como resultado dessas vicissitudes, avulta a ineficiência do aparato judiciário. A percepção desses problemas incentiva movimentos sociais em prol da adoção de “alternativas ao Direito”, como as que se traduzem nos chamados meios alternativos de solução de conflitos (alternative dispute resolution, $A D R)^{165}$.

\footnotetext{
${ }^{165}$ A bibliografia sobre o tema é rica. Entre outros autores, destacam-se: ANTÔNIO RODRIGUES DE FREITAS JUNIOR, "Conflitos de justiça e limites da mediação para a difusão da cultura da paz.", in: CARLOS ALBERTO DE SALLES (org.). As Grandes Transformações do Direito Processual Civil Brasileiro (homenagem ao Professor Kazuo Watanabe). São Paulo: Quartier Latin, 2009; KAZUO WATANABE, "Cultura da sentença e cultura da pacificação", in: FLÁVIO LUIZ YARSHELL, MAURÍCIO ZANOIDE DE MORAES. Estudos em homenagem à professora Ada Pellegrini Grinover, São Paulo: DPJ, 2005, pp. 684-690; CARLOS ALBERTO DE SALLES, "Mecanismos alternativos de solução de controvérsias e acesso à justiça: a inafastabilidade da tutela jurisdicional recolocada", in: LUIZ FUX, NELSON NERY JUNIOR, TERESA ARRUDA ALVIM WAMBIER, Processo e Constituição: estudos em homenagem ao professor Jose C. Barbosa Moreira. São Paulo: RT, 2006, pp. 779-785; BRYANT GARTH, "ADR and Civil Procedure: a Chapter or an organizing a theme?", in: 37 Journal Legal Education, 1987, pp. 34-36; ROGER FISHER, WILLIAM URY, BRUCE PATTON, Como chegar ao sim - negociação de acordos sem concessões, trad. Vera Ribeiro e Ana Luiza Borges, $2^{\mathrm{a}}$ ed., Rio de Janeiro: Imago, 2005, pp. 2131; ANDRÉ GOMMA DE AZEVEDO, CYNTIA CRISTINA DE CARVALHO SILVA, "Autocomposição, processos construtivos e a advocacia: breves comentários sobre a atuação de advogados em processos autocompositivos", in: Revista do advogado, n. ${ }^{\circ}$ 87, ano XXVI, set. 2006, pp. 115-123; JOSÉ RENATO NALINI, "O Brasil e a mediação penal", in: Revista dos Tribunais, São Paulo, vol. 87, n. ${ }^{\circ}$ 750, abr. 1998, pp. 472-487; LEONARD L. RISKIN, LÍLIA MAIA DE MORAIS SALES, Justiça e mediação de conflitos, Belo Horizonte: Del Rey, 2004, pp. 23-34; CÉLIA REGINA ZAPPAROLLI, "A experiência pacificadora da mediação: uma alternativa contemporânea para a implementação da cidadania e da justiça", in: MALVINA ESTER MUZSKAT (org.) Mediação de Conflitos: pacificando e prevenindo a violência, São Paulo: Lexus, 2003, pp. 50-74; MAURO CAPELLETTI, "Os métodos alternativos de solução de conflitos no quadro do
} 
Sucede que o surgimento de instrumentos de promoção dessas alternativas (que devolvem aos envolvidos a responsabilidade pela solução das disputas), coerentemente com a perspectiva expropriatória (2.2.5, supra), fomentou novas reações institucionais que, de algum modo, promoveram a incorporação parcial desses mecanismos ao processo.

Apesar de não interessar a esta tese um exame de cada um desses mecanismos, importa verificar de que forma seu surgimento se associa à ampliação do potencial protagonismo judicial com essa conotação propriamente processual, i.e., derivada do modelo de juiz ativo. Assim, cumpre destacar a maneira pela qual o Judiciário “se apropria” parcialmente desse instrumental por meio de nova reação juridificante, identificável em novas iniciativas de regulação e em alterações funcionais que afetam as instituições judiciais e os serviços jurisdicionais por elas prestados. Com efeito, o surgimento desses mecanismos alternativos fomenta novas reações estatais que, no bojo de reformas para tornar o processo cada vez mais eficaz, ampliam o ideário do juiz ativo para tornar o magistrado responsável, no processo, pela promoção de soluções não adjudicatórias de conflitos. Paralelamente à subsistência de mecanismos alternativos extrajudiciais (adjudicatórios e não adjudicatórios), promove-se, com essas reformas, o fortalecimento do elemento conciliatório no processo, com a participação ativa dos juízes no fomento de negociações, de acordos amigáveis e de outras formas de solução alternativa.

A incorporação dessa vertente não adjudicatória ao ideário do juiz ativo, ao mesmo tempo em que busca tornar mais eficiente e célere a canalização de demandas e sua pacificação formal, decorreria, segundo as lições de Teubner (2.2.5, supra), da “desconfiança” estatal em relação aos mecanismos extrajudiciais de soluções de conflitos. Como consequência dessa nova expropriação, o magistrado, ao lado de sua tradicional função adjudicatória, passa a desenvolver notável protagonismo no fomento de soluções não adjudicatórias para dar vazão à pletora de processos que comprometem a funcionalidade e a credibilidade institucionais.

Não nos parece exagerado afirmar que haveria certo paradoxo nessa alteração funcional decorrente da ampliação do modelo originário de “juiz ativo”, em

movimento universal de acesso à justiça", in: Revista de Processo, n. ${ }^{\circ}$ 174, pp. 82-97; OWEN FISS, Um novo processo civil: estudos norte-americanos sobre jurisdição, constituição e sociedade, São Paulo: RT, 2004, pp. 121-145; JEAN-FRANÇOIS SIX, Dinâmica de mediação, Belo Horizonte: Del Rey, 2001, pp. 225-251; OWEN FISS, JUDITH RESNIK, op.cit., pp. 452-461; LEONARD L. RISKIN et. al., Dispute resolution and lawyers, West, 2009, pp. 01-12. 
detrimento da ideia tradicional de jurisdição como atividade essencialmente adjudicatória e substitutiva $^{166}$. É que, do ponto de vista das intencionalidades daquele que apresenta a demanda ao Judiciário, haveria certa contradição nessa iniciativa se ela fosse movida, ab ovo, pelo intuito conciliatório. Indo além, não é difícil perceber, com base nessa mesma inferência, que o modelo ampliado de juiz ativo pode culminar com resultados discrepantes em relação ao seu ideário original (baseado na ideia de processo como instituição pública de bem-estar social - Wohlfahrtseinrichtung), uma vez que a substância qualitativa desses fins (propiciar solução adequada ao litígio, em busca da verdade real e da "justiça” do caso concreto) tende a ser obscurecida por medidas motivadas por preocupações eminentemente quantitativas e estatísticas, de pacificação formal (e não necessariamente substancial) do conflito.

A adoção desse ideário ampliado de “juiz ativo” tem ocorrido não só nos sistema de tradição romano-germânica, mas também na cultura jurídica anglo-saxônica. Com efeito, mesmo nos países da tradição da common law, a tendência adversarial tem se enfraquecido, dando lugar à administração judicial do conflito (judicial case management) por meio de um juiz gerente (managerial judge) e com papel ativo (active role), seja para a promoção de soluções adjudicadas, seja para fomentar a conciliação.

No âmbito da União Europeia, publicou-se, em 2002, um Green Paper específico sobre a solução alternativa de conflitos (alternative dispute resolution, ADR) em matéria comercial e civil (incluídos os aspectos trabalhista e do consumidor). Reconhecia o documento que, em vários países, os magistrados e tribunais estavam sobrecarregados de processos cuja apreciação ficava cada vez mais lenta, com custos cada vez mais altos e com manejo cada vez mais difícil graças à quantidade, complexidade e obscuridade técnica da legislação, fatores que não só dificultavam o acesso à Justiça judiciária, mas também comprometiam seriamente sua efetividade. Renovaram-se, assim, os interesses nos meios alternativos como forma de contornar essas dificuldades, em especial a crise de efetividade da justiça judiciária. Desse modo, as ADRs se tornaram aspecto axial da política pública europeia de aprimoramento do acesso à justiça (num sentido amplo). Com efeito, esses métodos são considerados complementares aos

\footnotetext{
166 “Assumindo que o sistema processual é impulsionado por uma série de escopos e que os Estado chama a si a atribuição de propiciar a consecução destes, uma das funções estatais é a de realizar os escopos do processo. Tal é a jurisdição, função exercida pelo Estado através de agentes adequados (os juízes), com vista à solução imperativa de conflitos interindividuais ou supraindividuais e aos demais escopos do sistema processual”. CANDIDO RANGEL DINAMARCO, Instituições de Direito Processual Civil, vol. 1, São Paulo: Malheiros, 2005, p. 329.
} 
processos judiciais, além de serem reputados mais adequados à natureza de certos conflitos, já que facilitam o diálogo e a reaproximação das partes. Sucede, todavia, que essas ADRs, no sentido amplo apresentado pelo Green Paper, são tanto as convencionais (conventional ADRs), consistentes em processos não judiciais de solução de conflitos (outof-court dispute resolution processes) conduzidos por um terceiro em posição de neutralidade em relação às partes (que podem se subsumir em várias categorias, conforme as disposiç̧ões legais a elas pertinentes); quanto as conduzidas pelo Judiciário ou por ele confiadas a um terceiro no contexto de um processo judicial (ADRs in the context of judicial proceedings).

A crescente utilização desses mecanismos no contexto dos processos (ADRs in the context of judicial proceedings) constitui tendência potencializada pelos incentivos da UE no sentido da harmonização da legislação. No que tange às leis processuais, os Estados-Membros são incentivados a vincular o juiz ao objetivo de promover ativamente um acordo entre as partes, mesmo quando os mecanismos de contenção da judicialização (como a obrigatoriedade de submissão prévia aos meios alternativos) não existirem ou não funcionarem.

Esse fomento ao recurso amplo às ADRs tem influenciado não só políticas governamentais, mas também políticas específicas dos próprios órgãos judiciários ${ }^{167}$. Não é difícil perceber, portanto, que, além dessa ampliação do ideário do juiz ativo, o desenvolvimento de políticas judiciárias dirigidas ao fomento das ADRs - seja com propósitos efetivamente pacificadores, seja com intuito de contenção da judicialização excessiva - revela outra forma de manifestação do potencial protagonismo judicial. Tratase, entretanto, de protagonismo cuja natureza não é processual e não corresponde à atuação da jurisdição stricto sensu, mas é visualizável de uma perspectiva mais ampla da Administração de conflitos, de ordem administrativo-institucional ${ }^{168}$.

\footnotetext{
${ }^{167}$ Nos termos do Green Paper: “(...)encourage judges to intervene actively in the search for an agreement between the parties"; v. UE. Green Paper on alternative dispute resolution in civil and commercial law, 2002. Disponível em eur-lex.europa.eu, acesso em 01-04-11. No âmbito da UE, a sobrecarga das Justiças era ainda mais complicada tendo em vista fatores como a frequência das disputas transnacionais, as interações intensas do mercado comum, a intensificação da mobilidade de mercadorias e pessoas, expansão do $e$ commerce e a diferença dos idiomas, de leis e de fatores financeiros. Convém notar que o acesso à justiça é considerado direito fundamental pelo artigo $6^{\circ}$ da European Convention for the Protection of Human Rights and Fundamental Freedoms. Ademais, o direito a recursos efetivos é princípio do direito comunitário europeu (article 47 da Charter of Fundamental Rights of the European Union). Outro estudo comparatístico sobre a inserção das ADRs no processo civil foi realizado por BRYANT GARTH. "ADR and Civil Procedure: Procedure: A Chapter or an Organizing Theme?", in: Journal Legal Education, 1987, pp. 34-36. ${ }^{168}$ Cf., tópico 4.3.9, infra.
} 


\subsubsection{Dois casos peculiares}

Os dois exemplos selecionados a seguir, num breve escorço comparatístico, são representativos da influência do modelo de juiz ativo de Klein e da convergência das experiências jurídicas em matéria processual, conforme o lineamento ampliado daquele modelo.

O primeiro exemplo é o da legislação processual da França, formalmente reformulada apenas em 1976. O segundo é o das leis processuais da Inglaterra, as quais resistiram, por muito tempo, às influências do sistema romano-germânico em geral e do modelo de "juiz ativo" em particular, mais ainda do que as normas e a prática judicial no sistema norte-americano ${ }^{169}$. O caso Francês demonstra um “descolamento” entre as regras processuais vigentes (que se reportavam ao modelo liberal) e a prática judicial de um magistrado que passou a conceber sua função no processo conforme o modelo do juiz ativo que emergia em outros países; o caso inglês, por sua vez, indica que mesmo o mais tradicional sistema da common law, por ocasião das transformações operadas com o Código de 1999, sofreu fortes influências do ideário do juiz ativo, em detrimento de seus institutos e costumes jurisprudenciais.

\subsection{França: “descolamento” entre o comportamento judicial e} as leis processuais

As repercussões do ideário do juiz ativo sobre o ordenamento jurídico francês foram examinadas por VAN RHEE, que destaca os abalos sofridos pela base liberal do Code de Procédure Civile napoleônico de 1806 (modelo para a construção processual oitocentista) quando da enunciação das teses de Klein e do advento do Código austríaco de 1895, no final do mesmo século.

Segundo o jurista, o próprio Klein notava que, na época, o juiz francês seria “mais ativo” do que o Código de Processo Civil daquele país sugeria que ele pudesse ser ${ }^{170}$. Assim, na própria França, as influências de Klein são notáveis no que tange ao

\footnotetext{
169 Sobre a mudança ocorrida nos EUA, de um modelo de juiz passivo para o de juiz ativo, v. ABRAM CHAYES, op.cit., pp. 1298, 1302. A experiência norte-americana será examinada noutro tópico, em especial por sua relevância no que tange ao tema da litigância de interesse público ou de direito público.

${ }^{170}$ C. H. VAN RHEE (ed.), European traditions in civil procedure. Oxford: Intersentia, 2005, p. 14. O autor comenta: "On the Continent, Austria is of course the country where the modern, strong, active judge originates. It was Franz Klein who emphasized that the conduct of civil litigation should not be left to the
} 
desenvolvimento da visão do juiz como conseiller de la mise en état, que superou, aos poucos, o modelo liberal do código processual de 1806.

Apesar de referido diploma haver sido revogado apenas em 1976, na prática os juízes já vinham exercendo uma espécie de protagonismo que buscava ampliar os poderes processuais previstos nas normas vigentes. Esse fortalecimento não oficial dos magistrados foi muito ressaltado por processualistas franceses ${ }^{171}$.

Essa constatação é relevante para dar substância a uma indagação: se o magistrado entender, à luz do ideário proposto por Klein, que o processo não acompanha pari passu as mudanças sociais, em que medida ele poderia flexibilizar seus pressupostos, relativizar sua forma ou ignorar suas prescrições? Até que ponto isso poderia ser feito para possibilitar uma manifestação judicial em relação a um conflito ou para viabilizar a condução do processo conforme esse ideário segundo o qual o magistrado é um ator, mais do que um expectador? Isso representaria um desrespeito ao “devido processo legal”, ou se aproximaria da busca de um “devido processo legal substancial”? ${ }^{172}$

No caso Francês, um comportamento tal dos juízes no processo revela outros traços de um potencial protagonismo judicial com conotação processual, antes mesmo da institucionalização do ideário do juiz ativo nas leis processuais.

initiative of the private parties themselves, since - in his view - civil litigation also affects society as a whole. The Austrian model would be influential in many others European countries (although the implementation of the active judge in the legal practice of these countries often would have to wait until well into the second half o the twentieth century” (p. 190). Destaca o autor que um dos primeiros países a sofrerem essa influência foi a Alemanha, a partir da década de 30.

${ }^{171}$ C. H. VAN RHEE, op.cit., pp. 7-14. No original: “(...) even though the French Code of Civil Procedure did not grant the French judge far-reaching case-management powers, such powers were, in practice, exercised by him without a legal basis in the Code".

${ }^{172}$ Ao explicitar o aspecto substancial do devido processo legal, observa Dinamarco que o “(...) direito ao processo justo é, em primeiro lugar, o direito ao processo tout court - assegurado pelo princípio da inafastabilidade do controle jurisdicional que a Constituição impõe mediante a chamada garantia da ação. Sem ingresso em juízo não se tem a efetividade de um processo qualquer e muito menos de um processo justo. Garantido o ingresso em juízo e até mesmo a obtenção de um provimento final de mérito, é indispensável que o processo se haja feito com aquelas garantias mínimas: a) de meios, pela observância dos princípios e garantias estabelecidas; b) de resultados, mediante a oferta de julgamentos justos, ou seja, portadores de tutela jurisdicional a quem efetivamente tenha razão. Os meios, sendo adequadamente empregados, constituem o melhor caminho para chegar a bons resultados. E, como afinal o que importa são os resultados justos do processo (processo civil de resultados), não basta que o juiz empregue meios adequados se ele vier a decidir mal; nem se admite que se aventure a decidir a causa segundo seus próprios critérios de justiça, sem ter empregado os meios ditados pela Constituição e pela lei. Segundo a experiência multissecular expressa nas garantias constitucionais, é grande o risco de erro quando os meios adequados não são cumpridos. Eis o conceito e conteúdo substancial da cláusula due process of law, amorfa e enigmática, que mais se colhe pelos sentimentos e intuição do que pelos métodos puramente racionais da inteligência” CANDIDO RANGEL DINAMARCO, Instituições de Direito Processual Civil, vol.1, op.cit., pp. 266-267. 


\subsection{Inglaterra: o active case management}

A Inglaterra adotou um Civil Procedure Rules and Practice Directions for civil litigation apenas em 1999. Com o diploma, varreu-se longa construção de case law, que deu lugar a um modelo bem distante do sistema adversarial e bem próximo do ideário do juiz ativo.

O objetivo prioritário (overriding objective, rule 1.1) do Código é o de promover o tratamento justo dos casos (deal with cases justly), assegurando-se, na medida do praticável, a celeridade, o equilíbrio na posição das partes, a redução dos custos e o tratamento "proporcional” de cada processo. O código fomenta a incidência dessa proporcionalidade (2.2.7.4, supra), em especial, em avaliações do valor da causa, da importância do caso, da complexidade das questões discutidas e da posição financeira de cada parte. As disposições preliminares também enfatizam que os órgãos judiciais devem buscar aquele objetivo prioritário tanto na interpretação de cada regra processual quanto no exercício de seus poderes (rule 1.2).

Ademais, sem olvidar o dever de cooperação das partes (rule 1.3), essas disposições introdutórias também definem os deveres dos julgadores de gerir o processo (duty to manage cases). Nesse sentido, institui-se um modelo de "gestão ativa dos casos" (active case management, rule 1.4), cujos ingredientes seriam: a) o fomento da cooperação das partes umas com as outras no que tange à marcha procedimental; b) a identificação das controvérsias nas fases iniciais do processo; c) a identificação dos problemas que demandem exame aprofundado, que possam ser julgados posteriormente, bem como daqueles mais simples, que possam ser resolvidos sumariamente; d) o estabelecimento da ordem de solução das controvérsias; e) sempre que os julgadores entenderem necessário, o fomento da utilização de mecanismos alternativos de solução de conflitos (ADR alternative dispute resolution procedures), com a facilitação do uso de procedimento adequado a tal finalidade; f) o auxílio às partes para a solução do conflito ou de parte dele;

g) a fixação de agendas para o controle do progresso do caso; h) a avaliação dos prováveis benefícios da adoção de determinada medida em relação ao custo dessa adoção; i) o tratamento da maior quantidade possível de aspectos do caso em uma mesma ocasião; j) a promoção do andamento do caso sem que as partes precisem comparecer ao órgão 
jurisdicional; k) a utilização da tecnologia; e l) o estabelecimento de regras para assegurar que o julgamento de um caso progrida de forma rápida e eficiente ${ }^{173}$.

Todas essas reformas foram motivadas pela percepção da insatisfação geral com a demora, os custos, a complexidade e as incertezas dos processos judiciais ingleses. Além disso, o case manegement, com a condução ativa do juiz, tem importância no contexto das group litigation orders (GLO), mecanismo de captação e tratamento de litígios de massa. O item 8 da referida practice direction dispõe que um juiz-gerente (managing judge) deverá ser indicado rapidamente para o tratamento de eventual GLO, assumindo, ao lado de juízes com funções específicas e auxiliares, a responsabilidade geral pelo gerenciamento das solicitações e pela identificação das questões relevantes dos $\operatorname{casos}^{174}$.

Nota-se, assim, num ordenamento jurídico tradicionalmente infenso a essas tendências normativas e institucionais, uma mudança relevante decorrente da forte influência do ideário de juiz ativo em sua concepção mais ampla (2.2.8.1, supra), engendrada pela evolução da juridificação ${ }^{175}$.

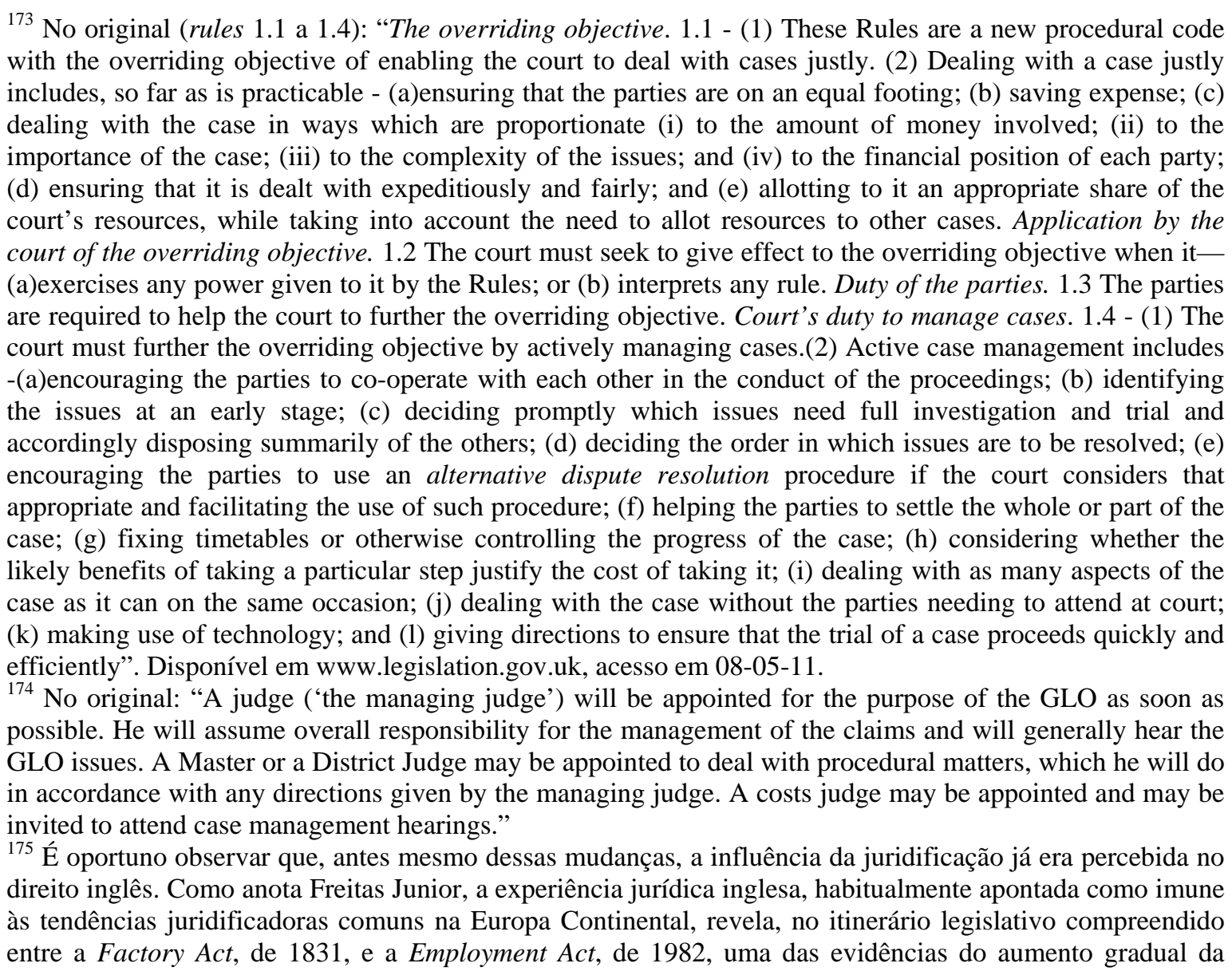




\subsubsection{Poder judiciário e litigância de interesse público}

Como foi visto, a multiplicação extraordinária das pretensões judicializáveis (inclusive as que transcendem a esfera de interesses dos indivíduos para alcançar demandas coletivas por justiça material) é um dos desdobramentos mais relevantes da juridificação no contexto do Estado Social e Democrático de Direito (2.2.2 e 2.2.4, supra).

Com isso, órgãos judiciais precisam lidar com a possibilidade de receberem, em meio a demandas que almejem a tutela de interesses de coletividades, de minorias e de grupos, pedidos de intervenção judicial que visem ao fomento de mudanças sociais $^{176}$.

No Brasil, essa problemática tem sido abordada, pela literatura jurídica, no âmbito das discussões sobre o “processo de interesse público" e os horizontes de tutela dos chamados direitos e interesses metaindividuais ${ }^{177}$.

Seguramente, o advento e a evolução de instrumentos processuais adequados à tutela desses interesses são variáveis relevantes para a compreensão dessa vertente promocional do potencial protagonismo judicial. Todavia, para percebê-la mais claramente, não se pode olvidar o exame da atuação dos diversos atores sociais no que concerne à mobilização da máquina judicial, ao uso dos instrumentos processuais e ao fomento da receptividade do Judiciário aos litígios de interesse público.

juridificação. ANTÔNIO RODRIGUES DE FREITAS JUNIOR, Os direitos sociais e a constituição de 1988: crise econômica e políticas de bem-estar, op.cit., p. 46.

${ }^{176}$ Importantes reflexões sobre o tema foram desenvolvidas em obra de GERALD ROSENBERG. The Hollow Hope: can courts bring about social change? $2^{\mathrm{a}}$ ed., Chicago, University of Chicago Press, 2008. A primeira edição da obra é de 1991. Rosenberg, ao avaliar o papel do Judiciário nos EUA, faz ponderações mais céticas sobre a ideia de que os tribunais possam afetar efetivamente as variáveis das mudanças sociais. Ele sustenta, assim, que haveria certa inanidade nos julgamentos. Isso porque a efetividade de tais decisões são contidas por restrições estruturais que limitam o poder judicial em relação à implementação de direitos. A respeito do tema, v., outrossim, a conhecida obra de ALEXANDER BICKEL, The least dangerous branch: the supreme court at the bar of politics. New Haven: Yale University, 1986.

177 CARLOS ALBERTO DE SALLES (org.). Processo Civil de Interesse Público, op.cit. No que tange à litigância de interesse público, v. HUMBERTO THEODORO JUNIOR, DIERLE NUNES, ALEXANDRE BAHIA, op.cit. 


\subsubsection{Public interest litigation nos EUA}

No caso dos EUA, influente estudo produzido na Universidade de Harvard diagnosticava, na década de 1970, uma profunda mudança no conceito de adjudicação, tradicionalmente vinculado à resolução de conflitos privados que não houvessem sido compostos espontaneamente. Essa abordagem individualista e liberal, segundo $\mathrm{CHAYES}^{178}$, não mais se adequava aos temas com os quais se defrontavam os tribunais norte-americanos, notadamente os federais, que não são, a rigor, órgãos de common law.

Como é sabido, normas federais, naquele país, são reservadas à atividade legislativa federal, de modo que a construção de precedentes pela common law, nesse caso, é um expediente necessário apenas na falta de um ato do Congresso Americano aplicável ao caso. Em tais situações, as Cortes são forçadas a considerar questões que não possam receber respostas apenas com base nos statutes ou na constituição. Diante dessas características institucionais e normativas, CHAYES constatava que o crescimento da litigiosidade em temas legais e constitucionais de interesse público vinha mudando o foco de muitos processos, que deixavam de lado as implicações das interações entre particulares $^{179}$ para dar atenção ao exame de políticas públicas e políticas regulatórias relevantes à solução do conflito judicializado. Em outras palavras, buscava-se esclarecer judicialmente o significado de um direito, de modo que se fixassem parâmetros para sua fruição e um regime de regulação ad futurum das relações entre os interessados, inclusive os ausentes. Esse tipo de litigiosidade, quando bem sucedida, não só estimulava a adoção de soluções com base nas diretrizes judicialmente fixadas, mas também engendrava um regime de contínua supervisão judicial.

Retomando, na linha das reflexões apresentadas nos tópicos anteriores (2.2.8 e 2.2.8.1, supra), a nomenclatura de RESNIK, pode-se afirmar que uma abordagem adversarial e o passivismo processual do juiz, por razão ainda mais forte, não caberiam nesses tipos de litígios, que exigiriam dos magistrados uma atuação de supervisores

\footnotetext{
178 ABRAM CHAYES, op.cit., pp. 1281-1283.

${ }^{179}$ É perspicaz a observação do autor, de que mesmo a decisão do caso Marbury v. Madison se vinculava a esse modelo de direito privado e ao sistema adversarial. No original: "The predominating influence of the private law model can be seen even in constitutional litigation, which, from its first appearance in Marbury $v$. Madison, was understood as an outgrowth of the judicial duty to decide otherwise-existing private disputes.” ABRAM CHAYES, op.cit., p. 1285.
} 
(managerial judges), durante o processo (pretrial phases) e após a decisão (postdecision judicial work) ${ }^{180}$.

Para CHAYES, diante de uma sociedade cada vez mais sujeita à regulação (2.2.1, supra), seria necessário conferir novos papéis aos juízes para enfrentar uma litigiosidade crescente, independentemente das discussões sobre a legitimidade da intervenção judicial em novos temas sociais e políticos. Baseada em direitos metaindividuais ou públicos, essa litigância então emergente teria o potencial de afetar interesses de coletividades, o que fugia do modelo individualista que vinha predominando nos EUA e diferia da realidade das class actions que se desenvolveria.

As discussões em muitos processos envolviam a investigação sobre "se” e “como" uma política ou um programa governamental seria realizado. O jurista diagnosticava que o reconhecimento da conotação política desses litígios alimentaria a pressão contra limitações ao instituto do standing ${ }^{181}$ e a outras barreiras à justiciabilidade de direitos (maturidade da causa, controvérsia do tema, o fato de o conflito envolver questões políticas, entre outros fatores normalmente citados como obstáculos à judicialização). Na verdade, essa pressão vinha se aprofundando pela insuficiência da tutela judicial, que se limitava à imposição de obrigações de não fazer. Com efeito, se um direito vinha sendo negado a um cidadão, não se poderia esperar que ele ingressasse em juízo postulando que o responsável “deixasse de negá-lo”. De forma mais flagrante, essa dificuldade vinha sendo percebida em temas como a tutela da saúde, a busca pela igualdade racial, as políticas educacionais, a discriminação para a celebração de contratos de trabalho e o meio ambiente. Ora, ponderava CHAYES, se uma intervenção judicial é postulada com base legal, supõe-se que a lei respectiva veicule um objetivo regulatório afirmativo (affirmative regulatory objective). E, se o processo for motivado por disposições constitucionais tradicionalmente interpretadas como contenções aos poderes governamentais, haveria uma tendência crescente de identificar valores afirmativos (affirmative values) a elas incorporados e que deveriam ser promovidos e tutelados pela ação judicial. Em qualquer caso, se o litígio revelasse que valores afirmativos (affirmative

\footnotetext{
${ }^{180}$ A autora trata da emergência do case management e da ideia de managerial judges, v. JUDITH RESNIK, “Managerial Judges”, op.cit., p. 376.

${ }^{181}$ Trata-se do direito de a parte demandar a implementação judicial de determinado direito ou obrigação ("to seek judicial enforcement of a duty or right”), o que depende, no sistema norte-americano, da demonstração: a) de que a conduta questionada, de fato, provocou prejuízos ao demandante; e b) de que o interesse cuja proteção se busca alcançar se encontra no âmbito da zona de interesses que se possam considerar protegidos ("meant to be regulated") pelas leis ou pela Constituição. BRYAN GARNER, op.cit., p. 590. Prima facie, trata-se de instituto análogo às condições da ação.
} 
values) ou objetivos regulatórios afirmativos (affirmative regulatory objective) houvessem sido frustrados, o socorro ou remédio visto como possível seria, frequentemente, um programa afirmativo (affirmative program) para implementá-los ${ }^{182}$.

É interessante notar a morfologia dos litígios de direito público esboçada por CHAYES $^{183}$, em contraste com o modelo adversarial.

Com efeito, no modelo "em crise”, o processo judicial seria um veículo para a solução de disputas entre particulares e com foco em interesses privados, conforme a seguinte estrutura: a) constituição bipolar do processo, com litígios organizados como uma competição entre dois indivíduos ou, pelo menos, entre dois interesses unitários diametralmente opostos, de modo que o conflito era decidido com base na ideia de "o vencedor leva tudo" (on a winner-takes-all basis); b) litígio retrospectivo, de forma que as controvérsias radicavam em um conjunto de eventos passados, em sua efetiva ocorrência e nas consequências para as relações jurídicas das partes; c) interdependência entre direito (right) e remédio (remedy), ou seja, o escopo deste último (um relief) era derivado, de forma mais ou menos lógica, da violação substantiva perceptível sob a teoria geral segundo a qual o demandante (plaintiff) alcançaria uma compensação a ser medida pelo dano causado em razão do desrespeito a determinada obrigação de responsabilidade do demandado (defendant's breach of duty); esse ressarcimento, num contrato, ocorria pelo pagamento, ao demandante, do montante que ele possuiria se excluída a quebra da obrigação; e, em matéria de responsabilidade civil (tort cases), pelo pagamento do valor correspondente ao dano causado; d) visualização do processo como caso encerrado em si mesmo (self-contained episode), de modo que o julgamento encerrava a participação da autoridade judicial e teria impacto limitado às partes, já que, de um lado, a vitória do demandante levava ora à transferência compensatória (compensatory transfer) de dinheiro em seu favor, ora à devolução de uma coisa ou à prática de um ato determinado; e, de outro, a vitória do demandado não mudaria, em essência, a situação dos litigantes (a loss

182 "If a mental patient complains that he has been denied a right to treatment, it will not do to order the superintendent to "cease to deny" it. So with segregation in education, discrimination in hiring, apportionment of legislative districts, environmental management. And the list could be extended. If judicial intervention is invoked on the basis of congressional enactment, the going assumption is that the statute embodies an affirmative regulatory objective. Even when the suit is premised on constitutional provisions, traditionally regarded as constraining government power, there is an increasing tendency to treat them as embodying affirmative values, to be fostered and encouraged by judicial action. In either case, if litigation discloses that the relevant purposes or values have been frustrated, the relief that seems to be called for is often an affirmative program to implement them”. ABRAM CHAYES, op.cit., p. 1295. Note-se que as ideias de Chayes reforçam a percepção da inter-relação entre a crescente juridificação (inclusive em países vinculados à tradição da common law) e a crescente judicialização de conflitos.

${ }^{183}$ ABRAM CHAYES, op.cit., p. 1302. 
lies where it has fallen); e) processo iniciado e controlado pelas partes (party-initiated and party-controlled), já que a organização do rito e a definição das questões era realizada pela troca de proposições entre os litigantes, aos quais caberia, inclusive, a responsabilidade pelo aparecimento da verdade dos fatos (fact development). O juiz, nesse modelo, era um árbitro neutro (neutral arbiter) das interações entre as partes, limitando-se a decidir questões de direito apenas quando elas fossem postas em discussão por um movimento específico dos litigantes.

Conquanto a importância explicativa desse modelo haja se sustentado por muito tempo, ele não mais se ajustaria, segundo CHAYES, às características dos litígios que vinham surgindo havia alguns anos nas Cortes Federais norte-americanas. É que esses processos apresentavam a seguinte estrutura: a) seu escopo não seria exogenamente constituído, mas modelado desde o início pela autoridade judicial e pelas partes, tendo em vista um objeto consistente na reivindicação de políticas e prestações governamentais, de natureza constitucional ou legal (vindication of constitutional or statutory policies); b) o processo não seria rigidamente bilateral em sua constituição, mas expansivo e amorfo (sprawling and amorphous); c) a inquirição da verdade dos fatos não seria histórica, retrospectiva ou meramente adjudicatória, mas preditiva e legislativa (predictive and legislative); d) os remédios ou as tutelas não seriam concebidos como compensações para infrações ou danos passados de forma logicamente derivada da responsabilidade substantiva (substantive liability), confinada, em seus impactos, às partes diretamente envolvidas; ao contrário, esses remédios e tutelas seriam prospectivos, desenvolvidos ad hoc, com demarcação flexível e aberta, e frequentemente teriam consequências relevantes para muitas pessoas, incluindo grupos estranhos ao processo; e) o remédio não necessariamente era imposto, uma vez que tenderia a ser negociado; f) a sentença não encerrava o envolvimento da autoridade judicial no caso e em suas questões subjacentes, cuja administração exigiria a contínua participação do Judiciário; g) o juiz não era mais passivo, com suas funções limitadas ao exame e à declaração de normas aplicáveis ao caso; mas ativo, com a responsabilidade não só de avaliar, em busca da verdade, a credibilidade dos fatos alegados, mas também de organizar e modelar o litígio para garantir um resultado justo, adequado, viável, praticável (2.2.8.1, supra); h) o objeto do processo (subject matter of the lawsuit) não radicava na disputa entre particulares cujos interesses são privados, mas na manifestação de descontentamento e no pedido de providências judiciais em relação à execução e ao funcionamento de políticas públicas. 
CHAYES explicava, dessarte, com base empírica, formas emergentes de litígios de direito público (ou de interesse público), em que os demandantes, com ou sem estratégias bem definidas, revelavam conceber o Judiciário como veículo de fomento de reformas sociais em temas relacionados à promoção não só de direitos civis e políticos (como a liberdade de expressão e a igualdade de gêneros ou racial), mas também de direitos econômicos e sociais (como a saúde, o trabalho e a educação).

O aumento da receptividade do Judiciário a essa litigiosidade de interesse público atraiu muitas críticas ${ }^{184}$. Entretanto, DENVIR destaca que em vários casos os resultados sociais dessa recepção foram benéficos ${ }^{185}$ : Roe v. Wade (1973), que tratou dos limites constitucionais do aborto; Reed v. Reed (1973), sobre discriminação sexual; Griggs v. Duke Power Co (1971), sobre procedimentos discriminatórios de contratação de empregados; e Brown v. Board of Education (1954), sobre a segregação racial em escolas. A decisão judicial no caso Brown v. Board of Education, a propósito, é comumente citada como o mais relevante exemplo de efetivo ativismo judicial da história de Suprema Corte norte-americana. Se houve críticas severas àquele julgamento, não se pode ignorar que ele também foi louvado pela propulsão que teria oferecido ao movimento dos direitos civis. Ademais, consoante sustenta COVER, o julgamento constituiu um marco inicial do judicial activism em prol da proteção das minorias ${ }^{186}$.

Com base nas ponderações de DENVIR, pode-se acrescentar que o sucesso desse tipo de litigância tem como ingredientes relevantes a conscientização dos juízes a respeito de seu papel democrático e a compreensão, pelos advogados, do horizonte de possibilidades do processo judicial ${ }^{187}$.

Como se vê, a emergência da litigância de interesse público fomentou uma série de reformas para tornar o processo adequado ao tratamento de conflitos que

\footnotetext{
${ }^{184}$ Sem dúvida, entretanto, os tribunais podem ser menos receptivos a mudanças sociais e econômicas do que os ramos propriamente políticos. Isto é, o fato de haver litigância de interesse público não implica necessariamente a ampliação da receptividade do Poder Judiciário.

185 JOHN DENVIR, "Towards a Political Theory of Public Interest Litigation", in: North Carolina Law Review, n. ${ }^{\circ}$ 54, pp. 1133-1134.

${ }^{186}$ ROBERT M. COVER. "The Origins of Judicial Activism in the Protection of Minorities", in: Yale Law Journal, vol. 91, 1982, p. 1287. Apesar disso, Gerald Rosenberg, coerentemente com sua visão cética a respeito do papel do Judiciário em reformas sociais, defende que a decisão não teve tanto impacto, diferentemente do que se costuma supor. Entre os motivos que aponta: a cobertura da mídia a respeito dos direitos civis era escassa, o comportamento das elites não mudou de imediato, livros com conteúdos racistas continuaram a ser publicados e a opinião pública em geral nem sequer sabia de sua existência. (GERALD ROSENBERG, op.cit., pp. 39 e ss.)

${ }^{187}$ No original: "Litigation will never play the role it might in social reform efforts until judges have a better understanding of the proper role of courts in a democracy and lawyers a better sense of the possible uses to which litigation can be put”. JOHN DENVIR, op.cit., pp. 1133-1134.
} 
transcendessem as características dos litígios privados. Com isso, alargaram-se os horizontes não só dos poderes processuais do magistrado (consoante um ampliado ideário de “juiz ativo”, cf. 2.2.8.1, supra), mas também das modificações na morfologia do processo, o que levou ao aumento significativo de sua visibilidade social, de sua relevância política e do alcance de seus resultados, adjudicatórios ou não adjudicatórios.

Como veremos no próximo tópico, o surgimento desses litígios e as reformas processuais que eles suscitaram não se restringiram à experiência norteamericana.

\subsubsection{Litigância de interesse público em outros países e estruturas} de suporte à mobilização jurídica

O que o estudo seminal de Chayes diagnosticou nos EUA passou a ser identificado, pouco a pouco, em outros países.

É oportuno relembrar que, tanto nos EUA quanto na Europa, a atuação do Judiciário em prol da promoção dos direitos civis e dos direitos sociais só ocorreu mais claramente após a Segunda Guerra Mundial, com a evolução da juridificação e a consolidação gradativa do Estado Social. Se recorrêssemos à visão de EPP, poderíamos associar o fenômeno ao colapso do governo democrático efetivo ("breakdown of democratic government”), uma vez que, após o término daquele conflito armado, as burocracias estatais cresceram além da capacidade de os processos legislativo e eleitoral prosseguirem com um controle mais direto sobre a sociedade. Assim, identificadas grandes lacunas no cumprimento de obrigações e responsabilidades democráticas (lack of democratic accountability) do Executivo e do Legislativo, a possibilidade de articulação jurídica da pretensão de controlar esses ramos fortaleceu a crença em mecanismos judiciais de desencadeamento de ações públicas ${ }^{188}$.

Observando fenômenos ocorridos a partir da década de 60, CAPPELLETTI, em diálogo com Chayes, nota que as mudanças apontadas pelo jurista

\footnotetext{
${ }^{188}$ CHARLES R. EPP, The Rights Revolution: Lawyers, activists, and Supreme Courts in Comparative Perspective, Chicago: University of Chicago Press, 1998, p. 16. Nesse mesmo sentido, Cappelletti destaca que a crescente intervenção jurídica da burocrática estatal, combinada com a dificuldade de uso do processo eleitoral para corrigir abusos, estimulou o desenvolvimento do discurso em defesa de direitos, legitimando o crescimento da supervisão judicial sobre o processo administrativo. MAURO CAPPELLETTI. "Repudiating Montesquieu? The expansion and Legitimacy of Constitutional Justice", in: Catholic University Law Review, n. ${ }^{\circ} 35,1985$, pp. 1-30.
} 
norte-americano ocorreram à medida que se consolidou um movimento mundial em torno dos litígios de interesse ou de direito público. Trata-se, como se vê, de aspectos relevantes do chamado movimento de acesso à justiça e dos instrumentos específicos de tutela dos interesses metaindividuais ${ }^{189}$.

Quando do exame dos aspectos normativos e institucionais da convergência das experiências jurídicas democráticas (2.2.7, supra), vimos que, na Alemanha, o desenvolvimento da jurisprudência constitucional passou a considerar, pouco a pouco, a problemática das precondições do exercício de direitos fundamentais, da abstenção legislativa, do dever de proteção e das prestações estatais necessárias à manutenção ou ao estabelecimento da liberdade no segmento da realidade social em que certo direito fundamental devesse produzir seus efeitos. Assim, essa evolução, aliada à ideia de proporcionalidade, contribuiu para que se tornassem mais visíveis os direitos fundamentais e os temas de interesse público que eles suscitam, fomentando novas manifestações do potencial protagonismo judicial no âmbito metaindividual.

No Canadá, EPP identifica, como relevante fator de emergência dos litígios de interesse público, a existência de uma estrutura de suporte à mobilização jurídica de grupos sociais (support structure for legal mobilization) baseada em recursos materiais e institucionais que habilitaram os litigantes a postular a implementação judicial de direitos. Essa estrutura envolveu advogados sensíveis à causa, associações criadas para a defesa de certos direitos e outros entes que possibilitaram demandas estrategicamente direcionadas e sustentáveis até os tribunais superiores. Ademais, garantiram-se os meios de financiamento dos custos do processo, o suporte a pesquisas em campos não legais e a promoção da publicidade eventualmente necessária ${ }^{190}$. O exame da experiência canadense

\footnotetext{
189 Sobre o tema, v. o riquíssimo estudo comparatístico de MAURO CAPPELLETTI, BRYANT GARTH, Acesso à Justiça, op.cit., pp. 50-51. Na obra, ele descreve a evolução do movimento de acesso à justiça, obstáculos à sua efetivação (em especial os custos, o tempo do processo, os problemas especiais referentes a interesses difusos e as possibilidades das partes, como recursos financeiros, aptidão para reconhecer um direito e propor uma ação em sua defesa). Ademais, descreve como, em especial a partir da década de 1960, as ondas de acesso a justiça (primeiro, a assistência judiciária para os pobres; segundo, a representação jurídica para a defesa de interesses difusos; terceiro, aprofundamento do acesso e eliminação de outros óbices) se sucederam ao redor do mundo. No que tange à segunda onda, dialogando com as premissas de Chayes, enfatiza o "movimento mundial" em direção ao que este último denominou de "litígios de direito público", com fortes repercussões sobre a compreensão do processo (revisão da legitimidade, discussão a respeito de representantes adequados, efeitos da coisa julgada, expansão da visão de função social do processo).

${ }_{190}$ CHARLES R. EPP, "Do Bills of Rights Matter? The Canadian Charter of Rights and Freedoms", in: American Political Science Review, vol. 90, n. ${ }^{\circ}$ 4, dez. 1996, p. 765. No original: "The data suggest that the Charter indeed has influenced the Court's agenda, although the effects are more limited than generally recognized. More important, the data suggest that a number of the influences often attributed to the Charter likely resulted instead from the growth of what I call the support structure for legal mobilization, consisting
} 
demonstra haver sido relativo o impulso político propiciado pela Canadian Charter of Rights and Freedoms, de 1982. É que a força de qualquer Bill of Rights tende a variar de acordo com a possibilidade de os grupos sociais se mobilizarem em prol de demandas judiciais estratégicas. Não parece se sustentar, dessa perspectiva, a suposição de que a mera declaração de direitos ou o compartilhamento de determinadas concepções doutrinárias sobre tais declarações, por mais vanguardistas que pretendam ser, seriam suficientes para moldar o desenvolvimento de movimentos políticos e sociais e a atuação do Judiciário. Em outras palavras, uma declaração de direitos fundamentais, por si só, não leva ao aumento da intervenção judicial no processo de elaboração de políticas públicas, como se bastassem tais garantias para que atores sociais demandassem em Juízo e, com isso, os tribunais passassem a se manifestar favoravelmente a essas postulações. Mesmo que os juízes sejam receptivos ${ }^{191}$ a tais demandas (compreendendo ampliativamente seu papel, a extensão de seus poderes, a legitimidade dos interessados ${ }^{192}$ e a própria justiciabilidade de determinados direitos); mesmo que os julgadores possam aplicar a mais criativa das doutrinas ou tenham a intenção (confessada ou não) de maximizar sua

of various resources that enable litigants to pursue rights-claims in court. The political significance of a bill of rights, then, depends on factors in civil society that are independent of constitutional structure”. Também sobre essa exagerada supervalorização das declarações de direitos como supostos mecanismos desencadeadores de "revoluções de direitos", v. CHARLES R. EPP, The Rights Revolution: Lawyers, activists, and Supreme Courts in Comparative Perspective, op.cit., p. 13.

${ }^{191}$ Isso também pode depender, segundo EPP, da eventual orientação política do magistrado: “(...) judges are likely to use their powers under a Bill of Rights only if they oppose public policy, yet many judges support public policies against right claims”. CHARLES R. EPP, The Rights Revolution: Lawyers, activists, and Supreme Courts in Comparative Perspective, op.cit., p. 14.

${ }^{192}$ Essa variável pode ter influência determinante sobre o alcance prático de institutos como as condições da ação, a legitimação para agir, a representatividade adequada, o standing to sue, a substituição processual, entre outros análogos em diferentes experiências jurídicas. Segundo Cappelletti, a ampliação desses institutos e de seus similares no direito comparado é uma das decorrências da transformação do direito processual, que se torna, mais e mais, o cenário no qual o interesse público, o grupal e o coletivo se mesclam e frequentemente prevalecem sobre os interesses individuais. Aqui, mais uma vez, recupera-se a ideia de que uma sociedade de massas engendra conflitos que exigem tratamento processual diferenciado daquele dispensado a interesses particulares. MAURO CAPPELLETTI, "Governmental and Private Advocates for the Public Interest in Civil Litigation: a Comparative Study”, op.cit., pp. 879-881. Descrevendo o standing (locus standi) como um filtro, v. JOHN DWYER, "Public Interest litigation. Who can start proceedings", in: Legal Service Bull, n. ${ }^{\circ}$ 6, 1981, p. 219.. Dwyer cita matérias de interesse público que vinham crescentemente ganhando atenção da opinião pública na época: serviços públicos, proteção do meio ambiente, o conforto urbano, patrimônio nacional, preservação das liberdades civis, proteção das minorias ou redução de suas desvantagens históricas, entre outros temas. Tratando da public interest litigation, especificamente sobre a questão da eliminação das "barreiras processuais”, v., outrossim, ROBERT MYERS, "Standing in public interest litigation: removing the procedural barriers”, in: Loyola of Los Angeles Law Review, vol. 15, 1981, pp. 2-28. Há, ainda, um grau maior ou menor de controle do Judiciário sobre sua própria agenda. EPP observa que quando a Suprema Corte dos EUA adquiriu controle de sua agenda em 1925, utilizou-se dessa discricionariedade para diminuir sua atenção em relação a disputas comuns envolvendo particulares; além disso, os tribunais do país, de um modo geral, à medida que adquiriram esse controle, mudaram suas agendas para, com predominância cada vez maior, dar atenção a disputas que envolvessem o interesse público de um modo geral. CHARLES R. EPP, The Rights Revolution: Lawyers, activists, and Supreme Courts in Comparative Perspective, op.cit., p. 15. 
influência sobre a sociedade; não se pode ignorar que o órgão judicial, antes de tudo e em regra, precisa ser (adequadamente) provocado ${ }^{193}$.

A referência à experiência da Índia pode enriquecer ainda mais essa problemática, uma vez que, num primeiro momento, a ausência de adequada mobilização social não impediu a eclosão de uma forma peculiar de litigância de interesse público. No caso, a iniciativa partiu do próprio Poder Judiciário, que não só iniciou as discussões sobre as questões que considerava relevantes, fazendo-as ingressar na agenda pública; mas também instigou a propositura de demandas. Ao fazê-lo, já anunciava sua abertura e, de certa forma, sinalizava quais seriam os resultados dos pedidos. Todavia, mesmo havendo desencadeado, nesse contexto de fraca mobilização social, a erupção de um protagonismo judicial sem precedentes naquele país, a iniciativa da Suprema Corte passou a enfrentar sérias dificuldades de sustentação, tendo em vista a falta de uma estrutura de suporte à mobilização jurídica ${ }^{194}$. Isso não impediu, entretanto, uma sucessão de atuações judiciais

${ }^{193}$ De um modo geral, a provocação do Judiciário ocorre à medida que os diferentes participantes de uma estrutura de suporte à mobilização jurídica visualizam determinadas demandas como possíveis. Essa percep̧̧ão leva ao desenvolvimento de um discurso baseado em direitos (constitucionais, legais, internacionais) e ao surgimento de uma agenda no plano sociológico (que pode ser fortalecida, sem dúvida, por normas internacionais sobre direitos humanos). Havendo aquela estrutura de suporte, pode-se buscar, pela promoção de litígios, o ingresso desses temas na agenda judicial.

${ }^{194}$ CHARLES R. EPP, The Rights Revolution: Lawyers, activists, and Supreme Courts in Comparative Perspective, op.cit., pp. 71-200. Em visita ao Brasil, realizada em agosto de 2008, o presidente da Suprema Corte da Índia, Konakuppakatil Balakrishnan, proferiu palestra no STF sobre a "prática do controle de constitucionalidade nos dias de hoje”. Na ocasião, observou que "o judiciário na Índia goza de um status elevado em razão de seu poder de 'controle de constitucionalidade' das ações do governo”, e que, "desde o final dos anos 70, ele expandiu ainda mais o âmbito de suas funções", por meio de duas estratégias que o transformaram "de um órgão de resolução de litígios positivista a um catalisador de mudanças sociais". A primeira é a ampliação do alcance da proteção dada à vida e à liberdade pessoal, com o que a corte exerceu seu papel inovador e criativo. A segunda, particularmente relevante a este tópico, é a evolução da public interest litigation. Segundo ele, esta seria uma "conquista marcante da interpretação constitucional indiana" e "o principal instrumento por meio do qual é dado aos pobres acesso aos tribunais". Para tornar isso possível, o judiciário indiano teria "improvisado" de maneira significativa, ampliando sua competência para "apreciar questões trazidas por partes que, de outro modo, não teriam o conhecimento sobre os seus direitos legais ou os recursos materiais para ter acesso a elas". Do mesmo modo, as Cortes "podem também conhecer de questões por conta própria, sem as exigências das formalidades processuais”, destacou. Em alguns casos pioneiros, tomaram conhecimento de certas questões por meio de cartas das partes lesadas. Em seguida, o reconhecimento de litígios de interesse público "passou a ser um recurso valioso", em especial após sucessivas decisões em que se suplantavam tradicionais óbices de legitimidade ativa para acolher pedidos e expandir direitos, o que eu foi feito, em grande medida, com base nas garantias da vida e da liberdade, previstos no artigo 21 da Constituição indiana. Num desses casos, um grupo de cidadãos (que teve sua legitimidade ativa reconhecida) obteve tutela contra um conselho municipal para a retirada de esgotos abertos que causavam mau cheiro e doenças. O palestrante salientou, ainda, três diferenças da noção tradicional de adjudicação em relação àquela que ocorreria por meio da public interest litigation, nos moldes praticados na Índia: a) o enfraquecimento da exigência de legitimidade ativa, que foi, no país, estendido a qualquer pessoa, o que difere da ideia de ação por representação e das class actions; b) a natureza dos procedimentos, que não seria estritamente 'adversarial’ (em que o juiz é figura passiva), já que os magistrados assumiram uma função mais ativa, buscando "mais informação sobre o assunto e dando instruções às autoridades públicas a esse respeito”; c) a ampliação de remédios judiciais disponíveis (inclusive injuctions - ordens de fazer). Em decorrência dessa postura, "o exercício dos poderes judiciais tem sido frequentemente descrito como 
(notabilizadas como "ativistas”) em prol da defesa de direitos fundamentais individuais e sociais previstos na constituição indiana, sobretudo em temas relacionados a condições degradantes de prisão, trabalho escravo, celeridade processual, tratamentos de saúde, direito à profissão e proteção ao meio ambiente ${ }^{195}$. Nota-se, como fator desencadeador dessas tutelas, um tipo peculiar de manifestação do potencial protagonismo judicial fora do processo e sem vínculo com o palco estritamente jurisdicional, dirigindo-se ao estímulo de demandas, à participação proativa na agenda pública e à sinalização de tendências decisórias.

Importa notar que o surgimento dessa estrutura de suporte à mobilização jurídica não é uma decorrência necessária de certos atributos de uma sociedade ou país. Ao contrário, nota-se considerável contingência seja em sua existência seja em suas estratégias e formas de atuação. Não se trata, assim, de consequência "automática” da industrialização, da modernização ou do grau de desenvolvimento humano de um povo. O exame da experiência inglesa corrobora essa afirmação ${ }^{196}$. O país, que se destaca entre os mais desenvolvidos do mundo, teria vivido, segundo EPP, uma revolução de direitos modesta. Com efeito, foi fraca a mobilização da sociedade civil inglesa, de um lado porque a estrutura de suporte à mobilização jurídica, até recentemente, era muito limitada; e, de outro lado, porque o Poder Judiciário era tradicionalmente refratário a litígios dessa natureza. Para ilustrar, note-se que apenas na década de 1990 se tornou perceptível a tendência de acolhimento de pedidos formulados em processos envolvendo direitos das mulheres. A luta relacionada às políticas de gênero, sobretudo no que concerne às relações de trabalho, revela outros dados importantes sobre a litigância de interesse público no caso inglês. É que, apesar de os european labor standards haverem instigado fortemente essas políticas nos anos 80, a agenda não se desenvolveu antes das demandas patrocinadas pela Comissão Britânica pela Igualdade de Oportunidades (British Equal Opportunities Commission - EOC). As atuações da EOC ocorreram tanto na Corte Europeia de Justiça

'legislação judicial’’. Entre os vários casos citados, é de se destacar o precedente no litígio Vishaka v. Estado de Rajasthan, em que o tribunal emitiu diretrizes para a criação de mecanismos de reparação contra assédio sexual a mulheres no local de trabalho, já que não havia nenhuma legislação que tratasse do assunto. É curioso notar, ademais, que a Suprema Corte indiana tem baixado normas "administrativas", de observância obrigatória. É o caso de normas contra a poluição editadas pela corte para tornar obrigatório o uso de filtros. STF (Notícias). Presidente da Suprema Corte indiana traça paralelo entre as Constituições do Brasil e da Índia, publ. 15-08-08, acesso em 11-03-11. Disponível em www.stf.jus.br.

${ }^{195}$ Citando vários casos da jurisprudência indiana, relacionando os temas do ativismo judicial à litigância de interesse público, v. JAMIE CASSELS, "Judicial Activism and Public Interest Litigation in India: Attempting the Impossible?”, in: American Journal of Comparative Law, vol. 37, 1989, p. 495.

${ }^{196}$ CHARLES R. EPP, The Rights Revolution: Lawyers, activists, and Supreme Courts in Comparative Perspective, op.cit., pp. 132-142. 
quanto nos tribunais ingleses, com o fim de potencializar pressões por mudanças nas leis do país. Sem essa insistência da EOC (promovendo litígios de interesse público para que esses temas fossem incorporados à agenda judicial), com recurso inclusive a instâncias judiciais europeias, a influência do direito comunitário sobre os direitos das trabalhadoras britânicas seria significativamente menor ${ }^{197}$.

O exame do caso da Holanda fornece informações relevantes para contestar a frequente suposição segundo a qual a busca pela implementação judicial de direitos sociais dependeria necessariamente da existência de um controle de constitucionalidade, difuso ou concentrado. Como destaca OLSON, apesar de o Judiciário holandês não possuir tal poder, a litigância de interesse público foi vigorosamente patrocinada pelo movimento feminista, cujas demandas promocionais de direitos civis vieram a ser acolhidas por um “ativismo judicial na interpretação da lei”, e não na aplicação da Constituição ou de qualquer declaração de direitos, que não previam aqueles direitos e nem autorizavam um controle judicial contramajoritário ${ }^{198}$. Essa mobilização estratégica foi favorecida pela proliferação, na legislação do país, de dispositivos com redação aberta e cuja aplicação demandava a integração judicial. Assim, desenvolveu-se uma forte litigância de interesse público de base legal em busca do aprimoramento da condição social da mulher, sobretudo nas relações de trabalho, sem a necessidade de recorrer ao controle de constitucionalidade ou a dispositivos constitucionais ${ }^{199}$.

O caso de Israel desvela outros aspectos interessantes. No país, nota-se que, a partir dos anos 80, diversos grupos de interesses decidiram reendereçar suas

197 CHARLES R. EPP, The Rights Revolution: Lawyers, activists, and Supreme Courts in Comparative Perspective, op.cit., pp. 16, 132. Como se vê, uma crescente "consciência de direitos" não é suficiente para promover a litigância de interesse público. Por outro lado, dificilmente um juiz “criaria” direitos sem nenhum suporte na cultura social e jurídica de seu povo, e muito menos estaria propenso a destruir aqueles que estiverem completamente arraigados nessa cultura ou a amparar aqueles que contrariarem padrões de comportamento largamente aceitos num Estado Democrático de Direito. A “consciência de direitos” é, assim, variável relevante, mas também não é suficiente. Para postular algo ao Judiciário, deve-se ter a consciência, ainda que seminal ou idealizada por outrem, de que existe determinada pretensão judicializável.

198 SUSAN OLSON, "Comparing Women's Rights Litigation in the Netherlands and the United States”, in: Polity, vol. 28, n. ${ }^{\circ}$ 2, 1995, pp. 189-219. Mesmo nos EUA, há casos relevantes de atuações do Judiciário, no campo da litigância de interesse público, baseadas apenas na interpretação de statutes, e não na Constituição, nem em precedentes.

199 SUSAN OLSON, op.cit., p. 194. Por oportuno, transcreve-se o seguinte excerto: "Particularly in the last two decades, the parliament has written less clear statutes that leave important questions for judicial interpretation". E, ao destacar a importância da receptividade dos juízes às demandas: "Ultimately in The Netherlands as in the United States, success is heavily dependent on judicial discretion, notwithstanding the civil law tradition discouraging judicial innovation. A wareness of this was apparent in respondents' speculations about the relative receptiveness to feminist cases of different district court presidents and of the Dutch Supreme Court compared to the highest administrative Court.” A autora destaca, num outro estágio, a importância, para essas causas, do manejo de regras comunitárias. 
demandas ao Judiciário, em especial à Suprema Corte, que vinha, pelos mecanismos processuais existentes, reconhecendo certa ampliação da legitimidade de diferentes atores para a postulação de direitos. De um modo geral, o número de demandas era um reflexo de condições institucionais favoráveis, inclusive quanto aos custos do processo. O que sobressai na experiência israelense, consoante estudo de $\operatorname{KRISHNAN}^{200}$, é que as estratégias e os objetivos das lideranças que promoviam os litígios orientavam a ocasião, a forma e a frequência das demandas dos grupos.

Notava-se que os grupos que recorriam ao Judiciário frequentemente tentavam visualizar estrategicamente todas as implicações das demandas e das decisões judiciais. Assim, é precisa a distinção de GALANTER ${ }^{201}$, para quem litigantes habituais (repeat players), diferentemente de litigantes eventuais (one-shooters), têm mais condições de planejar as demandas e de desenvolver vínculos relacionais informais com membros do Judiciário, além de diluir seus riscos, antecipar cenários e testar estratégias diferentes.

Ademais, conforme estudo de DOTAN, a experiência jurisdicional israelense é reveladora de uma forma peculiar e estratégica de uso, pelo próprio Judiciário, de mecanismos não adjudicatórios de composição de litígios de interesse público. Com efeito, o estudo do comportamento da Suprema Corte do país nos períodos críticos da Intifada (revolta popular de palestinos residentes nos territórios ocupados por Israel no final dos anos oitenta, nos primeiros anos da década de noventa e em vários momentos da década seguinte) reflete uma postura curiosa que teria resultado na ampliação da proteção às minorias palestinas, apesar do cenário nada propício a que isto ocorresse $\mathrm{e}^{202}$. O panorama político da época envolvia sérias dificuldades para os magistrados, que deveriam decidir demandas de minorias sem atrair reações agressivas do governo e da opinião pública. Se falhassem no enfrentamento desse desafio, além de prováveis prejuízos para as minorias, o desenrolar dos acontecimentos poderia levar a grave conflito e a instabilidades institucionais prejudiciais à autonomia do Judiciário israelense. Assim, optou-se pelo uso de técnicas informais que, ao longo da intervenção judicial, potencializaram os acordos entre as partes. A composição extrajudicial foi conduzida com a intermediação indireta da Corte Suprema e a participação do Procurador-Geral israelense, órgão que, não obstante

\footnotetext{
200 JAYANTH KUMAR KRISHNAN, “Public Interest Litigation in a Comparative Context”, in: Buffalo Public Interest Law Journal, vol. XX, 2001, 2002, pp. 19-99.

${ }^{201}$ MARC GALANTER.”Why the Haves Come out Ahead: Speculations on the limits of legal chance”, in: Law and Society Review, vol. 9, 1974, p. 95.

${ }^{202}$ YOAV DOTAN, “Judicial Rhetoric. Government Lawyers and Human Rights: The Case of the Israeli High Court of Justice During the Intifada”, in: Law \& Society Review, n. ${ }^{\circ} 33,1999$, pp. 319 e ss.
} 
representar o governo, era suficientemente independente dele. Desse modo, os resultados não adjudicatórios obtidos foram substancialmente favoráveis às minorias palestinas, quando comparados àqueles que o Judiciário vinha propiciando pela via adjudicada ${ }^{203}$.

Como se vê, esse breve estudo comparatístico do fenômeno da litigância de interesse público demonstra, nos casos citados, várias formas de manifestação do potencial protagonismo judicial em processos e também fora de um contexto estritamente jurisdicional.

\subsubsection{Poder Judiciário e meios de comunicação de massa}

À medida que a juridificação progrediu, o potencial protagonismo judicial cresceu e suas formas de manifestação se diversificaram. Paralelamente, o comportamento dos órgãos judiciais passou a ser cada vez mais observado pelos meios de comunicação.

A relação entre a mídia e o Poder Judiciário tende a ser, nas experiências democráticas da "Era da Informação", complexa e ambígua, como bem qualifica BADINTER. De início, essas relações se baseavam, de um lado, na busca, pelos mass media, da tutela judicial para a liberdade de expressão, de opinião e de imprensa; e, de outro lado, em postulações judiciais em face dos órgãos de comunicação, muitas vezes apontados como violadores de interesses individuais, em especial pelo abuso da liberdade que possuíam. Em ambas as situações, os mass media, ora como demandantes, ora como demandados, subordinavam-se às decisões do juiz ${ }^{204}$.

Em virtude da expansão dos meios de comunicação paralelamente ao crescimento da juridificação e do potencial protagonismo judicial, essas relações de poder se sofisticaram tremendamente. Com efeito, quanto mais largo o espectro das possibilidades de intervenção judicial, maior tende a ser a atenção que o Judiciário desperta

\footnotetext{
203 “ (...) the Attorney General is assumed to be the unbiased guardian of the rule of law and is answerable to the principles of the constitution alone” (YOAV DOTAN, p. 338). Na África do Sul, também há importantes atuações do Judiciário a partir da mobilização de grupos sociais. Comentando vários exemplos, entre eles o conhecido caso Grootboom (relacionado ao direito à moradia), v. CHRISTOPHER MBAZIRA, Litigating socio-economic rights in South Africa: a choice between corrective and distributive justice, Pretoria, Pretoria University Law Press, 2009, pp. 4, 43-47.

${ }^{204}$ ROBERT BADINTER, “Justice et médias dans la société de l'information: le couple infernal”, in: ROBERT BADINTER, STEPHEN BREYER, op.cit., p. 307.
} 
nos meios de comunicação ${ }^{205}$. Destarte, além daquelas duas formas de interação supracitadas, fortalece-se uma terceira bastante complexa, ambígua, de difícil apreensão e aparentemente não hierarquizada.

Muitas questões hoje levadas ao Judiciário integram um extenso rol de dilemas contemporâneos que transcendem o fenômeno jurídico para suscitar indagações técnicas, econômicas, éticas, políticas e científicas. E, em uma "sociedade do espetáculo”, essas questões tendem a contar com grande apelo midiático. Assim, além de interessada na cobertura de crimes, da corrupção de agentes públicos ou da vida de celebridades e personalidades, a mídia passa a supervisionar a postura judicial diante de temas como os limites de pesquisas biológicas, a intervenção em políticas públicas e na política em geral, a proteção dos direitos de minorias, os efeitos jurídicos de opções sexuais, a tutela ao meio ambiente, a promoção de ações afirmativas, a rediscussão dos limites para o aborto e a busca pela "verdade" na chamada justiça transicional. Em outras palavras, os meios de comunicação tendem a incorporar à sua agenda uma série de temas polêmicos que ingressam na agenda judicial ${ }^{206}$.

Pela repercussão potencial das decisões nesses casos, é inevitável que a mídia se torne particularmente interessada em seus antecedentes, nos processos decisórios e nos atores que deles participem (em especial os julgadores). Além de difundidas rapidamente, as notícias sobre determinadas decisões judiciais, sob as mais variadas angulações valorativas, veiculam diferentes interpretações sobre os mesmos fatos. Repentinamente, os magistrados que conduzem esses processos passam a se submeter à crítica midiática e, quando agradam, costumam ser associados à imagem de juízes "bons”, “prudentes”, “justos” e “engajados”; ou, quando desagradam, tendem a ser descritos como magistrados “maus”, “imprudentes” e “irresponsáveis”207.

\footnotetext{
${ }^{205}$ Veremos, a seguir, que a primeira referência conhecida à expressão ativismo judicial (judicial activism) surgiu, precisamente, em um periódico norte-americano. v. tópico 3.2.1, infra.

${ }^{206}$ Com efeito, os meios de comunicação de massa têm no mínimo três papeis sociais relevantes: observação de cenários amplos, a busca de um consenso entre diferentes segmentos da sociedade e a transmissão da cultura. Admitida, aqui, na esteira de MaCcombs, uma hipótese amplamente discutida pelos teóricos da opinião pública, segundo a qual a agenda dos meios de comunicação interfere na determinação da agenda pública (agenda setting), poderíamos observar aquele papel de "vigilância" como mecanismo de seleção do material com o qual se formam porções substanciais de nosso imaginário a respeito de um cenário mais amplo. Quando o centro das atenções da mídia se move de um tema para outro, ou quando enfoca os atributos dos objetos sob vigilância, o receptor passa a "perceber" aquele assunto e a se tornar mais atento a variáveis que transcendem sua capacidade de percepção individual imediata. Nesse sentido, pode-se dizer que, quanto maior a exposição à mídia em uma determinada cultura, maior a correspondência entre a agenda dos meios de comunicação e a agenda pública. MAXUELL MCCOMBS, Setting the Agenda: the mass media and public opinion, Malden: Blackwell Publishing, 2004, p. 134.

${ }^{207}$ Nesse sentido, v. ROBERT BADINTER, op.cit., pp. 308.
} 
As relações, assim, parecem invertidas, já que a mídia, não obstante destituída de autoridade coercitiva, ocupa uma posição de poder crítico (pouvoir critique) em relação às instituições judiciais e aos magistrados. Dessarte, se o impacto de qualquer conduta judicial é aferido não apenas pela observação dos efeitos que ela produz, mas também pela reação midiática que ela desperta; não seria despropositado sustentar que a atuação dos mass media teria certo potencial de influência, ainda que indireta e sutil, sobre o curso dos processos e seus resultados ${ }^{208}$.

Ademais, BADINTER acrescenta que, na era celebrização (starisation), certos magistrados, pelo exercício de suas funções ou mesmo por "vocação", tornam-se figuras midiáticas de grande importância. Muitos deles, consoante o citado jurista, promovem troca intensa de informações com os meios de comunicação, inclusive para colocar a mídia a serviço de seus propósitos. Ao conseguirem dar publicidade aos casos, podem até mesmo prevenir ou mitigar reações de quem pretenda exercer pressões baseadas em interesses econômicos ou políticos ${ }^{209}$.

Outro aspecto relevante dessa problemática difusa e ainda pouco explorada é que, nesse cenário de recíprocas influências, os tempos do Judiciário e da mídia não são coincidentes. De um lado, trabalha-se com regras processuais e procedimentais que tornam a marcha do caso lenta e prudente. De outro, busca-se manter a competitividade no mercado da informação, e para isso a notícia deve ser veiculada tão logo os fatos sejam descobertos. Hoje, à medida que os meios eletrônicos avançam, diminui assustadoramente esse espaço temporal entre a “descoberta” do fato, a elaboração da pauta e a divulgação da notícia. Com isso, o ingresso na agenda pública do potencial protagonismo judicial e de suas manifestações tende a sofrer o impacto da atuação dos meios de comunicação. É verdade que a opinião pública é fenômeno amorfo e dificilmente coincide com o que se encontra nos editoriais de jornais. Todavia, parece clara a tendência de os mass media influenciarem de alguma forma o modo como as pessoas visualizam o perfil dos juízes e as instituições judiciais em geral. Pode-se considerar, ademais, na linha

\footnotetext{
${ }^{208}$ ROBERT BADINTER, op.cit., pp. 308-313. "La Justice devient un spectacle dont les juges sont, parmi d'autres, les protagonistes. Or, tout être humain exposé au regard public change de comportement. Le juge ne se demande plus seulement quel sera l'impact de sa décision sur le fonctionnement de la société, mais comment les médias réagiront. C’est un élément qui est pris en considerátion. Ce qui fait que les médias se mettent eux-mêmes à exercer un contrôle de l'activité judiciaire: 'C'est un bon jugement', 'C'est un mauvais juge', ‘Untel est irresponsable'(...). Il n'est pas si simple de chevaucher avec noblesse une monture racée, dans une armure immaculée"

${ }^{209} \mathrm{O}$ autor cita casos de promotores italianos, franceses e espanhóis cujas conexões com os meios de comunicação revelaram “trocas” relevantes de informações. ROBERT BADINTER, op.cit., p. 308.
} 
do que defende BADINTER, que a presença do Judiciário e de seus membros na agenda midiática pode provocar certa influência sobre decisões políticas, além de afetar a motivação de atores sociais que pretendam buscar a solução judicial de conflitos atuais e futuros, a depender de como captem opiniões jurídicas e políticas de órgãos judiciais, divulgadas pelos mais diversos meios e com as mais variadas angulações ${ }^{210}$.

Referindo-se à Suprema Corte americana, BAUM afirma que, por esboçar versões da “opinião pública” e dos entendimentos da comunidade jurídica (como grupo qualificado que produz conhecimento doutrinário), a ação dos meios de comunicação de massa pode ter certo efeito sobre as decisões daquele órgão ${ }^{211}$. Em geral, mesmo que essa influência ocorra de forma bastante sutil, ela pode ser relevante em certas circunstâncias, em especial porque os mass media, de certa maneira, ao avaliarem o tempo inteiro o que a Suprema Corte faz, ligam o órgão não só ao público em geral, mas também aos legisladores e governantes ${ }^{212}$.

É verdade que, no exame da interação entre os meios de comunicação, a opinião pública e o Judiciário, é preciso considerar que os juízes não são órgãos representativos, isto é, os magistrados não dependem do que pensem os cidadãos para se manterem em seus cargos, diferentemente dos legisladores e governantes, cuja imagem, se não for mantida, pode prejudicar a reeleição normalmente almejada. Isso explica o porquê de decisões judiciais altamente impopulares em vários momentos da história ${ }^{213}$. Mesmo assim, a percepção da opinião pública parece ter algum efeito sobre as decisões judiciais. No caso dos EUA, isso ocorreria não só porque essa variável tende a ser considerada para legitimar a interpretação de certas disposições constitucionais, mas também porque a Suprema Corte sabe que o impacto de suas decisões depende, em parte, da aceitação dos julgamentos e do imaginário da massa do público acerca de sua autoridade como instituição. Desse modo, quanto mais favoravelmente o povo considerar a Corte e seu trabalho, mais seguirá as decisões que ela proferir, em lugar de embaraçá-las. Isso leva o órgão não só à elaboração de estratégias de modulação dos efeitos de seus julgamentos no tempo, mas também a ter cuidado na divulgação dos fatos. Dedica-se grande esmero à

\footnotetext{
${ }^{210}$ ROBERT BADINTER, op.cit., pp. 308-313.

${ }^{211}$ LAWRENCE BAUM, A Suprema Corte Americana, Rio de Janeiro: Forense, 1987, pp. 200-202.

${ }^{212}$ Cf. tópico 3.2.1, infra. Como veremos, a primeira referência à expressão ativismo judicial ocorreu no meio jornalístico, em análise (elaborada por Schlesinger) que muito contribuiu para organizar os debates que o tema suscitaria sob essa designação.

${ }^{213}$ Entre as decisões impopulares, ele cita a proibição da reza organizada em escolas públicas, a promoção do transporte de alunos por ônibus especiais para fomentar a integração racial e o reconhecimento dos direitos de acusados.
} 
fundamentação das decisões, de modo que elas se tornem, o tanto quanto possível, mais persuasivas e “desejáveis”. Não se pode desconsiderar, ainda, que alguns magistrados podem ter interesse pessoal na popularidade de seus julgamentos, seja pelo desejo de ser apreciado, seja por almejarem, apesar de isto ser raro, um futuro cargo eletivo ${ }^{214}$.

\subsection{Juridificação de relações sociais no Brasil e potencial} protagonismo judicial

Os aspectos e desdobramentos da juridificação destacados no tópico 2.2 plasmam ingredientes relevantes para a identificação do potencial protagonismo judicial nas experiências democráticas ocidentais. No Brasil, apenas com o advento da Constituição de 1988, que pôs fim às amarras antidemocráticas, esse potencial se consolidou efetivamente.

É que, não obstante alguns ingredientes da juridificação já estivessem presentes antes mesmo da redemocratização do país, as decisões judiciais em geral, se tivessem um mínimo de repercussão política ou se contrariassem de alguma maneira o hipertrofiado Executivo, seriam imediata e autoritariamente contidas.

Além de promover a redemocratização, o novo texto constitucional consagrava um modelo de Estado Providência que discrepava profundamente da realidade brasileira da época. Assim, já nos primeiros anos de vigência da Constituição de 1988, FREITAS JUNIOR observava que as reflexões acerca das promessas que ela trazia em matéria de direitos sociais vinham se desenvolvendo em clima de despontamento e descrença. Desapontamento com o que efetivamente havia sido alcançado ao longo da história legislativa brasileira; e descrença quanto ao que ainda se pretendia alcançar ante um horizonte de profunda crise social ${ }^{215}$.

Em busca das causas desse quadro que ainda é bastante atual, pode-se examinar a experiência brasileira de Welfare State desde suas origens, não só como instrumento de política macroeconômica, mas também como mecanismo de regulação da

\footnotetext{
${ }^{214}$ LAWRENCE BAUM, op.cit. 198-199. O autor refere que, no caso Brown v. Board of Education, a expectativa da Corte em relação à recepção da decisão em diferentes regiões do país levou os juízes a elaborar certa estratégia de implementação, que envolveu, v.g., prazo "indefinido" para seu cumprimento no Sul. Calculou-se que essa flexibilidade auxiliaria na aceitação da decisão. O autor também cita que várias decisões mais polêmicas chegam a citar pesquisas de opinião pública em sua fundamentação.

${ }^{215}$ ANTÔNIO RODRIGUES DE FREITAS JUNIOR, Os direitos sociais e a constituição de 1988: crise econômica e políticas de bem-estar, op.cit., p. 1.
} 
sociedade, o que corrobora a perspectiva da juridificação e permite identificar a evolução de seus impactos sobre a atividade judicial.

\subsubsection{Perplexidades suscitadas pela experiência brasileira de} “Welfare State” (1930 a 1988)

Na década de 1920, o exame da situação dos direitos sociais revelava que os conflitos trabalhistas eram regulados por legislação esparsa, e que muitas vezes eram contidos pelo aparato policial. As questões de saúde pública eram atribuídas às autoridades locais, sem nenhum programa de ação voltado a atendê-las. A educação era oferecida em rede escolar reduzida e que beneficiava poucos, em especial pela falta de organização de uma política educacional global. A previdência era predominantemente privada, organizada por empresas e categorias profissionais. A habitação, por sua vez, encontravase fora da agenda de qualquer política social. Esse cenário começou a ser modificado, segundo MEDEIROS, quando o intervencionismo estatal se intensificou a fim de conferir caráter urbano-industrial a uma economia agrário-exportadora. Para oferecer condições necessárias ao desenvolvimento da indústria e à integração da economia, o Estado precisava centralizar suas ações, inclusive pela regulamentação dos fatores de produção por meio de leis que dispusessem sobre as condições de trabalho. Antes dessa centralização, as intervenções, se não eram emergenciais, ocorriam de forma fragmentada, como na criação dos Departamentos Nacionais do Trabalho e da Saúde, do Código Sanitário e da Lei previdenciária Eloy Chaves, de $1923^{216}$.

A partir da década de 1930, as intervenções estatais integradoras se alinharam ao corporativismo, sobretudo após a Constituição de 1937, que substituiu o texto

\footnotetext{
${ }^{216}$ A descrição cronológica ora apresentada é baseada no estudo de MARCELO MEDEIROS, A Trajetória do Welfare State no Brasil: Papel Redistributivo das Políticas Sociais dos Anos 1930 aos Anos 1990, Brasília: IPEA, 2001, p. 8. Destaca-se, do texto, o seguinte excerto: "As circunstâncias do surgimento e do desenvolvimento do Welfare State no Brasil são diferentes (...). Além de ocorrer sob uma posição diferente na economia mundial, o processo de modernização brasileiro é marcadamente segmentado, com setores industriais modernos convivendo com setores tradicionais e com a economia agrário-exportadora. O controle do mercado para produtos industriais por meio de políticas de massificação do consumo foi um aspecto secundário para um Estado preocupado com estratégias protecionistas, disponibilidade de insumos e investimentos em bens de capital e infraestrutura. No período de industrialização do Brasil, a possibilidade de se utilizar o Welfare State como instrumento de controle da demanda agregada era reduzida. Problemas de superprodução estavam muito mais relacionados ao comportamento do setor externo do que a flutuações nos níveis nacionais da demanda e o número restrito de trabalhadores beneficiados limitava a efetividade das políticas como mecanismo de expansão do consumo.” O autor dialoga com uma série de estudiosos da experiência brasileira de "Welfare State", como Sonia Miriam Draibe, Tanya Barcellos, James Malloy e George Martine.
} 
constitucional de 1934 e, com ele, a primeira tentativa de dispor sobre a ordem econômica e social. Nesse período, houve uma sucessão de mudanças relevantes. Antagonismos entre as classes passaram a ser tratados como nocivos ao bem comum, e os conflitos de um modo geral, notadamente os estabelecidos entre capital e trabalho, deslocavam-se pouco a pouco para a esfera do Estado, que autoritariamente reprimia os movimentos de trabalhadores e suas tentativas de articulação política, tendência só interrompida, efetivamente, após o fim do regime militar ${ }^{217}$.

Construía-se, gradativamente, uma substanciosa base institucional e legal para o controle das políticas intervencionistas estatais. Leis criaram institutos de aposentadorias e pensões, ao lado de um sistema de seguridade cujas bases perduraram até os anos sessenta; políticas de saúde e de educação foram progressivamente centralizadas em âmbito federal e, além, disso, leis sobre relações de trabalho foram consolidadas na CLT, de 1943. Com enfático direcionamento protetivo aos trabalhadores urbanos, comerciários e industriários, essas normas, com o cuidado de não prejudicar os interesses das oligarquias rurais da época, tratavam de temas como organização sindical, negociação salarial, jornada de trabalho, férias, acidentes de trabalho, dispensas de empregados e tutela de mulheres e menores. Com o apoio institucional do Ministério do Trabalho, criado em 1930, essa regulação dava início a forte política governamental de controle das relações de trabalho.

Pela perspectiva da juridificação, o Estado brasileiro iniciava um processo de expansão de padrões regulatórios e promovia autoritariamente a expropriação de conflitos como forma de controle da sociedade (2.2.1 e 2.2.5, supra). Além do aumento deliberado da intervenção estatal na economia e do desenvolvimento de políticas nacionais como estratégia de desenvolvimento, o governo evitava, de forma repressiva e populista, que movimentos de trabalhadores apoiassem grupos de oposição. Nessa linha, as relações de trabalho foram despolitizadas (2.2, supra), já que os sindicatos, em lugar de atuarem como instrumentos de reivindicação, tornaram-se verdadeiros pontos de apoio do regime $^{218}$.

\footnotetext{
${ }^{217}$ MARCELO MEDEIROS, pp. 9-10. Tratando do processo de estruturação das premissas da economia nacional, v. CELSO FURTADO, Formação Econômica do Brasil, 32ª ed., São Paulo: Cia Editora Nacional, 2005. O autor descreve, entre outros temas, a maneira como o processo de industrialização exerceu papel importante na formação da economia nacional, culminando, no entanto, com expressivo aumento do excedente social e com surpreendente capacidade de conciliar desigualdade social e crescimento econômico, conforme destaca Plínio de Arruda Sampaio Junior, no prefácio da obra.

${ }^{218}$ MARCELO MEDEIROS, op.cit., pp. 11-12.
} 
Fez parte desse processo a criação da Justiça do Trabalho e o desenvolvimento inicial do Direito do Trabalho brasileiro. Não sobeja relembrar, neste átimo, que este ramo do Direito constitui verdadeiro paradigma para o processo de juridificação, cuja evolução pode ser compreendida pela observação das origens e do desenvolvimento dos institutos jurídicos trabalhistas. Quanto mais a juridificação se intensificou, mais o Direito do Trabalho se tornou distinto como ramo e mais suas determinações passaram a interferir sobre as condições de trabalho em suas especificidades, reestruturando, assim, a atividade de trabalhadores e de tomadores de seus serviços $^{219}$.

Nas décadas subsequentes, sobretudo no campo das relações de trabalho, continuaram intactas muitas das estruturas corporativas criadas naquele período, não obstante a mudança no sistema representativo e a emergência de um regime de democracia populista que perduraria até o início do regime militar ${ }^{220}$. Com efeito, até as mudanças ocorridas em 1964, o populismo era o traço fundamental da relação entre Sociedade e Estado, o que levou este último a ampliar suas funções para gerenciar o aprofundamento da concentração urbana e da "modernização" do país. Desse modo, o processo de juridificação foi intensificado para enfrentar questões emergentes do campo previdenciário (necessidade de unificação administrativa, universalização e uniformização de benefícios e serviços), da saúde (doenças de massa e necessidade de ampliação da assistência médica), do trabalho (discussões sobre a política salarial e lutas sindicais que se acirraram em decorrência do incentivo populista à mobilização das massas urbanas), da educação (demanda por democratização do ensino e por qualificação profissional) e da habitação (expressivo déficit habitacional que ampliava a dimensão social da questão) ${ }^{221}$.

\footnotetext{
${ }^{219}$ SPIROS SIMITIS, “Juridification of labour relations", op.cit., pp. 113, 119-120. Sobre o caso italiano, v. GINO GIUGNI, op.cit., p. 309. Acerca do caso brasileiro, v. ANTÔNIO RODRIGUES DE FREITAS JUNIOR, Os direitos sociais e a constituição de 1988: crise econômica e políticas de bem-estar, op.cit., pp. 44 e ss.

${ }^{220}$ No campo das relações sindicais, o "corporativismo de Estado", introduzido no Brasil ao longo dos anos trinta, conquanto possa expressar sinais de fraca exaustão, teve sua vida útil prolongada mediante a preservação de algumas figuras capazes de lhe dar sustentação: a) a solução jurisdicional dos conflitos de interesse, na forma específica do conhecido Poder Normativo atribuído aos Tribunais Trabalhistas; b) o sistema de arrecadação e de custeio compulsórios e extensivos a todos os pertencentes a cada categoria, à indiferença, portanto, do vínculo associativo; c) o monopólio jurídico da representação sindical, conferido aos organismos constituídos na forma da lei; e d) (...) a imposição legal de que haja apenas um sindicato representando cada categoria, na mesma base territorial - a chamada unicidade sindical. ANTÔNIO RODRIGUES DE FREITAS JUNIOR, Os Direitos Sociais e a Constituição de 1988: crise econômica e políticas de bem-estar, op.cit., pp. 133-135.

${ }^{221}$ MARCELO MEDEIROS, op.cit., pp. 12-14.
} 
Iniciado em 1964, o regime militar restaurou várias tradições da década de 1930 para promover a retração dos movimentos sindicais e sociais reivindicatórios. As políticas sociais, nesse período, organizavam-se em função do crescimento econômico, sem uma preocupação direta com o ideário redistributivo. O controle da sociedade, operado pela contínua expropriação de conflitos, era traço característico da estratégia de desenvolvimento nacional. Nesse novo cenário, o populismo dava lugar tanto a impulsos produtivos, por meio de políticas sociais dirigidas ao crescimento econômico; quanto a ações compensatórias que se traduziam em programas assistencialistas para minorar os impactos das desigualdades crescentes provocadas por um modelo de desenvolvimento que combinava concentração de renda e altíssimos custos sociais. Vinculadas a objetivos econômicos e produtivistas, as políticas sociais buscavam o autofinanciamento e a geração de excedentes aplicáveis no setor produtivo ou em outras políticas sociais ${ }^{222}$.

Estimulada a assumir fatias de setores como habitação, educação, saúde, previdência e alimentação, a iniciativa privada era peça-chave de um modelo que vinculava o desenvolvimento econômico à concentração de renda e ao incremento da pobreza. Dinamizados os interesses particulares nos centros idealizadores das políticas sociais, tornava-se difícil o sucesso de qualquer iniciativa redistributiva. Mecanismos perniciosos estimulavam a transferência de recursos para estratos de maior renda, que adquiriam assim maior capacidade de mobilização política, inclusive para influenciar decisões do Poder Público, de modo que as políticas sociais (com ações ineficazes, ineficientes e regressivas) sempre estivessem orientadas conforme interesses particulares.

Essa peculiar experiência de "Welfare State”, no Brasil, com o viés juridificante que desde os anos 1930 deu suporte a um controle social autoritário, apresentou, ao longo da década de 1970 e 1980, grande vocação para intensificar as desigualdades sociais e a marginalização, contrariamente aos objetivos do modelo de Estado Providência. No âmbito de uma estrutura estatal caracterizada pela centralização política e financeira em nível federal, pela fragmentação institucional, pelo autofinanciamento e pelo uso clientelístico das políticas sociais, todos os possíveis mecanismos redistributivos se tornavam ineficazes. Havendo grande distanciamento entre aqueles que formulavam e executavam políticas públicas, de um lado; e os seus supostos beneficiários, de outro, pouco se fazia para que recursos fossem utilizados de maneira

\footnotetext{
${ }^{222}$ Como destaca o autor, as políticas de educação eram direcionadas a formar trabalhadores qualificados e a aumentar a produtividade da mão de obra semiqualificada. (MARCELO MEDEIROS, op.cit., pp. 12-14.)
} 
impessoal e equitativa. Programas sociais governamentais, assim, tornavam-se inanes, instáveis, sem avaliação e tendentes à descontinuidade. Pesavam desproporcionalmente os interesses burocráticos, corporativos e privados na definição da dinâmica de funcionamento da máquina social do Estado. Desse modo, a dívida brasileira em matéria de “justiça social” e de implementação de direitos sociais cresceu assustadoramente ${ }^{223}$.

Observado esse breve histórico, não é difícil perceber diferenças claras entre as experiências de Welfare State do Brasil e dos países da Europa e da América do Norte. Entre nós, em especial até a promulgação da Constituição de 1988, além do grave comprometimento do aspecto redistributivo, a forma pela qual se desenvolveu a juridificação das relações sociais indicou uma tendência à expropriação autoritária dos conflitos, ao controle dos movimentos sociais e à contenção da tensão entre os poderes. À época, o potencial protagonismo judicial, de um modo geral, era fortemente contido pela hipertrofia do executivo. Assim, na segunda metade do Século XX, período em que o ideário do Estado Social se consolidava em outras experiências democráticas (EUA e Europa), com o crescente fortalecimento do Poder Judiciário, a trajetória política brasileira, até 1988, revelava séria contenção a essas mudanças institucionais.

\subsubsection{Juridificação, Constituição de 1988 e expansão efetiva do} potencial protagonismo judicial no Brasil

O fim do regime militar, a redemocratização e a nova Constituição trouxeram muitos avanços para a arena política da Nova República. Intensificou-se a atividade partidária, fortaleceu-se o movimento sindical e tornou-se viável uma efetiva participação popular no processo eleitoral. O avanço democrático, entretanto, veio acompanhado do desmantelamento das poucas e viciosas políticas sociais existentes. Nenhum programa social de maior impacto foi lançado e alguns foram até mesmo desativados, já que a crise econômica causava retração dos recursos que poderiam ser aplicados na área social. Dificuldades decorrentes da transição para a democracia (entre elas a necessidade de rever as estruturas legislativas e executivas montadas no período autoritário e que favoreciam o uso eleitoreiro das políticas sociais) obstaculizavam iniciativas de promoção efetiva de programas de maior alcance. O resgate da dívida social do país dependia de mudanças profundas, mas os impulsos reformistas iniciais se

\footnotetext{
${ }^{223}$ MARCELO MEDEIROS, op.cit., pp. 14- 17.
} 
limitaram aos programas emergenciais no campo da suplementação alimentar e à inclusão da reforma agrária e do seguro-desemprego na agenda governamental ${ }^{224}$.

Assim, não obstante as novas e abrangentes promessas constitucionais de efetivação de direitos sociais, era considerável o passivo a ser combatido pelas instituições estatais, inclusive as judiciais.

Quando da promulgação da Constituição de 1988, o Judiciário independente que renascia (ao lado de instituições remodeladas, como o Ministério Público) se defrontava com um cenário de profundo déficit de implementação de direitos. Na época, a marginalização social, a pobreza e a ineficiência de políticas sociais passaram a ocupar, cada vez mais, os debates públicos ${ }^{225}$.

Esses vazios em matéria de direitos sociais, deixados pela claudicante experiência brasileira de Welfare State, justificam a avaliação de CAMPILONGO, de que, no Brasil, “o processo que vai dos direitos civis aos políticos e destes aos direitos sociais não foi nem linear, nem cumulativo”. Muito ao contrário, de forma imperfeita, truncada e simultânea, a luta pela cidadania se desenvolveu “em todas essas frentes” e só encontrou condições efetivas de desenvolvimento após a Constituição de 1988. Destarte, como é comum em países periféricos, o desafio brasileiro, diferentemente da tarefa de países centrais, não é o de manter o padrão de eficácia da ordem jurídica ou a intensidade de garantias sociais; mas o de harmonizar os diferentes tipos de direitos para suprir vazios de efetividade e para alargar o alcance dessas garantias aos mais variados setores da sociedade, em especial às classes trabalhadoras. Sendo assim, são muito mais fortes os desafios redistributivos impostos ao sistema político e que, num cenário democrático, tendem a ser cobrados do sistema judicial ${ }^{226}$.

\footnotetext{
${ }^{224}$ MARCELO MEDEIROS, op.cit., pp. 17-18. O seguro-desemprego foi introduzido no Brasil apenas no ano de 1986, por intermédio do Decreto-Lei n. ${ }^{\circ}$ 2.284/86 (Decreto n. ${ }^{\circ}$ 92.608/86), embora já previsto na Constituição de 1946. Antes disso, desde os anos 40, menções fortuitas à seguridade no emprego e à compensação ao desempregado apareciam na legislação. As iniciativas do período militar se limitaram, na prática, a desempregados de firmas inadimplentes e a demissões envolvendo mais de cinquenta trabalhadores. Os critérios de elegibilidade dificultavam sobremaneira a efetividade do instituto. Mesmo em 1986, o instituto foi apenas um aspecto do plano de estabilização conhecido como "Plano Cruzado". ALEXANDRE DE FREITAS BARBOSA. "O programa seguro-desemprego como parte das políticas de emprego no Brasil", in: Cadernos de Pesquisa - CEBRAP, n. ${ }^{\circ}$, mai. 1997, p. 100.

${ }^{225}$ Mais recentemente, um importante estudo sobre a dimensão jurídica das políticas sociais no Brasil foi realizado por DIOGO ROSENTHAL COUTINHO. Direito, desenvolvimento e desigualdade: a dimensão jurídica das políticas sociais. FDUSP: Tese (Livre-Docência), 2010.

${ }^{226}$ CELSO FERNANDES CAMPILONGO, op.cit., pp. 31-32. O autor destaca que o esquema de evolução de direitos de Thomas Humphrey Marshall, que pressupõe “concepções de cidadania muito específicas”, pouco se relacionam com a realidade social brasileira.
} 
A consolidação da democracia num cenário de dificuldades econômicas (pacotes, inflação, crise fiscal), de degradação dos costumes político-administrativos (corrupção, desvios de função, impunidade) e de desagregação social (violência urbana, recrudescimento da miséria e pauperização da classe média) levou a um aumento das responsabilidades do Judiciário em face de uma conflituosidade cada vez mais explosiva. Afirmado o modelo de "Estado Social” na Constituição de 1988, inúmeras expectativas materiais se converteram em autênticas pretensões jurídicas $(2.2 .2 \text {, supra })^{227}$ e a democratização do acesso à justiça estimulou uma crescente procura pela tutela judicial ${ }^{228}$. Lançados nas mãos dos brasileiros vários mecanismos até então desconhecidos para a defesa de seus direitos e para a valorização da cidadania, a possibilidade de recurso ao sistema de justiça se tornou mais visível ${ }^{229}$.

Como se vê, vários fatores concorriam para a crise dos paradigmas convencionais do enquadramento teórico da atuação jurisdicional, entre eles a hipertrofia normativa, inclusive quanto às fontes do direito (2.2.1, supra); a ampliação das funções do Judiciário, levando a grande ambiguidade na definição dos fins da atuação jurisdicional (2.2.3, 2.2.5, 2.2.8.1, supra); e a expansão dos usuários dos serviços jurídicos, com o surgimento de novos atores em favor dos quais se alargou a noção de legitimação para agir, o que, de um lado, facilitou a demanda por tutela de interesses metaindividuais, e, de outro, acirrou o debate sobre o Direito e suas relações com os movimentos sociais (2.2.9, supra $)^{230}$.

Observando esse mesmo cenário, SILVA sustenta que o Brasil, na área social, apesar de figurar entre chamados "países em desenvolvimento”, padece de todos os problemas característicos dos países não desenvolvidos. Acrescenta o jurista que "a desigualdade social piora ainda mais o quadro”, já que a imensa maioria da população depende de políticas públicas. No âmbito jurídico, a conjunção de alguns fatores torna a situação ainda mais complexa, sobretudo após a promulgação da Constituição de 1988.

\footnotetext{
${ }^{227}$ CELSO FERNANDES CAMPILONGO, op.cit., pp. 30-47.

${ }^{228}$ MARIA TEREZA SADEK, "Poder Judiciário: uma nova instituição”, op.cit., pp. 30-31. A autora cita estatísticas apresentadas pelo estudo Justiça em Números (Associação dos Magistrados Brasileiros, 2009).

229 “Os agentes políticos encontram no Judiciário um novo interlocutor e uma nova arena tanto para seus confrontos quanto para contestar políticas governamentais e decisões de maiorias legislativas. O cidadão passou a ter na instituição um recurso para a garantia dos mais variados direitos e para a solução de disputas”. A autora destaca que "no que diz respeito à cidadania, a consagração de uma ampla gama de direitos - de primeira, de segunda e de terceira geração - e a democratização no acesso à justiça estimularam uma crescente procura por soluções judiciais. Com efeito, os números relativos à entrada de processos no Poder Judiciário mostram um aumento extraordinário no número de ações.” MARIA TEREZA SADEK, pp. 30-31. ${ }^{230}$ Nesse sentido, CELSO FERNANDES CAMPILONGO, op.cit., pp. 30-31.
} 
Isso porque, de um lado, as políticas públicas governamentais são insuficientes para satisfazer "a imensa demanda de uma população carente de serviços em quantidade e qualidade aceitáveis”; e, de outro lado, o novo texto constitucional ampliou a incorporação, em seu bojo, de "temas que já foram vistos como reservados ao campo da política, como a regulação do salário mínimo, a fixação de taxas de juros e a garantia de direitos à saúde, à educação, ao trabalho e à moradia”231.

Essa multiplicação de garantias individuais e sociais com a nota da materialização (2.2.2, supra) e com o recurso constante a cláusulas gerais, noções vagas $e$ conceitos jurídicos indeterminadas, que proliferam ao lado de dispositivos de caráter programático e principiológico, ao aprofundar entre nós a “indeterminação” do direito e o distanciamento progressivo de um modelo subsuntivo (2.2.1 e 2.2.4, supra), amplia significativamente o poder criativo e a discricionariedade dos juízes.

Percebe-se, nesse conjunto de constatações, a presença marcante de vários aspectos e desdobramentos da juridificação destacados no tópico 2.2, o que, num cenário de ascensão da efetiva independência política do Poder Judiciário, possibilitou o surgimento de uma série de manifestações do potencial protagonismo judicial no Brasil ${ }^{232}$.

Algumas das repercussões da emergência de um Judiciário independente no Brasil foram bem prognosticadas por REZEK às vésperas da promulgação da Constituição de 1988, em uma das primeiras interpretações a respeito de qual seria o significado social, político, jurídico e institucional dessa mudança. O jurista, ao vislumbrar a missão do Judiciário brasileiro, comparando-a com a tarefa das instituições judiciais dos EUA ao final do século XVIII, destacava que não se poderia dizer, pela perspectiva constitucional, qual era a estrutura com o maior poder e independência. A perplexidade dessa avaliação derivava do fato de o texto constitucional norte-americano ser marcado pela concisão e pela sobriedade de regras e princípios, num conjunto normativo que sempre colocou os magistrados diante do "desafio de detalhar, de especificar, de

\footnotetext{
${ }^{231}$ VIRGILIO AFONSO DA SILVA, “O Judiciário e as políticas públicas: entre transformação social e obstáculo à realização dos direitos sociais”, op.cit., pp. 587-599.

${ }^{232}$ CELSO FERNANDES CAMPILONGO, op.cit., p. 47. Tratando desse panorama de "sobrejuridificação" ou "hiperjuridicização", bem como da crise contemporânea do direito positivo, v. JOSÉ EDUARDO FARIA, Sociologia jurídica - direito e conjuntura, op.cit., p. 47. E, ainda, do mesmo autor, A globalização econômica e sua arquitetura jurídica - dez tendências do direito contemporâneo, op.cit., pp. 6-9. No caso Brasileiro, Nobre observa que a Constituição de 1988, além de haver se tornado referência central do debate político, "resultou em acentuada juridificação das relações sociais". MARCOS NOBRE, "Apontamentos sobre a pesquisa em direito no Brasil", in: Cadernos Direito GV, 2002. Campilongo fala, nesse sentido, de hipertrofia normativa, inclusive quanto às fontes do direito. CELSO FERNANDES CAMPILONGO, op.cit., p. 31.
} 
desdobrar, de criar todo o aparato circundante do texto-base”. No Brasil, diferentemente, a nova Constituição que estava nascendo era "gigantesca" e por isso mesmo “inevitavelmente dispersiva, suscetível de ostentar contradições tópicas a todo momento”. Isso imporia ao Judiciário brasileiro o dever, "não menos angustiante e não menos criativo, de dizer, diante daquele oceano de normas”, o que seria a Constituição, sua espinha dorsal e a forma pela qual aquela miríade de promessas haveria de ser implementada. O jurista prognosticava, ainda, que o STF brasileiro, diante desse superabundante instrumental jurídico constitucional, iria se defrontar com uma responsabilidade talvez tão expressiva quanto a da Suprema Corte americana, que ao longo de sua história desempenhou seu papel com um texto discreto e sintético. Esse novo perfil institucional do Judiciário brasileiro colocaria os juízes “entre dois fogos”: de um lado, o ardor dos que passariam a postular a efetivação imediata de tantas promessas e benefícios sociais; e, de outro lado, a pressão das forças que naquele momento esperavam o inverso, ou seja, que os juízes contivessem prudentemente essa implementação, de modo que ela pudesse ocorrer "sem traumatismos, sobretudo sem o colapso da economia”233.

Não é difícil perceber, desse modo, que o próprio Poder Legislativo foi responsável pela expansão das funções e pelo fortalecimento da independência institucional do Poder Judiciário (2.2.5, supra). Apesar de a Constituição de 1988 haver sido concebida por um constituinte congressional, com a natural valorização do Poder Legislativo, surgiram, em seu texto, vários instrumentos "com cores de autocrítica e autopenitência”. O controle incidental de constitucionalidade existente no Brasil desde a Constituição de 1891 foi mantido, ao mesmo tempo em que se ampliou a jurisdição constitucional abstrata e concentrada introduzida por emenda à Constituição de 1946, mas sem grandes repercussões antes de $1988^{234}$. Ademais, instituiu-se o mandado de injunção, a arguição de descumprimento de preceito fundamental e a ação direta de inconstitucionalidade por omissão.

Destarte, os próprios legisladores, com a criação desses instrumentos, estariam apostando na possibilidade de não honrarem as promessas feitas, algo que serviria de fundamento para que os legitimados pudessem se dirigir ao Judiciário. Com essa expansão da jurisdição constitucional ${ }^{235}$, todos os juízes e tribunais brasileiros

\footnotetext{
${ }^{233}$ JOSÉ FRANCISCO REZEK, "Princípios Fundamentais”, in: IVES GANDRA DA SILVA MARTINS (org.), op.cit., pp. 15-18.

${ }^{234}$ Nesse sentido, JOSÉ FRANCISCO REZEK, op.cit., p. 17.

${ }^{235}$ LUIS ROBERTO BARROSO, Curso de Direito Constitucional Contemporâneo, op.cit., p. 382.
} 
intensificaram a atividade interpretativa da Constituição. Abriu-se espaço para diversas formas de ingerência judicial na ordem política, seja em face de ações, seja para suprir omissões legislativas ou executivas. A contestação dos poderes políticos tem ocorrido, segundo diagnóstico de SADEK, em todos os órgãos do Judiciário, de todos os ramos, desde o juiz singular até os tribunais superiores. A demanda por liminares é um bom indicador desse tipo de estratégia, já que, mesmo que eventualmente suspensas em decisões posteriores, sua obtenção é relevante para a luta política, seja por retardar medidas, seja por provocar constrangimentos, seja, ainda, por tornar mais conhecidos determinados atores ${ }^{236}$.

236 “A polêmica, uma vez mais, não é só de princípios. Está em jogo a força relativa das instituições e de seus integrantes, como também a distribuição de poder no interior das instituições, a manutenção de privilégios e a efetivação de projetos políticos.” A vitalidade do Supremo é inquestionável. Os últimos anos testemunham seu protagonismo, decidindo ou postergando decisão, suscitando maior ou menor controvérsia. Sua presença é constante, como protagonista principal ou como ator pronto a entrar no palco. Tem tanto disciplinado matérias, atendo-se às suas clássicas atribuições, como legislado, adentrando em searas parlamentares. $\mathrm{O}$ presidente do Senado, ciente do risco do espaço perdido, reconheceu uma regra básica da política - a inexistência de vácuo. Ou, como consta dos escritos federalistas, "o poder é abusivo por natureza". Hoje, o que está em discussão não é o protagonismo do Judiciário, mas sua extensão e limites. MARIA TEREZA SADEK, “Ativismo Judiciário a pleno Vapor”, Jornal "O Estado de São Paulo”, publ. 01-09-08. Conforme destaca Mathew Taylor (MATTHEW TAYLOR, "Beyond Judicial Reform: Courts as Political Actors in Latin America", in: Latin American Research Review - Vol. 41, Number 2, 2006, pp. 269-280): "Em termos comparados, a atuação do Judiciário brasileiro é significativa. Nos 15 anos entre 1988 e 2002, o STF somente através do instrumento da Ação Direta de Inconstitucionalidade - Adin - concedeu decisões liminares ou de mérito invalidando parcialmente mais de 200 leis federais. Em comparação, entre 1994 e 2002, a Suprema Corte mexicana julgou a constitucionalidade de um pouco mais de 600 leis naquele país usando dois instrumentos parecidos com a Adin, mas invalidou somente 21 leis federais; em toda sua história, a Suprema Corte americana invalidou em torno de 135 leis federais apenas. Mesmo no governo de Fernando Henrique Cardoso - um presidente apoiado (pelo menos inicialmente) por uma ampla coalizão reformista -, o Judiciário federal como um todo foi convocado por atores externos para julgar todas as principais políticas públicas adotadas pelo Executivo e seus aliados no Congresso. O governo Fernando Henrique barganhou duramente para produzir maiorias legislativas que o permitissem superar as rígidas regras para a aprovação de emendas constitucionais ou leis complementares no Senado e na Câmara. Mas ao final desse imenso esforço político, a contestação judicial da reforma foi um acontecimento crônico, usado recorrentemente por grupos deixados de fora das negociações entre membros do parliamentary agenda cartel. As mais significativas e reais ameaças às reformas surgiram no Judiciário e não no Legislativo: das 10 principais iniciativas políticas aprovadas durante o governo Fernando Henrique, todas foram contestadas de alguma forma pelo Judiciário, e sete das 10 foram alteradas ou atrasadas de alguma maneira no STF. Em outras palavras, nem toda proposta do governo foi contestada judicialmente, mas as mais importantes e contenciosas certamente o foram, e com algum sucesso. No decorrer da última década, o Judiciário Federal revelou-se um importante ator político: tribunais federais repetidamente interromperam imensos leilões de privatização; a realização de uma delicada reforma no sistema de previdência social foi subvertida; e o Judiciário anulou ou mudou a legislação referente à reforma agrária, às reformas tributárias e a outras políticas públicas significativas. O Judiciário continua exercendo uma influência importante hoje. Durante o governo de Luiz Inácio Lula da Silva, tribunais também participaram da formulação de políticas governamentais de várias maneiras. Entre as mais recentes ilustrações: em 2005, o Judiciário federal aprovou uma grande aquisição empresarial pela Nestlé, revertendo decisão do Conselho Administrativo de Defesa Econômica - Cade, que havia rejeitado a operação; o STF interrompeu as investigações de corrupção dentro do Congresso durante 2006; juízes federais têm forçado governos estaduais a honrarem precatórios cujos valores são estimados em até US\$ 20 bilhões por ano; o STF negou, retroativamente, um aumento do Programa de Integração Social - PIS/COFINS, em uma decisão cujo custo, em tese, poderia chegar a quase $11 \%$ do total de tributos federais arrecadados; e assim por diante. À luz desse papel manifesto e tão 
Em 2008, referindo-se à independência do Judiciário brasileiro e à tensão crescente entre os poderes, o então presidente do STF, Gilmar Mendes, comentava a decisão daquele órgão sobre o direito de greve no serviço público. Afirmava, na ocasião, que o Congresso não conseguira deliberar “por uma disfuncionalidade”, que naquele caso envolveria a dificuldade de atuar contrariamente às organizações sindicais. Isso teria obrigado o Supremo a oferecer uma "resposta provisória” ao problema, até que eventualmente surgisse uma lei específica ${ }^{237}$. Como fator de incremento da busca por soluções judiciais e do impacto político da atuação do Judiciário, essa dificuldade deliberativa dos poderes estruturados pela regra da maioria é de profícua problematização e reaparece em vários casos conhecidos, como a recente decisão do STF em relação à união civil homoafetiva.

De um modo geral, o exame da política brasileira tende a variar entre dois extremos, segundo TAYLOR. Para alguns, o sistema político no país seria excessivamente consensual, repleto de jogadores de veto, a tornar o processo decisório intrinsecamente problemático e dependente de uma ampla maioria ${ }^{238}$. Para outros, o sistema político pode ser "mais majoritário do que se pensa"239. Há ainda aqueles que, em corrente intermediária, enfocam a evolução da experiência política pós-autoritária do ponto de vista das regras institucionais e da atuação dos atores envolvidos. O problema é que, independentemente da corrente, poucos consideram a questão das deliberações políticas

recorrente, torna-se claro que o Judiciário precisa ser melhor incorporado às nossas análises do sistema político.”

${ }^{237}$ Programa “Roda Viva” de 15-08-2008. Degravação disponível em www.stf.jus.br.

${ }^{238}$ O autor cita: “1) Congresso fraco, em que a representação desproporcional fortalece os Estados pequenos, enquanto os frágeis mecanismos de accountability eleitoral - resultado do sistema de representação proporcional com lista aberta - favorecem grupos de interesse organizados e facilitam a constante troca partidária; 2) um sistema partidário fraco, que permite a existência de um grande número de partidos fragmentados, instáveis e regionalizados; 3) a fraqueza do gabinete presidencial cujos ministérios são utilizados em parte como um instrumento para assegurar a manutenção das coalizões legislativas; 4) a natureza do Estado e, especialmente, dos servidores públicos, que tendem a lutar veementemente pela preservação de seus privilégios dentro da burocracia estatal; 5) um Senado com poderes sem paralelo para interferir em muitas questões políticas; e 6) o federalismo e, em particular, os poderosos governadores, especialmente o impacto deles nas discussões sobre assuntos fiscais da federação.” MATHEW TAYLOR, "O Judiciário e as políticas públicas no Brasil”, in: Dados, vol. 50, Rio de Janeiro, 2007, p. 231.

239 "Dentre os fatores citados por esse grupo estão: 1) o forte controle do presidente sobre a agenda política, facilitado pela concentração dos poderes orçamentários no Executivo, e os fortes poderes legislativos exercidos pelo presidente; 2) mecanismos robustos de controle partidário na arena legislativa (mas não na eleitoral); e 3) o poder do colégio de líderes na Câmara dos Deputados, que permite um forte controle sobre a agenda legislativa, geralmente por parte de aliados com estreita relação com o Poder Executivo. Como notam Figueiredo e Limongi (1999:24), apenas 0,026\% das propostas do Executivo votadas pelo Congresso foram rejeitadas no período posterior à Constituição de 1988. Enfim, existe uma abundância de regras internas que facilitam o controle do Congresso por aliados do governo e aumentam os incentivos para a cooperação dos congressistas com o Poder Executivo.” (MATHEW TAYLOR, “O Judiciário e as políticas públicas no Brasil”, op.cit., p. 232). 
em sua relação com a atuação judicial, e vice-versa. Essa desconsideração do embate interpoderes no tocante a temas de relevância pública seria uma falha radicada na “dificuldade de traduzir o impacto do Judiciário em termos claros e objetivos”. Assim, como um tema marginal e tido como acessível somente a especialistas, seu impacto é reconhecido "somente quando ocorre uma atuação inesperada” 240.

Contudo, essas atuações antes "inesperadas” se tornam cada vez mais previsíveis à medida que o Judiciário se fortalece politicamente.

$\mathrm{Na}$ sessão solene de instalação do ano Judiciário de 2009, o então Presidente do Senado sustentava que um dos aspectos mais marcantes desse fortalecimento do Judiciário brasileiro se situava na promoção de várias “alterações constitucionais e infraconstitucionais” em detrimento de disposições legislativas que refletiriam o

${ }^{240}$ No Brasil, assim como nos demais países da América Latina, os especialistas, notadamente no âmbito da Ciência Política, levaram "muitos anos após as transições dos regimes militares" para direcionar sua atenção para o papel político dos tribunais, e ainda pecariam pela pouca atenção dada à incorporação do Judiciário "à análise da tomada de decisões governamentais pelo sistema político como um todo". Com efeito, segundo Taylor: "Fora um núcleo restrito de cientistas políticos, poucos integrantes do mainstream da ciência política brasileira incorporam o Judiciário às suas análises com a mesma profundidade com que consideram o sistema partidário, o Legislativo e o Executivo ou, até mesmo, os movimentos sociais, as burocracias públicas ou as instituições econômicas. (...)Os tribunais agem em três dimensões de relevância para a ciência política, que podem ser descritas como as dimensões hobbesiana, smithiana e madisoniana. Estas dimensões têm impactos importantes, respectivamente, no monopólio da violência pelo Estado, nas regras de funcionamento da economia e na relação entre os poderes Executivo, Legislativo e Judiciário”. Importa registrar, desse ponto de vista politológico, uma síntese das conclusões do estudioso sobre o papel do Judiciário no sistema político brasileiro. Com efeito, para Taylor, o Judiciário brasileiro: a) embora não possua nem os poderes orçamentários do Legislativo, nem os poderes coercitivos do Executivo, detém considerável poder político como depositário da fé pública; b) desempenha um papel central na determinação e na aplicação de princípios constitucionais e ideais, decidindo "quais regras são legítimas e estão em concordância com as leis locais ou a Constituição, assim como quais ações (ou omissões) representam aberrações ou infrações”; c) pode influenciar o curso de políticas públicas, desde o tipo a ser implementado até a legalidade da conduta do administrador, conforme sua visão das regras legais existentes e das normas e tradições vigentes; d) pode ser usado como "mais uma oportunidade ou instância política", e não como "fonte de verdades constitucionais e legais", em especial quando se considera que juízes frequentemente operam com base em critérios outros que os unicamente legais quando julgam processos importantes; e) com seu crescimento, trouxe uma mudança no discurso sobre a influência judicial na política e, em especial, uma crítica muito forte, por parte dos poderes eleitos, aos "legisladores" não eleitos; f) com sua atuação, deixa claro o esmaecimento das suposta compartimentação dos poderes entre "funções judiciais, legislativas e executivas"; g) tem participação clara no processo político, na formação e na execução de políticas públicas, deixando pouco espaço para a proposição de que sua função seria apenas a de aplicar a lei; h) revela clara ambiguidade em sua atuação no campo político, tanto em termos da teoria democrática quanto na questão da formulação efetiva e eficaz das políticas públicas; i) tem exercido, não obstante as reclamações dirigidas às interferências políticas de juízes, importante papel democratizante do Judiciário, não obstante agir ora como uma espécie de "muro de lamentações", ora como "arena para o exercício da democracia" num cenário em que a relação entre Executivo e Legislativo foge, e muito, do ideal (MATHEW TAYLOR, "O Judiciário e as políticas públicas no Brasil”, op.cit., pp. 229-257). Sobre o tema, entre outras obras, v. ROGÉRIO BASTOS ARANTES, Judiciário e Política no Brasil, São Paulo: Idesp, 1997. MARCUS FARO DE CASTRO, "O Supremo Tribunal Federal e a Judicialização da Política”, in: Revista Brasileira de Ciências Sociais, vol. 12, n. 34. OSCAR VILHENA VIEIRA, Supremo Tribunal Federal: Jurisprudência Política. $2^{\text {a }}$ ed., São Paulo: Malheiros, 2002; e, do mesmo autor, Direitos fundamentais: uma leitura da jurisprudência do STF. São Paulo: FGV, 2006. LUIZ WERNECK VIANNA (org.), A Democracia e os Três Poderes no Brasil, Belo Horizonte: UFMG, 2002. 
“pensamento majoritário da sociedade” representada no Parlamento. Referido agente político acrescentava que o Legislativo se encontrava "limitado por sua própria natureza”, como um Poder mitigado pelo embate das "forças vivas da sociedade que o constituem e que internamente se contrapõem”. Via, assim, como natural o acirramento das tensões entre os Poderes e destacava que a atuação conjunta destes permitira reformas importantes no Judiciário, como a instituição da repercussão geral, da súmula vinculante e da lei dos recursos repetitivos (“solicitada” pelo do STJ para a racionalização dos seus procedimentos) $)^{241}$.

A referência a esses institutos adotados mediante reformas no Judiciário (em especial com a EC n. ${ }^{o}$ 45/2004) permite identificar outra mudança que se desenhou após a Constituição de 1988, decorrente da tendencial convergência institucional e normativa das experiências jurídicas democráticas (2.2.7, supra). Com efeito, o Brasil, afastando-se da tradição romanística, tem sofrido cada vez mais a influência de institutos de common law em suas reformas processuais e institucionais ${ }^{242}$, sobretudo para atender a pressões por previsibilidade e padronização decisória ${ }^{243}$. Nesse mesmo movimento de convergência, robusteceu-se, no discurso jurídico pátrio, o ideário dos direitos humanos e

\footnotetext{
${ }^{241}$ STF. Sessão Solene de instalação do ano Judiciário de 2009. Brasilia: Coordenadoria de Divulgação de Jurisprudência, 2009, p. 17.

${ }^{242}$ JOSÉ CARLOS MOREIRA ALVES, “Poder Judiciário”, in: IVES GANDRA DA SILVA MARTINS (org.), op.cit., p. 194. O jurista já destacava, no Brasil, a forte influência da experiência jurídica anglo-saxã sobre o redesenho do Judiciário e do ordenamento jurídico pátrio, notadamente em temas constitucionais. Do ponto de vista processual, Dinamarco, ao observar o cenário latino-americano, destaca a tendência de "absorção de maiores conhecimentos e mais institutos inerentes ao sistema common law", notadamente pelo pragmatismo de seus conceitos e estruturas. CÂNDIDO RANGEL DINAMARCO. Fundamentos do Processo Civil Moderno. vol. 2, op.cit., p. 741. A repercussão geral tem clara inspiração no writ of certiorari (do latim: "ser informado"), utilizado pela Suprema Corte norte americana para a seleção de casos a serem revistos (BRYAN GARNER. op.cit., p. 90), de modo que ela possua maior controle sobre sua própria agenda. Não sobeja evocar, mais uma vez, a relativização da tradicional divisão dos sistemas jurídicos em civil law e common law. Isso ocorreria dada a "tendência de os países do primeiro grupo valorizarem cada vez mais a jurisprudência (caso do Brasil, com o advento da súmula vinculante do STF”, ao passo que, "em contrapartida, os do segundo grupo tendem a prestigiar o direito escrito (caso dos Estados Unidos, com o Commercial Code, ou da própria Inglaterra, com as rules of civil procedure, de 1999. RODOLFO DE CAMARGO MANCUSO, op.cit., p. 161.

${ }^{243}$ José Eduardo Faria destaca com grande ênfase as pressões, provindas dos mais variados atores, pela adoção de padrões institucionais e normativos anglo-saxônicos, em especial pela possibilidade de, entre nós, combater o formalismo dos tribunais, a excessiva burocratização dos mecanismos processuais e falta de previsibilidade das decisões. Do âmbito internacional, essas pressões provêm, em especial, de órgãos como Banco Mundial, Banco Interamericano de Desenvolvimento, Agência internacional de Desenvolvimento, Conselho de Estudos Judiciais das Américas. No Brasil, a pressão é oriunda de "dirigentes do setor financeiro local e agentes econômicos locais empenhados em aumentar o volume de captação de investimentos estrangeiros e ampliar o volume de negócios em suas bolsas de valores, mercado de futuros, etc.”. JOSÉ EDUARDO FARIA, Sociologia jurídica - direito e conjuntura, op.cit., pp. 80-81.
} 
a construção teórica e jurisprudencial acerca dos direitos fundamentais ${ }^{244}$, o que tende a despertar debates relevantes sobre a migração de ideias provindas de outros sistemas e o manejo jurisprudencial da noção de proporcionalidade $e^{245}$.

Além disso, se o Brasil, ao longo do século XX, sofreu influxos importantes do ideário do “juiz ativo” (2.2.8, supra) ${ }^{246}$, após a Constituição de 1988 ficou ainda mais clara, entre nós, a ampliação desse modelo. Além das alterações na morfologia do processo para dar tratamento adequado aos chamados conflitos de massa (com o consequente aumento dos poderes do magistrado), os órgãos judiciais brasileiros parecem se distanciar cada vez mais do tradicional viés adjudicatório para fomentar, no processo, como forma alternativa de "pacificação" social, o uso de mecanismos não adjudicatórios de solução de conflitos. Ademais, a solução alternativa de conflitos tem sido incentivada amplamente no âmbito de políticas judiciárias do Conselho Nacional de Justiça (CNJ), o qual, desde 2006, promove o chamado Movimento pela Conciliação. Com a participação de instituições judiciais de todo o país, o movimento visa a divulgar e a incentivar a solução conciliatória de conflitos. Iniciada essa política, criaram-se centrais de conciliação, realizaram-se cursos técnicos, promoveram-se mutirões conciliatórios no âmbito dos tribunais e, desde 2009, ocorrem as Semanas Nacionais de Conciliação. A resolução n. ${ }^{\circ}$ 125, de 29 de novembro de 2010, do CNJ, que dispõe sobre a política judiciária nacional de tratamento adequado dos conflitos de interesses no âmbito do Poder Judiciário, trata especificamente da mediação e da conciliação judiciais ${ }^{247}$.

\footnotetext{
${ }^{244}$ A respeito dessas teorizações, v. VIRGÍliO AFONSO DA SILVA, Direitos fundamentais: conteúdo essencial, restrições e eficácia, passim.

${ }^{245}$ Cf. tópicos 2.2.7, 2.2.7.1, 2.2.7.2, 2.2.7.3 e 2.2.7.4 supra.

${ }^{246}$ Dinamarco fala, nesse sentido, de um ativismo judicial "inerente ao processo civil inquisitório", que tem sido aconselhado pela doutrina moderna nos congressos de direito processual. CANDIDO RANGEL DINAMARCO, Fundamentos do Processo Civil Moderno, vol. 2, op.cit., p. 742.

${ }^{247}$ Sem dúvida, o fomento de soluções não adjudicatórias de conflitos tem grande relevância do ponto de vista da pacificação social, sobretudo se considerados os efeitos negativos da chamada "cultura da sentença". Conforme nota WATANABE, a formação acadêmica do profissional do Direito no Brasil é voltada "para a solução contenciosa e adjudicada dos conflitos de interesses", algo que constitui um dos grandes obstáculos à utilização mais intensa da conciliação e da mediação. A mentalidade forjada nas academias, fortalecida pela práxis forense, orienta as principais carreiras jurídicas a fomentar soluções adjudicadas "autoritariamente pelo juiz, por meio de sentença", num cenário que se agrava pela "sobrecarga excessiva de serviços que têm os magistrados". KAZUO WATANABE, "Cultura da sentença e cultura da pacificação", op.cit., pp. 685-686. FREITAS JUNIOR, ao tratar da mediação, enfatiza o instrumento como "ferramenta para a cultura da paz", conforme o propósito evolutivo sintetizado por Watanabe (da "cultura da sentença" para a "cultura da pacificação"), mas pondera que esse processo, como modelo ideal-típico para os meios alternativos de solução dos conflitos (ADRs) não constituiria terapêutica devotada ao enfrentamento da "crise do Judiciário" que ocorre em vários países. Nesse sentido, muitas são as críticas contrárias ao uso desse modelo como forma de contornar a incapacidade de o Judiciário dar tratamento eficiente a conflitos emergentes em uma sociedade sobrejuridificada e cujos conflitos seriam excessivamente judicializados. Complementa o jurista: "Não nego que sua difusão seja capaz de oxigenar a mentalidade dos integrantes da comunidade do direito.
} 
Há, ainda, outros reflexos da juridificação decorrente da consagração, pela Constituição de 1988, de um modelo de Estado Social. Como foi visto, um dos aspectos mais relevantes do "surto" de juridificação típico do demokratisch und sozialen Rechtsstaat é a ampliação significativa dos contornos jurídicos de pretensões materiais. No Brasil, esse processo também implica, como desdobramento da extensa previsão de direitos individuais e sociais contida na Constituição, o surgimento de estatutos específicos que reconhecem direitos de grupos sociais considerados em sua especificidade ou na especificidade das relações que travam em sociedade. Assim, criaram-se leis para ampliar a tutela de interesses de idosos, mulheres, crianças, adolescentes, pessoas com deficiência, consumidores, investidores, contribuintes, grupos étnicos, trabalhadores, minorias e

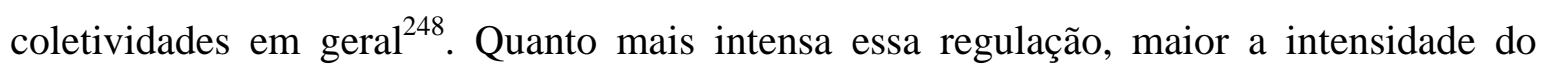
fenômeno da expropriação de conflitos, que perdeu, em 1988, não só o aspecto autoritário de outrora, mas também a ênfase em litígios individuais. Abre-se espaço, desse modo, para a litigância de interesse público. No que tange a esses litígios, são notórias as expectativas em torno do Judiciário, que oferece uma via de contestação das ações e omissões legislativas e governamentais em matéria de elaboração e execução de políticas públicas, de forma a fortalecer, pelas mais variadas formas de controle judicial contramajoritário, a tensão entre os Poderes da República e a crise na divisão de suas funções (2.2.3 e 2.2.6, supra $)^{249}$.
Os graves déficits de mobilização social reivindicatória da implementação desses novos direitos foram, em certa medida, compensados pela

Por sinal, creio mesmo previsível que produza efeitos culturais e comportamentais - muito apreciáveis nessa região. Nem rejeito, antecipadamente, a hipótese, por muitos aceita, de que a difusão da cultura da paz, como resultado, entre outros fatores, do crescente emprego da mediação e de outros meios alternativos de administração de conflitos, seja capaz de produzir efeitos, também igualmente saudáveis, na atuação de Judiciário - quer sob o ângulo da sua funcionalidade, quer sob o de sua eficácia. Nesse sentido, proporcionando, como subproduto, a redução do fenômeno a que os juristas lusitanos batizaram de 'tempo de justiça’. Isso também não autoriza nem sequer justifica o vezo, de certa desidiosa e indefensável política de Judiciário, de preconizar a mediação como um instrumento destinado à redução do problema da oferta pela constrição da demanda”. ANTÔNIO RODRIGUES DE FREITAS JUNIOR. "Conflitos de justiça e limites da mediação para a difusão da cultura da paz.“, op.cit. Em outras palavras, na impossibilidade de emitir soluções adjudicatórias que qualitativa e quantitativamente atendam à explosão da litigiosidade, as instituições judiciais passam a tratar as soluções não adjudicatórias como formas de dar vazão à demanda, fomentando-as no processo e fora dele, com as inconsistências já examinadas nesta tese (2.2.8.1, supra).

248 Além da Lei n. ${ }^{\circ}$ 7.347/85 (Lei da Ação Civil Pública), podem ser citadas as leis n. ${ }^{\circ}$ 7.853/89 (deficientes), 7.913/89 (investidores), 8.069/90 (crianças e adolescentes), 8.078/90 (consumidores), 10.257/01 (estatuto da cidade), 10.741/03 (idoso), 12.288/10 (igualdade racial),

${ }^{249}$ Sobre a crise na divisão funcional de poderes no Brasil, pela perspectiva da formulação e da execução de políticas públicas, v., entre outros estudos, o de FABIO KONDER COMPARATO, "Ensaio sobre o juízo de constitucionalidade de políticas públicas”, in: Revista de Informação Legislativa, ano 35, n. ${ }^{\circ}$ 138, abr./jun. 1998. 
reformulação das funções do Ministério Público em $1988^{250}$. Com essa renovação, o Parquet, no campo dos litígios de interesse público, tornou-se órgão central de uma estrutura estatal de suporte à mobilização jurídica (2.2.9.2, supra) de interesses titularizados pelos mais diversos grupos sociais e pela coletividade como um todo. Essa estrutura institucional recebeu, ao lado de um repertório riquíssimo de normas de direito material, instrumentos processuais que compuseram um processo civil de interesse público, na precisa expressão de WATANABE ${ }^{251}$.

Consoante as lições de Chayes, Cappelletti, Epp, Denvir, Garth e outros estudiosos do tema (2.2.9, supra), a recepção judicial de demandas de interesse público encontra obstáculos ainda maiores se não há mecanismos processuais e institucionais de tutela $^{252}$. Ora, no que concerne especificamente aos aspectos institucionais, a renovação do Ministério Público com a nota da independência funcional foi um passo decisivo, dada a possibilidade de o órgão defender temas de interesse público (primário) independentemente dos interesses governamentais (secundários, político-administrativos) ou privados. Num contexto de severos déficits na implementação de direitos, marginalização social e vulnerabilidade de grupos minoritários, esses mecanismos institucionais suprem, em certa medida, as deficiências em uma estrutura não estatal de suporte (associações, sindicatos, organizações não governamentais, etc.) ${ }^{253}$.

\footnotetext{
${ }^{250}$ Mais recentemente, no Brasil, tem ganhado força a estruturação da Defensoria Pública. Para um estudo comparatístico de instituições análogas, v. importante estudo realizado na década de 70 por MAURO CAPPELLETTI, "Governmental and private advocates for the public interest in civil litigaton: a comparative study”, op.cit., p. 793.

${ }^{251}$ KAZUO WATANABE, “Processo Civil de Interesse Público: Introdução”, in: CARLOS ALBERTO DE SALLES (org.). Processo civil e interesse público: o processo como instrumento de defesa social. São Paulo: RT, 2003, p. 15.

${ }^{252}$ MAURO CAPPELLETTI, BRYANT GARTH, Acesso à Justiça, op.cit., pp. 49-67.

${ }^{253}$ Afora as atribuições relacionadas à persecução penal e à atuação processual como órgão custos legis, o Ministério Público, no que tange especificamente aos litígios de interesse público, atua, num primeiro momento, pela a percep̧̧ão de demandas metaindividuais. Essa percepção, com base em critérios legais e constitucionais, contempla, de um lado, o recebimento de representações, pedidos de interferência e comunicações provindas de outros órgãos; e, de outro lado, a chamada atuação ex officio, particularmente importante diante de déficits de cidadania, vulnerabilidade de grupos, educação deficiente, lacunas na consciência de direitos e óbices que prejudicam a acessibilidade à justiça. Em seguida, a atuação ministerial pode caminhar em dois sentidos diferentes. Se o órgão vinculado ao caso entender, na condução de expedientes investigatórios (como o inquérito civil), que o conflito mereça intervenção direta sobre o cenário conflituoso, poderá canalizar a demanda percebida para uma solução extrajudicial. Nos casos em que isto não seja possível (em geral pela resistência daquele de quem depende a resolução do conflito, seja uma parte privada, seja o governo; ou pela percepção de que o caso merece ser desde logo judicializado, v.g., pela urgência das medidas), o conflito é canalizado para o Poder Judiciário. Se a intervenção extrajudicial é bem sucedida, os resultados alcançados, em geral consolidados em compromissos de ajustamento de conduta, podem transcender aquele que seria obtido em juízo, pela flexibilidade na redação de cláusulas e pela possibilidade de enfocar com grande proximidade o problema concreto. Assim, surge um potencial protagonismo desses órgãos estatais, que se traduziria em posturas de ativismo estatal autônomo promocional de interesses metaindividuais. Há muitos outros instrumentos de atuação que podem potencializar esse
} 
Como foi visto (2.2.9.2, supra), a atuação dessa estrutura de suporte (em sua parcela estatal e não estatal) tende a fomentar a ampliação da agenda do Poder Judiciário, de forma a estimular a manifestação de um potencial protagonismo judicial que traduza um ativismo judicial "aderente aos megaconflitos”, como descreve MANCUSO ${ }^{254}$. Consoante destaca WATANABE, é difícil elucubrar quais seriam os limites da canalização desses conflitos para o Poder Judiciário, à vista da facilitação do acesso à Justiça ${ }^{255}$.

Afinal, como garantir oportunidades adequadas de manifestação àqueles que serão afetados pelas decisões? Até que ponto um julgamento pode vincular partes que não participaram do processo? Como conferir ao juiz instrumentos que possam tornar possível e efetiva a sua intervenção em matérias tão mais complexas do que as típicas do processo individual?

ativismo, como os poderes de requisição, as audiências públicas e as notificações recomendatórias. Na hipótese da (re)canalização do litígio para o Judiciário, a natureza dos temas judicializados tende a fomentar a manifestação do potencial protagonismo judicial em tipos específicos de ativismo judicial.

${ }^{254}$ RODOLFO DE CAMARGO MANCUSO, op.cit., p. 385. Novamente, parece-nos relevante observar que uma "fraca mobilização social" não é fenômeno típico de países em desenvolvimento, nem que uma "forte mobilização social" é esperada em países desenvolvidos. Basta, para derrubar esses preconceitos, lembrar do caso Argentino e Inglês, respectivamente, como contraexemplos. Cf. tópico 2.2.9.2, supra. Não se pode ignorar que muitos desses litígios de interesse público se dissipam em demandas individuais. Podem ser citados, ilustrativamente, vários exemplos de interferência judicial em políticas de saúde, obrigando administradores públicos a redefinirem prioridades e a se defrontar com uma situação de alteração na alocação de recursos. Silva observa que, em 2004, estudantes da Faculdade de Direito da USP realizaram pesquisa empírica envolvendo todas as decisões do Tribunal de Justiça de São Paulo relacionadas a casos de pedidos de concessão de remédios para o tratamento da AIDS entre janeiro de 1997 e junho de 2004. O resultado apontou que, em $85 \%$ dos casos, os autores dos pedidos recebiam os medicamentos que requeriam. Todavia, ao observarmos outros dados, como avaliações da OMS, inclusive em relação às motivações das políticas de distribuição de medicamentos contra o HIV, fica claro que a realização dos direitos sociais discutidos nesses casos, bem como em qualquer caso em que se discutam esses direitos, "por depender da implementação de políticas públicas, é tarefa que depende sobretudo do governo e das pressões da sociedade civil mobilizada". VIRGILIO AFONSO DA SILVA, "O Judiciário e as políticas públicas: entre transformação social e obstáculo à realização dos direitos sociais”, op.cit., pp. 594-595. O autor cita, ainda, relevante relatório de pesquisa: JOSÉ EDUARDO FARIA, DIOGO ROSENTHAL COUTINHO (org.). $O$ Judiciário e as políticas públicas de saúde no Brasil: o caso AIDS. São Paulo: Faculdade de Direito da USP (Relatório de Pesquisa), 2004.

${ }^{255}$ KAZUO WATANABE, "Processo Civil de Interesse Público: Introdução”, op.cit., p. 17. O jurista relata, a demonstrar, lucidamente, a complexidade dessa indagação e a extensão do acesso à justiça, que antes mesmo da lei da ação civil pública ele sustentara, em trabalho acadêmico, a legitimação ordinária das associações civis para a tutela jurisdicional dos interesses difusos e coletivos stricto sensu,sustentando tratar-se não de legitimação extraordinária, e sim de legitimação ordinária. Referindo a distinção entre "direito subjetivo" (judicializável) e "interesse legítimo" (judicializável desde que fosse protegido sob a forma de direito subjetivo), relatou que, já na década de 70, quando judicava, antes mesmo da LACP ou do CDC, entendia, assim como parte da comunidade jurídica de então, que "já havia a possibilidade de judicialização" de interesses legítimos, mas a mentalidade da época, "formada à luz das lições centradas em conceito clássico de direito subjetivo, impedia a abertura do acesso à Justiça por parte desses interesses", o que as leis processuais supracitadas vieram a propiciar. E complementa: "É esse o significado político mais importante que vemos no processo civil de interesse público”. 
Como último desdobramento da expansão da juridificação no Brasil depois de 1988, pode-se destacar o aumento das interações entre o Poder Judiciário e os meios de comunicação de massa ${ }^{256}$, que em geral parecem desvelar as características abordadas no tópico 2.2.10, supra, a atrair toda a problemática apresentada.

\subsubsection{Especificidades do potencial protagonismo judicial na Justiça}

\section{do Trabalho}

\subsubsection{Breves considerações históricas}

A intensificação da juridificação levou à ampliação do controle estatal sobre as relações sociais em geral. Um dos desdobramentos desse processo foi o crescimento do potencial protagonismo judicial (2.2, supra).

Como destaca SIMITIS, o Direito do Trabalho é verdadeiro símbolo paradigmático desse processo juridificante, uma vez que a colonização do mundo da vida pelo Direito pode ser compreendida pela observação das origens e do desenvolvimento de institutos jurídicos trabalhistas, materiais e processuais. Com efeito, quanto mais aquele processo se intensificou, mais o Direito do Trabalho se tornou distinto como ramo e mais suas determinações passaram a interferir sobre as condições de trabalho em suas especificidades, reestruturando a atividade dos trabalhadores e dos tomadores de seus serviços, em fenômeno que ocorreu em todo o mundo ${ }^{257}$.

No Brasil, ainda que a experiência brasileira de Estado-Providência possua consideráveis lacunas e inconsistências (2.3.1, supra), o processo juridificante é bem visível nas origens e na expansão não só das normas trabalhistas, mas também das instituições criadas para aplicá-las.

A Justiça do Trabalho sofreu várias transformações ao longo de sua existência, com relevantes implicações sobre a atuação, as garantias e a independência de seus órgãos. Um sistema administrativo nacional de solução de conflitos trabalhistas começou a ser esboçado apenas com a criação, em 1923, do Conselho Nacional do

\footnotetext{
${ }^{256}$ HUMBERTO THEODORO JUNIOR, DIERLE NUNES, ALEXANDRE BAHIA, op.cit., p. 14.

${ }^{257}$ SPIROS SIMITIS, “Juridification of labour relations”, in: GUNTHER TEUBNER, op.cit., pp. 113, 119120. Sobre o caso italiano, v. GINO GIUGNI, "Juridification of italian labor relations", in: Comparative Labour Law Journal, n. ${ }^{\circ}$ 8, 1986-1987, p. 309. Sobre o caso brasileiro, v. ANTÔNIO RODRIGUES DE FREITAS JUNIOR, Os direitos sociais e a constituição de 1988: crise econômica e políticas de bem-estar, op.cit., pp. 44 e ss.
} 
Trabalho, no âmbito do Ministério da Agricultura, Indústria e Comércio, pondo fim a algumas experiências adjudicatórias regionais, também sem caráter jurisdicional. Na época, as decisões dos órgãos desse sistema (entre eles as juntas de Conciliação e Julgamento, surgidas em $1932^{258}$ ) podiam ser alteradas ao talante do Ministro do Trabalho ou revistas integralmente pela Justiça Comum ${ }^{259}$.

A ineficiência desses mecanismos levou à tentativa de instituição de uma Justiça do Trabalho de natureza jurisdicional. Todavia, quando da criação do órgão pela Assembleia Constituinte de 1934, prevaleceu o entendimento de que “a mentalidade judiciária” seria “inadequada à solução dos conflitos trabalhistas”, e que juízes leigos, “despidos de senso jurídico e de formalismos”, decidiriam “mais prontamente as controvérsias laborais”. Assim, em suas origens, a Justiça do Trabalho, subordinada ao Poder Executivo, além de não possuir caráter jurisdicional ${ }^{260}$, não era independente e seus membros não gozavam das garantias da magistratura.

Posteriormente à sua criação, surgiram propostas legislativas para a estruturação do órgão, de suas funções e de sua composição. Travaram-se, na época, acirrados debates entre Waldemar Ferreira (deputado designado na Comissão de Constituição e Justiça) e Oliveira Vianna (que supervisionou a elaboração do projeto) ${ }^{261}$. Vianna, sociólogo e defensor do corporativismo, era favorável à outorga de poder normativo à novel "Justiça do Trabalho", o que era contestado por Ferreira sob o fundamento de que não poderia o Legislativo, considerado o princípio da "separação de poderes”, delegar a outro órgão estatal a prerrogativa de editar normas gerais e abstratas. Em defesa de seu ponto de vista, Vianna argumentava que nada impediria que essa prerrogativa fosse delegada pelo Legislativo, o que seria necessário diante da constatação

\footnotetext{
${ }^{258}$ Criadas pelo Decreto n. ${ }^{\circ} 22.132 / 1932$.

${ }^{259}$ IVES GANDRA DA SILVA MARTINS FILHO, "Breve história de Justiça do Trabalho”, in: IRANY FERRARI, AMAURI MASCARO NASCIMENTO, IVES GANDRA DA SILVA MARTINS FILHO, História do Trabalho, do Direito do Trabalho e da Justiça do Trabalho - Homenagem a Armando Casimiro Mota. São Paulo: LTr, 2002, pp. 193-197.

${ }^{260}$ Dispunha o artigo 122 da Constituição de 1934: "Para dirimir questões entre empregadores e empregados, regidas pela legislação social, fica instituída a Justiça do Trabalho, à qual não se aplica o disposto no Capítulo IV do Título I (Poder Judiciário). Parágrafo único - A constituição dos Tribunais do Trabalho e das Comissões de Conciliação obedecerá sempre ao princípio da eleição de membros, metade pelas associações representativas dos empregados, e metade pelas dos empregadores, sendo o presidente de livre nomeação do Governo, escolhido entre pessoas de experiência e notória capacidade moral e intelectual.”

${ }^{261}$ As teses foram cristalizadas em duas importantes obras: WALDEMAR MARTINS FERREIRA, Princípios de Legislação Social e Direito Judiciário do Trabalho, São Paulo: São Paulo, 1938; e FRANCISCO JOSÉ DE OLIVEIRA VIANNA. Problemas de Direito Corporativo. Rio de Janeiro: José Olímpio, 1938.
} 
de que normas assim editadas pela Justiça do Trabalho seriam mais eficientes do que as que promanassem diretamente dos legisladores.

Como se vê, a preocupação comum era a de instituir uma Justiça barata, norteada pela oralidade processual, avessa ao formalismo jurídico e que contrabalançasse a desigualdade social e econômica das partes litigantes ${ }^{262}$. No que tange ao tratamento de conflitos coletivos, entretanto, era grande a polêmica a respeito do poder normativo.

Tamanha era a importância política do modelo de administração de conflitos trabalhistas pretendido pelo governo Vargas que este último, em mensagem à Nação, por ocasião do fechamento Congresso e da outorga da Carta de 1937, mencionou, entre os argumentos para as medidas de exceção, a “resistência do Legislativo" à aprovação do projeto de lei referente à estruturação da Justiça do Trabalho ${ }^{263}$. No novo texto constitucional outorgado, a natureza administrativa do órgão era mantida ${ }^{264}$, o que só se alterou com a Constituição de 1946, que incorporou a Justiça do Trabalho ao Poder Judiciário $^{265}$.

Esse brevíssimo panorama da história institucional da Justiça do Trabalho permite inferências relevantes para o objeto desta tese.

Em primeiro lugar, a Justiça do Trabalho brasileira foi criada em um contexto de crescente expropriação de conflitos pelo Estado (2.2.5, supra), sobretudo os travados entre capital e trabalho. Assim, a instituição de uma "Justiça” trabalhista vinculada ao Poder Executivo possuía, no momento em que os padrões regulatórios iniciavam uma expansão sem precedentes (2.2.1, supra), inequívoca finalidade de controle social (2.2.5, supra).

Em segundo lugar, as propostas de instituição do chamado poder normativo, com vocação para o estabelecimento de regras gerais e abstratas, já suscitavam, à época, sérias preocupações com os limites dessa função normativa da Justiça do Trabalho, que constituiria, para muitos, usurpação de prerrogativas do Legislativo. Indo além, parece razoável a observação de que, se de início a alegada "usurpação" seria

\footnotetext{
262 IVES GANDRA DA SILVA MARTINS FILHO, op.cit., p. 197.

263 IVES GANDRA DA SILVA MARTINS FILHO, p. 200.

264 Dispunha o artigo 139 da Carta de 1937: "Para dirimir os conflitos oriundos das relações entre empregadores e empregados, reguladas na legislação social, é instituída a Justiça do Trabalho, que será regulada em lei e à qual não se aplicam as disposições desta Constituição relativas à competência, ao recrutamento e às prerrogativas da Justiça comum."

${ }^{265}$ Registre-se, todavia, que no RE n. ${ }^{\circ} 6.310 / 43$, o STF reconheceu o caráter de órgão judicante da Justiça do Trabalho, observando que o juiz do Trabalho, “embora sem as prerrogativas do magistrado comum”, era juiz, "proferindo julgamentos na solução de determinados litígios”.
} 
realizada pelo Poder Executivo (ao qual se subordinavam os órgãos trabalhistas), em 1946, com a incorporação da Justiça do Trabalho ao Poder Judiciário, seriam os órgãos judiciais os supostos “usurpadores”, o que traz à tona as mesmas perplexidades já discutidas no tópico 2.2.3, supra.

Em terceiro lugar, é bastante curioso notar que, no momento da criação da Justiça do Trabalho, a ideia de que a tradicional mentalidade judiciária seria “inadequada à solução dos conflitos trabalhistas” levou à adoção de uma alternativa que privilegiava um processo decisório célere, barato, norteado pela oralidade processual, avesso ao formalismo jurídico. Ora, ironicamente, a Justiça do Trabalho nascia sem o caráter jurisdicional, mas já desvelava, nos atributos citados, uma diretriz que conduziu todas as transformações pelas quais o Poder Judiciário e o processo judicial (inclusive o comum) passaram ao longo do século XX, à medida que a juridificação se consolidou. É que a concepção de processo (a princípio não jurisdicional) e de “julgador” que predominava nas origens da Justiça do Trabalho correspondia, em essência, ao ideário do juiz ativo (2.2.8, supra). Ademais, antecipando-se à ampliação do modelo (2.2.8.1), a Justiça do Trabalho também surgia com ênfase em soluções conciliatórias. Não se pode esquecer que a instituição fora criada para promover certo controle das relações sociais pelo Estado, expediente considerado relevante em época na qual se buscava evitar “ameaças” à "paz social” emergentes no embate de interesses entre capital e trabalho. Todavia, isso não impediu que aqueles aspectos sobressaíssem na prática das decisões judiciais trabalhistas. No momento em que a Justiça do Trabalho se tornou órgão jurisdicional, em 1946, esses atributos se fortaleceram ainda mais.

Consideradas essas características, a Justiça do Trabalho, no âmbito dos conflitos socioeconômicos sobre os quais sua intervenção ocorria, já revelava aspectos seminais de um potencial protagonismo judicial antes mesmo da Constituição de 1988, quando esse potencial passou a ser mais visível no Judiciário como um todo. Essa força do Judiciário trabalhista pode ser associada, igualmente, à proliferação de teses jurídicas produzidas pelo TST, como veremos a seguir.

Com efeito, no caso da Justiça do Trabalho, esse potencial protagonismo judicial seminal pode ser identificado no contexto dos dissídios coletivos, pelo exercício do poder normativo; na força do chamado direito sumular trabalhista; e no modelo trabalhista de juiz ativo. Esses aspectos se tornaram ainda mais evidentes após a Constituição de 1988 (2.3.2, supra). 


\subsubsection{Os dissídios coletivos e o poder normativo}

No Brasil, pode-se dizer que, num sentido amplo, existe um poder normativo conferido por lei aos sindicatos e aos empregadores para que, no exercício de sua autonomia e por meio de negociações coletivas, estipulem convenções coletivas e acordos coletivos aplicáveis às relações de trabalho estabelecidas em seus respectivos âmbitos.

O objeto do exame deste tópico, entretanto, é o poder normativo stricto sensu que possuem os Tribunais do Trabalho de proferir sentenças aplicáveis a todos os membros das categorias envolvidas num dissídio coletivo. Com essa atribuição, que desde 1988 é constitucional, o Judiciário tem a função de instituir normas jurídicas, ainda que de efeito limitado, aplicáveis às relações individuais de trabalho dos setores representados no processo $^{266}$.

Desde suas origens, o poder normativo é muito criticado. Alguns o consideram desestímulo à negociação coletiva ${ }^{267}$, ao passo que outros entendem se tratar, do ponto de vista político, de “invasão da competência do Legislativo pelo Judiciário”. Há quem aponte, ademais, como decorrência de seu exercício, um indesejável efeito inibitório de greves, já que a eventual declaração de sua abusividade deve implicar o término do movimento, mesmo que em prejuízo das pretensões sindicais ${ }^{268}$.

Como destaca NASCIMENTO, o dissídio coletivo, processo que dá ensejo ao exercício do poder normativo, seria restrito a países cujas instituições trabalhistas tiveram formação doutrinária e legal autoritária, de inspiração organicista ou corporativista, como próprio às experiências autocráticas de natureza fascista da primeira metade do século XX, na Europa ${ }^{269}$. Não é difícil perceber, destarte, que o dissídio coletivo e o poder normativo se associam, do ponto de vista da juridificação, à iniciativa estatal de

\footnotetext{
${ }^{266}$ AMAURI MASCARO NASCIMENTO, Iniciação ao Direito do Trabalho. São Paulo: LTr, 2009, pp. 9697.

${ }^{267}$ Bezerra Leite observa que "a função anômala do Poder Normativo da Justiça do Trabalho", como "criador de normas heterônomas gerais e abstratas aplicáveis às categorias profissionais e econômicas e que produzirão efeitos nas relações individuais de trabalho" tem como consequência o desencorajamento da "solução democrática da autocomposição dos conflitos coletivos, adotada em quase todas as democracias contemporâneas”. CARLOS HENRIQUE BEZERRA LEITE. Curso de Direito Processual do Trabalho. São Paulo: LTr, 2009, p. 967.

${ }^{268}$ AMAURI MASCARO NASCIMENTO. Iniciação ao Direito do Trabalho, op.cit., p. 96. Acrescenta o autor que "em outros países não é atribuído poder normativo aos órgãos judiciais, em observância ao principio segundo o qual a função jurisdicional é aplicar a lei existente e não criar normas e condições de trabalho por meio de sentenças em conflitos coletivos".

${ }^{269}$ MAURÍCIO GODINHO DELGADO. Curso de Direito do Trabalho. $5^{a}$ ed., São Paulo: LTr, 2006, p. 1295.
} 
expropriação dos conflitos (2.2.5 e 2.3.1, supra). É o que explica, em certos casos, a possibilidade de "instauração da instância”, na redação original da CLT, inclusive por “iniciativa do presidente"270.

Algumas características do poder normativo (preservadas desde sua instituição, não obstante as modificações operadas pela EC n. ${ }^{\circ}$ 45/2004) permitem identificar aspectos relevantes à compreensão das destacadas especificidades do potencial protagonismo judicial na Justiça do Trabalho.

Como foi visto, o exercício desse poder implica a possibilidade, ainda que limitada às categorias envolvidas no dissídio coletivo, da instituição de normas gerais e abstratas. A Constituição, em seu artigo 114, $\S 2^{\circ}$, com a redação que lhe conferiu a EC n. ${ }^{\circ}$ 45/2004, estatui que, ajuizado o dissídio coletivo de natureza econômica, poderá a Justiça do Trabalho decidir o conflito, "respeitadas as disposições mínimas legais de proteção ao trabalho, bem como as convencionadas anteriormente”271. A redação originária do dispositivo era ainda mais abrangente, por não referir, como limitação, as regras “convencionadas anteriormente”, mas apenas as "disposições convencionais e legais mínimas de proteção ao trabalho”.

Desse modo, ao menos do ponto de vista da literalidade do texto constitucional, teria havido uma redução do espectro de ação do poder normativo. Todavia, como não há um conteúdo precisamente definido nem para os dissídios coletivos, nem para os limites do exercício do poder normativo, há certo potencial, subjacente a tais institutos, que envolve não apenas a aptidão de atrair demandas das mais variadas formas e com os mais variados fins; mas também, se recebidas essas demandas e como consequência das postulações formuladas, o ensejo para que surjam outros tipos de pronunciamento jurisdicional além dos declaratórios e constitutivos.

Em outras palavras, surge a oportunidade para o fomento, inclusive estratégico $^{272}$, de formas alternativas de exercício do poder normativo. Essa suspeita está bem ilustrada nas perplexidades da doutrina jurídica trabalhista, que destaca, de um lado,

\footnotetext{
${ }^{270}$ Note-se, ademais, a clareza do artigo 865 da CLT: "sempre que, no decorrer do dissídio, houver ameaça de perturbação da ordem, o presidente requisitará à autoridade competente as providências que se tornarem necessárias.”

${ }^{271}$ Não há referência, na norma constitucional vigente, à categoria do dissídio coletivo de natureza jurídica. Na redação anterior, o dispositivo previa: "Recusando-se qualquer das partes à negociação ou à arbitragem, é facultado aos respectivos sindicatos ajuizar dissídio coletivo, podendo a Justiça do Trabalho estabelecer normas e condições, respeitadas as disposições convencionais e legais mínimas de proteção ao trabalho.”

${ }^{272}$ Não se duvida de que, mesmo antes de 1988, o movimento sindical, no âmbito dos embates promovidos por categorias profissionais mais fortes, já fomentava a atuação do Judiciário, em especial a Justiça do Trabalho, com os mais variados objetivos, inclusive estratégicos.
} 
as dificuldades de enquadrar certos tipos de dissídios coletivos na classificação tradicional do instituto; e, de outro, determinados pronunciamento jurisdicionais que discrepam de concepções mais ou menos consagradas pela comunidade jurídica trabalhista.

A concepção doutrinária clássica de dissídio coletivo os classifica em três tipos, conforme a natureza econômica, jurídica ou mista. Dissídios coletivos de natureza econômica (originários, revisionais ou de extensão) seriam ações constitutivas que visam “à prolação de sentença normativa que criará novas normas ou condições de trabalho que irão vigorar no âmbito das relações empregatícias individuais (CR, art. 114, § 2º”. Por sua vez, dissídios coletivos de natureza jurídica seriam ações declaratórias cujo objeto residiria apenas na "interpretação de normas coletivas preexistentes que vigoram no âmbito de uma dada categoria”. Haveria, ainda, dissídios coletivos de natureza mista, relacionados ao movimento grevista e com a função de, por meio de sentença normativa, declarar “a abusividade (ou não) do movimento de paralisação concertada do trabalho”, de forma a constituir, ao mesmo tempo, novas condições de trabalho ${ }^{273}$. Classificação análoga foi consagrada no artigo 220 do Regimento Interno do TST (Resolução Administrativa TST

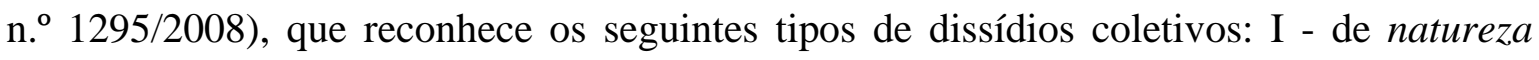
econômica, para a instituição de normas e condições de trabalho; II - de natureza jurídica, para interpretação de cláusulas de sentenças normativas, de instrumentos de negociação coletiva, acordos e convenções coletivas, de disposições legais particulares de categoria profissional ou econômica e de atos normativos; III - originários, quando inexistentes ou em vigor normas e condições especiais de trabalho, decretadas em sentença normativa; IV - de revisão, quando destinados a reavaliar normas e condições coletivas de trabalho preexistentes, que se hajam tornado injustas ou ineficazes pela modificação das circunstâncias que as ditaram; e; V - de declaração sobre a paralisação do trabalho decorrente de greve.

Essas classificações só vieram a receber certo amparo legal nos artigos $1^{\circ}$ e 10 da Lei n. ${ }^{\circ} 7.701 / 1988^{274}$. Mais recentemente, com a EC n. ${ }^{\circ}$ 45, elas foram em parte adotadas, tendo em vista que o texto constitucional referiu expressamente o dissídio

${ }^{273}$ CARLOS HENRIQUE BEZERRA LEITE. Curso de Direito Processual do Trabalho, op.cit., pp. 10771078.

${ }^{274}$ Dispõe o artigo $1^{\text {o: }}$ " $O$ Tribunal Superior do Trabalho, nos processos de sua competência, será dividido em turmas e seções especializadas para a conciliação e julgamento de dissídios coletivos de natureza econômica ou jurídica e de dissídios individuais (...)“. Já o artigo 10 prescreve: "Nos dissídios coletivos de natureza econômica ou jurídica de competência originária ou recursal da seção normativa do Tribunal Superior do Trabalho, a sentença poderá ser objeto de ação de cumprimento com a publicação da certidão de julgamento.” 
coletivo de natureza econômica. Como destaca SILVA, isso chegou a suscitar dúvidas acerca da eventual proibição de outros tipos de dissídio coletivo, como o de natureza jurídica $^{275}$. Após destacar esta hipótese em seu aprofundado estudo, o doutrinador observa que a função dos dissídios coletivos de natureza jurídica seria a de esclarecer normas coletivas que muitas vezes pecam pela clareza, não obstante as negociações coletivas de que se originaram haverem sido bem-sucedidas. A relevância dessa função esclarecedora tornou esse tipo de dissídio coletivo tão importante quanto o de natureza econômica, uma vez que, a depender do entendimento adotado pelos tribunais trabalhistas, o impacto financeiro de uma decisão interpretativa “pode ser tão explosivo quanto a elaboração de uma norma coletiva a partir do ponto zero"276.

De um modo geral, sem olvidar algumas finalidades específicas normalmente apontadas na doutrina ${ }^{277}$, não se duvida de que, em sua feição tradicional, os dissídios coletivos sempre serviram para a instituição de normas, quer as destinadas às condições de trabalho, quer as dirigidas ao esclarecimento de prescrições normativas. Destarte, consoante essa concepção tradicional, SILVA sustenta não ser admissível o uso do dissídio coletivo para aplicar o direito ao caso concreto, como seria o caso de provimentos jurisdicionais destinados a "reintegrar trabalhadores ou condenar o empregador no pagamento de salários e demais vantagens”. Nessa linha, "medidas executivas” estariam “completamente fora do alcance dos dissídios coletivos” em sua feição tradicional e dogmática. Assim, justificar-se-ia o teor da orientação jurisprudencial (OJ) n. ${ }^{\circ} 3$ da Seção de Dissídios Coletivos (SDC) do TST, que propõe serem “incompatíveis com a natureza e finalidade do dissídio coletivo as pretensões de provimento judicial de arresto, apreensão ou depósito”. Ademais, dessa perspectiva tradicional, o Poder Judiciário, tanto por não tratar normalmente de "demandas em tese" quanto por não emitir “pareceres jurídicos”, não poderia ser acionado por um sindicato que postulasse em Juízo a interpretação de uma lei genérica e abstrata. É nesse sentido a OJ n. ${ }^{\circ}$

275 Conforme bem observa HOMERO BATISTA MATEUS DA SILVA, Curso de Direito do Trabalho Aplicado - Direito Coletivo do Trabalho, vol. 8, São Paulo: Elsevier, 2009, p. 196.

276 "Então, ao mesmo tempo que o sindicato obreiro celebrava o vencimento das resistências dos empregadores sobre determinado assunto, o sindicato patronal comemorava a inserção da cláusula mais restritiva. Ao raiar do quinto dia útil do mês subsequente, os holerites revelam que o empregador adotou a interpretação mais enxuta e fez encolher o valor do pagamento. Os temas são de uma variabilidade impressionante, abrangendo bases de cálculo, incidência sucessiva de percentuais, reflexos e integrações, pagamento de benefícios assistenciais durante férias, licenças médicas e demais afastamentos, exigências de comprovação documental, contagem de tempo de serviço para bonificações e assim sucessivamente" (HOMERO BATISTA MATEUS DA SILVA, p. 197).

${ }^{277}$ Entre elas, a obtenção de interpretação de cláusulas de regulamentos de empresa e até mesmo de dispositivos legais de alcance limitado a determinadas categorias (profissões regulamentadas). 
7 da SDC do TST, segundo a qual "não se presta o dissídio coletivo de natureza jurídica à interpretação de normas de caráter genérico”. O mesmo doutrinador relembra que, por esse motivo, o “Tribunal Superior do Trabalho passou a refutar dissídios jurídicos para interpretar se a aposentadoria era causa extintiva de contrato de trabalho”, ou para “declinar a natureza jurídica de algumas parcelas controvertidas”. Tampouco se aceita o uso desse tipo de dissídio para a análise da quantidade de dirigentes sindicais (CLT, art. 522) ou para se declarar a representatividade sindical (CLT, artigo 577) ${ }^{278}$.

Não obstante essas limitações reconhecidas pela dogmática do Direito do Trabalho, a própria doutrina aponta casos curiosos de utilização dos dissídios coletivos com outras finalidades, em especial quando a negociação coletiva não traz resultados satisfatórios.

É o caso do fomento sindical ao exercício do poder normativo não para interpretar uma lei específica, geral e abstrata, mas para examinar um "vazio legislativo”, como bem descreveu SILVA. No conhecido caso das dispensas coletivas da Embraer, a Justiça do Trabalho, após intensos debates, não só considerou possível o "uso do dissídio coletivo para a interpretação do limbo jurídico, como também apresentou diversas soluções passíveis de serem implementadas pelo legislador inerte”. Consoante destacou, com indisfarçável perplexidade, o referido doutrinador, "não é todo dia que se vê um dissídio coletivo de natureza jurídica assumir importância tão expressiva na solução das controvérsias trabalhistas e muito menos ganhar as páginas da grande imprensa” (1.1, supra).

Essa perplexidade tem fundamento, já que o entendimento até então cristalizado na doutrina e na jurisprudência trabalhista (refletidos na OJ n. ${ }^{\circ} 7$ da SDC do TST) afastava a possibilidade de temas genéricos serem suscitados para apreciação abstrata da Justiça do Trabalho. Em outros termos, pela perspectiva da dogmática trabalhista, a

\footnotetext{
278 HOMERO BATISTA MATEUS DA SILVA. op.cit. Nesse sentido, v. OJ SDC n. 9 do TST: "ENQUADRAMENTO SINDICAL. INCOMPETÊNCIA MATERIAL DA JUSTIÇA DO TRABALHO. Inserida em 27.03.1998. O dissídio coletivo não é meio próprio para o Sindicato vir a obter o reconhecimento de que a categoria que representa é diferenciada, pois esta matéria - enquadramento sindical - envolve a interpretação de norma genérica, notadamente do art. 577 da CLT”. E, ainda, a OJ SDC n. ${ }^{\circ}$ 36, também do TST: "EMPREGADOS DE EMPRESA DE PROCESSAMENTO DE DADOS. RECONHECIMENTO COMO CATEGORIA DIFERENCIADA. IMPOSSIBILIDADE. Inserida em 07.12.1998. É por lei e não por decisão judicial, que as categorias diferenciadas são reconhecidas como tais. De outra parte, no que tange aos profissionais da informática, o trabalho que desempenham sofre alterações, de acordo com a atividade econômica exercida pelo empregador."
} 
função de produzir "interpretação de cláusula normativa ou de norma de uso restrito" constituiria a "essência dos dissídios coletivos de natureza jurídica”279.

Assim, o que o jurista qualificou como "uso do dissídio coletivo de natureza jurídica para situações limítrofes” também poderia ser lido como ruptura (pelo menos no caso concreto sob exame, sem que isto signifique, necessariamente mudança ad futurum e independentemente de a não ocorrência de outros casos similares levarem a um problema de coerência decisória) em relação a precedentes jurisprudenciais para atender a situações que a Justiça do Trabalho, provocada por movimento aparentemente estratégico dos sindicatos, reputou de grande relevância do ponto de vista socioeconômico. Essa observação confirma a suspeita de que o dissídio coletivo, que nasceu com o intuito expropriatório e “pacificador” já comentado, poderia ser utilizado com outros fins.

A corroborar essa assertiva, nota-se que, na época das dispensas dos trabalhadores da Embraer, outras demandas com a mesma finalidade foram veiculadas em ações civis públicas ajuizadas em primeiro grau de jurisdição ${ }^{280}$. Destarte, haveria, em tais dissídios coletivos, menos a invocação do poder normativo em sua acepção tradicional (relacionada à criação de normas gerais e abstratas aplicáveis à categoria ou ao esclarecimento de prescrições normativas) e mais o fomento a certas formas de manifestação de um potencial protagonismo judicial (inclusive mediante provimentos condenatórios) em prol de interesses cuja tutela é buscada pelos sindicatos. Em outros termos, esses usos “curiosos” de dissídio coletivo podem resultar em sentenças normativas com provimentos condenatórios que poderiam ser obtidos, “em tese”, se respeitada a via tradicional, pelo ajuizamento, em $1^{\circ}$ grau, perante o juiz singular, de reclamações trabalhistas (individuais ou plúrimas) ou de ações civis públicas.

Pela perspectiva da litigância de interesse público (2.2.9, supra), são de fácil visualização os motivos pelos quais as atraentes características do poder normativo, em tempo de expansão do potencial protagonismo judicial, têm levado, inclusive, a propostas doutrinárias que defendem seja ele estendido a outros ramos do Poder Judiciário.

Ilustrativamente, quando se discutem critérios para a alocação dos recursos públicos, financeiros e sanitários em programas de saúde e em outras políticas

\footnotetext{
${ }^{279}$ HOMERO BATISTA MATEUS DA SILVA, op.cit., pp. 199-200.

$280 \mathrm{Na}$ mesma época, para enfrentar dispensas coletivas de 1.200 empregados da CSN (Companhia Siderúrgica Nacional), o MPT ajuizou ação civil pública perante a Vara do Trabalho de Volta Redonda (ACP n. ${ }^{\circ}$ 0010700-12.2009.5.01.0343, em que figurava como terceiro interessado o Sindicato dos Trabalhadores nas Industrias Metalúrgicas, Mecânicas de Material Elétrico, de Material Eletrônico e de Informática de Barra Mansa, Volta Redonda, Resende, Itatiaia, Quatis, Porto Real e Pinheiral).
} 
públicas, surgem questionamentos sobre os limites e as possibilidades do controle judicial nesta seara. SARLET e FIGUEIREDO (ao afirmarem que a solução para tais questionamentos não se situaria em “extremos”, isto é, “nem no ativismo judicial exacerbado, nem tampouco na omissão judicial a respeito”) defendem a criação de "mecanismos e foros adequados para a discussão, revigorando o sentido do princípio da separação dos Poderes como harmonização e mútua colaboração”. Aprofundando a proposta, os juristas sustentam que a "tendência de elaboração de pautas objetivas (standards) que possam auxiliar o magistrado na decisão do caso concreto” mereceria “todo o aplauso e reconhecimento”, por indicar “uma diretriz mais segura a ser perseguida, tanto nas ações individuais quanto na tutela coletiva da saúde”. Essas medidas seriam úteis desde que "não resultem em desconsideração da individualidade dos casos e acarretem a funcionalização do direito fundamental e da dignidade de cada pessoa em prol de um absoluto interesse coletivo”. Neste ponto, eles enfatizam a importância da discussão proposta "por diversos doutrinadores” acerca das “ações coletivas sobre o direito à saúde”, especialmente se novos instrumentos surgirem. Além da intervenção do amicus curiae, que agregaria "elementos fáticos importantes à compreensão da matéria e, pois, ao deslinde da própria causa”, seriam desejáveis “novas formas de acordos pré-judiciais” ou, quando isso não se mostrasse possível, “competências normativas semelhantes àquelas já vigentes no (também social) direito do trabalho”281.

\subsubsection{Direito sumular trabalhista}

A jurisprudência é vista, na tradição romano-germânica, como um entendimento que se infere, indutivamente, da observação empírica de decisões reiteradas acerca de determinado tema. Parte desses entendimentos (em geral a parcela considerada dominante, majoritária, iterativa, pacífica, atual ou notória) é cristalizada em enunciados de súmulas e outros verbetes que refletem tendências jurisprudenciais oficialmente reconhecidas pelos tribunais.

No âmbito da Justiça do Trabalho, mesmo antes da Constituição de 1988, o TST já desenvolvia substancioso “Direito Sumular”282. Ademais, como destaca

${ }^{281}$ INGO WOLFGANG SARLET, MARIANA FILCHTINER FIGUEIREDO, “Algumas considerações sobre o direito fundamental à proteção e promoção da saúde aos 20 anos da Constituição Federal de 1988”, in: Revista de Direito do Consumidor n. ${ }^{\circ} 67,2008$, pp. 125-172.

${ }^{282}$ A feliz expressão é de IVES GANDRA DA SILVA MARTINS FILHO, op.cit., p. 222. 
CARRION, os prejulgados, cujos dispositivos instituidores não teriam sido recepcionados pela Constituição de 1946, tiveram, não obstante isso, efetiva “utilidade em certos casos”, desde que o TST editou o primeiro deles, em $1963^{283}$. A obrigatoriedade de seu seguimento para as instâncias inferiores (a incluir o Juiz de Direito no exercício de jurisdição trabalhista), destarte, operava desde 1946, quando da incorporação da Justiça do Trabalho ao Poder Judiciário ${ }^{284}$. Décadas depois, esses precedentes foram transformados em súmulas pela Resolução Administrativa n. ${ }^{0}$ 102/82 do TST ${ }^{285}$, quando expressamente perderam seu caráter vinculante. No período, foram editados sessenta prejulgados, que se tornaram, pela resolução supracitada, as súmulas n. ${ }^{0} 130$ a 179 (consideradas as revogações de alguns deles).

Conquanto sem caráter vinculante, vários precedentes do TST se notabilizaram e se notabilizam por seu caráter criativo. É o caso da súmula n. ${ }^{\circ}$ 291, sobre horas extraordinárias, que instituiu indenização não prevista em lei; e de vários enunciados sobre trabalho bancário, direito processual, natureza de verbas e tantos outros temas, a justificar a assertiva de que a produção sumular teria se tornado "fonte formal de direito" 286 .

\footnotetext{
${ }^{283}$ VALENTIN CARRION. Comentários à Consolidação das Leis do Trabalho. 33a ed., São Paulo: Saraiva, 2008, p. 809. Nesse sentido, v. AMAURI MASCARO NASCIMENTO, Iniciação ao Direito do Trabalho, op.cit., p. 95

${ }^{284}$ Dispunha o artigo 902 da CLT, na redação revogada pela Lei n. ${ }^{0}$ 7033/1982: "É facultado ao Tribunal Superior do Trabalho estabelecer prejulgados, na forma que prescrever o seu regimento interno. $\S 1^{\circ}$ Sempre que o estabelecimento do prejulgado for pedido em processo sobre o qual já haja pronunciado o Tribunal Regional do Trabalho, deverá o requerimento ser apresentado dentro do prazo de dez dias contados da data em que for publicada a decisão. $\S 2^{\circ}$ - Considera-se revogado ou reformado o prejulgado sempre que o Tribunal Superior do Trabalho, funcionando completo, pronunciar-se, em tese ou em concreto, sobre a hipótese do prejulgado firmando nova interpretação. Em tais casos, o acórdão fará remissão expressa à alteração ou revogação do prejulgado. $\S 3^{\circ}$ - O requerimento de prejulgado terá efeito suspensivo sempre que pedido na forma do $\S 1^{\circ}$ deste artigo. $\S 4^{\circ}$ - Uma vez estabelecido o prejulgado, os Tribunais Regionais do Trabalho, as Juntas de Conciliação e Julgamento e os Juízes de Direito investidos da jurisdição da Justiça do Trabalho ficarão obrigados a respeitá-lo. $\S 5^{\circ}$ - Considera-se revogado ou reformado o prejulgado sempre que a Câmara de Justiça do Trabalho, funcionando completa, pronunciar-se, em tese ou em concreto, sobre a hipótese do prejulgado, firmando nova interpretação. Em tais casos, o acórdão fará remissão expressa à alteração ou revogação do prejulgado.”

${ }^{285}$ Posteriormente, os verbetes foram renomeados, e passaram a ser chamados, com a RA n. ${ }^{\circ} 44 / 85$, “enunciados". Em 2005, retomou-se a designação "súmula”. Estas não se confundem com os precedentes normativos, que são uma "relação de matérias habitualmente apreciadas nos dissídios coletivos e a forma como são decididas”. AMAURI MASCARO NASCIMENTO. Iniciação ao Direito do Trabalho, op.cit., p. 96.

${ }^{286}$ Como observa IVES GANDRA DA SILVA MARTINS FILHO, op.cit., p. 223. Para Nascimento, a jurisprudência trabalhista "é sabidamente, fonte do direito". AMAURI MASCARO NASCIMENTO, op.cit., p. 95. O artigo $8^{\circ}$ da CLT situa a jurisprudência entre as fontes subsidiárias do Direito do Trabalho, ao prever: "As autoridades administrativas e a Justiça do Trabalho, na falta de disposições legais ou contratuais, decidirão, conforme o caso, pela jurisprudência, por analogia, por equidade e outros princípios e normas gerais de direito, principalmente do direito do trabalho, e, ainda, de acordo com os usos e costumes, o direito comparado, mas sempre de maneira que nenhum interesse de classe ou particular prevaleça sobre o
} 
Essas conclusões são corroboradas pela observação, extraída da dogmática trabalhista, de que, contemporaneamente, haveria um “indissimulável papel jurígeno” da jurisprudência, o qual, no Direito do Trabalho, seria “determinante para a compreensão da própria estrutura e dinâmica” de seu conjunto. Assim, se deslocarmos nosso olhar para a "dinâmica jurídica concreta”, percebe-se que as “interpretações dos tribunais a respeito da ordem jurídica” podem funcionar como “atos-regra incidentes sobre situações futuras semelhantes”287.

A prática judiciária trabalhista em relação à profusão de verbetes jurisprudenciais produzidos pelo TST traz à tona, novamente, as constatações comparatísticas de que, mesmo em ordens jurídicas de tradição romano-germânica: a) os juízes sempre foram influenciados por decisões anteriores; b) é comum a referência dos próprios juízes e tribunais a decisões passadas em casos similares sub judice; c) a prática judicial de órgãos de instâncias inferiores de vários países demonstra que suas decisões são afetadas pela autoridade e pelo conteúdo argumentativo de decisões anteriores das instâncias superiores, seja porque, havendo um raciocínio oficial já construído e cristalizado, poupa-se tempo de julgamento (o que, num cenário de judicialização excessiva, incrementa a celeridade na prestação jurisdicional); seja porque a percepção desse atalho tende a engendrar um provimento jurisdicional em consonância com o precedente, de forma a contornar a expectativa de que, se o julgador decidir diferentemente, sua decisão será possivelmente reformada (2.2.7.1, supra).

Assim, no caso do TST, mesmo que os precedentes editados pelo órgão não tenham força vinculante, seus enunciados possuem inequívoca força persuasiva quando indicam: a) os sentidos oficiais para o legislado; b) a compreensão jurisprudencial do que não houver sido satisfatoriamente regulado na visão do Tribunal; c) a integração de eventuais lacunas normativas (de direito material ou de direito processual) em relação a situações com as quais o Judiciário normalmente se defronte, mas para as quais não haja uma “desejável” regulação legal expressa; d) a releitura de dispositivos legais, inclusive nos casos em que isto implique o afastamento de alguns aspectos literais de sua redação.

Em todos esses casos, não obstante as resistências que eventualmente surjam, existe uma clara pretensão padronizadora de decisões pela neutralização de sentidos

interesse público.” No caso da Justiça do Trabalho, Ferraz Junior reconhece esse caráter de fonte à jurisprudência, dada a natureza específica do Direito do Trabalho, "voltado não tanto à regulação de conflitos, mas a uma verdadeira proteção ao trabalhador”, permitindo a constituição de normas gerais com base na equidade”. TÉRCIO SAMPAIO FERRAZ JUNIOR, op.cit., p. 246.

${ }^{287}$ MAURÍCIO GODINHO DELGADO, op.cit., pp. 169-171. 
divergentes daquele consolidado oficialmente no enunciado, o que bem se ajusta à perspectiva apresentada no tópico 2.2.7.1, supra.

Como se vê, são perceptíveis, também na Justiça do Trabalho, os reflexos da chamada convergência das experiências jurídicas em relação aos padrões normativos e institucionais. No Brasil, o TST, que sempre teve um papel proeminente na construção de teses jurídicas (desvelando, nesse aspecto, manifestação específica de um potencial protagonismo judicial), fortaleceu ainda mais essa função após a Constituição de 1988. Note-se que isto poderá ser ampliado com a eventual aprovação da PEC n. ${ }^{\circ}$ 358/2005 e a instituição, no âmbito daquele órgão de cúpula judiciária trabalhista, das reclamações e das súmulas impeditivas de recursos ${ }^{288}$.

Comparativamente ao STF e ao STJ, o TST figura na primeira posição do "ranking” da produção de teses jurídicas. Do ponto de vista estritamente quantitativo (no limite do que este prisma possa revelar e admitidas eventuais distorções qualitativas decorrentes de tal limitação), existem no TST, entre precedentes cancelados, vigentes e remanejados, 1.244 verbetes persuasivos (entre súmulas, precedentes normativos e orientações jurisprudenciais do tribunal pleno/órgão especial; da SBDI-I, da SBDI-II e da SDC), constantemente revisados e alterados à medida que os entendimentos se modificam. No STF, o total é de 736 súmulas persuasivas e 32 súmulas vinculantes editadas. O STJ, por sua vez, já elaborou 470 súmulas, as quais, mesmo se somadas às do extinto Tribunal Federal de Recursos, totalizariam 735 verbetes persuasivos. Importa não olvidar que, diferentemente dos enunciados das súmulas do STF e do STJ, vários verbetes do TST têm mais de uma proposição. Ilustrativamente, as "campeãs" no número de itens são a súmula 6 (equiparação salarial) e a súmula n. ${ }^{\circ} 100$ (ação rescisória), ambas com dez itens.

\footnotetext{
${ }^{288}$ A PEC n. ${ }^{\circ}$ 358/2005, entre outras medidas, institui a chamada "súmula impeditiva de recursos. Com a possível reforma, a competência do TST poderia ser ampliada: "Art. 111-B. O Tribunal Superior do Trabalho poderá, de ofício ou por provocação, mediante decisão de dois terços dos seus membros, após reiteradas decisões sobre a matéria, aprovar súmula que, a partir de sua publicação, constituir-se-á em impedimento à interposição de quaisquer recursos contra decisão que a houver aplicado, bem como proceder à sua revisão ou cancelamento, na forma estabelecida em lei. § $1^{\circ} \mathrm{A}$ súmula terá por objetivo a validade, a interpretação e a eficácia de normas determinadas, acerca das quais haja controvérsia atual entre órgãos judiciários ou entre esses e a administração pública que acarrete grave insegurança jurídica e relevante multiplicação de processos sobre questão idêntica. $\S 2^{\circ}$ Sem prejuízo do que vier a ser estabelecido em lei, a aprovação, revisão ou cancelamento de súmula poderá ser provocada originariamente perante o Tribunal Superior do Trabalho por aqueles que podem propor a ação direta de inconstitucionalidade. $\S 3^{\circ}$ São insuscetíveis de recurso e de quaisquer meios de impugnação e incidentes as decisões judiciais, em qualquer instância, que deem à legislação trabalhista a interpretação determinada pela súmula impeditiva de recurso.”
} 


\subsubsection{O pioneirismo do modelo trabalhista de juiz ativo}

Como foi visto (2.3.3., supra), a mentalidade judiciária que vigia na época em que a Justiça do Trabalho (administrativa) foi criada não era considerada adequada à solução dos conflitos trabalhistas, já que o processo deveria ser célere, barato, norteado pela oralidade processual, avesso ao formalismo jurídico e com mecanismos que reequilibrassem a desigualdade social e econômica das partes litigantes. Não é despiciendo repetir que, ironicamente, a Justiça do Trabalho, que nascia sem o caráter jurisdicional, já desvelava, nos atributos citados, o ideário do juiz ativo, diretriz que conduziu todas as transformações pelas quais o Poder Judiciário e o processo judicial (inclusive o comum) passaram ao longo do século XX, à medida que a juridificação se consolidou (2.2.8, supra).

Primeira experiência bem sucedida de consagração da função social na arquitetura do processo, o modelo do “juiz ativo” ressai claramente nas disposições da CLT, inclusive em relação ao fomento das soluções judiciais não adjudicatórias ${ }^{289}$. Mais recentemente, com o fortalecimento da tutela metaindividual, os poderes dos juízes do Trabalho se expandiram para dar tratamento adequado a conflitos de interesse público e de massa (2.2.8.1, supra).

Ademais, há uma peculiaridade do Direito Processual do Trabalho brasileiro que fortalece ainda mais a atuação ativa do magistrado. Trata-se da possibilidade de aplicar subsidiariamente dispositivos processuais de outros diplomas legais. No caso do processo de conhecimento, o artigo 769 da CLT prescreve, para os casos omissos, a possibilidade de recorrer ao direito processual comum como fonte subsidiária, exceto se houver incompatibilidade com as regras processuais trabalhistas. Esse dispositivo sempre se cercou de polêmicas na doutrina, seja pela dificuldade de delimitar, com absoluta precisão, os critérios para a identificação de lacunas; seja pelas incertezas suscitadas pela noção de “incompatibilidade”290 . Com o avanço das reformas no processo comum, ganham

\footnotetext{
${ }^{289}$ Nesse sentido, os artigos 764 ("os dissídios individuais ou coletivos submetidos à apreciação da Justiça do Trabalho serão sempre sujeitos à conciliação") e 765 ("Os Juízos e Tribunais do Trabalho terão ampla liberdade na direção do processo e velarão pelo andamento rápido das causas, podendo determinar qualquer diligência necessária ao esclarecimento delas") da CLT.

${ }^{290}$ Ilustrativamente, nota-se, na jurisprudência do TST, uma insistente reforma de julgados que têm aplicado o artigo 475-J ao processo do trabalho. TST. RR 668/2006-005-13-40 (num. antiga). rel. Min. Aloysio Corrêa da Veiga, julg. 20-02-08, publ. 28-03-08. Transcreve-se, por oportuno, a ementa: "RECURSO DE REVISTA. MULTA DO ART. 475-J DO CPC. INCOMPATIBILIDADE COM O PROCESSO DO TRABALHO. REGRA PRÓPRIA COM PRAZO REDUZIDO. MEDIDA COERCITIVA NO PROCESSO
} 
força as propostas que, em prol da almejada efetividade do processo e como forma de tornar o instrumental processual adequado às mudanças sociais (2.2.8 e 2.2.8.2.1, supra), defendem o recurso mais frequente àquelas fontes subsidiárias, inclusive com a relativização dos requisitos citados, o que tem sido justificado pela teleologia específica das normas processuais trabalhistas ${ }^{291}$.

Seja como for, nota-se que a abertura relativamente ambígua do Direito Processual do Trabalho ao processo comum tem fortalecido ainda mais certas formas de manifestação do potencial protagonismo judicial em sua perspectiva processual, o que, na Justiça do Trabalho, dada a originária adoção do ideário do juiz ativo, sempre existiu em medida razoável.

TRABALHO DIFERENCIADA DO PROCESSO CIVIL O art. 475-J do CPC determina que o devedor que, no prazo de quinze dias, não tiver efetuado o pagamento da dívida, tenha acrescido multa de $10 \%$ sobre o valor da execução e, a requerimento do credor, mandado de penhora e avaliação. A decisão que determina a incidência de multa do art. 475-J do CPC, em processo trabalhista, viola o art. 889 da CLT, uma vez que a aplicação do processo civil, subsidiariamente, apenas é possível quando houver omissão da CLT, seguindo, primeira mente, a linha traçada pela Lei de Execução fiscal, para apenas após fazer incidir o CPC. Ainda assim, deve ser compatível a regra contida no processo civil com a norma trabalhista, nos termos do art. 769 da CLT, o que não ocorre no caso de cominação de multa no prazo de quinze dias, quando o art. 880 da CLT determina a execução em 48 horas, sob pena de penhora, não de multa. Recurso de revista conhecido e provido para afastar a multa do art. 475-J do CPC.”

${ }^{291}$ Souto Maior propõe, nesse sentido: “(...) se o princípio é o da melhoria contínua da prestação jurisdicional, não se pode utilizar o argumento de que há previsão a respeito na CLT, como forma de rechaçar algum avanço que tenha havido neste sentido no processo comum, sob pena de negar a própria intenção do legislador ao fixar os critérios de aplicação subsidiária do processo civil. Notoriamente, o que se pretendeu (daí o aspecto teleológico da questão) foi impedir que a irrefletida e irrestrita aplicação das normas do processo civil evitasse a maior efetividade da prestação jurisdicional trabalhista que se buscava com a criação de um procedimento próprio na CLT (mais célere, mais simples, mais acessível). Trata-se, portanto, de uma regra de proteção, que se justifica historicamente. Não se pode, por óbvio, usar a regra de proteção do sistema como óbice ao seu avanço. Do contrário, pode-se ter um processo civil mais efetivo que o processo do trabalho, o que é inconcebível, já que o crédito trabalhista merece tratamento privilegiado no ordenamento jurídico como um todo. Em suma, quando há alguma alteração no processo civil o seu reflexo na esfera trabalhista só pode ser benéfico, tanto sob o prisma do processo do trabalho quanto do direito do trabalho, dado o caráter instrumental da ciência processual.” JORGE LUIZ SOUTO MAIOR, "Reflexos das alterações do Código de Processo Civil no processo do trabalho”, in: Revista LTr, vol. 70, n. ${ }^{\circ}$ 8, São Paulo, 2006, pp. 920-921. Note-se, aliás, o interessante caso francês, destacado no tópico 2.2.8.2.1, supra. 


\title{
CAPÍTULO 3
}

\section{NOÇÕES DE ATIVISMO JUDICIAL: PROBLEMATIZAÇÃO E REFLEXÕES CONCEITUAIS}

\begin{abstract}
Sumário: 3.1 Objetivos do capítulo; 3.2 O ativismo judicial na experiência jurídica dos EUA; 3.2.1 A origem dos debates; 3.2.2 Noções comuns na retórica da crítica judicial nos EUA; 3.2.3 Ativismo judicial e controle político da composição de tribunais; 3.3 Debates sobre o ativismo judicial em outros países; 3.4 Panorama das discussões sobre o ativismo judicial no Brasil; 3.4.1 Perspectiva constitucional; 3.4.1.1 Noções presentes em decisões do STF e em discursos de seus ministros; 3.4.2 Perspectiva processual; 3.4.2.1 Críticas aos instrumentos processuais de padronização decisória; 3.4.3 Perspectiva trabalhista; 3.4.3.1 Noções presentes em decisões do TST; 3.4.3.2 Noções de ativismo judicial nos debates entre magistrados do Trabalho; 3.4.4 Direito alternativo, uso alternativo do direito e manifestações do potencial protagonismo judicial.
\end{abstract}

\subsection{Objetivos do capítulo}

No capítulo anterior, descreveu-se a maneira pela qual o processo de juridificação, gradativamente, fez emergir um potencial protagonismo judicial. Examinouse, ademais, uma série de manifestações desse potencial, cujos atributos são substancialmente distintos do poder judicial em seu sentido tradicional.

Destinado à investigação mais específica dessas manifestações, este capítulo enfocará formas específicas de agir judicial frequentemente referidas pela designação “ativismo judicial”. Identificados os fenômenos que estão por detrás dos vários usos dessa designação, será possível, à luz da exposição do capítulo 2, construir, no capítulo 4, os chamados tipos ideais de ativismo judicial.

\subsection{O ativismo judicial na experiência jurídica dos EUA}

\subsubsection{A origem dos debates}

Curiosamente, uma das primeiras referências ao ativismo judicial (judicial activism) não surgiu nas críticas de um jurista ou de um cientista político, mas nas análises do norte-americano Arthur Schlesinger, influente historiador, crítico social e 
ganhador de dois prêmios Pulitzer. Em artigo escrito em 1947 para a revista Fortune, ele sugeria que as divergências entre os magistrados que então compunham a Suprema Corte norte-americana estariam radicadas, basicamente, em duas teorias conflitantes a respeito da função judicial e de qual deveria ser a postura daquele órgão, sobretudo em casos relacionados a políticas governamentais. Black e Douglas seriam defensores de uma conduta ativista (judicial activism), ao passo que Frankfurter e Jackson seriam adeptos da autocontenção (judicial self-restraint). Havia, ainda, aqueles que se situavam em posição intermediária, como Reed e Vinson.

SCHLESINGER notava que os adeptos do ativismo, de um lado, tomavam decisões orientadas pelos resultados pretendidos; ao passo que os defensores da autocontenção, de outro, estariam apegados a determinados valores do processo democrático $^{292}$. Os chamados ativistas, sem discutir especificamente a constitucionalidade do New Deal, consideravam o Judiciário um instrumento de realização de justiça social e de promoção do Welfare State. Segundo essa visão, tal engajamento seria necessário, sobretudo, para tutelar a parcela da sociedade que dependia da orientação adotada nos casos judicializados. Em outras palavras, não se poderia adotar uma postura de autocontenção diante de uma demanda social relevante levada ao Judiciário. Argumentavase, nesse sentido, que o raciocínio jurídico seria flexível e pouco científico, de modo que não haveria respostas judiciais inatacáveis. Ao contrário, os recursos argumentativos seriam tão abrangentes que, nos casos em que houvesse uma diferença razoável de opiniões, um juiz poderia decidir em qualquer dos sentidos, sem que isto implicasse deformar a lógica jurídica. As escolhas jurídicas dos juízes (que não seriam nem neutras nem objetivas, mas políticas e éticas) deveriam ser orientadas, assim, pelos resultados sociais almejados.

Diferentemente, os defensores da autocontenção, desconfiados das noções de "justiça” que cada juiz poderia veicular em seus julgamentos, partiam da

\footnotetext{
${ }^{292}$ A descrição desse panorama se encontra nas memórias de Schlesinger. ARTHUR M. SCHLESINGER. A Life in the Twentieth Century: Innocent Beginnings, 1917-1950. New York: Mariner, 2002, pp. 421-425. É interessante a descrição, pelo próprio Schlesinger, da reação de cada Justice. Destaco o seguinte excerto, no original: “'(...) I feel badly about the Supreme Court repercussions', I wrote to my parents. 'Everyone is apparently mad at me-Douglas very hurt and very mad, because he thought I was on his side; Black, resigned; [Frank] Murphy furious and wanting to sue me for libel; Jackson, mad; Frankfurter, annoyed because he is credited with having inspired the piece; [Stanley] Reed, annoyed because of the way he was brushed off; etc. It is much simpler to write about dead people". Também sobre as origens da expressão, v. KEENAN KMIEC, “The Origin and Current Meanings of "Judicial Activism", in: California Law Review, n. ${ }^{\circ}$ 92, 2004, p. 1447. Young comenta outra distinção: minimalismo judicial v. maximalismo judicial. ERNEST A. YOUNG, "Judicial Activism and Conservative Politics", in: Colorado Law Review, n. ${ }^{\circ}$ 73, 2002, pp. 1181-1204.
} 
premissa de que a interpretação da lei não poderia ser misturada com a atividade política ou com escolhas éticas, de modo que não haveria tantas respostas aceitáveis quanto presumiam os defensores do ativismo. A variabilidade das noções de justiça e a impossibilidade de fazê-las convergir deveria levar o Judiciário a se pautar pela resistência ao impulso da supremacia judicial. De forma coerente com a tradicional conotação majoritária do processo democrático, isso fortaleceria os legisladores em sua missão de promover os objetivos que a maioria pudesse desejar, mesmo que os próprios magistrados não concordassem com os possíveis resultados dos julgamentos orientados por esses valores $^{293}$.

Como destaca KMIEC, a análise de Schlesinger, apesar de não primar pela precisão conceitual, contribuiu consideravelmente para o debate sobre o ativismo judicial. É que, transcendendo a simples condenação ou a mera apologia das práticas ativistas, ele pôs em relevo parcela importante da problemática emergente nessas discussões: a tensão entre decisões de juízes não eleitos versus vontade dos legisladores e governantes democraticamente eleitos; a oposição entre julgamentos pragmáticos (resultsoriented) e julgamentos orientados por princípios (principle-oriented); as diferenças entre um uso restrito e a utilização criativa de precedentes; a dificuldade de levar às ultimas consequências a ideia de supremacia democrática da maioria sem prejudicar os interesses legítimos das minorias; e as repercussões políticas de certas formas de aplicação do direito $^{294}$.

Seguramente, antes mesmo de o debate ser orientado pela designação ativismo judicial, as manifestações de um potencial protagonismo judicial já eram avaliadas sob os mais diversos epítetos, notadamente pela perspectiva dos membros dos poderes Legislativo e Executivo. Ilustrativamente, quando decisões estabeleciam regras consideradas imponíveis apenas pelo direito legislado, eram qualificadas como forma de legislação judicial (judicial legislation). Conquanto esta seja, num certo sentido, uma das características da ordem jurídica de países vinculados à tradição da common law, não se pode considerar rara, em especial nos EUA, a visualização, na crítica judicial, de posturas judiciais consideradas abusivas dessa função da jurisdição. Com efeito, a alegação de usurpação da função legislativa sempre foi frequente na avaliação teórica e prática do

\footnotetext{
${ }^{293}$ ARTHUR M. SCHLESINGER, op.cit., pp. 421-425.

${ }^{294}$ KEENAN KMIEC, op.cit., pp. 1450-1459.
} 
judicial review ${ }^{295}$, de forma que alguns fenômenos que passaram a ser referidos pela designação judicial activism já vinham sendo debatidos havia muito tempo ${ }^{296}$.

Como já se afirmou neste trabalho com base nas lições de Tocqueville, a tradicional força política e jurídica das instituições judiciárias norte-americanas (notadamente após o caso Marbury v. Madison, de 1803, que reconheceu o princípio da supremacia da Constituição) revelava um pioneiro potencial protagonismo judicial, que ao longo das décadas subsequentes foi se expandindo à medida que evoluiu a juridificação. Destarte, desde que se reconheceu esse potencial em suas primeiras manifestações, emergiu certa obsessão ${ }^{297}$ dos juristas por saber se determinada decisão extrapola os limites da função judicial, se é ou não ativista, contramajoritária, antidemocrática, excessivamente criativa ou indesejada pelos constituintes.

\subsubsection{Noções comuns na retórica da crítica judicial nos EUA}

Não é difícil perceber o porquê de os juristas, sociólogos e cientistas políticos norte-americanos identificarem tantos obstáculos à construção de uma acepção unívoca de judicial activism. Além da variabilidade de significados da expressão, muitos dos que dela se utilizam não deixam claro a que fenômenos se referem. Ademais, a designação é muitas vezes utilizada de forma estigmatizante, o que em geral ocorre, com grande carga de subjetivismo, para disfarçar um juízo de discordância ou de desapreço por certa postura judicial, pejorativamente havida por "ativista”298.

\footnotetext{
${ }^{295}$ Ademais, no caso dos EUA, como bem observa Habermas, a controvérsia sobre a legitimidade da jurisprudência constitucional "segue mais na linha politológica do que na metodologia do direito". JÜRGEN HABERMAS, Direito e democracia entre facticidade e validade, vol. 1, op.cit., p. 330. Sobre o tema, v., também, Lawrence Baum (op.cit., p. 260), que destaca que o judicial review foi exercido desde que a corte foi criada, em diferentes períodos da história norte-americana. Fala-se em judicial review como a prerrogativa do Judiciário de rever os atos dos outros Poderes do Estado (Executivo e Legislativo) pelo reconhecimento de sua inconstitucionalidade (conforme definição do Black’s Law Dictionary, op.cit., p. 349).

${ }^{296}$ Kmiec destaca que os debates sobre a chamada judicial legislation já eram fortes no século XIX, e que se intensificaram nas primeiras décadas do século XX. Bentham, ao responder à alegação de que a criação de normas seria a característica mais forte da common law, teria qualificado a prática, derivada, segundo ele, de um "sofisma infeliz", como "usurpação da função legislativa". As discussões sobre a "legislação judicial" teriam sido particularmente vivas durante a chamada Era Lochner, em que o Judiciário foi severamente criticado por fazer prevalecer os interesses empresariais ao derrubar atos de legislação social em nome do “devido processo legal”. KEENAN KMIEC, op.cit., pp. 1441-1445.

${ }^{297}$ Sobre essa "obsessão", ERWIN CHEMERINSKY, “The Price of Asking the Wrong Question: An Essay on Constitutional Scholarship and Judicial Review”, in: Texas Law Review, n. ${ }^{\circ} 62,1984$.

${ }^{298}$ WILLIAM P. MARSHALL, “Conservatives and the Seven Sins of Judicial Activism”, in: Colorado Law Review, vol. 73, 2002, p. 1217. O autor cita, ilustrativamente, um dos comentários irônicos a respeito: “(...) Judge Goodwin states this point more succinctly: judicial activism means a decision one does not like".
} 
Não se deve desconsiderar, ainda, a grande inconsistência no próprio discurso quer dos defensores quer dos críticos do ativismo. Nesse sentido, BAUM, ao comentar a dicotomia ativismo versus autocontenção, nota que os pareceres favoráveis e desfavoráveis ao assunto se alternam no discurso político tanto dos liberais quanto dos conservadores $^{299}$. Assim, não é difícil identificar um ativismo judicial praticado por magistrados de orientação conservadora e que pregavam a autocontenção, mas que em determinado momento entenderam necessário contestar a autoridade do Congresso Americano.

Além disso, o ativismo judicial não constitui sempre uma postura de defesa do Bill of Rights ou dos interesses de minorias. A corroborar essa assertiva, poderíamos citar, v.g., casos como Lochner v. New York (1905) ${ }^{300}$ e Dred Scott v. Stanford (1857), cujos resultados negavam a implementação de direitos, respectivamente sociais (trabalhistas) e individuais (direitos da personalidade e liberdade individual) ${ }^{301}$.

CHOUDHRY e HUNTER notam que, a depender de quem discursa e em que contexto, a expressão ativismo judicial ora se dirige a posturas de ruptura em relação a precedentes bem estabelecidos; ora a decisões supostamente adotadas conforme as preferências dos juízes; ora a decisões que reexaminam os papéis institucionais do Judiciário em relação aos outros Poderes, reacomodando-os diante da necessidade de decidir um caso concreto. Fala-se, comumente, em “incursões indevidas” do Judiciário no domínio das demais funções estatais cujos representantes são eleitos pelo voto; ou, noutros casos, em “usurpação” de poderes legislativos pelos juízes. Os autores destacam que outra grande dificuldade atrelada ao tema é justamente a delimitação precisa da função judicial, de modo que se possa identificar o que é devido ou indevido. Como não se tem um índice

\footnotetext{
${ }^{299}$ Com efeito, o autor relata que “(...) os liberais que defenderam a contenção judicial governamental da economia, mais tarde aprovaram o ativismo da Corte em defesa das liberdades civis nos anos 60". E, noutro trecho, nota que "até mesmo os juízes de mente mais ativista apoiam a contenção judicial em algumas situações”. Como se vê, não se trata de opção baseada na conviç̧ão a respeito do papel da corte. Tudo depende do contexto jurídico e, principalmente, político. LAWRENCE BAUM, op.cit., pp. 17-18. Essas inconsistências dos discursos liberal e conservador, no que tange à oposição ativismo v. contenção, foram bem descritas, em especial quanto aos conservadores, por William Marshal, a ser examinado a seguir. A doutrina de Berger é confessadamente adepta da autocontenção. RAOUL BERGER, "Government by judiciary: some countercriticism”, in: Texas Law Review, n. ${ }^{\circ}$ 56, 1977-1978. O autor sustenta que o respeito aos limites do poder judicial são da essência da democracia.

${ }^{300} \mathrm{O}$ caso envolveu um ato legislativo de Nova Iorque que limitava o número de horas que um padeiro poderia trabalhar (dez horas por dia e sessenta por semana). Por cinco votos a quatro, a Corte Suprema rejeitou o argumento de que a lei seria necessária para proteger a saúde dos padeiros, decidindo que a legislação do trabalho atentaria contra a liberdade de contratar.

${ }^{301}$ Como observa KMIEC, sobre a decisão: "Critics assailed the Court's preference for business interests as it repeatedly struck down social legislation in the name of substantive Due Process”, op.cit.
} 
claro de atribuições que não poderiam ser “usurpadas”, dada a impossibilidade dessa demarcação num Estado Democrático de Direito, é preciso deixar claros os critérios de identificação de um e de outro tipo de postura judicial ${ }^{302}$.

No exame da vastíssima produção doutrinária sobre o ativismo judicial nos $\mathrm{EUA}^{303}$, nota-se grande consenso a respeito da ambiguidade da designação judicial activism, ampliada, de um lado, pela variabilidade histórica dos fenômenos por ela referidos; e, de outro, por sua associação a correntes teóricas que polarizavam as disputas políticas e constitucionais.

A tendência de observação e de avaliação da postura decisória de magistrados está impregnada no próprio imaginário social e político dos norteamericanos $^{304}$. Desse modo, o passar dos anos trouxe diversos aportes conotativos à expressão ativismo judicial, conforme a situação e a linha de pensamento. Vários fenômenos associados às discussões sobre o tema receberam diferentes nomes em diferentes épocas, o que contribuiu, inclusive, para o surgimento de expressões designativas de correntes teóricas e seus defensores. Como exemplos dessas correntes que se opunham, ELY cita o interpretativismo (interpretivism), doutrina alinhada ao positivismo segundo a qual os juízes, diante de questões constitucionais, deveriam se limitar a aplicar normas positivadas ou claramente extraíveis da Constituição; e o não interpretativismo (non interpretivism), corrente segundo a qual o julgador estaria autorizado a transcender os parâmetros encerrados nos "quatro cantos do documento" e partir de outros referenciais. Ao tratar da maneira como a expressão ativismo judicial se enquadra nessas discussões, o próprio jurista reconhece que a expressão adquiriu uma bagagem extensa que pode facilmente enganar e conduzir a conclusões equivocadas ${ }^{305}$.

O exame dessas e de outras concepções, entretanto, revela a crença compartilhada de que a inferência completa pode não ocorrer apenas com base no texto constitucional (v.g., o legislador pode não haver previsto dada situação concreta). Desse modo, nota-se um potencial de atuação que, a depender da maneira como se manifeste, pode ser visto como prática do chamado ativismo judicial.

\footnotetext{
${ }^{302}$ SUJIT CHOUDHRY, CLAIRE E. HUNTER, op.cit., p. 526.

303 Apenas na base de dados Heinonline, foram encontrados mais de 15 mil textos a respeito.

${ }^{304}$ MICHAEL GERHARDT, "The Rhetoric of judicial critique: from judicial restraint to the virtual Bill of Rights”, in: William \& Mary Bill of Rights Journal, vol. 10, 2002, pp. 585-586. Destacando as influências da “opinião pública” sobre as decisões da Suprema Corte Americana, v. LAWRENCE BAUM, op.cit., p. 198.

${ }^{305}$ JOHN HART ELY, Democracy and Distrust: a theory of judicial review. Cambridge : Harvard University Press, 2002, pp. 1-2.
} 
Conquanto seja possível apontar problemas no alcance das acepções adiante investigadas, não se pode deixar de reconhecer, em cada uma delas, a tentativa de explicar manifestações relevantes do poder judicial ou, mais especificamente, do potencial protagonismo judicial.

Várias acepções de ativismo judicial foram examinadas por MARSHALL. Sem olvidar a ambiguidade da expressão, dos termos que a constituem e dos qualificativos que podem acompanhá-la, ele observa que a identificação do fenômeno depende, em geral, do exame das repercussões de certa decisão num cenário mais amplo, a incluir seus reflexos extrajudiciais e certos aspectos que transcendem a visão estritamente jurídica. Ao enfocar o uso das noções por ele examinadas, o jurista nota importantes diferenças na avaliação de posturas judiciais semelhantes que, qualificadas como “conservadoras” em determinados momentos e situações históricas; tempos depois passaram a ser consideradas "liberais”, ou vice-versa ${ }^{306}$. Aprofundando ainda mais essa visão em estudo de vários casos, ele identifica certa insinceridade no discurso dos que, declarando-se "conservadores", condenam um ativismo liberal que muito se assemelha, noutros contextos, à própria postura conservadora ${ }^{307}$.

Sem desconsiderar essas perplexidades, o jurista apontou sete acepções que considerou mais frequentes nos debates sobre o ativismo judicial ${ }^{308}$.

A primeira noção destacada por MARSHALL vincula a expressão ativismo judicial à atitude contramajoritária dos juízes (counter-majoritarian activism). Trata-se da resistência que se manifesta na invalidação de atos (sobretudo normas gerais e abstratas) dos Poderes democraticamente eleitos. Fica claro, nos vários casos examinados

\footnotetext{
${ }^{306}$ Como exemplos, Marshall cita Clinton v. Jones (1997) e R.A.V. v. City of St. Paul (1992). O autor nota: "A non-conservative result, in short, can be the product of a conservative opinion" (WILLIAM P. MARSHALL, op.cit., p. 1219).

${ }^{307}$ WILLIAM P. MARSHALL, op.cit., pp. 1223-1229. Em última análise, a intenção de Marshall é a de demonstrar a insinceridade (traduzida no que ele chama de "pecados", sins) na expressão "ativismo judicial" presente no discurso dos juízes que se consideravam conservadores, os quais adotavam as mesmas práticas que eles condenavam na postura dos juízes "liberais". Marshall não sugere que decisões ativistas ou de autocontenção são necessariamente certas ou erradas. Destaque-se, por oportuno, o seguinte excerto: "I conclude that the conservatives have indeed been activist (...) Their fault, if any, is in their disingenuousness. They, or more often their defenders, claim that theirs is a jurisprudence more principled and more restrained than that of their liberal counterparts when in fact it is nothing more than a jurisprudence designed to effectuate particular results."

${ }^{308}$ Manejando, em seus estudos, os sete tipos de ativismo judicial apresentados por Marshall, v. ALEXANDRE GARRIDO DA SILVA (et al.). "Delimitando as categorias de judicialização da política e de ativismo judicial: o caso da manipulação das células-tronco embrionárias", in: Revista da Faculdade de Direito de Uberlândia, vol. 36, 2008. JOSÉ RIBAS VIEIRA. "Verso e reverso: a judicialização da política e o ativismo judicial no Brasil”, in: Estação Científica (Ed. Especial Direito) Juiz de Fora, vol. 1, n. ${ }^{\circ} 4$, out./nov. 2009.
} 
por ele, que esse tipo de ativismo não é característico de uma única orientação política, já que tanto "liberais” quanto “conservadores” se utilizam frequentemente do judicial review.

A segunda noção frequentemente associada ao ativismo judicial, segundo o jurista, refere-se ao desrespeito à doutrina do originalismo (non-originalist activism). A bandeira originalista, comum no discurso conservador, prega a lealdade dos juízes ao texto normativo e à “intenção original” dos legisladores ${ }^{309}$. Nota-se, nos vários casos examinados no estudo, que os próprios conservadores, conforme a conveniência política, não só decidiram de forma "não originalista”, mas chegaram ao ponto de proceder a uma “defesa originalista” de alguns desvios da literalidade do texto. Para ele, destarte, se essas incongruências não servem para afirmar que esta ou aquela decisão teria sido “equivocada”, demonstram que um originalismo rígido, além de não ser apto a confrontar a complexidade crescente das relações sociais e políticas, também não seria capaz de esconder a grande incoerência entre o discurso de seus adeptos, de um lado, e o conteúdo das decisões tomadas sob essa bandeira, de outro. Nessa linha, o originalismo seria uma doutrina de conveniência, sem consistência em sua aplicação, além de obscurecer, por detrás do estandarte de respeito ao “texto” ou à “intenção do legislador”, as verdadeiras intenções decisórias daqueles que se declaram “fiéis” a esse ideário ${ }^{310}$.

A terceira noção frequente, segundo o estudo sob exame, relaciona o ativismo judicial à desconsideração, pelo Judiciário, de orientações decisórias constantes de precedentes estabelecidos (precedential activism). Trata-se de casos em que esses precedentes são considerados inadequados como parâmetros decisórios. Foi o que ocorreu, ilustrativamente, com a decisão no caso Brown v. Board of Education, que derrubou o precedente anterior, Plessy v. Ferguson, e com isso pôs fim à segregação racial em escolas. Segundo MARSHALL, esse tipo de ativismo pode ocorrer, também: a) quando se reinterpretam os limites de determinado instituto ou de determinada cláusula, construindose nova orientação que, se não leva à derrubada do precedente, engendra seu

\footnotetext{
${ }^{309}$ Essas ideias nos fazem recuperar as proposições e Ely, segundo o qual a maior peculiaridade do interpretativismo (alinhado ao originalismo) é a insistência em que o trabalho dos ramos políticos pode ser invalidado apenas de acordo com inferências cujo ponto de partida, cuja premissa fundamental, há de ser extraída da Constituição. O fato de que a inferência completa poderá não ocorrer apenas com base na Constituição - já que, inclusive, a situação pode não haver sido prevista - é uma crença compartilhada. JOHN HART ELY, op.cit., p. 2.

${ }^{310}$ Destaca o jurista: "The conservatives' non-originalist decisions, in short, can be defended, but their defense must rest upon grounds ostensibly hostile to the conservatives' own purported foundational principles. They must acknowledge that a non-originalist judicial "activism" may at times be warranted.”. E, mais adiante, ele assevera: "Originalism is a doctrine of convenience and, even then, not consistently applied” (WILLIAM P. MARSHALL, op.cit., pp. 1229-1232)
} 
enfraquecimento; b) quando se restabelece um precedente antigo; ou c) quando, na aplicação de uma norma legal (statute), ela é interpretada contrariamente à chamada “statutory construction”, cuja função é a de tornar mais rígidos os efeitos do stare decisis. Em outros termos, fala-se em decisão que contraria certa tendência construída ao longo de vários anos de decisões tomadas no mesmo sentido ${ }^{311}$.

A quarta acepção identificada pelo jurista aponta o ativismo judicial como mudança na percepção dos julgadores em relação aos limites dos próprios poderes, o que pode implicar ora o estreitamento, ora o alargamento das fronteiras das funções e atribuições jurisdicionais. Ilustrativamente, esse ativismo jurisdicional (jurisdictional activism) ocorreria na hipótese de o Judiciário modificar, pela maneira como percebe a incidência do instituto do standing num caso concreto, o grau de aceitabilidade da demanda, mostrando-se mais ou menos aberto à sua propositura, o que poderia estimular ou conter a judicialização em relação ao tema ${ }^{312}$.

A quinta noção de ativismo judicial que segundo MARSHALL é frequentemente identificável em comentários críticos de decisões judiciais se reporta à criação de novas teorias e direitos que se incorporam ao discurso doutrinário e jurisprudencial. Conquanto se trate da tradição anglo-saxã, é preciso evocar, para a adequada compreensão dessa noção de ativismo judicial caracterizada pelo jurista como criatividade judicial (judicial creativity), que os tribunais federais nos EUA não são, a rigor, tribunais de common law, com um poder geral de desenvolver e refinar suas próprias regras. Ao contrário, normas federais são reservadas à legislação federal, de modo que a construção da common law constitui expediente necessário apenas na falta de um ato do Congresso Americano aplicável ao caso, hipótese em que as cortes são forçadas a considerar questões que não possam receber respostas apenas com base nos statutes. Notese, ademais, que, se o Congresso regulamentar a matéria posteriormente à edição de um precedente por um tribunal federal, a necessidade de recorrer a este último, excepcional e

\footnotetext{
${ }^{311}$ Marshall pondera que, neste último caso, valores institucionais estão claramente em jogo, uma vez que a redução do valor do stare decisis, independentemente de isto ser justificável, pode ser destrutivo para o rule of law. WILLIAM P. MARSHALL, op.cit., pp. 1232-1236. Destaquem-se, do original, os seguintes excertos: "After all, there is precedential weight even in the decisions with which one disagrees. Institutional values are also at stake: demeaning the value of stare decisis is destructive to the rule of law. Conservatives, of course, are not alone in dismissive treatment of contrary precedent, but they have done little to promote precedential restraint as an institutional value”; “(...) For example, in Holder v. Hall,107 Justices Scalia and Thomas rejected the general rule that statutory construction was entitled to strict stare decisis effect, arguing in that case that the Voting Rights Act should be reconstrued in a manner inconsistent with over twenty-five years of precedent."

${ }^{312}$ WILLIAM P. MARSHALL, op.cit., pp. 1236-1240.
} 
subsidiariamente construído, desaparece ${ }^{313}$. Como foi visto, aliás, esse expediente tem se tornado cada vez mais comum na chamada era dos estatutos (the age of statutes) vivenciada pela tradição da common law (2.2.7.1, supra).

É interessante notar, seguindo a linha do citado estudo, que esse tipo criativo de ativismo judicial pode ser motivado por novos problemas e por novas questões que antes não eram visualizáveis pelo escopo da teoria ou da doutrina anteriores. Esses temas de certa maneira "testam” a aplicabilidade de ideias sedimentadas. É o que tem ocorrido com avanços na medicina e nas ciências biológicas em geral, que servem como fomentadores de novas reflexões sobre a privacidade, a personalidade e a autonomia individual. Indubitavelmente, avanços na ciência tendem a impulsionar novas conceituações jurídicas e novos enfoques doutrinários; e, independentemente de mudanças sociais e tecnológicas, o simples reconhecimento de novos direitos pode ser necessário para limitar efeitos não previstos ou não desejados de doutrinas e concepções dominantes. É interessante observar que essa criatividade judicial pode ser utilizada para os mais diversos fins jurídicos, políticos ou sociais, seja para promover direitos, seja para restringilos.

A sexta acepção destacada no estudo de MARSHALL vincula o ativismo judicial a decisões que impõem "remédios” jurisdicionais a determinadas situações levadas ao conhecimento do Judiciário. Trata-se de uma espécie de “terapêutica judicial” na qual o poder público é instado a adotar medidas destinadas à implementação de direitos (remedial activism $^{314}$ ). Em linhas gerais, esse ativismo judicial “corretivo” leva à imposição de obrigações a outros Poderes, passando o Judiciário a desenvolver uma função de supervisão de outras instituições estatais ${ }^{315}$. De um modo geral, trata-se da intervenção judicial em litígios de interesse público (2.2.9, supra).

\footnotetext{
${ }^{313}$ Em parte, esse esclarecimento é feito pelo próprio Marshall: “(...) and no argument from constitutional structure can justify the Court's creation of federal tort law in this case (federal courts are, after all, not common law courts). In fact, the judicial activism demonstrated in this case is breathtaking from any perspective” (WILLIAM P. MARSHALL, op.cit., p. 1231).

${ }^{314}$ Remedy, conforme definição extraída do Black Law's Dictionary (BRYAN GARNER, op.cit., p. 536), consiste na implementação de um direito ou a reparação de um dano por intermédio do Judiciário.

${ }^{315}$ Nesses casos, os conservadores teriam uma postura bem diferente dos liberais, por intentarem, de fato, evitar essas práticas, como observa o jurista: "There is at least one area where the conservatives have been thoroughly consistent about rejecting a form of judicial activism: the judiciary's use of its remedial powers to impose affirmative obligations on government. In fact, the conservatives have been quite active in bringing this 'remedial activism' to an end. They have used the Equal Protection Clause to end court oversight of school desegregation, the Eleventh Amendment to bar judicially imposed reform of mental hospitals, and the standing doctrine to prevent judicial supervision of police enforcement methods" WILLIAM P. MARSHALL, op.cit., p. 1242).
} 
A sétima acepção identificada pelo jurista relaciona o ativismo judicial ao uso do Poder Judiciário para alcançar objetivos partidários (partisan activism). Neste caso, que para o jurista norte-americano seria a pior forma de ativismo judicial, as decisões dos tribunais podem ser influenciadas pela agenda político-partidária.

Depois de explicitar cada uma dessas noções e de examinar casos, o autor conclui que mesmo nos julgamentos dos chamados “conservadores" podem ser visualizados vários traços da conduta que o próprio discurso conservador condena. O que Marshall quer afirmar é que, se o ativismo judicial dos conservadores puder ser considerado defensável para, v.g., compensar a falha dos legisladores, igualmente defensável seria, sob esse fundamento, o ativismo judicial dos liberais. Além dessa incoerência no discurso, os conservadores tendem a se apegar ao argumento originalista apenas quando ele serve à causa conservadora.

Assim, o exame das decisões consideradas ativistas (tanto as tomadas por liberais quanto as tomadas por conservadores) conforme esse conjunto de noções leva à conclusão de que a presença ou não do ativismo judicial na atividade decisória de Suprema Corte americana não depende da orientação política dos membros que a controlam. Como corolário, a afirmação dos conservadores de que suas decisões se pautariam pela autocontenção (ou, ainda, por um pretensamente “adequado” método de decisão) seria no mínimo suspeita, à falta de qualquer indício, na prática decisória conservadora, que a corrobore. É fácil perceber, portanto, que a atividade decisória da Suprema Corte Americana é orientada, em grande medida, pelos resultados almejados ${ }^{316}$.

WAYNE, dialogando com as proposições de Marshall ao comentar as críticas que vinha recebendo por suas decisões, defende que a expressão ativismo judicial é frequentemente utilizada para induzir a reprovação pública de decisões judiciais que não agradem os políticos ${ }^{317}$. É interessante notar as ponderações que ele traz sobre a busca do significado da constituição, um dos mais antigos debates da história política dos EUA (com no mínimo três séculos). Em suas reflexões, ele nota que, não obstante a antiguidade do debate, muitos ainda relutam em reconhecer que ele se trava num campo inevitavelmente político e fortemente carregado de ingredientes valorativos ${ }^{318}$. Ademais, ele considera,

\footnotetext{
${ }^{316}$ Isso corrobora a assertiva de Ely, segundo o qual seria equivocado supor que haveria uma necessária correlação entre uma postura interpretativista e o judicial restraint ou a moderação judicial. JOHN HART ELY, op.cit., p. 1.

${ }^{317}$ WILLIAM WAYNE, "The Two Faces of Judicial Activism", in: George Washington Law Review, n. ${ }^{\circ}$, vol. 61, nov. 1992.

${ }^{318}$ WILLIAM WAYNE, op.cit., pp. 3-4.
} 
lucidamente, que muitas noções correntes nesses debates não seriam baseadas nos mesmos critérios, e assim uma decisão reputada ativista com base em um deles não seria ativista com base em outro ${ }^{319}$.

KMIEC, em seu estudo sobre diferentes noções de ativismo judicial, retoma as ideias seminais de Schlesinger (3.2.1, supra) e as proposições de diversos autores (inclusive Marshall) para destacar outras dificuldades.

A primeira dificuldade apontada por ele radica na suposição de que, em sua vertente contramajoritária, o ativismo judicial não estaria em todos os casos de exercício do judicial review, mas apenas nos chamados casos "difíceis", de “constitucionalidade discutível” (arguably constitutional actions of other branches). Consoante pondera o jurista, o problema estaria em supor que essa distinção poderia encerrar os debates, quando em lugar disso ela suscitaria muitos outros. Ora, a afirmação de que determinada lei "é inconstitucional”, mesmo nos casos em que tal vício possa ser considerado "claro", depende muito da maneira pela qual o autor dessa afirmação entende a constituição e concebe o papel da Suprema Corte ou do Poder Judiciário em geral. As respostas a essas indagações sobre a questionabilidade das normas pela perspectiva constitucional, se já não são fáceis, possivelmente veiculariam outras proposições igualmente discutíveis e de difícil aceitação uniforme. Em outros termos, esse subjetivismo do exame das posturas judiciais, a que se refere KMIEC, leva-nos a perplexidades similares às engendradas pelos debates entre originalistas e não originalistas ou entre interpretativistas e não interpretativistas ${ }^{320}$.

Não nos parece exagero sustentar, nesse sentido, uma clara imperscrutabilidade da vontade dos juízes e do que se costuma chamar de voluntarismo judicial.

O argumento de SOWELL permite aprofundar essa elucubração. Ao problematizar a tese originalista, ele destaca ser muito comum a proposta de moderação no discurso dos adeptos desse ideário, que prega a preservação da “intenção original” dos legisladores (com o que seriam invalidados apenas textos legais considerados contrários àquela intenção). Ele pondera, entretanto, que, diferentemente do que se poderia pensar, o originalismo não invocaria a “intenção psicológica” ou os “valores filosóficos” que motivaram a lei, mas o significado cognitivo original de seu texto, seu sentido mais usual,

\footnotetext{
${ }^{319}$ Conforme observa o autor, citando exemplos, p. 1220.

${ }^{320}$ KEENAN KMIEC, op.cit., pp. 1463 e ss.
} 
conhecido e popular. Assim, não se investigaria a vontade do legislador, mas o significado da lei quando ela fora editada. Seria a este significado que o julgador haveria de se ater, abstendo-se, portanto, de inovar ou de impor suas preferências ideológicas e crenças pessoais de forma voluntarista, sem qualquer preocupação com o resultado de suas decisões. Contudo, ao destacar que a dificuldade de controlar esse voluntarismo seria uma das inquietações mais marcantes nas discussões sobre o ativismo judicial nos EUA, ele próprio pondera que tanto os defensores quanto os críticos do ativismo judicial costumam censurar essas posturas puramente ou tendencialmente pessoais. De um lado, os opositores do ativismo judicial são obviamente contrários a tal voluntarismo que segundo eles estaria embutido em uma decisão ativista (cuja fundamentação, para essa linha de pensamento, seria construída com elementos colhidos em terrenos extrínsecos ou contrários à Constituição). De outro lado, os entusiastas do ativismo também são contrários às posturas voluntaristas, e costumam sustentar que o ativismo judicial “legítimo” não seria pautado em preferências pessoais para delimitar as balizas dos provimentos jurisdicionais, mas na própria Constituição. Consoante esse segundo grupo, portanto, o próprio texto constitucional exigiria, para a defesa dos valores que ele alberga, uma postura ativista em face de indivíduos, grupos, instituições e violações de suas determinações, sem que isso pudesse, nesse sentido, ser considerado uma espécie de voluntarismo ${ }^{321}$.

Sem dar repostas a tal problemática (talvez pela impossibilidade de fazêlo), SOWELL ainda sugere que, em razão dessas dificuldades e pelo poder que possuem de introduzir mudanças no sentido do texto das leis, os juízes poderiam chegar ao ponto de, sub-repticiamente, promover pequenos e imperceptíveis coups d'état, diferentes de golpes mais visíveis, ostensivos e abrangentes (como um golpe militar). E pondera que, para uma democracia constitucional, os riscos dessas pequenas mudanças seriam relevantes no longo prazo, em razão do efeito cumulativo dessas “usurpações” de poder por sub-repção (constitutivas de precedentes fomentadores de usurpações ainda maiores por outros agentes, inclusive com visões diferentes). SOWELL, assim, contesta a linha de pensamento que supõe a necessidade de um ativismo judicial para garantir a aplicação da lei a novos fatos e circunstâncias sociais (para eliminar uma alegada "escravidão perante o passado” e perante legisladores constituintes que “ditassem as regras do túmulo”). Afinal, para o jurista, o conflito não existe entre os vivos e os mortos, mas inter vivos, a tornar clara a tensão entre aqueles que pretendem que o controle das mudanças ocorra por

${ }^{321}$ THOMAS SOWELL, Judicial activism reconsidered. Stanford: Stanford University, 1989, p. 2. 
intermédio dos juízes, de um lado; e os que defendem que isto ocorra por meio de outros agentes, sobretudo os legisladores, de outro. Com isso, o autor, apesar de considerar o dinamismo do sentido das leis, levanta a preocupação tanto com a forma das mudanças normativas eventualmente necessárias, quanto com a dificuldade de limitar o poder dos agentes que podem promovê-las ${ }^{322}$.

Essas e outras dificuldades podem ser visualizadas de outro prisma. Com efeito, os críticos do ativismo judicial em geral não defendem a eliminação do judicial review, mesmo que reconheçam o caráter contramajoritário de uma decisão do Judiciário que se sobreponha à deliberação dos Poderes estruturados pela regra da maioria. Ora, o exercício do judicial review baseado no intento dos constituintes, como prega o interpretativismo, seria, por esse critério, antidemocrático. Todavia, o argumento dos interpretativistas (que pregam o uso do judicial review em nome de uma prerrogativa revisional que possibilitaria defender a Constituição) também poderia ser usado pelos não interpretativistas, como bem nota CHEMERINSKY ${ }^{323}$. Se pusermos o foco da problemática sobre a dificuldade de mensurar ou delimitar o quantum de liberdade que teriam os juízes para interpretar a Constituição ou as leis, surgem aporias que parecem incontornáveis ${ }^{324}$.

Mais uma vez, cumpre observar que menos a possibilidade de declarar a inconstitucionalidade, e mais a possibilidade de não declarar uma lei inconstitucional (e aqui, com a pretensão de consistência e coesão, evocamos a noção de potencial protagonismo judicial) corrobora a afirmação de que a invalidação de atos de outros poderes, independentemente de a inconstitucionalidade ser discutível ou não, seria um tipo específico de ativismo judicial.

Além dessas dificuldades relacionadas ao ativismo judicial em conexão com o judicial review, outra importante ponderação de KMIEC, baseada em distinções relevantes, mas normalmente ignoradas, dirige-se à noção de ativismo judicial como desapego ou desconsideração de precedentes. Adotando como critério o órgão instituidor,

\footnotetext{
${ }^{322}$ THOMAS SOWELL, op.cit., p. 32.

${ }^{323}$ ERWIN CHEMERINSKY, op.cit., pp. 1209-1210.

${ }^{324}$ Esse questionamento central estaria obscurecido, para o jurista, em razão do debate infrutífero entre as correntes supracitadas e pelo foco na "regra da maioria". Em outras palavras, ele defende a insuficiência da definição procedimentalista de democracia, e enfatiza, como alternativa, retomando a preocupação de Tocqueville, a necessidade de acrescer a esses debates o valor da proteção contra a "tirania das maiorias". Desse modo, o autor põe em destaque a tensão entre a defesa da regra da maioria e o reconhecimento da necessidade de serem impostos limites às decisões judiciais democráticas baseadas naquela regra, notadamente porque elas podem também prejudicar minorias (ERWIN CHEMERINSKY, op.cit., p. 1210).
} 
ele vislumbra diferenças entre precedentes verticais e precedentes horizontais. Os primeiros (vertical ou controlling precedents) devem ser respeitados por cortes inferiores como direito estabelecido (settled law), ao passo que os precedentes horizontais (horizontal precedents) dariam substância a uma tendência de acatamento, por determinado tribunal, de suas próprias decisões em casos similares, evitando-se o chamado overruling e os consequentes prejuízos à consistência do stare decisis. Em ambos os casos, a desconsideração de precedentes costuma ser vista como forma de ativismo judicial. No caso dos precedentes horizontais, o debate pode ser ainda mais polêmico, já que não é raro que o apego excessivo ao stare decisis resulte na manutenção de entendimentos com proposições possivelmente inconstitucionais. Assim, poder-se-ia sustentar que desconsiderar um precedente horizontal que houvesse incorrido nesse equívoco não seria ativismo judicial, mas, decisão constitucionalmente adequada. Mas isso, por outro lado, leva-nos novamente às cizânias intermináveis acerca da constitucionalidade “discutível”.

Outras vicissitudes surgem quando se examinam as camadas hierárquicas do stare decisis das quais promanam os precedentes.

Existe uma tradição que leva a Suprema Corte a reconhecer a posição privilegiada dos tribunais inferiores, em especial as cortes estaduais (consideradas guardiãs da common law), no que concerne à modificação de seus precedentes (common law precedents). Entende-se que a atuação desses tribunais garantiria a evolução dos precedentes ao longo do tempo. Como a jurisprudência, naquela tradição, é claramente uma fonte do direito, a decisão contrária desses tribunais em relação a um precedente se assemelharia à atuação dos legisladores, na hipótese de editarem uma lei em sentido contrário àquela que, com o mesmo objeto, seria então revogada.

O mesmo não ocorre com os precedentes constitucionais (constitutional law precedents). Pela dificuldade de emendar a constituição, a Suprema Corte se torna o único instrumento institucional eficaz para a mudança de doutrinas constitucionais que se considerem obsoletas. Por sua vez, os precedentes baseados em leis (statutory precedents) costumam desfrutar de uma presunção superforte de correção (super-strong presumption of correctness), já que a interpretação que lhe dá fundamento passa a ser considerada parte do statute, de modo que superar a opinião anterior significaria repelir e reescrever a própria lei, algo que apenas os legisladores, em tese, poderiam fazer ${ }^{325}$.

${ }^{325}$ KEENAN KMIEC, op.cit., pp. 1469-1470. 
Desse modo, os precedentes não podem ser considerados fenômenos uniformes. Conceituar o ativismo judicial como desapego a precedentes depende de certo aprofundamento conceitual que esclareça de que tipo de precedente se trata, que tipo de fonte do direito se discute e que tipo de função dela derivada está em jogo.

A matéria se complica ainda mais na hipótese de dispositivos constitucionais e legais apresentarem texto semelhante ao de precedentes de common law. Quando os statutes se baseiam em disposições genéricas, tendem a estimular a criação judicial, de modo que, na prática, um preceito formal e tecnicamente legislativo (statutory provision) adquire substância de common law ${ }^{326}$. Em outras palavras, isso daria lugar a um tipo de direito constitucional que derivaria cada vez menos do texto constitucional, aproximando-se, paradoxalmente, da própria produção da common law. Com isso, qualquer crítica que se faça a esse processo, ou ao ativismo judicial que se entenda estar vinculado a ele, deve considerar a natureza, a função e as fontes dos precedentes.

A relação entre o ativismo judicial e a criatividade judicial é objeto de um terceiro aprofundamento crítico proposto por KMIEC. Nesse sentido, ele examina a noção de ativismo judicial como judicial legislation. Com base nessa noção, a identificação de uma conduta judicial “ativista” não explica, por si só, se a decisão foi "boa” ou "ruim”. Mesmo que se considere que determinado caso revela exercício “inadequado” da função judicial, na prática as consequências da decisão adotada podem ser favoráveis e socialmente desejadas. Foi o que ocorreu em vários casos decididos pela chamada corte de Warren, entre 1953 e 1969. Nesse período, encontram-se julgamentos amiúde referidos como representativos de um ativismo judicial instituidor de regras gerais e abstratas similares às das leis. Tais decisões representaram avanços significativos em matéria de civil rights e receberam ampla aceitação social ${ }^{327}$. Assim, se em muitos casos uma decisão pode ser "boa” pelo prisma dos resultados, o uso da expressão ativismo judicial como sinônimo de “decisão ruim” não só deixa de lado a explicitação dos critérios pelos quais uma decisão deva ser considerada imprópria, perigosa ou errada; mas também ignora fatores que, pela perspectiva consequencialista, podem ser relevantes, por enfraquecerem a ideia de que “ativista” seria, necessariamente, sinônimo de "ruim” ou “ilegítimo”.

\footnotetext{
${ }^{326}$ KEENAN KMIEC, op.cit., p. 1470.

${ }^{327}$ KEENAN KMIEC, op.cit., p. 1473.
} 
Não obstante KMIEC não refira essa idéia, parece relevante, aqui, distinguir uma postura voluntarista (no sentido propriamente kantiano, referente a uma vontade “boa”, conforme um dever, sem preocupação com as consequências) de uma postura consequencialista, pragmática, que se dirija aos resultados. Uma decisão "boa” pelo primeiro prisma (o de uma vontade boa, conforme, v.g., o dever de respeitar o ideário democrático, com a conotação majoritária que implique um não agir ou a não atuação de um potencial protagonismo) pode ser ruim quanto aos seus resultados; ao passo que uma decisão "ruim" do ponto de vista do esperado respeito àqueles valores democráticos majoritários pode ser "boa” quanto aos resultados alcançados ${ }^{328}$. Parece relevante, neste ponto, e mais uma vez, referir às perspectivas weberianas das éticas da responsabilidade e da convicção (2.2.4.1, supra).

Os critérios que destaquem o pragmatismo das decisões também podem apresentar problemas. É que eles tendem a levar a uma noção de ativismo judicial que enfatize o fato de determinados julgamentos haverem sido orientados pelos resultados “almejados” (result-oriented judging). Para KMIEC, esta noção se diferencia das demais por possuir um aspecto de consciência no julgamento (scienter element). Os que assim descrevem o ativismo judicial entendem se tratar não do simples desacato a determinações dos outros poderes, ou da falha na manutenção da previsibilidade e da uniformidade das normas. Soma-se a isto um objetivo não oficial, não declarado. Assim, uma decisão seria ativista se o juiz, por motivo velado e que transcenda o processo (ulterior motive), desviase de pontos de partida definidores da correção (baseline of correctness) de seu julgamento. Novamente, todavia, além do subjetivismo dessa avaliação, não são claros os pretensos pontos de partida que norteariam o reconhecimento do quanto a decisão “ativista” teria se desviado de uma decisão “correta”. Seja como for, não se pode deixar de considerar que o elemento scienter, que daria substância a esse pragmatismo, apesar de em geral ser obscuro e de não poder ser objeto de apreensão incontestável, é variável relevante dessa noção corrente nas discussões sobre o tema ${ }^{329}$.

Para DWORKIN, o aspecto pragmático seria o ingrediente mais importante do ativismo judicial, fenômeno que ele define como uma "forma perigosa de

\footnotetext{
${ }^{328}$ Isso traz à tona, mais uma vez, a ideia que a atividade decisória seria eminentemente pragmática, e não de métodos. A mesma ideia foi destacada neste trabalho quando do exame da doutrina, mais abrangente, de Marcelo Neves, no que tange à metodologia decisória (tópico 2.2.4, supra). E, de um modo geral, emerge das conclusões já destacadas a respeito das consequências do processo de juridificação do mundo da vida e da construção de um cenário de potencial protagonismo judicial (Cf. tópico 2.2, supra).

${ }^{329}$ KMIEC, op.cit., pp. 1463-1477.
} 
pragmatismo". Nesse sentido, uma justiça ativista, a fim de impor aos outros ramos do governo sua própria visão de justiça, ignora o texto da constituição, a história de sua construção, as decisões anteriores da Suprema Corte que a interpretam e as tradições consolidadas da cultura política. Como forma de evitar essa forma de ativismo e toda a prática jurisdicional que dela se aproxime, ele sustenta a ideia de "direito como integridade" (law as integrity). Essa noção serviria como um guia para estimular magistrados à promoção e ao fortalecimento da constituição por meio da interpretação, sem deixar que suas decisões ignorem a prática constitucional. Apesar de admitir que uma postura interpretativa num julgamento possa empregar o que ele chama de moralidade política (political morality), o jurista afirma que essa visão do direito (como integridade) culminaria com uma espécie de lealdade (fairness) derivada da sensibilidade em relação às tradições políticas e culturais de um país. Desse modo, a alternativa ao que ele chama de passivismo (passivism) não seria um ativismo imaturo (crude activism), subordinado apenas ao senso de justiça de um juiz; mas um julgamento mais refinado e perspicaz, caso a caso, que daria lugar a muitas virtudes políticas e, diferentemente do ativismo, não levaria à prática de atos tiranos em desfavor de ninguém ${ }^{330}$.

Em certa medida, as "tradições" referidas por Dworkin parecem se relacionar à manutenção da construção teórica sobre a metodologia interpretativa (interpretative methodology), também problematizada por KMIEC. Aplicada à compreensão de dispositivos constitucionais e legais, e independentemente das críticas que possam existir em relação aos chamados “cânones interpretativos”, o desvio quantitativo ou qualitativo dos métodos comumente aceitos, a adoção de métodos não convencionais ou as diferentes formas de uso de um método, mesmo que tradicional, podem engendrar outra noção de ativismo judicial ${ }^{331}$. Mais uma vez, entretanto, as infindáveis divergências de opinião a respeito do que constituiria uma ferramenta interpretativa "adequada” tornam difícil o preciso delineamento do que seriam metodologias “corretas”. Ademais, não

\footnotetext{
${ }^{330}$ No original: “(...) law as integrity is sensitive to a nation's political traditions and culture and therefore to a conception of fairness that is fit for a constitution. The alternative to passivism is not a crude activism harnessed only to a judge's sense of justice, but a more finegrained and discriminating judgment, case by case, that gives place to many political virtues but, unlike either activism or passivism, gives tyranny to none”. RONALD DWORKIN, Law's Empire. Cambridge: Harvard University Press, 1986. p. 378.

${ }^{331}$ Não é despiciendo, neste átimo, evocar NAGEL, que observa que juízes identificam e exploram a ambiguidades e incertezas; e que a interpretação, em si, é um processo necessário apenas quando entendimentos estabelecidos são questionados, i.e., pela busca de alguma mudança no sentido normalmente aceito. ROBERT NAGEL, Constitutional cultures: the mentality and consequences of judicial review. Los Angeles: University of California Press, 1989, p. 11. Sobre os juízes, ele observa "They identify and exploit ambiguity and uncertainty(...)", e, além disso, "(...) interpretation itself is a process that is necessary only when established understandings are challenged, when some change in accepted meaning is called for."
} 
obstante haver pontos de consenso, não há acordo sobre qual seria o “modo apropriado” de interpretar disposições legais ou constitucionais. Mesmo que isto envolva o uso de cânones tradicionais (como os critérios sistemático, textual e histórico), pode haver, não obstante a concordância a respeito de quantos e quais cânones interpretativos devam ser usados, discordância sobre o resultado a que eles levariam em razão das diferentes formas possíveis de sua utilização. Assim, se parece clara a identificação da recorrência de mais essa noção de ativismo judicial, parecem ser obscuros os seus critérios ${ }^{332}$.

São relativamente comuns as noções que consideram o ativismo judicial um desvio. Se assim for, o problema é esclarecer de que se desvia, em que sentido se caminha, quais os caminhos alternativos, entre outras dúvidas e perplexidades já destacadas. Para tentar contornar, no limite do possível, essas dificuldades, é oportuno observar que (afora o uso da expressão como sinônimo de discordância ou desgosto), em todas as noções examinadas o ativismo judicial não se afigura como um fenômeno "intransitivo", mas como um agir judicial que tem um objeto. Com efeito, quando um magistrado pratica o ativismo judicial, ele age em relação a algo (um quid), faz opções por determinados caminhos cujo seguimento não é inexorável. Sem dúvida, haveria outros que, pragmaticamente (2.2.4, supra), para o bem ou para o mal, ele poderia seguir.

Nessa linha, MCWHINNEY ${ }^{333}$ nota que as noções de ativismo judicial, se excessivamente simplificadas e sem referência precisa a um objeto, tendem a ser inúteis ${ }^{334}$.

\footnotetext{
${ }^{332}$ Kmiec cita exemplos: "This happened when Alberto Gonzales, as a Justice of the Supreme Court of Texas, condemned fellow Justice Priscilla Owen's interpretation of a statute as 'an unconscionable act of judicial activism.' Gonzales contended that Owen disregarded the text and legislative history of Texas's Parental Notification Act in order to reach her conclusion. Although Owen agreed that the text and history of a statute are the touchstones of statutory interpretation, she came to a different conclusion. Therefore, one reading of Gonzales's statement is that Owen employed these tools of statutory interpretation improperly." (KEENAN KMIEC, op.cit., p. 1475).

${ }^{333}$ EDWARD MCWHINNEY, "The Great Debate: Activism and Self-Restraint and Current Dilemmas in Judicial. Policy-Making”, in: New York University Law Review, n. ${ }^{\circ}$ 3, 1958, pp. 775, 778.

${ }^{334}$ THOMAS SOWELL, op.cit., p. 1. O mesmo autor observa, na linha do que já se afirmou, que a designação "ativismo judicial" adquiriu tantos significados que atualmente mais confunde do que esclarece. Reconhece, todavia, que isto não constituiria motivo para não refletir a respeito, sob o fundamento simplista da "inutilidade" supostamente derivada da "vagueza" ou da "incerteza" da designação. Ora, no centro dessas discussões, encontrar-se-iam preocupações acerca do verdadeiro significado do Direito, de sua função e de sua sobrevivência. Assim, se o abandono do tema não é uma opção (haja vista a importância dos fenômenos discutidos), as tentativas de buscar conceitos, definições e classificações se tornam imperativas. A mais usual das dicotomias, que opõe ao ativismo judicial (judicial activism) ao que seria seu oposto, a "contenção" ou "moderação" judicial (judicial restraint), faz emergir, assim, a indagação a respeito do sentido relativo de uma e de outra. Em outras palavras, uma determinada postura é ativista ou moderada em relação a que?
} 


\subsubsection{Ativismo judicial e controle político da composição de tribunais}

Também em relação à experiência dos EUA, cumpre examinar, brevemente, algumas repercussões da expectativa de agentes políticos em relação ao potencial protagonismo judicial e a certas formas de sua manifestação.

Com efeito, o Senado norte-americano, ao examinar indicações às vagas de juízes da Suprema Corte ou de tribunais federais (questionnaire for judicial nominees), tem reiteradamente solicitado, aos candidatos, opiniões sobre posturas judiciais normalmente classificadas como ativistas ${ }^{335}$.

A justificativa daquele órgão político, constante do próprio questionnaire, baseia-se no reconhecimento de que os debates sobre o papel do Judiciário em relação à sociedade e ao próprio governo estariam se intensificando nos últimos anos, à medida que se fortalece, na crítica acadêmica e popular, a ideia de que os magistrados poderiam “usurpar” prerrogativas dos outros Poderes ${ }^{336}$.

Nesse sentido, são cinco as noções de “ativismo judicial” citadas nesses documentos oficiais, relacionadas às seguintes possibilidades (qualificadas como tendências) de agir judicial: a) preferência, nas decisões, pela solução do problema (problem-solution) em detrimento do objeto das reclamações ou do descontentamento das partes (grievance resolution); b) emprego de uma demanda individual como um veículo de imposição, nos julgamentos, de ordens com alcance mais largo e que se estendam a classes mais amplas de grupos de indivíduos; c) imposição de obrigações amplas (afirmativas ou positivas) a autoridades governamentais e à sociedade; d) flexibilização de pressupostos processuais como o standing e a maturidade (ripeness) da causa; e) imposição de seus poderes em face de outras instituições, como uma espécie de administrador com contínua responsabilidade de vigilância ${ }^{337}$.

\footnotetext{
${ }^{335}$ A resposta a tais questionários são exigidas antes da audiência pública sobre a indicação. O documento está disponível em www.uscourts.gov, acesso em 20-03-11. Cite-se um excerto, para ilustrar: “(...) Please discuss your views on the role of the judiciary in our governmental system and the criticism involving ‘judicial activism””.

${ }^{336}$ Um exemplo, entre outros, é o questionário dirigido ao Justice Samuel Alito, cuja indicação para a Suprema Corte foi confirmada pelo Senado, em indicação de George W. Bush, em 2006. Disponível em www.cbsnews.com/elements/2005/10/31/in_depth_us/interactivehomemenu995172.shtml, acesso em 17-0510.

${ }^{337}$ A tradução é livre. No original: "Some of the characteristics of this 'judicial activism' have been said to include: a. a tendency by the judiciary toward problem-solution rather than grievance-resolution; $b$. a tendency by the judiciary to employ the individual plaintiff as a vehicle for the imposition of far-reaching orders extending to broad classes of individuals; c. a tendency by the judiciary to impose broad, affirmative duties upon governments and society; d. a tendency by the judiciary toward loosening jurisdictional
} 
Nota-se, assim, nítida intenção de controle da acessibilidade do candidato ao cargo conforme as expectativas que este suscitar em relação ao seu comportamento futuro. Se de um lado o candidato tende a responder escrupulosamente ao questionário; isso não impede que, de outro lado, o Senado avalie a vida pregressa daquele consoante os critérios que estabelecer. Como resultado, poderá advir uma reprovação, o que nos EUA não é raro ocorrer, diferentemente do Brasil.

Se tomarmos como critério o que chamamos de potencial protagonismo judicial (como subproduto da juridificação), pode-se dizer que, quanto maior sua percepção (que se fortalece à medida que se avolumam as práticas ativistas), maior a sofisticação e o rigor desse "filtro" do controle político.

Em outras palavras, nos EUA, no Brasil ou em qualquer outro país, quanto maior a percepção do potencial protagonismo judicial, maior será o interesse de diferentes grupos na escolha de magistrados de tribunais, sobretudo os superiores. Nesse cenário, mais grupos de pressão tendem a manifestar sua opinião; mais determinantes serão as intenções declaradas e a vida pregressa do indicado; mais a agenda dos meios de comunicação tende a provocar, na agenda pública, debates sobre o perfil desses candidatos, seja antes, seja depois da escolha (o que poderá subministrar dados inclusive a seleções futuras).

\subsection{Debates sobre o ativismo judicial em outros países}

Considerando que o progresso da juridificação construiu tendência de aproximação das experiências jurídicas democráticas em relação a padrões normativos e institucionais (2.2.7, supra), pode-se dizer que, com poucas exceções atreladas às peculiaridades da tradição política e jurídica de um ou de outro país, as noções de ativismo judicial até aqui examinadas se referem a fenômenos, debates e perplexidades também presentes em outras experiências jurídicas ocidentais ${ }^{338}$. Assim, mutatis mutandis, as

requirements such as standing and ripeness; and e. a tendency by the judiciary to impose itself upon other institutions in the manner of an administrator with continuing oversight responsibilities”. Disponível em www.uscourts.gov, acesso em 20-03-11.

${ }^{338}$ ROBERT BADINER, STEPHEN BREYER, op. cit. Os participantes da obra (juristas dos EUA, França, Alemanha, Itália e França) são unânimes, ao lado de muitos outros estudiosos examinados nesta tese, no reconhecimento não só da expansão do poder dos juízes nas democracias ocidentais, mas também da maneira convergente pela qual essa expansão ocorre. 
mesmas discussões (como já se antecipou no tópico 2.2.9.2 supra) tendem a se replicar em outros países, inclusive no Brasil.

No Canadá, o uso da expressão judicial activism tem se associado, de um modo geral, a decisões judiciais relacionadas à Carta Canadense de Direitos e Liberdades, de 1982. Todavia, a elocução ainda é pouco definida, como destaca ELLIOTT ${ }^{339}$.

Na África do Sul, na Índia e mesmo em países menos desenvolvidos, nota-se uma grande explosão na litigiosidade em matéria de direitos sociais, em uma tendência na qual muitos visualizam um “ativismo judicial que promove, sem ofender, os valores democráticos”340.

Na Espanha, as noções mais comuns vinculam o ativismo judicial à implementação de direitos, à politização da justiça, ao pragmatismo judicial, ao exercício da jurisdição constitucional e à criatividade judicial (notadamente em matéria de direitos

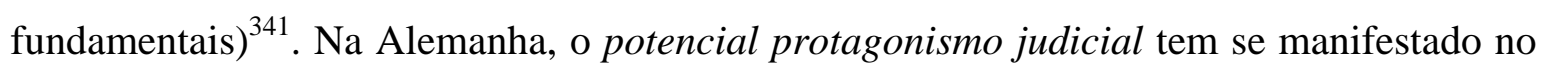
ativismo da Corte Constitucional Alemã, notadamente em matéria de direitos fundamentais (2.2.7.4, supra).

De uma perspectiva comparatística, ZAGREBELSKY, ao enfatizar a importância contemporânea do controle judicial contramajoritário, observa que as constituições europeias contêm grande número de disposições que consagram princípios e

339 DOUGLAS ELLIOTT, "Judicial Activism and the Threat to Democracy", in: University of New Brunswick Law Journal, n. ${ }^{\circ}$ 199, 2004. Em recente visita ao Brasil, a presidente da Suprema Corte canadense, Beverly McLachlin, observava, sobre o tema: "Os tribunais canadenses (e até 1949 a Comissão Jurídica do Conselho Privado da Inglaterra) têm tido um papel importante, desde a criação do país em 1867, na resolução de questões originadas pela divisão dos poderes entre o governo federal e as províncias. Embora isso ainda seja um aspecto fundamental do trabalho da Corte Suprema do Canadá, foi ultrapassado em termos numéricos por objeções à legitimidade das leis e da ação do governo sob a Carta de Direitos e Liberdades, desde a sua adoção há mais de 25 anos. Muitas e muitas vezes, a Corte tem tido de decidir se determinadas leis ou ações do governo violam a Carta e, em casos afirmativos, se o Estado tem demonstrado que a limitação dos direitos é 'justificável numa sociedade livre e democrática’. O novo papel jurídico, estimulado pela Carta, não deixou de provocar controvérsia. Detratores da Carta argumentam que é errado juízes não eleitos terem o direito de "derrubar" leis adotadas por parlamentares eleitos. Eles acusam os juízes de "ativismo jurídico", e questionam a legitimidade da própria instituição constitucionalmente designada para tomar decisões a respeito de temas de legitimidade governamental. Deve ser dito em sua defesa que os juízes fazem apenas o que a constituição exige que façam, e que o "ativismo jurídico" frequentemente significa apenas que o crítico não aprova a decisão da Corte. Sem buscar minimizar a importância das críticas à corte, deve-se dizer que pesquisas sugerem que os canadenses confiam em seus juízes”. STF. Controle Constitucional pelo Judiciário: Palavras da Excelentíssima Senhora Beverly McLachlin, p.C. Presidente da Suprema Corte do Canadá, Brasília, publ. 30-11-07. Disponível em www.stf.jus.br.

${ }_{340}$ ROBERTO GARGARELLA, PILAR DOMINGO, THEUNIS ROUX (org.). Courts And Social Transformation in New Democracies: An Institutional Voice for the Poor? Ashgate, 2006, p. 2.

${ }^{341}$ EDUARDO GARCIA ENTERIA, "Princípio de legalidad, Estado material de Derecho y faculdades interpretativas e constructivas de la jurisprudência en la Constituición”, in: Revista Española de Derecho Constitucional. Madrid, Centro de Estudios Constitucionales, n. ${ }^{\circ}$ 10, jan./abr. 1984. e FRANCISCO RUBIO LLORENTE, "La jurisdición constitucional como forma de creación del derecho", in: Revista Española de Derecho Constitucional. Madrid, Centro de Estudios Constitucionales, n. ${ }^{\circ}$ 22, jan./abr. 1988. 
que não se destinam apenas a propósitos individuais, exigindo, também, o alinhamento a interesses gerais. Ilustrativamente, ele cita o artigo $3^{\circ}$ da Constituição italiana, que atribui ao Estado a tarefa de "remover os obstáculos econômicos e sociais que, limitando de fato a liberdade e a igualdade dos cidadãos, impeçam o pleno desenvolvimento da pessoa humana e a efetiva participação de todos os trabalhadores na organização política, econômica e social do país”342. Tratando-se de dever do Estado, a possibilidade de invocálo em Juízo desvela, igualmente, um potencial protagonismo judicial que pode se traduzir em certos tipos de ativismo judicial.

BILANCIA ao examinar o fenômeno do ativismo judicial no caso italiano, cita uma série de noções que poderiam ser associadas à expressão ativismo de juízes (attivismo dei giudici): o controle judicial de políticas públicas, o combate à impunidade de parte da classe política, o excesso de exposição midiática de alguns juízes e, em especial, também no plano da jurisdição constitucional, o protagonismo que se costuma vislumbrar na primeira fase de vida de uma nova constituição, quando se revela forte tensão entre leis velhas e a nova ordem jurídica. Neste último sentido, segundo o jurista, a magistratura italiana teria sido responsável, no curso da década de 1970, com o movimento em prol do uso alternativo do direito, por uma importante contribuição à reabertura do debate sobre os atrasos na atuação constitucional pela via legislativa. Com efeito, essa mobilização, que segundo ele transcendeu os debates jurídicos, pelas relevantes repercussões culturais que trouxe, foi objeto do manifesto, em dois volumes, de Pietro Barcellona, intitulado L'uso alternativo del diritto. Para BILANCIA, o movimento teria sido responsável pela renovação das reflexões dos juízes a respeito de seu papel na interpretação do direito em geral, sobretudo pela valorização dos princípios e dos valores contidos no texto constitucional. Tratava-se de uma espécie de prenúncio de importantes

\footnotetext{
${ }^{342}$ No original: "E` compito della Repubblica rimuovere gli ostacoli di ordine economico e sociale, che, limitando di fatto la libertà e l'eguaglianza dei cittadini, impediscono il pieno sviluppo della persona umana e l'effettiva partecipazione di tutti i lavoratori all'organizzazione politica, economica e sociale del Paese." O autor, em crítica a Dworkin, destaca que um direito baseado em princípios, ainda mais se argumentos políticos são incorporados a tais princípios, põe em relevo o difícil problema da relação entre a avaliação judicial (judicial evaluation) e a discrição legislativa (legislative discretion). Este problema, que seria "subestimado ou ignorado pelos positivistas", tem sido discutido há muito tempo, tornando-se mais agudo nas últimas décadas "à medida que as cortes constitucionais foram autorizadas a rever a legislação”. Esse novo poder contrapõe a legitimidade dos tribunais à legitimidade democrática do legislador: "jurisprudência v. princípio da maioria". GUSTAVO ZAGREBELSKY, "Ronald Dworkin’s principle based constitucionalism: an italian point of view", in: International Journal of Constitutional Law, vol. $1, n .{ }^{\circ} 4$, 2003, pp. 642-644. Referindo-se, em texto bastante instigante, ao papel do juiz comunitário na construção da Europa política, Azzariti parte descrição do processo de giurisprudenzializzazione del diritto costituzionale, GAETANO AZZARITI, "Verso um governo dei giudici? Il ruolo dei giudici comunitari nella costruzione dell’Europa politica”, in: ROGÉRIO GESTA LEAL, MONIA LEAL (org.), op.cit., pp. 27-49.
} 
avanços no que tange ao processo de adequação do ordenamento italiano ao novo espírito constitucional. Como toda batalha cultural (conclui o jurista), o movimento "não foi sempre linear e privado de excessos e críticas, mas contribuiu, sem dúvida, para estimular um relevante processo de renovação cultural” que passou a orientar não apenas a tutela constitucional dos cidadãos, mas também reformas em vários campos do direito, como o Direito do Trabalho e o Direito Ambiental ${ }^{343}$.

Ademais, ao examinar uma noção de ativismo judicial mais vinculada ao cenário europeu, ele destaca que a função jurisdicional estaria imersa em novas tensões, que se relacionam a uma tendência de "jurisdicionalização" (giurisdizionalizzazione) do direito. Essa tendência seria ainda mais complexa em países integrados ao ordenamento supranacional, dada a abertura do ordenamento interno às instâncias europeias e comunitárias. Desse modo, os juízes, independentemente de sua vontade, teriam se tornado um instrumento de integração jurídica e de composição de um produto normativo muito complexo e inorgânico. A reflexão sobre o ativismo judicial tende a se concentrar, para esse doutrinador, nos fundamentos e nos limites da discricionariedade interpretativa do juiz, o que envolve não apenas balizas legislativas, mas também os princípios constitucionais e o próprio direito comunitário ${ }^{344}$.

CANIVET, por sua vez, com base no caso francês, sem olvidar ingredientes comparatísticos tão caros à experiência jurídica europeia, dá ênfase à ambiguidade da jurisprudência como fonte do direito, o que nos remete, mais uma vez, à noção de ativismo judicial como atuação criativa do magistrado. Ele sustenta que as construções jurisprudenciais deveriam funcionar como mecanismos de redução da tensão, existente em qualquer sistema de direito, entre a função de legiferar e a de julgar. Todavia, por serem de naturezas diversas e discutíveis ao infinito (discutable à l'infini), os argumentos envolvidos na defesa da chamada "prudência interpretativa" (prudence interpretative) em oposição ao ativismo judicial (activisme judiciaire) não permitem encerrar os debates sobre os limites da aptidão criativa do juiz. Com efeito, o potencial exercício do poder criativo do magistrado seria variável de acordo com a época, o assunto,

${ }^{343}$ FRANCESCO BILANCIA, "I giudici, il legislatore, la Corte costituzionale e la gestione delle politiche pubbliche: alcuni esempli di supplenza politica nell'ordinamento italiano”, in: ROGÉRIO GESTA LEAL, MONIA LEAL (org.), op.cit., p. 60.

${ }^{344}$ FRANCESCO BILANCIA, op.cit., p. 61. Essa tensão, segundo o autor, seria clara no caso italiano: “(...) soprattutto in uma fase storica caratterizzata, come quella italiana attuale, da uma drammatica crisi della politica e della sua capacita di orientare gli sviluppi equilibrati dell'ordenamento". Note-se que o que ele chama de giurisdizionalizzazione se associa, pela perspectiva desta tese, ao incremento da judicialização decorrente do processo de juridificação (v., em especial, os Tópicos 2.2.1, 2.2.2 e 2.2.5, supra). 
a idade do texto legal, a natureza da jurisdição, as técnicas de interpretação, as circunstâncias do caso e as características do sistema judiciário. O jurista conclui que o trabalho do juiz seria, em boa medida, inspirado pelo realismo, e longe de se encontrarem opostos em um conflito dogmático estéril, o legislador e o magistrado teriam, na verdade, um papel complementar na permanência e na continuidade do direito, que natural e democraticamente deixaria a última palavra para o julgador ${ }^{345}$.

\subsection{Panorama das discussões sobre o ativismo judicial no Brasil}

Os debates sobre o ativismo judicial no Brasil são recentes e, afora a abordagem da ciência política, as discussões se concentram nos estudos de teoria constitucional e da teoria do processo ${ }^{346}$. Ademais, nota-se que várias referências ao fenômeno

${ }^{345}$ GUY CANIVET, “Activisme judiciaire. Introduction générale”, in: Archives de philosophie du droit, n. 50, 2007. Introduzindo o texto, o autor destaca: "Dans son ambigüité en tant que source du droit, la notion de jurisprudence este précisément destinée à réduire la tension qui, dans tout système de droit, existe entre la fonction de légiférer et celle de juger. De natures diverses et discutables à l'infini, les arguments de la prudence interprétative opposés à l'activisme judiciaire ne permettent pas de trancher définitivement le débat, parfois conflictuel, sur le pouvoir Du juge de créer le droit, en pratique, variable selon les époques, les domaines, les matières, l'ancienneté des textes, la nature des jurisdictions, les techniques d’interprétation, les circonstances et les systèmes judiciaires. L’oeuvre prétorienne est avant tout inspirée de réalisme. Loin de s'opposer dans un conflit de pouvir stérile et dogmatique, le législateur et le juge on en réalité um role complémentaire dans la permanence et la continuité du droit qui laisse naturellement - et démocratiquement - le dernier mota u premier.” O texto está disponível em www.courdecassation.fr, acesso em 12-03-2011. Também sobre a experiência francesa, em especial sobre a criação jurisprudencial do Conseil d'Etat, baseada no princípio da proporcionalidade, v. ROBERT BADINTER, op.cit., pp. 70-71.

346 MARCOS PAULO VERISSIMO, “A constituição de 1988, vinte anos depois: suprema corte e ativismo judicial ‘à brasileira””, in: Revista Direito GV, vol. 4, n. ${ }^{\circ}$ 2. São Paulo: jul./dez. 2008; Tratam do tema, ainda, direta ou indiretamente, VANICE REGINA LIRIO VALLE (org.). Ativismo jurisdicional e o Supremo Tribunal Federal. São Paulo: Juruá, 2009; RODOLFO DE CAMARGO MANCUSO, op.cit.; JOSÉ RIBAS VIEIRA, MARGARIDA MARIA LACOMBE CAMARGO, ALEXANDRE GARRIDO DA SILVA, “O Supremo Tribunal Federal como arquiteto institucional: a judicialização da política e o ativismo judicial”, in: Revista Acadêmica Versus (UFRJ). ago. 2009, pp. 76-84. ”. ALEXANDRE GARRIDO DA SILVA (et al.). op.cit. JOSÉ RIBAS VIEIRA. "Verso e reverso: a judicialização da política e o ativismo judicial no Brasil”, op.cit. LUIS ROBERTO BARROSO, Curso de Direito Constitucional Contemporâneo, op.cit.; LUIS ROBERTO BARROSO. “Judicialização, ativismo judicial e legitimidade democrática”, in: RDE. Revista de Direito do Estado, vol. 13, 2009, pp. 71-91. ROGÉRIO GESTA LEAL, MONIA LEAL (org.). Ativismo judicial e déficits democráticos: algumas experiências latino-americanas e europeias. Rio de Janeiro: Lumen Iuris, 2011, pp. 27-49. ELIVAL DA SILVA RAMOS, op.cit.; v., outrossim, OSCAR VILHENA VIEIRA. "Supremocracia", in: Revista Direito GV, São Paulo, jul-dez 2008, pp. 441-464. Vieira destaca, curiosamente, que, em 1968, Aliomar Baleeiro publicara texto intitulado "O Supremo Tribunal Federal, esse outro desconhecido". Sobre a obra clássica de nosso direito constitucional, ele destaca que seu título "não poderia estar em maior descompasso com a proeminência do Supremo Tribunal Federal no cenário político atual. Raros são os dias em que as decisões do Tribunal não se tornam manchete dos principais jornais brasileiros, seja no caderno de política, economia, legislação, polícia (e como!) e eventualmente nas páginas de ciências, educação e cultura. Na academia, por sua vez, multiplica-se o número de trabalhos destinados a analisar os diversos aspectos da vida e da atuação do Supremo, seja nas faculdades de direito, seja nos programas de ciência política, sociologia, história, etc. O tema da interpretação constitucional que, no passado, ocupava um espaço residual na preocupação dos nossos constitucionalistas, passou a ser o principal 
são feitas em discursos de representantes de órgãos judiciais de cúpula e na própria ação associativa de magistrados.

\subsubsection{Perspectiva constitucional}

BARROSO, após relembrar a origem norte-americana das discussões, destaca que o ativismo judicial, no Brasil, estaria atrelado à "virtuosa ascensão institucional do Poder Judiciário” ocorrida após a recuperação das liberdades democráticas e das garantias da magistratura. Isso teria permitido que os juízes e tribunais, ao deixarem de ser "um departamento técnico especializado”, passassem a desempenhar um papel político efetivo, “dividindo espaço com o Legislativo e o Executivo”, o que provocou uma modificação substantiva na relação da sociedade com as instituições judiciais, impondo reformas estruturais e suscitando questões complexas acerca da extensão dos poderes judiciais ${ }^{347}$.

foco de atenção de uma nova geração de juristas. Ponderação de valores, princípios ou moralidade, tornaramse temas comuns aos estudos de direito constitucional. Por outro lado, a ciência política, depois de longo período de desatenção em relação às instituições, despertou para a necessidade de compreender melhor o papel do direito e das agências responsáveis pela sua aplicação. Neste novo amanhecer da ciência política, com viés mais institucionalista, o Supremo tem se tornado objeto privilegiado de muitos autores.Até os economistas passaram a analisar as consequências, não raramente tomadas como externalidades pouco desejáveis, das decisões judiciais. Surpreendente, no entanto, tem sido a atenção que os não especialistas têm dedicado ao Tribunal; a cada habeas corpus polêmico, o Supremo torna-se mais presente na vida das pessoas; a cada julgamento de uma Ação Direita de Inconstitucionalidade, pelo plenário do Supremo, acompanhado por milhões de pessoas pela "TV Justiça” ou pela internet, um maior número de brasileiros vai se acostumando ao fato de que questões cruciais de natureza política, moral ou mesmo econômicas são decididas por um tribunal, composto por onze pessoas, para as quais jamais votaram e a partir de uma linguagem de difícil compreensão, para quem não é versado em direito. Embora o Supremo tenha desempenhado posição relevante nos regimes constitucionais anteriores, com momentos de enorme fertilidade jurisprudencial e proeminência política, como na Primeira República, ou ainda de grande coragem moral, como no início do período militar, não há como comparar a atual proeminência do Tribunal, com a sua atuação passada.”

${ }^{347}$ Barroso relembra, na linha do que já se expôs nesta tese, que as origens dos debates sobre o ativismo judicial remontam aos primórdios do constitucionalismo norte-americano, tornando-se, em determinado momento, universal, à medida que o tema passou a gravitar em torno das tensões e superposições entre constitucionalismo e democracia. Destaquem-se, do texto do jurista, os seguintes excertos: "É bem de ver, no entanto, que a ideia de democracia não se resume ao princípio majoritário, ao governo da maioria. Há outros princípios a serem preservados e há direitos da minoria a serem respeitados. Cidadão é diferente de eleitor; governo do povo não é governo do eleitorado. No geral, o processo político majoritário se move por interesses, ao passo que a lógica democrática se inspira em valores. E, muitas vezes, só restará o Judiciário para preservá-los. O déficit democrático do Judiciário, decorrente da dificuldade contramajoritária, não é necessariamente maior que o do Legislativo, cuja composição pode estar afetada por disfunções diversas, dentre as quais o uso da máquina administrativa nas campanhas, o abuso do poder econômico, a manipulação dos meios de comunicação. O papel do Judiciário e, especialmente, das cortes constitucionais e supremos tribunais deve ser resguardar o processo democrático e promover os valores constitucionais, superando o déficit de legitimidade dos demais Poderes, quando seja o caso; sem, contudo, desqualificar sua própria atuação, exercendo preferências políticas de modo voluntarista em lugar de realizar os princípios constitucionais. Além disso, em países de tradição democrática menos enraizada, cabe ao tribunal constitucional funcionar como garantidor da estabilidade institucional, arbitrando conflitos entre Poderes ou entre estes e a sociedade civil. Estes os seus grandes papéis: resguardar os valores fundamentais e os procedimentos democráticos, assim como assegurar a estabilidade institucional (...). No Brasil, só mais 
Nessa linha, o constitucionalista situa o ativismo judicial, de um modo geral, no âmbito das tensões que se desenvolvem entre o processo político majoritário (eleições, debate público, Congresso, Chefes do Executivo) e a interpretação constitucional. A substância do ativismo judicial seria, para ele, uma participação mais ampla do Judiciário na arena política em prol da preservação de valores democráticos e da concretização dos fins constitucionais, com maior interferência no espaço de atuação dos outros dois Poderes para contornar o “déficit de legitimidade" de legisladores e governantes. Ilustrativamente, a postura ativista se manifestaria, para o constitucionalista, na "aplicação direta da Constituição a situações não expressamente contempladas em seu texto e independentemente de manifestação do legislador"; na “declaração de inconstitucionalidade de atos normativos emanados do legislador, com base em critérios menos rígidos que os de patente e ostensiva violação da Constituição”; e na “imposição de condutas ou de abstenções do Poder Público, notadamente em matéria de políticas públicas”348. Noutro estudo, o mesmo autor define o ativismo judicial como "a atitude, a escolha de um modo específico e proativo de interpretar a Constituição, expandindo o seu sentido e alcance”; o que teria lugar diante da "retração do Poder Legislativo” e de “certo descolamento entre a classe política e a sociedade civil, impedindo que as demandas sociais sejam atendidas de maneira efetiva”349.

Desse modo, recorrendo a noções forjadas nos debates norte-americanos, o jurista opõe o ativismo judicial à autocontenção judicial. Assim, segundo ele, se orientados pela proposta de autocontenção, os juízes tenderiam a "reduzir ao mínimo sua interferência nas ações dos outros Poderes”. Essa postura oposta ao ativismo restringiria “o espaço de incidência da Constituição em favor do legislador ordinário”. Com base nessas ideias, ele diagnostica que a autocontenção, dada a falta de espaço para práticas ativistas, constituiria a inequívoca linha de atuação de juízes e tribunais no Brasil antes da Constituição de $1988^{350}$.

recentemente se começam a produzir estudos acerca do ponto de equilíbrio entre supremacia da Constituição, interpretação constitucional pelo Judiciário e processo político majoritário. O texto prolixo da Constituição, a disfuncionalidade do Judiciário e a crise de legitimidade que envolve o Executivo e o Legislativo tornam a tarefa complexa.” LUIS ROBERTO BARROSO, Curso de Direito Constitucional Contemporâneo, op.cit., pp. 387391.

${ }^{348}$ LUIS ROBERTO BARROSO, Curso de Direito Constitucional Contemporâneo, op.cit., pp. 283-284.

${ }^{349}$ LUIS ROBERTO BARROSO. Judicialização, ativismo judicial e legitimidade democrática, op.cit., pp. 71-91.

${ }^{350}$ Para Barroso, o ativismo judicial não envolve a invasão do campo da criação livre do Direito, mas a tentativa de “extrair o máximo das potencialidades do texto constitucional”. O mesmo doutrinador visualiza, em ambas as posturas - a ativista e a da contenção -, o argumento comum da supremacia judicial, consistente na ideia de que “deve caber ao Judiciário a última palavra acerca da interpretação da Constituição e das leis”. Sustenta-se, nessa linha, que o fundamento para o Judiciário sobrepor sua vontade à dos agentes eleitos dos outros Poderes estaria na “confluência de ideias que produzem o constitucionalismo democrático”, modelo em que a Constituição deve, primeiro, "assegurar as regras do jogo democrático, propiciando a "participação política ampla e o governo da 
RAMOS, ao refletir sobre o tema em contribuição aprofundada acerca dos "parâmetros dogmáticos do ativismo judicial em matéria constitucional”, sustenta que o fenômeno se manifestaria no exercício da função jurisdicional para além dos limites “impostos pelo próprio ordenamento que incumbe, institucionalmente, ao Poder Judiciário fazer atuar, resolvendo litígios de feições subjetivas (conflitos de interesse) e controvérsias jurídicas de

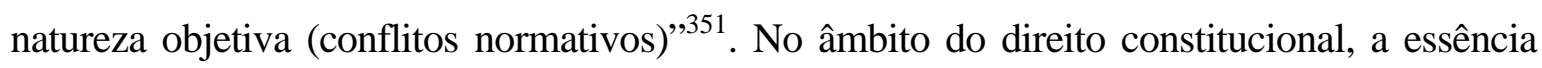
dessa noção envolveria o "menoscabo aos marcos normativos que balizam a atividade de concretização de normas constitucionais por juízes e tribunais”, de modo que esse tipo de ativismo judicial poderia ocorrer em "toda e qualquer situação que envolva a aplicação da Constituição por esses órgãos”352. Nesse sentido, de um ponto de vista dogmático, RAMOS sustenta haver "limites substanciais” para a atividade típica de interpretação e de aplicação de normas pelo Poder Judiciário ${ }^{353}$. Desrespeitados esses limites, a norma de decisão concretizada pelo juiz poderia desbordar do direito aplicado de várias formas, como pelo não reconhecimento de revogação ou da invalidade de dispositivo legal; pela ampliação, redução ou alteração do espaço de interpretação que ele comporta (interpretação descolada dos limites textuais, por atribuição de efeitos com ele incompatíveis, que devessem ser sopesados por outro poder); e pela “mutação constitucional” (alteração do significado sem mudança do texto). Ao investigar os antecedentes ${ }^{354}$ e os fatores contemporâneos de impulsão do ativismo judicial no Brasil, o mesmo jurista identifica certo voluntarismo fomentado pelo

maioria”, sem olvidar a proteção de “valores e direitos fundamentais” mesmo que "contra a vontade circunstancial de quem tem mais votos". Num cenário de processo político majoritário obstruído por forças políticas minoritárias, diante de "vicissitudes históricas da tramitação legislativa” ou, ainda, em contexto no qual "os direitos fundamentais de um grupo politicamente menos expressivo podem ser sufocados”, "somente "o Judiciário e, mais especificamente, o tribunal constitucional pode fazer avançar o processo político e social, ao menos com a urgência esperável”. Isso justificaria ou explicaria as posturas ativistas. Ao contrário, “quando o processo político majoritário está funcionando com representatividade e legitimidade, com debate público amplo, juízes e tribunais deverão ser menos pró-ativos”. LUIS ROBERTO BARROSO, Curso de Direito Constitucional Contemporâneo, op.cit., pp. 284-286.

${ }^{351}$ ELIVAL DA SILVA RAMOS, op.cit., p. 99.

${ }^{352}$ ELIVAL DA SILVA RAMOS, op.cit., pp. 110-111.

${ }^{353}$ ELIVAL DA SILVA RAMOS, op.cit., p. 110.

${ }^{354}$ No âmbito da jurisprudência constitucional, o antecedente mais relevante do ativismo judicial se situa no histórico da doutrina brasileira do habeas corpus. Surgida em casos de grande repercussão social e política e provocada em grande medida pela criatividade, cultura jurídica e respeitabilidade pública de Rui Barbosa, essa doutrina influenciou a construção pretoriana que, com a condução tecnicamente precisa de Pedro Lessa, tornou o instituto apto a proteger outros direitos e liberdades constitucionais. À época, esses direitos não possuíam proteção com a mesma eficácia, já que o mandado de segurança só surgiria com a Constituição de 1934. A garantia processual do habeas corpus, instituída no Brasil em 1832, seria direcionada, a princípio, "apenas à tutela da liberdade de locomoção”, então resguardada pela Constituição de 1824. Com a Constituição de 1891, o mesmo instituto foi previsto para as hipóteses em que o indivíduo sofresse ou se achasse em iminente perigo de sofrer “violência ou coação por ilegalidade ou abuso de poder”. Essa redação imprecisa abriu caminho para que surgissem teses segundo as quais o habeas corpus poderia ser utilizado em prol de outros direitos e liberdades individuais (Rui Barbosa havia intentado o mesmo com o instituto dos interditos possessórios, “cuja serventia para 
descompasso entre promessas constitucionais e a realidade da maior parte da população. É que, num cenário jurídico e político conformado por um modelo de Estado-Providência (2.2, 2.2.2, 2.3.2, supra), seria comum a crença de que juízes e tribunais poderiam “queimar etapas” para concretizar, no presente, um "programa que a Constituição delineou prospectivamente”,355. Esse voluntarismo também seria fortalecido, no Brasil, pela expansão do controle de constitucionalidade de normas, não apenas o difuso, mas sobretudo o abstrato, com seus efeitos erga omnes e temporalmente moduláveis, em especial com o advento das EC n. ${ }^{\circ}$ 3/1993 e 45/2004. Com efeito, ampliada a legitimação para agir nessas ações e instituídos mecanismos de arguição de descumprimento de direito fundamental, de declaração de constitucionalidade e de questionamento da inconstitucionalidade por omissão, surge um espaço de manejo judicial ainda maior de conceitos jurídicos indeterminados e de normas-princípio, cuja "formulação textual fluída permite ao órgão de controle maior liberdade de ação no exercício de sua função hermenêutico-concretizadora”. Para ele, "textos veiculadores de conceitos jurídicos indeterminados”, por permitirem a incursão do Poder Judiciário em “zona de significação dúbia”, podem importar em “obstacularização do exercício da discricionariedade legislativa ou

a correção dos atos ofensivos a direitos constitucionais foi por ele engenhosamente arquitetada”, com base em escólios doutrinários que amparavam a "teoria da posse de direitos pessoais”.). Todavia, após memoráveis embates e com a bem sucedida e ponderada contenção empreendida por Pedro Lessa, a jurisprudência do STF caminhou em trilha intermediária, descrita por RAMOS como permeio entre "o conservadorismo de inspiração autoritária, dos que pretendiam manter o habeas corpus atrelado à estrita proteção da liberdade física de locomoção" e os "arroubos voluntaristas de outros tantos, que projetavam para o instituto um desenho peculiar ao direito brasileiro". Esta segunda orientação, de acordo com o jurista, seria quase que totalmente desvinculada da "origem histórica" do instituto e ultrapassaria "o espaço de interpretação autorizado pela textualidade do dispositivo-sede". Para RAMOS, essas duas orientações que polarizavam os debates demonstrariam o limite tênue entre o "insidioso descaminho do ativismo judicial" e "a ousadia e a criatividade no exercício da função jurisprudencial, indispensáveis à rápida adaptação do sistema jurídico diante de novas necessidades sociais”. A doutrina pretoriana sob exame, que perdurou até 1926 (ao defender entendimento intermediário em relação a duas orientações que se contrapunham) reconhecia a extensão do uso do habeas corpus à defesa de direitos conexos à liberdade de locomoção, desde que fossem incontestáveis, líquidos e certos. Todavia, isso não impediu que, no âmbito do próprio STF, surgissem entendimentos que pretendiam ampliar a aplicação da doutrina brasileira do habeas corpus. Por suscitar resistências, essa possibilidade de o STF interferir em questões políticas deu ensejo à Emenda Constitucional n. ${ }^{\circ}$ 3/1926, consagradora de uma posição restritiva, refratária àquela doutrina. Esse intento de contenção levou à remodelação doutrina brasileira do habeas corpus, e um instrumento que lograsse substituir o seu uso ampliado (para incluir casos que não fossem de ilegal constrangimento ao direito de locomoção e à liberdade física do indivíduo) só surgiu com o mandado de segurança, em 1934. No entanto, as iniciativas de contenção desse potencial protagonismo judicial se intensificaram. O artigo 68 da Constituição de 1934 vedava ao Judiciário “conhecer de questões exclusivamente políticas”, texto repetido pelo artigo 94 da Constituição de 1937. De um modo geral, não obstante esse importante precedente, tal potencial só ressurgiu, efetivamente, após a Constituição de 1988. v. rico histórico apresentado por ELIVAL DA SILVA RAMOS, op.cit., pp. 188-190. Pondere-se, entretanto, conforme o tópico 2.3.3, supra.

${ }^{355}$ ELIVAL DA SILVA RAMOS, op.cit., pp. 228-233. O autor, nesse aspecto, é veemente no que tange à situação brasileira: "Tenho para mim que se trata de arroubos reveladores de imaturidade institucional, próprios de um Estado com escassa experiência democrática e que vive as primeiras décadas de vigência de uma Constituição que sinalizou, efusivamente, para dias melhores, como é próprio das Constituições programáticas de nosso tempo". 
administrativa assentada no princípio da 'separação de poderes', princípio esse que resultaria, afinal, violado"356.

Entre outros fatores de impulsão do ativismo judicial, RAMOS chama a atenção, de um lado, para a tendencial atividade normativa atípica do STF, sobretudo pelo mandado de injunção e pelas súmulas vinculantes; e, de outro, para certos dilemas institucionais do constitucionalismo brasileiro, radicados na tensão entre o "reforço à tarefa de controle jurídico da função legislativa”, as "pressões no sentido de concretizar plenamente a Constituição social-democrática de 1988”, os “limites que o nosso sistema jurídico estabelece ao manejo da função jurisdicional”, e a “ineficiência dos Poderes representativos na adoção das providências normativas adequadas àquela concretização”357.

SILVA, ao examinar a questão da justiciabilidade de direitos sociais, destaca que, frequentemente, o tema é tratado pela oposição entre a opção pelo ativismo judicial ou pela contenção. Se os partidários da ideia de contenção judicial defendem que os juízes deveriam se manter afastados de decisões relativas a políticas públicas, isso não significa, segundo ele, que toda corrente ativista "tenha necessariamente que defender o seu oposto, ou seja, que os juízes devam sempre decidir sobre políticas públicas”. Nesse sentido, sustenta o jurista ser possível defender uma forma de ativismo judicial que, não obstante reconheça a legitimidade dos juízes para discutir políticas públicas, seja limitada “por uma série de razões estruturais”. Isso significa, para ele, que, embora o ativismo judicial seja uma possibilidade, ele “depende de diversas mudanças estruturais na educação

${ }^{356}$ E acrescenta: “A descoberta desse instrumental, relativamente recente no constitucionalismo, tende a provocar certo 'deslumbramento' em Cortes Constitucionais jovens ou em tribunais consagrados, que passem a exercer mais intensamente o controle de constitucionalidade. Apenas o amadurecimento institucional e o self-restraint que sempre o acompanha, fornece o antídoto a esse fator de impulsão do ativismo judicial”. Nessa linha, o constitucionalista critica veementemente o chamado neoconstitucionalismo ao apontar, nele, certa "fragilidade teorética”, e lamenta sua larga difusão no meio acadêmico, doutrinário e jurisprudencial. Para o jurista, não se trataria nem sequer de um “movimento” ou “escola”, considerando a falta de aglutinação de seus integrantes ao redor de um corpo coerente de postulados ou de propostas. Assim, a única peculiaridade do neoconstitucionalismo seria o "exagero na valorização dos princípios constitucionais”, já que a afirmação do caráter vinculante das normas-princípio já havia, segundo ele, sido incorporada pelo constitucionalismo há muito tempo. O neoconstitucionalismo envolveria uma principiologização do direito constitucional, que passa a “desprezar regras em favor de princípios e deles extrair desdobramentos que competiria ao legislador infraconstitucional disciplinar”. Ao observar que “a maior parte dos escritos nacionais associados ao ‘ideário’ do neoconstitucionalismo contemplam manifestações de um difuso moralismo jurídico e, nesse sentido, constituiriam um fator de impulsão do ativismo judicial”, é enfático: “(...) a fragilidade teórica do neoconstitucionalismo pode ser também aquilatada: pela indevida invocação de autores estrangeiros que, supostamente, teriam rompido com o positivismo jurídico, quando, na verdade, o que professam nada mais é do que um positivismo renovado (em geral, com a incorporação da viragem hermenêutica ocorrida em meados do século passado), pelo recurso frequente a uma retórica vazia e passionalista; e, finalmente, pelo fato de que "os partidários dos pós-postivismo, como, em geral, os críticos do positivismo jurídico, constroem uma imagem caricatural de seu adversário teórico que não encontra correspondência nos escritos dos mais conhecidos juspositivistas do século XX”. ELIVAL DA SILVA RAMOS, op.cit., pp. 233-246.

${ }^{357}$ ELIVAL DA SILVA RAMOS, op.cit., pp. 246-252. 
jurídica, na organização dos tribunais e, sobretudo, nos procedimentos judiciais, para que passe a ser possível tratar os direitos sociais e sobre eles decidir de forma coletiva” ${ }^{358}$. Ao reconhecer essas dificuldades, ele refere um “ativismo judicial despreparado” na atividade de vários tribunais brasileiros ${ }^{359}$.

${ }^{358}$ VIRGILIO AFONSO DA SILVA, "O Judiciário e as políticas públicas: entre transformação social e obstáculo à realização dos direitos sociais", op.cit., pp. 596-598 "Por exemplo, ao distribuir tratamentos médicos de forma individual (i.e., sem considerar as políticas governamentais na área), os juízes podem estar prejudicando outras políticas públicas na área da saúde (ou em outras áreas), mesmo que eles consigam 'resolver' alguns casos isolados. Isso porque, em um cenário de recursos escassos, o dinheiro tem que ser necessariamente retirado de outros programas para atender as decisões judiciais". $\mathrm{O}$ autor assim conclui seu estudo: "Contudo, o fato de serem "não menos jurídicas" não me parece implicar que as normas que garantem direitos sociais devam ser tratadas como se tivessem a mesma estrutura daquelas que garantem direitos civis e políticos, nem que sejam justiciáveis da mesma maneira. Se isso está correto, e se o Judiciário não é capaz de pensar em saúde, educação, moradia etc., de forma coletiva e global, talvez ele devesse deixar essa tarefa para o processo político. Mas não é possível ignorar que as demandas individuais continuarão a existir e que os juízes continuarão a ter que decidir sobre elas. Se, pelas razões expostas, o Judiciário não deve distribuir medicamentos ou bens similares deforma irracional a indivíduos, ele deveria ser capaz de canalizar as demandas individuais e, em uma espécie de diálogo constitucional, exigir explicações objetivas e transparentes sobre a alocação de recursos públicos por meio das políticas governamentais, de forma a estar apto a questionar tais alocações com os poderes políticos sempre que necessário for. Ainda mais importante seria o papel do Judiciário, em conjunto com o Ministério Público, como controlador das políticas públicas já existentes. Boa parte dos problemas de efetividade do direito à saúde (e também de outros direitos sociais) decorre muito mais de desvios na execução de políticas públicas do que de falhas na elaboração dessas mesmas políticas. Nesses termos - ou seja, como controlador da execução de políticas já existentes -, o Judiciário conseguiria, ao mesmo tempo, pensar os direitos sociais de forma global, respeitar as políticas públicas planejadas pelos poderes políticos, não fazer realocação irracional e individualista de recursos escassos e, sobretudo, realizar com maior eficiência os direitos sociais. Contudo, é óbvio que, para que isso ocorra, o papel do Judiciário e o foco da ação do Ministério Público têm que ser repensados. Ainda mais: em um país no qual a separação de poderes é interpretada como sinônimo de não-diálogo entre os poderes, como muitas vezes ocorre no Brasil, essa é uma tarefa difícil de ser realizada. Como foi demonstrado anteriormente, contudo, soluções simples, como a distribuição de remédios de forma desordenada, irracional e individualista não irá contribuir para a real implementação dos direitos sociais no país”.

${ }^{359}$ Noutra obra, o mesmo autor, ao referir a problemática da efetividade dos direitos fundamentais no Brasil (tema em que se concentra grande parcela dos debates sobre o ativismo judicial em nosso país), nota duas posturas diversas e propõe uma terceira via. Com efeito, referindo-se ao tema dos limites de atuação do Poder Judiciário, sem contudo citar a expressão "ativismo judicial", ele observa que, de um lado, "com base em uma determinada concepção de separação de Poderes, pode-se imaginar que nada resta aos operadores do direito, sobretudo aos juízes, senão esperar por uma ação dos Poderes políticos". De outro lado, com base em concepção diversa, "podese imaginar que a tarefa do operador do direito, sobretudo do juiz, é substituir os juízos de conveniência e oportunidade dos Poderes políticos pelos seus próprios". Ao tentar encontrar um denominador comum, o constitucionalista defende que "nem uma nem outra posturas são as mais adequadas". Ao enfatizar as exigências argumentativas que as restrições e a proteção aos direitos fundamentais impõem, a postura mais adequada seria aquela que se disponha "a um desenvolvimento e a uma proteção dos direitos fundamentais baseados nem na omissão nem na ação isolada e irracional, mas a partir de um diálogo constitucional fundado nessas premissas de comunicação intersubjetiva entre os Poderes estatais e a comunidade”. VIRGÍLIO AFONSO DA SILVA, Direitos fundamentais: conteúdo essencial, restrições e eficácia, op.cit., p. 255. 


\subsubsection{Noções presentes em decisões do STF e em discursos de seus}

ministros

A menção à prática do “ativismo judicial” em decisões (em obiter dictum) e em manifestações oficiais de ministros do STF, dada a posição institucional do órgão no Poder Judiciário brasileiro, é de grande relevância ${ }^{360}$.

No MS n. ${ }^{\circ}$ 26915/DF, impetrado por deputados federais para questionar ato do presidente da Câmara, alegava-se inobservância do devido processo legislativo. Na decisão monocrática que indeferiu o pedido liminar, o ministro Gilmar Mendes, examinando a permeabilidade do STF às chamadas questões políticas, destacava que o órgão, alternando momentos de "maior e menor ativismo judicial”, vinha consolidando o entendimento de que "a discricionariedade das medidas políticas não impede o seu controle judicial, desde que haja violação a direitos assegurados pela Constituição”. Reconheceu, ademais, que, na última década, o STF vinha atuando ativamente para promover esse tipo de controle. Ponderou, entretanto, que esses juízos não poderiam ser desacompanhados de “reflexão crítica acurada”, dada a preocupação substancial com a indevida interferência de um Poder sobre outro ${ }^{361}$.

Em julgamento recente, nos autos do ARE 646366/RJ (em agravo interposto para contestar decisão que negou seguimento a recurso extraordinário) a referência ao ativismo judicial foi acompanhada da constatação de que a "moderna doutrina vem admitindo uma postura mais ativa do julgador na atividade instrutória do processo”, uma vez que "o direito processual civil passa a ser estudado com foco no direito público". Nesse sentido, possuiria o julgador a faculdade de “determinar a produção de provas que entenda relevantes para a formação do seu convencimento sobre os fatos alegados pelas partes no processo" (2.2.8, supra) ${ }^{362}$.

\footnotetext{
${ }^{360}$ As informações foram encontradas em pesquisa jurisprudencial disponível em: www.stf.jus.br. É importante destacar, entretanto, que o exame da memória institucional do STF revela que nos primeiros anos do século XX já se debatia uma alegada "ditadura da justiça". STF. Memória jurisprudencial: Ministro Epitacio Pessôa. Brasília : Supremo Tribunal Federal, 2009.

${ }^{361}$ MS 26915/DF, rel. Min. Ellen Gracie, julg. 8-10-07, DJU de 16.10.2007.

362 "AGRAVO LEGAL - PRODUÇÃO DE PROVA EX OFFICIO - ATIVISMO JUDICIAL - LIVRE CONVENCIMENTO MOTIVADO - A moderna doutrina vem admitindo uma postura mais ativa do julgador na atividade instrutória do processo, uma vez que o direito processual civil passa a ser estudado com foco no direito público. Possui o julgador faculdade para determinar a produção de provas que entenda relevantes para a formação do seu convencimento sobre os fatos alegados pelas partes no processo. Irrelevante para o deslinde da controvérsia a realização de prova pericial, sendo certo que a vistoria é o procedimento adequado, pois visa delimitar a área do imóvel da agravada, objeto de despejo. Negado
} 
Já no AI 767681/GO, que culminou com a conversão do apelo em recurso extraordinário (relacionado a ação civil pública com a qual se buscavam reformas em estabelecimento prisional), discutiu-se decisão do Tribunal de Justiça de Goiás na qual se considerou que o “ativismo judicial” deveria se "ater à concessão de tutela preventiva para determinar a inclusão no orçamento vindouro de verba destinada ao implemento de providências”, que deveriam ser eleitas pela Administração para o "restabelecimento das condições do estabelecimento prisional do Município, de forma a garantir o mínimo vital aos presos e razoável segurança à comunidade, evitando-se a perpetuação do ilícito”363.

Na ADPF 132/RJ, sobre a união estável homoafetiva, o voto do ministro Celso de Melo, corroborando decisão unânime, referiu que o julgamento não poderia ser qualificado como prática do ativismo judicial (o ministro exortava os leitores a que não fizessem tal alegação, já antecipando que isso seria feito), mas como um “comportamento afirmativo do Poder Judiciário” que implicou “uma positiva criação jurisprudencial do direito", inclusive pela necessidade de "fazer prevalecer a primazia da Constituição", transgredida e desrespeitada “por pura e simples omissão dos poderes públicos”. O STF, desse modo, ao suprir, de forma criativa, as omissões inconstitucionais dos órgãos estatais, não faria nada além de “cumprir a sua missão constitucional”. Referido voto reconhecia, entretanto, que as "práticas de ativismo judicial, embora moderadamente desempenhadas" pelo STF em “momentos excepcionais”, tornavam-se necessárias quando “os órgãos do Poder Público se omitem ou retardam, excessivamente, o cumprimento de obrigações a que estão sujeitos”, ainda mais “se se tiver presente que o Poder Judiciário, tratando-se de comportamentos estatais ofensivos à Constituição, não pode se reduzir a uma posição de pura passividade»364.

provimento ao recurso”. ARE 646366/RJ, rel. Min. Ricardo Lewandowski, DJe n. ${ }^{\circ}$ 177, julg. 13-09-11, publ. 15-09-11.

363 "Agravo de instrumento. Constitucional e Administrativo. Ação civil pública. Precariedade de estabelecimento prisional. Reformas. Ausência de previsão orçamentária. Alegada ofensa ao princípio constitucional da separação dos poderes. Agravo provido. Conversão dos autos em recurso extraordinário. Submissão do recurso ao procedimento de repercussão geral da questão constitucional.”AI 767681/GO, rel. Min. Carmen Lúcia, julg. 05-11-10, DJe n. ${ }^{\circ} 222$, publ. 19-11-10.

${ }^{364}$ ADPF 132/RJ, rel. Min. Carlos Ayres Brito DJe n. ${ }^{\circ}$ 89, julg. 05-05-11, publ. 13-05-11. Conjuntamente, foi julgada a ADI 4277/DF, rel. Min. Carlos Ayres Brito, DJe n. ${ }^{\circ}$ 89, julg. 05-05-11, publ. 13-05-11. Em discurso na sessão solene de 23-04-08, o ministro Celso de Mello defendeu as mesmas ideias, sustentando que: “A omissão do Estado - que deixa de cumprir, em maior ou em menor extensão, a imposição ditada pelo texto constitucional - qualifica-se como comportamento revestido da maior gravidade político-jurídica, eis que, mediante inércia, o Poder Público também desrespeita a Constituição, também ofende direitos que nela se fundam e também impede, por ausência (ou insuficiência) de medidas concretizadoras, a própria aplicabilidade dos postulados e princípios da Lei Fundamental. (...) O fato inquestionável é um só: a inércia estatal em tornar efetivas as imposições constitucionais traduz inaceitável gesto de desprezo pela Constituição e configura comportamento que revela um incompreensível sentimento de desapreço pela 
Ademais, há, em pronunciamentos oficiais dos ministros do STF, várias referências ao ativismo judicial, associado, em cada caso, às seguintes posturas: a) ação em face de "necessidade institucional, quando os órgãos do Poder Público se omitem ou retardam, excessivamente, o cumprimento de obrigações a que estão sujeitos por expressa determinação do próprio estatuto constitucional”365; b) suprimento judicial de lacunas legislativas, prática instrumentalizada, entre outros meios, pelo mandado de injunção ${ }^{366}$; c) atuação proativa em cenários de "quase esgotamento de outras vias para o exercício dos direitos fundamentais e garantia dos direitos humanos”, como em casos relacionados ao direito de greve de servidores públicos, fidelidade partidária, progressão de regime prisional, nepotismo, uso de algemas e direito das minorias de requerer a criação de Comissões Parlamentares de Inquérito no Congresso Nacional $^{367}$; d) atuação motivada pela “preocupação dos juízes em garantir a efetividade dos direitos fundamentais”, algo que teria se tornado, na verdade, “o novo papel do Poder Judiciário”368; e) atuação para

autoridade, pelo valor e pelo alto significado de que se reveste a Constituição da República. Nada mais nocivo, perigoso e ilegítimo do que elaborar uma Constituição, sem a vontade de fazê-la cumprir integralmente, ou, então, de apenas executá-la com o propósito subalterno de torná-la aplicável somente nos pontos que se mostrarem convenientes aos desígnios dos governantes, em detrimento dos interesses maiores dos cidadãos(...)É preciso, pois, reafirmar a soberania da Constituição, proclamando-lhe a superioridade sobre todos os atos do Poder Público e sobre todas as instituições do Estado, o que permite reconhecer, no contexto do Estado Democrático de Direito, a plena legitimidade da atuação do Poder Judiciário na restauração da ordem jurídica lesada e, em particular, a intervenção do Supremo Tribunal Federal, que detém, em tema de interpretação constitucional, e por força de expressa delegação que lhe foi atribuída pela própria Assembleia Nacional Constituinte, o monopólio da última palavra, de que já falava Rui Barbosa, em discurso parlamentar que proferiu, como Senador da República, em 29 de dezembro de 1914”. STF, DJe n. ${ }^{\circ}$ 97/2008, publ. 30-05-08.

${ }^{365}$ Recentemente, ao responder a pergunta de jornalista, Celso de Melo reforçou que não se poderia censurar o "eventual ativismo judicial" exercido pelo Supremo. Isso porque a elaboração de uma Constituição deveria vir acompanhada da "vontade de fazê-la cumprir integralmente”, e não de "apenas executá-la com o propósito subalterno de torná-la aplicável somente nos pontos que se mostrarem convenientes aos desígnios dos governantes, em detrimento dos interesses maiores dos cidadãos”. Assim, as práticas de ativismo judicial, que reputou moderadas no STF e incidente apenas em "momentos excepcionais", tornar-se-iam "uma necessidade institucional, quando os órgãos do Poder Público se omitem ou retardam, excessivamente, o cumprimento de obrigações a que estão sujeitos por expressa determinação do próprio estatuto constitucional”. STF (Notícias). Celso Mello defende ativismo judicial do Supremo e pesquisas científicas, publ. 23-04-08, acesso em 11-03-11. Disponível em www.stf.jus.br.

${ }^{366}$ Em encontro com o presidente da Colômbia, este relatou que, diante das dificuldades que o país tem enfrentado em razão da "omissão do Parlamento em regulamentar direitos assegurados pela Constituição de 1991”, o Poder Judiciário do país vinha exercendo "o papel do Congresso colombiano, sendo taxado de praticar 'ativismo judicial'”. Ao comentarem o relato, os ministros do STF afirmaram que a situação também ocorreria no Brasil, e referiram, como instrumento específico para questionar essa omissão legislativa, o mandado de injunção. STF (Notícias). Presidente do STF recebe presidente da Colômbia em sua primeira viagem internacional após a posse. publ. 01-09-10, acesso em 11-03-11. Disponível em www.stf.jus.br.

367 STF (Notícias). Ministro Gilmar Mendes vota no sentido de que Presidente da República deve entregar Battisti à Itália, publ. 18-11-09, acesso em 11-03-11. Disponível em www.stf.jus.br.

${ }^{368}$ No encontro de Cortes Supremas do Mercosul, a ministra Cármen Lúcia definiu o ativismo judicial como a "preocupação dos juízes em garantir a efetividade dos direitos fundamentais”, algo que teria se tornado, na verdade, “o novo papel do Poder Judiciário”. Acrescentou a ministra que uma coisa é a conquista formal, e outra o cumprimento rigoroso dessas disposições, em relação ao qual quem daria a última palavra seria o 
promover judicialmente o respeito ao "mínimo existencial para o cidadão e a reserva do possível para o Estado"369; g) desempenho de “missão institucional” inclusive fora dos autos, como no caso de o Judiciário, por meio de seus representantes, propor projetos de lei, rediscutir política criminal ineficiente e participar de fóruns sociais e debates públicos $^{370}$; h) atuação em face de "uma necessidade transitória de o Poder Judiciário suprir omissões do Poder Legislativo ou do Poder Executivo que são lesivas aos direitos das pessoas em geral ou da comunidade como um todo", possibilitada por meios processuais idôneos e como decorrência da provocação de interessados com "legitimidade para ajuizar uma ação em defesa de seus direitos”, sem desrespeito, "nem indevida interferência na esfera dos outros poderes”, e muito menos “transgressão ao princípio da separação dos poderes”371; i) atuação que não se confunde com a judicialização da política, “quando as questões políticas estão configuradas como verdadeiras questões de Direito”372.

Judiciário. STF (Notícias). Leitura de declaração encerra VIII Encontro de Cortes Supremas do Mercosul, publ. 26-11-10, acesso em 11-03-11. Disponível em www.stf.jus.br.

${ }^{369}$ Relevante, ademais, é a recente manifestação do mais novo ministro do STF, Luiz Fux. Questionado sobre o ativismo judicial e a judicialização de políticas públicas, recorreu, para definir o fenômeno, à ideia de "balanceamento do mínimo existencial para o cidadão e a reserva do possível para o Estado". Esse balanceamento deve pautar as decisões judiciais, segundo ele. STF (Notícias). Luiz Fux (...) ministro do STF, publ. 09-02-11, acesso em 11-03-11. Disponível em www.stf.jus.br.

${ }^{370}$ Foram os temas referidos pelo ministro Gilmar Mendes ao responder pergunta sobre o "ativismo judicial" e a postura do Judiciário "fora dos autos". STF (Notícias). Ministro Gilmar Mendes responde ao vivo perguntas enviadas pelo YouTube, publ. 16-04-10, acesso em 11-03-11. Disponível em www.stf.jus.br.

371 Em novembro de 2010, no noticiário do sítio do STF na internet, foram publicadas manifestações do ministro Celso de Melo sobre "opiniões de que o Tribunal extrapola suas atribuições ao promover ativismo judicial”. Na ocasião, o ministro definiu o ativismo como “uma necessidade transitória de o Poder Judiciário suprir omissões do Poder Legislativo ou do Poder Executivo que são lesivas aos direitos das pessoas em geral ou da comunidade como um todo". Segundo ele, essa atividade seria possibilitada por meios processuais idôneos e adequados, que permitem ao Judiciário proferir decisões nesse sentido, de modo que, não haveria desrespeito, "nem indevida interferência na esfera dos outros poderes", e muito menos "transgressão ao princípio da separação dos poderes”. Defendeu, nessa linha, que essas decisões do STF não seriam ativistas, mas se os críticos insistissem em classificá-las dessa forma, tratar-se-ia de "ativismo moderado", que seria "necessário pela injustificável omissão do Congresso Nacional” e diante da provocação do interessado com "legitimidade para ajuizar uma ação em defesa de seus direitos". Prosseguindo em sua reflexão, Melo visualiza um cenário em que "a Constituição brasileira está sendo permanentemente reescrita nos tribunais", sem olvidar que "O STF tem hoje o monopólio da última palavra sobre o que é constitucional e o que não é constitucional". Sugeriu, por fim, um paralelo entre o que vinha fazendo o STF e a "atuação da Suprema Corte americana, também acusada de ativismo judicial", sem o qual, no entanto, "o processo de integração racial não teria sido acelerado naquele país”. Referia-se o ministro a críticas dirigidas a decisões sobre fidelidade partidária, progressão de regime prisional para crimes hediondos, nepotismo, uso de algemas e outras relativas à garantia do direito à saúde e à vida. STF (notícias). Suprema Corte brasileira e o exercício de suas atribuições constitucionais, publ. 15-11-10. Disponível em www.stf.jus.br, acesso em 10-03-11. Extrai-se da publicação, ainda, excerto da manifestação do ministro acerca dos mandados de injunção que buscavam o reconhecimento do direito de greve para o funcionalismo público: "O que fez o Supremo Tribunal? Legislou? Não. Editou algum provimento normativo em substituição a uma lei já aprovada pelo Congresso Nacional? Não. O STF exerceu primeiro uma competência que a Constituição lhe deu, qual seja a de julgar mandados de injunção impetrados contra omissões do Congresso Nacional”.

${ }^{372}$ Em viagem aos EUA, Gilmar Mendes, então presidente do STF, explicou o ativismo judicial como mecanismo de proteção da Constituição e dos direitos fundamentais, e defendeu que não haveria 
Noutro cenário, considerou-se o ativismo judicial, no que tange ao papel do STF na construção da estabilidade institucional do país, como uma “injusta acusação”, já que o órgão estaria “consciente do dever político em dar respostas constitucionais necessárias a demandas sociais oriundas da incapacidade de soluções autônomas”373.

É interessante notar o destaque, no discurso dos próprios ministros, para a atuação institucional "fora do processo". Além dos exemplos já citados, evoque-se que, em 2008, o então presidente do STF, Gilmar Mendes, propusera a criação de uma comissão no Congresso Nacional para tratar dos temas constitucionais que ainda não haviam sido regulamentados. A proposta foi justificada pelo fato de o Poder Judiciário “não poder se omitir” diante dessas lacunas ${ }^{374}$.

A ideia de Mendes era a de que o STF informasse “de maneira solene” as matérias constitucionais em relação às quais houvesse omissão legislativa, de modo que a Câmara e o Senado adotassem um procedimento especial nesses casos. A época, o STF havia se pronunciado sobre temas polêmicos, como a aplicação da Lei de Greve (Lei n. ${ }^{\circ}$ 7783/89) ao servidor público. Na ocasião, observava Mendes que o ativismo judicial do STF não seria "uma manifestação de desapreço com o Congresso Nacional, mas uma tentativa de concretizar a Constituição Federal”, e que "um pouco desse ativismo" decorreria do próprio modelo constitucional brasileiro. Destacou, ainda, que muitas vezes o STF seria estimulado pelos próprios parlamentares a desenvolver práticas ativistas, seja quando se trata de evitar que "a maioria asfixie as minorias” (ele refere, v.g., a determinação judicial de instalação de CPIs), seja quando parlamentares, para resolver disputas interna corporis, postulam ao Judiciário, detentor da "última palavra", uma solução para essas questões políticas ${ }^{375}$ (2.2.3 e 2.2.6, supra).

“judicialização da política quando as questões políticas estão configuradas como verdadeiras questões de Direito”. STF (Notícias). STF reafirma o papel do Brasil perante as cortes constitucionais do mundo, publ. 31-10-08, acesso em 11-03-11. Disponível em www.stf.jus.br

${ }^{373} \mathrm{O}$ ministro Cezar Peluso, ao assumir a presidência do STF, afirmou que a estabilidade institucional do país também é obra do Supremo, que tem tido papel eminente e de grande contribuição sob injusta acusação de ativismo político porque "consciente do dever político em dar respostas constitucionais necessárias a demandas sociais oriundas da incapacidade de soluções autônomas”. STF (Notícias). Ministro Cezar Peluso assume Presidência do STF e firma compromisso com a sociedade, publ. 23-04-10, acesso em 11-03-11. Disponível em www.stf.jus.br.

${ }^{374}$ Conforme a Revista Consultor Jurídico, em 26-11-08.

375 "Presidente do STF propõe formação de comissão no Congresso para tratar de temas constitucionais ainda não regulamentados”, publ. 26-11-08, disponível em: www.stf.jus.br, acesso em 19-03-11. Do mesmo debate (segundo se extrai da publicação), participou o Senador Demóstenes Torres, que afirmou que "o ativismo do Judiciário é uma decorrência da falta de apetite legislativo do Congresso Nacional”. Ele ponderou que o STF tem atuado seriamente em face das lacunas deixadas pelo Legislativo, e que muitas vezes são os próprios parlamentares que provocam o Tribunal. "O ativismo Judiciário chegou para ficar e o STF tem cumprido sua função de uma maneira fantástica, como nunca cumpriu, e repara um erro histórico de omissão legislativa 
Não sobeja observar que em várias dessas decisões do STF e, igualmente, nas manifestações públicas examinadas, são citados aspectos institucionais e normativos das experiências jurídicas de outros países, a corroborar a perspectiva apresentada no tópico 2.2.7, supra.

\subsubsection{Perspectiva processual}

No Brasil, a noção de ativismo judicial no processo deriva da influência do ideário do “juiz ativo” (2.2.8, supra).

DINAMARCO, em seus Fundamentos do Processo Civil Moderno, ressalta que, no Brasil, a concepção sobre os deveres e poderes do juiz é inspirada no processo civil francês, que exige do magistrado a participação efetiva no processo ${ }^{376}$. Como foi visto, as leis processuais francesas mais recentes foram influenciadas pelo modelo de Klein (2.2.8.2.1, supra), o que justifica a observação do renomado processualista brasileiro, de que a globalização da ciência processual constitui importante canal de comunicação, permitindo a troca de ideias que podem se tornar, inclusive, princípios que transpõem fronteiras. Nessa linha, destacando que a lei processual impõe ao juiz, entre seus deveres fundamentais, o da participação efetiva, o processualista entende que, no processo, isso se traduziria na "perspectiva do ativismo judicial”, objeto de "ardorosos alvitres nos congressos internacionais de direito processual, marcados pela tônica da efetividade do processo”. A definição de ativismo judicial que ele propõe é fundada na postura participativa do juiz, na “iniciativa probatória”, no “efetivo comando do processo” e na “constante integração na problemática ali residente”, inclusive mediante o “diálogo com os litigantes”377.

No direito processual civil vigente, o papel ativo do juiz se traduz, ilustrativamente, nas prescrições do artigo 331 do CPC, instituído "para o efetivo cumprimento do princípio da imediatidade, que é uma das bases do processo oral adotado

consolidada”, concluiu. Noutra oportunidade, o então presidente do STF, Gilmar Mendes, em entrevista ao programa Roda Viva, destacou: "Sabemos que temos uma Constituição que já preconiza certo ativismo quando cobra que o Judiciário controle as omissões inconstitucionais do legislador. Temos ação direta por omissão, temos mandado de injunção, e o próprio Supremo Tribunal Federal decidiu, por exemplo, naquele caso célebre das greves do serviço público, que era necessário balizar essas greves, tendo em vista a ausência de regulação por parte do Poder Legislativo.” (Degravação disponível em www.stf.jus.br).

${ }^{376}$ CÂNDIDO RANGEL DINAMARCO, Fundamentos do processo civil moderno, op.cit., v. 1, pp. 130-131.

${ }^{377}$ CÂNDIDO RANGEL DINAMARCO, Fundamentos do processo civil moderno, op.cit., v. 2, p. 742. 
pelo nosso legislador»378, como bem destaca WATANABE. Coerentemente com essa perspectiva, o ativismo judicial foi enunciado como "princípio da tutela jurisdicional coletiva” pelo artigo $2^{\circ}$ do Anteprojeto de Código Brasileiro de Processos Coletivos ${ }^{379}$.

Como se vê, o modelo do juiz ativo, orientador das leis processuais contemporâneas e das reformas no processo, traduz-se em noções de ativismo judicial presentes na doutrina. Note-se que essas noções tem considerado a acepção ampliada desse ideário, com atenção especial para a promoção judicial de soluções não adjudicatórias e para o tratamento adequado de megaconflitos (2.2.8.1, supra). Nesse sentido, MANCUSO associa o ativismo judicial ao "crescente acesso à Justiça de novos megainteresses que vão se disseminando ao interno da sociedade”. Para o jurista, esse ativismo judicial, desde que prudente e lúcido, poderá, para o tratamento daqueles conflitos, exigir “certa dose de criatividade, justificada e ponderada, em ordem à formulação da norma concreta capaz de resolver a pendência de modo justo”. Ele acrescenta, em seu relevante estudo sobre a função judicial contemporânea, que esse ativismo judicial "aderente aos megaconflitos” decorreria das transformações na função judicial propiciadas pela “massificação da sociedade, a globalização da economia e a explosão da litigiosidade”, o que exigiu dos magistrados a revisão da tradicional postura de neutralidade e distanciamento $(2.2 .9 \text {, supra })^{380}$.

\subsubsection{Críticas aos instrumentos processuais de padronização}

decisória

No tópico 2.2.7.1, supra, examinamos a tendência de o aprofundamento da juridificação levar à busca da eliminação de incertezas decisórias num cenário de fortes pressões por previsibilidade e velocidade de julgamentos. Ademais, ao examinarmos o caso brasileiro (2.2.3.2, supra), destacou-se a tendência de os tribunais superiores se fortalecerem como formuladores de teses jurídicas vinculantes e persuasivas com a pretensão de neutralizar entendimentos divergentes acerca das normas.

Desse modo, a promoção da padronização decisória, no mundo inteiro, constitui importante forma de manifestação de um potencial protagonismo judicial.

\footnotetext{
${ }^{378}$ KAZUO WATANABE, "Cultura da sentença e cultura da pacificação", op.cit., p. 687.

${ }^{379}$ Acessível em www.direitoprocessual.org.br. Versão de janeiro de 2007.

${ }^{380}$ RODOLFO DE CAMARGO MANCUSO, op.cit., pp. 384-391.
} 
No Brasil, essa tendência tem sido bastante criticada. THEODORO JUNIOR, NUNES e BAHIA constatam que, "em face de inúmeros fatores, o sistema processual brasileiro costuma trabalhar com a eficiência quantitativa”, o que implica a busca pela “alta produtividade das decisões” e pela “uniformização superficial dos entendimentos” antes de um exaustivo debate sobre os casos. Com isso, os juízes e tribunais seriam relegados a um papel de "autômatos do sistema" em face da fixação de “pautas decisórias e decisões padrão” pelos Tribunais Superiores. Em outras palavras, os demais órgãos judiciais, compelidos a repetir esses padrões, ficariam impedidos de proferir decisões maturadas e forjadas no debate processual.

Ademais, considerando as novas formas de litigiosidade, esses estudiosos sustentam que as reformas processuais têm fortalecido essa tendência de uniformização da jurisprudência, facilitando a elaboração de standards interpretativos com base no julgamento de alguns casos. Assim, um tribunal superior, diante da multiplicidade de processos (mesmo que cada conflito de um grupo de litígios “agrupados” possua suas especificidades), tende a observar apenas o que neles avulte como tema central. Definida a tese em relação a esse tema, todos os demais casos serão julgados da mesma forma. Se de um lado essa padronização produz um aumento de eficiência quantitativa e fomenta certa previsibilidade radicada no engessamento dos posicionamentos; de outro ela tende a fortalecer uma concepção de hierarquia judiciária (tribunais superiores, tribunais inferiores e juízes) em detrimento da independência interna de cada órgão judicial (cf. 2.2.7.1, supra $)^{381}$. Como exemplos desses instrumentos de padronização decisória para a “resolução quantitativa das demandas seriais”, referidos processualistas referem as técnicas de julgamento liminar (artigos 518, $\S 1^{\circ}$, e 285-A, do CPC), as súmulas vinculantes, a repercussão geral e o procedimento para o julgamento de recursos repetitivos (Lei n. ${ }^{\circ}$ $11.672 / 2008)^{382}$.

\footnotetext{
${ }^{381}$ HUMBERTO THEODORO JUNIOR, DIERLE NUNES, ALEXANDRE BAHIA, op.cit., pp. 10-52.

${ }^{382}$ HUMBERTO THEODORO JUNIOR, DIERLE NUNES, ALEXANDRE BAHIA, op.cit., p. 30. Note-se, por oportuno, que entre os instrumentos previstos no projeto de lei n. ${ }^{\circ}$ 166/2010 (novo Código de Processo Civil), destaca-se o chamado incidente de resolução de demandas repetitivas. É relevante citar, ademais, a PEC n. ${ }^{\circ}$ 358/2005, que, entre outras medidas, institui a chamada "súmula impeditiva de recursos" no âmbito do STJ e do TST. Dallari também critica essas soluções que levam ao seguimento obrigatório ("o que é completamente diferente de estarem sendo acolhidas por terem autoridade”) de decisões de órgãos de cúpula judiciária. DALMO DE ABREU DALLARI, op.cit., p. 66.
} 


\subsubsection{Perspectiva trabalhista}

Não obstante as especificidades do potencial protagonismo judicial na Justiça do Trabalho (2.2.3, supra) serem anteriores à Constituição de 1988, apenas recentemente certos comportamentos dos órgãos judiciais trabalhistas têm sido associados ao chamado ativismo judicial.

Em tese de doutorado defendida nesta Faculdade de Direito em 2010, TEODORO sustenta que o ativismo judicial teria como substância a atuação de um juiz "que incorpora as vicissitudes do meio social, as conquistas das classes envolvidas, a própria evolução do Poder Judiciário e tem por fim a realização de direitos fundamentais”. Desse modo, ele haveria de se utilizar de mecanismos "disponibilizados pelo próprio sistema jurídico, ou advindos da criatividade jurídica, para realizar sua função social”. Nessa linha, o estudo associa o fenômeno à “atividade judicial criadora mediante utilização da cláusula geral, direito judicial, judicialização da política e politização do Judiciário”. Consoante o que defende a autora, o próprio juiz teria “reelaborado” seu papel, “ao abandonar a submissão irrestrita às leis ou às doutrinas e jurisprudências estabelecidas quando de sua inserção no Estado Social de Direito”. Todavia, em momento de “crise desse Estado Social”, ganharia relevo, segundo ela, a “formação ética e intelectual desses magistrados”, i.e., o juiz haveria de ter visão “ampla e profunda dada por determinados estudos que lhe permitam conhecer bem a realidade para a qual trabalha, a fim de se aproximar o máximo da verdade real e assim efetivar direitos trabalhistas”. Com isso, o magistrado não apenas “conheceria” a realidade, mas também poderia “coordenar e transformar essa sociedade complexa”383. A mesma estudiosa sustenta que "somente um juiz com formação ética humanista e que busca a justiça desenvolverá o ativismo para efetivar direitos trabalhistas", e acrescenta que o magistrado, para esse fim, pode "negar a lei, caso esta venha a acarretar decisões injustas”. Dessarte, a autora conclui que o ativismo judicial surgiria como um "instrumento importante para a efetivação de direitos trabalhistas” e para enfrentar “omissões do Poder Legislativo”384.

BRANCO, por sua vez, sustenta que o ativismo judicial teria sido “proposto” e “deflagrado por meio do neoconstitucionalismo”, considerado o propósito de estabelecer, pelas vias judiciárias, uma vinculação entre as funções legislativa, executiva e

\footnotetext{
${ }^{383}$ MARIA CECÍLIA MÁXIMO TEODORO, O juiz ativo e os direitos trabalhistas, São Paulo: LTr, 2011, p. 150.

${ }^{384}$ MARIA CECÍLIA MÁXIMO TEODORO, op.cit., p. 178.
} 
judicial e sua “vocação originária” de “concretização da Constituição”. Acrescenta a autora que essa postura do magistrado "somente se justifica pelo compromisso de efetivação dos direitos humanos fundamentais”. Do contrário, esse ativismo seria "negativo”, i.e., oposto “à plataforma emancipatória do neoconstitucionalismo”, cuja proposta é a de "plena concretização da eficácia normativa da Constituição”385.

COUTINHO e FILHO associam o ativismo judicial na Justiça do Trabalho à produção de súmulas e orientações jurisprudenciais que extrapolam o texto legal e criam novas regras jurídicas autônomas e abstratas, inovando no ordenamento jurídico e invadindo, assim, a esfera política legislativa ${ }^{386}$. Segundo os autores, o problema “estará na sua manifestação divorciada dos princípios do Direito”. Em exame de várias súmulas, eles apontam verbetes que: a) inovam, ao tratarem de matéria não regulamentada por lei; b) propõem interpretações que seriam incompatíveis com o conteúdo de dispositivos legais; ou c) contrariam princípios do Direito do Trabalho.

Em relação às noções citadas, parece oportuno apresentar algumas reflexões.

Primeiro, pela perspectiva desta tese, não teriam sido os juízes, sponte propria, os responsáveis pelas transformações em suas funções ou pelo abandono da postura de "submissão irrestrita às leis ou às doutrinas e jurisprudências estabelecidas". Na verdade, essas transformações parecem decorrer de mudanças estruturais (examinadas pela perspectiva da juridificação) que engendraram um potencial protagonismo judicial. A “vontade” dos juízes, num cenário de efetiva independência dos órgãos judiciais, situar-seia no fazer atuar desse potencial, apenas.

Segundo, o ativismo judicial não parece envolver, necessariamente, a realização de direitos fundamentais. Haveria certa ambivalência (ou, mais precisamente, uma multidirecionalidade) das formas de manifestação do potencial protagonismo que se traduzem no ativismo judicial. Em outros termos, a atuação desse potencial pode implicar não só a promoção, mas também a restrição de direitos fundamentais ou de qualquer outro direito.

Terceiro, parece oportuno considerar que a criatividade judicial, as várias formas de tratar as chamadas omissões legislativas e as decisões com propostas

\footnotetext{
${ }^{385}$ ANA PAULA TAUCEDA BRANCO, "O ativismo judicial negativo investigado em súmulas editadas pelo Tribunal Superior do Trabalho”, in: GRIJALBO F. COUTINHO et. al. (coord.), op.cit., p. 43.

${ }^{386}$ GRIJALBO FERNANDES COUTINHO, HUGO CAVALCANTI MELO FILHO, "O ativismo judicial do TST como fator de flexibilização do Direito do Trabalho”, in: GRIJALBO F. COUTINHO et. al. (coord.), op.cit., p. 125.
} 
confessadamente contra legem, independentemente de sua motivação ética ou ideológica, revelam diferentes traços da manifestação do potencial protagonismo judicial. Em todas essas situações, a problemática das cláusulas gerais e das noções “em branco” pode ser abordada pela perspectiva apresentada nos tópicos 2.2.1, 2.2.2 e 2.2.4, supra.

Quarto, diante da chamada "crise do Estado Social” (modelo que, no Brasil, não obstante as declarações constitucionais, sempre vivenciou, na prática, certa agonia, como vimos no tópico 2.3.1, supra) não nos parece crível que a formação dos magistrados, pura e simplesmente, possa torná-los aptos a solucionar a falta de efetividade dos direitos sociais. Não nos parece possível, ademais, que os juízes possam assumir toda a responsabilidade de, num Estado com graves déficits, contornar todos eles, por mais intensa que seja a promoção do “alargamento" de sua visão sobre a realidade por meio de estudos ou cursos de formação, reciclagem ou capacitação. Supor essa possibilidade, aliás, parece envolver o risco de ignorar que eventuais perícias e estudos técnicos produzidos para “alargar a visão do magistrado" podem ser eventualmente contaminados por interesses de uma ou de outra parte envolvida, o que costuma merecer a avaliação cuidadosa do julgador $^{387}$.

Por outro lado, se não se ignora a importância de tais estudos técnicos (em alguns casos imprescindíveis), sua existência não resolveria o problema decisório em seu todo. A abertura dos órgãos judiciais para o diálogo com a sociedade (por meio, v.g. de audiências públicas) e para a visualização de outras perspectivas pelas quais interesses conflituosos possam ser percebidos (inclusive por meio de formação adequada) parecem ser instrumentos com certa efetividade, mas sempre subsistirão óbices a que o julgador transcenda adequadamente a compreensão de outros fenômenos além do jurídico. De qualquer modo, há ainda dificuldades práticas a serem enfrentadas, entre elas a já examinada ambiguidade da dimensão contemporânea da figura do juiz ativo (2.2.8.1, supra). Para ilustrar essas dificuldades, pode-se indagar: como poderia o magistrado, num caso complexo de litígio de interesse público (acompanhado de um problema de omissão legislativa e de infinitas

\footnotetext{
${ }^{387}$ No que tange à "abertura de espaço para que setores interessados possam intervir na elaboração de decisões normativas que lhes dizem respeito", o Judiciário vivenciaria esse processo pela "crescente presença, nos julgamentos, de atores a priori estranhos ao direito, mas familiarizados com sua linguagem”, o chamados amici curiae, cuja atuação, no entanto, é marcada por uma série de dúvidas e ambiguidades. A principal dela envolve saber até que ponto esses “especialistas, peritos e 'autoridades científicas' não podem aproveitar-se da assimetria das informações em suas áreas de atuação para manipular, ocultar e justificar e/ou desqualificar, com argumentos pretensamente técnicos, decisões não-técnicas, juízos de valor e preferências políticas". Não se sabe, ainda, qual sua "legitimidade para responder aos diferentes problemas, perigos e incertezas que, com suas pesquisas, experimentos e invenções, de algum modo ajudam a criar”. JOSÉ EDUARDO FARIA, Sociologia jurídica - direito e conjuntura, op.cit., pp. 73-74.
} 
possibilidades decisórias), dedicar-se à atividade hercúlea de conhecer todos os aspectos da realidade, de ouvir todos os interessados e de captar todas as dimensões do conflito, se metas quantitativas dele são exigidas seja para a prolação de sentenças, seja para a promoção de acordos? Como identificar (para tentar contornar) os prejuízos (perdas qualitativas na prestação jurisdicional) escamoteados por resultados meramente quantitativos? Em que medida as citadas metas (ou a suposição de que toda a responsabilidade pela correção de déficits sociais caberia ao juiz) ignoram os limites cognoscitivos e psicofisiológicos da pessoa humana do julgador, com graves consequências pessoais e, possivelmente, funcionais? ${ }^{388}$.

Não se pode deixar de registrar a suspeita de que mesmo a mais vasta formação humanística (sociológica, filosófica, econômica, política e jurídica), por si só, não seria apta a garantir a ampliação da cognição judicial de modo que ela contemplasse todos os aspectos e a todas as perspectivas relevantes para o deslinde do conflito.

É possível que essa formação também não seja apta a garantir (o que é igualmente importante) o tempo e o auxílio necessários à tomada de decisões mais complexas, muitas das quais nem mesmo os Poderes Legislativo e Executivo, circundados por técnicos, conseguem ultimar. Não nos parece simples supor, portanto, sejam de fácil elaboração provimentos jurisdicionais a um só tempo legítimos e consentâneos com parâmetros jurídicos, econômicos, sociais, culturais e aptos, por si sós, à promoção da justiça social ou à solução de todos os complexos problemas subjacentes a determinados casos (como os relacionados a políticas públicas), seja na Justiça do Trabalho, seja em qualquer ramo do Poder Judiciário, já que o controle sobre todas as variáveis do processo e (o que parece mais importante) sobre os seus resultados escapam das mãos do juiz. Seja como for, o reconhecimento dessas

\footnotetext{
388 Recentemente, a Anamatra realizou pesquisa sobre a situação de saúde e condições do exercício profissional dos magistrados trabalhistas do Brasil. Ao todo, 706 juízes associados à entidade responderam ao questionário, correspondendo a $20,6 \%$ da totalidade do quadro de associados. Alguns resultados foram apresentados em maio de 2011, sob a coordenação da professora Ada Ávila Assunção, da Faculdade de Medicina da Universidade Federal de Minas Gerais (UFMG). De acordo com os dados levantados em relação a um período de um ano, 33\% dos juízes estiveram de licença-médica e, num mês específico, 26\% deixaram de realizar tarefas habituais devido a algum problema de saúde. Ainda sobre a saúde dos participantes, 41,5\% declararam ter diagnóstico médico de depressão, 17,5\% informaram usar medicamentos para depressão ou ansiedade, 54\% dormem mal, 28\% estão tristes atualmente e 51\% disseram ser frequentemente ou muito frequentemente vítimas de insônia. A pesquisa revelou dados relevantes sobre a rotina atribulada dos magistrados, mostrando que mesmo quando estão fora da Vara ou do Tribunal permanecem exercendo as atividades da prestação jurisdicional. Dos 706 participantes, 84\% costumam trabalhar em casa, 70\% declararam trabalhar aos finais de semana e 64\% disseram trabalhar nas férias. Foram minuciosamente estudadas as condições de trabalho existentes na atualidade, e as exposições a eventos e situações, sendo elas, as seguintes: vivência de situação agressiva, controle sobre o trabalho, demandas físicas, demandas psicológicas e emocionais, apoio social, recompensas obtidas no trabalho, satisfação no trabalho, conforto no trabalho, características do ambiente de trabalho. O estudo foi controlado pelo Comitê de Ética em Pesquisa da UFMG, tendo sido oferecido a todo magistrado o Termo de Consentimento Livre e Esclarecido no momento de acesso ao site da pesquisa. Disponível em: www.anamatra.org.br, acesso em 25-05-11.
} 
dificuldades não significa que o Judiciário deva se afastar do debate público. Muito ao contrário, intervenções judiciais, em muitos casos, são necessárias e importantes, apesar de não parecer razoável supor sejam elas panaceias.

Quinto, o ativismo judicial parece menos derivado do chamado neoconstitucionalismo do que das variáveis complexas que tentamos apreender, em sua maior parte ou em sua parcela mais importante, no tópico 2.2, supra.

Essas observações parecem relevantes para o propósito geral de construir os tipos ideais de ativismo judicial, tarefa do próximo capítulo.

\subsubsection{Noções presentes em decisões do TST}

Em algumas decisões do TST, o ativismo judicial é referido como “princípio” consistente na “orientação para que o julgador, a despeito da imparcialidade, adote conduta participativa no processo, em cooperação com as partes”. Nesse sentido, no ROMS n. ${ }^{\circ}$ 494/2007-000-12-00.1, o relator, ao minudenciar essa concepção, defende que tal princípio se dirigiria “o órgão julgador, e, por consubstanciar regras de orientação e não de normas de fundamentação das decisões", estaria situado "na órbita do direito judiciário”. No caso, o recorrente (impetrante) invocava referido “princípio” a fim de superar a extinção do processo por ausência de autenticação de documentos ${ }^{389}$.

A mesma noção foi referida no julgamento de embargos de declaração nas ações rescisórias n. ${ }^{\circ} 1624106-62.2005 .5 .00 .0000^{390}$ e n. ${ }^{\circ} 146400-04.2005 .5 .03 .0000^{391}$. No caso, o chamado "princípio do ativismo judicial” foi utilizado para justificar o acolhimento dos embargos de declaração “apenas para prestar esclarecimentos” que auxiliassem os embargantes “na compreensão dos fundamentos elencados”.

\footnotetext{
389 TST. ROMS-494/2007-000-12-00.1, rel. Min. Alberto Luiz Bresciani F. Pereira, julg. 09-06-09

390 TST. AR 1624106-62.2005.5.00.0000, rel. Min. Emmanoel Pereira, julg. 08-02-11.

391 TST. AR 146400-04.2005.5.03.0000, rel. Min. Emmanoel Pereira, julg. 22-02-11.
} 


\subsubsection{Noções de ativismo judicial nos debates entre magistrados do}

Trabalho

O ativismo judicial foi objeto de intensas discussões em uma das comissões temáticas do $15^{\circ}$ Congresso Nacional de Juízes do Trabalho, organizado pela Anamatra (Associação Nacional dos Magistrados da Justiça do Trabalho), intitulado “A constituição, o Trabalho e a Democracia: tensões e perspectivas”, em 2010. Em Assembleia Geral, magistrados, como conclusão dos debates travados durante o evento, aprovaram teses reveladoras de certas linhas de pensamento compartilhadas pela classe.

Entre essas teses, destacam-se as seguintes: a) “a omissão do Poder Legislativo compromete a qualidade institucional e justifica o ativismo judicial para dar efetividade aos direitos garantidos na Constituição Federal”; b) o “exercício da democracia no Estado Democrático de Direito exige do Poder Judiciário uma postura mais ativa, o que se denominou ativismo judiciário, que nada mais é do que o desempenho das funções judiciais de forma a garantir a plena aplicação dos princípios e valores positivados na Constituição Federal”; c) o "Poder Judiciário teve suas funções ampliadas e dele se exige que desempenhe, finalmente, sua função política”; d) “o juiz do trabalho pode determinar medidas que impliquem obrigações para as partes e terceiros para assegurar a efetividade das decisões judiciais e a razoável duração do processo, ainda que não estejam expressamente requeridas”; e) “em face da inércia absoluta do legislador ordinário em regulamentar a matéria, o Juiz poderá efetivar o direito no caso concreto”392.

Interessa notar que, na abertura de referido evento, o discurso do presidente do TST, ao referir os temas que seriam debatidos, destacou que a "segurança jurídica” seria “fiadora da própria estabilidade econômica”. Advertiu ponderosamente, ainda, não ser desejável, “ante seus reflexos negativos para a magistratura e para a

\footnotetext{
392 Esse ativismo "associativo" não é novo, apesar de recentemente haver ganhado mais força. Nos idos de 2002, em congresso promovido pela Associação dos Magistrados do Trabalho da 22ª Região (Amatra XXII), o então presidente da Anamatra, Hugo Melo, tratou do tema "ativismo judicial como fenômeno transformador da sociedade", destacando "a posição dos magistrados na sociedade e seu relacionamento com os poderes político e econômico". Disponível em: www.tst.gov.br ("Notícias do TST”), publ. 27-09-02. Quatro anos depois, em 2006, José Nilton Pandelot, em seu discurso de posse, também fez menção a um "associativismo entre os Juízes do Trabalho" que daria substância a um "ativismo judicial trabalhista". Referia, inclusive, a necessidade de a associação promover lutas "em parceria com o TST, junto ao Congresso Nacional, pela superação obstáculos na aprovação dos projetos de lei que versam sobre a reforma do processo do trabalho, e que se encontram, incompreensivelmente, paralisados, enquanto os projetos que contemplam a lei processual civil foram aprovados e já entraram em vigor”, publ. 17-04-06. Discurso do presidente da Anamatra, José Nilton Pandelot. Notícias do TST, publ. 17-04-06, acesso em 10-03-11. Disponível em www.tst.jus.br.
} 
sociedade”, a adoção de decisões que, independentemente de seus fundamentos, tragam surpresas aos litigantes, “porque proferidas em contradição e, não raro, em confronto com as leis vigentes" ${ }^{393}$.

A propósito das colocações do ministro, importa não olvidar que, à época, palpitavam as discussões sobre a suspensão judicial de dispensas coletivas (1.1, supra). Aliás, note-se que outra comissão, naquele mesmo evento, havia aprovado entendimento de que "a dispensa coletiva, para que seja válida e legítima, demanda fundados motivos econômicos ou estruturais que ameacem inviabilizar de fato o funcionamento da empresa”, razão pela qual seria necessária “a submissão prévia de tais motivos, expostos pelo empregador, à consulta do ente representativo da categoria, ou, ao menos, à previsão em norma coletiva para legitimar a dispensa com efeitos coletivos”. Note-se que, indo além do próprio precedente da Justiça do Trabalho “fixado" no caso Embraer (5.2, infra), apontavam os juízes, no evento, que eventual descumprimento dos requisitos ali referidos levaria à “reintegração dos empregados dispensados”394.

No mesmo Congresso de magistrados, em painel sobre a "concretização dos direitos econômicos e sociais”, a problemática do ativismo judicial foi claramente relacionada à postura do Judiciário trabalhista no caso das dispensas coletivas ${ }^{395}$. O desembargador Gustavo Alkmin, da $1^{\text {a }}$ Região, demonstrava seu “descontentamento com a atuação do Tribunal Superior do Trabalho em relação aos direitos do trabalhador”, tendo em vista a concepção de que o juiz do trabalho deveria construir direitos em defesa do “emprego" e da "paz nas relações sociais e de capital”. Afirmava, nessa linha, a importância do ativismo judicial como instrumento de construção de direitos, como um “princípio que deve ter em mente a concretização da Constituição e a efetivação de direitos humanos e de proteção ao trabalhador”. Acrescentava o magistrado que a ausência desses vetores nas decisões judiciais implicaria um “ativismo judicial às avessas”, como estaria ocorrendo, segundo ele, em determinadas súmulas do TST, que teriam culminado com a alegada destruição de direitos.

Ademais, foi classificada como "ativista" a decisão da Justiça do Trabalho sobre os despedimentos coletivos no caso Embraer. A própria representante do

\footnotetext{
393 Ministro Moura França defende segurança jurídica. Notícias do TST. Disponível em www.tst.jus.br, publ. 29-04-10, acesso em 29-11-10.

394 As teses e demais informações sobre o evento estão disponíveis em: www.conamat.com.br/conamat, acesso em 10-11-10.

395 O texto é intitulado “Juiz e ministra divergem sobre ativismo judicial”, de 01-05-10, disponível em: www.anamatra.org.br, acesso em 10-05-10.
} 
TST, ministra Kátia Arruda, defendeu que o resultado do processo teria sido histórico, com posição “inovadora em nosso Direito”, por haver estabelecido a exigência da negociação prévia como requisito de validade das dispensas em massa ${ }^{396}$. Destacou, ainda, que a decisão se baseara em "interpretação integradora e principiológica do direito pátrio e também do direito comparado", apesar de não regulamentada “a previsão constitucional relativa à proibição de despedida arbitrária ou sem justa causa, nos casos de despedidas massivas, coletivas, que atingem, de uma vez só, centenas de trabalhadores”.

\subsubsection{Direito alternativo, uso alternativo do direito e manifestações}

\section{do potencial protagonismo judicial}

De um modo geral, as propostas de "uso alternativo do Direito" e de um “direito alternativo” têm suas vertentes imbricadas à proposta metodológica da Teoria Crítica, desenvolvida e desdobrada após estudos de Max Horkheimer (1895-1973) e do pensamento da Escola de Frankfurt, seguindo a tradição marxista de crítica da economia política ${ }^{397}$.

\footnotetext{
${ }^{396}$ Note-se que a ministra, no caso da Embraer, ficou vencida, ao lado do ministro relator no TST, no que tange à aplicação dos efeitos desse requisito de validade àquele caso concreto. Isso porque a corte, por maioria, entendeu necessário limitar os efeitos da decisão judicial, neste particular, a casos futuros, como veremos ao longo deste trabalho.

${ }^{397}$ Marcos Nobre leciona que o conceito foi proposto por Horkheimer em 1937, no texto "Teoria Tradicional e Teoria Crítica", data de 1937. A proposta de Horkheimer foi também conhecida como "materialismo interdisciplinar", já que, apesar de "valorizar a especialização em seus aspectos positivos", tentava "garantir uma certa unidade para os resultados das pesquisas" no âmbito das ciências humanas (economia, direito, ciência política, psicologia, entre outras). Essa unidade será alcançada pela referência à obra de Marx. "Há certamente muitos sentidos de 'crítica', na própria tradição da Teoria Crítica. Mas o sentido fundamental é de que não é possível mostrar 'como as coisas são' senão a partir da perspectiva de 'como deveriam ser': 'crítica' significa, antes de mais nada, dizer o que é em vista do que ainda não é mais pode ser. Note-se, portanto, que não se trata de um ponto de vista utópico, no sentido de irrealizável ou inalcançável, mas de enxergar no mundo real as suas potencialidades melhores, de compreender o que é tendo em vista o melhor que ele traz embutido em si”. O mesmo autor pondera que a relação entre a teoria crítica e a Escola de Frankfurt deve ser relativizada e investigada, transcendendo a mera referência aos nomes que participaram desses debates e sem olvidar que "ter a obra de Marx como referência, como horizonte comum, não significa partilhar dos mesmos diagnósticos e das mesmas opiniões”. Com efeito, “o desenvolvimento da teoria crítica mostra que havia acirradas divergências” entre os que participaram desses debates. Ademais, é característica fundamental da Teoria Crítica "ser permanentemente renovada e exercitada, não podendo ser fixada em um conjunto de teses imutáveis". Em outras palavras, "tomar a obra de Marx como referência primeira da investigação não significa tomá-la como uma doutrina acabada, mas como um conjunto de problemas e de perguntas que cabe atualizar a cada vez, segundo cada constelação histórica específica”. E, mais adiante, o autor esclarece um aspecto bastante presente no discurso da chamada teoria crítica do direito e dos movimentos do "direito alternativo" e do "uso alternativo do direito": "a atitude crítica não se volta apenas para o conhecimento, mas para a própria realidade das condições sociais capitalistas", e por isso "o comportamento crítico tem sua fonte na orientação para a emancipação relativamente à dominação vigente". MARCOS NOBRE. Teoria Crítica. $2^{a}$ ed., São Paulo: Zahar, 2004, pp. 9-23, p. 41. Desdobramento contemporâneo dessa linha de pensamento é a chamada Teoria Crítica dos Direitos Humanos. Sobre o tema, v. obra organizada por ALEJANDRO ROSILLO (org.). Teoria Crítica dos Direitos humanos no Século XXI.
} 
COELHO, ao investigar os antecedentes que teriam forjado uma "ambiência favorável ao pensamento crítico no seio da intelectualidade”, nota que, no Direito brasileiro, a orientação alternativista teve impulso inicial sob a influência de Luis Alberto Warat, Roberto Lyra Filho, Roberto Aguiar, entre outros juristas. Também teria influenciado aquela orientação o pensamento da chamada hermenêutica jurídica crítica, desenvolvido em universidades e em eventos da magistratura e do Ministério Público, sobretudo em Santa Catarina e no Rio Grande do $\mathrm{Sul}^{398}$.

Com essas bases, a ideia de uso alternativo do direito, no Brasil, adquiriu contornos próprios, consolidando-se no movimento do Direito Alternativo. O grupo de adeptos desse movimento, especialmente magistrados, em decisões judiciais e trabalhos teóricos produzidos ao longo da década de noventa, “punham declaradamente o direito acima da lei”, na descrição de COELHO. Posteriormente, a organização associativa desses magistrados resultou em adoção de posição política favorável aos hipossuficientes, consoante a bandeira do Direito do Trabalho. As premissas do movimento do Direito Alternativo, segundo o citado jurista, reconheciam que a lei vinha sendo "usada como instrumento de dominação"; que o texto legal não encerraria todo o direito; e, mais ainda, que existem leis injustas, cuja aplicabilidade pode ser recusada em nome de um compromisso superior, com a própria consciência e com a sociedade ${ }^{399}$.

Apesar de haver pontos de contato, seria possível distinguir, segundo COELHO, o "uso alternativo do direito” do “direito alternativo”. O primeiro constituiria o uso do direito qualificado como "hegemônico, identificado no direito positivo, para conseguir resultados não propriamente compatíveis, ou pelo menos não esperados por esse mesmo direito oficial”; o segundo, por sua vez, alude à “existência de um ordenamento, inserido ou paralelo ao direito hegemônico, mas que legitima o afastamento, a não observância ou mesmo a violação das normas desse direito" ${ }^{400}$.

Porto Alegre, EDIPUC, 2008. Na obra, há contribuições de vários juristas, v.g., Amilton Bueno de Carvalho, David Sánchez Rubio, Joaquín Herrera Flores, Juan Carlos Suárez e Salo de Carvalho.

${ }^{398}$ LUIS FERNANDO COELHO, Teoria Crítica do Direito, $3^{\mathrm{a}}$ ed. (revisada e ampliada). Belo Horizonte: Del Rey, 2003, p. 315.

${ }^{399}$ Segundo Coelho, a teoria do uso alternativo do direito foi divulgada no Brasil com base nas ideias de Lópes Calera (Espanha), Pietro Barcelona (Itália), Jean Arnaud e Michel Miaille (França). Ademais, além da "influência exercida pelo movimento italiano da Magistratura Democrática, tiveram intensa repercussão na América Latina os textos produzidos pela Associacion Critique Du Droit” (LUIS FERNANDO COELHO, op.cit., pp. 321-330).

${ }^{400} \mathrm{O}$ autor, apesar de comungar das ideias fundamentais do grupo, critica a utilização do termo alternativo, "seja como uso alternativo, dos juristas europeus, seja como direito alternativo", e prefere referir, simplesmente, à "crítica do direito" (LUIS FERNANDO COELHO, op.cit., pp. 330-332). Para aprofundamento, v., entre outros autores, GOFFREDO DA SILVA TELLES JÚNIOR, "O chamado direito alternativo”, in: Revista da Faculdade de Direito da USP, São Paulo, vol. 94, 1999, pp. 73-80; EDMUNDO 
Os ideais de uma e de outra vertente sob exame, entretanto, não são novos, já que vinculados à antiga tradição ocidental de luta pela justiça, pela liberdade e pela igualdade. A novidade residiria apenas em seu contexto e no "fôlego daqueles que abandonaram o conformismo com o status quo”, como resume LOPES. Para o jurista, o movimento sob exame deve ser encarado de dois pontos de vista distintos. Primeiro, como uma "tentativa de resposta às questões que foram trazidas pelo próprio desenvolvimento social brasileiro” (acesso ao Judiciário, litigiosidade entre grupos desiguais econômica e socialmente, confronto com políticas públicas, etc.) e que "não foram suscitadas pelos profissionais do direito ou pelos juízes em primeiro lugar”. Elas teriam sido judicializadas “como reivindicações inadiáveis das massas marginalizadas, embora certamente através de grupos pioneiros”. Segundo, como uma oportunidade de discutir questões políticas (relacionadas ao poder de julgar, a seus limites e à sua função social) e metodológicas (concernentes à concepção de direito, a seu fundamento racional e à necessidade de juristas serem formados de maneira nova e diversa, com maior interdisciplinaridade no seu saber e com mais abertura para o universo social em que vão atuar, sem olvidar, ademais, um maior rigor na sua própria disciplina) $)^{401}$.

Em suma, por suas formas de manifestação, tanto o chamado movimento do direito alternativo quanto o uso alternativo do direito, independente de quaisquer de seus méritos ou deméritos, representaram manifestações (com vários de seus traços) de um potencial protagonismo judicial no Brasil.

LIMA DE ARRUDA JUNIOR (coord). Lições de direito alternativo. São Paulo: Acadêmica, 1992; AMILTON BUENO DE CARVALHO, SALO DE CARVALHO (org.), Direito alternativo brasileiro $e$ pensamento, $1^{\text {a }}$ ed., Rio de Janeiro: Lumen Iuris, 2004. AMILTON BUENO DE CARVALHO. Direito Alternativo. Teoria e Prática. $5^{a}$ ed., Rio de Janeiro: Lumen Iuris, 2004; LÉDIO ROSA DE ANDRADE. Introdução ao Direito Alternativo Brasileiro. $1^{\text {a }}$ ed., Livraria do Advogado, 1996. Na época em que os debates sobre o tema eram bastante acirrados, Lopes notava que pesavam sobre o movimento do direito alternativo no Brasil "algumas definições, dadas por seus opositores em geral", que mereceriam atenção pelo debate teórico que suscitavam e pelas implicações práticas traziam. Em estudo sobre essas definições, ressaltava que“(...) uma diz que o direito alternativo nada mais é do que uma recuperação tardia da Escola Histórica, ou da Escola do Direito Livre. Outra afirma que o direito alternativo põe em risco o fundamento do Estado Democrático de Direito, ao praticamente abolir o princípio da legalidade. Outra diz respeito à parcialidade dos adeptos do direito alternativo”. Examinando a consistência de tais críticas, Lopes identificava precedentes do direito alternativo não na Escola Histórica, nem na Escola do Direito Livre, mas em algumas vertentes das escolas do direito natural, dada sua inserção política. JOSÉ REINALDO DE LIMA LOPES, op.cit., pp. 255-257. Em relação às manifestações do Direito Alternativo no Direito do Trabalho, v. CARLOS ARTUR PAULON. Direito Alternativo do Trabalho. São Paulo: LTr, 1984; ROBERTO LYRA FILHO. Direito do Capital e Direito do Trabalho. Porto Alegre: Sérgio Antônio Fabris, 1982.

${ }^{401}$ JOSÉ REINALDO DE LIMA LOPES, op.cit., pp. 260-263. 


\title{
CAPÍTULO 4
}

\section{ATIVISMO JUDICIAL: TIPOS IDEAIS}

\begin{abstract}
Sumário: 4.1 Objetivos do capítulo; 4.2 Esclarecimentos complementares sobre a construção dos tipos ideais de ativismo judicial; 4.3 Tipos ideais de ativismo judicial; 4.3.1 Ativismo judicial contramajoritário; 4.3.2 Ativismo judicial jurisdicional; 4.3.3 Ativismo judicial promocional; 4.3.4 Ativismo judicial criativo; 4.3.5 Ativismo judicial de padronização decisória; 4.3.6 Ativismo judicial em face de precedentes; 4.3.7 Ativismo judicial contra legem; 4.3.8 Ativismo judicial processual; 4.3.9 Ativismo judicial extraprocessual.
\end{abstract}

\subsection{Objetivos do capítulo}

Ao longo deste trabalho, foram examinados os principais aspectos e desdobramentos da juridificação que culminaram, nas experiências democráticas ocidentais, com a expansão do potencial protagonismo judicial. Além disso, pela problematização de diferentes noções de ativismo judicial, foi possível identificar, nas várias manifestações concretas daquele potencial, uma série de ingredientes empíricos relevantes para a construção de tipos ideais, conforme metodologia weberiana ${ }^{402}$.

Com efeito, a apreensão dos vários tipos de manifestação desse potencial pode ser realizada por intermédio de tipos puros de ativismo judicial, cada qual com seu objeto bem definido. Com a construção desses tipos, poder-se-á não só examinar a incidência do ativismo judicial na Justiça do Trabalho, mas também contribuir com os debates sobre o labor judicial, inclusive para futuros estudos que partam, em diálogo com essas proposições, para a elaboração de outras perguntas sobre a função judicial em seus moldes contemporâneos, as dificuldades que ela enfrenta e as mudanças pelas quais ela tem passado.

${ }^{402}$ Cf. tópico 1.2.3, supra. 


\subsection{Esclarecimentos complementares sobre a construção dos tipos} ideais de ativismo judicial

Como foi visto, os pressupostos desta tese separam o agir judicial (antecedido de um potencial) de questões como a metodologia decisória, as técnicas interpretativas, a ideologia do juiz, entre outros aspetos. Assim, enfatiza-se, na construção dos tipos, o agir em si, bem como o objeto ao qual esse agir transita. Essas proposições têm uma série de consequências.

Primeiro, a construção de tipos ideais não se baseou na suposição de que haja metodologias decisórias adequadas ou inadequadas, técnicas interpretativas legítimas ou ilegítimas, doutrinas boas ou ruins. Não relacionamos, portanto, os critérios de identificação do ativismo judicial à interpretação constitucional ou à chamada teoria dos princípios. Nessa mesma linha, não se associou nenhum tipo de ativismo judicial a tendências políticas ou ideológicas (liberalismo, neoliberalismo, conservadorismo, esquerdismo, direitismo), nem a linhas de pensamento como o originalismo, o textualismo ou o interpretativismo. Também não se afirma que os tipos se vinculam ao pensamento positivista, pós-positivista, realista, moralista ou neoconstitucionalista. Trata-se de opção metodológica ${ }^{403}$ que não pressupõe nem sugere o abandono do positivismo jurídico. Falar em tipos ideais de ativismo judicial também não significa supor que condutas concretas nas quais eles possam ser identificados seriam absolutamente irrepreensíveis do ponto de vista da dogmática jurídica.

Segundo, poderão ser distintos os resultados almejados por determinada decisão e os resultados efetivamente alcançados por ela. Dada essa possibilidade de frustração de expectativas, não parece possível definir até que ponto uma decisão deveria ser apenas jurídica e até que ponto poderia o juiz adotar postura mais preocupada com os resultados. Assim, se praticar determinado tipo de ativismo judicial em relação a um objeto pode ser justificável pela perspectiva jurídica; não praticá-lo (em relação a esse mesmo objeto) pode ser também defensável pela perspectiva socioeconômica ou política. Isso reforça a proposição de que os resultados do ativismo judicial escapam em boa medida do controle do órgão que age, notadamente se seus critérios decisórios são exclusivamente jurídicos. A percepção de possibilidades decisórias cada vez mais numerosas e a

\footnotetext{
${ }^{403}$ Esclarecida no tópico 1.2, supra.
} 
impossibilidade de determinar "respostas certas" a priori tende a tornar impreciso qualquer critério de identificação do ativismo judicial que suponha o contrário ${ }^{404}$. Como corolário, as concepções que se seguem não supõem que o ativismo judicial dependeria de uma ou de outra forma de conceber a metodologia decisória ou a hermenêutica legal ou constitucional. Em outras palavras, a identificação do ativismo judicial não depende, neste trabalho, da percepção subjetiva a respeito da correção ou da incorreção do uso de determinada concepção metodológica sobre a atividade decisória. Isso não quer dizer que o aspecto metodológico-decisório seja irrelevante, especialmente quando aferíveis, na fundamentação da decisão, os critérios nos quais se baseia um julgamento. Sem dúvida, a fundamentação da decisão pode revelar não só os escrúpulos do julgador no que tange à necessidade de legitimar suas decisões e de dialogar com a cultura jurídica de seu tempo, mas também a orientação preponderante do magistrado do ponto de vista das éticas da conviç̧ão e da responsabilidade (2.2.4.1, supra).

Terceiro, a distinção entre o ativismo judicial e a autocontenção parece ser útil para demonstrar que um magistrado pode agir em relação a um objeto determinado (um quid) da mesma forma que pode optar por não fazê-lo ${ }^{405}$. Todavia, essa autocontenção em face de certo quid pode ser interpretada como uma conduta ativista em face de outro quid. Afinal, já se disse que optar por não optar é, em essência, fazer uma escolha, de modo que, ao não intervir, um juiz não faz nada além de reforçar a política existente, e isto, indiretamente, pode também ser visto como uma forma de ativismo ${ }^{406}$. Desse modo, tudo depende da identificação dos vetores da decisão do magistrado, vale dizer, os valores éticos e políticos que a decisão consagra em detrimento de outras escolhas valorativas possíveis $^{407}$. Não se pode afirmar, consequentemente, que haveria uma forma ou outra de jurisdição absolutamente não ativista. Nossa preocupação, portanto, é menos a de identificar uma postura não ativista, e mais a de observar as formas mais proeminentes de manifestação de um potencial protagonismo judicial, pondo em destaque os seus objetos. Advirta-se que o espectro de tal potencial, pela complexidade de sua substância, pode não se encerrar necessariamente nos pontos descritos nesta tese. Como corolário, os tipos adiante examinados constituem um minimum minimorum, com base nos aspectos e desdobramentos da juridificação examinados no capítulo 2 e nos fenômenos observados

\footnotetext{
${ }^{404}$ Cf. tópico 2.2.4, supra.

${ }^{405}$ Cf. tópico 1.2.1, supra. Na introdução, esclarecemos o porquê de isto não se relacionar a um non liquet.

${ }^{406}$ Cf. nota 23, supra.

${ }^{407}$ Cf. tópico 3.2.2, supra.
} 
nas reflexões do capítulo 3. Não sobeja relembrar, a propósito, que a construção de tipos ideais à moda de Weber implica sempre uma apreensão parcial, e não total, da realidade.

Quarto, é importante registrar que dificilmente um órgão judicial pratica o ativismo judicial sem nenhum suporte na cultura social e jurídica de seu povo. Com efeito, há concepções mais ou menos arraigadas na experiência jurídica na qual o julgador se insere, de modo que, em geral, a atuação concreta do potencial protagonismo judicial costuma dialogar com esses padrões éticos e valorativos. Assim, o ativismo judicial dificilmente seria associado à "extrema injustiça” ou a "suma justiça”, cujos critérios de percepção tendem a ser claros e a estar presentes não só na ordem jurídica, mas no imaginário e na conduta das pessoas. Ademais, na prática do ativismo judicial, o julgador tende a dialogar com a postulação, o que pressupõe, da parte daquele que estiver demandando, um mínimo de consciência a respeito dos contornos jurídicos de determinada pretensão. Como foi visto, entretanto, esses contornos costumam ser facilmente visualizáveis num cenário sobrejuridificado.

Por fim, os tipos relacionados à atividade jurisdicional stricto sensu podem ser percebidos, na prática judicial, em vários momentos da tramitação de um mesmo processo. Sua aferição, desse modo, não ocorre exclusivamente pelo resultado que prevaleceu após o esgotamento das vias recursais. Em outros termos, mesmo as decisões que antecipem tutelas, promovam medidas cautelares ou modifiquem o curso do processo são de observação relevante para a compreensão da atuação dos órgãos judiciais.

Como se vê, essas ponderações se dirigem mais especificamente à manifestação do potencial protagonismo judicial que ocorre no âmbito da jurisdição stricto sensu (ou como decorrência desse papel do Poder Judiciário). Todavia, a incidência do ativismo judicial pode ser diagnosticada fora do contexto processual ou jurisdicional.

\subsection{Tipos ideais de ativismo judicial}

\subsubsection{Ativismo judicial contramajoritário}

Trata-se de um dos tipos mais antigos de manifestação do potencial protagonismo judicial. Não obstante seja ele comum na experiência norte-americana desde o início do século XIX, sua ocorrência se tornou perceptível noutros países à medida que, 
com a evolução da juridificação, mecanismos de controle de constitucionalidade foram mutatis mutandis adotados e ampliados ${ }^{408}$.

O ativismo judicial contramajoritário é identificável em decisões judiciais que considerem inconstitucionais determinados atos ou omissões dos Poderes Legislativo e Executivo, instituições estruturadas democraticamente pela regra da maioria. Assim, ele se manifesta na proclamação contramajoritária que considere inconstitucional certa postura estatal (comissiva ou omissiva). Com isso, elide-se a presunção de conformidade dessas posturas em relação à Constituição. Considerando que todos os tipos de ativismo judicial são formas de concretização de um potencial protagonismo judicial, pode-se afirmar que, em razão daquela presunção, um órgão judicial poderia não reconhecer a inconstitucionalidade em certo caso concreto. Desse modo, não seria de relevância prática, para a aferição do tipo, a distinção entre casos difíceis (inconstitucionalidade "flagrante”), casos fáceis (inconstitucionalidade "patente”) e casos intermediários (“inconstitucionalidade discutível” ou “questionável”) 409.

Examina-se, apenas, na identificação do tipo ideal sob exame, o ato do órgão judicial que proclama o resultado contramajoritário, reconhecendo a inconstitucionalidade (em caráter principal ou incidental). Evitam-se, com isso, avaliações que dependam dos “olhos do observador”, i.e., da maneira pela qual quem discursa sobre o tema entende a Constituição ou concebe o papel do Poder Judiciário ${ }^{410}$.

No que concerne ao controle da postura comissiva do Estado, o ativismo judicial contramajoritário ocorre, na forma concentrada, por meio do reconhecimento da inconstitucionalidade do ato atacado, que perde, parcial ou totalmente, seu fundamento de validade $^{411}$. Já na forma difusa, o reconhecimento da inconstitucionalidade é incidental, mas decisivo para o resultado do litígio, de modo que pode ocorrer tanto no julgamento de processos em que se examinem pretensões em face do Estado e suas instituições; quanto na

\footnotetext{
${ }^{408}$ Cf. tópicos 2.2.3 e 2.2.6, supra.

${ }^{409}$ Cf. tópico 3.2.2, supra.

${ }^{410}$ Cf. tópicos 2.2.4 e 3.2.2, supra.

${ }^{411}$ No caso de esse reconhecimento incidir sobre atos normativos, sem implicar a eliminação ou redução de seu texto (mas apenas a neutralização de interpretações consideradas incompatíveis com a Constituição), o que ocorreria, mais claramente, não obstante os traços contramajoritários, seria outro tipo de ativismo, a seguir examinado, dirigido à padronização decisória. Cf. tópico 4.3.5, infra. Note-se que um tipo ideal é construído pela abstração e combinação de um indefinido número de elementos que, embora encontrados na realidade, são raramente descobertos nesta forma pura. Um tipo ideal não é, assim, nem uma descrição de um aspecto definido da realidade, nem uma hipótese; mas pode ajudar tanto na descrição quanto na explicação. Cf. tópico 1.2.3.
} 
solução de litígios entre particulares nos quais haja questão incidental de natureza constitucional.

No que tange ao controle da postura omissiva do Estado, o ativismo judicial contramajoritário enfoca o descumprimento do dever estatal de praticar determinado ato (prestações positivas, legislar, regulamentar determinado direito, etc.). Na forma concentrada, declara-se a inconstitucionalidade da omissão como uma espécie de admoestação ao órgão inerte, que então é exortado, sem caráter obrigatório, a suprir a lacuna. Todavia, o órgão judicial ativista (no sentido contramajoritário), além de tal admoestação, poderá dirigir seu potencial protagonismo à prática de outros tipos de ativismo judicial. Ilustrativamente, se além da admoestação pela omissão o próprio Poder Judiciário suprir a falta do ato, pode haver, se a lacuna colmatada for normativa, um

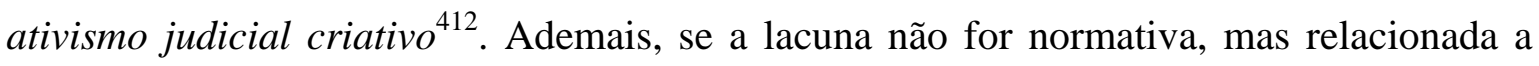
prestações estatais, o suprimento determinado constituiria um ativismo judicial promocional $^{413}$. Na forma difusa, a alegação da inconstitucionalidade da omissão é sempre pressuposto de um pedido cujo deferimento depende do reconhecimento incidenter tantum daquele vício, de modo que, nessa modalidade, tenderá também a se combinar com outros $\operatorname{tipos}^{414}$.

A ocorrência desse tipo de ativismo judicial tende a ser considerada, em muitos casos, antidemocrática, violadora do princípio da "separação de poderes" e indicativa da judicialização da política ou de questões políticas ${ }^{415}$.

\subsubsection{Ativismo judicial jurisdicional}

O ativismo judicial jurisdicional tem estrutura que, metaforicamente, poderia ser caracterizada como pendular, por se revelar na conduta judicial que ora amplia, ora reduz, num caso concreto, os limites dos poderes que os órgãos judiciais considerem possuir. Mais especificamente, modificam-se, por seu intermédio, num caso concreto, os

\footnotetext{
${ }^{412}$ Cf. tópico 4.3.4, infra.

${ }^{413}$ Cf. tópicos 4.3.3, infra; 2.2.9, supra. Importa observar que o ativismo judicial promocional não depende, necessariamente, da existência de um controle de constitucionalidade. Cf. tópico 2.2.9.1, supra.

${ }^{414}$ Consoante exposição no tópico 1.2.3, os tipos de ativismo judicial tendem a se misturar no real, de modo que, para identificá-los, devemos definir cada um deles.

${ }^{415}$ Cf. tópicos 1.2.5, 3.2.2, 3.3, 3.4.1 e 3.4.1.1, supra.
} 
entendimentos sobre variáveis como a justiciabilidade de determinados direitos e sua receptividade processual $^{416}$.

Como se vê, alterações nessas variáveis provocam um avanço ou um recuo das fronteiras da atuação judicial, modificando-se, desse modo, a chamada agenda judicial. Isso pode ocorrer em todos os órgãos judiciais, singulares ou colegiados, independentemente do grau de jurisdição.

Por intermédio do ativismo judicial jurisdicional, a ampliação da agenda judicial ocorre não só quando os órgãos judiciais ingressam em campos temáticos em relação aos quais ainda não houve decisões, mas também na hipótese de esses órgãos passarem a reapreciar questões cujo exame fora abandonado no passado. Esse "abandono" corresponde à redução da agenda judicial, verificável pela retirada de determinado tema do espectro de questões normalmente apreciadas no mérito (favoravelmente ou não) pelo órgão judicial. Tanto a postura de deixar de examinar o mérito de determinadas postulações (como consequência do não recebimento das demandas) que antes vinham sendo apreciadas quanto a reincorporação futura desse exame à agenda judicial envolveria também um ativismo em face de precedentes ${ }^{417}$.

O potencial protagonismo judicial que se manifesta no ativismo judicial jurisdicional será tanto maior quanto mais indeterminadas ${ }^{418}$ forem as normas definidoras do direito postulado, da competência do órgão judicial e das variáveis processuais de recepção de demandas ${ }^{419}$, inclusive no que diz respeito ao grau de controle, pelo órgão judicial, de sua própria agenda ${ }^{420}$.

O simples fato de a demanda haver sido recebida e de seu mérito haver sido discutido implica a incorporação, pela agenda judicial, de um conflito que antes era relevante apenas no plano sociológico, político ou econômico. Essa incorporação pode fomentar tanto novas demandas (especialmente se a postulação houver logrado êxito) quanto a construção de tendências jurisprudenciais, seja pela rejeição das postulações, seja por seu acolhimento. Importa notar que, sobretudo no caso de litígios de interesse público,

\footnotetext{
${ }^{416}$ Importantes, para a compreensão deste tipo, em especial, os tópicos 1.3, 2.2.1, 2.2.2, 2.2.3, 2.2.9, 2.2.9.1, 2.3.2 e 3.2.2, supra. Entre as variáveis processuais, trata-se de questões como competência, condições da ação, pressupostos processuais e institutos como o standing.

${ }^{417}$ Cf. tópico 4.3.6, infra.

${ }^{418}$ Cf. tópico 2.2.1, supra. Como foi visto, essas características tendem a se intensificar como desdobramento da crescente juridificação das relações sociais.

${ }^{419}$ Cf. reflexões constantes dos tópicos 2.2.9.1, 2.2.9.2 e 3.2.2, supra.

${ }^{420}$ Cf. tópicos 2.3.2 e 2.2.7.1, supra.
} 
a ampliação da agenda judicial tende a ser patrocinada, estrategicamente ou não, por estruturas de suporte à mobilização jurídica, estatais ou não estatais ${ }^{421}$.

Ademais, indícios de que o ativismo judicial jurisdicional será confirmado em decisão final podem ser aferidos no momento da não recepção ou da recepção (inclusive com eventual tutela antecipatória) de determinada demanda. É relevante notar que, apesar de sua confirmação só ocorrer com a decisão final, eventual ampliação da agenda tende a produzir efeitos relevantes ao longo do processo (sociológicos, políticos, midiáticos, etc.).

A ampliação da agenda judicial pelo ativismo judicial jurisdicional tende a possibilitar a incidência, no mesmo caso, de outros tipos de ativismo judicial.

\subsubsection{Ativismo judicial promocional}

O ativismo judicial promocional se dirige ao controle da efetividade dos direitos fundamentais individuais (direitos civis e políticos - liberdades negativas) e da implementação de direitos sociais (direitos econômicos e sociais - liberdades positivas).

No caso das liberdades negativas, não se trata pura e simplesmente de garantir judicialmente a abstenção estatal, mas de determinar que o Estado atue para garantir as precondições do exercício de direitos fundamentais, i.e., para que se façam presentes os pré-requisitos normativos ou materiais para sua fruição, o que transcende a vontade exclusivamente individual. No que tange às liberdades positivas, trata-se especificamente das demandas por justiça material juridificadas conforme o modelo de Estado Social e Democrático de Direito. Pode-se dizer, inclusive, que a incidência da perspectiva prestacional sobre as liberdades negativas decorreria, igualmente, desse modelo de Estado-Providência ${ }^{422}$. Nessa linha de raciocínio, o ativismo judicial promocional ocorre: a) no momento em que o órgão judicial, mediante provocação adequada, determina ao Estado a realização de certos atos de um modo específico, seja para corrigir condutas estatais judicialmente havidas por desviantes, seja para suprir omissões $^{423}$; b) no acompanhamento da execução das determinações judiciais com esses

\footnotetext{
${ }^{421}$ Cf. tópicos 2.2.9, 2.2.9.1, 2.2.9.2, 2.3.2, 2.3.3.2, supra.

${ }^{422}$ Cf. tópicos 2.2, 2.2.2, 2.2.7.2, 2.2.7.4, 2.2.9, 2.3.1 e 2.3.2, supra.

${ }^{423}$ Se essas omissões forem normativas, pode haver, neste átimo, a incidência do ativismo judicial criativo (tópico 4.3.4, infra). É que o ativismo judicial promocional pode depender do esclarecimento judicial do significado de um direito, o que envolve a fixação de parâmetros para sua fruição e um regime de regulação ad futurum das relações entre os interessados, inclusive os ausentes.
} 
fins, hipótese em que o órgão judicial funciona como um supervisor da postura estatal até o momento em que ela for considerada regular ${ }^{424}$; c) no átimo em que determinada medida postulada em juízo é concedida concretamente, após o reconhecimento do nexo entre a conduta estatal omissiva, desviante ou insuficiente, de um lado, e a falta de efetividade do direito, de outro lado ${ }^{425}$.

Percebe-se que o ativismo judicial promocional pode ocorrer em processos nos quais figurem como réus entes estatais ou apenas particulares. Neste último caso, o objeto do processo é a discussão de uma obrigação que seria imposta ao réu caso o Estado não houvesse se mostrado omisso ${ }^{426}$. Assim, mesmo quando um ente estatal não figurar no polo passivo, o tipo de demanda que leva o Poder Judiciário a esse tipo de manifestação do potencial protagonismo judicial não se funda num conflito entre particulares com interesses meramente privados. Isso porque, em todos esses processos, figurando o Estado como réu ou não, a percepção da juridicidade do descontentamento do demandante no que tange à postura estatal (omisso diante de cenários desfavoráveis à fruição de direitos individuais; negligente em relação à inexistência ou ao mau funcionamento de políticas públicas; imprevidente no que toca à regulamentação de determinados assuntos) é determinante para a adoção das providências judiciais.

Conquanto possua traços contramajoritários ${ }^{427}$, a ocorrência do ativismo judicial promocional não depende necessariamente da existência de instrumentos de controle de constitucionalidade ou de exaustivas previsões de direitos fundamentais (sejam individuais, sejam sociais) num texto constitucional ${ }^{428}$. Com efeito, fomentado em geral pela litigância de interesse público, que canaliza demandas de coletividades e grupos representados por atores sociais que integrem uma estrutura (estatal ou não estatal) de suporte à mobilização jurídica ${ }^{429}$, as postulações, estratégicas ou não, podem ser fundadas

424 Cf. tópico 3.2.2, supra. O ativismo judicial promocional adquire, nesses casos, um caráter de "terapêutica” judicial dirigida à correção da omissão ou da atuação desviante ou insuficiente de outros Poderes (ações afirmativas dos direitos de "minorias” e de coletividades marginalizadas, intervenção em políticas públicas, imposição de reformas em hospitais e estabelecimentos prisionais, etc.). Desse modo, o ato do julgamento não encerra, pura e simplesmente, a participação da autoridade judicial no caso e em suas questões subjacentes, cuja administração exige a contínua participação do Judiciário

${ }^{425}$ Isso pode envolver, inclusive, o reconhecimento de uma omissão inconstitucional. Cf. tópico 4.3.1, supra. Ilustrativamente, pode-se evocar os casos envolvendo o direito à saúde, cf. tópico 2.3.2, supra.

${ }^{426}$ Em outros termos, a conduta desses particulares seria outra se determinados direitos houvessem sido implementados ou se estivessem presentes as precondições de seu exercício. Cf. tópico 1.1, supra; e 5.2, infra.

${ }^{427}$ Cf. tópico 4.3.1, supra.

${ }^{428}$ Cf. tópico 2.2.9.1, supra.

${ }^{429}$ Com efeito, trata-se de atores cuja função é a de substituir ou de representar coletividades e grupos a fim de superar óbices das mais variadas ordens que impedem o acesso ao Judiciário (operacionais, culturais, 
nos mais variados e amplos repertórios normativos. Num cenário de expansão dos padrões regulatórios, aumento da indeterminação do direito e ampla materialização do direito formal, esse ativismo judicial promocional (sem olvidar a contribuição retórica da própria postulação) pode ser fundamentado em regras e princípios existentes em Constituições, em leis (notadamente aquelas cujos dispositivos possuam noções abertas, cláusulas gerais e noções indeterminadas) e em normas internacionais e comunitárias sobre direitos humanos. Não é incomum, ainda, o uso de conceitos-chave que, pela criatividade jurisprudencial ${ }^{430}$, parecem adquirir contornos normativos na prática decisória (mínimo existencial, reserva do possível, proporcionalidade, razoabilidade, entre outras noções essencialmente éticas e valorativas) ${ }^{431}$.

Referir o atributo promocional desse tipo de ativismo judicial poderia levar à afirmação precipitada de que a tutela oferecida ocorreria sem qualquer restrição ao direito tutelado ou a outro que, num caso concreto, esteja em jogo. Sucede que a tendência a um grande aumento de colisões entre direitos fundamentais tende a levar à restrição de um ou de outro quando isto for considerado necessário ${ }^{432}$.

Os processos nos quais se pratica o ativismo judicial promocional, notadamente em relação às chamadas políticas públicas, tendem a ser de alta complexidade, o que dificulta o trabalho cognitivo e decisório do magistrado. Em geral, o problema é resolvido pela perspectiva exclusivamente jurídica, o que não garante que, no plano dos fatos, o provimento jurisdicional alcançará os efeitos almejados, nem permite supor que a solução judicialmente imposta seria necessariamente a melhor ${ }^{433}$. Os melhores resultados, sem dúvida, são antecedidos dos mais amplos debates públicos, o que pode

políticos, sociais, econômicos). Esses atores (representantes adequados, substitutos processuais, legitimados autônomos e figuras análogas), sobretudo quando instituídos pelo Estado, podem ser investidos de poderes de promoção extrajudicial da solução de conflitos casos. Todavia, quando não logram êxito nessa tentativa compositiva não adjudicatória, tendem a recorrer ao Poder Judiciário. Mesmo que não haja uma estrutura de suporte, há casos de ativismo judicial promocional antecedido de um ativismo judicial extraprocessual, praticado pelo próprio Poder Judiciário (caso indiano) para sinalizar a abertura a determinadas demandas. Todavia, a ausência de uma estrutura (seja ela estatal ou não estatal) de suporte à mobilização jurídica ou o seu não surgimento após um primeiro impulso traz dificuldades à manutenção do movimento. Cf. tópico 2.2.9.1, supra.

${ }^{430}$ Cf. tópico 4.3.4, infra.

${ }^{431}$ Cf. tópicos 2.2.1, 2.2.2, 2.2.3, 2.2.7, 2.2.7.2, 2.2.7.3. 2.2.7.4 e 2.2.9.2, supra.

${ }^{432}$ Cf. tópico 2.2.7.2, supra. Por esse motivo, evitamos afirmar que haveria, em "oposição" a um ativismo judicial promocional, um ativismo judicial restritivo ou "não promocional". De certa maneira, o ativismo judicial promocional teria uma estrutura complexa, já que ao mesmo tempo em que dá mais concretude a certos direitos, tende a restringir outros.

${ }^{433}$ Cf. crítica constante do tópico 3.4.3, supra. 
ocorrer inclusive no âmbito do processo, de forma a garantir uma decisão que, na medida do possível, combine as éticas da convicção e da responsabilidade ${ }^{434}$.

Vê-se, dessarte, o porquê de esses processos (que em geral envolvem, diretamente ou indiretamente, interesses metaindividuais) apresentarem regras e princípios específicos que conferem ao órgão judicial poderes ainda mais amplos de condução, em consonância com o ideário alargado do juiz ativo (reconhecimento do processo como instituição pública de bem estar social, promoção preferencial de soluções não adjudicatórias, adequação aos litígios de massa). Destarte, surge um cenário propício a que o ativismo judicial promocional se combine a um ativismo judicial processual, fomentado por aquele ideário ${ }^{435}$.

No âmbito dos processos em que possa se manifestar o ativismo judicial promocional, notadamente quando se tratar de litígios de interesse público, mesmo as decisões desfavoráveis no mérito podem desencadear importantes respostas jurídicas e não jurídicas por parte dos que estão diretamente ou indiretamente envolvidos com o litígio, com resultados sociais, políticos e econômicos relevantes ${ }^{436}$.

Historicamente, o ativismo judicial promocional passou a ocorrer como um dos reflexos do quarto surto de juridificação, correspondente ao Estado Social e Democrático de Direito. Nos EUA e na Europa, esse tipo de ativismo judicial passou a se manifestar a partir da segunda metade do século XX; e, no Brasil, tornou-se perceptível após a Constituição de $1988^{437}$.

Em suas primeiras manifestações, o ativismo judicial promocional tende a estar associado a um ativismo judicial jurisdicional ${ }^{438}$ e a um ativismo judicial em face de precedentes ${ }^{439}$. Com efeito, o órgão judicial, para examinar pela primeira vez o mérito de um processo sobre certo tema, precisa reavaliar as variáveis de recepção da demanda,

\footnotetext{
${ }^{434}$ Cf. tópico 2.2.4.1, supra.

${ }^{435}$ Cf. tópico 2.2.8, 2.2.8.2 (supra) e 4.3.8, infra.

${ }^{436}$ Cf. tópico 2.2.9.1, supra. No tópico 1.1 ofereceu-se exemplo de um caso que parece haver provocado, não obstante os resultados finais muito aquém das postulações, importantes efeitos políticos, sociais, midiáticos, etc. O caso será examinado (com base nos tipos ideais ora construídos), no item 5.2, infra. Sobretudo em processos que envolvam interesses metaindividuais, a dimensão social, econômica e política a eles subjacente é mais visível, de modo que seu estudo seria deficiente se fosse limitado ao exame da procedência ou da improcedência dos pedidos. Com efeito, quando essas demandas são adequadamente planejadas e alcançam o objetivo de serem reconhecidas, podem ter tanto um impacto imediato quanto um efeito a ser sentido no longo prazo, em especial quando se examina o comportamento dos atores políticos.

${ }^{437}$ Quanto a essa cronologia, v. tópicos 2.2, 2.2.2, 2.2.3, 2.2.9, 2.3.1 e 2.3.2, supra.

${ }^{438}$ Cf. tópico 4.3.2, supra.

${ }^{439}$ Cf. tópico 4.3.6, infra.
} 
inclusive para superar precedentes anteriores que hajam consolidado um entendimento contrário a essa recepção ${ }^{440}$.

O tipo sob exame é um dos indicativos da ambiguidade contemporânea da função judicial ${ }^{441}$ e, de uma perspectiva mais ampla, da crise da divisão funcional dos poderes $^{442}$.

Mesmo que se costume afirmar que o Poder Judiciário seria o órgão menos competente para estabelecer soluções de longo prazo e de longo alcance (seja para garantir precondições necessárias à fruição de direitos fundamentais individuais, seja para implementar direitos sociais e políticas públicas neles fundadas), não se duvida de que, em muitos momentos históricos, a provocação adequada de órgãos judiciais para que praticassem um ativismo judicial promocional deu ensejo a transformações sociais e políticas que, sem essa intervenção, talvez levassem muito tempo para se iniciar ${ }^{443}$.

\subsubsection{Ativismo judicial criativo}

Como foi visto, a intensificação da juridificação das relações sociais levou à expansão do potencial protagonismo judicial também no que concerne às possibilidades de participação do Poder Judiciário na criação do direito. Essa criação, em geral, ocorre num amplo espaço aberto pela "indeterminação" dos textos normativos e pelo largo alcance de normas que contemplam demandas por justiça material. Tais fatores, pelas repercussões sobre a atividade judicante, indicam o enfraquecimento do modelo subsuntivo e o fortalecimento da função pragmática da hermenêutica jurídica ${ }^{444}$.

A desconstrução da ficção da não criatividade judicial, corolário dessas constatações, poderia levar à suposição de que toda decisão judicial envolveria o tipo sob exame, já que, de certa maneira, ao aplicar a norma ao caso concreto, o juiz participa de sua criação.

\footnotetext{
${ }^{440} \mathrm{Na}$ verdade, os fatores de desencadeamento do ativismo judicial promocional se inserem em processo complexo que não se resume às oportunidades concedidas pela constituição ou pela postura judicial "esperada” pelos litigantes com base na independência do Judiciário ou naquilo que diz a lei. Muitas vezes a aceitação judicial dessas postulações vem antecedida de longo período de resistência; ou, ao contrário, um período de receptividade judicial pode ser sucedido por outro de rejeição a essas demandas, o que se costuma classificar como "retrocesso".

${ }^{441}$ Cf. tópico 2.3.2, supra.

${ }^{442}$ Cf. tópico 2.2.3, supra.

${ }^{443}$ Cf. tópico 2.2.9.1, 3.2.2, 3.4.1.1, supra.

${ }^{444}$ Cf. tópicos 2.2.1, 2.2.2, 2.2.3, 2.2.4, 2.2.7.1, 2.2.7.3, 2.2.7.4,2.3.2, 3.2.2, supra.
} 
Todavia, este tipo de manifestação do potencial protagonismo judicial pode ser visualizado em situações em que a criação judicial é mais proeminente do que a mera aplicação lógico-dedutiva ${ }^{445}$. Desse modo, o ativismo judicial criativo ocorre: a) na instituição judicial de normas gerais e abstratas para suprir, provisoriamente, lacunas deixadas pelo órgão com atribuição de legislar ou regulamentar um tema; b) na imposição, sem previsão expressa em normas positivas, de direitos, de obrigações ou de limites para relações jurídicas; c) no estabelecimento (diante da inexistência de regras específicas) de regulamento ad hoc para casos concretos, em especial pelo manejo de normas de grande amplitude e generalidade (como os princípios), em detrimento, inclusive, dos métodos tradicionais de integração de lacunas (v.g., a analogia); d) na aplicação, sempre decisiva para a solução dos casos, de critérios, princípios, cláusulas, conceitos e noções consideradas “implícitas” ou engendradas pela influência da migração de ideias provindas de outras experiências jurídicas ${ }^{446}$, de modo que, criadas essas novas “teorias”, a própria jurisprudência tende a desenvolvê-las e a refiná-las ${ }^{447}$.

O ativismo judicial criativo pode ser fomentado por novos problemas e situações antes não visualizáveis pelo escopo da lei, da doutrina ou da própria jurisprudência anteriores. Esses temas (como tem ocorrido na medicina e nas ciências biológicas em geral) testam a aplicabilidade de ideias sedimentadas, instigando novas

\footnotetext{
${ }^{445}$ Cf. tópico 2.2.4, supra.

446 Inclui-se, aqui, a aplicação do direito estrangeiro (leis e constituições de outros países) ou de normas previstas em tratados e convenções internacionais e de direito comunitário que não integrem o ordenamento jurídico de cujo repertório possa se valer o órgão judicial. Como foi visto, essa prática tem sido diagnosticada, com certa frequência, no âmbito do direito comparado, pela metáfora da migração de ideias, que se traduz, além do uso do direito estrangeiro e internacional, no recurso a julgamentos de órgãos judiciais de outros países como uma fonte de saber prático no processo decisório de casos considerados difíceis, sobretudo na hipótese de o material jurídico positivo disponível haver se esgotado, conforme os fins almejados pelo órgão decisor. Sem dúvida, não se trata de nada muito estranho. Afinal, aqueles que agem conforme suas próprias tradições constitucionais tendem, em especial num mundo globalizado, a se interessar tanto pela forma como atores que ocupem o mesmo papel em outras experiências jurídico-constitucionais interpretam suas próprias tradições sobre a mesma matéria; quanto pela maneira com que tribunais internacionais interpretam tratados de direitos humanos. Trata-se de examinar linguagens semelhantes, valores semelhantes e "necessidades de sentido" semelhantes. São esses móveis que motivam, antes mesmo de decisões judiciais serem tomadas, as influências do direito de um país na elaboração legislativa e constitucional de outro; e isto expande ainda mais o espectro dessa metáfora da "migração”, a demonstrar que ela ocorre em vários estágios dos ciclos de vida das constituições, a incluir sua gênese. Em todos os países em que isso ocorre, nota-se que demandas de justificação precisam ser satisfeitas. O problema que se põe (mesmo para países como a África do Sul, cuja constituição prevê expressamente o dever dos juízes de “considerar" o direito estrangeiro, comparado e internacional na interpretação de direitos fundamentais) é o de saber como esse uso será feito. Mais do que isso, haverá, possivelmente, questionamentos sobre a prática do ativismo judicial e a possível erosão da soberania pelas “forças da globalização" e das experiências supranacionais de constitucionalização (como no caso da Constituição Europeia). Cf. tópico 2.2.7.3.

447 Cf. tópicos 2.2.7.2, 2.2.7.3, 2.2.7.4. Incluímos, neste tipo, a construção de teses jurídicas criativas consubstanciadas em súmulas e verbetes, vinculantes ou não.
} 
reflexões sobre uso da tecnologia, privacidade, sexualidade, personalidade, autonomia individual, entre outros assuntos. Em outras palavras, à medida que progridem o estado da técnica, o estado da arte e as relações humanas, o juiz tende a ser procurado para oferecer soluções para conflitos que surgem em razão dessa evolução. Com isso, podem surgir novas conceituações jurídicas e enfoques jurisprudenciais que repercutem sobre a solução do caso, sobre as discussões da comunidade jurídica e até sobre as próprias relações sociais. A identificação dessa inovação ocorre, na prática, pelos questionamentos que se costumam dirigir à autoridade judicial em razão de o entendimento tradicionalmente estabelecido haver sido abandonado (levando ora ao acolhimento de demandas contrárias a concepções antes aceitas; ora à rejeição de postulações que, por perspectiva anterior, costumavam receber a tutela judicial).

Ademais, independentemente de mudanças sociais e tecnológicas, o reconhecimento jurisprudencial de novos direitos ou de novas restrições a direitos existentes pode ser necessário para limitar efeitos não previstos ou não desejados de doutrinas e concepções dominantes. Assim, o ativismo judicial criativo (como de um modo geral ocorre, aliás, com qualquer tipo de ativismo judicial) pode ser utilizado tanto para a tutela de interesses juridicamente protegidos quanto para sua restrição ${ }^{448}$.

O ativismo judicial criativo pode estar associado a outros tipos de ativismo judicial, como o promocional, o jurisdicional, o que se realiza em face de precedentes e o de padronização decisória ${ }^{449}$. A combinação com este último ocorre na construção de teses jurídicas criativas (por meio de súmulas, verbetes e outros expedientes persuasivos ou vinculantes) que consolidem oficialmente um entendimento a respeito de determinada norma ou tema ${ }^{450}$.

Nada impede que o Poder Legislativo regulamente a matéria diferentemente da forma pela qual o ativismo judicial criativo a considerou, mas em geral a construção jurisprudencial tende a ser levada em consideração no momento da edição da lei ${ }^{451}$.

\footnotetext{
${ }^{448}$ Cf. tópico 3.2.2, supra. Vimos que isso pode resultar, inclusive, do ativismo judicial promocional (Cf. tópico 4.3.3, supra).

${ }^{449}$ Cf. tópicos 4.3.2, 4.3.3, supra; 4.3.5, 4.3.6, infra.

${ }^{450}$ Cf. tópicos 2.2.7.1, 2.3.2, 2.3.3.3, supra; e 4.3.5, infra. Ademais, com a nota da "indeterminação" (2.2.1, supra), o direito (de qualquer ramo) parece derivar cada vez menos do texto e cada vez mais da produção jurisprudencial. Acrescente-se que a edição de uma tese jurídica jurisprudencial não elimina completamente o dissenso interpretativo, já que ela própria terá de ser interpretada.

${ }^{451}$ Cf. tópicos 1.1, 2.3.3.3, supra; 5.6.5, infra.
} 


\subsubsection{Ativismo judicial de padronização decisória}

O ativismo judicial de padronização decisória instrumentaliza a busca pela eliminação de incertezas jurídicas decorrentes da "indeterminação" do direito e da proliferação de decisões discrepantes em um cenário de relações sociais sobrejuridificadas, judicialização excessiva e fortes pressões por segurança jurídica, redução de processos repetitivos, previsibilidade de orientações jurisprudenciais e velocidade de julgamentos ${ }^{452}$.

Essa forma específica de manifestação do potencial protagonismo judicial implica a enunciação de teses jurídicas (vinculantes ou não vinculantes) que consubstanciem a consolidação de entendimento jurisprudencial sobre determinado assunto. Isto ocorre, em geral, pela fixação de uma interpretação de disposições normativas, ora para legitimar determinados sentidos para o legislado (dentre as várias interpretações possíveis), ora para fornecer parâmetros complementares do que não se considerar satisfatoriamente regulado. Neste último caso, essas teses jurídicas tendem a minudenciar cláusulas gerais, princípios e demais formas de normatização associadas a noções indeterminadas ${ }^{453}$.

São variadas as formas de enunciação dessas teses oficiais. Nos casos em que essa enunciação não se vincula diretamente a um processo, sua iniciativa decorre do incremento (constatado ou esperado) da judicialização de conflitos que poderiam receber tratamento uniforme. Assim, não obstante motivada quer pela existência de muitos litígios quer pela expectativa de seu crescimento quantitativo, a edição dessas teses (persuasivas ou normativas) nem sempre ocorre no contexto processual, de modo que a lógica de sua produção não respeita, necessariamente, as ideias de inércia ou de inafastabilidade ${ }^{454}$.

No caso da edição de teses jurídicas constitutivas de precedentes não vinculantes, sua aptidão padronizadora radica em seu considerável efeito persuasivo. Destarte, ao praticarem o ativismo judicial de padronização decisória pela produção de teses desse tipo, os órgãos judiciais superiores: a) controlam as expectativas das partes e, sobretudo, dos julgadores que, pelo sistema recursal, poderiam ter seu entendimento reformado, o que sugere, sutilmente, a inutilidade de eventual resistência; b) criam certo desconforto para os julgadores, muitos dos quais, segundo apontam os comparatistas, tendem a

\footnotetext{
${ }^{452}$ Cf. tópicos 2.2.7.1, 2.3.2, 2.3.3.3, supra.

${ }^{453}$ Cf. tópico 2.2.1, 2.2.3, 2.2.4, 2.2.4.1, 2.2.7.1, supra.

${ }^{454}$ Cf. nota 129, supra.
} 
refrear posturas de desconsideração de precedentes ${ }^{455}$ diante do temor de que sua carreira seja negativamente afetada pelo excesso de revisões de suas decisões (em outros termos, isso tende a gerar mais decisões em consonância com o que pensam os órgãos judiciais superiores do que julgamentos divergentes); c) fortalecem uma tendência já tradicional (mesmo em países de tradição romano-germânica) de qualquer órgão judicial ser influenciado por decisões anteriores, seja porque litigantes tendem a articulá-las como argumentos, seja porque os próprios órgãos julgadores tendem a manter linhas decisórias adotadas em casos similares àquele sub judice; d) enunciam entendimentos cuja autoridade em geral é reconhecida pela comunidade jurídica, a corroborar, na prática, a ideia de hierarquia judiciária; e) oferecem um raciocínio oficial já construído e cristalizado, o que, num cenário de judicialização excessiva e busca de celeridade, pode diminuir o tempo necessário para o julgamento dos $\operatorname{casos}^{456}$.

Essas características, como foi visto, levam os comparatistas à conclusão de que juízes e tribunais da tradição romano-germânica não agem de forma substancialmente diversa de seus correlatos anglo-saxônicos ${ }^{457}$. Desse modo, mesmo que o efeito padronizador da enunciação de teses jurídicas não vinculantes (que contam com certa presunção relativa de correção) seja de intensidade menor, o grau de persuasão desses precedentes é considerável e muitas vezes decisivo.

Todavia, no caso da edição de teses jurídicas constitutivas de precedentes vinculantes, o ativismo judicial sob exame tem efeitos padronizadores de grande intensidade, especialmente por reivindicar uma presunção absoluta de correção. É que a fixação da tese, com os fins já destacados, simplesmente neutraliza entendimentos divergentes. As interpretações então fixadas se tornam as únicas oficialmente autorizadas, independentemente de qualquer concepção doutrinária ou jurisprudencial em sentido diverso. Isso afeta, inclusive, eventual tese jurídica persuasiva produzida por tribunais hierarquicamente subordinados. No caso de tese jurídica que verse sobre norma

\footnotetext{
455 Cf. tópico 4.3.6, supra.

${ }^{456}$ Cf. tópicos 2.2.7.1, 2.3.3.3, 3.4.2.1, supra. O ativismo judicial de padronização decisória tende a estar ligado a mecanismos que ampliam o controle, pelos tribunais superiores, de sua própria agenda. Ilustrativamente, isso ocorre pelo controle da acessibilidade ao órgão como instância recursal.

${ }^{457}$ Cf. tópico 2.2.7.1, supra. Ademais, vimos que, historicamente, no âmbito da common law, a substância do stare decisis estaria menos no apego a uma regra puramente formal de respeito a decisões anteriores, e mais no costume de referir precedentes pelos mais variados motivos. Assim, o que estaria ocorrendo com a tradição da civil law, contemporaneamente, seria uma valorização formal dos precedentes, de modo a legitimar e a estimular ainda mais essa forma de manifestação da função judicial.
} 
constitucional, a edição, pelo órgão judicial competente, de um precedente vinculante que a consagre, teria efeitos análogos ao de uma emenda constitucional ${ }^{458}$.

Do ponto de vista das repercussões intrainstitucionais, precedentes que veiculem teses vinculantes ou não vinculantes, com as diferentes intensidades examinadas, tendem a enfraquecer a independência de órgãos judiciais de instâncias que se subordinem a decisões dos órgãos judiciais enunciadores daqueles entendimentos. $\mathrm{O}$ efeito padronizador, entretanto, sobretudo no caso de súmulas vinculantes, transcendendo as repercussões intrainstitucionais, produz efeitos interinstitucionais, já que obrigam a prática administrativa dos demais poderes e podem influenciar a produção legislativa.

O ativismo judicial de padronização decisória desvela certa ambivalência do precedente. É que este, ao veicular certa tese, transcende sua função originária, que é compositiva concreta, para tender à função regulatória abstrata ${ }^{459}$. Em outras palavras, ele opera como mecanismo de controle das incertezas da lei, e de certa forma incorpora os atributos de generalidade e de abstração do objeto controlado ${ }^{460}$. Todavia, a enunciação das teses jurídicas (vinculantes ou não vinculantes) não elimina $o$ problema do dissenso interpretativo, já que tais enunciados também precisam ser interpretados $^{461}$.

Note-se, ademais, que os efeitos padronizadores tendem a ser ainda maiores quando se trata de litígios de interesse público, demandas de massa e interesses metaindividuais. Além disso, diante da expectativa de surgimento de novos casos, um único processo individual que sirva de pretexto para a edição de teses jurídicas persuasivas ou vinculantes pode ter um alcance muito maior do que o esperado ${ }^{462}$.

\footnotetext{
${ }^{458}$ Ora, no caso dos tribunais constitucionais, esse expediente torna determinada interpretação, de certa maneira, uma parte da Constituição. Cf. tópicos 3.4.1, 3.4.1.1, 3.2.2, 4.3.1, supra.

${ }^{459}$ Cf. tópico 2.2.7.1, supra.

${ }^{460}$ Paralelamente, vimos que, na experiência dos países vinculados à tradição da common law, a adoção crescente do direito legislado (statutorification) busca de um lado eliminar as incertezas produzidas pela própria common law, a exemplo do que ocorre com a multiplicação descontrolada de precedentes (que de qualquer modo não são inafastáveis, haja vista a possibilidade de incidência do distinguishing ou do overruling); e, de outro lado, contornar a insuficiência de dinamismo desse sistema em relação à necessidade de promover soluções rápidas, conforme as demandas por certeza que se renovam a cada instante. O statute, assim, surge como instrumento de "domesticação" dos precedentes, e se torna, curiosamente, cada vez mais próximo da regulação específica de casos. Cf. tópico 2.2.7.1, supra.

${ }^{461}$ No processo de criação indutiva do precedente, esse ganho de generalidade e abstração pode implicar a desconsideração de aspectos concretos relevantes, a dificultar sua aplicação dedutiva a casos concretos futuros. Essa dificuldade pode resultar, inclusive, na desconsideração de variáveis importantes para a promoção de uma pacificação substancial de determinado conflito, o que não se confunde com sua pacificação formal, propiciada por uma decisão padrão. Cf. 2.2.7.1 e 3.4.2.1, supra.

${ }^{462}$ Cf. tópico 2.2.9.2 e 3.4.2.1, supra; e 4.3.8, infra.
} 
É preciso considerar que o ativismo judicial de padronização decisória pode tanto se combinar quanto se contrapor (como mecanismo de contenção) a outros tipos de ativismo judicial. Cite-se, ilustrativamente, sua prática para conter o ativismo judicial em face de precedentes (plano vertical), objeto do próximo tópico.

Observe-se, por fim, que uma única decisão de um tribunal de cúpula, a depender de sua repercussão no âmbito da comunidade jurídica (a incluir, em especial, os magistrados), poderá produzir efeitos persuasivos significativos pela simples enunciação da tese jurídica, independentemente da edição de um verbete não vinculante que a consagre $^{463}$.

\subsubsection{Ativismo judicial em face de precedentes}

Tradicionalmente, tanto no sistema anglo-saxônico ${ }^{464}$ quanto, $a$ fortiori $^{465}$, no sistema romanístico, é possível, de um lado, que órgãos judiciais inferiores decidam contrariamente a órgãos judiciais de mesma hierarquia ou de hierarquia superior (do ponto de vista recursal); e, de outro, que os próprios órgãos judiciais, pelos mais variados motivos, revejam seus entendimentos anteriores. Como foi visto, esse cenário tradicional se modificou pouco a pouco com os desdobramentos da juridificação e seus reflexos sobre a função judicial, que levaram a certo enfraquecimento da independência da magistratura de primeira instância e ao consequente fortalecimento de órgãos judiciais de cúpula, tornando ainda mais clara a ideia de hierarquia judicial ${ }^{466}$.

Como desdobramento da juridificação, decisões judiciais tendem a ser tomadas num cenário de dissenso estrutural sobre o significado de normas ${ }^{467}$. Assim, em meio à multiplicação de entendimentos conflitantes da comunidade jurídica (a incluir os julgadores) e da sociedade, os órgãos judiciais de cúpula, pelos motivos explicitados no

\footnotetext{
${ }^{463}$ Esses verbetes funcionam como facilitadores da consolidação jurisprudencial, mas não são condições necessárias do aludido efeito de padronização decisória.

${ }^{464}$ Cf. tópico 3.2.2, supra. Não é despiciendo evocar, mais uma vez, a existência de institutos como o distinguishing e o overruling.

${ }^{465}$ Cf. tópico 2.2.7.1, supra. Como vimos, na tradição do sistema romanístico os órgãos judiciais não se vinculam nem às decisões de órgãos judiciais superiores na hierarquia judiciária, nem a outros órgãos judiciais da mesma hierarquia, e tampouco às próprias decisões. Isto decorre, como bem lembra Ferraz Junior, da regra estrutural da independência da magistratura judicial, i.e., o juiz deve julgar segundo a lei e conforme sua consciência. Essa regra, entretanto, pelos motivos já examinados, tem sido bastante relativizada.

${ }^{466}$ Cf. tópicos 2.2.7.1, 2.3.2, 2.3.3.3, 3.4.2.1 e 4.3.5, supra.

467 Cf. tópicos 2.2.1, 2.2.2, 2.2.4. Ilustrativamente, casos muito semelhantes, se submetidos a diferentes órgãos judiciais, tendem a receber soluções diversas, do mesmo modo que, se apreciados por um mesmo órgão judicial colegiado, a depender de sua composição, podem ser decidido de forma diferente.
} 
tópico anterior, tendem a enunciar teses jurídicas (vinculantes ou não vinculantes) que consubstanciem a consolidação de entendimento jurisprudencial sobre determinado assunto $^{468}$. Fixada a interpretação, essas teses dão substância a precedentes (enunciados em súmulas e verbetes assemelhados) oficialmente reconhecidos como orientação jurisprudencial.

Nesse cenário, o ativismo judicial em face de precedentes pode ocorrer no plano horizontal ou no plano vertical.

No plano horizontal, verifica-se essa forma de manifestação do potencial protagonismo judicial na hipótese de determinado órgão judicial desconsiderar teses jurídicas (vinculantes ou não vinculantes) em voga na sua própria praxis decisória ${ }^{469}$, deixando de aplicá-las num caso concreto ou modificando-as pela construção de outras teses. Essa ruptura é divisada na relação de um determinado órgão judicial com sua própria construção jurisprudencial $^{470}$.

No plano vertical, o ativismo judicial em face de precedentes ocorre na hipótese de um órgão judicial inferior na hierarquia judiciária desconsiderar precedentes persuasivos ou vinculantes de um órgão judicial superior, que editara padrões decisórios oficialmente reconhecidos como jurisprudência oficial.

Releva notar, no que tange aos precedentes vinculantes, que sua edição, como foi visto no tópico anterior, visa à padronização decisória (perspectiva vertical), efeito que é reforçado pela presunção absoluta de correção e pelos atributos de generalidade e de abstração similares aos das leis ${ }^{471}$. Por seu turno, sua revisão pelo órgão judicial que o editara (em fenômeno assemelhado ao da revogação de uma norma) constituiria um ativismo judicial em face de precedentes (plano horizontal). Nesse sentido, seu desrespeito por um órgão inferior (plano vertical) constituiria situação assemelhada à decisão contra legem, apesar de com esta não se confundir ${ }^{472}$.

\footnotetext{
${ }^{468}$ Cf. tópico 4.3.6, supra.

${ }^{469}$ Pode ocorrer, desse modo, com o restabelecimento de um precedente antigo.

${ }^{470}$ Pela perspectiva da padronização decisória (discutida no tópico anterior), não se pode negar o impacto da modificação de um precedente (mesmo não vinculante) não só no plano sociológico, mas também pela perspectiva judiciária (fator que pode influenciar o controle da agenda do órgão judicial que haja instituído o precedente, as expectativas dos demandantes em relação ao que pode ser postulado ou às decisões das quais se possa recorrer com prognóstico razoável de sucesso ou insucesso, entre outras questões).

${ }^{471}$ Cf. tópico 4.3.5, supra.

${ }^{472}$ Cf. tópico 4.3.7, infra.
} 
Ainda no plano vertical, o ativismo judicial em face de precedentes não vinculantes é igualmente relevante, dada a densidade dos efeitos persuasivos das teses jurídicas que esses precedentes veiculam, comentados no tópico anterior.

Destaque-se que diversos mecanismos processuais (tutelas de urgência, reclamações, etc.) tendem a ser utilizados para conter decisões que, no plano vertical, consubstanciem o ativismo judicial em face de precedentes.

\subsubsection{Ativismo judicial contra legem}

Em meio à pluralidade de valores, interesses conflitantes e expectativas contraditórias em torno de normas associadas a noções indeterminadas, pretensões de justiça material e máximas éticas e políticas, o potencial protagonismo judicial pode se manifestar em entendimento que leve à negação da aplicação de uma norma válida.

Não se trata da declaração ou do reconhecimento incidental de eventual inconstitucionalidade da norma (como no caso do ativismo judicial contramajoritário) ${ }^{473}$, mas de seu afastamento por ser ela considerada “injusta”, “anacrônica” e “inadequada” como critério orientador da decisão pelos mais variados motivos, em geral não jurídicos (ideológicos, políticos, filosóficos) $^{474}$.

Note-se que o ativismo judicial contra legem, ao negar a aplicação de determinada norma válida, no átimo subsequente e como condição sine qua non para a solução do caso, tende a instituir um regramento ad hoc aplicável ao litígio, de forma a se combinar com um ativismo judicial criativo.

\subsubsection{Ativismo judicial processual}

O potencial protagonismo judicial que dá ensejo ao ativismo judicial processual tem suas raízes na incorporação do ideário do juiz ativo pelas normas processuais de grande parte das democracias ocidentais.

Como foi visto, entre os valores consagrados como fundamentos desse ideário e que passaram a orientar o direito processual, destacam-se a oralidade, $a$ celeridade, a eficiência, a redução dos custos, a simplificação dos ritos, a busca da

\footnotetext{
${ }^{473}$ Cf. tópico 4.3.1, supra.

${ }^{474}$ Cf. tópicos 1.2.2 e 3.4.4, supra.
} 
verdade real, a flexibilização das formalidades e a facilitação do acesso à justiça. $\mathrm{O}$ processo assim moldado (consoante o paradigma fundado por Klein, que se ampliou consideravelmente à medida que progrediu o processo de juridificação ao longo do século $\mathrm{XX)}$ é visto como instituição pública de bem-estar social ${ }^{475}$.

Nele, o magistrado é concebido como gestor ativo do processo, sem subordinação à iniciativa das partes, o que tende a afastá-lo dos parâmetros da neutralidade, da passividade e de outros atributos essencialmente adversariais. Para administrar ativamente o processo e interferir decisivamente sobre o seu curso (que deverá ser eficiente, justo, rápido e efetivo em seus resultados), o magistrado assim concebido recebe uma série de poderes, inclusive para o controle formal do procedimento, a definição do escopo do litígio, a distribuição da carga probatória e até mesmo a recusa a determinados tipos de propostas conciliatórias formuladas pelas partes. Vimos, todavia, que esses poderes instrumentais do juiz se alteraram paralelamente à modificação gradativa da estrutura e das funções do processo, de modo que o ideário do juiz ativo se ampliou, tornando-se, num certo sentido, ambíguo ${ }^{476}$. Se num primeiro momento ele contemplava preocupações eminentemente adjudicatórias e vinculadas à composição de conflitos entre indivíduos, a emergência dos conflitos de massa e das fortes reivindicações pela criação de mecanismos não adjudicatórios levou à ampliação gradativa dos escopos do processo, à medida que o estado, pelo aprofundamento da juridificação, colonizou aqueles conflitos e demandas sociais. Consequentemente, ampliaram-se as funções instrumentais do juiz ativo, que recebeu poderes processuais especiais para dar tratamento a interesses metaindividuais e para fomentar, inclusive no âmbito do processo, a adoção de soluções não adjudicatórias (negociações, acordos amigáveis e outras formas de solução alternativa). Esse forte viés não adjudicatório tende a emergir, como foi visto, da percepção da necessidade de dar vazão à pletora de processos que comprometem a funcionalidade e a credibilidade das instituições judiciais ${ }^{477}$.

Além dessas raízes, outros aspectos e desdobramentos da juridificação também foram responsáveis pela expansão do potencial protagonismo judicial no campo

\footnotetext{
${ }^{475}$ Cf. tópicos 2.2, 2.2.1, 2.2.5, 2.2.8, 2.2.8.1, 2.2.8.2, supra. Sem dúvida, a ideia de juiz ativo (associada à percepção do processo como instituição pública de bem-estar social) se ajusta claramente, sobretudo em suas origens, ao ideário do Estado Social e Democrático de Direito, construído pelo quarto surto de colonização do mundo da vida. Cf. tópico 2.2, supra.

${ }^{476}$ A respeito da aludida ambiguidade, são importantes as reflexões constantes dos tópicos 2.2.8.1 e 2.3.2, supra.

${ }^{477}$ Cf. tópicos 2.1, 2.2, 2.2.5 e 2.2.8, supra. Note-se, neste átimo, a importância da perspectiva expropriatória de conflitos.
} 
propriamente processual. Considerando que o processo é constituído por normas jurídicas (de direito processual), cada um dos atos de seu iter procedimental encontra fundamento naquelas normas. Destarte, pode-se afirmar que o juiz, para praticar atos processuais, deve aplicar as normas jurídicas que os regulem; e, no momento dessa aplicação, vê-se diante do mesmo contexto no qual (em qualquer outra situação de aplicação judicial do direito ao caso concreto) seu potencial protagonismo judicial pode se manifestar em vários tipos de ativismo judicial.

Em outras palavras, em cada átimo de aplicação do direito processual, o ativismo judicial processual combina um modelo institucionalizado de juiz ativo (em sua acepção ampla) com outras formas de ativismo judicial que, fortalecendo esse modelo, adquirem uma conotação processual instrumental ${ }^{478}$.

É verdade que, mesmo sem o reconhecimento formal de mais poderes aos magistrados, nada impediu que as influências do ideário do juiz ativo se fizessem sentir em algumas experiências jurídicas ${ }^{479}$. Todavia, a institucionalização desse ideário, paralelamente às transformações sofridas pelo direito e pelas instituições judiciais como desdobramentos da juridificação, incrementou substancialmente a manifestação do potencial protagonismo judicial no âmbito processual.

Como articulação instrumental do ideário do juiz ativo e de vários tipos de ativismo judicial, o ativismo judicial processual ocorre, ilustrativamente, no afastamento de regras processuais, seja por haverem sido incidentalmente reputadas inconstitucionais (ativismo judicial contramajoritário), seja por sua alegada injustiça, anacronismo ou inadequação (ativismo judicial contra legem); e na criação judicial de normas ad hoc para suprir lacunas deixadas pelo órgão com atribuição de legislar ou regulamentar um tema de direito processual (ativismo judicial criativo). Note-se que essa criação processual tende a ser subministrada por critérios, princípios, cláusulas, conceitos e noções consideradas "implícitas" ou engendradas pela influência da migração de ideias provindas de outras experiências jurídicas (de modo que, como foi visto, criadas essas novas “teorias”, a própria jurisprudência tende a desenvolvê-las e a refiná-las). Como

\footnotetext{
${ }^{478}$ Parece oportuno evocar, mais uma vez, que o processo é visto, segundo esse ideário, como instituição pública de bem-estar social. Sabe-se que instituições dessa natureza são típicas do Estado Social e Democrático de Direito. Assim, a função instrumental do processo envolve a canalização de demandas por justiça material; imperativos éticos, máximas políticas e outras noções que passaram a integrar as normas jurídicas e contribuir para a chamada indeterminação do direito (inclusive do direito processual). Cf. tópicos 2.2.1 e 2.2.2, supra.

${ }^{479}$ Cf. tópicos 2.2.8.2.1 e 2.2.9.2, supra.
} 
resultado do uso desses poderes processuais, o juiz tende a exercer um amplo controle do processo e de seus resultados, o que pode incluir o deferimento de medidas ultra petita e a modulação discricionária dos efeitos temporais de determinada decisão, em especial por preocupações com o impacto que ela possa provocar ${ }^{480}$.

Por fim, o ativismo judicial processual pode envolver o uso de um processo específico sub judice (de alcance restrito às partes diretamente interessadas) como veículo de imposição (ou tentativa de imposição), nos julgamentos, de ordens com alcance mais largo e que se estendam a classes mais amplas de grupos de indivíduos.

\subsubsection{Ativismo judicial extraprocessual}

O fortalecimento institucional do Poder Judiciário faz a atuação dos órgãos judiciais transcender o exercício da jurisdição stricto sensu, de modo que o potencial protagonismo judicial tende a se manifestar em variados cenários sociais e políticos.

Apesar da dificuldade de apreender a totalidade dessa miríade de formas de manifestação desse potencial fora do contexto jurisdicional stricto sensu, podem ser citadas algumas hipóteses: a) a ação de grupos de magistrados em prol de uma causa ou tema; b) a ação de órgãos de cúpula administrativa do Poder Judiciário em defesa de interesses propriamente institucionais; c) o engajamento em relação à discussão de projetos de lei; d) a promoção de campanhas em prol de políticas públicas com conotação judiciária; e) a participação de juízes, na condição de magistrados, em fóruns sociais e debates públicos; f) o estímulo direto ou indireto à litigância; g) a realização de audiências públicas desvinculadas de processos judiciais; h) a promoção de políticas judiciárias relacionadas à administração de conflitos; i) a elaboração de manifestos de magistrados em prol de uma causa; e j) a exposição midiática com os mais diversos fins ${ }^{481}$.

\footnotetext{
${ }^{480}$ Cf. nota 214, supra; tópico 5.2.3, infra.

${ }^{481}$ Cf. situações concretas expostas nos tópicos 1.1, 2.2.8.1, 2.2.9.2, 2.2.10, 2.3.2, 2.3.3.4, 3.3, 3.4.1.1, supra; 5.5, infra.
} 


\title{
CAPÍTULO 5
}

\section{ATIVISMO JUDICIAL NA JUSTIÇA DO TRABALHO}

\begin{abstract}
5.1 Objetivos do capítulo; 5.2 Ativismo judicial no Caso Embraer (dispensas em massa); 5.2.1 Linhas gerais do litígio e decisão liminar; 5.2.2 Julgamento do dissídio coletivo de natureza jurídica (TRT); 5.2.3 Julgamento do recurso ordinário (TST); 5.2.4 Observações conclusivas sobre o caso; 5.3 Ativismo judicial no direito sumular trabalhista; 5.4 Exame de outros julgados ; 5.4.1 Controle judicial de políticas públicas; 5.4.2 Exploração sexual de crianças e adolescentes para fins comerciais; 5.4.3 Dispensas discriminatórias de portadores do vírus HIV; 5.5 Ativismo judicial extraprocessual da magistratura do Trabalho; 5.6 Ativismo judicial no STF e seus reflexos na Justiça do Trabalho; 5.6.1 Breves considerações sobre o ativismo judicial no STF; 5.6.2 Limitação à garantia de emprego da gestante; 5.6.3 A definição da base de calculo do adicional de insalubridade; 5.6.4 Terceirização e responsabilidade subsidiária da Administração pública; 5.6.5 Reflexos trabalhistas de outros julgados do STF.
\end{abstract}

\subsection{Objetivos do capítulo}

Neste capítulo, conforme linha descrita no capítulo 1, examinar-se-á o ativismo judicial na Justiça do Trabalho à luz dos capítulos 2, 3 e 4, que se dedicaram, respectivamente: a) à compreensão da maneira pela qual um potencial protagonismo judicial emergiu ao longo do processo de juridificação pela qual passaram as experiências democráticas ocidentais, a incluir o Brasil, sem olvidar as peculiaridades desse potencial no âmbito da Justiça do Trabalho brasileira; b) à problematização, com reflexões eminentemente empíricas, de diferentes noções de ativismo judicial; c) à construção de tipos ideais de ativismo judicial, como formas de manifestação do potencial protagonismo judicial (contramajoritário, jurisdicional, promocional, criativo, de padronização decisória, em face de precedentes, contra legem, processual e extraprocessual).

Destarte, foram selecionados alguns casos e fenômenos representativos de um ou mais tipos de ativismo judicial. Considerando a riqueza de aspectos que apresenta, o caso Embraer foi estudado com mais ênfase.

Pondere-se que, em todos os casos de manifestação do ativismo judicial em cenários propriamente jurisdicionais, pareceu-nos de grande relevância considerar decisões antecipatórias ou mesmo alguns julgamentos que posteriormente foram reformados quando da apreciação de recursos. Pelos motivos já explicitados, não parece 
razoável supor (quer do ponto de vista jurídico, quer do ponto de vista sociológico) que o processo só produza efeitos dos mais variados tipos apenas depois da formação da coisa julgada.

\subsection{Ativismo judicial no Caso Embraer (dispensas em massa)}

\subsubsection{Linhas gerais do litígio e decisão liminar}

O “Caso Embraer” foi brevemente referido, em suas repercussões mais gerais, no capítulo introdutório. Ademais, quando examinamos o poder normativo para a compreensão das peculiaridades do potencial protagonismo judicial na Justiça do Trabalho, foram destacadas várias perplexidades que o mesmo caso suscitou, quer em razão do uso peculiar, pelos sindicados, da via do dissídio coletivo; quer em virtude do teor das decisões proferidas pelos órgãos judiciais trabalhistas envolvidos.

Por sua grande repercussão, o caso, além de estimular uma série de discussões sobre um alegado ativismo judicial na Justiça do Trabalho, foi examinado atentamente pela doutrina jurídica trabalhista ${ }^{482}$.

Cumpre, neste átimo, identificar, com foco em alguns momentos relevantes do processo, a existência ou não de elementos que indiquem manifestações do potencial protagonismo judicial no caso, considerados os tipos de ativismo judicial construídos no capítulo anterior. Note-se que há referências não apenas às decisões (liminar e julgamentos do TRT e do TST), mas à forma de condução do processo e a fatos relevantes ocorridos durante sua tramitação. É útil relembrar, de início, os contornos do caso.

O dissídio coletivo foi ajuizado no TRT da $15^{\mathrm{a}}$ Região por entidades sindicais que demandavam em face da Embraer $^{483}$. Afirmavam os suscitantes que a empresa, com base na alegada necessidade de reduzir custos em face da chamada "crise econômica”, havia dispensado milhares de seus trabalhadores, além de anunciar que outros seriam igualmente despedidos. Isto representaria, sem contar o impacto socioeconômico e familiar, a redução de mais de quatro mil postos de trabalho de um total de 22 mil.

\footnotetext{
${ }^{482}$ Cf. tópicos 1.1 e 2.3.3.2, supra.

${ }^{483}$ O ajuizamento ocorreu em 26-02-09, pelo Sindicato dos Metalúrgicos de São José dos Campos e Região, do Sindicato dos Metalúrgicos de Botucatu e da Federação dos Metalúrgicos de São Paulo. Outra empresa do mesmo grupo econômico da Embraer figurava no polo passivo.
} 
Postulou-se, a título de antecipação de tutela, a suspensão das rescisões contratuais, e, em caráter definitivo, a declaração de nulidade das dispensas realizadas.

A decisão liminar foi proferida no mesmo dia do protocolo da petição inicial. Ao fundamentar a medida, o presidente do TRT entendeu se tratar de dissídio coletivo de natureza jurídica. A fundamentação da decisão antecipatória dialogava com a linha argumentativa apresentada na postulação, que combinava uma série de referências normativas com considerações econômicas e sociais. Além disso, ao abordar a omissão do legislador em relação à regulamentação efetiva do $7^{\circ}$, I, da Constituição, a decisão destacava ser pouco palpável a promessa constitucional de "relação de emprego protegida contra despedida arbitrária ou sem justa causa”. Assim, em face dessa lacuna, agravada não apenas pela letargia legislativa, mas também pela denúncia à Convenção n. ${ }^{\circ} 158$ da OIT, o julgador sustentava que aquele seria o "momento de repensar o assunto", em especial para, à luz da convenção, considerar “inválida a dispensa arbitrária”, inclusive para determinar a reintegração dos trabalhadores ou, se isto se tornasse inviável, para garantir-lhes uma indenização. Vislumbrando nesse conjunto de aspectos um "relevante fundamento da impossibilidade de se proceder a demissões em massa sem prévia negociação sindical”, o julgador deferiu o pedido liminar e determinou a suspensão de milhares de rescisões contratuais operadas pela empresa ${ }^{484}$.

Ora, a decisão, ao supor a "impossibilidade de se proceder a demissões em massa sem prévia negociação sindical” sem qualquer norma expressa nesse sentido, praticou um ativismo judicial criativo, sem olvidar alguns traços de ativismo judicial contramajoritário (o que se repetiu nas decisões do TRT e do TST), pela insurgência em face da omissão legislativa no que tange à regulamentação dos despedimentos em massa. Ademais, nas várias tentativas de conciliação que se sucederam, os esforços do presidente do tribunal envolveram a promoção, inclusive, de uma “reunião informal” para tratar do caso, a configurar, pela ampla flexibilização procedimental realizada em função do exercício dos poderes conciliatórios (típicos do ideário do juiz ativo inerente ao direito processual do trabalho), um ativismo judicial processual ${ }^{485}$.

\footnotetext{
${ }^{484}$ A decisão limitou a incidência dessa suspensão às dispensas realizadas desde o dia 19-02-09, bem como aos casos em que o despedimento houvesse sido realizado "sem justa causa ou sob o fundamento de dificuldades financeiras decorrentes da crise econômica global”, além das que "viessem a ocorrer sob igual forma ou justificativa”, até a data da audiência de conciliação, realizada no dia 05-03-09.

${ }^{485}$ Cf. tópicos 2.3.3.4, 4.3.1, 4.3.4, 4.3.8, supra.
} 


\subsubsection{Julgamento do dissídio coletivo de natureza jurídica (TRT)}

No julgamento do caso pelo TRT da $15^{\mathrm{a}}$ Região $^{486}$, a recepção da demanda como “dissídio coletivo de natureza jurídica” foi confirmada, preliminares foram rejeitadas e pretensões foram acolhidas.

Apesar de afastar a hipótese de reintegração, a decisão apresentou longa fundamentação para sustentar a "abusividade” do procedimento das suscitadas de "praticar a dispensa coletiva sem nenhuma negociação coletiva prévia com as entidades sindicais, nem instituição de programa de demissão voluntária incentivada”. Destaquem-se, por oportuno, alguns pontos importantes da decisão.

As questões preliminares, que poderiam implicar a extinção do processo sem exame do mérito, foram todas rejeitadas. No que tange às alegações de não cabimento, no caso, dos dissídios coletivos de natureza jurídica (segundo observavam as suscitadas, tratava-se de pedidos condenatórios e o poder normativo não poderia impor obrigações que

${ }^{486}$ Ementa: “CRISE ECONÔMICA - DEMISSÃO EM MASSA - AUSÊNCIA DE PRÉVIA NEGOCAÇÃO COLETIVA - ABUSIVIDADE - COMPENSAÇÃO FINANCEIRA - PERTINÊNCIA. As demissões coletivas ou em massa relacionadas a uma causa objetiva da empresa, de ordem técnico-estrutural ou econômico-conjuntural, como a atual crise econômica internacional, não podem prescindir de um tratamento jurídico de proteção aos empregados, com maior amplitude do que se dá para as demissões individuais e sem justa causa, por ser esta insuficiente, ante a gravidade e o impacto socioeconômico do fato. Assim, governos, empresas e sindicatos devem ser criativos na construção de normas que criem mecanismos que, concreta e efetivamente, minimizem os efeitos da dispensa coletiva de trabalhadores pelas empresas. À míngua de legislação específica que preveja procedimento preventivo, o único caminho é a negociação coletiva prévia entre a empresa e os sindicatos profissionais. Submetido o fato à apreciação do Poder Judiciário, sopesando os interesses em jogo: liberdade de iniciativa e dignidade da pessoa humana do cidadão trabalhador, cabe-lhe proferir decisão que preserve o equilíbrio de tais valores. Infelizmente não há no Brasil, a exemplo da União Europeia (Directiva 98/59), Argentina (Ley n. ${ }^{\circ}$ 24.013/91), Espanha (Ley del Estatuto de los Trabajadores de 1995), França (Lei do Trabalho de 1995), Itália (Lei n. ${ }^{\circ}$ 223/91), México (Ley Federal del Trabajo de 1970, cf. texto vigente - última reforma foi publicada no DOF de 17/01/2006) e Portugal (Código do Trabalho), legislação que crie procedimentos de escalonamento de demissões que levem em conta o tempo de serviço na empresa, a idade, os encargos familiares, ou aqueles em que a empresa necessite de autorização de autoridade, ou de um período de consultas aos sindicatos profissionais, podendo culminar com previsão de períodos de reciclagens, suspensão temporária dos contratos, aviso prévio prolongado, indenizações, etc. No caso, a EMBRAER efetuou a demissão de $20 \%$ dos seus empregados, mais de 4.200 trabalhadores, sob o argumento de que a crise econômica mundial afetou diretamente suas atividades, porque totalmente dependentes do mercado internacional, especialmente dos Estados Unidos da América, matriz da atual crise. Na ausência de negociação prévia e diante do insucesso da conciliação, na fase judicial só resta a esta Eg. Corte, finalmente, decidir com fundamento no art. $4^{\circ}$ da Lei de Introdução ao Código Civil e no art. $8^{\circ}$ da Consolidação das Leis do Trabalho. Assim, com base na orientação dos princípios constitucionais expressos e implícitos, no direito comparado, a partir dos ensinamentos de Robert Alexy e Ronald Dworkin, Paulo Bonavides e outros acerca da força normativa dos princípios jurídicos, é razoável que se reconheça a abusividade da demissão coletiva, por ausência de negociação. Finalmente, não sobrevivendo mais no ordenamento jurídico a estabilidade no emprego, exceto as garantias provisórias, é inarredável que se atribua, com fundamento no art. 422 do CC - boa-fé objetiva - o direito a uma compensação financeira para cada demitido. Dissídio coletivo que se julga parcialmente procedente (negrito acrescido)". TRT $15^{a}$ Região n. ${ }^{\circ}$ 30900-12.2009.5.15.0000 (DC), rel. Des. José Antônio Pancotti. 
se sobrepusessem à legislação ${ }^{487}$ ); afirmou o relator que tal tipo de processo, como “criação doutrinária e jurisprudencial”, não teria nem "um regramento procedimental específico" nem “condições de admissibilidade da ação ou pressupostos processuais" especiais, condicionantes de sua instauração, diversos dos já existentes em relação aos dissídios coletivos de natureza econômica. Destarte, o tribunal considerou inaplicável a OJ n. 7 da SDC do TST, segundo a qual "o dissídio coletivo de natureza jurídica não se presta à interpretação de normas de caráter genérico”.

Assim, tanto quanto a decisão liminar, ao não aplicar referida orientação jurisprudencial persuasiva do TST, o TRT praticou um ativismo judicial em face de precedentes, considerado em seu plano vertical; e, ao mesmo tempo, ao reconfigurar as variáveis de justiciabilidade dos direitos discutidos e a receptividade processual à sua judicialização, também praticou um ativismo judicial jurisdicional. Fez-se presente inequivocamente, ademais, um ativismo judicial processual ${ }^{488}$. Com efeito, note-se que, na fundamentação da decisão que propiciou a inusitada ampliação da agenda judicial trabalhista, o órgão regional considerou aquele dissídio coletivo como um "instrumento de intervenção do Poder Judiciário nos conflitos privados” quando estes envolvessem questões de interesse coletivo ou de interesse público que reclamassem "uma atuação estatal urgente, pronta e eficaz, em prol da paz social”. Os “fatos políticos, econômicos e sociais” subjacentes ao caso imporiam uma “revisão crítica do processo judicial”, bem como uma "reflexão quanto aos meios necessários para que os direitos do cidadão sejam amplamente considerados”. A finalidade dessa revisão seria libertar o Poder Judiciário da “ortodoxia do processo judicial”, que “conduziria à frustração da atividade jurisdicional efetiva”. Além disso, ao reafirmar a possibilidade de um dissídio coletivo de natureza jurídica que propiciasse a interpretação das normas já existentes (leis, acordos coletivos, convenções coletivas e sentenças normativas incidentes sobre as relações de trabalho de uma dada categoria), o TRT ponderou que a construção doutrinária e jurisprudencial (conforme a supracitada OJ n. ${ }^{\circ} 07$ da SDC do TST), ao criar esse tipo de dissídio coletivo, avançara a ponto de instituir "requisitos não previstos em lei para a admissibilidade desta ação e para a instauração do processo”. Esses requisitos, segundo o referido Tribunal, tendo em vista a "relevância das matérias" discutidas naquele caso, seriam de aplicação limitada. A reflexão específica sobre o cabimento do dissídio coletivo foi encerrada com a

\footnotetext{
${ }^{487}$ A propósito, v. item 2.3.3.2, supra.

${ }^{488}$ Cf. tópicos 4.3.2, 4.3.6 e 4.3.8, supra.
} 
afirmação de que não seria razoável nem justo que o órgão judicial se escudasse “em formalidades procedimentais para frustrar o pronunciamento sobre o fundo da questão”.

No que concerne ao mérito, o reconhecido “ineditismo da matéria” e as constatadas lacunas $^{489}$ na ordem jurídica brasileira levaram à aplicação do artigo $8^{\circ}$ da CLT, que autoriza, à falta de disposições legais ou contratuais, o recurso a outras fontes (jurisprudência, analogia, equidade, princípios, usos e costumes e direito comparado) para dar solução aos casos submetidos à Justiça do Trabalho.

Nesse sentido, buscaram-se subsídios decisórios no direito de outros países, em normas de direito comunitário e internacional e em teorias oriundas de outras experiências jurídicas ${ }^{490}$. Com base em teorizações relacionadas à chamada "força normativa dos princípios”, afirmou-se que “o controle judicial dos atos jurídicos públicos ou privados, individuais ou coletivos" demandaria "uma nova postura da atividade jurisdicional”, a tornar possível "reconhecer que é mais amplo o espectro constitucional de proteção ao trabalhador em caso de dispensa coletiva”491.

No que tange à polêmica denúncia pelo governo brasileiro da Convenção n. ${ }^{\circ} 158$ da OIT, ocorrida em 1996, a decisão considerava que, não obstante o ato estar sub judice no $\mathrm{STF}^{492}$, nada impediria que seus comandos fossem "interpretados como

\footnotetext{
${ }^{489}$ Consoante a decisão, a lacuna envolveria, de um lado, a falta de regulamentação dos despedimentos em massa; e, de outro, a limitação da proteção instituída no artigo $7^{\circ}$, I, da CR, que teria se resumido, até então, na elevação da multa sobre o saldo do FGTS. Nesse cenário, considerou-se que as dispensas em massa não poderiam prescindir de regulamentação jurídica "com maior amplitude do que a que se dá para as demissões individuais e sem justa causa, por ser esta insuficiente, ante a gravidade e o impacto socioeconômico do fato".

${ }^{490}$ Note-se, a propósito, o conjunto de considerações constantes dos tópicos 2.2.7.3 e 4.3.4, supra. Além de um histórico doutrinário sobre as dispensas coletivas, apresentou-se minucioso exame das normas existentes para regulá-las no direito internacional (normas da OIT, em especial a Convenção n. ${ }^{\circ}$ 158), no direito comunitário (diretivas da União Europeia) e em ordenamentos jurídicos de outros países (Espanha, França, Itália, Portugal, México e Argentina).

${ }^{491}$ Várias teorias doutrinárias das mais diversas orientações metodológicas foram citadas para fundamentar a conclusão. Afirmou-se, inclusive, que, além das regras e dos princípios (estes com "prevalência $e$ preferência"), o "gênero norma" contemplaria a própria "argumentação jurídica". Defendeu-se a chamada "força normativa dos princípios"; a defesa dos "fundamentos do Estado Democrático de Direito preconizados na Constituição da República do Brasil, definidos entre os Princípios Fundamentais”, entre eles o da dignidade da pessoa humana; e uma série de normas constitucionais abertas (valor social do trabalho, livre iniciativa, prevalência dos Direitos Humanos, entre outros. Com base nesse "espectro de princípios basilares", afirmava a decisão que "as demissões coletivas de trabalhadores por empresas, quer sejam por inovações tecnológicas, automações, crises econômicas etc., quer por supressão de estabelecimentos, por seus impactos econômicos e sociais, não são imunes a uma rede de proteção dos trabalhadores atingidos"; e que essa proteção "deve ter outros parâmetros que não aqueles que o Direito do Trabalho expressamente concede aos trabalhadores que sofrem demissões individuais".

${ }^{492}$ O parecer da Procuradoria Geral da República opinou pela improcedência das postulações, à vista do "entendimento de poder o Chefe do Governo denunciar tratados internacionais, independentemente de manifestação ou oitiva do congresso nacional”. Após três votos pela procedência e um pela improcedência, o caso ainda aguarda um julgamento definitivo. O último voto (pela procedência) foi proferido pelo ministro
} 
princípios gerais de direito do trabalho, conforme a doutrina da normatividade dos princípios jurídicos”. Assim, o TRT não considerava lícitas as demissões coletivas realizadas. E, conquanto não haja determinado a reintegração, julgou parcialmente procedentes os pedidos formulados no “dissídio coletivo de natureza jurídica”.

Examinados esses aspectos da decisão, nota-se, claramente, um ativismo judicial criativo na declaração da "abusividade do procedimento das suscitadas ao praticar a dispensa coletiva, sem nenhuma negociação coletiva prévia com as entidades sindicais, nem instituição de programa de demissão voluntária incentivada”. Apesar de essa declaração não haver implicado a reintegração dos trabalhadores, o Tribunal, também no exercício daquele tipo de ativismo judicial, como consequência da declarada abusividade, instituiu "o direito de cada empregado demitido a uma compensação financeira independentemente das verbas rescisórias"; e determinou a "manutenção dos planos de assistência médica aos trabalhadores demitidos e seus familiares por doze meses”493. Ademais, o julgamento estabeleceu que, nos casos de "reativação dos postos de trabalho de acordo com as necessidades da empresa”, dever-se-ia dar preferência, na seleção, aos empregados despedidos que se apresentassem e preenchessem as qualificações exigidas pelos cargos disponíveis, o que seria mantido por dois anos ${ }^{494}$.

Joaquim Barbosa, destacando que, não bastassem as várias razões jurídicas e políticas que fundamentam a premissa de que "quaisquer tratados somente podem ser denunciados com a anuência prévia do Congresso Nacional”, as circunstâncias do caso deixariam mais evidente aquela necessidade: primeiro, "a forma com que o Congresso Nacional aprovou o texto da Convenção 158 da OIT”; e, segundo, "o fato de a Convenção 158 da OIT versar sobre direitos humanos".

493 Note-se que, não obstante a decisão do TRT haver reconhecido que não havia o direito à reintegração, limitou a insubsistência da liminar concedida, de modo que os efeitos desta incidissem no lapso que se iniciava com dispensa e se encerrava no momento da realização da primeira audiência de conciliação no TRT, em 13-03-09.

${ }^{494}$ Importa referir que essas soluções (indenização, planos de saúde e preferência para a recontratação) já haviam sido cogitadas ao longo dos debates conciliatórios. Assim, se de um lado se reconheceu não ser possível "sustentar a vedação absoluta das dispensas nestas circunstâncias” e menos ainda a "reintegração", medida que nem mesmo as legislações que tratam do tema contemplam, limitando-se a "traçar procedimentos prévios” que "desaguam sempre em indenização”; de outro observou a decisão que, naquele caso, além da conduta reprovável de simplesmente proceder às dispensas sem qualquer notificação prévia, a empresa fora "radicalmente intransigente”, sem nada oferecer quando forçada a comparecer em Juízo “para negociar”. 


\subsubsection{Julgamento do recurso ordinário (TST)}

A empresa, o sindicato e os assistentes interpuseram recurso ordinário ao TST, julgado em 10 de agosto de $2009^{495}$.

495 TST. RODC 30900-12.2009.5.15.0000, rel. Min. Maurício Godinho Delgado, DJe n. ${ }^{\circ}$ 177, julg. 10-08-09, publ. 04-09-09. Pelo presidente da Corte foi concedido efeito suspensivo ao recurso até o julgamento final do caso pelo órgão. Eis a ementa do julgado: "RECURSO ORDINÁRIO EM DISSÍDIO COLETIVO. DISPENSAS TRABALHISTAS COLETIVAS. MATÉRIA DE DIREITO COLETIVO. IMPERATIVA INTERVENIÊNCIA SINDICAL. RESTRIÇÕES JURÍDICAS ÀS DISPENSAS COLETIVAS. ORDEM CONSTITUCIONAL E INFRACONSTITUCIONAL DEMOCRÁTICA EXISTENTE DESDE 1988. A sociedade produzida pelo sistema capitalista é, essencialmente, uma sociedade de massas. A lógica de funcionamento do sistema econômico-social induz a concentração e centralização não apenas de riquezas, mas também de comunidades, dinâmicas socioeconômicas e de problemas destas resultantes. A massificação das dinâmicas e dos problemas das pessoas e grupos sociais nas comunidades humanas, hoje, impacta de modo frontal a estrutura e o funcionamento operacional do próprio Direito. Parte significativa dos danos mais relevantes na presente sociedade e das correspondentes pretensões jurídicas têm natureza massiva. O caráter massivo de tais danos e pretensões obriga o Direito a se adequar, deslocando-se da matriz individualista de enfoque, compreensão e enfrentamento dos problemas a que tradicionalmente perfilou-se. A construção de uma matriz jurídica adequada à massividade dos danos e pretensões característicos de uma sociedade contemporânea - sem prejuízo da preservação da matriz individualista, apta a tratar os danos e pretensões de natureza estritamente atomizada - é, talvez, o desafio mais moderno proposto ao universo jurídico, e é sob esse aspecto que a questão aqui proposta será analisada. As dispensas coletivas realizadas de maneira maciça e avassaladora, somente seriam juridicamente possíveis em um campo normativo hiperindividualista, sem qualquer regulamentação social, instigador da existência de mercado hobbesiano na vida econômica, inclusive entre empresas e trabalhadores, tal como, por exemplo, respaldado por Carta Constitucional como a de 1891, já há mais um século superada no país. Na vigência da Constituição de 1988, das convenções internacionais da OIT ratificadas pelo Brasil relativas a direitos humanos e, por consequência, direitos trabalhistas, e em face da leitura atualizada da legislação infraconstitucional do país, é inevitável concluir-se pela presença de um Estado Democrático de Direito no Brasil, de um regime de império da norma jurídica (e não do poder incontrastável privado), de uma sociedade civilizada, de uma cultura de bem-estar social e respeito à dignidade dos seres humanos, tudo repelindo, imperativamente, dispensas massivas de pessoas, abalando empresa, cidade e toda uma importante região. Em consequência, fica fixada, por interpretação da ordem jurídica, a premissa de que "a negociação coletiva é imprescindível para a dispensa em massa de trabalhadores". DISPENSAS COLETIVAS TRABALHISTAS. EFEITOS JURÍDICOS. A ordem constitucional e infraconstitucional democrática brasileira, desde a Constituição de 1988 e diplomas internacionais ratificados (Convenções OIT n. ${ }^{\circ}$ 11, 87, 98, 135, 141 e 151, ilustrativamente), não permite o manejo meramente unilateral e potestativista das dispensas trabalhistas coletivas, por de tratar de ato/fato coletivo, inerente ao Direito Coletivo do Trabalho, e não Direito Individual, exigindo, por consequência, a participação do(s) respectivo(s) sindicato(s) profissional(is) obreiro(s). Regras e princípios constitucionais que determinam o respeito à dignidade da pessoa humana (art. $1^{\circ}$, III, CF), a valorização do trabalho e especialmente do emprego (arts. $1^{\circ}$, IV, 6o e 170, VIII, CF), a subordinação da propriedade à sua função socioambiental (arts. 5o, XXIII e 170, III, CF) e a intervenção sindical nas questões coletivas trabalhistas (art. 8o, III e VI, CF), tudo impõe que se reconheça distinção normativa entre as dispensas meramente tópicas e individuais e as dispensas massivas, coletivas, as quais são social, econômica, familiar e comunitariamente impactantes. Nesta linha, seria inválida a dispensa coletiva enquanto não negociada com o sindicato de trabalhadores, espontaneamente ou no plano do processo judicial coletivo. A d. Maioria, contudo, decidiu apenas fixar a premissa, para casos futuros, de que "a negociação coletiva é imprescindível para a dispensa em massa de trabalhadores", observados os fundamentos supra. Recurso ordinário a que se dá provimento parcial”. Cite-se ademais, o dispositivo do acórdão: ““ACORDAM os Ministros da Seção Especializada em Dissídios Coletivos do Tribunal Superior do Trabalho, por maioria: I - RECURSO ORDINÁRIO DA EMBRAER E OUTRA: 1 - negar provimento ao recurso quanto às questões preliminares renovadas, vencidos os Exmos. Srs. Ministros João Oreste Dalazen, Dora Maria da Costa, Fernando Eizo Ono e Milton de Moura França que, considerando se tratar de reclamação trabalhista típica sob a forma de dissídio individual plúrimo, davam provimento ao recurso a fim de anular o processo, a partir do acórdão recorrido, determinando o envio dos autos para distribuição a uma das Varas do Trabalho de São José dos Campos, para 
No que tange aos vícios processuais novamente alegados pelas suscitadas, o ministro relator observou que, não obstante a finalidade específica do dissídio coletivo de natureza jurídica, de interpretar e declarar o alcance das “cláusulas de sentenças normativas, de instrumentos de negociação coletiva, acordos e convenções coletivas, de disposições legais atinentes à categoria profissional ou econômica e de atos normativos”, tratar-se-ia de situação processual "excepcionalíssima, não se enquadrando inteiramente na figura clássica do dissídio coletivo de natureza jurídica”.

Em outras palavras, o TST reconheceu que a questão examinada era “eminentemente jurídica”, a envolver "interpretação quanto ao aspecto fundamental da ordem jurídica”, consistente em definir “se as dispensas massivas são, ou não, regidas do mesmo modo normativo que as dispensas meramente individuais e, não o sendo, quais as consequências jurídicas de sua regência normativa específica”. Registrou-se na decisão que não havia regramento específico na ordem jurídica a prever de que maneira o conflito deveria ser decidido, por se tratar “de figura incomum, diferindo das demais hipóteses já previstas no ordenamento e devidamente regulamentadas por lei, pela doutrina e pela jurisprudência”. Do mesmo modo que o órgão judicial a quo, o ministro relator entendeu ser inviável a aplicação, ao caso, “de requisitos formais previstos para situações diversas, com o objetivo de impossibilitar o julgamento da causa”.

Desse modo, note-se também haver fortes traços, no julgamento do recurso ordinário, de um ativismo judicial jurisdicional combinado com um ativismo judicial processual. É importante destacar que quatro dos ministros (João Oreste Dalazen,

instrução e julgamento da lide; 2 - dar provimento ao recurso para afastar a declaração de abusividade das dispensas, vencidos os Exmos. Srs. Ministros Relator e Kátia Arruda; 3 - dar provimento ao recurso para afastar a prorrogação dos contratos de trabalho até 13-03-09, vencidos os Exmos. Srs. Ministros Relator, Carlos Alberto Reis de Paula, Walmir Oliveira da Costa e Kátia Arruda; 4 - negar provimento ao recurso quanto às demais matérias, fixando a premissa de que a negociação coletiva é imprescindível para a dispensa em massa de trabalhadores, vencidos os Exmos. Srs. Ministros João Oreste Dalazen, Dora Maria da Costa, Fernando Eizo Ono e Milton de Moura França relativamente à fixação dessa premissa; II - RECURSOS ORDINÁRIOS INTERPOSTOS PELOS SINDICATO DOS METALÚRGICOS DE SÃO JOSÉ DOS CAMPOS E REGIÃO E OUTROS E PELO SINDIAEROESPACIAL - negar provimento aos recursos, vencidos os Exmos. Srs. Ministros Relator e Kátia Arruda, que lhes davam provimento parcial para, mantendo as demais condenações da Corte Regional, fixar a compensação financeira aos empregados dispensados na seguinte proporção: o valor correspondente a dois meses de aviso prévio para os empregados com até dois anos de prestação de serviços para as empresas; o valor correspondente a três meses de aviso prévio para os empregados que possuam de dois a quatro anos de prestação de serviços para as empresas; o valor correspondente a quatro meses de aviso prévio para os empregados que possuam de quatro a oito anos de prestação de serviços para as empresas; o valor correspondente a cinco meses de aviso prévio para os empregados que possuam mais de oito anos de prestação de serviços para as empresas. Juntarão voto divergente/convergente os Exmos. Srs. Ministros João Oreste Dalazen e Milton de Moura França. Notas degravadas e revisadas do pronunciamento do Exmo. Sr. Ministro Carlos Alberto Reis de Paula serão juntadas aos autos.” 
Dora Maria da Costa, Fernando Eizo Ono e Milton de Moura França) consideraram se tratar de “reclamação trabalhista típica sob a forma de dissídio individual plúrimo”, e em razão disso davam provimento ao recurso a fim de “anular o processo, a partir do acórdão recorrido, determinando o envio dos autos para distribuição a uma das Varas do Trabalho de São José dos Campos, para instrução e julgamento da lide»496. Prevaleceu, nessa matéria, entretanto, o entendimento do relator, que reconhecia a singularidade do caso (bem como as lacunas processuais e materiais) e afirmava que não se furtaria "da obrigação de dirimir a ação, não importando a nomenclatura a ela conferida” considerando a necessidade de “encontrar soluções adequadas” que possibilitassem “a devida prestação jurisdicional" 497 .

Conforme já se observou neste trabalho ${ }^{498}$, a Justiça do Trabalho corroborou, no caso, o manejo dos dissídios coletivos em situações que discrepam flagrantemente de seu uso comum e do que dispõe a própria OJ n. ${ }^{\circ} 07$ da SDC do TST. A corte trabalhista de cúpula, na fundamentação da decisão, considerou a medida cabível por se tratar de "conflito social de máxima relevância, que não pode ser desprezado por mera formalidade processual”, em especial porque repercussões do caso influenciariam “não apenas os diretamente interessados, mas a sociedade como um todo”. Note-se, assim, que, além de coonestar a ampliação da agenda da Justiça do Trabalho iniciada no TRT, a decisão do TST praticou, ao desconsiderar sua própria tese jurídica, um ativismo judicial em face de precedentes (plano horizontal). No exame da alegação das empresas suscitadas de que o poder normativo não poderia invadir o "espaço destinado ao Poder Legislativo”, o relator reiterou, sucintamente, tratar-se de hipótese “excepcionalíssima” de uso dos dissídios coletivos.

No mérito, a fundamentação da decisão do recurso enfocou, preponderantemente, a declaração do Tribunal Regional sobre a abusividade da dispensa coletiva realizada. As empresas sustentavam não só que o ato fora praticado "com a absoluta observância da legislação relativa às reparações dos contratos de trabalho, não havendo abuso de direito na prática”, mas também que a decisão a quo se utilizara de

\footnotetext{
${ }^{496}$ Por outro prisma possível, é curioso notar que, no caso das dispensas coletivas de mais de mil empregados da CSN (Companhia Siderúrgica Nacional) não foi instaurado dissídio coletivo, mas ajuizada, pelo MPT, uma ação civil pública perante a Vara do Trabalho de Volta Redonda (ACP n. ${ }^{\circ}$ 0010700-12.2009.5.01.0343, em que figurava como terceiro interessado o Sindicato dos Trabalhadores nas Industrias Metalúrgicas, Mecânicas de Material Elétrico, de Material Eletrônico e de Informática de Barra Mansa, Volta Redonda, Resende, Itatiaia, Quatis, Porto Real e Pinheiral).

${ }^{497}$ Note-se que, em parecer, o MPT opinou pela extinção do processo sem resolução do mérito.

${ }^{498}$ Cf. tópico 2.3.3.2, supra.
} 
princípios “de forma supletiva”. Com isso, pretendiam fosse cassado o acórdão recorrido, excluindo-se por completo a declaração de abuso de direito e a extensão dos contratos de trabalho pelo período compreendido entre a data da dispensa e a realização da primeira audiência de conciliação.

A decisão do TST, ao introduzir o exame do mérito, sustentou que parte significativa dos “danos mais relevantes na presente sociedade" e "das correspondentes pretensões jurídicas” teriam natureza massiva. Essas características da sociedade contemporânea (caráter massivo de danos e pretensões) obrigariam “o Direito a se adequar, deslocando-se da matriz individualista de enfoque”, para enfrentar "o desafio mais moderno proposto ao universo jurídico”, consistente na construção, paralelamente àquilo que já existe para o tratamento de conflitos individuais, de "uma matriz jurídica adequada à massividade dos danos e pretensões característicos da sociedade contemporânea”499.

Em diálogo com a decisão do TRT, o relator evocou, mais uma vez, a lacuna na normatização das dispensas coletivas no Brasil, notadamente pela perspectiva do “direito fundamental de todos dos trabalhadores à relação de emprego protegida contra a despedida arbitrária ou sem justa causa” (artigo $7^{\circ}$, I, da CR), que estaria regulamentado apenas para o caso dispensas individuais, à vista da previsão do artigo 10 do Ato das Disposições Constitucionais Transitórias (ADCT).

Com efeito, em resumo, a decisão: a) reconhecia a singularidade jurídica da dispensa coletiva "em sua estrutura, dimensão, profundidade, efeitos, impactos e repercussões”, tendo em vista as especificidades desse "fato econômico, social e jurídico", decorrentes da “acentuação da lesão provocada e pelo alargamento de seus efeitos”, os quais além dos trabalhadores e suas famílias atingiriam "toda a comunidade empresarial, trabalhista, citadina e até mesmo regional, abalando, ainda, o mercado econômico interno" ${ }^{500}$; b) afirmava que, como "ato, conduta ou fato massivo, envolvendo significativa

\footnotetext{
${ }^{499}$ É pertinente, neste ponto, evocar as reflexões do tópico 2.2.9, supra.

${ }^{500}$ Para justificar a identificada singularidade das dispensas coletivas, o relator refletiu: "Nota-se, num exercício analógico, que a diferença entre fatos individuais ou específicos e fatos coletivos pode ser observada em outras searas do direito. Uma conduta omissiva do trabalhador, que deixa de comparecer ao posto de trabalho, por exemplo, possui punição prevista pelo direito, podendo ser considerada até mesmo como justa causa para rescisão do contrato de trabalho pelo empregador, nos termos do art. 482 da CLT. Já uma conduta omissiva de uma coletividade, sejam empregados de um setor ou de toda uma empresa, não é infração trabalhista, mas um direito constitucionalmente previsto, ou seja, o direito de greve (art. $9^{\circ}, \mathrm{CF} / 88$ ). A diferença entre o individual e o coletivo também pode ser observada no campo das ciências. Uma doença individual é um fato com estrutura, dimensão e repercussão localizadas, pontuais, individuais e tópicas, ao passo que uma epidemia do mesmo mal tem dimensão, profundidade, impacto e, dessa forma, estrutura diferentes. Portanto, tanto na vida social como nas ciências, e como também no direito, os fatos estritamente
} 
coletividade de trabalhadores”, a dispensa coletiva constituiria “matéria típica, específica e obrigatória” do direito coletivo do trabalho; e c) após indicar, com base no artigo $8^{\circ}$ da CLT, os pontos de apoio do julgamento (que em linhas gerais corroboravam a fundamentação do TRT), sustentava que a ordem jurídica, à falta de previsão de que um ato de tamanho impacto pudesse ser "realizado arbitrariamente e de maneira estritamente individual”, não permitiria o “manejo meramente unilateral e potestativista das dispensas trabalhistas coletivas” ${ }^{\text {501 }}$. Por fim, a decisão concluía:

"Em síntese: as dispensas coletivas de trabalhadores, substantiva e proporcionalmente distintas das dispensas individuais, não podem ser exercitadas de modo unilateral e potestativo pelo empregador, sendo matéria de Direito Coletivo do Trabalho, devendo ser submetidas à prévia negociação coletiva trabalhista ou, sendo inviável, ao processo judicial de dissídio coletivo, que irá lhe regular os termos e efeitos pertinentes. Neste ponto, para os casos futuros, a d. Maioria da SDC fixou tal premissa (embora a d. Maioria, para o caso vertente nestes autos, não reconheça abusividade ou falta de boa-fé objetiva na dispensa massiva perpetrada - até mesmo porque a premissa aqui fixada não era ainda acolhida na Jurisprudência até então dominante). A premissa ora fixada é: 'a negociação coletiva é imprescindível para a dispensa em massa de trabalhadores'” (destaques acrescidos).

O julgado, neste ponto, merece exame mais pormenorizado. É que, como se vê, a maioria dos ministros da SDC, não obstante fixar a referida "premissa" "502, afastou sua incidência sobre aquele caso particular (vencidos os ministros Maurício Godinho

individuais são manifestamente distintos dos fatos coletivos, massivos. Os eventos da dispensa coletiva e da dispensa individual de trabalhadores de certa empresa não poderiam obedecer a outra lógica.”

${ }^{501}$ E observou: "Nesse quadro, a inércia do legislador em regulamentar as consequências e sanções previstas no caso de dispensa coletiva não pode impedir a aplicação de direitos previstos constitucionalmente, como estabelecido no já citado art. $7^{\circ}$, I, além de outros, como a dignidade da pessoa humana e os valores sociais do trabalho e da livre iniciativa, que são fundamentos da República. A Carta Magna prevê, ainda, que a ordem econômica é fundada na valorização do trabalho humano, e tem, entre seus princípios, a busca do pleno emprego". O relator ponderou, inclusive, que, em seu entendimento (e neste ponto foi vencido), a dispensa coletiva "não regulada e atenuada pela negociação coletiva até mesmo ensejaria indenização compensatória superior às simples verbas da estrita dispensa individual, a par de outros efeitos em conformidade com a situação concreta enfocada".

502 Divergiram, no que tange à fixação da premissa, os Ministros João Oreste Dalazen, Dora Maria da Costa, Fernando Eizo Ono e Milton de Moura França. 
Delgado e Kátia Arruda), reformando, neste ponto, a decisão do TRT, que reconhecia a abusividade e a falta de boa-fé objetiva na dispensa massiva realizada.

A justificativa oferecida na decisão do TST foi a de que aquela premissa “não era ainda acolhida na Jurisprudência até então dominante”, assertiva da qual se pode extrair a inferência de que, se houvesse um caso futuro, o julgamento, neste particular, seria diferente. Em outros termos, a intenção declarada do TST, com a fixação da premissa, foi a de que a negociação coletiva ou a sentença normativa passassem, a partir de então, a fixar as condutas para o enfrentamento de crises econômicas e empresariais, de forma a atenuar o impacto da dispensa coletiva ${ }^{503}$. Ponderava o relator, entretanto, que ele e a Ministra Kátia Arruda divergiram do entendimento vencedor, o qual, reconhecendo que a jurisprudência era “pacífica em não restringir as dispensas coletivas”, deu provimento ao recurso ordinário das empresas para afastar a declaração de abusividade do ato e a alegada “afronta à boa-fé objetiva”. Tendo em vista, como corolário, que “não caberia invalidar o ato empresarial de ruptura, nem estender os contratos para dias ou semanas adicionais”, a maioria dos votantes ${ }^{504}$ também afastou a prorrogação dos contratos $^{505}$ propiciada pela decisão liminar que suspendera as dispensas (mantida, em

503 Isso poderia ser feito, conforme destacado no julgado, por medidas dirigidas ao “conjunto dos trabalhadores ou a uma parcela deles, seja pela adoção da suspensão do contrato de trabalho para participação do empregado em curso ou programa de qualificação profissional oferecido pelo empregador (art. 476-a da CLT), seja pela criação de Programas de Demissão Voluntária (PDVs), seja pela observação de outras fórmulas atenuantes instituídas pelas partes coletivas negociadas”. Nos casos em que a dispensa se afigurar inevitável, essa mesma negociação - judicial ou extrajudicial - poderia estabelecer "critérios de preferência social”, tais como "a despedida dos mais jovens em benefício dos mais velhos, dos que não tenham encargos familiares em benefício dos que tenham, e assim sucessivamente”. Ressalvar-se-iam, do todo modo, as situações de trabalhadores com "garantias de emprego, tais como licença previdenciária, ou com debilidades físicas reconhecidas, portadores de necessidades especiais, gestantes, dirigentes sindicais e diretores eleitos de CIPAs, além de outros casos” que mereceriam exclusão do rol dos passíveis de desligamento. Levou-se em consideração, ademais, com base no já citado artigo $8^{\circ}$ da CLT, que consuetudinariamente, nas dispensas massivas, instituem-se os "PDVs, PDIs e similares, os quais estabelecem valores indenizatórios pagos segundo o tempo de serviço, a manutenção, ainda que temporária, de certas vantagens adicionais criadas pela empresa (planos de saúde, por exemplo)”. Pode-se dizer que o reconhecimento, para a validade da dispensa coletiva, do requisito procedimental da negociação coletiva, fortaleceu este instrumento.

${ }^{504}$ Foram vencidos, neste aspecto, além do relator, os Ministros Carlos Alberto Reis de Paula, Walmir Oliveira da Costa e Kátia Arruda.

${ }^{505}$ Isso também prejudicou os recursos dos sindicatos dos trabalhadores (vencidos dois ministros, entre eles o relator). Reafirmou-se, neste ponto, que a vedação da dispensa arbitrária não implicaria, por si só, o direito à reintegração. Note-se que o relator propunha, em juízo de “equidade, razoabilidade e proporcionalidade”: a) a limitação dos efeitos da liminar na forma proposta pelo TRT; b) a manutenção da condenação ao pagamento do plano de assistência médica dos trabalhadores com respeito ao período acrescido pelos efeitos da liminar; c) a manutenção do direito de preferência dos empregados dispensados no caso de reativação dos postos de trabalho; d) a alteração da compensação financeira concedida aos empregados dispensados, para que obedecesse certa proporção em relação ao aviso prévio (que seria de dois meses para empregados com até dois anos; três meses para empregados com dois a quatro anos; e quatro meses para os empregados com quatro a oito anos; e cinco meses de aviso para os empregados com mais de oito anos de prestação de serviços para as empresas). Em outras palavras, o ativismo judicial criativo, se o colegiado houvesse acolhido 
parte, pelo TRT, que reconheceu seus efeitos até a data da primeira audiência de conciliação).

A inusitada exclusão da incidência, sobre o caso sub judice, da criativa “premissa” então fixada pelo TST (que reivindicava apenas efeitos "para os casos futuros”) foi justificada por se tratar de mudança substancial na orientação jurisprudencial da Corte. Parece razoável examinar o motivo dessa exclusão à luz da teleologia da chamada modulação de efeitos temporais, muito comum na jurisprudência do STF.

Com efeito, essa modulação de efeitos temporais de determinado entendimento jurisprudencial é justificada por preocupações com a segurança jurídica, imperativo que também se aplicaria à evolução jurisprudencial, de forma a determinar seja “o cuidado novo sobre tema antigo pela jurisdição concebido como forma de certeza e não causa de sobressaltos para os cidadãos” ${ }^{\text {,06 }}$.

Note-se, ademais, que o fato e a forma da criação da referida tese jurídica ou premissa: a) discrepava da jurisprudência até então pacífica no tribunal; $b$ ) reivindicava, já em sua edição, não apenas pela repercussão do caso, mas também pela posição ocupada pela mais alta corte do Trabalho no país, fortíssima carga persuasiva, sinalizando ad futurum novas tendências decisórias ${ }^{507}$ não só para a comunidade jurídica trabalhista (a incluir os magistrados de órgãos judiciais de instâncias inferiores), mas também para a sociedade em geral (mercado, empresas, sindicatos, trabalhadores e demais atores sociais potencialmente interessados) ${ }^{508}$; c) sugeria que a decisão naquele processo (que de um ponto de vista estritamente dogmático seria de alcance restrito às categorias, às partes e a terceiros juridicamente interessados) impunha ordens com alcance mais largo, extensíveis a todas as eventuais dispensas futuras, excluída (pela modulação de efeitos supracitada) a incidência sobre aquele caso concreto $^{509}$. Vislumbra-se, assim, na combinação desses aspectos, uma amálgama que envolve o ativismo judicial criativo, o

a proposta do relator no que tange à proporcionalidade do aviso prévio, seria ainda mais sofisticado, a alcançar, inclusive, a regulamentação ad hoc do direito previsto no artigo $7^{\circ}$, XXI, da CR.

506 “(...) Razões de segurança jurídica, e que se impõem também na evolução jurisprudencial, determinam seja o cuidado novo sobre tema antigo pela jurisdição concebido como forma de certeza e não causa de sobressaltos para os cidadãos. (...)”. Esse fundamento se encontra em vários julgados do STF, v.g., MS 26.604, rel. Min. Cármen Lúcia, DJe 3-10-08, julg. 04-10-07; MS 26.602, rel. Min. Eros Grau, DJE de 1710-08, julg. 4-10-07; MS 26.603, rel. Min. Celso de Mello, julg. 4-10-07, Plenário, DJE de 19-12-08.

${ }^{507}$ Cf. tópico 1.3, 2.2.7.1, supra.

508 Sobre as repercussões do caso no âmbito das discussões associativas dos magistrados, v., outrossim, tópico 3.4.3.2, supra.

${ }^{509}$ Consoante o ensinamento de Délio Maranhão, “assim como a Nação é o limite máximo de extensão da norma legal, a categoria é o limite máximo de extensão da sentença normativa”. ARNALDO SÜSSEKIND et. al. Instituições de direito do Trabalho, 23ª ed., São Paulo: LTr, 2003, p. 156. 
ativismo judicial em face de precedentes (considerado, aqui, no plano horizontal), o ativismo judicial de padronização decisória e o ativismo judicial processual ${ }^{510}$. Parecem claros, ademais, traços de ativismo judicial promocional, uma vez que a tese fixada implica uma obrigação que seria imponível aos particulares se o Estado houvesse legislado a respeito das dispensas coletivas de modo condizente com a teleologia constitucional, com as normas internacionais e com as experiências colhidas no direito estrangeiro, conforme se extrai da decisão ${ }^{511}$.

Por fim, como vimos no capítulo introdutório, houve uma série de manifestações de magistrados do trabalho nos meios de comunicação em geral (sob a forma de manifestos e artigos publicados na imprensa), em defesa da decisão e da postura da Justiça do Trabalho naquele caso, a desvelar um ativismo judicial extraprocessual, fora do contexto do processo e do exercício stricto sensu da jurisdição. Esse tipo de ativismo judicial foi percebido, igualmente, na elaboração de teses jurídicas em congresso que reunia diversos magistrados. Essas teses propunham (com inspiração no caso Embraer, discutido no evento, e em outros casos similares) o entendimento de que "a dispensa coletiva, para que seja válida e legítima, demanda fundados motivos econômicos ou estruturais que ameacem inviabilizar de fato o funcionamento da empresa”, razão pela qual seria necessária “a submissão prévia de tais motivos, expostos pelo empregador, à consulta do ente representativo da categoria, ou, ao menos, à previsão em norma coletiva para legitimar a dispensa com efeitos coletivos”. Note-se que, indo além do próprio precedente persuasivo da Justiça do Trabalho sobre essas dispensas (o qual, como veremos a seguir, não fixara uma sanção para o descumprimento da “premissa” estabelecida), propunham os magistrados que eventual descumprimento dos requisitos ali referidos deveria levar à “reintegração dos empregados dispensados”512.

\footnotetext{
${ }^{510}$ Além dos aspectos já destacados para demonstrar a condução ativa do processo pelos órgãos judiciais envolvidos (com a flexibilização do procedimento e dispensa de requisitos processuais consagrados na jurisprudência da Justiça do Trabalho), vale evocar mais uma vez que, ao longo de todo o processo (das audiências conciliatórias oficiais e "informais") até o TST, várias tentativas de composição se sucederam. Note-se que, no julgamento do processo no TRT, o relator observava que o dissídio fora ajuizado a fim de que o Tribunal atuasse "como mediador".

${ }^{511}$ Cf. tópicos 4.3.3, 4.3.4, 4.3.5, 4.3.6, 4.3.8, supra.

${ }^{512} \mathrm{Cf}$. tópicos 1.1 e 3.4.3.2, supra.
} 


\subsubsection{Observações conclusivas sobre o caso}

A título conclusivo, oferecem-se outras reflexões sobre o caso.

Primeiro, verifica-se que ele traz à tona uma série de questões relacionadas aos chamados litígios de interesse público, com o tendencial esgarçamento, nessas demandas, das concepções tradicionais dos institutos processuais; a orientação mais prospectiva do que retrospectiva; a importância das estruturas de suporte à mobilização jurídica (no caso os sindicatos, que fortaleceram sua legitimidade); a escolha possivelmente estratégica do tipo de demanda a ser ajuizada, conforme os resultados jurídicos, políticos, sociais, econômicos e midiáticos esperados, notadamente quando se tratar de repeat players ${ }^{513}$.

Segundo, considerando que, captados no plano sociológico, os litígios podem assumir várias conotações jurídicas; e que, na mesma época, houve pelo menos um caso de ajuizamento de demanda similar pela via da ação civil pública, perante o juiz singular, em primeiro grau ${ }^{514}$, pergunta-se: do ponto de vista estratégico, qual seria a forma mais efetiva de enfrentamento judicial das dispensas coletivas, do ponto de vista do fomento ao protagonismo judicial? As repercussões de uma tutela liminar eventualmente deferida em uma ação civil pública ajuizada perante um juiz singular seria a mesma de um provimento antecipatório alcançado num dissídio coletivo “de natureza jurídica”, em decisão da presidência de um Tribunal do Trabalho “no exercício do poder normativo”? Se os interesses individuais não houvessem sido molecularizados, quais seriam as diferenças dos resultados finais (jurídicos, políticos, sociais, econômicos e midiáticos) de milhares de reclamações trabalhistas individuais, ainda que incidisse nesses casos, mutatis mutandis, os mesmos tipos de ativismo judicial?

Terceiro, não parecem bem mapeadas as repercussões do precedente então firmado e as várias questões que ele suscita, o que é relevante diante da constatação de que surgiram e tendem a surgir outras decisões dos TRTs que podem ser avaliadas à luz

\footnotetext{
${ }^{513}$ Cf. tópicos 2.3.9, 2.3.9.1, 2.3.9.2, 2.3.3.2, supra. É curioso notar que, pelas repercussões do caso, houve tentativa de ingresso, na almejada condição de amicus curiae, da "Associação Brasileira de Defesa dos Direitos e Garantias Fundamentais do Cidadão (ABRAC)”, o que foi rejeitado pelo TRT, que não deixava de reconhecer a notória "repercussão geral” do tema em razão de a demissão coletiva implicar "nefastos efeitos socioeconômicos na vida das pessoas".

514 Trata-se da ACP n. ${ }^{\circ}$ 0010700-12.2009.5.01.0343, em que figurava como terceiro interessado o Sindicato dos Trabalhadores nas Industrias Metalúrgicas, Mecânicas de Material Elétrico, de Material Eletrônico e de Informática de Barra Mansa, Volta Redonda, Resende, Itatiaia, Quatis, Porto Real e Pinheiral.
} 
da "premissa” fixada pelo TST, de modo ativista, no caso Embraer ${ }^{515}$. Num certo sentido, a fixação da premissa foi insuficiente para dirimir as dúvidas já existentes antes de sua existência, além de haver suscitado várias outras. Para ilustrar, indaga-se: qual a natureza jurídica da citada premissa criada a respeito das dispensas coletivas? Qual seria a sanção para o seu descumprimento se, não obstante deixar clara a nulidade da dispensa que desrespeitar o requisito procedimental da negociação coletiva, não se admitir o retorno ao status quo ante (a reintegração)? Como cumprir a decisão? Caberia a cada Tribunal decidir? Que é dispensa coletiva? O que seria, afinal, de “natureza coletiva”, o fato da dispensa ou as relações jurídicas emergentes deste fato? Quantas dispensas individuais, consideradas em conjunto, seriam suficientes para caracterizar uma dispensa coletiva, a atrair a tese jurídica fixada na "premissa” do TST? Só seriam consideradas as dispensas realizadas num único dia? Seriam consideradas as dispensas realizadas num lapso temporal específico? A quem cabe decidir se a natureza da dispensa é coletiva? Como identificar uma “dispensa coletiva” eventualmente disfarçada de dispensa individual, na hipótese de o empregador programá-las, pulverizá-las ao longo de um certo número de meses? Quais seriam as providências em face de tal expediente? Haveriam de ser ajuizados vários dissídios coletivos? A decisão examinada não implicaria um paradoxo, já que, ao tentar pacificar o conflito, estabeleceu requistos meramente procedimentais para a realização de uma “dispensa coletiva”, abstendo-se de definir os atributos desta última e, desse modo, ao

\footnotetext{
${ }^{515}$ Ilustrativamente, no processo TRT $15^{\mathrm{a}}$ Região n. ${ }^{\circ}$ 0014673-10.2010.5.15.0000 (DC) foram suspensas liminarmente as dispensas de 200 trabalhadores da Foxconn do Brasil (às vésperas do Natal de 2010). No julgamento desse "dissídio coletivo de natureza jurídica", o resultado foi similar à decisão do Regional no caso Embraer, com referência expressa à "premissa" fixada pelo TST. Já no Processo TRT $15^{\text {a }}$ Região n. ${ }^{\circ}$ 0000184-31.2011.5.15.0000 (DC), o mesmo tipo de intervenção judicial liminar ocorreu em relação à dispensa de 170 trabalhadores da Avibrás Indústria Aeroespacial S.A., encerrado com acordo que possibilitaria a recontratação, conforme se extrai do ato da homologação da conciliação: “(...) as partes se conciliaram (fls. 214/215), nos seguintes termos: 'A partir do adiantamento do contrato no valor de aproximadamente $\mathrm{R} \$ 150.000 .000,00$ (cento e cinquenta milhões de reais), a empresa se compromete a proceder a recontratação de 170 trabalhadores demitidos, desde que atendam às qualificações necessárias às vagas, bem como a proceder ao pagamento de uma indenização correspondente a 02 (dois) salários nominais, até o limite do teto de $\mathrm{R} \$ 7.500,00$ (sete mil e quinhentos reais) àqueles que contarem com até 02 (dois) anos de serviço na empresa, e não tiverem interesse na recontratação; assim como o pagamento de 03 (três) salários nominais àqueles que contarem de 02 (dois) a 05 (cinco) anos de trabalho na empresa, também com o teto de $\mathrm{R} \$ 7.500,00$ (sete mil e quinhentos reais), àqueles que não tiverem interesse na recontratação; assim como o pagamento de 04 (quatro) salários nominais àqueles que contarem com mais de 05 (cinco) anos de serviço, também limitado ao teto de $\mathrm{R} \$ 7.500,00$ (sete mil e quinhentos reais), àqueles que não tiverem interesse na recontratação; garantir convênio médico até 30.06.2011 a todos os trabalhadores demitidos; garantir a reintegração imediata àqueles trabalhadores com estabilidade provisória no emprego, desde que devidamente comprovado; caso não haja regularidade com relação às verbas devidas ao trabalhador, o sindicato se reserva o direito de não proceder à homologação, havendo nesse caso a incidência do pagamento de uma multa de $50 \%$ sobre o valor que estaria faltando na rescisão. Nesse caso, o sindicato procederá um aviso ao Setor de Pessoal da empresa, que se compromete a corrigir a anormalidade no prazo de 24 horas, havendo incidência da multa somente na hipótese do não atendimento’”.
} 
mesmo tempo em que capturou o litígio para solucioná-lo, devolveu-o para a sociedade sem resolvê-lo integralmente? ?16 $^{51}$

E mais: quais seriam os limites para a flexibilização dos dissídios coletivos, tanto por um ativismo judicial jurisdicional (potencialmente ampliativo da agenda do Poder Judiciário trabalhista ${ }^{517}$ ), quanto pela possibilidade da prática de outros tipos de ativismo judicial (processual, criativo, promocional, contra legem, entre outros)?

É verdade que se costuma afirmar que o exercício do poder normativo no contexto de um dissídio coletivo não configuraria atividade jurisdicional stricto sensu. No entanto, com a identificação da incidência de vários tipos de ativismo judicial no caso, todas as ambiguidades destacadas (uso alternativo e estratégico dos dissídios coletivos, prolação de decisões com traços inequivocamente condenatórios, entre tantos outros aspectos) parecem não só contestar aquela concepção, mas também suscitar novas e aprofundadas reflexões ${ }^{518}$.

Como se vê, o caso examinado possui vários atributos relevantes para a compreensão das peculiaridades do potencial protagonismo judicial na Justiça do Trabalho, particularmente sensível aos vários influxos da juridificação em razão de sua competência material estar atrelada à aplicação do ramo do direito (o Direito do Trabalho) que constitui um paradigma simbólico desse processo de colonização jurídica do mundo da vida $^{519}$. Ao mesmo tempo, o exame do caso pela perspectiva dos tipos ideais de ativismo judicial permite denunciar uma série de paradoxos e vicissitudes inerentes não só ao processo de juridificação, mas também ao próprio fenômeno da judicialização.

\footnotetext{
${ }^{516}$ E poderia ser formulada outra pergunta relevante: considerando que a prévia negociação seria premissa da validade da dispensa, de que tipo de negociação coletiva se trata, considerando que sua simples realização não se confunde com o seu resultado eventual (que pode variar entre a absoluta falta de acordo e o consenso integral)?

${ }^{517}$ Não parece equivocada a afirmação de que o simples fato de haver sido proferida uma decisão de mérito no caso já representa um fato relevante do ponto de vista do potencial protagonismo judicial e de sua manifestação, o ativismo judicial, independentemente do resultado favorável à pretensão sindical. Isso porque se ampliou, inequivocamente, a agenda judicial, de modo que, em relação às dispensas coletivas, a agenda sindical e os próprios sindicatos deixaram de ser meros outsiders. Note-se que nem mesmo a questão do "cumum acordo" ( $\left(2^{\circ}\right.$ do artigo 114 da CR) foi discutida a fundo no caso.

${ }^{518}$ Pode-se indagar, ainda, se o TST fixaria, em situações futuras e em relação a outros temas, outras "premissas" da mesma natureza.

${ }^{519}$ Cf. tópicos 2.3.3, 2.3.3.1, 2.3.3.2,3 2.3.3.4, supra.
} 


\subsection{Ativismo judicial no direito sumular trabalhista}

Como foi visto, uma das peculiaridades do potencial protagonismo judicial na Justiça do Trabalho (ao lado do poder normativo e do modelo trabalhista de juiz ativo), mesmo antes da Constituição de 1988, é o chamado Direito Sumular desenvolvido pelo $\operatorname{TST}^{520}$.

Comparativamente ao STF e ao STJ, o TST figura na primeira posição do “ranking” da produção dessas teses jurídicas. Do ponto de vista estritamente quantitativo (no limite do que este prisma possa revelar e admitidas eventuais distorções qualitativas decorrentes desta limitação), existem no TST, entre precedentes cancelados, vigentes e remanejados, 1.244 verbetes persuasivos (entre súmulas, precedentes normativos e orientações jurisprudenciais do tribunal pleno/órgão especial; da SBDI-I, da SBDI-II e da SDC), constantemente revisados e alterados à medida que os entendimentos se modificam. No STF, o total é de 736 súmulas persuasivas e 32 súmulas vinculantes editadas. O STJ, por sua vez, já elaborou 470 súmulas, as quais, mesmo se somadas às do extinto TFR, totalizariam 735 verbetes “persuasivos”. Importa não olvidar que, diferentemente dos enunciados das súmulas do STF e do STJ, vários verbetes do TST têm mais de uma proposição. Ilustrativamente, as "campeãs" no número de itens são a súmula 6 (equiparação salarial) e a súmula n. ${ }^{0} 100$ (ação rescisória), ambas com dez itens.

A fortíssima aptidão persuasiva das teses jurídicas desenvolvidas pelo TST desvela, pela simples possibilidade de sua edição, um potencial protagonismo judicial que pode se traduzir em vários tipos de ativismo judicial.

O ativismo judicial de padronização decisória ocorre pela enunciação, nos verbetes sumulares, de teses jurídicas trabalhistas com notável força persuasiva e que reivindicam presunção relativa de correção ${ }^{521}$.

Ademais, se de um lado o TST é o tribunal superior que mais produz teses jurídicas, de outro é também o que mais as modifica. Com efeito, de todos os precedentes editados pela corte, cerca de quinhentos têm um "histórico" que indica alterações na redação, acréscimos, aglutinações e cancelamentos. Assim, visualiza-se certa recorrência na prática do ativismo judicial em face de precedentes, especificamente no

\footnotetext{
${ }^{520}$ Cf. tópico 2.3.3.3, supra.

${ }^{521}$ Cf. tópico 4.3.5, supra. Afirmou-se, ademais, que esse potencial poderá ser ampliado com a eventual aprovação da PEC n. ${ }^{\circ}$ 358/2005 e a instituição das reclamações para o TST e das súmulas impeditivas de recursos.
} 
plano horizontal $^{522}$. Em muitos casos, esse ativismo implicou a modificação não de um mero detalhe de redação, mas da substância da própria tese, inclusive para eventual outra tese que se poderia considerar oposta ${ }^{523}$.

Além disso, em várias das teses sumulares do TST, nota-se claramente um ativismo judicial criativo. É o caso da súmula n. ${ }^{\circ} 331$ (terceirização), da súmula n. ${ }^{\circ} 291$ (sobre horas extraordinárias), que instituiu indenização praeter legem, sem nenhuma previsão legal; e de vários precedentes sobre o trabalho bancário (v.g., a súmula n. ${ }^{\circ} 102^{524}$ ), direito processual (súmula n. ${ }^{\circ} 218^{525}$ e OJ n. ${ }^{0} 130^{526}$ da SDI 2) e tantos outros temas (v.g., natureza de verbas pagas ao trabalhador, reflexos salariais, efeitos temporais do contrato de trabalho, prescrição, estabilidades, garantias de emprego). O conjunto desses precedentes

${ }^{522}$ Cf. tópico 4.3.6, supra.
${ }^{523}$ A proposição não se refere a alterações que ocorreram em decorrência de mudanças legislativas.
${ }^{524}$ Em sua redação atual, prevê o verbete: "Súmula n. ${ }^{\circ}$ 102. BANCÁRIO. CARGO DE CONFIANÇA 524 Em sua redação atual, prevê o verbete: "Súmula n.o 102. BANCÁRIO. CARGO DE CONFIANÇA
(mantida) - Res. 174/2011, DEJT divulgado em 27, 30 e 31.05.2011. I - A configuração, ou não, do exercício da função de confiança a que se refere o art. 224, § $2^{\circ}$, da CLT, dependente da prova das reais atribuições do empregado, é insuscetível de exame mediante recurso de revista ou de embargos. (ex-súmula n.o 204 alterada pela Res. 121/2003, DJ 21.11.2003). II - O bancário que exerce a função a que se refere o $\S 2^{\circ}$ do art. 224 da CLT e recebe gratificação não inferior a um terço de seu salário já tem remuneradas as duas horas extraordinárias excedentes de seis. (ex-súmula n. ${ }^{\circ} 166$ - RA 102/1982, DJ 11.10.1982 e DJ 15.10.1982). III Ao bancário exercente de cargo de confiança previsto no artigo 224, § $2^{\circ}$, da CLT são devidas as $7^{\text {a }}$ e $8^{\text {a }}$ horas, como extras, no período em que se verificar o pagamento a menor da gratificação de $1 / 3$. (ex-OJ n. ${ }^{\circ}$ 288 da SBDI-1 - DJ 11.08.2003). IV - O bancário sujeito à regra do art. 224, § 2², da CLT cumpre jornada de trabalho de 8 (oito) horas, sendo extraordinárias as trabalhadas além da oitava. (ex-súmula n. ${ }^{\circ}$ 232- RA 14/1985, DJ 19.09.1985). V - O advogado empregado de banco, pelo simples exercício da advocacia, não exerce cargo de confiança, não se enquadrando, portanto, na hipótese do $\S 2^{\circ}$ do art. 224 da CLT. (ex-OJ n. ${ }^{\circ}$ 222 da SBDI-1 - inserida em 20.06.2001). VI - O caixa bancário, ainda que caixa executivo, não exerce cargo de confiança. Se perceber gratificação igual ou superior a um terço do salário do posto efetivo, essa remunera apenas a maior responsabilidade do cargo e não as duas horas extraordinárias além da sexta. (ex-súmula n.ํำ 102 - RA 66/1980, DJ 18.06.1980 e republicada DJ 14.07.1980). VII - O bancário exercente de função de confiança, que percebe a gratificação não inferior ao terço legal, ainda que norma coletiva contemple percentual superior, não tem direito às sétima e oitava horas como extras, mas tão somente às diferenças de gratificação de função, se postuladas. (ex-OJ n. ${ }^{\circ} 15$ da SBDI-1 - inserida em 14.03.1994)."

${ }^{525}$ Súmula n. ${ }^{\circ} 218$ (redação atual) "RECURSO DE REVISTA. ACÓRDÃO PROFERIDO EM AGRAVO DE INSTRUMENTO (mantida) - Res. 121/2003, DJ 19, 20 e 21.11.2003. É incabível recurso de revista interposto de acórdão regional prolatado em agravo de instrumento."

${ }^{526}$ OJ SDI2 n. ${ }^{\circ}$ 130. AÇÃO CIVIL PÚBLICA. COMPETÊNCIA TERRITORIAL. EXTENSÃO DO DANO CAUSADO OU A SER REPARADO. APLICAÇÃO ANALÓGICA DO ART. 93 DO CÓDIGO DE DEFESA DO CONSUMIDOR. DJ 04.05.2004. Para a fixação da competência territorial em sede de ação civil pública, cumpre tomar em conta a extensão do dano causado ou a ser reparado, pautando-se pela incidência analógica do art. 93 do Código de Defesa do Consumidor. Assim, se a extensão do dano a ser reparado limitar-se ao âmbito regional, a competência é de uma das Varas do Trabalho da Capital do Estado; se for de âmbito suprarregional ou nacional, o foro é o do Distrito Federal”. O artigo 93 do CDC, por sua vez, estabelece: “Art. 93. Ressalvada a competência da Justiça Federal, é competente para a causa a justiça local: I - no foro do lugar onde ocorreu ou deva ocorrer o dano, quando de âmbito local; II - no foro da Capital do Estado ou no do Distrito Federal, para os danos de âmbito nacional ou regional, aplicando-se as regras do Código de Processo Civil aos casos de competência concorrente." Como se vê, o artigo 93 do CDC não se refere a dano suprarregional. 
fortemente persuasivos parece revelar uma espécie de “regulamentação” jurisprudencial das leis trabalhistas, fruto desse ativismo judicial criativo praticado pelo TST $^{527}$.

As possibilidades de problematização das repercussões desse "Direito Sumular” são amplas, inclusive no caso do cancelamento de precedentes. A título ilustrativo, não sobeja evocar o exemplo da súmula n. ${ }^{\circ}$ 310, que limitava drasticamente o alcance do artigo $8^{\circ}$, III, da CR, ao negar a possibilidade de "substituição processual pelo

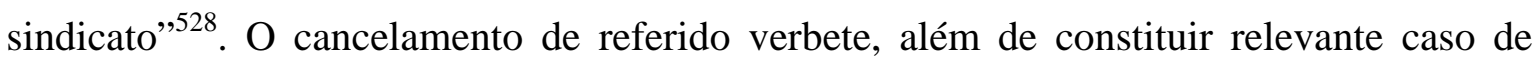
ativismo judicial em face de precedentes (plano horizontal), revela claros traços de ativismo judicial jurisdicional, uma vez que a mudança do entendimento jurisprudencial sob exame sinalizava (contrariamente ao que previa o precedente então cancelado) a abertura da agenda judicial trabalhista para demandas coletivas sindicais.

\subsection{Exame de outros julgados}

\subsubsection{Controle judicial de políticas públicas}

Normalmente ajuizadas pelo Ministério Público do Trabalho (MPT), algumas ações civis públicas têm buscado promover o controle judicial de políticas públicas pela Justiça do Trabalho, o que, pela perspectiva desta tese, fomenta um potencial protagonismo judicial típico dos litígios de interesse público. O Parquet trabalhista,

\footnotetext{
${ }^{527}$ Cf. 2.3.3.3, supra. Ilustrativamente, citem-se, entre tantas outras teses jurídicas, as das súmulas n. ${ }^{\circ}$ 6, 253, 261, 294, 326, 327, 331, 340, 363, 369, 371, 376.

${ }^{528}$ Dizia a redação da súmula cancelada: "SUBSTITUIÇÃO PROCESSUAL. SINDICATO (cancelamento mantido) - Res. 121/2003, DJ 19, 20 e 21.11.2003 e republicada DJ 25.11.2003. I - O art. 8º, III, da Constituição da República não assegura a substituição processual pelo sindicato. II - A substituição processual autorizada ao sindicato pelas Leis n. ${ }^{\circ}$ s 6.708, de 30.10.1979, e 7.238, de 29.10.1984, limitada aos associados, restringe-se às demandas que visem aos reajustes salariais previstos em lei, ajuizadas até 03.07.1989, data em que entrou em vigor a Lei n. ${ }^{\circ}$ 7.788/1989. III - A Lei n. ${ }^{0}$ 7.788/1989, em seu art. $8^{\circ}$, assegurou, durante sua vigência, a legitimidade do sindicato como substituto processual da categoria. IV - A substituição processual autorizada pela Lei . $^{\circ}$ 8.073, de 30.07.1990, ao sindicato alcança todos os integrantes da categoria e é restrita às demandas que visem à satisfação de reajustes salariais específicos resultantes de disposição prevista em lei de política salarial. V - Em qualquer ação proposta pelo sindicato como substituto processual, todos os substituídos serão individualizados na petição inicial e, para o início da execução, devidamente identificados pelo número da Carteira de Trabalho e Previdência Social ou de qualquer documento de identidade. VI - É lícito aos substituídos integrar a lide como assistente litisconsorcial, acordar, transigir e renunciar, independentemente de autorização ou anuência do substituto. VII - Na liquidação da sentença exequenda, promovida pelo substituto, serão individualizados os valores devidos a cada substituído, cujos depósitos para quitação serão levantados através de guias expedidas em seu nome ou de procurador com poderes especiais para esse fim, inclusive nas ações de cumprimento. VIII - Quando o sindicato for o autor da ação na condição de substituto processual, não serão devidos honorários advocatícios. Histórico: Súmula cancelada - Res. 119/2003, DJ 01.10.2003 Redação original - Res. 1/1993, DJ 06, 10 e 12.05.1993.”
} 
instituição eminentemente promocional, é um dos principais atores estatais que compõem a estrutura de suporte à mobilização jurídica no Brasil ${ }^{529}$.

Um caso ilustrativo desse tipo de atuação ministerial é o da ACP n. ${ }^{\circ}$ 0498100-48.2007.5.09.0245 $5^{530}$, na qual o MPT postulava fosse o Município de Pinhais compelido a adotar diversas ações direcionadas à erradicação do trabalho de crianças e de adolescentes na coleta do lixo e à modificação das condições de trabalho de adultos catadores de materiais recicláveis, que até então eram consideradas insalubres e indignas. Assim, além de almejar medidas de proteção de crianças e adolescentes, a demanda ministerial buscava a instituição de gestão compartilhada de resíduos sólidos recicláveis por meio da organização de catadores adultos em associações ou cooperativas, sendo esta a estratégia considerada “principal” para a erradicação do trabalho de menores na coleta do lixo.

O Município de Pinhais afirmava que já vinha empreendendo esforços objetivando prestar aos cidadãos condições dignas de sobrevivência, e que qualquer medida adicional demandaria "vultosos recurso públicos e desnecessário trabalho legislativo e organizacional". Ao decidir o conflito, o magistrado observou que a implementação dos “direitos econômicos, sociais e culturais, a priori, compete aos Poderes Executivo e Legislativo, porém, em caso de omissão destes, legítima se faz a atuação do Poder Judiciário”. Ademais, acrescentou que a inserção social e a melhoria das condições de vida e trabalho daquelas pessoas que viviam em "estado de miserabilidade" eram medidas que se impunham, afigurando-se o cooperativismo como "estratégia para tanto",531.

\footnotetext{
${ }^{529}$ Sobre as estruturas de suporte à mobilização jurídica, v. tópico 2.2.9.2, supra.

${ }^{530}$ Ajuizada na Vara do Trabalho de Pinhais, Estado do Paraná, atualmente em fase de execução.

${ }^{531}$ Destaquem-se, por oportuno, os seguintes excertos da decisão: “A inserção formal de catadores e catadoras em programas de coleta seletiva vai ao encontro de dois dos fundamentes da República Federativa do Brasil, quais sejam, a dignidade da pessoa humana e o valor social do trabalho (CF, art. $1^{\circ}$ ), além de consubstancializar-se como um dos vetores a erradicar a pobreza e a marginalização, a reduzir as desigualdades sociais e a alcançar uma sociedade livre, justa e solidária (CF, art. $3^{\circ}$ ) e de concretizar o dever do Estado imposto no art. 227 da Constituição. Para atingir o objetivo proposto é essencial que o Poder Público Municipal incentive a organização formal dos catadores de materiais recicláveis, prestando-lhes a devida assessoria a fim de que seja elaborada a ata de constituição e o estatuto da organização, levando-a ao registro, e crie um plano municipal de gerenciamento de resíduos sólidos para implementação progressiva de coleta seletiva, no qual as associações/cooperativas criadas passem a realizar, com prioridade, a coleta em questão. Necessário também se faz a implementação de campanha permanente de educação ambiental direcionada à segregação de resíduos recicláveis e divulgação do programa com a indicação de que os catadores são responsáveis pela coleta seletiva, bem como o fornecimento de meios necessários à realização da coleta do material pelos trabalhadores. Observo que as medidas até então adotadas pelo Município de Pinhais, segundo se verifica nos autos, não se mostram satisfatórias. A documentação trazida pelo réu, além de confirmar a marginalização social e econômica vivenciada pelas famílias de catadores de materiais
} 
Além de referir uma série de questões de justiça material com base em dispositivos constitucionais, o julgador sustentou que as medidas até então adotadas pelo poder público não eram suficientes, e que a atuação do município de forma “descomprometida com a proteção e implementação dos direitos fundamentais" constituiria agressão à Constituição. Ao destacar os óbices econômicos para a efetivação dos direitos sociais, asseverou, em diálogo com a postulação, que "os custos com os direitos de primeira e de segunda dimensão são próximos, até porque a consumação de qualquer direito (positivo ou negativo) implica gastos”. Ademais, ressaltou que "a não implementação dos direitos em questão, justificada pela insuficiência de recursos”, encontraria óbices no "mínimo existencial”, definido, na decisão, como “conjunto de ações sociais do Estado destinadas a garantir a dignidade (física, espiritual e intelectual) da pessoa humana, em especial àquelas pessoas que se encontrem em situação de necessidade”, a atrair a proteção do Estado para "para suprir carências humanas passíveis de juridicização”. Nota-se, assim, com base na fundamentação e no decisum que acolheu várias demandas ministeriais, traços de vários tipos de ativismo judicial.

Com efeito, foram impostas, ao réu, as seguintes obrigações: a) inclusão de catadores de materiais recicláveis e de seus familiares em cadastro único do Governo Federal; b) organização dos catadores de materiais recicláveis em associações ou cooperativas; c) prestação de assessoria a fim de constituir essas entidades, respeitada a liberdade associativa; d) criação de um "plano municipal de gerenciamento de resíduos sólidos para implementação progressiva de coleta seletiva” para que toda a cidade fosse

recicláveis, demonstra que os seus membros não estão sendo suficientemente atendidos pelos programas sociais indicados na defesa. Ademais, as poucas medidas adotadas pelo governo municipal são direcionadas às pessoas carentes em geral, inexistindo um programa adequado e comprometido com a inclusão social dos catadores de materiais recicláveis, e consequentemente, com suas crianças e adolescentes. Se o próprio réu afirma que 'o foco principal do Município tem sido o cuidado com a preservação ambiental' e 'não medir esforços objetivando prestar aos cidadão condições dignas de sobrevivência', por que se omite em tomar medidas efetivas em relação à coletividade em questão? Sob a luz da atual Constituição, é inadmissível uma atuação estatal descomprometida com a proteção e implementação dos direitos fundamentais, mormente os envolvidos na presente ação. Reconheço que a satisfação dos direitos econômicos, sociais e culturais encontra maiores obstáculos que a dos direitos civis e políticos, notadamente porque estes, muitas vezes, implementam-se pela mera omissão, independentemente de atividades materiais, enquanto aqueles encontram limites de cunho econômico e político. Todavia, tal fato não conduz à ideia de que as normas disciplinadoras de direitos sociais são desprovidas de juridicidade, e nem justifica a ausência de sua materialização pelo Poder Público. Oportuno destacar, conforme já ventilado na exordial, que há estudos demonstrando que os custos com os direitos de primeira e de segunda dimensão são próximos, até porque a consumação de qualquer direito (positivo ou negativo) implica gastos. Outrossim, a não implementação dos direitos em questão, justificada pela insuficiência de recursos, encontra óbice no 'mínimo existencial'. O mínimo existencial envolve o conjunto de ações sociais do Estado destinadas a garantir a dignidade (física, espiritual e intelectual) da pessoa humana, em especial àquelas pessoas que se encontrem em situação de necessidade, pois a sua fundamentalidade existe justamente para suprir carências humanas passíveis de juridicização e merecedoras de proteção e fomento pelo Estado.” 
atendida ao final do prazo estabelecido, de modo que as associações/cooperativas criadas passassem a realizar, posto que sem exclusividade, “a coleta do resíduo sólido reciclável produzido no Município, diretamente e/ou mediante o apoio operacional da Administração Pública municipal”; e) implementação de “campanha permanente de educação ambiental direcionada à segregação de resíduos recicláveis e à valorização da atividade desenvolvida pelos catadores de materiais recicláveis"; f) oferecimento de “meios necessários à realização da coleta do material pelos trabalhadores"; g) confecção de "material de divulgação do programa de separação seletiva do lixo”.

Dessarte, amalgamaram-se, na decisão: o ativismo judicial contramajoritário $^{532}$ (pela referência à inconstitucionalidade da omissão municipal), o ativismo judicial jurisdicional $^{533}$ (em razão da ampliação da agenda judicial trabalhista, que contemplou tema e forma de intervenção judicial bastante infrequentes na Justiça do Trabalho $^{534}$ ), o ativismo judicial promocional ${ }^{535}$ (pela imposição, ao poder público, de determinadas medidas a serem realizadas de um modo específico, dentre os muitos possíveis, para corrigir desvios e suprir omissões, de forma que a conduta do município

${ }^{532}$ Cf. tópico 4.3.1, supra.
${ }^{533}$ Cf. tópico 4.3.2, supra.
${ }^{534}$ A corroborar essa infrequência, note-se que no caso da ACP n. ${ }^{\circ}$ 0047100-15.2010.5.16.0006 (Vara do ${ }^{534}$ A corroborar essa infrequência, note-se que no caso da ACP n. ${ }^{\circ}$ 0047100-15.2010.5.16.0006 (Vara do
Trabalho de Chapadinha/MA), o juiz do trabalho manteve a agenda judicial trabalhista fechada, asseverando, em exígua sentença: “conquanto não se possa deixar de enaltecer a iniciativa do requerente, que revelou preocupação com esta grave chaga social e apontou caminhos capazes de amainá-la, não imagino como possa acolher sua pretensão, pois entendo que falta a esta Justiça do Trabalho competência material para deslindar este feito". Acrescentou o julgador: "A leitura do rol de pedidos (...) permite inferir que o desejo do Ministério Público do Trabalho - MPT poderá ser resumido na seguinte expressão: adoção de políticas públicas. Engendradas sob as mais variadas formas (ações legislativas, alocação de recursos, fiscalização, apoio aos órgãos ancilares, etc.) pretende o parquet trabalhista que sejam encetadas medidas de índole administrativa, assunto que escapa das atribuições desta Justiça Especializada, segundo a competência definida no art. 114 da Constituição Federal/88. De fato, não se tem como divisar, dentre as várias hipóteses ali existentes, qualquer parecença que autorize conclusão diferente. Visando roborar seus argumentos, o autor trouxe à liça o inciso I, do art. 114 da Constituição Federal/88. Referida norma trata de relações de trabalho existentes entre os obreiros e os entes de direito público que os albergam. Não se cogita nesta ação da existência de trabalho infantil que tenha como seu tomador o Município de Vargem Grande. Ao revés, pretende-se que ente público adote, no âmbito da sua competência, medidas capazes de impedir que outros o demandem. Conforme já foi afirmado, trata-se de incompetência absoluta, cuja invocação deve ser feita de ofício, a teor do que dispõe o art. 113 do Código de Processo Civil, o que proclamo neste ato, indicando como competente uma a Vara da Justiça Estadual, Comarca de Vargem Grande, incumbida dos feitos da Fazenda Pública, para onde deverão seguir os autos”. Reformando a sentença, entretanto, o TRT da $16^{\mathrm{a}}$ Região entendeu, ao oferecer sua interpretação do artigo114 da CR, que a "causa de pedir desta ação está estritamente voltada à relação de trabalho, ao trabalho irregular, e especificamente à tomada de providências urgentes para assegurar direitos constitucionais e legais das crianças e jovens do município reclamado, através de medidas que visem combater a erradicação do trabalho infantil”. E, assim, abriu a agenda judicial trabalhista, determinando o retorno do caso à Vara do Trabalho para julgamento do mérito. O processo ainda está pendente de julgamento, e nada impede que, em eventual recurso ao TST, haja outra modificação no entendimento sobre a competência.

535 Cf. tópico 4.3.3, supra. 
passou a ser supervisionada judicialmente) e o ativismo judicial criativo $^{536}$ (pelo estabelecimento de regulação ad hoc para o caso concreto, justificado pela articulação de noções indeterminadas, princípios constitucionais e conceitos-chave como a "garantia do mínimo existencial”, ${ }^{, 537}$ ).

\subsubsection{Exploração sexual de crianças e adolescentes para fins}

\section{comerciais}

Outro caso relevante ilustrativo de um ativismo judicial jurisdicional ocorreu no julgamento do recurso ordinário interposto pelo MPT nos autos de ação civil pública ajuizada para desarticular rede de exploração sexual de crianças e adolescentes para fins comerciais no Município de Sapé/PB.

Buscava-se, no caso, a responsabilização de todos os envolvidos pelo dano causado a interesses metaindividuais. Em primeiro grau, finda a instrução e prolatada a sentença, o juiz do Trabalho acolheu a preliminar de incompetência material da Justiça do Trabalho, determinando a remessa dos autos à justiça comum. Entretanto, na apreciação do recurso do MPT, o TRT da $13^{\mathrm{a}}$ Região, ao reconhecer (por maioria) aquela competência, condenou vários dos demandados, solidariamente, ao pagamento de indenização por danos morais coletivos ${ }^{538}$.

O caso recebeu, inclusive, o selo de processo "histórico”, normalmente oferecido a questões muito relevantes ou inéditas. Nesse que teria sido o primeiro exame, pela Justiça do Trabalho, de demandas relacionadas à exploração sexual de crianças e

\footnotetext{
${ }^{536}$ Cf. tópico 4.3.4, supra.

${ }^{537}$ Note-se que, no caso, a ideia de "mínimo existencial” parece haver adquirido contornos normativos. Sobre esses conceitos-chave, v. tópicos 2.2.7.2 e 2.2.7.4, supra.

${ }^{538}$ Transcreve-se, por oportuno, a ementa do julgado: “AÇÃO CIVIL PÚBLICA. RESPONSABILIZAÇÃO POR DANO MORAL COLETIVO. EXPLORAÇÃO DO TRABALHO SEXUAL DE ADOLESCENTES. ILÍCITO TRABALHISTA. COMPETÊNCIA DA JUSTIÇA DO TRABALHO. Em se tratando de Ação Civil Pública que persegue a responsabilização por dano moral coletivo, em decorrência da exploração do trabalho sexual de adolescentes a competência é da Justiça do Trabalho. Inteligência do Decreto 3.596/2000, ratificador da Convenção 182 da OIT. DANO MORAL COLETIVO. LESÃO À SOCIEDADE. PROSTITUIÇÃO INFANTIL. PROVA TESTEMUNHAL SUFICIENTE. Constatada a participação de alguns dos réus no esquema de prostituição infantil, é de ser imposta a condenação correspondente. INQUÉRITO POLICIAL. PROVA DESCOMPROMETIDA COM O CONTRADITÓRIO. DEPOIMENTO NÃO- CONFIRMADO NA ESFERA JUDICIAL. No contexto da prova, o processo coletivo, que tem conteúdo objetivo, aproxima-se do penal. A teor do art. 155 do CPP, o juiz formará sua convicção pela livre apreciação da prova produzida em contraditório judicial, não podendo fundamentar sua decisão exclusivamente nos elementos informativos colhidos na investigação, seja aquela advinda do inquérito policial, seja a produzida no inquérito civil público, ainda mais quando, por ocasião dos depoimentos na esfera judicial as testemunhas deixam de confirmar as alegações outrora firmadas por ocasião da oitiva policial.”
} 
adolescentes para fins comerciais, foi necessário que os próprios órgãos judiciais trabalhistas redefinissem sua competência. Se prevalecesse o entendimento do juiz de primeiro grau no que tange a essa temática cuja judicialização é recente e que no caso foi pioneira, a demanda nem sequer seria apreciada pela Justiça do Trabalho.

É importante destacar que o tema é, hoje, estratégico no âmbito do MPT, que tem proposto, com o reforço desse precedente, outras demandas em prol da ampliação da agenda judicial em relação aos litígios de interesse público concernentes à exploração sexual de crianças e adolescentes, considerada uma das piores formas de trabalho infantil segundo a Convenção n. ${ }^{\circ} 182$ da OIT.

Como se nota, a incidência dos diversos tipos de ativismo judicial tende a ser substancialmente influenciada pelo conteúdo das postulações, estratégicas ou não, dos demandantes.

\subsubsection{Dispensas discriminatórias de portadores do vírus HIV}

Não há previsão legal ou constitucional de estabilidade ou de garantia de emprego para o portador do vírus HIV. Todavia, há forte tendência jurisprudencial de reconhecimento da ilicitude da dispensa discriminatória desses trabalhadores.

Com efeito, o TST, em seus julgados, tem reiterado o entendimento de que, "não obstante a ausência de legislação que assegure a garantia provisória no emprego do empregado portador do vírus HIV”, deve ser reconhecido o “direito à reintegração” quando esse trabalhador é demitido sem justa causa, “em face das garantias constitucionais relativas ao direito à vida, ao trabalho e à dignidade da pessoa humana”. Nesses casos, o caráter discriminatório do despedimento tem sido presumido, de forma a fazer recair sobre o empregador “o ônus de comprovar que não tinha ciência da condição do empregado ou que o ato de dispensa tinha outra motivação lícita”,539.

\footnotetext{
${ }^{539}$ No RR 61600-92/2005, 1ª turma, rel. Min. Lélio Bentes Corrêa, julg. 22-06-11, o relator destacou: "Este Tribunal Superior tem firmado entendimento no sentido de que, não obstante a ausência de legislação que assegure a garantia provisória no emprego do empregado portador do vírus HIV, é inequívoco o seu direito à reintegração quando demitido sem justa causa, em face das garantias constitucionais relativas ao direito à vida, ao trabalho e à dignidade da pessoa humana, insculpidos nos artigos $1^{\circ}$, III e IV, $3^{\circ}$, IV, $5^{\circ}$, cabeça e XLI, 170 e 193 da Constituição da República, além da previsão contida no artigo 7º I, da Lei Magna, que veda a despedida arbitrária, com conteúdo discriminatório. Nesse contexto, a jurisprudência desta Corte superior firmou-se no sentido de que se presume discriminatória a dispensa do empregado portador do vírus HIV. Desse modo, recai sobre o empregador o ônus de comprovar que não tinha ciência da condição do empregado ou que o ato de dispensa tinha outra motivação, lícita. (...)Importante observar que esse entendimento jurisprudencial revela-se consentâneo com a normativa internacional consagrada tanto na
} 
Baseado no espectro do artigo $8^{\circ}$ da CLT, é amplo o repertório utilizado para a construção desse entendimento jurisprudencial: normas constitucionais que vedam a discriminação em geral, leis específicas que condenam práticas discriminatórias nas relações de trabalho e normas da OIT (em especial as convenções n. ${ }^{0} 111$ e 117).

Destarte, nos vários precedentes existentes nesse sentido, podem ser vislumbrados claramente traços de ativismo judicial criativo e de ativismo judicial promocional $^{540}$.

\subsection{Ativismo judicial extraprocessual da magistratura do Trabalho}

A magistratura trabalhista em geral se destaca por engajado e relevante ativismo judicial extraprocessual de conotação associativa, algo que se revela no próprio discurso de representantes de entidades que congregam juízes.

Nos idos de 2002, em congresso promovido por associação de magistrados trabalhistas piauienses, o então presidente da Anamatra, Hugo Melo, na palestra de abertura, tratou do tema "ativismo judicial como fenômeno transformador da sociedade”, destacando “a posição dos magistrados na sociedade e seu relacionamento com os poderes político e econômico"541.

Quatro anos depois, em 2006, José Nilton Pandelot, em seu discurso de posse na presidência da Anamatra, também fez menção a um "associativismo entre os Juízes do Trabalho" que daria substância a um "ativismo judicial trabalhista”. Referia,

Recomendação n. 200 da Organização Internacional do Trabalho, sobre HIV e AIDS e o Mundo do Trabalho, adotada em 2010, quanto na Convenção n. ${ }^{\circ} 111$ daquele mesmo organismo internacional, ratificada pelo Brasil em 26.11.1965 e promulgada mediante o Decreto n. ${ }^{\circ}$ 62.150, de 19.01.1968.” No mesmo sentido: "RECURSO DE REVISTA. ESTABILIDADE. PORTADOR DO VÍRUS HIV. A jurisprudência desta Corte se firmou no sentido de que o empregado, portador do vírus HIV, em face das garantias constitucionais que vedam a prática discriminatória e asseguram a dignidade da pessoa humana, tem direito à reintegração, não obstante a inexistência de legislação que assegure a estabilidade ou a garantia no emprego, presumindo-se discriminatória a sua dispensa imotivada. Recurso de revista a que se dá provimento.” (TST-RR - 11290036.2005.5.02.0432, rel. Min. Kátia Magalhães Arruda, 5a Turma, DEJT de 06-05-011). E, também: "DESPEDIDA DISCRIMINATÓRIA. EMPREGADO PORTADOR DO HIV. REINTEGRAÇÃO. Esta Corte tem-se posicionado no sentido de que, quando da dispensa imotivada do portador do HIV, ciente o empregador da doença, resta presumida a ocorrência de discriminação. Precedentes. Agravo de instrumento conhecido e desprovido.” (TST-AIRR-195740-92.2008.5.02.0434, rel. Min. Alberto Luiz Bresciani de Fontan Pereira, $3^{\text {a }}$ Turma, DEJT 03-09-2010). Cite-se, ainda: RECURSO DE REVISTA DA RECLAMADA. REINTEGRAÇÃO. EMPREGADO PORTADOR DO VÍRUS DA AIDS. PRESUNÇÃO DE DESPEDIDA DISCRIMINATÓRIA. A jurisprudência do Tribunal Superior do Trabalho, em se tratando de empregado portador do vírus HIV, entende que há uma presunção da dispensa discriminatória do trabalhador, sendo ônus da Reclamada demonstrar que o ato teve outra causa como fundamento. (...)” (TST-RR - 995120006.2006.5.09.0025, rel. Min. Maria de Assis Calsing, $4^{\mathrm{a}}$ Turma, DEJT de 19-03-2010).

${ }^{540}$ Cf. tópicos 4.3 .3 e 4.3.4, supra.

${ }^{541}$ Notícias do TST, publ. 27-09-02, acesso em 10/03/11. Disponível em www.tst.jus.br. 
inclusive, a necessidade de a associação promover lutas "em parceria com o TST, junto ao Congresso Nacional, pela superação de obstáculos na aprovação dos projetos de lei” sobre a reforma do processo do trabalho, que se encontravam, já naquela época, “incompreensivelmente, paralisados”, ao passo que os projetos de reforma no processo civil já estavam aprovados e em vigor ${ }^{542}$.

É interessante notar que esse ativismo judicial extraprocessual com notas associativas já se dirigiu ao fomento do ativismo judicial contramajoritário do STF em tema de grande relevância. Com efeito, a Anamatra, ao lado da ANPT (Associação Nacional dos Procuradores do Trabalho) ajuizou, no STF, a ADI n. ${ }^{\circ}$ 4.066, na qual se contesta a constitucionalidade da legislação federal que permite o "uso seguro e controlado” do amianto no Brasil (Lei n. $\left.{ }^{0} 9.055 / 1995\right)^{543}$.

Outro exemplo relevante dessa mobilização associativa ocorreu em evento promovido pela Anamatra em 2010, no qual centenas de juízes do Trabalho se organizaram para aprovar teses jurídicas que serviriam de norte para sua atuação judicial, entre elas, as seguintes: a) “a omissão do Poder Legislativo compromete a qualidade institucional e justifica o ativismo judicial para dar efetividade aos direitos garantidos na Constituição Federal”; b) o "exercício da democracia no Estado Democrático de Direito exige do Poder Judiciário uma postura mais ativa, o que se denominou ativismo judiciário, que nada mais é do que o desempenho das funções judiciais de forma a garantir a plena aplicação dos princípios e valores positivados na Constituição Federal”; c) o "Poder Judiciário teve suas funções ampliadas e dele se exige que desempenhe, finalmente, sua

\footnotetext{
${ }^{542}$ Notícias do TST, publ. 17-04-06, acesso em 10/03/11. Disponível em www.tst.jus.br.

${ }^{543}$ ADI 4066/DF, rel. Min. Carlos Ayres Britto. Interessa notar, a respeito do tema, a apreciação do pedido de medida cautelar na ADI 3.937-MC, rel. Min. Marco Aurélio, voto do Min. Carlos Britto, julg. 04-06-2008, DJE de 10-10-2008: “Acontece que esse caso me parece peculiar, e muito peculiar - se o superlativo for admitido eu diria peculiaríssimo -, porque a lei federal faz remissão à Convenção da OIT 162, art. $3^{\circ}$, que, por versar tema que no Brasil é tido como de direito fundamental (saúde), tem o status de norma supralegal. Estaria, portanto, acima da própria lei federal que dispõe sobre a comercialização, produção, transporte, etc., do amianto. (...) De maneira que, retomando o discurso do Ministro Joaquim Barbosa, a norma estadual, no caso, cumpre muito mais a Constituição Federal nesse plano da proteção à saúde ou de evitar riscos à saúde humana, à saúde da população em geral, dos trabalhadores em particular e do meio ambiente. A legislação estadual está muito mais próxima dos desígnios constitucionais, e, portanto, realiza melhor esse sumo princípio da eficacidade máxima da Constituição em matéria de direitos fundamentais, e muito mais próxima da OIT, também, do que a legislação federal. Então, parece-me um caso muito interessante de contraposição de norma suplementar com a norma geral, levando-nos a reconhecer a superioridade da norma suplementar sobre a norma geral. E, como estamos em sede de cautelar, há dois princípios que desaconselham o referendum à cautelar: o princípio da precaução, que busca evitar riscos ou danos à saúde e ao meio ambiente para gerações presentes; e o princípio da prevenção, que tem a mesma finalidade para gerações futuras. Nesse caso, portanto, o periculum in mora é invertido e a plausibilidade do direito também contraindica o referendum a cautelar. Senhor Presidente, portanto, pedindo todas as vênias, acompanho a dissidência e também não referendo a cautelar.”
} 
função política”; d) “o juiz do trabalho pode determinar medidas que impliquem obrigações para as partes e terceiros para assegurar a efetividade das decisões judiciais e a razoável duração do processo, ainda que não estejam expressamente requeridas”; e) “em face da inércia absoluta do legislador ordinário em regulamentar a matéria, o Juiz poderá efetivar o direito no caso concreto" ${ }^{, 544}$.

Não sobeja relembrar que, à época do caso Embraer, publicou-se manifesto intitulado “contra oportunismos e em defesa do direito social”, assinado por dezenas de juízes do Trabalho ${ }^{545}$.

Traços do ativismo judicial extraprocessual também estão presentes, com conotação institucional, em uma série de propostas bem sucedidas de mudanças no processo do trabalho. É o caso do procedimento sumaríssimo (Lei n. ${ }^{\circ}$ 9.957/2000) e das comissões de conciliação prévia (Lei n. ${ }^{0}$ 9.958/2000), cuja criação foi motivada por iniciativa do TST.

\footnotetext{
${ }^{544}$ Cf. tópico 3.4.3.2, supra. Ademais, no referido tópico, como foi visto, o discurso do presidente do TST, na abertura de referido evento, destacou que a "segurança jurídica" seria "fiadora da própria estabilidade econômica(...)". Advertiu, ainda, não ser desejável, "ante seus reflexos negativos para a magistratura e para a sociedade”, a adoção de decisões que, independentemente de seus fundamentos, tragam surpresas aos litigantes, "porque proferidas em contradição e, não raro, em confronto com as leis vigentes". A propósito das colocações do ministro, importa não olvidar que, à época, palpitavam as discussões sobre a suspensão judicial de dispensas coletivas. A presença desse tema nos debates pode ser ilustrada pelo fato de outra comissão, naquele mesmo evento, haver aprovado entendimento de que "a dispensa coletiva, para que seja válida e legítima, demanda fundados motivos econômicos ou estruturais que ameacem inviabilizar de fato o funcionamento da empresa", razão pela qual seria necessária "a submissão prévia de tais motivos, expostos pelo empregador, à consulta do ente representativo da categoria, ou, ao menos, à previsão em norma coletiva para legitimar a dispensa com efeitos coletivos". Note-se que, indo além do próprio precedente da Justiça do Trabalho, examinado nesta tese no tópico 5.2, supra, apontavam os juízes, no evento, que eventual descumprimento dos requisitos ali referidos levaria à "reintegração dos empregados dispensados". No mesmo Congresso de magistrados, em painel sobre a "concretização dos direitos econômicos e sociais", a problemática do ativismo judicial foi claramente associada à postura do Judiciário trabalhista no caso das dispensas coletivas. De um lado, o desembargador Gustavo Alkmin, da $1^{\text {a }}$ Região, demonstrava seu "descontentamento com a atuação do Tribunal Superior do Trabalho em relação aos direitos do trabalhador", tendo em vista a concepção, que defendia, de que o juiz do trabalho deveria construir direitos em defesa do "emprego" e da "paz nas relações sociais e de capital". Afirmava, nessa linha de pensamento, a importância do ativismo judicial como instrumento de construção de direitos, como um "princípio que deve ter em mente a concretização da Constituição e a efetivação de direitos humanos e de proteção ao trabalhador". Acrescentava o magistrado que a ausência desses vetores ativistas nas decisões judiciais implicaria um "ativismo judicial às avessas", como estaria ocorrendo, segundo ele, em determinadas súmulas do TST, que teriam culminado com a alegada destruição de direitos. De outro lado, foi classificada como "ativista" a decisão da Justiça do Trabalho sobre os despedimentos coletivos no caso Embraer. A própria representante do TST, ministra Kátia Arruda, defendeu que o resultado do processo teria sido histórico, com posição "inovadora em nosso Direito", por haver estabelecido a exigência da negociação prévia como requisito de validade das dispensas em massa. Destacou, ainda, que a decisão se baseara em "interpretação integradora e principiológica do direito pátrio e também do direito comparado", apesar de não regulamentada "a previsão constitucional relativa à proibição de despedida arbitrária ou sem justa causa, nos casos de despedidas massivas, coletivas, que atingem, de uma vez só, centenas de trabalhadores”.

${ }^{545}$ Cf. tópico 1.1, supra.
} 
Os mesmos traços desse tipo de ativismo judicial podem ser percebidos na primeira audiência pública da história do TST realizada em 2011 para discutir diferentes perspectivas a respeito da terceirização, um dos temas mais polêmicos do Direito do Trabalho em todo o mundo ${ }^{546}$. O evento, relevante para a eventual alteração da orientação daquele Tribunal em relação ao tema, foi convocado após uma mudança no Regimento Interno da Corte ${ }^{547}$.

No caso do TST, a prática das audiências públicas, já usuais no âmbito do STF, tem a intenção declarada de promover a oitiva do "depoimento de pessoas com experiência e autoridade em determinada matéria” e que possam auxiliar no esclarecimento de "questões ou circunstâncias de fato, subjacentes a dissídio de grande repercussão social ou econômica, pendente de julgamento no âmbito do Tribunal”.

Eventos dessa natureza, quando organizados por órgãos de cúpula do Poder Judiciário, despertam grande atenção dos meios de comunicação. Note-se que, na audiência pública citada, ao conceder entrevista coletiva sobre o tema discutido, o presidente do TST não deixou de externar sua posição pessoal em relação à matéria, a sinalizar, inclusive, não só uma possível tendência de reformulação da jurisprudência do Tribunal, mas possíveis repercussões daquele evento no campo político, uma vez que o material coletado foi encaminhado ao Congresso Nacional como subsídio para as discussões em torno do “marco regulatório” da terceirização ${ }^{548}$.

\footnotetext{
546 Discutiu-se amplamente a prática da terceirização nos setores bancário, de energia elétrica, de telecomunicações e de tecnologia da informação, bem como o critério da atividade-fim do tomador dos serviços, consagrado criativamente, pelo TST, na súmula n. ${ }^{\circ} 331$. Cf. tópico 5.3, supra.

${ }^{547}$ Foram incluídos, pelo Ato Regimental n. ${ }^{\circ}$ 1/2011, dois incisos para autorizar o presidente do TST a convocar audiência pública e a deliberar sobre os participantes. Com a alteração, poderá a presidência do órgão: "excepcionalmente, convocar audiência pública, de ofício ou a requerimento de cada uma das Seções Especializadas ou de suas Subseções, pela maioria de seus integrantes, para ouvir o depoimento de pessoas com experiência e autoridade em determinada matéria, sempre que entender necessário o esclarecimento de questões ou circunstâncias de fato, subjacentes a dissídio de grande repercussão social ou econômica, pendente de julgamento no âmbito do Tribunal" (inciso XXXVI); e "decidir, de forma irrecorrível, sobre a manifestação de terceiros, subscrita por procurador habilitado, em audiências públicas" (inciso XXXV).

${ }^{548}$ Com efeito, o ministro defendeu a "adoção a responsabilidade solidária, por parte do tomador de serviço, pelo descumprimento de obrigações trabalhistas", o que seria, segundo ele, um grande "avanço social", de forma a induzir "as empresas que contratam a prestação de serviços a participar mais do processo de fiscalização". Além disso, o presidente do órgão destacou que, em sua visão, a "terceirização na atividadefim" constituiria a "negação do Direito do Trabalho", apesar de reconhecer a "dificuldade de definição entre áreas meio e fim”, já que não haveria "um rigor científico absoluto", de modo que o "critério ainda é um mal menor diante da possibilidade de abertura plena e desenfreada da terceirização". Notícias do TST, publ. 0510-2011, acesso em 05-10-11. Disponível em www.tst.jus.br.
} 


\subsection{Ativismo judicial no STF e seus reflexos na Justiça do Trabalho}

\subsubsection{Breves considerações sobre o ativismo judicial no STF}

Se não se pode afirmar, sem referência a estudos quantitativos com critérios claros, que o STF seria uma um tribunal ativista, ao menos é possível identificar, em casos de grande repercussão, a manifestação inequívoca do potencial protagonismo judicial da Corte Suprema Brasileira, com consideráveis reflexos não só para as relações de trabalho e a prática judicial trabalhista, mas para um conjunto mais amplo de relações sociais, econômicas e políticas.

Nos últimos anos, o STF, dentre os órgãos judiciais brasileiros, é o que parece haver recebido mais fortemente os influxos da juridificação no que tange ao desenvolvimento de um potencial protagonismo judicial ${ }^{549}$.

Em outras palavras, a expansão dos padrões regulatórios e o aumento da chamada indeterminação do direito, no Brasil, ocorreu em grande medida com o patrocínio da Constituição de 1988, em fenômeno recorrentemente referido como a “constitucionalização” do Direito material e processual. Ademais, a Constituição foi responsável, como reflexo das justas demandas sociais que emergiram em razão da claudicante experiência brasileira de Estado-Providência, por uma amplíssima materialização do direito formal. Compromissos éticos e políticos, metas de justiça material e declarações de direitos fundamentais individuais e sociais povoam o texto constitucional como uma tentativa de suprimento, pelo Direito, de graves lacunas socioeconômicas e déficits de democracia e de cidadania.

Num cenário em que a expropriação estatal dos conflitos perde seu norte autoritário e tudo pode ter uma conotação constitucional, a independência política do Poder Judiciário e a ampliação dos mecanismos de controle judicial contramajoritário ressoam fortemente no STF, que se torna o grande guardião das promessas constitucionais.

Obviamente, isso aprofunda a crise na divisão funcional dos poderes, uma vez que a ineficiência e os obstáculos enfrentados pela máquina administrativa e legislativa despertam em todos os campos sociais não só a percepção de compromissos descumpridos, mas o desapontamento e a descrença em relação aos poderes estruturados

\footnotetext{
549 Recuperaram-se, neste tópico, mais uma vez, várias noções e proposições apresentadas na tese. Cf. capítulos 1, 2, 3 e 4 .
} 
pela regra da maioria. Emerge, com isso, no Brasil, a litigância de interesse público como um mecanismo de canalização, para o Judiciário (por meio de uma emergente estrutura de suporte à mobilização jurídica, estatal e não estatal) todas aquelas demandas pelo cumprimento de promessas, denunciando tanto as insuficiências do processo judicial tradicional para dar tratamento à explosão da conflituosidade e à própria complexidade de novos conflitos, quanto os graves prejuízos que a regra da maioria pode trazer, se levada às últimas consequências, para os interesses das minorias.

Provocado, o Supremo é instado a participar do debate público e a fomentá-lo ainda mais para ampliar sua cognição. Afinal, terá de decidir e (distanciado de um modelo decisório lógico-dedutivo ou meramente “subsuntivo”), para fazê-lo, escolherá, dentre as inúmeras possibilidades interpretativas, aquela solução que se mostrar presumivelmente mais adequada à ordem constitucional, com o desafio de combinar, nas decisões, as éticas da convicção e da responsabilidade $e^{550}$.

Nesse percurso, o STF terá de lidar não só com as pressões do mercado em busca de segurança e previsibilidade; mas também com uma série de aspectos normativos e institucionais da convergência das experiências jurídicas democráticas, como a ambivalência das teses jurídicas que editar com força persuasiva ou vinculante, a necessidade de respeito aos direitos fundamentais e humanos, a crescente migração de ideias provindas das mais variadas experiências jurídicas democráticas, o refinamento jurisprudencial do critério da proporcionalidade (que cada vez mais adquire conotação normativa) e o uso de um modelo ampliado de “juiz ativo” cuja institucionalização, no processo, cresce a cada dia.

Ademais, se tudo pode ter uma conotação constitucional, novos temas e problemas judicializados tendem a testar constantemente a aplicabilidade de ideias sedimentadas, instigando novas reflexões sobre o uso da tecnologia, o direito à privacidade, a bioética, a sexualidade, a personalidade e a autonomia individual. À medida que progridem o estado da técnica, o estado da arte e as relações humanas, o STF tem sido procurado para que solucione conflitos que surgem em razão dessa evolução. Assim, tendem a emergir novas conceituações jurídicas e enfoques jurisprudenciais que repercutem sobre a solução do caso, sobre as discussões da comunidade jurídica e sobre as

${ }^{550}$ Cf. tópicos 2.2.4.1, supra. 
relações sociais em geral. Não é difícil perceber, portanto, o porquê de o STF e seus ministros serem cada vez mais visíveis do ponto de vista midiático ${ }^{551}$.

Dessarte, no Supremo, o potencial protagonismo judicial tende naturalmente a se materializar no ativismo judicial, em decisões que combinam vários de seus tipos.

O ativismo judicial contramajoritário tem ocorrido frequentemente pelo exercício do controle de constitucionalidade concentrado e difuso ${ }^{552}$. O ativismo judicial jurisdicional tem se tornado mais claro não só pelo exame de temas importantes que ingressam na agenda do Supremo, mas também pelo crescente controle exercido pelo órgão (refinado por institutos como a repercussão geral e pelos efeitos recursais de suas súmulas) sobre essa agenda. O ativismo judicial promocional, ao lado do ativismo judicial criativo, tem permeado fortemente as decisões do STF, em especial no caso do tratamento das lacunas derivadas das omissões consideradas inconstitucionais, em mandados de injunção e em arguições de descumprimento de preceito fundamental. Por outro lado, a enunciação de teses jurídicas persuasivas, a edição de súmulas vinculantes ${ }^{553} e$ os pronunciamentos com efeitos erga omnes traduzem, além do ativismo judicial criativo, um ativismo judicial de padronização decisória em matéria constitucional que tende a produzir efeitos neutralizadores de eventuais entendimentos divergentes (o que se fortalece pela possibilidade de uso de instrumentos como as reclamações) ${ }^{554}$.

\footnotetext{
${ }^{551}$ Cf. tópicos 2.2.3, 2.2.6 e 2.2.7, supra.

${ }^{552}$ Registram-se, atualmente, milhares de ações diretas de inconstitucionalidade e mandados de injunção, centenas de arguições de descumprimento de preceito fundamental e dezenas de ações diretas de inconstitucionalidade por omissão. E, como é sabido, em número significativo desses processos, o Supremo tem atacado atos e omissões consideradas inconstitucionais.

553 “Art. 103-A. O Supremo Tribunal Federal poderá, de ofício ou por provocação, mediante decisão de dois terços dos seus membros, após reiteradas decisões sobre matéria constitucional, aprovar súmula que, a partir de sua publicação na imprensa oficial, terá efeito vinculante em relação aos demais órgãos do Poder Judiciário e à administração pública direta e indireta, nas esferas federal, estadual e municipal, bem como proceder à sua revisão ou cancelamento, na forma estabelecida em lei. (Incluído pela Emenda Constitucional n. ${ }^{\circ} 45$, de 2004). $\S 1^{\circ}$ A súmula terá por objetivo a validade, a interpretação e a eficácia de normas determinadas, acerca das quais haja controvérsia atual entre órgãos judiciários ou entre esses e a administração pública que acarrete grave insegurança jurídica e relevante multiplicação de processos sobre questão idêntica. $\S 2^{\circ}$ Sem prejuízo do que vier a ser estabelecido em lei, a aprovação, revisão ou cancelamento de súmula poderá ser provocada por aqueles que podem propor a ação direta de inconstitucionalidade. $\S 3^{\circ}$ Do ato administrativo ou decisão judicial que contrariar a súmula aplicável ou que indevidamente a aplicar, caberá reclamação ao Supremo Tribunal Federal que, julgando-a procedente, anulará o ato administrativo ou cassará a decisão judicial reclamada, e determinará que outra seja proferida com ou sem a aplicação da súmula, conforme o caso." O dispositivo foi regulamentado pela Lei n. ${ }^{\circ}$ $11.417 / 2006$.

${ }^{554}$ Em outras palavras, é possível conter, v.g., por meio das reclamações, o ativismo judicial em face de precedentes do Supremo (plano vertical).
} 
Ademais, tende a ganhar grande visibilidade no STF o ativismo judicial em face de precedentes (plano horizontal), uma vez que a mudança de entendimento da Corte sobre o significado da Constituição tende a repercutir de forma importante sobre as relações jurídicas e sociais em geral. O ativismo judicial processual, por sua vez, emerge pela exigência, nos casos julgados pelo Supremo, de uma atuação judicial em consonância com o ideário do juiz ativo, o que em geral é institucionalizado nas normas processuais constitucionais $^{555}$.

Traços dos diversos tipos de ativismo judicial citados podem ser encontrados nas decisões do STF em de processos que trataram de temas como união civil homoafetiva $^{556}$, interrupção da gravidez no caso de anencefalia $^{557}$, nepotismo ${ }^{558}$,

555 Como foi visto, a institucionalização processual do ideário do juiz ativo tende a diversificar os mecanismos de administração judicial do processo. Exemplos desses mecanismos, no caso do STF, são as medidas cautelares, a modulação de efeitos temporais, designação de peritos e as audiências públicas. É interessante notar, a propósito, as características da Lei n. ${ }^{\circ}$ 9.868/1999 (ADI e ADC). Em vários de seus julgados, o STF, notadamente quando aprecia demandas de interesse público com conotação promocional, faz referência a um "macroprocesso", com destaque para a atuação "célere e efetiva”. Cf. ADPF 54-QO, rel. Min. Marco Aurélio, julg. 27-4-2005, Plenário, DJ de 31-8-07.

556 “.(...) no tocante ao tema do emprego da sexualidade humana, haveria liberdade do mais largo espectro ante silêncio intencional da Constituição. Apontou que essa total ausência de previsão normativoconstitucional referente à fruição da preferência sexual, em primeiro lugar, possibilitaria a incidência da regra de que 'tudo aquilo que não estiver juridicamente proibido, ou obrigado, está juridicamente permitido'. (...) Desse modo, anotou que se deveria extrair do sistema a proposição de que a isonomia entre casais heteroafetivos e pares homoafetivos somente ganharia plenitude de sentido se desembocasse no igual direito subjetivo à formação de uma autonomizada família, constituída, em regra, com as mesmas notas factuais da visibilidade, continuidade e durabilidade (CF, art. 226, § $3^{\circ}$ ). (...) Arrematou que a solução apresentada daria concreção aos princípios da dignidade da pessoa humana, da igualdade, da liberdade, da proteção das minorias, da não discriminação e outros.” (ADI 4.277 e ADPF 132, rel. Min. Ayres Britto, julg. 4 e 5-5-11, Plenário, Informativo 625.) No mesmo sentido: RE 477.554-AgR, rel. Min. Celso de Mello, julg. 16-811,Segunda Turma, DJE de 26-8-11. Na ampla cobertura do julgamento, pela imprensa, ficavam claras as oposições ideológicas a respeito do tema. Ilustrativamente, na "Folha de São Paulo" do dia 6 de maio de 2011, liam-se artigos intitulados "Vitória gay, vitória do país" (referindo expressamente uma a derrota da "igreja, dos conservadores em geral e dos homofóbicos em particular"); “Justiça e afetividade” (sustentando que "o Brasil foi dormir ontem mais justo, mais humano e mais contemporâneo, depois da votação do Supremo suprindo um lapso da lei e reconhecendo o direito de casais homoafetivos à partilha de bens, pensão e herança"); "Há um espaço para mudar a aplicação da Constituição sem ter de emendar seu texto" (em que se afirmava que, "se fosse necessária uma emenda à Constituição, seria preciso o voto favorável de pelo menos 357 congressistas", e que "evangélicos, católicos e outros grupos pressionariam os congressistas" e “provavelmente não se mudaria a Constituição”). Além disso, no jornal "O Estado de São Paulo” do dia anterior, especialista se manifestava no sentido de que "Constituição só reconheceria união 'entre homem e mulher"” e que o Judiciário não estaria autorizado a 'preencher uma lacuna que não existe”.

557 "(...) Pendente de julgamento a arguição de descumprimento de preceito fundamental, processos criminais em curso, em face da interrupção da gravidez no caso de anencefalia, devem ficar suspensos até o crivo final do STF. Arguição de descumprimento de preceito fundamental - Liminar - Anencefalia - Interrupção da gravidez - Glosa penal - Afastamento - Mitigação. Na dicção da ilustrada maioria, entendimento em relação ao qual guardo reserva, não prevalece, em arguição de descumprimento de preceito fundamental, liminar no sentido de afastar a glosa penal relativamente àqueles que venham a participar da interrupção da gravidez no caso de anencefalia." (ADPF 54-QO, rel. Min. Marco Aurélio, julg. 27-4-2005, Plenário, DJ de 31-8-07.). Extrai-se dos autos a seguinte ponderação do ministro Eros Grau: "A insegurança jurídica referida decorre da concessão de uma liminar satisfativa que, durante quatro meses, permitiu que como se a lei tivesse sido reescrita, como se o Código Penal tivesse sido reescrito pela Corte, como legislador positivo - permitiu que 
infidelidade partidária ${ }^{559}$, controle judicial de políticas públicas (notadamente em matéria de saúde $e^{560}$ e educação ${ }^{561}$ ), greve de servidores públicos ${ }^{562}$ e direitos sociais trabalhistas, como veremos no próximo tópico.

uma terceira modalidade de aborto passasse a ser admitida.” Assim, no julgamento da questão de ordem, por maioria, revogou-se a segunda parte da liminar antes deferida, que reconhecia o direito constitucional da gestante de submeter-se a operação terapêutica de parto de fetos anencefálicos (vencidos os Ministros Relator, Carlos Britto, Celso de Mello e Sepúlveda Pertence).

${ }^{558}$ Conforme a súmula vinculante n. ${ }^{\circ} 13:$ "A nomeação de cônjuge, companheiro ou parente em linha reta, colateral ou por afinidade, até o terceiro grau, inclusive, da autoridade nomeante ou de servidor da mesma pessoa jurídica investido em cargo de direção, chefia ou assessoramento, para o exercício de cargo em comissão ou de confiança ou, ainda, de função gratificada na administração pública direta e indireta em qualquer dos Poderes da União, dos Estados, do Distrito Federal e dos Municípios, compreendido o ajuste mediante designações recíprocas, viola a Constituição Federal. DJe n. ${ }^{\circ} 162$ de 29-08-08 (Precedentes: ADI 1521 MC, MS 23780, ADC 12 - em que foi declarada a constitucionalidade da Resolução n. ${ }^{\circ}$ 7, do CNJ -, ADC 12, RE 579951).

559 “A fidelidade partidária é corolário lógico-jurídico necessário do sistema constitucional vigente, sem necessidade de sua expressão literal. Sem ela não há atenção aos princípios obrigatórios que informam o ordenamento constitucional” (MS 26.604, rel. Min. Cármen Lúcia, julg. 4-10-07, Plenário, DJE de 3-10-08). No mesmo sentido: MS 26.602, rel. Min. Eros Grau, julg. 4-10-07, Plenário, DJE de 17-10-08; MS 26.603, rel. Min. Celso de Mello, julg. 4-10-07, Plenário, DJE de 19-12-08. Vide: MS 30.260 e MS 30.272, rel. Min. Cármen Lúcia, julg. 27-4-11, Plenário, Informativo 624.

560 " O Poder Público, qualquer que seja a esfera institucional de sua atuação no plano da organização federativa brasileira, não pode mostrar-se indiferente ao problema da saúde da população, sob pena de incidir, ainda que por censurável omissão, em grave comportamento inconstitucional. (...) O reconhecimento judicial da validade jurídica de programas de distribuição gratuita de medicamentos a pessoas carentes, inclusive àquelas portadoras do vírus HIV/AIDS, dá efetividade a preceitos fundamentais da Constituição da República (arts. $5^{\circ}$, caput, e 196) e representa, na concreção do seu alcance, um gesto reverente e solidário de apreço à vida e à saúde das pessoas, especialmente daquelas que nada têm e nada possuem, a não ser a consciência de sua própria humanidade e de sua essencial dignidade." (RE 271.286-AgR, rel. Min. Celso de Mello, julg. 12-9-2000, Segunda Turma, Plenário, DJ de 24-11-2000.) No mesmo sentido: RE 368.564, Rel. p/ o ac. Min. Marco Aurélio, julg. 13-4-11, Primeira Turma, DJE de 10-8-11; STA 175-AgR, rel. Min. Presidente Gilmar Mendes, julg. 17-3-10, Plenário, DJE de 30-4-10. E, ainda: "O Estado deve criar meios para prover serviços médico-hospitalares e fornecimento de medicamentos, além da implementação de políticas públicas preventivas, mercê de os entes federativos garantirem recursos em seus orçamentos para implementação delas.” (RE 607.381-AgR, rel. Min. Luiz Fux, julg. 31-5-11, Primeira Turma, DJE de 17-611.); "O recebimento de medicamentos pelo Estado é direito fundamental, podendo o requerente pleiteá-los de qualquer um dos entes federativos, desde que demonstrada sua necessidade e a impossibilidade de custeálos com recursos próprios. Isso por que, uma vez satisfeitos tais requisitos, o ente federativo deve se pautar no espírito de solidariedade para conferir efetividade ao direito garantido pela Constituição, e não criar entraves jurídicos para postergar a devida prestação jurisdicional.” (RE 607.381-AgR, rel. Min. Luiz Fux, julg. 31-5-11, Primeira Turma, DJE de 17-6-11.) No mesmo sentido: AI 553.712-AgR, rel. Min. Ricardo Lewandowski, julg. 19-5-09, Primeira Turma, DJE de 5-6-09; AI 604.949-AgR, rel. Min. Eros Grau, julg. 24-10-06, Segunda Turma, DJ de 24-11-06; "O direito a saúde é prerrogativa constitucional indisponível, garantido mediante a implementação de políticas públicas, impondo ao Estado a obrigação de criar condições objetivas que possibilitem o efetivo acesso a tal serviço.” (AI 734.487-AgR, rel. Min. Ellen Gracie, julg. 3-810, Segunda Turma, DJE de 20-8-10.) Vide: RE 436.996-AgR, rel. Min. Celso de Mello, julg. 22-11-2005, Segunda Turma, DJ de 3-2-06; RE 271.286-AgR, rel. Min. Celso de Mello, julg. 12-9-2000, Segunda Turma, DJ de 24-11-2000.

561 "A educação infantil representa prerrogativa constitucional indisponível, que, deferida às crianças, a estas assegura (...) o atendimento em creche e o acesso à pré-escola (CF, art. 208, IV). Essa prerrogativa jurídica, em consequência, impõe, ao Estado, por efeito da alta significação social de que se reveste a educação infantil, a obrigação constitucional de criar condições objetivas que possibilitem, de maneira concreta, em favor das 'crianças até cinco anos de idade' (CF, art. 208, IV), o efetivo acesso e atendimento em creches e unidades de pré-escola, sob pena de configurar-se inaceitável omissão governamental, apta a frustrar, injustamente, por inércia, o integral adimplemento, pelo Poder Público, de prestação estatal que lhe impôs o próprio texto da CF. A educação infantil, por qualificar-se como direito fundamental de toda criança, não se 
No caso dos mandados de injunção, o exame da evolução da jurisprudência do STF permite observar que, ao longo do tempo, a Corte passou da prática de um ativismo judicial eminentemente contramajoritário (em face de omissões inconstitucionais, com a consequente admoestação do órgão omisso) para a combinação

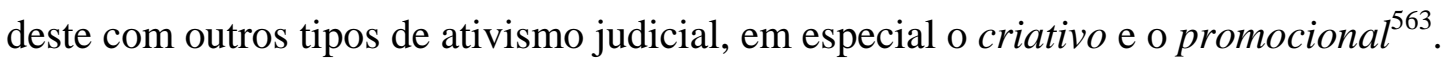

expõe, em seu processo de concretização, a avaliações meramente discricionárias da administração pública nem se subordina a razões de puro pragmatismo governamental.” (ARE 639.337-AgR, rel. Min. Celso de Mello, julg. 23-8-11, Segunda Turma, DJE de 15-9-11.) No mesmo sentido: RE 464.143-AgR, rel. Min. Ellen Gracie, julg. 15-12-09, Segunda Turma, DJE de 19-2-10; RE 594.018-AgR, rel. Min. Eros Grau, julg. 23-6-09, Segunda Turma, DJE de 7-8-09; mesmo sentido: AI 592.075-AgR, rel. Min. Ricardo Lewandowski, julg. 19-5-09, Primeira Turma, DJE de 5-6-09; RE 384.201-AgR, rel. Min. Marco Aurélio, julg. 26-4-07, Segunda Turma, DJ de 3-8-07. “(...) A questão da legitimidade constitucional do controle e da intervenção do poder Judiciário em tema de implementação de políticas públicas, quando configurada hipótese de abusividade governamental. Dimensão política da jurisdição constitucional atribuída ao Supremo Tribunal Federal. Inoponibilidade do arbítrio estatal à efetivação dos direitos sociais, econômicos e culturais. Caráter relativo da liberdade de conformação do legislador. Considerações em torno da cláusula da 'reserva do possível'. Necessidade de preservação, em favor dos indivíduos, da integridade e da intangibilidade do núcleo consubstanciador do 'mínimo existencial'(...)” (ADPF 45-MC, rel. Min. Celso de Mello, decisão em 29.04.04, DJ 04-05-04). Note-se que o objetivo da ADPF 45 foi alcançado pela edição da Lei n. ${ }^{\circ}$ 10.777/2003, posterior ao ajuizamento, o que levou o STF a demanda prejudicada.

${ }^{562}$ MI 708, rel. Min. Gilmar Mendes, julg. 25-10-07, Plenário, DJE de 31-10-08. No mesmo sentido: MI 3.322, rel. Min. Celso de Mello, decisão monocrática, julg. 01-06-11, DJE 6-6-11; MI 1.967, rel. Min. Celso de Mello, decisão monocrática, julg. 24-5-11, DJE de 27-5-11. Vide: MS 22.690, rel. Min. Celso de Mello, julg. 17-4-1997, Plenário, DJ de 7-12-06.

${ }^{563}$ Isso pode ser percebido pelo exame cronológico dos julgados, cf., dos mais recentes para os mais antigos: MI 788, rel. Min. Carlos Britto, julg. 15-04-09; MI 795, rel. Min. Cármen Lúcia, julg. 15-04-09; MI 796, rel. Min. Carlos Britto, julg. 15-04-09; MI 797, rel. Min. Cármen Lúcia, julg. 15-04-09; MI 808, rel. Min. Carlos Britto, julg. 15-04-09; MI 809, rel. Min. Cármen Lúcia, julg. 15-04-09; MI 815, rel. Min. Carlos Britto, julg. 15-04-09; MI 825, rel. Min. Carlos Britto, julg. 15-04-09; MI 828, rel. Min. Cármen Lúcia, julg. 15-04-09; MI 841, rel. Min. Cármen Lúcia, julg. 15-04-09; MI 850, rel. Min. Cármen Lúcia, julg. 15-04-09; MI 857, rel. Min. Cármen Lúcia, julg. 15-04-09; MI 879, rel. Min. Cármen Lúcia, julg. 15-04-09; MI 905, rel. Min. Cármen Lúcia, julg. 15-04-09; MI 927, rel. Min. Cármen Lúcia, julg. 15-04-09; MI 938, rel. Min. Cármen Lúcia, julg. 15-04-09; MI 962, rel. Min. Cármen Lúcia, julg. 15-04-09; MI 998, rel. Min. Cármen Lúcia, julg. 15-04-09; MI 758, rel. Min. Marco Aurélio, julg. 01-07-08; MI 670, rel. Min. Maurício Corrêa, julg. 25-102007; MI 708, rel. Min. Gilmar Mendes, julg. 25-10-2007; MI 712, rel. Min. Eros Grau, julg. 25-10-2007; MI 721, rel. Min. Marco Aurélio, julg. 30-8-2007; ADI 3682, rel. Min. Gilmar Mendes, julg. 9-5-2007; MI 695, rel. Min. Sepúlveda Pertence, julg. 1-3-2007; ADI 3276, rel. Min. Eros Grau, julg. 2-6-2005; MI 278, rel. Min. Carlos Velloso, julg. 3-10-2001; MI 95, rel. Min. Carlos Velloso, julg. 7-10-1992; MI 124, rel. Min. Carlos Velloso, julg. 7-10-1992; MI 369, rel. Min. Sidney Sanches, julg. 19-8-1992. Como destaca Elival da Silva Ramos, até recentemente o STF "se recusava a exercer competência normativa em sede de mandado de injunção”, já que prevalecia a orientação cristalizada no MI n. ${ }^{0}$ 107-3/DF, que, na prática, equiparava o instituto à ação direta de inconstitucionalidade por omissão. Mudança relevante foi sinalizada com o MI n. ${ }^{0}$ 721-7/DF, que assegurou à impetrante, desde logo, o direito cuja efetivação houvera sido obstada pela ausência de legislação integrativa (direito do servidor à aposentadoria em condições especiais, previsto no artigo 40 , $\S 4^{\circ}$, da CR), ao passo que, em precedentes anteriores, a injunção apenas removera a carência normativa, remetendo os impetrantes às vias ordinárias para a concretização de direitos. O STF foi ainda mais longe ao julgar os Mandados de injunção n. ${ }^{\circ}$ 670-9/ES, 708-0/DF e 712-8/PA n. ${ }^{\text {, }}$, referentes à mora do legislativo em relação à regulamentação do direito de greve do servidor público (artigo 37, VII, da CR), que já havia sido reconhecida pela Corte, mas que, nos julgamentos citados, levou os ministros “ao suprimento normativo pela via injuncional”, assumindo que caberia ao STF proceder, subsidiária e provisoriamente, à regulamentação do "modo de exercício do direito com eficácia erga

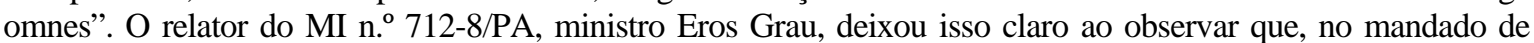
injunção, "o Poder Judiciário não define norma de decisão, mas enuncia o texto normativo que faltava para, no caso, tornar viável o exercício do direito de greve dos servidores públicos”. Os debates então travados acerca da atribuição da eficácia erga omnes ao suprimento normativo prestado pelo STF, as ressalvas feitas pela maioria, de 
No que tange ao ativismo judicial extraprocessual, evoquem-se, mais uma vez, os exemplos referidos no tópico 3.4.1.1, nos quais se percebe, fora do processo, notadamente no cenário político e social, uma forte mobilização desse órgão de cúpula do Judiciário, por meio de seus representantes.

Por fim, note-se ser menos visível, no STF, o ativismo judicial contra legem. É que a conotação de um caso examinado pelo Supremo tende a ser sempre constitucional, de modo que dispositivo legal tenderá a ser afastado por inconstitucionalidade, e não por alegado anacronismo, inadequação ou injustiça.

Apresentado esse panorama, cumpre examinar, em alguns casos selecionados (de grande relevância para a efetividade dos direitos sociais trabalhistas), as repercussões do ativismo judicial do STF sobre a prática judicial trabalhista.

\subsubsection{Limitação à garantia de emprego da gestante}

O primeiro caso relevante envolve as limitações à garantia de emprego da gestante, prevista no artigo 10, II, “b”, do ADCT. Com efeito, desde 1997, a tese que prevalecia no TST era a da antiga redação da OJ n. ${ }^{\circ} 88$ da SBDI-1, segundo a qual "a ausência de cumprimento da obrigação de comunicar ao empregador o estado gravídico, em determinado prazo após a rescisão, conforme previsto em norma coletiva que condiciona a estabilidade a esta comunicação", afastaria “o direito à indenização decorrente da estabilidade".

Todavia, o tema ganhou relevância na jurisprudência do STF, que passou a considerar o direito inderrogável, bastando, para sua fruição, a confirmação objetiva do estado fisiológico da gravidez, independentemente da comunicação prévia de tal estado ao empregador $^{564}$.

Isso deu impulso a pressões pela modificação da orientação jurisprudencial do TST, o que foi feito apenas em 2004, quando a redação da referida OJ, em consonância com o entendimento do STF, passou a enunciar a tese de que o

que cada situação de omissão legislativa deve merecer tratamento próprio quanto à forma de ser superada; e a existência de três votos em contrário, insistindo na prevalência da orientação perfilhada no MI n. ${ }^{\circ}$ 721-7, "ainda deixam dúvidas quanto à consolidação dessa nova viragem jurisprudencial”. ELIVAL DA SILVA RAMOS, op.cit., p. 259.

${ }^{564}$ Ilustrativamente: “EMENTA: RECURSO EXTRAORDINÁRIO. TRABALHISTA. (...) 3. ADCT-CF/88, artigo 10, II, b. Norma transitória que não condiciona a fruição do benefício concedido à empregada gestante à comunicação de sua gravidez ao empregador. Precedente. Agravo regimental não provido.” RE 339713/SP, $2^{\mathrm{a}}$ Turma, rel. Min. Maurício Corrêa, julg. 18-06-2002, DJ 02-08-2002. 
desconhecimento do estado gravídico pelo empregador não afastaria o direito ao pagamento da indenização decorrente da estabilidade ${ }^{565}$. Mais adiante, em 2005, a súmula n. ${ }^{\circ} 244$ do TST (que desde 2003 garantia a reintegração ao longo do período de estabilidade), incorporou a referida orientação jurisprudencial.

É interessante notar que a motivação mais forte para o TST alterar sua jurisprudência foi a percepção de que estaria julgando contrariamente ao entendimento do STF em relação ao tema.

Em outras palavras, pela perspectiva dos tipos do ativismo judicial, podese dizer que essa percepção, pelo TST, de que vinha praticando, no plano vertical, o ativismo judicial em face de precedentes (já que a OJ n. ${ }^{\circ} 88$ da SBDI-1 do TST contrariava tese jurídica de relevância crescente no STF, apesar de não ser ela sumulada nem vinculante) levou o órgão trabalhista a modificar seu entendimento. Nessa linha de raciocínio, o TST, ao modificar sua jurisprudência para evitar o ativismo judicial em face de precedentes oriundos do STF (plano vertical), praticou-o (no plano horizontal), em face da própria jurisprudência.

\footnotetext{
${ }^{565}$ O sítio do TST na internet (Notícias do TST) anunciava, em 05-03-2004, que, a pedido da Associação Brasileira de Advogados Trabalhistas (fundado na afirmação, pelo STF, da inderrogabilidade do direito), a comissão de jurisprudência do Tribunal examinaria, em caráter de urgência, o cancelamento da referida orientação jurisprudencial. Com efeito, note-se o histórico da referida OJ SDI1 n. ${ }^{\circ}$ 88. GESTANTE. ESTABILIDADE PROVISÓRIA. Nova redação - DJ 16.04.04 - republicado DJ 04.05.2004 (cancelada em decorrência da nova redação conferida à Súmula n. ${ }^{\circ}$ 244, DJ 20.04.2005). O desconhecimento do estado gravídico pelo empregador, não afasta o direito ao pagamento da indenização decorrente da estabilidade. (art. 10, II, "b", ADCT). Legislação: CF/1988, art. 10, II, "b", ADCT. Histórico: Redação original. 88. Gestante. Estabilidade provisória. Inserida em 28.04.97. O desconhecimento do estado gravídico pelo empregador, *salvo previsão contrária em norma coletiva, não afasta o direito ao pagamento da indenização decorrente da estabilidade. (art. 10, II, "b", ADCT). A ausência de cumprimento da obrigação de comunicar à empregadora o estado gravídico, em determinado prazo após a rescisão, conforme previsto em norma coletiva que condiciona a estabilidade a esta comunicação, afasta o direito à indenização decorrente da estabilidade. Transcreve-se, por oportuno, a Súmula n. ${ }^{\circ}$ 244, que incorporou a OJ supracitada: "GESTANTE. ESTABILIDADE PROVISÓRIA (incorporadas as Orientações Jurisprudenciais n. ${ }^{\circ}$ s 88 e 196 da SBDI-1) Res. 129/2005, DJ 20, 22 e 25.04.2005. I - O desconhecimento do estado gravídico pelo empregador não afasta o direito ao pagamento da indenização decorrente da estabilidade (art. 10, II, "b" do ADCT). (ex-OJ n. ${ }^{\circ}$ 88 da SBDI-1 - DJ 16.04.2004 e republicada DJ 04.05.2004). II - A garantia de emprego à gestante só autoriza a reintegração se esta se der durante o período de estabilidade. Do contrário, a garantia restringe-se aos salários e demais direitos correspondentes ao período de estabilidade. (ex-súmula n. ${ }^{\circ} 244$ - alterada pela Res. 121/2003, DJ 21.11.2003). III - Não há direito da empregada gestante à estabilidade provisória na hipótese de admissão mediante contrato de experiência, visto que a extinção da relação de emprego, em face do término do prazo, não constitui dispensa arbitrária ou sem justa causa. (ex-OJ n. ${ }^{\circ} 196$ da SBDI-1 - inserida em 08.11.2000). Histórico: Súmula alterada - Res. 121/2003, DJ 19, 20 e 21.11.2003. n. ${ }^{\circ} 244$ Gestante. Garantia de emprego. A garantia de emprego à gestante só autoriza a reintegração se esta se der durante o período de estabilidade. Do contrário, a garantia restringe-se aos salários e demais direitos correspondentes ao período de estabilidade. Redação original - Res. 15/1985, DJ 05, 06 e 09.12.1985. n. ${ }^{\circ} 244$ Gestante Garantia de emprego. A garantia de emprego à gestante não autoriza a reintegração, assegurando-lhe apenas o direito a salários e vantagens correspondentes ao período e seus reflexos.”
} 
Com isso, modificou-se entendimento que vigia há vários anos. Dada a força persuasiva das decisões do STF em matéria constitucional, não foi necessário que o órgão, no caso, editasse precedente para promover esse efeito de padronização decisória que em certo sentido emana de seus julgamentos.

\subsubsection{A definição da base de calculo do adicional de insalubridade}

A evolução da jurisprudência do TST vis $a$ vis com a do STF no que tange à definição da base de cálculo do adicional de insalubridade é curiosa e permite interessante problematização ${ }^{566}$. Neste tópico, examinaremos os efeitos do ativismo judicial de padronização decisória praticado pelo STF sobre as teses jurídicas desenvolvidas pelo TST em relação àquele tema.

Desde a promulgação da Constituição até 2008, prevalecia o entendimento de que a vedação de vinculação do salário mínimo "para qualquer fim" (artigo $7^{\circ}, I V$ ) não afetaria diretamente a legislação ordinária, já que o fundamento daquela limitação radicaria na intenção de conter a chamada indexação da economia. Um dos dispositivos que tiveram sua aplicabilidade preservada, tendo em vista esse entendimento, foi o artigo 192 da CLT, segundo o qual o exercício de trabalho em condições insalubres, acima dos limites de tolerância estabelecidos pelo Ministério do Trabalho assegura a percepção de adicional de insalubridade em percentual (variável conforme a agressividade do agente) incidente sobre o salário-mínimo ${ }^{567}$. Em consonância com essa visão, as teses jurídicas do TST propunham que o “percentual do adicional de insalubridade” incidiria sobre o salário mínimo, à exceção dos casos em que o empregado recebesse salárioprofissional "por força de lei, convenção coletiva ou sentença normativa" ${ }^{568}$.

\footnotetext{
${ }^{566}$ Interessante estudo sobre o tema foi apresentado por HOMERO BATISTA MATEUS DA SILVA, Curso de Direito do Trabalho Aplicado, vol. 3, São Paulo: Campus, 2008. pp. 95-102. Extraíram, da apresentação cronológica do jurista, alguns fatos que reputamos importantes para os fins deste tópico.

${ }^{567}$ HOMERO BATISTA MATEUS DA SILVA, Curso de Direito do Trabalho Aplicado, v. 3, op.cit., p. 99.

${ }^{568}$ Note-se a substancial diferença da redação das súmulas do TST referentes ao tema antes e depois de 2606-2008, logo após a edição da súmula vinculante 4 do STF, em 30-04-2008. Súmula n. ${ }^{\circ} 17$ do TST: "ADICIONAL DE INSALUBRIDADE (cancelada na sessão do Tribunal Pleno realizada em 26.06.2008) Res. 148/2008, DJ 04 e 07.07.2008 - Republicada DJ 08, 09 e 10.07.2008. O adicional de insalubridade devido a empregado que, por força de lei, convenção coletiva ou sentença normativa, percebe salário profissional será sobre este calculado. Histórico: Súmula restaurada - Res. 121/2003, DJ 19, 20 e 21.11.2003 Súmula cancelada - Res. 29/1994, DJ 12, 17 e 19.05.1994 Redação original - RA 28/1969, DO-GB 21.08.1969 n. ${ }^{\circ} 17 \mathrm{O}$ adicional-insalubridade devido a empregado que percebe, por força de lei, convenção coletiva ou sentença normativa, salário-profissional, será sobre este calculado.” Súmula n. ${ }^{\circ} 228$ do TST: "ADICIONAL DE INSALUBRIDADE. BASE DE CÁLCULO (redação alterada na sessão do Tribunal Pleno em 26.06.2008) - Res. 148/2008, DJ 04 e 07.07.2008 - Republicada DJ 08, 09 e 10.07.2008. A partir
} 
Em abril 2008, entretanto, o STF, com base em uma série de precedentes, editou a súmula vinculante n. ${ }^{\circ}$, segundo a qual o salário mínimo não poderia "ser usado como indexador de base de cálculo de vantagem de servidor público ou de empregado, nem ser substituído por decisão judicial”, exceto nos casos expressamente previstos na Constituição $^{569}$. Surgiu, de imediato, a necessidade de interpretar a súmula. O Supremo, para evitar o entendimento (que seria corolário do verbete sumular) de que o artigo 192 da CLT não teria sido recepcionado, modulou os efeitos do enunciado vinculante para fixar a interpretação de que o adicional de insalubridade, enquanto não superada a referida inconstitucionalidade por meio de lei ou convenção coletiva, deveria continuar a ser calculado com base no salário mínimo ${ }^{570}$.

A parte final do enunciado é instigante, por estabelecer que decisão judicial não pode suprir a lacuna surgida em decorrência do afastamento do salário mínimo como critério. Em outros termos, com base na presunção absoluta de correção da tese jurídica vinculante, neutralizou-se, expressamente, qualquer possibilidade de atuação criativa de outros órgãos judiciais, que se viram impedidos, inclusive, de utilizar a analogia (artigo $4^{\circ}$ da Lei de Introdução ao Código Civil).

Em julho de 2008, num período de muita indecisão a respeito de qual seria a melhor interpretação para o verbete vinculante, o TST cancelou a súmula n. ${ }^{\circ} 17$ e reeditou a súmula $n .^{\circ}$ 228, que passou a enunciar a tese de que, desde a publicação da súmula vinculante n. ${ }^{\circ}$, o adicional de insalubridade seria “calculado sobre o salário básico, salvo critério mais vantajoso fixado em instrumento coletivo”. A nova tese (que

de 9 de maio de 2008, data da publicação da Súmula Vinculante n. ${ }^{\circ} 4$ do Supremo Tribunal Federal, o adicional de insalubridade será calculado sobre o salário básico, salvo critério mais vantajoso fixado em instrumento coletivo. Histórico: Nova redação - Res. 121/2003, DJ 19, 20 e 21.11.2003. n. ${ }^{0} 228$ Adicional de insalubridade. Base de cálculo $\mathrm{O}$ percentual do adicional de insalubridade incide sobre o salário mínimo de que cogita o art. 76 da CLT, salvo as hipóteses previstas na Súmula n. ${ }^{\circ}$ 17. Redação original - Res. 14/1985, DJ 19.09.1985 e 24, 25 e 26.09.1985 n. 228 Adicional de Insalubridade. Base de cálculo O percentual do adicional de insalubridade incide sobre o salário-mínimo de que cogita o art. 76 da Consolidação das Leis do Trabalho."

${ }^{569}$ A súmula vinculante teve origem no RE 565.714/SP, rel. Min. Cármen Lúcia, julg. 30-04-2008.

${ }^{570}$ Mais recentemente: "Piso salarial dos técnicos em radiologia. Adicional de insalubridade. Vinculação ao salário mínimo. Súmula Vinculante 4. (...) O art. 16 da Lei 7.394/1985 deve ser declarado ilegítimo, por não recepção, mas os critérios estabelecidos pela referida lei devem continuar sendo aplicados, até que sobrevenha norma que fixe nova base de cálculo, seja lei federal, editada pelo Congresso Nacional, sejam convenções ou acordos coletivos de trabalho, ou, ainda, lei estadual, editada conforme delegação prevista na LC 103/2000. Congelamento da base de cálculo em questão, para que seja calculada de acordo com o valor de dois salários mínimos vigentes na data do trânsito em julgado desta decisão, de modo a desindexar o salário mínimo. Solução que, a um só tempo, repele do ordenamento jurídico lei incompatível com a Constituição atual, não deixe um vácuo legislativo que acabaria por eliminar direitos dos trabalhadores, mas também não esvazia o conteúdo da decisão proferida por este STF.” (ADPF 151-MC, rel. p/ ac. Min. Gilmar Mendes, julg. 02-02-11, DJE de 6-5-2011). 
combinava, prima facie, o ativismo judicial criativo e o ativismo judicial de padronização decisória) era radicada na aplicação analógica do artigo 193 da CLT, que trata da periculosidade.

Sucede que o teor da súmula, por seus efeitos persuasivos, suscitou reações imediatas diante da expectativa de que sua aplicação generalizada incitaria (tanto no TST quanto em outros órgãos judiciais trabalhistas) justamente o que o STF (combinando traços de três tipos de ativismo judicial - contramajoritário, criativo e, sobretudo, de padronização decisória) buscava evitar: a possibilidade de uma decisão judicial, diante do vazio normativo, fixar outro critério.

Poucos dias depois, provocado pelo ajuizamento da reclamação n. ${ }^{\circ} 6266$, o STF deferiu medida liminar para "suspender a aplicação” da súmula n. ${ }^{\circ} 228$ do TST na parte em que "permitia” a utilização do salário básico "para calcular o adicional de insalubridade”. Tanto na demanda reclamatória quanto na decisão liminar, é interessante notar a percepção dos fortes efeitos persuasivos do precedente do TST. Em outras palavras, essa percepção levou o Supremo a neutralizar a tese da corte de cúpula da Justiça do Trabalho; tese que, mesmo não constituindo per se uma decisão, teria a aptidão de exercer forte influência sobre a judicialização de novos conflitos e sobre o julgamento dos já ajuizados $^{571}$. Após prestar esclarecimentos ao STF, o TST passou a seguir a orientação do daquele, inclusive em relação aos recursos extraordinários.

Note-se que a medida suspensiva da súmula buscou evitar que demandas baseadas na tese criativa do TST levassem a decisões contrárias à súmula vinculante, mesmo que aplicado o expediente analógico. Em outras palavras, pela perspectiva do potencial protagonismo judicial, essas decisões contrárias à súmula vinculante constituiriam um ativismo judicial em face de precedentes (plano vertical), dado o desacato de tese jurídica fixada pelo STF com presunção absoluta de correção.

\footnotetext{
${ }^{571}$ Rcl 6266 MC/DF, min. Gilmar Mendes, julg. 15-07-08, public. 05-08-2008. Na reclamação ajuizada pela CNI (Confederação Nacional da Indústria), alegava-se que a nova redação da Súmula n. ${ }^{\circ}$ 228/TST, ao fixar o salário básico como base de cálculo do adicional de insalubridade, estaria em conflito com a súmula vinculante $\mathrm{n}^{\circ} 4$ (fumus boni iuris). Para dar sustentação à alegada urgência da pretensão cautelar (periculum in mora), a reclamante alertava para a "gravíssima insegurança jurídica", além de "reflexos danosos e irreparáveis para os empregadores representados pela CNI" e "a proliferação incontinenti de ações, já passíveis de ajuizamento desde a publicação da Resolução do Tribunal Superior do Trabalho n. ${ }^{\circ}$ 148/2008, que dá nova redação à Súmula n. ${ }^{\circ} 228 ”$. Importa observar que o procurador-geral da República se manifestou pela improcedência da reclamação.
} 


\subsubsection{Terceirização e responsabilidade subsidiária da Administração}

pública

A súmula n. ${ }^{\circ} 331$ do TST, sobre a legalidade do "contrato de prestação de serviços” (terceirização), pode ser problematizada pela visualização de traços de ativismo judicial dos tipos contramajoritário e em face de precedentes ${ }^{572}$.

Com efeito, o exame do histórico do verbete, em princípio, revela a combinação clara do ativismo judicial de padronização decisória (dada a força persuasiva da enunciação, em geral tratada com conotação normativa) com o ativismo judicial criativo (pela estipulação de soluções e critérios não previstos na legislação, como a responsabilização subsidiária e a distinção entre atividade-fim e atividade-meio).

Ademais, a tese jurídica consubstanciada em referido precedente, em diálogo com a doutrina trabalhista, foi sendo sofisticada com sucessivos aportes criativos.

572 Súmula n. ${ }^{\circ}$ 331: “CONTRATO DE PRESTAÇÃO DE SERVIÇOS. LEGALIDADE (nova redação do item IV e inseridos os itens V e VI à redação) - Res. 174/2011, DEJT divulgado em 27, 30 e 31.05.2011. I A contratação de trabalhadores por empresa interposta é ilegal, formando-se o vínculo diretamente com o tomador dos serviços, salvo no caso de trabalho temporário (Lei n. ${ }^{\circ}$ 6.019, de 03.01.1974). II - A contratação irregular de trabalhador, mediante empresa interposta, não gera vínculo de emprego com os órgãos da Administração Pública direta, indireta ou fundacional (art. 37, II, da CF/1988).III - Não forma vínculo de emprego com o tomador a contratação de serviços de vigilância (Lei n. ${ }^{\circ}$ 7.102, de 20.06.1983) e de conservação e limpeza, bem como a de serviços especializados ligados à atividade-meio do tomador, desde que inexistente a pessoalidade e a subordinação direta. IV - O inadimplemento das obrigações trabalhistas, por parte do empregador, implica a responsabilidade subsidiária do tomador dos serviços quanto àquelas obrigações, desde que haja participado da relação processual e conste também do título executivo judicial. V - Os entes integrantes da Administração Pública direta e indireta respondem subsidiariamente, nas mesmas condições do item IV, caso evidenciada a sua conduta culposa no cumprimento das obrigações da Lei $\mathrm{n}^{\circ}{ }^{\circ}$ 8.666, de 21.06.1993, especialmente na fiscalização do cumprimento das obrigações contratuais e legais da prestadora de serviço como empregadora. A aludida responsabilidade não decorre de mero inadimplemento das obrigações trabalhistas assumidas pela empresa regularmente contratada. VI - A responsabilidade subsidiária do tomador de serviços abrange todas as verbas decorrentes da condenação referentes ao período da prestação laboral.Histórico: Súmula mantida - Res. 121/2003, DJ 19, 20 e 21.11.2003. Súmula alterada (inciso IV) - Res. 96/2000, DJ 18, 19 e 20.09.2000. n. ${ }^{\circ} 331$ (...) IV - O inadimplemento das obrigações trabalhistas, por parte do empregador, implica a responsabilidade subsidiária do tomador dos serviços, quanto àquelas obrigações, inclusive quanto aos órgãos da administração direta, das autarquias, das fundações públicas, das empresas públicas e das sociedades de economia mista, desde que hajam participado da relação processual e constem também do título executivo judicial (art. 71 da Lei n. ${ }^{\circ}$ 8.666, de 21.06.1993). Redação original (revisão da Súmula n. ${ }^{\circ}$ 256) - Res. 23/1993, DJ 21, 28.12.1993 e 04.01.1994. n. ${ }^{\circ} 331$ (...) II - A contratação irregular de trabalhador, através de empresa interposta, não gera vínculo de emprego com os órgãos da Administração Pública Direta, Indireta ou Fundacional (art. 37, II, da Constituição da República). (...) IV - O inadimplemento das obrigações trabalhistas, por parte do empregador, implica na responsabilidade subsidiária do tomador dos serviços, quanto àquelas obrigações, desde que hajam participado da relação processual e constem também do título executivo judicial.” Como se vê, a súmula n. ${ }^{\circ}$ 331 resulta da evolução jurisprudencial do entendimento seminal da súmula n. ${ }^{\circ}$ 256: "CONTRATO DE PRESTAÇÃO DE SERVIÇOS. LEGALIDADE (cancelada) - Res. 121/2003, DJ 19, 20 e 21.11.2003 Salvo os casos de trabalho temporário e de serviço de vigilância, previstos nas Leis n. ${ }^{\circ}$ s 6.019, de 03.01.1974, e 7.102, de 20.06.1983, é ilegal a contratação de trabalhadores por empresa interposta, formando-se o vínculo empregatício diretamente com o tomador dos serviços. Histórico: Revista pela Súmula n. ${ }^{0} 331$ - Res. 23/1993, DJ 21.12.1993 e 04.01.1994 Redação original - Res. 4/1986, DJ 30.09.1986, 01 e 02.10.1986.” 
Num deles, fixou-se a tese de que a chamada responsabilidade subsidiária alcançaria os “órgãos da administração direta, das autarquias, das fundações públicas, das empresas públicas e das sociedades de economia mista” se houvessem "participado da relação processual” e constassem “do título executivo judicial”, não obstante o teor do artigo 71 da Lei n. ${ }^{\circ}$ 8.666/93, referido no próprio item IV da súmula.

Sucede que, provocado por meio de diversas reclamações, o STF afirmou que a súmula 331 ensejou nas Cortes trabalhistas regionais e no próprio Supremo uma enorme controvérsia a respeito da eventual inconstitucionalidade sugerida no verbete, entendimento que vinha sendo usado para afastar o $\S 1^{\circ}$ do referido dispositivo da referida Lei de Licitações ${ }^{573}$.

Isso levou à suspensão de várias decisões do TST, sob o fundamento de que teria havido desrespeito à súmula vinculante n. ${ }^{\circ} 10$ (cláusula de reserva de plenário prevista no artigo 97 da CR) e indevida negativa de vigência ao citado dispositivo ${ }^{574}$.

Para contornar esses questionamentos, o TST, em novo aporte criativo à tese jurídica consolidada na súmula, esclareceu que a responsabilidade subsidiária teria seu fundamento não na inconstitucionalidade do $\S 1^{\circ}$ do artigo 71 da Lei n. ${ }^{\circ}$ 8.666/93 (cuja constitucionalidade havia, aliás, sido declarada pelo Supremo ${ }^{575}$ ), mas na “conduta culposa” da Administração no que tange ao cumprimento das obrigações da Lei n. ${ }^{\circ}$ 8.666/93, sobretudo pela ausência de "fiscalização do cumprimento das obrigações contratuais e legais da prestadora de serviço como empregadora”. Com efeito, ao se manifestar sobre a mudança na redação do verbete, o presidente da corte observou que, não obstante o fundamento antes adotado pelo TST houvesse sido derrubado pelo STF (que

\footnotetext{
573 “Acórdão que entendeu ser aplicável ao caso o que dispõe o inciso IV da Súmula TST 331, sem a consequente declaração de inconstitucionalidade do art. 71, § $1^{\circ}$, da Lei 8.666/1993 com a observância da cláusula da reserva de Plenário, nos termos do art. 97 da CF. Não houve no julgamento do incidente de uniformização de jurisprudência (...) a declaração formal da inconstitucionalidade do art. 71 , $\S 1^{\circ}$, da Lei 8.666/1993, mas apenas e tão somente a atribuição de certa interpretação ao mencionado dispositivo legal. (...) As disposições insertas no art. 71, § $1^{\circ}$, da Lei 8.666/1993 e no inciso IV da Súmula TST 331 são diametralmente opostas. $\mathrm{O}$ art. $71, \S 1^{\circ}$, da Lei 8.666/1993 prevê que a inadimplência do contratado não transfere aos entes públicos a responsabilidade pelo pagamento de encargos trabalhistas, fiscais e comerciais, enquanto o inciso IV da Súmula TST 331 dispõe que o inadimplemento das obrigações trabalhistas pelo contratado implica a responsabilidade subsidiária da Administração Pública, se tomadora dos serviços. O acórdão impugnado, ao aplicar ao presente caso a interpretação consagrada pelo TST no item IV do Enunciado 331, esvaziou a força normativa do art. $71, \S 1^{\circ}$, da Lei 8.666/1993. Ocorrência de negativa implícita de vigência ao art. $71, \S 1^{\circ}$, da Lei 8.666/1993, sem que o Plenário do TST tivesse declarado formalmente a sua inconstitucionalidade. Ofensa à autoridade da Súmula Vinculante 10 devidamente configurada.” (Rcl 8.150-AgR, Rel. p/ o ac. Min. Ellen Gracie, julg. 24-11-10, Plenário, DJE de 3-3-11.) No mesmo sentido: Rcl 7.517-AgR, rel. Min. Ricardo Lewandowski, julg. 24-11-10, Plenário, DJE de 14-4-11.

${ }^{574}$ Cf. Rcl AgR 7901/AM, rel. Min. Carmen Lúcia, julg. 01-12-2010, public. 02-12-10.

${ }^{575}$ ADC 16, rel. Min. Cezar Peluso, julg. 24-11-10, Plenário, Informativo 610.
} 
afirmou a constitucionalidade do dispositivo cuja incidência seria afastada na hipótese anterior da súmula, de modo que a Justiça do Trabalho, “só por este fundamento”, não poderia “reconhecer a responsabilidade”), seria possível chegar "ao mesmo resultado por um outro caminho, outro fundamento”, i.e., “a eventual conduta culposa do ente público, caso evidenciada no processo", permitiria o "reconhecimento de que ele responde pelas obrigações" ${ }^{576}$.

\subsubsection{Reflexos trabalhistas de outros julgados do STF}

O STF, sobretudo pela edição de súmulas vinculantes e pelo exercício do controle de constitucionalidade, tem produzido decisões com grandes impactos sobre a prática judicial trabalhista.

No que tange à possibilidade de controle de constitucionalidade pelos órgãos judiciais colegiados em geral, o Supremo fixou a tese de que haveria violação da “cláusula de reserva de plenário” na decisão de órgão fracionário de Tribunal que, “embora não declare expressamente a inconstitucionalidade de lei ou ato normativo do poder público, afasta sua incidência, no todo ou em parte” (súmula vinculante n. ${ }^{\circ} 10$ ). Em outras palavras, a súmula traduz um ativismo judicial de padronização decisória dirigido especificamente à limitação dos mecanismos de controle de constitucionalidade que poderiam levar à prática do ativismo judicial contramajoritário pelos órgãos fracionários de um Tribunal, como no caso citado no tópico anterior. Na Justiça do Trabalho, em especial no TST, a edição da súmula levou à suspensão de vários processos que seriam julgados por seus órgãos colegiados para que a questão da inconstitucionalidade “em tese” fosse apreciada, antes, pelo pleno ${ }^{577}$.

Em relação à competência da Justiça do Trabalho, não sobeja evocar a polêmica decisão na ADI n. ${ }^{3}$ 3395. Nela, ao examinar a nova redação do artigo 114 da Constituição (conferida pela EC n. ${ }^{\circ}$ 45/2004), o STF afastou do alcance do dispositivo as ações oriundas de relações de trabalho envolvendo servidores com vínculo de natureza jurídico-administrativa, de um lado, e entes de direito público externo e da administração pública direta e indireta da União, dos Estados, do Distrito Federal e dos Municípios, de

\footnotetext{
${ }^{576}$ Cf. Notícias do TST. Terceirização na administração pública: presidente do TST esclarece mudanças. publ. 24-05-11. Disponível em www.tst.jus.br, acesso em 02-06-11.

577 Ilustrativamente, foi o caso dos seguintes recursos: E-RR 845/2007-020-09-00.5, E-RR 79118/2006-09109-00.7, E-RR 159/2007-459-09-00.6, RR 985/2006-005-24-00.8.
} 
outro $^{578}$. A decisão gerou reflexos sobre uma série de outros processos em que se discutiram controvérsias surgidas em decorrência daquele julgamento, como a competência para apreciar causas que envolvessem servidores temporários ${ }^{579}$, greve de servidores públicos $^{580}$ e tutela do meio ambiente do trabalho na Administração Pública ${ }^{581}$.

578 "Esse é o teor da decisão liminar exarada pelo Min. Nelson Jobim, ora trazida ao referendo deste Plenário: 'A Associação dos Juízes Federais do Brasil - AJUFE - propõe a presente ação contra o inciso I do art. 114 da CF, na redação dada pela EC 45/2004. Sustenta que no processo legislativo, quando da promulgação da emenda constitucional, houve supressão de parte do texto aprovado pelo Senado. Câmara dos Deputados. Informa que a Câmara dos Deputados, na PEC 96/1992, ao apreciar o art. 115, 'aprovou em dois turnos, uma redação ... que ... ganhou um inciso I...'(...). Teve tal dispositivo a seguinte redação: ‘Art. 115. Compete à Justiça do Trabalho processar e julgar: I - as ações oriundas da relação de trabalho, abrangidos os entes de direito público externo e da administração pública direta e indireta da União, dos Estados, do Distrito Federal e dos Municípios.' Senado Federal. A PEC, no Senado Federal, tomou número 29/2000. Naquela Casa, a Comissão de Constituição, Justiça e Cidadania manifestou-se pela divisão da '... proposta originária entre (a) texto destinado à promulgação e (b) texto destinado ao retorno para a Câmara dos Deputados’ (Parecer 451/2004, fls. 4, 177 e 243). O SF aprovou tal inciso com acréscimo. O novo texto ficou assim redigido: ‘Art. 114. Compete à Justiça do Trabalho processar e julgar: I - as ações oriundas da relação de trabalho, abrangidos os entes de direito público externo e da administração pública direta e indireta da União, dos Estados, do Distrito Federal e dos Municípios, exceto os servidores ocupantes de cargos criados por lei, de provimento efetivo ou em comissão, incluídas as autarquias e fundações públicas dos referidos entes da federação’. (Fls. 4 e 280). Informa, ainda, que, na redação final do texto para promulgação, nos termos do Parecer 1.747 (fl. 495), a parte final acima destacada foi suprimida. Por isso, remanesceu, na promulgação, a redação oriunda da Câmara dos Deputados, sem o acréscimo. No texto que voltou à Câmara de Deputados (PEC 358/2005), o SF fez constar a redação por ele aprovada, com o referido acréscimo (Parecer 1.748/2004, fl. 502). (...) Entendo presentes os requisitos para a concessão e manutenção da liminar. A necessidade de se definir a interpretação do art. 114, I, acrescido pela EC 45/2004, conforme à Constituição da República, é consistente. O Supremo Tribunal Federal já decidiu, no julgamento da ADI n. 492 (rel. Min. Carlos Velloso, DJ de 12-3-1993), ser inconstitucional a inclusão, no âmbito de competência da Justiça do Trabalho, das causas que envolvam o Poder Público e seus servidores estatutários. (...) A decisão foi que a Constituição da República não autoriza conferir à expressão relação de trabalho alcance capaz de abranger o liame de natureza estatutária que vincula o Poder Público e seus servidores. Daí, ter-se afirmado a incompetência da Justiça do Trabalho para julgar litígios entre ambos. Ora, ao atribuir à Justiça do Trabalho competência para apreciar 'as ações oriundas da relação de trabalho, abrangidos os entes de direito público externo e da administração pública direta e indireta da União, dos Estados, do Distrito Federal e dos Municípios’, o art. 114, I, da Constituição, não incluiu, em seu âmbito material de validade, as relações de natureza jurídicoadministrativa dos servidores públicos. Logo, é pertinente a interpretação conforme à Constituição, emprestada pela decisão liminar, diante do caráter polissêmico da norma. E, à sua luz, perde força o argumento de inconstitucionalidade formal. A redação dada pelo Senado Federal à norma e suprimida à promulgação em nada alteraria o âmbito semântico do texto definitivo. Afinal, apenas tornaria expressa, naquela regra de competência, a exceção relativa aos servidores públicos estatutários, que o art. 114, I, já contém implicitamente, ao referir-se só a ‘ações oriundas da relação de trabalho', com a qual não se confunde a relação jurídico-administrativa (ADI n. ${ }^{0}$ 492, rel. Min. Carlos Velloso, DJ de 12-3-1993). Ora, se proposição jurídica emendada pelo Senado não possui âmbito de validade diverso da aprovada pela Câmara e como tal promulgada, não há excogitar violação ao art. 60 , § $2^{\circ}$, da Constituição da República (ADI n. ${ }^{\circ}$ 2.666, rel. Min. Ellen Gracie, DJ de 6-12-2002; ADC n. ${ }^{\circ}$ 3, rel. Min. Nelson Jobim, DJ de 9-5-2003; ADI n. ${ }^{\circ}$ 2.031, rel. Min. Ellen Gracie, DJ de 17-10-2003).” (ADI 3.395-MC, voto do rel. Min. Cezar Peluso, julgamento em 5-4-2006, Plenário, DJ de 10-11-2006.)

579 "Servidores públicos. Regime temporário. Justiça do Trabalho. Incompetência. No julgamento da ADI n. ${ }^{\circ}$ 3.395/DF-MC, este Supremo Tribunal suspendeu toda e qualquer interpretação do inciso I do art. 114 da CF (na redação da EC 45/2004) que inserisse, na competência da Justiça do Trabalho, a apreciação de causas instauradas entre o Poder Público e seus servidores, a ele vinculados por típica relação de ordem estatutária ou de caráter jurídico-administrativo. As contratações temporárias para suprir os serviços públicos estão no âmbito de relação jurídico-administrativa, sendo competente para dirimir os conflitos a Justiça comum e não a Justiça especializada." (Rcl 4.872, Rel. p/ o ac. Min. Menezes Direito, julg. 21-8-2008, DJE de 7-11-2008.) No mesmo sentido: Rcl 7.157-AgR, rel. Min. Dias Toffoli, julg. 17-2-2010, DJE de 19-3-2010; Rcl 4.045- 
Também em relação à competência da Justiça do Trabalho, nota-se claramente um ativismo judicial de padronização decisória a fim de eliminar dúvidas e inseguranças decorrentes da diversidade de interpretações produzidas tanto pela Justiça Comum quanto pela Justiça Especializada após a EC n. ${ }^{\circ}$ 45/2004. Com efeito, o STF, para pôr fim a uma série de conflitos de competência que vinham sendo suscitados, editou súmulas vinculantes para atribuir à Justiça do Trabalho a competência para processar e julgar tanto ações possessórias ajuizadas "em decorrência do exercício do direito de greve pelos trabalhadores da iniciativa privada" (súmula vinculante 23$)^{582}$ quanto "ações de indenização por danos morais e patrimoniais decorrentes de acidente de trabalho propostas por empregado contra empregador” (súmula vinculante 22$)^{583}$.

MC-AgR, rel. Min. Cezar Peluso, julg. 14-10-2009, DJE de 19-3-2010; Rcl 5.924-AgR, Rcl 7.066-AgR e Rcl 7.115-AgR, rel. Min. Eros Grau, julg. 23-9-2009, DJE de 23-10-2009; Rcl 7.028-AgR e Rcl 7.234-AgR, rel. Min. Ellen Gracie, julg. 16-9-2009, DJE de 16-10-2009; Rcl 6.568, rel. Min. Eros Grau, julg. 21-5-2009, DJE de 25-9-2009.

580 "Direito de greve dos servidores públicos civis. Hipótese de omissão legislativa inconstitucional. Mora judicial, por diversas vezes, declarada pelo Plenário do STF. Riscos de consolidação de típica omissão judicial quanto à matéria. A experiência do direito comparado. Legitimidade de adoção de alternativas normativas e institucionais de superação da situação de omissão. (...) Apesar das modificações implementadas pela EC 19/1998 quanto à modificação da reserva legal de lei complementar para a de lei ordinária específica (CF, art. 37, VII), observa-se que o direito de greve dos servidores públicos civis continua sem receber tratamento legislativo minimamente satisfatório para garantir o exercício dessa prerrogativa em consonância com imperativos constitucionais. Tendo em vista as imperiosas balizas jurídicopolíticas que demandam a concretização do direito de greve a todos os trabalhadores, o STF não pode se abster de reconhecer que, assim como o controle judicial deve incidir sobre a atividade do legislador, é possível que a Corte Constitucional atue também nos casos de inatividade ou omissão do Legislativo. A mora legislativa em questão já foi, por diversas vezes, declarada na ordem constitucional brasileira. Por esse motivo, a permanência dessa situação de ausência de regulamentação do direito de greve dos servidores públicos civis passa a invocar, para si, os riscos de consolidação de uma típica omissão judicial. Na experiência do direito comparado (em especial, na Alemanha e na Itália), admite-se que o Poder Judiciário adote medidas normativas como alternativa legítima de superação de omissões inconstitucionais, sem que a proteção judicial efetiva a direitos fundamentais se configure como ofensa ao modelo de separação de poderes (CF, art. 2).” (MI 708, rel. Min. Gilmar Mendes, julg. 25-10-07, Plenário, DJE de 31-10-08.) No mesmo sentido: MI 3.322, rel. Min. Celso de Mello, decisão monocrática, julg. 01-6-11, DJE de 6-6-11; MI 1.967, rel. Min. Celso de Mello, decisão monocrática, julg. 24-5-11, DJE de 27-5-11. Vide: MS 22.690, rel. Min. Celso de Mello, julg. 17-4-1997, Plenário, DJ de 7-12-06.

${ }^{581}$ O próprio STF, na súmula n. ${ }^{\circ} 736$ (ainda vigente), estabelece que "compete à Justiça do Trabalho julgar as ações que tenham como causa de pedir o descumprimento de normas trabalhistas relativas à segurança, higiene e saúde dos trabalhadores".

${ }^{582} \mathrm{O}$ verbete foi produzido com base em processos de reconhecida repercussão geral, como no caso do RE 579.648, rel. p/ ac. Min. Cármen Lúcia, julg. 10-9-2008, DJE de 6-3-2009: "Competência jurisdicional. Justiça do Trabalho X Justiça comum. Ação de Interdito Proibitório. Movimento grevista. Acesso de funcionários e clientes à agencia bancária: 'piquete'. Art. 114, II, da CF. Jurisprudência do STF. Competência da Justiça do Trabalho. 'A determinação da competência da Justiça do Trabalho não importa que dependa a solução da lide de questões de direito civil' (Conflito de Jurisdição 6.959), bastando que a questão submetida à apreciação judicial decorra da relação de emprego. Ação de interdito proibitório cuja causa de pedir decorre de movimento grevista, ainda que de forma preventiva. O exercício do direito de greve respeita a relação de emprego, pelo que a EC 45/2003 incluiu, expressamente, na competência da Justiça do Trabalho conhecer e julgar as ações dele decorrentes (art. 114, II, da CF).”

${ }^{583} \mathrm{~A}$ súmula incluiu, em seu espectro, expressamente, as causas que ainda não possuíam "sentença de mérito em primeiro grau quando da promulgação da Emenda Constitucional 45/2004”. Também neste caso a súmula 
Importa, ainda, considerar os impactos, sobre a execução trabalhista, da súmula vinculante $n .^{\circ}$ 25, que estabelece ser "ilícita a prisão civil de depositário infiel, qualquer que seja a modalidade do depósito”. Pela interpretação conferida ao art. 50, LXVII, da CR, a ilicitude decorreria do reconhecimento da supralegalidade da Convenção Americana sobre Direitos Humanos (Pacto de S. José da Costa Rica, art. $7^{\circ}, \S 7^{\circ}$ ) e do Pacto Internacional sobre Direitos Civis e Políticos (artigo 11).

Ademais, em recente julgado, o TST confirmou a tese de decisão regional que reconheceu a nulidade de contrato de trabalho celebrado contrariamente à súmula vinculante n. ${ }^{\circ} 13$ do STF, sobre a prática do nepotismo ${ }^{584}$.

Como se vê, o espaço para a atuação ativista do STF em matéria trabalhista é amplo. O exemplo da omissão legislativa em relação ao aviso prévio proporcional é igualmente curioso. Já há algum tempo a matéria vinha sendo judicializada na Justiça do Trabalho. Para a jurisprudência do TST, a "proporcionalidade do aviso prévio, com base no tempo de serviço”, dependeria da legislação regulamentadora, uma vez que, segundo a $\mathrm{OJ}$ n. ${ }^{\circ} 84$ da SBDI-1, o artigo $7^{\circ}$, XXI, da CR não seria

foi editada com base em processos com reconhecida repercussão geral, nos quais se afirmava: "A competência para julgar ações de indenização por danos morais e materiais decorrentes de acidente de trabalho, após a edição da EC 45/2004, é da Justiça do Trabalho. (...) O ajuizamento da ação de indenização pelos sucessores não altera a competência da Justiça especializada. A transferência do direito patrimonial em decorrência do óbito do empregado é irrelevante." (CC 7.545, rel. Min. Eros Grau, julg. 3-6-2009, Plenário, DJE de 14-8-2009.) No mesmo sentido: RE 600.091, rel. Min. Dias Toffoli, julg. 25-5-2011, Plenário, DJE de 15-8-2011, com repercussão geral; RE 482.797-ED, rel. Min. Ricardo Lewandowski, julg. 13-5-2008, Primeira Turma, DJE de 27-6-2008; RE 509.353-ED, rel. Min. Sepúlveda Pertence, julg. 25-6-2007, Primeira Turma, DJ de 17-8-2007; RE 503.278-AgR, rel. Min. Ayres Britto, julg. 26-4-2007, Primeira Turma, DJ de 3-8-2007.

${ }^{584}$ No AIRR - 64800-56.2009.5.01.0038 (1 $1^{\mathrm{a}}$ turma, rel. Min. Walmir Oliveira da Costa, julg. 10-08-2011), o TST, ao negar provimento ao agravo (confirmando a decisão a quo), determinou fosse comunicado o Ministério Público do Estado do Rio de Janeiro, "para aferição de possível ilicitude administrativa" que levou o relator a considerar o contrato nulo, pelo desrespeito à súmula vinculante . $^{\circ} 13$ do STF. Destaquem-se os seguintes excertos: " Extrai-se, portanto, da fundamentação, que o Tribunal Regional, a partir do exame do acervo probatório dos autos, concluiu pela nulidade do ato de admissão do reclamante, com fundamento na diretriz estabelecida pela Súmula Vinculante n. ${ }^{\circ} 13$ do STF, porquanto designado, por seu irmão, este no exercício do cargo de Diretor-Presidente da TurisRio - sociedade de economia mista estadual -, para exercer função de assessor econômico e comercial no Gabinete da Presidência daquele ente estatal.Nesse contexto, irrelevante tratar-se de cargo em comissão, de livre nomeação, na medida em que restou configurada vedada prática de nepotismo a macular o ato de admissão/nomeação de parente na Administração Pública, a teor do entendimento consagrado na Súmula Vinculante n. ${ }^{\circ} 13$ do excelso STF, vazada nos seguintes termos: 'A nomeação de cônjuge, companheiro ou parente em linha reta, colateral ou por afinidade, até o terceiro-grau, inclusive, da autoridade nomeante ou de servidor da mesma pessoa jurídica investido em cargo de direção, chefia ou assessoramento, para o exercício de cargo em comissão ou de confiança ou, ainda, de função gratificada na administração pública direta e indireta em qualquer dos Poderes da União, dos Estados, do Distrito Federal e dos Municípios, compreendido o ajuste mediante designações recíprocas, viola a Constituição Federal'.Inviável, pois, a pretensão de que seja observada a ressalva contida na parte final do inciso II do art. 37 da Constituição Federal, porquanto maculado o ato jurídico com vício de nulidade absoluta que fere a moralidade pública - princípio norteador de todo ato administrativo, conforme a diretriz estabelecida no caput do mesmo dispositivo constitucional, como corretamente concluiu o acórdão recorrido." 
autoaplicável $^{585}$. Todavia, em meados de 2011, o STF, ao apreciar mandados de injunção ajuizados para questionar aquela omissão legislativa, chegou a cogitar da possibilidade de regulamentar provisoriamente a matéria ${ }^{586}$, o que suscitou grande repercussão. De um lado, várias opiniões, inclusive a do presidente do TST, alegavam que a medida poderia implicar “usurpação” do papel do Congresso ${ }^{587}$; de outro, empresários chegaram a encaminhar propostas ao Supremo com a pretensão de que fossem consideradas por ocasião da regulamentação do assunto pela via judicial ${ }^{588}$.

A possibilidade de mais essa atuação do potencial protagonismo do STF (que combinaria o ativismo judicial dos tipos contramajoritário, criativo e promocional), entretanto, perdeu força após a Lei n. ${ }^{\circ}$ 12.056/2011, que regulamentou o aviso prévio proporcional para estabelecer o acréscimo de três dias por ano de serviço prestado na mesma empresa, até o máximo de sessenta dias, perfazendo um total de até noventa dias.

${ }^{585}$ OJ n. ${ }^{\circ} 84$ da SBDI-1 do TST: "AVISO PRÉVIO. PROPORCIONALIDADE. Inserida em 28-04-97. A proporcionalidade do aviso prévio, com base no tempo de serviço, depende da legislação regulamentadora, visto que o art. $7^{\circ}$, inc. XXI, da CF/1988 não é autoaplicável."

${ }^{586}$ MI 943/DF, MI 1010/DF, MI 1074/DF e MI 1090/DF. Notícia publicada no endereço eletrônico do STF em 22-06-11 relata que o julgamento desses casos foi suspenso depois de o relator se pronunciar pela procedência das ações, com a sugestão de que o Plenário sobrestasse o julgamento até que fosse explicitado o direito pleiteado naqueles casos concretos. O manancial a ser pesquisado envolveria, segundo a mesma noticia, as experiências de outros países, as normas da OIT e os projetos em tramitação no Congresso Nacional que propunham a regulamentação do dispositivo constitucional. Durante os debates em torno dos processos, os ministros observaram que o STF deveria manter o avanço em relação a decisões antigas (que apenas advertiam o Congresso Nacional sobre a necessidade de regulamentar o respectivo dispositivo invocado), de forma que se adotasse regra específica para o caso concreto, inclusive para estimular o Poder Legislativo a votar uma lei regulamentadora. Foram citados dois precedentes em que o STF agira desta forma (o MI 721, relacionado à omissão legislativa na regulamentação do $\S 4^{\circ}$ do artigo 40 da CR, que confere o direito à contagem diferenciada do tempo de serviço em decorrência de atividade em trabalho insalubre; e o MI 708, em que foi solucionada provisoriamente a omissão legislativa quanto ao direito de greve no serviço público, determinando a aplicação das regras vigentes para o setor privado, no que coubesse, até regulamentação do artigo 37, inciso VII, da CR). As propostas preliminares dos ministros foram em vários sentidos, havendo tomado vulto, em várias delas, a disposição do artigo $8^{\circ}$ da CLT no que tange à aplicação do direito comparado. Assim, além da referência a projetos de lei existentes, foram citadas as experiências das leis trabalhistas da Alemanha, da Dinamarca, da Suíça e da Itália. Ao sugerir a suspensão dos debates para aprofundar os estudos sobre o tema, o ministro Gilmar Mendes ponderou que, de qualquer forma, em primeiro lugar a legitimidade para regulamentar o assunto seria do Congresso Nacional. Disponível em: www.stf.jus.br. Não é comum, na Justiça do Trabalho, o manejo do mandado de injunção. Sobre o tema, EVANNA SOARES, "Mandado de injunção na justiça do trabalho", in: Genesis: revista de direito do trabalho, vol. 20, n. ${ }^{\circ}$ 116, ago. 2002, pp. 193-209. A autora cita alguns exemplos, colhidos da jurisprudência do TST, inclusive em relação ao aviso prévio proporcional, mas em nenhum deles houve decisão favorável.

${ }_{587}$ Cf. Jornal "Folha de São Paulo", edição de 25-06-2011 (Caderno Mercado). A notícia registra que, segundo o presidente do TST, tratar-se-ia de "uma providência inarredável do STF, em face da omissão do Congresso". Antecipando possíveis dúvidas, o magistrado elucubrava sobre o alcance da decisão: "Vai beneficiar tão somente os impetrantes [da ação] ou o Supremo vai editar uma norma aplicável a todos os demais casos?” E concluía: “A meu juízo, [...] vai dizer qual é o aviso prévio proporcional no caso concreto. Há um princípio de separação de Poderes e, no meu entender, o Supremo não pode editar uma norma com conteúdo de generalidade, de coerção, como se fosse legislador."

${ }^{588}$ Cf. Jornal "Folha de São Paulo", edição de 20-08-2011 (Caderno Mercado). Da notícia, extrai-se que confederações de vários setores enviaram documento com propostas sobre o tema ao STF, quando este sinalizou que pretendia regulamentar, temporariamente, o assunto. 


\section{CONCLUSÃO}

A título de conclusão, não seria possível apresentar, resumida e superficialmente, todas as ideias defendidas ao longo deste trabalho. O intuito, neste átimo, só poderia ser o de encerrar a argumentação apresentada.

Com efeito, adotado o conceito de juridificação das relações sociais como fio condutor das reflexões empreendidas, demonstrou-se que esse complexo processo de colonização do mundo da vida pelo Direito fez emergir, gradativamente, um potencial protagonismo judicial em grande parte das experiências democráticas ocidentais. Desse modo, ficou claro que a expansão do Poder Judiciário não ocorre, pura e simplesmente, por meio da prática do chamado ativismo judicial. Na verdade, este último, em suas várias formas, consiste na manifestação de um potencial que lhe antecede e que constitui condição de sua possibilidade.

Para auxiliar a identificação desse potencial, destacaram-se, entre os aspectos e desdobramentos mais importantes do referido processo de juridificação: a expansão dos padrões regulatórios; a “indeterminação” do direito contemporâneo; a materialização do direito formal; a crise da divisão funcional dos poderes; o enfraquecimento progressivo de um modelo decisório eminentemente subsuntivo; o fortalecimento da função pragmática da hermenêutica jurídica; a expropriação de conflitos; a ampliação do controle judicial contramajoritário; o aumento da independência política do Poder Judiciário; a convergência normativa e institucional das experiências jurídicas democráticas; a influência do ideário do juiz ativo, ampliado para contemplar o tratamento de conflitos de massa e a promoção judicial de soluções não adjudicatórias; a expansão da litigância de interesse público; e, ainda, as mudanças na relação entre os órgãos judiciais e os meios de comunicação de massa.

Por essa perspectiva abrangente, o exame da maneira pela qual o potencial protagonismo judicial emergiu em diferentes experiências jurídicas ao longo do processo de juridificação (sem olvidar as especificidades da experiência brasileira e as peculiaridades da Justiça do Trabalho, que foi situada num cenário mais amplo de transformações na função judicial) forneceu relevantes ingredientes comparatísticos para a problematização de diferentes noções de ativismo judicial. Notou-se que todas essas noções têm como preocupação axial a compreensão das formas pelas quais a função judicial atua para além das fronteiras da concepção tradicional de jurisdição. 
Para captar essas diferentes formas de manifestação (que no Brasil se tornaram mais perceptíveis após a redemocratização propiciada pela Constituição de 1988) construíram-se, com base em metodologia weberiana, tipos ideais de ativismo judicial: contramajoritário, jurisdicional, promocional, criativo, de padronização decisória, em face de precedentes, contra legem, processual e extraprocessual. Com a construção desses tipos, que consubstanciam a síntese das reflexões conceituais empreendidas, pretendeu-se edificar um instrumental investigativo relevante para a compreensão da atuação contemporânea do Poder Judiciário.

No que tange à Justiça do Trabalho, a investigação desta tese, baseada nesse instrumental, realizou-se pela seleção de situações e fatos representativos da incidência de um ou mais tipos de ativismo judicial, com ênfase em casos relacionados à tutela de direitos sociais trabalhistas previstos na Constituição de 1988 (despedimentos em massa, controle judicial de políticas públicas, terceirização, dispensas discriminatórias de portadores do vírus HIV, proteção à maternidade, combate à exploração sexual de crianças e adolescentes para fins comerciais, entre outros). Considerando a riqueza de aspectos relevantes que apresenta e a grande repercussão que suscitou e ainda parece suscitar, o caso da atuação da Justiça do Trabalho em face das dispensas em massa da Embraer foi estudado com mais ênfase.

Não se deixou de lado, dada a centralidade do papel do STF na ordem jurídica brasileira, o exame de alguns dos reflexos do ativismo judicial praticado pelo Supremo sobre a atividade judicante da Justiça do Trabalho e sobre os direitos do Trabalho e Processual do Trabalho.

Com isso, demonstraram-se vários efeitos, sobre a jurisdição trabalhista, das transformações pelas quais a função judicial tem passado no mundo contemporâneo. Percebeu-se, ademais, que certos matizes do potencial protagonismo judicial já estavam presentes no nascedouro da Justiça do Trabalho.

A tese, desse modo, pretendeu fornecer contribuição relevante para a avaliação da atuação das instituições judiciais trabalhistas, considerado o papel da Justiça do Trabalho de promover a efetividade do Direito do Trabalho, a instrumentalidade do Direito Processual do Trabalho e a tutela dos direitos sociais fundamentais do trabalhador.

De um modo geral, examinar de perto a atuação dos órgãos judiciais nas democracias constitucionais contemporâneas se justifica por serem essas ordens jurídicas caudatárias do projeto humanístico iluminista de maximização da liberdade, da igualdade e da fraternidade de que se originaram os ideários dos direitos fundamentais e dos direitos 
humanos. Esse projeto, justificado, à moda de Kant, por um dever moral que funda um dever jurídico, torna o respeito à dignidade da pessoa humana um vetor inexorável de todas as normas e de sua aplicação. Destarte, toda atuação estatal (e, como corolário, todo o agir judicial) deve partir da concepção de pessoa humana como fim em si (Zweck an sich), absoluto, incondicional, por contraposição aos fins relativos ou de intermediação. Em sua Metafísica dos Costumes, Kant define o fim em si (a pessoa humana) como objetivo e necessário, opondo-se aos fins subjetivos e contingentes. Se o ser humano se situa acima de qualquer preço, a pessoa não deve ser valorada como um meio para o fim de outros ou mesmo para seus próprios fins, mas como um fim em si mesmo. Essa consagrada perspectiva kantiana, como se vê, é indissociável do projeto de modernidade e de sua apropriação pelo Direito, com a enunciação e a ampliação, à medida que evoluiu a juridificação, dos direitos e garantias fundamentais, individuais e sociais.

Note-se que essa mesma reflexão kantiana revela um preocupante paradoxo com o qual a Justiça do Trabalho deve habilmente lidar no momento de definir o sentido em que se materializará seu potencial protagonismo judicial. É que a ordem jurídica trabalhista, ao pretender contribuir com a acessibilidade às pré-condições de exercício efetivo dos direitos e garantias fundamentais como um todo, busca, em última análise, mitigar os efeitos perversos da aparentemente incontornável instrumentalização da pessoa do trabalhador em relações de trabalho subordinado ${ }^{589}$.

Considerados, assim, os riscos que essa razão instrumental imanente a tais relações traz à razão objetiva da dignidade da pessoa humana, a preocupação com o papel dos juízes se torna ainda mais relevante num cenário econômico, social e político de complexidade crescente e no qual tem ganhado força um discurso intransigente de defesa da autonomia da vontade em prejuízo de conquistas históricas tão caras à civilização ocidental, consubstanciadas não apenas nos direitos fundamentais individuais, mas também nos direitos fundamentais sociais, em especial os trabalhistas.

Essas considerações nos auxiliam a concluir uma ponderação de ordem metodológica apresentada na introdução deste trabalho. Com efeito, se não foi nossa intenção construir um pensamento de Filosofia da Justiça ou um discurso ideológico (apologético ou condenatório, de justificação formal ou material) acerca do ativismo judicial; isso não significa que aderimos a qualquer tipo de relativismo que implique a

\footnotetext{
${ }^{589}$ Evoque-se, para ilustrar essa instrumentalização, as sempre oportunas, atuais e sutilmente cruéis cenas iniciais do personagem de Chaplin em “Tempos Modernos”.
} 
negação do valor da pessoa humana e dos fins estabelecidos pela ordem jurídica como corolário de um projeto humanístico no qual acreditamos fortemente e pelo qual toda e qualquer forma de agir judicial deve se orientar em primeiro lugar. Não se deixa de reconhecer, entretanto, a pluralidade de valores e interesses conflitantes emergentes na sociedade contemporânea, que engendram uma miríade de expectativas colidentes em torno de textos normativos, a tornar ainda mais desafiadora a atividade de julgar com justiça, convicção e responsabilidade.

Dessarte, as múltiplas possibilidades de concretização do potencial protagonismo judicial em diferentes tipos de ativismo judicial trazem grandes dilemas éticos para os órgãos judiciais trabalhistas, dos quais se espera, sempre, um compromisso imparcial e austero com a efetividade dos direitos fundamentais individuais e sociais no âmbito das relações de trabalho. 


\section{BIBLIOGRAFIA CITADA}

ALEXY, Robert. Teoria da Argumentação Jurídica. São Paulo: Landy, 2001.

ALMEIDA, Renato Rua de. "Subsiste no Brasil o direito potestativo do empregador nas despedidas em massa?”, in: Revista $L T r$, vol. 73, n. ${ }^{\circ}$ 4, abr. 2009.

ALVES, José Carlos Moreira. "Poder Judiciário”, in: MARTINS, Ives Gandra da Silva (org.). A Constituição Brasileira de 1988: Interpretações. Rio de Janeiro: Forense Universitária, 1988.

ANDRADE, Lédio Rosa de. Introdução ao Direito Alternativo Brasileiro. $1^{\text {a }}$ ed., Livraria do Advogado, 1996.

ARANTES, Rogério Bastos. Judiciário e Política no Brasil. São Paulo: Idesp, 1997.

ARISTÓTELES. Ética a Nicômaco. São Paulo: Abril, 1984.

ARON, Raymond. Etapas do pensamento sociológico. $8^{\mathrm{a}}$ ed. São Paulo: Dom Quixote, 2007.

ARRUDA JUNIOR. Edmundo Lima de (coord.). Lições de direito alternativo. São Paulo: Acadêmica, 1992.

ARRUDA, Kátia Magalhães; COSTA, Walmir Oliveira da (org.). Direitos Coletivos do Trabalho na Visão do TST - Homenagem ao Ministro Rider Nogueira de Brito. São Paulo: LTr, 2011.

AZEVEDO, André Gomma de; SILVA, Cyntia Cristina de Carvalho. "Autocomposição, processos construtivos e a advocacia: breves comentários sobre a atuação de advogados em processos autocompositivos", in: Revista do advogado, n. ${ }^{\circ}$ 87, ano XXVI, set. 2006.

BADINER, Robert; BREYER, Stephen. Les entretiens de Provence: Le juge dans la société contemporaine. Paris: Arthème Fayard-Publications de la Sorbonne, 2003.

BARBOSA, Alexandre de Freitas. "O programa seguro-desemprego como parte das políticas de emprego no Brasil", in: Cadernos de Pesquisa - CEBRAP, n. ${ }^{\circ}$ 7, mai. 1997. 
BARROSO, Luis Roberto. “Judicialização, ativismo judicial e legitimidade democrática”, in: RDE. Revista de Direito do Estado, vol. 13, 2009. . Curso de Direito Constitucional contemporâneo. São Paulo: Saraiva, 2009.

BAUM, Lawrence. A Suprema Corte Americana. Rio de Janeiro: Forense, 1987.

BAUMAN, Zygmunt. Consuming life, Cambridge: Polity, 2007.

BEATTY, David M. The Ultimate Rule of Law. New York, Oxford University Press, 2004.

BENDIX, Reinhard. Max Weber: um perfil intelectual. Brasília: UnB, 1986.

BERGER, Raoul. “Government by judiciary: some countercriticism”, in: Texas Law Review, n. ${ }^{\circ}$ 56, 1977-1978.

BICKEL, Alexander. The least dangerous branch: the supreme court at the bar of politics. New Haven: Yale University, 1986.

BLICHNER, Lars; MOLANDER, Anders. "Mapping Juridification”, in: European Law Journal, vol. 14, jan. 2008.

BOBBIO, Norberto. Positivismo Jurídico: lições de Filosofia do Direito. São Paulo: Ícone, 1995.

BROOKER, Penny. "The juridification of alternative dispute resolution”, in: Anglo American Law Review, vol. XX, 1999.

CALABRESI, Guido. A Common Law for the Age of Statutes. Lawbook: Nova Jersey, 1999.

CAMPILONGO, Celso Fernandes. "Os desafios do Judiciário: um enquadramento teórico”, in: FARIA, José Eduardo (org.). Direitos humanos, direitos sociais e justiça. São Paulo: Malheiros, 1994. Política, Sistema Jurídico e Decisão Judicial. São Paulo, Max Limonad, 2002.

CANIVET, Guy. "Activisme judiciaire: introduction générale”, in: Archives de philosophie du droit, n. ${ }^{\circ}$ 50, 2007. 
CAPELLETTI, Mauro. "Os métodos alternativos de solução de conflitos no quadro do movimento universal de acesso à justiça", in: Revista de Processo, n. ${ }^{\circ} 174$. . "Repudiating Montesquieu? The expansion and Legitimacy of Constitutional Justice", in: Catholic University Law Review, n. ${ }^{\circ}$ 35, 1985. . "Trends of 'Procedural Justice in Contemporary Europe'", in: KAUFMANN, Arthur (org.). Rechtsstaat und Menschenwürde. Festschrift Für Werner Maihofer Zum 70 Geburststag. Frankfurt Am Main: Klosterman, 1988.

CAPELLETTI, Mauro. "Governmental and Private Advocates for the Public Interest in Civil Litigation: a Comparative Study”, in: Michigan Law Review, n. ${ }^{\circ}$ 793, 1975.

Juízes Legisladores. Porto Alegre: Sérgio Antônio Fabris, 1999.

CAPELLETTI, Mauro; GARTH, Bryant. Acesso à Justiça. Porto Alegre: Sérgio Antônio Fabris, 1988.

CARRION, Valentin. Comentários à Consolidação das Leis do Trabalho. 33a ed., São Paulo: Saraiva, 2008.

CARVAlHO, Amilton Bueno de. Direito Alternativo. Teoria e Prática. $5^{\mathrm{a}}$ ed., Rio de Janeiro: Lumen Iuris, 2004.

CARVAlHO, Amilton Bueno de; CARVALHO, Salo de (org.). Direito alternativo brasileiro e pensamento, $1^{\text {a }}$ ed., Rio de Janeiro: Lumen Iuris, 2004.

CASSELS, Jamie. "Judicial Activism and Public Interest Litigation in India: Attempting the Impossible?”, in: American Journal of Comparative Law, vol. 37, 1989.

CASTRO, Marcus Faro de. "O Supremo Tribunal Federal e a Judicialização da Política”, in: Revista Brasileira de Ciências Sociais, vol. 12, n. 34.

CHAYES, Abram. “The role of the judge in public law litigation”, in: Harvard Law Review, vol. 89, n. ${ }^{\circ}$ 7, mai. 1976.

CHEMERINSKY, Erwin. "The price of asking the wrong question: an essay on constitutional scholarship and judicial review”, in: Texas Law Review, $n .^{\circ}$ 62, 1983-1984. 
CHOUDHRY, Sujit (org.). The Migration of Constitutional Ideas. Cambridge: Cambridge University Press, 2006.

CHOUDHRY, Sujit; HUNTER, Claire E. "Measuring Judicial activism on the Supreme Court of Canada: a comment on Newfoundland (Treasury Board v. Nape)”, in: McGill Law Journal, vol. 48, 2003.

COELHO, Luis Fernando. Teoria Crítica do Direito. $3^{\mathrm{a}}$ ed (revisada e ampliada). Belo Horizonte: Del Rey, 2003.

COMPARATO, Fabio Konder. "Ensaio sobre o juízo de constitucionalidade de políticas públicas”, in: Revista de Informação Legislativa, ano 35, n. ${ }^{\circ}$ 138, abr./jun. 1998.

CORREIA, Marcus Orione Gonçalves. “A análise dos julgados envolvendo a demissão coletiva na Embraer”, in: COUTINHO, Grijalbo (et. al.) (coord.). O mundo do Trabalho: leituras críticas da jurisprudência do TST em defesa do Direito do Trabalho. São Paulo: LTr, 2011.

COUTINHO, Diogo Rosenthal. Direito, desenvolvimento $e$ desigualdade: a dimensão jurídica das políticas sociais. FDUSP: Tese (Livre-Docência), 2010.

COUTINHO, Grijalbo F. (et. al.) (coord.). O mundo do Trabalho: leituras críticas da jurisprudência do TST em defesa do Direito do Trabalho. São Paulo: LTr, 2011.

COVER, Robert M. "The Origins of Judicial Activism in the Protection of Minorities”, in: Yale Law Journal, vol. 91, 1982.

DALLARI, Dalmo de Abreu. O poder dos juízes. $3^{\mathrm{a}}$ ed., São Paulo: Saraiva, 2010.

DELGADO, Maurício Godinho. Curso de Direito do Trabalho. 5a ed., São Paulo: LTr, 2006.

DENVIR, John. "Towards a Political Theory of Public Interest Litigation", in: North Carolina Law Review, n. 54.

DICAPRIO, Lisa. The origins of the welfare state: women, work, and the French Revolution. Chicago: University of Illinois Press: 2007. 
DINAMARCO, Candido Rangel. Fundamentos do processo civil moderno, $5^{\mathrm{a}}$ ed., tomo I, São Paulo: Malheiros, 2002. . Instituições de Direito Processual Civil. vol. 1, São Paulo: Malheiros, 2005.

DORSEN, Norman. “The relevance of foreign legal materials in U.S. constitutional cases: A conversation between Justice Antonin Scalia and Justice Stephen Breyer”, in: International Journal of Constitutional Law, vol. 3, out. 2005.

DOTAN, Yoav. “Judicial Rhetoric. Government Lawyers and Human Rights: The Case of the Israeli High Court of Justice During the Intifada”, in: Law \& Society Review, n. ${ }^{\circ}$ 33, 1999.

DWORKIN, Ronald. "Un pontificat laic”, in: BADINTER, Robert; BREYER, Sephen. Les Entretiens de Provence: Le juge dans societé contemporaine. Paris: Fayard: 2003. Law's Empire. Cambridge: Harvard University Press, 1986.

DWYER, John. "Public Interest litigation. Who can start proceedings", in: Legal Service Bull, n. ${ }^{\circ}$ 6, 1981.

ELLIOTT, Douglas. "Judicial Activism and the Threat to Democracy", in: University of New Brunswick Law Journal, n. ${ }^{\circ}$ 199, 2004.

ELY, John Hart. Democracy and Distrust. Cambridge: Harvard University Press, 2002.

ENTERIA, Eduardo Garcia. "Princípio de legalidad, Estado material de Derecho y faculdades interpretativas e constructivas del a jurisprudência em la Constituición”, in: Revista Española de Derecho Constitucional. Madrid, Centro de Estudios Constitucionales, n. ${ }^{\circ}$ 10, jan./abr. 1984.

EPP, Charles R. The Rights Revolution: Lawyers, activists, and Supreme Courts in Comparative Perspective. Chicago: University of Chicago Press, 1998. . "Do Bills of Rights Matter? The Canadian Charter of Rights and Freedoms", in: American Political Science Review, vol. 90, n. ${ }^{\circ}$ 4, dez. 1996. 
FARIA, José Eduardo. “A definição do interesse público”, in: SALLES, Carlos Alberto de. Processo Civil de Interesse público. São Paulo: RT, 2003. - “A globalização econômica e sua arquitetura jurídica - dez tendências do direito contemporâneo”, in: Revista Academia Judicial, Florianópolis: dez. 2010. . "Poucas certezas e muitas dúvidas”, Texto de seminário no International Institute for Sociologia of Law, Onnati, jul. 2009. . Sociologia Jurídica - Direito e Conjuntura. $2^{\mathrm{a}}$ ed. São Paulo: Saraiva, 2010. . Os novos desafios da justiça do trabalho. São Paulo: LTr, 1995.

FARIA, José Eduardo (org.). Direitos humanos, direitos sociais e justiça. São Paulo: Malheiros, 1994.

FERRARI, Irany; NASCIMENTO, Amauri Mascaro; MARTINS FILHO, Ives Gandra da Silva. História do Trabalho, do Direito do Trabalho e da Justiça do Trabalho - Homenagem a Armando Casimiro Mota. São Paulo: LTr, 2002.

FERRAZ JUNIOR, Tércio Sampaio. Introdução ao Estudo do Direito: técnica, decisão, dominação. $4^{\mathrm{a}}$ ed., São Paulo.

FERREIRA, Waldemar Martins. Princípios de Legislação Social e Direito Judiciário do Trabalho. São Paulo: São Paulo, 1938.

FILHO, Roberto Lyra. Direito do Capital e Direito do Trabalho. Porto Alegre: Sérgio Antônio Fabris, 1982.

FISHER, Roger; URY, William; PATTON, Bruce. Como chegar ao sim - negociação de acordos sem concessões, trad. Vera Ribeiro e Ana Luiza Borges, $2^{\mathrm{a}}$ ed., Rio de Janeiro: Imago, 2005.

FISS, Owen. Um novo processo civil: estudos norte-americanos sobre jurisdição, constituição e sociedade. São Paulo: RT, 2004.

FISS, Owen; RESNIK, Judith. Adjudication and its alternatives - an introduction to procedure. New York: Thomson West, 2003. 
FLOOD, John; CAIGER, Andrew. "Lawyers and Arbitration: The Juridification of Construction Disputes", in: The Modern Law Review, vol. 56, n. ${ }^{\circ} 3$ (Dispute Resolution. Civil Justice and Its Alternatives), mai. 1993.

FREITAS JUNIOR, Antônio Rodrigues de. "Conflitos de justiça e limites da mediação para a difusão da cultura da paz.“, in: SALLES, Carlos Alberto de (org.). As Grandes Transformações do Direito Processual Civil Brasileiro -Homenagem ao Professor Kazuo Watanabe (homenagem ao Professor Kazuo Watanabe). São Paulo: Quartier Latin, 2009. - Os Direitos Sociais e a Constituição de 1988. Rio de Janeiro: Forense, 1993.

FUNKEN, Katja. The Best of Both Worlds - The Trend Towards Convergence of the Civil Law and the Common Law System, jul. 2003 (SSRN).

FURTADO, Celso. Formação Econômica do Brasil, 32a ed., São Paulo: Cia Editora Nacional, 2005.

GALANTER, Marc. "Why the Haves Come out Ahead: Speculations on the limits of legal chance”, in: Law and Society Review. vol. 9, 1974.

GARGARELlA, Roberto; DOMINGO, Pilar; ROUX, Theunis (org.). Courts And Social Transformation in New Democracies: an institutional voice for the poor? Ashgate, 2006.

GARNER, Bryan (org.). Black Law Dictionary. Westgroup, 1996.

GARTH, Bryant. "ADR and Civil Procedure: a Chapter or an organizing a theme?", in: 37 Journal Legal Education, 1987.

GERHARDT, Michael. "The Rhetoric of judicial critique: from judicial restraint to the virtual Bill of Rights”. In: William \& Mary Bill of Rights Journal, vol. 10, 2002.

GIDDENS, Anthony. Capitalism \& Modern Social Theory - An Analysis of the Writings of Marx, Durkheim and Max Weber. Cambridge: Cambridge University Press, 1971.

- Política, Sociologia e Teoria Social: encontros com o pensamento social clássico e contemporâneo. São Paulo: Fundação Editora da UNESP, 1998. 
GIUGNI, Gino. "Juridification of italian labor relations”, in: Comparative Labour Law Journal, n. ${ }^{\circ}$ 8, 1986-1987.

GOLDSWORTHY, Jeffrey. "Questioning the Migration of Constitutional Ideas: Rights, Constitutionalism and the Limits of Convergence", in: SUJIT CHOUDHRY (org.). The Migration of Constitutional Ideas. Cambridge: Cambridge University Press, 2006.

GRIMM, Dieter. "L'activisme judiciaire”, in: BADINTER, Robert; BREYER, Sephen. Les Entretiens de Provence: Le juge dans societé contemporaine. Paris, Sorbonne: 2003.

GUEIROS, Evandro Leite. “Ativismo judicial”, in: STJ: dez anos a serviço da justiça: doutrina. Brasília: STJ, 1999.

HÄBERLE, Peter. Hermenêutica Constitucional. A sociedade aberta dos intérpretes da Constituição: contribuição para a interpretação pluralista $e$ “procedimental” da Constituição. Porto Alegre: Sergio Antônio Fabris. 2002.

HABERMAS, Jürgen. Direito e democracia entre facticidade e validade, Rio de Janeiro, Tempo Brasileiro, 1997, vols. 1 e 2. Teoria de la accion comunicativa, vol. 2, Madrid: Taurus, 1987.

HIRSCHL, Ran. "The New Constitutionalism and the Judicialization of Pure Politics Worldwide”, in: Fordham L. Rev, n. ${ }^{\circ}$ 2, vol. 75, 2006.

HOUAISS, Antônio; VILLAR, Mauro de Salles. Dicionário Houaiss da Língua Portuguesa. $1^{\text {a }}$ ed. Rio de Janeiro: Objetiva, 2001.

IPEA. Para a Década de 90: prioridades e perspectivas de políticas públicas - Políticas Sociais e Organização do Trabalho. Brasília: IPEA, 1989. vol. 4.

KANT, Immanuel. A metafísica dos costumes (A doutrina do direito e a doutrina da virtude), Trad. Edson Bini, São Paulo, Edipro, 2003.

KELSEN, Hans. Teoria Geral do Direito e do Estado, trad. Luis Carlos Borges, São Paulo: Martins Fontes, 2002. Teoria pura do Direito. São Paulo: Martins Fontes, 1999.

KLEIN, Franz. Zeit - und Geistesströmungen im Prozesse. Frankfurt am Main: Vittorio Klostermann, 1958. 
KMIEC, Keenan. "The Origin and Current Meanings of "Judicial Activism”, in: California Law Review, n. ${ }^{\circ}$ 92, 2004.

KRISHNAN, Jayanth Kumar. "Public Interest Litigation in a Comparative Context”, in: Buffalo Public Interest Law Journal, vol. XX, 2001, 2002.

KUHN, Thomas. A estrutura das revoluções científicas, São Paulo: Perspectiva, 1982.

KUMM, Mattias. “Democratic constitutionalism encounters international law: terms of engagement”, in: SUJIT CHOUDHRY (org.). The Migration of Constitutional Ideas. Cambridge: Cambridge University Press, 2006.

LANG, Maurice Eugen. Codification in the British Empire and America. Nova Jersey: Lawbook, 2005.

LARENZ, Karl. Metodologia da ciência do direito. $3^{\text {a }}$ ed., Lisboa: Fundação Calouste Gulbenkian, 1997.

LEAL, Rogério Gesta; LEAL, Monia (org.). Ativismo judicial e déficits democráticos: algumas experiências latino-americanas e europeias. Rio de Janeiro: Lumen Iuris, 2011.

LEITE, Carlos Henrique Bezerra. Curso de Direito Processual do Trabalho. São Paulo: LTr, 2009.

LIBERATI, Edmondo Bruti, "Potere e giustizia", in: LIBERATI, Edmondo Bruti; CERETTI, Adolfo; GIASANTI, Alberto (org.). Governo dei Giudici: la magistratura tra diritto e politica. Milano: Feltrinelli, 1996.

LLORENTE, Francisco Rubio. "La jurisdición constitucional como forma de creación del derecho”, in: Revista Española de Derecho Constitucional. Madrid,

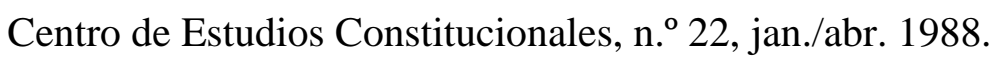

LOPES, José Reinaldo de Lima. "Em torno do direito alternativo”, in: Revista de informação legislativa, ano 31, n. ${ }^{\circ}$ 121. Brasília: Senado Federal, 1994.

MAIOR, Jorge Luiz Souto. "Reflexos das alterações do Código de Processo Civil no processo do trabalho”, in: Revista LTr, vol. 70, n. ${ }^{\circ}$ 8, São Paulo, 2006.

MANCUSO, Rodolfo de Camargo. A resolução dos conflitos e a função judicial no contemporâneo Estado de Direito. São Paulo: Revista dos Tribunais, 2009.

MARSHALL, William P. "Conservatives and the Seven Sins of Judicial Activism”, in: Colorado Law Review, vol. 73, 2002. 
MARTINEZ, Wladimir Novaes. "Licença qualificatória em face da crise econômica”, in: Revista LTr, ano 73, n. ${ }^{0}$ 1, São Paulo: LTr, jan. 2009.

MARTINS, Ives Gandra da Silva (org.). A Constituição Brasileira de 1988: Interpretações. Rio de Janeiro: Forense Universitária, 1988.

MARTINS, Sérgio Pinto. “Despedida coletiva”, in: Revista Magister de direito trabalhista e previdenciário, vol. 6, n. 31, jul./ago., 2009.

MAZZILLI, Hugo Nigro. A defesa dos interesses difusos em Juízo. 21 ${ }^{\text {a }}$ ed., São Paulo: Saraiva, 2008.

MBAZIRA, Christopher. Litigating socio-economic rights in South Africa: a choice between corrective and distributive justice. Pretoria, Pretoria University Law Press, 2009.

MCCOMBS, Maxuell. Setting the Agenda: the mass media and public opinion. Malden: Blackwell Publishing, 2004.

MCWHINNEY, Edward. "The Great Debate: Activism and SelfRestraint and Current Dilemmas in Judicial. Policy-Making”, in: New York University Law Review, n. ${ }^{\circ}$ 3, 1958.

MEDEIROS, Marcelo. A Trajetória do Welfare State no Brasil: Papel Redistributivo das Políticas Sociais dos Anos 1930 aos Anos 1990, Brasilia: IPEA, 2001.

MENDES, Gilmar Ferreira. "Controle de Constitucionalidade: Hermenêutica Constitucional e Revisão de Fatos e Prognoses Legislativos pelo órgão judicial", in: Revista Jurídica da Presidência da República, Brasília, vol. 1, n. ${ }^{\circ}$ 8, jan. 2000.

MERRYMAN, John Henry; PÉREZ-PERDOMO, Rogelio. The civil law tradition: an introduction to the legal systems of Europe and Latin America. $3^{\mathrm{a}}$ ed., Stanford: 2007.

MONTESQUIEU. O espírito das leis. $3^{\mathrm{a}}$ ed, São Paulo: Martins Fontes, 2005.

MORAES, Alexandre de. Jurisdição constitucional e tribunais constitucionais. $2^{\mathrm{a}}$ ed., São Paulo: Atlas, 2003.

MYERS, Robert. "Standing in public interest litigation: removing the procedural barriers”, in: Loyola of Los Angeles Law Review, vol. 15, 1981. 
NAGEL, Robert. Constitutional cultures: the mentality and consequences of judicial review. Los Angeles: University of California Press, 1989.

NALINI, José Renato. "O Brasil e a mediação penal", in: Revista dos

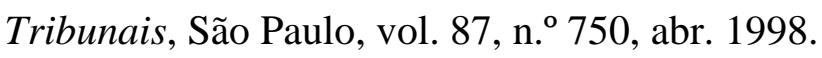

NASCIMENTO, Amauri Mascaro. "Crise econômica, despedimentos e alternativas para a manutenção dos empregos”, in: Revista $L T r$, ano 73, n. ${ }^{\circ}$ 1, São Paulo: LTr, jan. 2009. Iniciação ao Direito do Trabalho. São Paulo: LTr, 2009.

NELKEN, David. "Eugen Ehrlich, Living Law, and Plural Legalities”, in: Theoretical Inquiries in Law, n. ${ }^{\circ}$ 9, 2008.

NEVES, Marcelo. Entre Têmis e Leviatã: o estado democrático de direito a partir e além de Luhmann e Habermas. São Paulo: Martins Fontes, 2006.

NOBRE, Marcos. “Apontamentos sobre a pesquisa em direito no Brasil”, in: Cadernos Direito GV, 2002.

Teoria Crítica. 2a ed., São Paulo: Zahar, 2004.

OIT. Global Employment Trends For Youth - Special issue on the impact of global economic crisis on youth, Genebra: OIT, 2010.

Global Employment Trends. Genebra: OIT, 2010. OIT. Global Employment Trends. Genebra: OIT, 2009.

OLSON, Susan. "Comparing Women's Rights Litigation in the Netherlands and the United States”, in: Polity, vol. 28, n. ${ }^{\circ}$ 2, 1995.

PAULON, Carlos Artur. Direito Alternativo do Trabalho. São Paulo: LTr, 1984.

PORTINARO, Pier Paolo. “Oltre lo Stato di Diritto - Tirannia del giudici o anarchia degli avvocati”, in: COSTA, Pietro; ZOLO, Danilo (org.). Lo stato di diritto: storia, teoria, crítica. $2^{\text {a }}$ ed., Milano: Giangiacomo, 2003.

RAMOS, Elival da Silva. Parâmetros dogmáticos do ativismo judicial em matéria constitucional. São Paulo: Faculdade de Direito da USP (Tese de Titularidade), 2009.

RAMSEY, Michael. "International materials and Domestic Rights: Reflections on Atkins and Lawrence”, in: American Journal of International Law, n. ${ }^{\circ}$ 98, 2004. 
REALE, Miguel. Filosofia do Direito. São Paulo: Saraiva, 2002.

RESNIK, Judith. "Managerial Judges”, in: Harvard Law Review, 96,

1982.

REZEK, José Francisco. “Princípios Fundamentais”, in: MARTINS, Ives Gandra da Silva (org.), A Constituição Brasileira de 1988: Interpretações. Rio de Janeiro: Forense Universitária, 1988.

RISKIN, Leonard L. (et. al.) Dispute resolution and lawyers. West, 2009.

RISKIN, Leonard L., SALES, Lília Maia de Morais. Justiça e mediação de conflitos, Belo Horizonte: Del Rey, 2004.

ROSENBERG, Gerald. The Hollow Hope: can courts bring about social change? 2a ed., Chicago, University of Chicago Press, 2008.

ROSILLO, Alejandro (org.). Teoria Crítica dos Direitos humanos no Século XXI. Porto Alegre, EDIPUC, 2008.

RUSSELL MILLER. "Lords of Democracy: The Judicialization of 'Pure Politics' in the United States and Germany”, in: Wash \& Lee Law Review, 61, 2004.

SADEK, Maria Tereza. "Poder Judiciário: uma nova instituição”, in: DANTAS, Humberto (et. al.). Reforma do Estado Brasileiro: perspectivas e desafios. Rio de Janeiro: Fundação Konrad Adenauer, 2010.

SALLES, Carlos Alberto de (org.). "Mecanismos alternativos de solução de controvérsias e acesso à justiça: a inafastabilidade da tutela jurisdicional recolocada", in: FUX, Luiz; NERY JUNIOR, Nelson; WAMBIER, Teresa Arruda Alvim. Processo e Constituição: estudos em homenagem ao professor Jose C. Barbosa Moreira. São Paulo: RT, 2006.

SALLES, Carlos Alberto de (org.). Processo civil e interesse público: o processo como instrumento de defesa social. São Paulo: RT, 2003.

SANTOS, Boaventura Sousa. O discurso e o poder: ensaio sobre a sociologia da retórica jurídica, Sérgio Antonio Fabris: Porto Alegre, 2008.

SANTOS, Enoque Ribeiro dos. "Revisitando um plano nacional de ação frente ao desemprego”, in: Revista LTr, ano 73, n. 3, São Paulo: LTr, mar. 2009.

SARLET, Ingo Wolfgang; FIGUEIREDO, Mariana Filchtiner. “Algumas considerações sobre o direito fundamental à proteção e promoção da saúde aos 20 anos da Constituição Federal de 1988”, in: Revista de Direito do Consumidor n. ${ }^{\circ}$ 67, 2008. 
SCHLESINGER, Arthur M. A Life in the Twentieth Century: Innocent Beginnings, 1917-1950. New York: Mariner, 2002.

SCHUCK, Peter. "Why don't law professors do more empirical research?”, in: Journal of Legal Education, n. ${ }^{\circ}$ 39, 1989.

SCHWAB, Jürgen. Cinquenta anos de Jurisprudência do Tribunal Constitucional Alemão. Org. Leonardo Martins. Montevidéu: Konrad Adenauer, 2005.

SILVA, Alexandre Garrido da (et al.). "Delimitando as categorias de judicialização da política e de ativismo judicial: o caso da manipulação das células-tronco embrionárias”, in: Revista da Faculdade de Direito de Uberlândia, vol. 36, 2008.

SILVA, Antônio Álvares da. "Dispensa coletiva e seu controle pelo judiciário”, Revista LTr, vol. 73, n. ㅇ 6, jun., 2009.

SILVA, Homero Batista Mateus da. Curso de Direito do Trabalho Aplicado - Direito Coletivo do Trabalho, vol. 8, São Paulo: Elsevier, 2009. Curso de Direito do Trabalho Aplicado, vol. 3, São Paulo: Campus, 2008.

SILVA, Virgilio Afonso da. “O Judiciário e as políticas públicas: entre transformação social e obstáculo à realização dos direitos sociais”, in: SOUZA NETO, Cláudio Pereira de; SARMENTO, Daniel. Direitos sociais: fundamentação, judicialização e direitos sociais em espécies. Rio de Janeiro: Lumen Juris, 2008. . Direitos fundamentais: conteúdo essencial, restrições e eficácia. São Paulo: Malheiros, 2009.

SIMITIS, Spiros. “Juridification of labour relations”, in: TEUBNER, Gunter (org.), Juridification of Social Spheres: A Comparative Analysis in the Areas of Labor, Corporate, Antitrust and Social Welfare Law. Berlin, New York: Gruyter, 1987.

SIX, Jean-François. Dinâmica de mediação, Belo Horizonte: Del Rey, 2001.

SMITS, Jan (org.). Enciclopedia of Comparative Law. Cheltenham: Elgar, 2006.

SOARES, Evanna. "Mandado de injunção na justiça do trabalho", in: Genesis: revista de direito do trabalho, vol. 20, n. ${ }^{\circ}$ 116, ago. 2002.

SOWELL, Thomas. Judicial activism reconsidered. Stanford: Stanford University, 1989. 
STF. Memória jurisprudencial: Ministro Epitacio Pessôa. Brasília: Supremo Tribunal Federal, 2009.

STRECK, Lênio Luiz. Jurisdição constitucional e hermenêutica: uma nova crítica do Direito. Porto Alegre: Livraria do Advogado, 2002.

SÜSSEKIND, Arnaldo (et. al.). Instituições de direito do Trabalho, $23^{\mathrm{a}}$ ed., São Paulo: LTr, 2003.

SWEET, ALEC STONE. Governing with Judges: Constitutional Politics in Europe. Oxford: Oxford University Press, 2000.

TATE, Neal; VALLINDER, Torbjorn (org.), The Global Expansion of Judicial Power. New York: New York University Press, 1995.

TAYLOR, Mathew. "Beyond Judicial Reform: Courts as Political Actors in Latin America”, in: Latin American Research Review - Vol. 41, Number 2, 2006. . “O Judiciário e as políticas públicas no Brasil”, in: Dados, vol. 50, Rio de Janeiro, 2007.

TELLES JÚNIOR, Goffredo da Silva. "O chamado direito alternativo”, in: Revista da Faculdade de Direito da USP, São Paulo, vol. 94, 1999.

TEODORO, Maria Cecília Máximo. O juiz ativo e os direitos do trabalhistas. São Paulo: LTr, 2011.

TEUBNER, Gunter (org.), Juridification of Social Spheres: A Comparative Analysis in the Areas of Labor, Corporate, Antitrust and Social Welfare Law, Berlin, New York: Gruyter, 1987.

TEUBNER, Gunther. "Juridification: concepts, aspects, limits, solutions”, in: TEUBNER, Gunther. (org.), Juridification of Social Spheres: A Comparative Analysis in the Areas of Labor, Corporate, Antitrust and Social Welfare Law, Berlin, New York: Gruyter, 1987.

THEODORO JUNIOR, Humberto; NUNES, Dierle; BAHIA, Alexandre. “Breves Considerações sobre a politização do Judiciário e sobre o panorama de aplicação no direito brasileiro - análise da Convergência entre o civil law e o common law e dos problemas da padronização decisória”, in: Revista de Processo, Ano 35, n. ${ }^{\circ}$ 189, nov. 2010.

TOCQUEVILlE, Alexis de. Democracy in America. New York: New American Library, 1956. 
TRUBEK, David M. "Max Weber sobre direito e ascensão do capitalismo”, trad. José Rafael Zullo, in: Revista Direito GV, vol. 3 n. o 1, jan./jul. 2007.

UE. Green Paper on alternative dispute resolution in civil and commercial law, 2002.

VALLE, Vanice Regina Lirio (org.). Ativismo jurisdicional e o Supremo Tribunal Federal. São Paulo: Juruá, 2009.

VAN RHEE, C. H. “Civil Litigation in Twentieth Century Europe”, in: Buffalo Law Review, vol. 11. European traditions in civil procedure. Oxford: Intersentia, 2005.

VERISSIMO, Marcos Paulo. “A constituição de 1988, vinte anos depois: suprema corte e ativismo judicial 'à brasileira'”, in: Revista Direito GV, vol. 4, n. ${ }^{\circ}$ 2. São Paulo: jul./dez. 2008; Tratam do tema, ainda, direta ou indiretamente.

VIANNA, Francisco José de Oliveira. Problemas de Direito Corporativo. Rio de Janeiro: José Olímpio, 1938.

VIANNA, Luiz Werneck (org.). A Democracia e os Três Poderes no Brasil, Belo Horizonte: UFMG, 2002.

VIEIRA, José Ribas; CAMARGO, Margarida Maria Lacombe; SILVA, Alexandre Garrido. “O Supremo Tribunal Federal como arquiteto institucional: a judicialização da política e o ativismo judicial”, in: Revista Acadêmica Versus (UFRJ). ago. 2009.

VIEIRA, José Ribas. "Verso e reverso: a judicialização da política e o ativismo judicial no Brasil”, in: Estação Científica (Ed. Especial Direito) Juiz de Fora, vol. 1, n. ${ }^{\circ} 4$, out./nov. 2009.

VIEIRA, Oscar Vilhena. "Supremocracia", in: Revista Direito GV, São Paulo, jul-dez 2008.

Direitos fundamentais: uma leitura da jurisprudência do STF. São Paulo: FGV, 2006. . Supremo Tribunal Federal: Jurisprudência Política. 2a ed., São Paulo: Malheiros, 2002. 
WATANABE, Kazuo. "Cultura da sentença e cultura da pacificação", in: YARSHELL, Flávio Luiz; MORAES, Maurício Zanoide. Estudos em homenagem à professora Ada Pellegrini Grinover. São Paulo: DPJ, 2005. . “Processo Civil de Interesse Público: Introdução”, in: SALLES, Carlos Alberto de (org.). Processo civil e interesse público: o processo como instrumento de defesa social. São Paulo: RT, 2003.

WAYNE, William. "The Two Faces of Judicial Activism", in: George Washington Law Review, n. ${ }^{\circ}$ 1. Vol. 61, nov. 1992.

WEBER, Max. Textos selecionados, São Paulo: Nova Cultural, 1997. . Ciência e Política: duas vocações. São Paulo: Cultrix, 2004.

YOUNG, Ernest A. "Judicial Activism and Conservative Politics”, in: Colorado Law Review, n. ${ }^{\circ}$ 73, 2002.

ZAGREBELSKY, Gustavo. "Ronald Dworkin's principle based constitucionalism: an italian point of view”, in: International Journal of Constitutional Law, vol. 1, n. ${ }^{\circ}$, 2003.

ZAPPAROLLI, Célia Regina. "A experiência pacificadora da mediação: uma alternativa contemporânea para a implementação da cidadania e da justiça", in: MUZSKAT, Malvina Ester (org.) Mediação de Conflitos: pacificando e prevenindo a violência. São Paulo: Lexus, 2003. 


\section{RESUMO}

A juridificação das relações sociais, processo complexo de colonização do mundo da vida pelo Direito, fez emergir um potencial protagonismo judicial em grande parte das experiências democráticas ocidentais. Entre os aspectos e desdobramentos mais importantes desse processo, que auxiliam a identificação desse potencial, destacam-se: a expansão dos padrões regulatórios; a "indeterminação" do direito contemporâneo; a materialização do direito formal; a crise da divisão funcional dos poderes; o afastamento de um modelo decisório eminentemente subsuntivo; o fortalecimento da função pragmática da hermenêutica jurídica; a expropriação de conflitos; a ampliação do controle judicial contramajoritário; o aumento da independência política do Poder Judiciário; a convergência normativa e institucional das experiências jurídicas democráticas; a influência do ideário do juiz ativo, ampliado para contemplar o tratamento de conflitos de massa e a promoção judicial de soluções não adjudicatórias; a expansão da litigância de interesse público; e, ainda, as mudanças na relação entre os órgãos judiciais e os meios de comunicação de massa.

O potencial protagonismo judicial, ao avançar as fronteiras do poder judicial em sua concepção tradicional, manifesta-se de diferentes formas que podem ser representadas em tipos ideais de ativismo judicial, construídos, nesta tese, conforme metodologia weberiana, de modo que permitam uma investigação profunda sobre a atuação do Poder Judiciário em geral. Neste trabalho, o manejo investigativo desses tipos "puros" de ativismo judicial para o exame da atuação concreta da Justiça do Trabalho demonstra, de um lado, alguns dos efeitos das transformações contemporâneas na função judicial sobre aquele ramo do Judiciário; e, de outro, diversas formas de manifestação do potencial protagonismo judicial trabalhista, seja em sua feição mais nova, seja em sua índole mais tradicional, renovada após a Constituição de 1988. Ademais, esse estudo da atuação contemporânea dos órgãos judiciais fornece dados relevantes para a avaliação da efetividade do Direito do Trabalho, da instrumentalidade do Direito Processual do Trabalho e do alcance da tutela judicial dos direitos sociais fundamentais do trabalhador. 


\begin{abstract}
The juridification of social relations, a complex life-world colonization process by means of law, has raised the potential of judicial protagonism in most democratic countries. The most important aspects and outcomes of this process that help recognize the mentioned potential are the following: legal expansion; indeterminacy of contemporary law; materialization of law; crisis on the model of functional power division; deviation from a model of decision-making based on subsunctions; pragmatic function strenghtening of legal interpretation; expropriation of conflicts; extension of countermajoritarian judicial control; increase of political independence of the judiciary Power; normative and institutional convergence of democratic legal systems; influence of the active judge doctrine, that has been enhanced for the purpose of dealing with mass disputes and the judicial fostering of non-adjudicatory dispute resolution; expansion of public interest litigation; and change in relationship between Mass Media and the Judiciary.

The potential of judicial protagonism goes beyond the traditional boundaries of judicial power, and can be represented by ideal types of judicial activism, which have been formed, in this thesis, according to Weber's methodology, in order that they allow a profound investigation of the judicial activity at large. The use of pure types of judicial activism for the analysis of real activity of the Labor Justice institutions real activity shows, on one hand, some of the impacts of contemporary transformations of judicial function on that branch of Brazilian judiciary; and, on the other hand, myriad forms of manifestating the potential of judicial protagonism, not only in its new forms, but also in its traditional format, which was renewed after the Constitution of 1988. Moreover, the analysis of the contemporary activity of Labor Justice institutions provides relevant information for evaluating the effectiveness of Labor Law, the instrumental function of Labor Procedural Law and the range of judicial enforcement of worker's fundamental social rights.
\end{abstract}




\section{RIASSUNTO}

La giuridificazione delle relazioni sociali, un complesso processo di colonizzazione del mondo della vita dal Diritto, ha generato un potenziale protagonismo giudiziale in gran parte dei paesi democratici occidentali. Tra gli aspetti e gli sviluppi più importanti di questo processo, che aiutano ad identificare il citato potenziale, i punti salienti sono i seguenti: la espansione degli standard normativi; la "indeterminatezza" del diritto contemporaneo; la materializzazione del diritto formale; la crisi della divisione funzionale dei poteri; l'abbandono di un modello decisionale con caratteristica notevolmente sussuntiva, rafforzando la funzione pragmatica dell'interpretazione giuridica; l'espropriazione dei conflitti; l'espansione di controllo giudiziale contro-maggioritario; maggiore indipendenza del giudiziario dal punto di vista politico; la convergenza normativa e istituzionali degli paesi democratici; l'influenza delle idee di giudici attivi, che é stato ampliato per includere il trattamento dei conflitti delle masse e la fomentazione delle soluzione non aggiudicative; la espansione del contenzioso di interesse pubblico; e i cambiamenti nel rapporto tra il Potere Giudiziario ed i mezzi di comunicazione di massa.

Il potenziale protagonismo giudiziale, oltre i confini del Potere Giudiziario nella sua concezione tradizionale, si manifesta in diverse forme che possono essere rappresentati in tipi ideali di attivismo giudiziario, che sono stati costruiti, in questa tesi, sulla base della metodologia di Weber, in modo da consentire un esame più approfundato delle funzione del potere giudiziario. L'uso dei tipi puri di attivismo giudiziario per esaminare la attuazione concreta della Giustizia del Lavoro dimostra, da un lato, alcuni degli effetti sul questo ramo giudiziario dei cambiamenti contemporanei nella funzione giudiziale; e, d'altra parte, varie manifestazioni del potenziale protagonismo giudiziale, sia nelle sue nuove forme, sia nella loro natura più tradizionale, rinnovata grazie alla Costituzione del 1988. Inoltre, questo studio della attuazione contemporanea degli organi giudiziali fornisce dati rilevanti per valutare l'efficacia del Diritto del Lavoro, la strumentalità del Diritto processuale del Lavoro e la scala della tutela giurisdizionale dei diritti sociali fondamentali dei lavoratori. 


\section{RÉSUMÉ}

La juridification des rapports sociaux, constituant un processus complexe de colonisation du monde de la vie par le Droit, a fait émerger un protagonisme judiciaire potentiel dans une grande partie des expériences démocratiques occidentales. Parmi les aspects et les dédoublements les plus importants de ce processus, de par leur rôle dans l'identification de ce potentiel, il faut retenir: l'expansion des normes de régulation; "lindétermination" du droit contemporain; la matérialisation du droit formel; la crise de la division fonctionnelle des pouvoirs; le rejet d'un modèle décisoire essentiellement basé sur les opérations de la subsomption; l'affermissement de la fonction pragmatique de l'herméneutique juridique; l'expropriation de conflits; l'élargissement du contrôle judiciaire contre-majoritaire; l'augmentation de l'indépendance politique du Pouvoir Judiciaire; la convergence normative et institutionnelle des expériences juridiques démocratiques; l'influence de la pensée du juge actif, augmentée de façon à contempler le traitement des conflits de masse et la promotion judiciaire de solutions non adjudicatives; l'expansion des poursuites liées à l'intérêt public; et, enfin, les changements dans le rapport entre les organes judiciaires et les moyens de communication de masse.

Dans la mesure où il dépasse les frontières du pouvoir judiciaire dans sa conception traditionnelle, le protagonisme judiciaire potentiel se manifeste de différentes façons qui peuvent être représentées par des types idéaux d'activisme judiciaire. Dans la présente thèse, ces types ont été construits, en conformité avec la méthodologie wébérienne, comme un instrument d'investigation profonde de la conduite du Pouvoir Judiciaire en général. L'emploi, à des fins d'investigation, de ces types “purs” d'activisme judiciaire dans l'examen de la conduite concrète de la Justice du Travail révèle, d'un côté, certains des effets que les transformations contemporaines de la fonction judiciaire ont

produits sur cette branche du Judiciaire; et, de l'autre, les différentes formes de manifestation du protagonisme judiciaire potentiel, soit dans son aspect le plus récent, soit dans son expression la plus traditionnelle, renouvelée après la Constitution de 1988. De plus, cette étude de la conduite contemporaine des organes judiciaires fournit des données appréciables pour l'évaluation de l'efficacité du Droit du Travail, de l'instrumentalité du Droit Procédural du Travail et de la portée de la protection judiciaire des droits sociaux fondamentaux du travailleur. 